Review

\title{
EFFECTS OF ENERGY AND MACRONUTRIENT INTAKE ON COGNITIVE FUNCTION THROUGH THE LIFESPAN
}

\author{
Edward Leigh Gibson \\ Department of Psychology, University of Roehampton, London, UK \\ I.gibson@ roehampton.ac.uk
}

Communicated by Valdis Pīrāgs

\begin{abstract}
This paper reviews effects of both insufficient and excessive energy and macronutrient intake on cognition over the lifespan, including the prenatal period, infancy, childhood, and adulthood. In the brain, the hippocampus is particularly vulnerable to both protein malnutrition and energy undernutrition in utero or infancy, resulting in impaired neurogenesis and deficits in memory and spatial learning, reduced anxiety and increased impulsivity, reflected in impairments of neurotransmitter systems. Conversely, higher protein intake is associated with improved motor development but not mental development, whereas breastfeeding benefits mental development. Nevertheless, pre- and post-natal protein-energy supplementation has been shown to improve cognition in later childhood, and in adulthood, above energy alone. Similarly, $n$-3 essential fatty acid intake during pregnancy may have long-lasting effects on children's cognitive abilities. However, over-nutrition, particularly during gestation, may lead to metabolic programming that increases risk of cognitive impairment. In undernourished school children, breakfasts can benefit cognitive performance. In normally nourished children, benefits of breakfast are less clear; nevertheless, acutely, breakfasts lower in glycaemic index can benefit memory, whereas higher glycaemic breakfasts may improve vigilance. This difference depends on the impact of the carbohydrate on cortisol release. In adolescents and adults, moderate carbohydrate loads can benefit cognition, provided that glucoregulation is efficient. Protein intake may benefit memory by restraining task-related cortisol release. Chronically high intake of saturated fats may contribute to cognitive decline, whereas $n-3$ fatty acids, and perhaps reduced energy intake, may be protective. With aging populations, dietary prediction of cognition in adults is a key area for research.
\end{abstract}

Key words: glucose, protein, fatty acids, memory, dementia, cortisol, breakfast, cognition.

\section{INTRODUCTION}

This review will briefly consider the impact on cognitive development and function, of variation in intake (insufficient or excessive) of the macronutrients, protein, carbohydrate and fat, and, where its effects can be separated, energy, over the human lifespan. For each macronutrient, attention will be paid to what is known about the role of specific forms for cognition and brain function. This review is mainly concerned with evidence in human beings, and emphasis is placed on highlighting current understanding of the evidence, rather than an extensive review of the literature.

All the macronutrients can provide energy, albeit with differing priorities and target organs, as well as carbon for structural functions, and many forms are fundamental to cellular processes governing growth, signalling and survival (Mann and Truswell, 2012). For the brain specifically, carbohydrates provide glucose as the primary energy source, amino acids in proteins provide the precursors for synthesis of neurotransmitters and create their receptors, while fatty acids provide the structural basis of neuronal cell membranes. These properties point to ways in which macronutrient intake may be crucial for optimal brain function.

Firstly, the importance of adequate intake of energy and protein, both for the pregnant mother and thus the intrauterine nutritional environment for the foetus, and for the neonate and infant child, will be considered. Breastfeeding will briefly be compared to formula feeding, as the quantity and quality of fats and protein may have implications for cognitive development.

Next, the review will discuss evidence for the benefits of breakfast, and other meal types, for cognitive function in school children, adolescents and adults, comparing effects of different forms of breakfast, including the nature of the carbohydrates and the glycaemic index of the meal. For adolescents and adults, there is extensive literature on the effects of glucose loads on cognition, particularly memory and attention: this literature will be summarised, and the strengths and weaknesses of the evidence, and its implications, discussed. 
Finally, evidence will be presented for the impact of different sorts of fat, and of total energy intake, on cognition in adults, both young and old; including discussion of the impact of diet over the lifespan on risk of cognitive decline in old age. Consideration will be given to possible mechanisms that might explain observed effects of diet on cognition, as well as limitations of current interpretations of the evidence.

\section{MACRONUTRIENT INFLUENCES ON PRENATAL DE- VELOPMENT AND INFANT AND CHILD COGNITION}

The gestational and neonatal periods are crucial for brain growth, with the majority of neural development occurring within the first year after birth. Although environment and interventions can counteract early developmental disadvantage to some extent, early childhood cognitive function has been shown to predict later school performance (GranthamMcGregor et al., 2007). Regrettably, approximately 200 million children around the world still suffer retarded development due to either malnutrition, as well as other effects of extreme poverty (Grantham-McGregor et al., 2007). Data from the World Health Organisation on prevalence of nutritional status in preschool children from developing countries show that about $10 \%$ are wasted (loss of body tissue especially muscle), $17 \%$ are underweight and $29 \%$ are stunted (Anonymous, 2012). These children are often born small for gestational age, having suffered in utero from the effects of malnutrition and disease on their mothers, including during their mothers' own infancy (Victora et al., 2008), and are most likely to suffer cognitive impairments too (Grantham-McGregor et al., 2007). However, it is difficult to determine from these natural observations in epidemiological studies just what deficiencies are responsible for what consequences, as these children will typically be suffering from multiple deficiencies, both of macronutrients and energy, and key micronutrients such as iodine and iron, as well as frequent infections, diarrhoea and dehydration, and all the psychosocial impairments associated with extreme poverty (Grantham-McGregor et al., 2007). Nevertheless, there have been some important intervention studies that have included indicators of cognitive development; these are now considered.

Protein-energy malnutrition. The major nutritional insult to infants and children worldwide is protein-energy malnutrition (PEM), which refers to insufficient intake of energy and protein (the two invariably occur together in 'natural' malnutrition) such that development is retarded. There are three forms: (a) marasmus (primarily an energy deficiency), characterised by severe wasting, but with good appetite; (b) kwashiorkor (primarily a protein deficiency), often seen in slightly older infants, is distinguished by presence of oedema and loss of appetite. By contrast with marasmus, the pathological signs may be more concerning (Mann andTruswell, 2012); (c) marasmic kwashiorkor, describes the presence of severe wasting and stunted growth, but also oedema, and so is likely to reflect both lack of energy and protein.
Although there is little consensus as to why children may develop either marasmus or kwashiorkor, the mortality rate for the latter is far higher than the former (Mann andTruswell, 2012). However, a recent study investigated whether the outcome of PEM for a given infant is determined by pre-existing metabolic differences that might arise from differing intrauterine nutritional environments. Specifically, Forrester et al. (2012) examined medical records of Jamaican children with diagnoses of kwashiorkor ( $\mathrm{n}=$ $391)$, marasmus $(\mathrm{n}=383)$, and marasmic kwashiorkor $(\mathrm{n}=$ 375): children of lower birth weight were more likely to have developed marasmus, whereas those with higher birth weights developed the more maladaptive kwashiorkor, with marasmic-kwashiorkor children having intermediate birth weights. This was interpreted as supporting maternal nutritional 'programming' of the child's metabolism in utero via epigenetic effects.

Alamy and Bengelloun (2012) recently reviewed evidence from effects of pre- and post-natal rodent models of protein and/or energy malnutrition on brain morphology and function, and on behaviour. An important conclusion was that both protein malnutrition and energy undernutrition in these models produce similar effects on health, brain and behaviour to those seen in malnourished children in developing countries. In fact, both forms of nutritional insult can damage the hippocampus, and result in deficits in learning and memory (Zhang et al., 2010 ); postnatal and post-weaning malnutrition may be at least as damaging to the brain as that occurring prenatally, perhaps because the foetus may gain some protection by sacrificial changes in the mother's nutritional status (Alamy and Bengelloun, 2012).

The hippocampus is also part of the brain's emotional circuitry known as the limbic system: thus, it is not surprising that malnutrition has been found to reduce anxiety-related behaviour, and increase impulsivity. These effects may be mediated by changes in GABAergic, noradrenergic and serotonergic transmitter systems (Alamy and Bengelloun, 2012), and possibly also by the hunger-related hormone, ghrelin, which is known to increase novelty seeking and risk taking (Symmonds et al., 2010; Hansson et al., 2011).

How reversible are these deficits? The animal literature suggests that nutritional rehabilitation may allow recovery of body weight and even brain weight, but deficits in learning and memory and other behaviours tend to persist despite a return to adequate nutrition (Alamy and Bengelloun, 2012).

For infants, both intervention and observational studies suggest that higher intake of animal protein benefits growth and motor development, but may not improve mental function, in contrast to effects of breastfeeding (Kuklina et al., 2004; Morgan et al., 2004). One randomised controlled trial (RCT) in 294 pregnant Taiwanese women found that motor, but not mental, development of the infant offspring was improved by a protein-calorie supplement during pregnancy and breast feeding (Margolis, 2010). 
However, mental benefits of early supplementation seem to emerge in older children. A particularly influential longterm study, the Oriente Longitudinal Study (Institute of Nutrition of Central America and Panama, 1969 to 1977), has produced a wealth of information on effects of proteinenergy supplementation in mothers and children on mental and physical development (Engle and Fernandez, 2010). The intervention targeted all children under eight years in four villages in rural Guatemala, which were allocated one of two supplement drinks: 'Atole', containing $11.5 \mathrm{~g}$ protein and 682 kJ energy per cup, and 'Fresco', containing no protein and $247 \mathrm{~kJ}$ per cup; both drinks also contained vitamins and minerals. By adolescence, Atole resulted in superior cognition vs. Fresco, most evidently in children from lower socioeconomic status (SES) families (Pollitt, Gorman, Engle, Rivera and Martorell, 1995). However, the design does not exclude the possibility that the benefit of Atole is partly due to the extra energy, as much as to the protein, since the former may be more limiting in those villages: in correlational analyses, both greater energy intake and growth were positively related to cognitive performance (Engle and Fernandez, 2010). Importantly, these data have led to a more complex theoretical interpretation of how supplements improve cognition: that is, there is a positive feedback model in which supplementation hastens physical development and promotes proactive, appetitive and prosocial behaviours, which in turn allow for greater opportunities for social support, interaction, exploration and learning, leading to faster cognitive development (Engle and Fernandez, 2010).

Some other studies have been able to show relations between pre- or post-natal diet and adult cognition; however, the specific effects on cognition vary with the form of deficit. For example, data from 737 adults in their late fifties from the Dutch Famine Cohorts, who were in utero during famine in World War II, showed significantly impaired selective attention (de Rooij et al., 2010). However, they showed no deficits in memory or perceptual motor skills tests. By contrast, in a large epidemiological study of 18,436 Chinese adults aged at least 50 (Guangzhou Biobank Cohort), recalled frequency of meat eating during childhood was strongly positively associated with verbal memory after adjusting for likely confounding factors (Heys et al., 2010).

In summary, insufficiency of either protein or energy or both, pre- and/or post-natally, can impair psychomotor development and aspects of cognitive function. The relative importance of protein vs. energy for specific aspects of cognitive development is less clear, at least in human beings.

Polyunsaturated fatty acids in pregnancy, infancy and childhood. Long-chain polyunsaturated fatty acids (PUFA), specifically the n-6 PUFA arachidonic acid (AA), and the n-3 series PUFAs, eicosapentaenoic acid (EPA) and docosahexaenoic acid (DHA) are major structural and functional components of the CNS. These PUFA are synthesised from the dietary fatty acids linoleic acid (n-6) and alpha-linolenic acid (n-3), and are available from the diet in sources such as many plant or seed oils (for AA) and animal tissues espe- cially oily fish (AA, EPA, DHA). These are essential fatty acids (EFA), with a wide range of biochemical and physiological functions, including as precursors for immune regulatory and anti-inflammatory chemicals that convey cardiovascular health benefits (Calder et al., 2010). However, their role as major components of phospholipid bilayers in cell membranes, and in promotion of neurogenesis and neuroprotection, intracellular signalling and ion channel regulation, makes them of particular interest as contributors to CNS function and therefore cognitive development. The balance of n-3 to n-6 fatty acids may be critical for maintaining membrane fluidity and thus receptor expression. Thus, there has been considerable attention paid to the importance of such PUFAs for cognitive development in infants and young children (Calder et al., 2010; Karr, Alexander and Winningham, 2011).

The rapid development of the brain during the third trimester of gestation and the first few months after birth make this period particularly sensitive to supply of both n-3 and n-6 EFA. The foetus depends on delivery via the placenta and the neonate via breast milk (or formula if not breastfed), so the maternal EFA status should be a key factor in neonate brain development. Indeed, there is a striking protective effect of maternal oily fish consumption, or supplementation with EPA and/or DHA, against premature birth or miscarriage (Cetin and Koletzko, 2008), as well as predicting greater visual and motor development and verbal intelligence quotient (verbal IQ) (Helland et al., 2003; Daniels et al., 2004) and improved social behaviour (Hibbeln et al., 2007). An emerging complexity is that polymorphisms associated with the fatty acid desaturase (FADS) gene cluster can affect the synthesis of EFA, especially for $n-6$ fatty acids in the foetus, as well as levels in breast milk, likely adding to variation in associations with brain development (Lattka et al., 2013).

Delivery of EFA to neonates via breast milk might contribute to the beneficial effects of breastfeeding on cognitive development, though not all studies support an association (Keim et al., 2012), perhaps because of confounding by maternal and neonate FADS genotypes (Steer et al., 2010). Breastfeeding is often confounded with maternal IQ and socioeconomic status (Holme et al., 2010), especially in countries such as the UK where infants breastfed even for 6-8 weeks are in the minority (Department of Health, 2011). Nevertheless, the results of a large-scale cluster-randomised controlled breastfeeding promotion, conducted in 31 maternity units in Belarus, support a clear beneficial effect of exclusive breastfeeding on children's IQ (Kramer et al., 2008).

By contrast, interventions involving EFA supplementation of breast milk or formula, and in diets of older children, have suggested either no, or only weak, benefit (Karr et al., 2011). A plausible conclusion is that the main benefit from higher intake of PUFAs is to be found during rapid brain development in utero and early infancy, although methodological weaknesses may contribute (Meldrum et al., 2011). The existence of a critical window for dietary impact on 
cognitive development has been underlined by recent evidence from the Avon Longitudinal Study of Parents and Children (ALSPAC) cohort: a 'health-conscious' diet (salad, rice, pasta, fish, fruit) at age 3, but not later ages, was associated with significantly improved IQ at age 8.5 years, whereas children eating more of a 'processed' diet (high in sugar and fat) tended to have lower IQ (Northstone et al., 2012). This suggests that well-designed interventions are worthwhile and may yet produce clearer benefits.

Carbohydrates, breakfast and cognitive function in school-age children. Breakfast has potential to be 'the most important meal of the day' in young school-age children, by improving the benefit children receive from education at school. Moreover, it is widely accepted that the brain glucose utilisation rate in children is twice that of adults, with evidence from positron emission tomography (PET) that this high rate is maintained from age 4 to 10 years, then gradually declines to adult levels after age 16 (Chugani, 1998). Thus, primary school years should theoretically be a critical period for cognitive function being sensitive to energy supply and perhaps to carbohydrate-rich breakfasts in particular. Detailed consideration of the effects of breakfast vs. no breakfast on cognition is beyond the scope of this review, since it would not address mechanisms specific to particular macronutrients. To date, the consensus is that a benefit of breakfast on cognitive function in healthy children is disappointingly small and inconsistent, but greater in children with a history of suboptimal nutritional status (Hoyland et al., 2009). Also, for performance on a few tests, particularly involving speed of information processing, there is evidence that fasted children do better than those receiving breakfast (Gibson and Green, 2002), a finding that also emerges from studies in adults, and presumably reflects differential effects of acute nutritional status on arousal (Gibson, 2007).

Variation in glucose utilisation rates with age could have contributed to variable results reported by Wesnes et al. (2003): 9-16 year old children were given either $38 \mathrm{~g}$ of glucose in a drink or two cereal-based breakfasts ( $29 \mathrm{~g}$ or 38 g carbohydrate) or no breakfast. Performance in spatial and working memory (but not attention) declined in the nobreakfast group during the morning, but even more so after glucose, at least for word recall. By contrast, performance after either of the cereals had not declined at all by midday, suggesting that the form rather than amount of carbohydrate may be critical.

Thus, there has been considerable interest in whether the glycaemic index (GI) and/or glycaemic load (GL, the product of \% GI and weight of carbohydrate) of breakfasts differentially affects performance. Several studies have supported a benefit of low-GI/GL breakfasts on cognition, especially memory, in 6-11 year-old children compared to high-GI/GL breakfasts (Mahoney et al., 2005; Benton et al., 2007; Ingwersen et al., 2007).

The interpretation of these findings, and practical implications, are complicated by evidence that increases in blood glucose for three hours after breakfasts varying in carbohydrate content and form are determined more by GL than by GI, although insulin levels are influenced by GI (Micha and Nelson, 2011). With the exception of the study by Benton et al., (2007), the impact of GL was not assessed. However, in an observational study of the impact of reported breakfast GI and GL on cognition in 60 11-14 year-old children, performance on different cognitive domains varied by GI, GL or both (Micha et al., 2010). However, limitations of this study include the self-reported meal information, and categorisation of GI and GL by median split (medians were 61 and 27 , respectively).

To try to account for this sort of variation in findings, Gibson and Green (2002) argued that the impact of these sorts of dietary manipulations on cognitive function "is likely to reflect individual differences in neurohormonal influences on glucose synthesis and uptake, interacting with task involvement and stress reactions, as well as nutritional state" (Gibson and Green, 2002, p. 186). For example, it is well established that food and performance testing alter autonomic nervous system (ANS) activity, which in turn can alter blood glucose levels and arousal state (Gibson and Green, 2002; Rogers and Lloyd, 1994). Gibson (2007) has further developed a theory that proposes that a mealinduced increase in blood glucose can interact with the stress of task performance to provoke a particularly marked increase in release of the glucocorticoid hormone cortisol, via activation of the limbic hypothalamic pituitary adrenal (HPA) axis, which in turn will alter cognitive function. This is based on evidence that a glucose drink prior to a stressful task elicits a large stress-induced cortisol release that correlates with post-drink blood glucose levels, and that high cortisol is associated with poorer memory (Kirschbaum et al., 1997).

A recent study, in 74 11-14 year-old children, explicitly set out to investigate the relationships between breakfasts varying in GI and GL, cortisol, mood and cognitive function, using a $2 \times 2$ high/low-GI by high/low-GL design, as already validated by Micah et al., (2011). The high- and low-GI breakfasts used cornflakes and muesli respectively, and GL was varied by using different amounts of the breakfast cereals and with or without apple juice. High-GI breakfasts (irrespective of GL, and energy levels) resulted in higher cortisol levels both immediately before and after the cognitive testing. Relative to low-GI breakfasts, high-GI meals impaired verbal memory but improved speed of information processing, similar to reports in adults (Gibson, 2007). If verbal memory is more important for learning at school than information processing speed, then low-GI breakfasts would be the preferred nutritional preparation for school (Micha $e t$ al., 2011). Of course, most studies comparing GL/GI differences also vary the other macronutrients, and perhaps total energy, particularly for meals differing in GI, so mechanistic interpretations need to be made cautiously.

In adolescents aged 14-17 years, recall of words after a 60min delay was slightly impaired after a high-GI (and higher GL) breakfast, but at 100 min was improved, whereas per- 
formance after a low-GI breakfast remained unchanged (Smith and Foster, 2008). These times coincided, respectively, with the peak change in blood glucose and the point at which blood glucose had returned to baseline. In line with the theory discussed earlier, it is possible that the impairment at 60 min reflects a greater increase in cortisol induced by the high-GI breakfast (and so higher blood glucose) in combination with a demanding task, but this was not assessed.

\section{MACRONUTRIENT EFFECTS ON COGNITION IN YOUNG ADULTS}

Facilitation of cognitive function by glucose. The majority of research relevant to macronutrients and cognition in young adults has concerned the effects of glucose drinks, and there have been several recent reviews of this glucose facilitation effect (Gibson, 2007; Hoyland et al., 2008; Smith et al., 2011). This section will briefly summarise the consensus, interpret recent new evidence and discuss the implications.

The idea that ingesting glucose could improve cognitive function emerged from the knowledge that glucose is the primary energy source for the brain, and hypoglycaemia is associated with cognitive impairment, although even in the early studies there were indications that the relationship may be more complex. For example, it became clear that the nature of the task (cognitive domain and difficulty), the dose of glucose and the glucoregulatory efficiency of participants could all influence the outcomes (Gibson and Green, 2002; Meikle et al., 2004; Riby et al., 2004); moreover, the association between changes in peripheral blood glucose and delivery of glucose to neurones is loose at best, not least because glucose (and blood) supply to neurones is mediated by astrocytes and oligodendrocytes (Lee et al., 2012).
A systematic review of the impact of glucoregulation on cognition concluded that it was clearly associated with poorer performance, especially for memory and in older people (Lamport et al., 2009); moreover, ingesting glucose was more likely to benefit those with poor glucoregulation. Indeed, the effect of glucoregulation can obscure any treatment benefit from glucose (Messier et al., 2011). These findings could again suggest a role for elevated cortisol levels. Furthermore, dissociation of task difficulty from task domain suggests that glucose facilitation of cognition is dependent more on domain (e.g. memory) than on task difficulty (Riby et al., 2006).

Given this non-linear relationship between blood glucose and performance across individuals, it is perhaps not surprising that several studies found an inverse-U shaped dose-response curve, with the most beneficial dose seeming to be about $25 \mathrm{~g}$ glucose, although this varied somewhat with the nature of the task (Gibson, 2007). In a recent study involving administration of $0 \mathrm{~g}, 15 \mathrm{~g}, 25 \mathrm{~g}, 50 \mathrm{~g}$ or $60 \mathrm{~g}$ glucose, there was some support for a peak benefit at $25 \mathrm{~g}$, particularly for longer-delay verbal memory tasks, but this dose relationship was less apparent in others, such as working memory tasks (Sünram-Lea et al., 2011). One moderating factor was again glucoregulation, such that participants with high blood glucose responses to the higher doses were less likely to show benefits from those doses. The basis of the narrow effective dose range may relate to the brain's management of energy supply (Peters et al., 2004), where oversupply of glucose could provoke greater inhibitory neuronal activity (Gibson, 2007), and/or a trade-off between speed of learning and speed of recall (Sünram-Lea et al., 2011). However, moderation by counter-regulatory hormones or other neuroendocrine responses may also play a part (Gibson, 2007; Rogers and Lloyd, 1994) (see Fig. 1).

To some extent, another study has shed light on the question of whether the glucose dose is dependent on energy

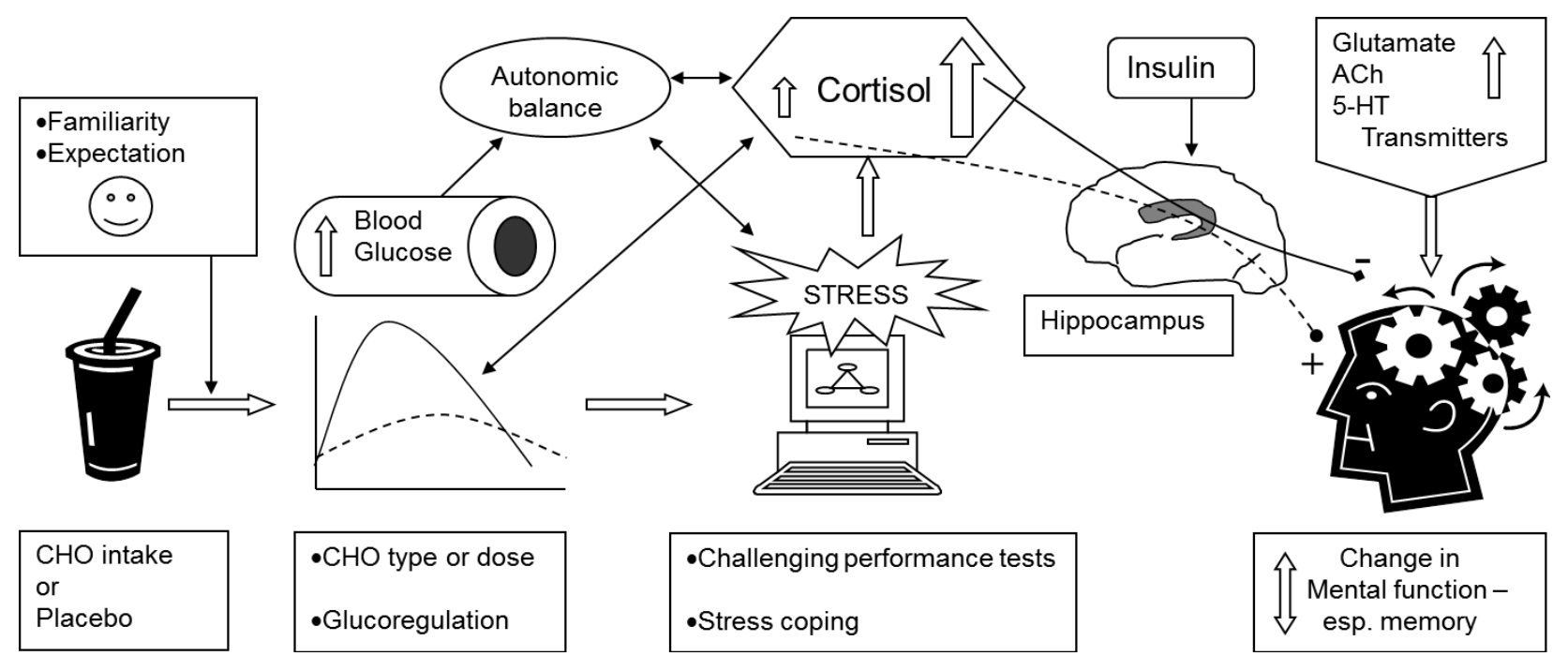

Fig. 1. This diagram summarises putative pathways linking carbohydrate intake and mental function, including various influences that can prevent or reverse an otherwise beneficial effect. Moderate increases in blood glucose are more likely to improve mental function, especially memory. Conversely, higher glucose increases, especially if accompanied by poor glucose tolerance, may enhance release of cortisol during the challenging performance tests, which could result in relatively impaired cognition (CHO, carbohydrate; ACh, acetylcholine; 5-HT, 5-hydroxytryptamine or serotonin). Reproduced from Gibson (2007) with permission of the author. 
status. Thus, Owen et al. (2012) examined the interaction of a 12-hr vs. 2-hr fast on cognitive function following either a 25 -g or 60-g dose of glucose (or placebo): the higher dose benefited performance after the longer fast, and vice-versa for the shorter fast, suggesting that the dose-response curve is shifted to the right by energy deprivation. Interestingly, regardless of the drink condition, those participants with better glucoregulation appeared to be calmer and to perform better: this might implicate higher levels of counterregulatory hormones such as adrenaline or cortisol, which would raise blood glucose, being present in poor glucoregulators and perhaps impairing performance on some tasks. A further complication by is that a high-GI vs. low-GI evening meal can improve memory following a high-GI breakfast the next day (Lamport et al., 2011).

Acute effects of meals varying in macronutrient content on cognition in adults. Whereas eating breakfast at all may benefit memory (Gibson and Green, 2002), this section briefly considers a series of studies where the macronutrient content, and/or GI or GL of the breakfasts was varied. Clearly, the results for breakfasts of differing GI and GL in children, discussed above, suggest that the relationships between these factors and cognitive performance are not straightforward. Benton et al. (2003) compared 'breakfasts' consisting of decaffeinated tea or coffee with skimmed milk, a sugar-free orange drink, and either $50 \mathrm{~g}$ of a plain biscuit (low GI) or $50 \mathrm{~g}$ of a cereal bar (high GI) on verbal memory performance. Significant differences in global memory scores were only apparent for performance at 150 and 210 min after breakfast (by which time blood glucose had returned to baseline, but cortisol may have been raised); participants recalled more words at these times after the low-GI food than after the high-GI food.

In another study, in participants with good glucose tolerance, variation in breakfast GL had little impact on their verbal memory; by contrast, poor glucoregulators performed worse on the word recall test after 30 and $50 \mathrm{~g}$ carbohydrate breakfasts compared to a $15 \mathrm{~g}$ carbohydrate meal (Nabb and Benton, 2006). This again suggests that a large rise in blood glucose has a negative effect on memory. Conversely, higher blood glucose was associated with improved performance on vigilance and reaction time tests. These differential findings are similar to those reported recently in children (Micha et al., 2011), and it is therefore not surprising that glucose ingestion or high-GI food also impairs memory in Type II diabetics (Papanikolaou et al., 2006).

In a comparison of muesli (low GI) versus cornflakes (high GI) versus an overnight fast, participants' reaction times on a Stroop colour-word test were quickest when fasted (cp. arousing effect of deprivation discussed above), intermediate after cornflakes and slowest after muesli (Gibson, 2007); however, the 'Stroop effect' of failure of response inhibition to incongruent colour-word stimuli did not differ between breakfasts, suggesting that the effect was specific to information processing speed. On a word recall test, number of words remembered did not differ across breakfasts, al- though after muesli participants produced more new words not listed (false positives); also, only this muesli group resisted deterioration in mood from before to after testing.

For macronutrient content, there is surprisingly little evidence to support a consistent pattern of effects (Hoyland et al., 2008). However, in one carefully designed study, Fischer et al. (2001) fed subjects different 'breakfasts' consisting of one of three 400-kcal vanilla creams with that contained either protein, fat or carbohydrate. The fat condition produced the most reliable benefit for cognitive performance, including memory, attention and choice reaction time relative to protein or carbohydrate intake. This was attributed to the comparative absence of glycaemic and hormonal (insulin, glucagon and cortisol) perturbations in the 3 $\mathrm{hr}$ following fat ingestion, relative to the other two macronutrients. In a subsequent study using similar methods, effects on performance and hormones were assessed after $400-\mathrm{kcal}$ meals varying in carbohydrate and protein in the respective proportions of 4:1,1:1, and 1:4 (Fischer et al., 2002). Effects varied over time, with an early benefit from the high-carbohydrate food on attention and decision times, whereas after the first hour, the higher protein conditions produced greater improvements in performance.

These later effects from protein maybe related to changes in availability of neurotransmitter precursor amino acids, such as tryptophan (TRP) and tyrosine (TYR), to the brain. Typically, high-protein results in less TRP being available to the brain via competitive transport across the blood brain barrier, thus reducing brain serotonin synthesis, and possibly increasing alertness and thus influencing cognition (Gibson and Green, 2002). In support of this, studies comparing high-protein/low-carbohydrate vs. low-protein/high-carbohydrate lunches have found that high protein intake was associated with faster responses and more alertness, although also greater susceptibility to distraction (Lieberman et al., 1986; Smith et al., 1988)

In a recent well-designed cross-over study, comparing macronutrient effects on cognition, Jones et al., (2012) tested the effects of isocaloric $300-\mathrm{ml}$ drinks (145 kcal) containing either $38 \mathrm{~g}$ glucose (contrary to the $25 \mathrm{~g}$ stated in the abstract; E. Jones, personal communication), $36 \mathrm{~g}$ (whey) protein or $16 \mathrm{~g}$ vegetable oil (in emulsion), or a non-caloric placebo (aspartame), on memory and attention. The results differed from some previous findings, but did share similarities with the macronutrient proportion effects reported by Fischer et al., (2002): glucose enhanced attention and glucose and fat slightly increased speed of processing at 15 min after the drink, but glucose impaired working memory at $60 \mathrm{~min}$. By contrast, protein enhanced working memory at $15 \mathrm{~min}$ and episodic memory at $60 \mathrm{~min}$. Rather than consequences of initial nutrient absorption, the early effects might reflect expectations in response to sensory differences, which would have been apparent even though the drinks were taken through a straw from opaque containers, and all flavoured with lemon juice; for example, alertness was rated as higher at $10 \mathrm{~min}$ than at baseline and later, for all drinks including sweet placebo. Quenching of thirst is a 
possibility for this effect, as the authors suggested. However, the effects might result from neurohormonal responses to sensory or early nutrient detection. At 60 mins, differential effects reflecting absorbed nutrients are more likely; the impaired memory after $38 \mathrm{~g}$ glucose is similar to the effect of the same dose of glucose in children, and is in line with previous evidence that large increases in blood glucose are associated with memory impairment.

However, these results do not yet allow for reliable predictions of acute cognitive effects from macronutrient intake, let alone understanding of mechanisms. As pointed out by a systematic review of the area, there are too few studies comparing effects of protein, fat and carbohydrate manipulations on cognition to date (Hoyland et al., 2008).

What is the relationship between such findings comparing variations in macronutrient intakes and the effects of glucose drinks discussed above? One difference may be the absolute energy values concerned; that is, the optimal dose of 25 g glucose contains just 94 kcal energy, so greater levels of energy from breakfasts or macronutrient loads may invoke quite different neurohormonal consequences that in turn alter cognitive function in different ways and with different temporal effects (Gibson and Green, 2002). Indeed, larger doses of glucose might well be sedating, via increased TRP entry to brain (Gibson, 2007).

Dietary fats and cognitive function in young adults. A recent longitudinal epidemiological study has found evidence for cognitive decline in adults as early as young middle-age: a cohort of 10,308 British civil servants aged 45-70 (the Whitehall II study) was assessed for cognitive function on three occasions over ten years (Singh-Manoux et al., 2012). Cognitive decline was apparent in all age groups, even in those aged 45-49 at baseline; moreover, the effect was probably underestimated due to practice effects. Such cognitive decline in a relatively healthy group is most likely to be due to lifestyle factors including diet, perhaps interacting with genetic susceptibility. Yet, detectable cognitive decline is thought to result from changes taking place over 20-30 years (Launer, 2005); therefore it is possible that chronic dietary factors may already be affecting the cognition of younger adults.

There is already good evidence (see the next section) that chronic intake of dietary saturated fats can adversely affect cognitive function in the elderly (Kalmijn et al., 2004; Kanoski and Davidson, 2011). This includes the finding that the fat intake of 40-50 year-olds predicted cognitive decline 20 years later (Eskelinen et al., 2008). Gibson et al., (2011) tested the hypothesis that habitual consumption of dietary fats could be predictive of cognitive function in women aged $25-45$ years $(\mathrm{N}=38)$. The women's dietary fat intakes, particularly trans fats and the saturated fat to PUFA ratio, were negatively related to learning and memory performance: no associations with carbohydrate or protein intake were found.
EFFECTS OF MACRONUTRIENTS AND ENERGY INTAKE ON COGNITION IN MIDDLE-AGED AND ELDERLY ADULTS

Impact of glucose and glucoregulation on cognitive function in older adults. The negative impact of poor glucoregulation on cognitive function seems if anything to be more marked in older adults, perhaps in part because of lower baseline performance. A systematic review of studies relating glucoregulation to cognition considered 23 studies of which 20 contained middle-aged or elderly participants (Lamport et al., 2009). Twelve of these studies assessed impaired glucose tolerance (IGT) using an oral glucose tolerance test (OGTT): most of these did not support a relationship between glucose tolerance and cognition; however, the tests were mostly quite crude assessments of cognitive impairment such as the Mini Mental State Examination (MMSE). Also, the one study that measured glucose tolerance longitudinally did find a negative effect of impaired glucose tolerance (Vanhanen et al., 1998), with hyperinsulinaemia being a significant predictor of impairment.

The remaining studies examined relations between glucose tolerance within the normal range and cognition: whilst most of these studies used more sensitive measures of cognition, the assessment of glucose tolerance was inconsistent and usually cruder than using an OGTT. Even so, the majority of the studies found evidence for a negative relationship between impaired glucose tolerance and cognitive performance, particularly for memory-based tests, although there were some inconsistent differences between sexes. Several of these studies also examined the impact of ingesting glucose on cognition. In 57 non-diabetic men and women aged 55-84, poor glucoregulators performed worse on tests of working memory, verbal memory and executive function, with the more elderly (over 72) being worst affected (Messier et al., 2003).

Another study addressed whether the GI of foods might differentially affect cognition in the elderly: in ten men and ten women aged 60-82 years, without diabetes, Kaplan et al. (2000) compared the effects of three carbohydrate-rich foods varying in GI (glucose, potato, barley, or placebo) on cognitive performance. The foods did not differ in their effects overall, nor did changes in blood glucose arising from eating them, but those with baseline indices of poor glucoregulation benefited more from the foods vs. placebo, except on tests of attention.

A subsequent study by Kaplan et al. (2001), in men and women aged 61-79, compared effects of pure glucose, whey protein or fat emulsion in isocaloric $774 \mathrm{~kJ}$ drinks with a placebo non-caloric drink. All the macronutrients improved memory compared to placebo, despite blood glucose only rising appreciably after glucose. On other tests, there was some variation between macronutrients, such as improved visuomotor performance after glucose, and better attention $60 \mathrm{~min}$ after the fat drink. This suggests that there is an acute benefit from energy intake independent of blood 
glucose changes, but also some differential effects of macronutrients.

Dietary fats and cognitive function in older adults. Both experimental studies in animals and epidemiological studies in older humans supported a link between high saturated fat intake and cognitive decline, or suggested a protective effect of higher PUFA intake (Kalmijn, 2000). However, there were exceptions: in 2002, results from a large 6-year prospective study of 5,395 Dutch adults (the Rotterdam Study), which included a semi-quantitative food frequency questionnaire, and monitoring for dementia, did not find any association between either high intakes of saturated and trans fats, and cholesterol, or low intakes of MUFA and PUFA, and risk of developing dementia, after adjusting for likely confounds (Engelhart et al., 2002). Nevertheless, only $3.6 \%$ had been diagnosed with dementia over that period, and more subtle declines in cognitive function were not assessed. In a three-year prospective study of 482 women aged 60 or more, no association between cognitive decline and intake of saturated and trans fats was found; however, greater MUFA intake was associated with less decline (Naqvi et al., 2011).

Nevertheless, evidence continues to grow that supports dietary fats being important risk factors for cognitive health in older adults. For example, in a cross-sectional study of 1613 adults aged 45-70 (Kalmijn et al., 2004), intake of n-3 PUFA, EPA and DHA was associated with reduced cognitive decline; by contrast, dietary cholesterol and saturated fats were associated with increased decline, after adjusting for confounders including energy. In a six-year longitudinal study of 2560 American adults aged 65 or over, high intakes of saturated and trans fats, and low intake of MUFA and PUFA/saturated fat ratio, were associated with cognitive decline (Morris et al., 2004). In the Women's Health Study, in 6,183 older participants over less than a decade, higher intake of saturated fat, and lower intakes of MUFA, were associated with worse global cognition and verbal memory (Okereke et al., 2012).

Beyond mild cognitive decline, there is growing interest in risk factors for dementia, given the world's increasingly elderly population. Over the last decade or so, several observational epidemiological studies, including thousands of participants, have examined the relationship between fish consumption, and/or n-3 fatty acid intake, or blood or erythrocyte membrane levels of n-3 fatty acids and incidence of dementia (Brown, 2012). The majority reported a protective effect of higher fish or n-3 intake, or higher membrane levels of n-3 EFAs; the negative studies tended to be smaller sample sizes, the exception being data from the Rotterdam cohort study discussed earlier. There are also some reports of increased risk of dementia associated with high n-6:n-3 fatty acid ratio (Conquer et al., 2000). An additional complication is that people vary in genetic predispositions affecting metabolism and functions of dietary fats: for example, carriers of the $\varepsilon 4$ allele for apolipoprotein-E have deficiencies in lipid transport and metabolism and increased risk of dementia including Alzheimer's disease (Martins et al., 2006); they also seem to be more resistant to potentially beneficial changes from n-3 EFA supplementation (Barberger-Gateau et al., 2011), although there is one report of this phenotype benefiting from n-3 EFA supplements (van de Rest et al., 2008). Moreover, FADS genotypes (discussed above) may influence the availability of n-3 fatty acids from the diet to the brain (Brown, 2012).

The logical progression from observational evidence that does not allow causal conclusions is to conduct RCTs of $n-3$ EFA supplementation. A limited number of such studies have been conducted, although they vary considerably in both intervention period (6-40 months) and treatment doses (0.2-1.8 g EPA; 0.4-2 g DHA). Treatments were effective in increasing biomarkers of EFA incorporation, but by and large did not show significant benefits to cognitive function across a range of performance domains, nor differences in cognitive decline compared to placebo. However, subgroup analyses suggest that benefits can be detected if those with adequate EFA intake and participants with more than mild cognitive impairment at baseline are excluded (Brown, 2012). Nevertheless, a recent Cochrane Database review of three of the longer interventions (2-3 years) concluded that there was no evidence overall that n-3 EFA supplements either prevented dementia or benefited cognition in healthy older adults, although only one of the studies used sensitive tests over a range of cognitive functions (Sydenham et al., 2012).

\section{EFFECTS OF CHRONIC ENERGY RESTRICTION ON COGNITIVE FUNCTION IN ADULTS}

In animal models, especially studies in rodents, but also non-human primates, long-term caloric restriction, in the region of $25-40 \%$ below standard energy intake, has been shown to increase longevity and indices of health, including amelioration of age-related decline in learning and memory (Mattson, 2010). Likely mechanisms include enhancing brain energy efficiency, particularly in the hippocampus, for example by increasing insulin sensitivity via glucagon-like peptide 1 (GLP-1) activity (Mattson, 2010). Beneficial effects on synaptic plasticity by increasing brain derived neurotrophic factor (BDNF) may also be a mechanism (Stranahan and Mattson, 2011). Nevertheless, not all animal studies have been able to show benefits to cognition following chronic caloric restriction in rodents (Bellush et al., 1996).

It has been argued that cognitive function in human beings might similarly benefit from restricted energy intake, given the global predominance of excess energy and fat intake, and obesity (Kanoski and Davidson, 2011). However, there are few studies that have tested this hypothesis in human adults, and these mainly involve quite short-term restrictions, use of overweight or obese participants, as well as variation in the ketogenic effects of the diets (Kretsch et al., 1997; Krikorian et al., 2012). 
In 49 moderately overweight 50-80 year-old men and women, an intervention to reduce energy intake by $30 \%$ improved memory after three months, compared to either a group attempting to increase unsaturated fat intake or a control group (Witte et al., 2009). The improvement in memory was significantly related to the reduction in fasting insulin in the caloric restriction group. These and other encouraging findings have led to the start of a long-term intervention, the CALERIE study (Comprehensive Assessment of the Longterm Effects of Reducing Intake of Energy) (Rochon et al., 2011), that will investigate outcomes including cognition, in non-obese adults, following two years on a $25 \%$ energy reduction diet.

\section{SUMMARY AND CONCLUSIONS}

It is clear that both macronutrient and energy intake can have substantial impacts on cognitive function at all stages of the lifespan, particularly where there is obvious insufficiency or excess. The number of children at risk of dietrelated retarded development globally remains disturbingly high. The hippocampus is particularly vulnerable to protein and energy deficiencies, resulting in impaired neurogenesis and deficits in memory and spatial learning, reduced anxiety and increased impulsivity, reflected in impairments of neurotransmitter systems. Pre- and post-natal protein-energy supplementation has been shown to improve cognition in later childhood above energy alone; developmental assessment in very young children may be biased to detecting psychomotor rather than cognitive improvements. Both maternal undernutrition and low protein intake during childhood can impair cognitive function in adulthood.

Higher maternal intake of n-3 EFA during pregnancy has been associated with better cognitive, behavioural and psychomotor outcomes of offspring. Nevertheless, EFA supplementation in young children has not produced consistent evidence of benefits, perhaps indicating a sensitive period for the need for EFA during early brain development. Yet, a diet dominated by energy-rich, high-fat/sugar foods and low in EFA specifically in early childhood may impair cognitive development.

In undernourished school children, breakfasts can benefit cognitive performance. In normally nourished children, adolescents and adults, benefits of breakfast are less clear; nevertheless, acutely, breakfasts lower in GI can benefit memory, whereas higher glycaemic breakfasts may improve vigilance or speed of information processing. This difference depends on the impact of the carbohydrate on cortisol release, with higher GI breakfasts being more likely to result in increased cortisol levels during challenging tasks. These effects interact with differences in glucoregulation, particularly in older adults. Protein intake may benefit memory, perhaps by restraining task-related cortisol release.

Chronically high intake of saturated fats may impair memory, even in relatively young adults. In time, this is likely to contribute to cognitive decline and dementia, whereas in- take of n-3 fatty acids may be protective. There is also preliminary evidence that a reduction in energy intake may improve cognition, at least in older adults, possibly mediated by improved insulin sensitivity. Dietary prediction of cognition in adults is a key area for research, especially given our increasing lifespans and the cost to society of caring for our elderly population.

\section{ACKNOWLEDGEMENTS}

This review was prepared for the proceedings of the inaugural International Conference on Nutrition and Health, University of Latvia, Riga, 4-6 September, 2012. I am grateful to the conference organising committee (Chair: Professor Dr. Ida Jäkobsone) for the invitation to speak, and for funding my attendance.

\section{REFERENCES}

Alamy, M., Bengelloun, W. A. (2012). Malnutrition and brain development: An analysis of the effects of inadequate diet during different stages of life in rat. Neurosci. Biobehav. Rev., 36 (6), 1463-1480.

Anonymous (2011). Department of Health. Statistical release: Breastfeeding initiation and prevalence at 6 to 8 weeks - Quarter 2, 2011/12.

https://www.gov.uk/government/publications/breastfeeding-initiationand-prevalence-at-6-to-8-weeks-quarter-2-2011-12 (last accessed 15.07.2012).

Anonymous (2012). Global and regional trend estimates for child malnutrition. Global Database on Child Growth and Malnutrition. World Health Organisation. Retrieved June 15th, 2012, from

http://www.who.int/nutgrowthdb/estimates/en/index.html

Barberger-Gateau, P., Samieri, C., Feart, C., Plourde, M. (2011). Dietary omega 3 polyunsaturated fatty acids and Alzheimer's disease: Interaction with apolipoprotein E genotype. Curr. Alzheimer Res., 8 (5), 479-491.

Bellush, L. L., Wright, A. M., Walker, J. P., Kopchick, J., Colvin, R. A. (1996). Caloric restriction and spatial learning in old mice. Physiol. Behav., 60 (2), 541-547.

Benton, D., Maconie, A., Williams, C. (2007). The influence of the glycaemic load of breakfast on the behaviour of children in school. Physiol. Behav., 92 (4), 717-724.

Benton, D., Ruffin, M. P., Lassel, T., Nabb, S., Messaoudi, M., Vinoy, S., Desor, D., Lang, V. (2003). The delivery rate of dietary carbohydrates affects cognitive performance in both rats and humans. Psychopharmacol., 166 (1), 86-90.

Brown, L. A. (2012). Consumption of fish and omega-3 polyunsaturated fatty acids: Impact on cognitive function in older age and dementia. In: L. Riby, M. Smith, J. Foster (eds.). Nutrition and Mental Performance: A Lifespan Perspective (pp. 212-240). Basingstoke: Palgrave Macmillan.

Calder, P. C., Dangour, A. D., Diekman, C., Eilander, A., Koletzko, B., Meijer, G. W., Mozaffarian, D., Niinikoski, H., Osendarp, S. J., Pietinen, P., Schuit, J., Uauy, R. (2010). Essential fats for future health. Proceedings of the 9th Unilever Nutrition Symposium, 26-27 May 2010. Eur. J. Clin. Nutr., 64 Suppl 4, S1-13.

Cetin, I., Koletzko, B. (2008). Long-chain omega-3 fatty acid supply in pregnancy and lactation. Curr. Opin. Clin. Nutr. Metab. Care, 11 (3), 297-302.

Chugani, H. T. (1998). A critical period of brain development: Studies of cerebral glucose utilization with PET. Prev. Med., 27 (2), 184-188.

Conquer, J. A., Tierney, M. C., Zecevic, J., Bettger, W. J., Fisher, R. H. (2000). Fatty acid analysis of blood plasma of patients with Alzheimer's disease, other types of dementia, and cognitive impairment. Lipids, 35 (12), 1305-1312. 
Daniels, J. L., Longnecker, M. P., Rowland, A. S., Golding, J. (2004). Fish intake during pregnancy and early cognitive development of offspring. Epidemiol., 15 (4), 394-402.

de Rooij, S. R., Wouters, H., Yonker, J. E., Painter, R. C., Roseboom, T. J. (2010). Prenatal undernutrition and cognitive function in late adulthood. Proc. Natl. Acad. Sci. U.S.A, 107 (39), 16881-16886.

Engelhart, M. J., Geerlings, M. I., Ruitenberg, A., Van Swieten, J. C., Hofman, A., Witteman, J. C., Breteler, M. M. (2002). Diet and risk of dementia: Does fat matter?: The Rotterdam Study. IANA task force on nutrition and cognitive decline with aging. Neurology, 59 (12), 1915-1921.

Engle, P. L. \& Fernandez, P. D. (2010). INCAP studies of malnutrition and cognitive behavior. Food Nutr. Bull., 31 (1), 83-94.

Eskelinen, M. H., Ngandu, T., Helkala, E. L., Tuomilehto, J., Nissinen, A., Soininen, H., Kivipelto, M. (2008). Fat intake at midlife and cognitive impairment later in life: A population-based CAIDE study. Int. J. Geriat. Psychiat., 23 (7), 741-747.

Fischer, K., Colombani, P. C., Langhans, W., Wenk, C. (2001). Cognitive performance and its relationship with postprandial metabolic changes after ingestion of different macronutrients in the morning. Brit. J. Nutr., 85 (3), 393-405.

Fischer, K., Colombani, P. C., Langhans, W., Wenk, C. (2002). Carbohydrate to protein ratio in food and cognitive performance in the morning. Physiol. Behav., 75 (3), 411-423.

Forrester, T. E., Badaloo, A. V., Boyne, M. S., Osmond, C., Thompson, D., Green, C., Taylor-Bryan, C., Barnett, A., Soares-Wynter, S., Hanson, M. A., Beedle, A. S., Gluckman, P. D. (2012). Prenatal factors contribute to the emergence of kwashiorkor or marasmus in severe undernutrition: evidence for the predictive adaptation model. PLoS One., 7 (4), e35907. Epub 32012 Apr 35930.

Gibson, E. L. (2007). Carbohydrates and mental function: Feeding or impeding the brain? Nutr. Bull., 32 Suppl., 71-83.

Gibson, E. L., Barr, S. \& Jeanes, Y. M. (2011). Habitual fat intake predicts cognitive function in young women. Appetite, 57, 542.

Gibson, E. L., Green, M. W. (2002). Nutritional influences on cognitive function: Mechanisms of susceptibility. Nutr. Res. Rev., 15 (1), 169-206.

Grantham-McGregor, S., Cheung, Y. B., Cueto, S., Glewwe, P., Richter, L., Strupp, B. (2007). Developmental potential in the first 5 years for children in developing countries. Lancet, 369 (9555), 60-70.

Hansson, C., Haage, D., Taube, M., Egecioglu, E., Salome, N. \& Dickson, S. L. (2011). Central administration of ghrelin alters emotional responses in rats: behavioural, electrophysiological and molecular evidence. Neurosci., $180,201-211$.

Helland, I. B., Smith, L., Saarem, K., Saugstad, O. D., Drevon, C. A. (2003). Maternal supplementation with very-long-chain n-3 fatty acids during pregnancy and lactation augments children's IQ at 4 years of age. Pediatrics, 111 (1), e39-44

Heys, M., Jiang, C., Schooling, C. M., Zhang, W., Cheng, K. K., Lam, T. H., Leung, G. M. (2010). Is childhood meat eating associated with better later adulthood cognition in a developing population? Eur. J. Epidemiol., 25 (7), 507-516.

Hibbeln, J. R., Davis, J. M., Steer, C., Emmett, P., Rogers, I., Williams, C., Golding, J. (2007). Maternal seafood consumption in pregnancy and neurodevelopmental outcomes in childhood (ALSPAC study): An observational cohort study. Lancet, 369 (9561), 578-585.

Holme, A., MacArthur, C., Lancashire, R. (2010). The effects of breastfeeding on cognitive and neurological development of children at 9 years. Child Care Health Dev., 36 (4), 583-590.

Hoyland, A., Dye, L., Lawton, C. L. (2009). A systematic review of the effect of breakfast on the cognitive performance of children and adolescents. Nutr. Res. Rev., 22 (2), 220-243.
Hoyland, A., Lawton, C. L., Dye, L. (2008). Acute effects of macronutrient manipulations on cognitive test performance in healthy young adults: A systematic research review. Neurosci. Biobehav. Rev., 32 (1), 72-85.

Ingwersen, J., Defeyter, M. A., Kennedy, D. O., Wesnes, K. A., Scholey, A. B. (2007). A low glycaemic index breakfast cereal preferentially prevents children's cognitive performance from declining throughout the morning. Appetite, 49 (1), 240-244.

Jones, E. K., Sunram-Lea, S. I., Wesnes, K. A. (2012). Acute ingestion of different macronutrients differentially enhances aspects of memory and attention in healthy young adults. Biol. Psychol., 89 (2), 477-486.

Kalmijn, S. (2000). Fatty acid intake and the risk of dementia and cognitive decline: A review of clinical and epidemiological studies. J. Nutr. Health Aging, 4 (4), 202-207.

Kalmijn, S., van Boxtel, M. P., Ocke, M., Verschuren, W. M., Kromhout, D., Launer, L. J. (2004). Dietary intake of fatty acids and fish in relation to cognitive performance at middle age. Neurology, 62 (2), 275-280.

Kanoski, S. E., Davidson, T. L. (2011). Western diet consumption and cognitive impairment: Links to hippocampal dysfunction and obesity. Physiol. Behav., 103 (1), 59-68.

Kaplan, R. J., Greenwood, C. E., Winocur, G., Wolever, T. M. S. (2000). Cognitive performance is associated with glucose regulation in healthy elderly persons and can be enhanced with glucose and dietary carbohydrates. Amer. J. Clin. Nutr., 72 (3), 825-836.

Kaplan, R. J., Greenwood, C. E., Winocur, G., Wolever, T. M. S. (2001). Dietary protein, carbohydrate, and fat enhance memory performance in the healthy elderly. Amer. J. Clin. Nutr., 74 (5), 687-693.

Karr, J. E., Alexander, J. E., Winningham, R. G. (2011). Omega-3 polyunsaturated fatty acids and cognition throughout the lifespan: a review. Nutr. Neurosci., 14 (5), 216-225.

Keim, S. A., Daniels, J. L., Siega-Riz, A. M., Herring, A. H., Dole, N., Scheidt, P. C. (2012). Breastfeeding and long-chain polyunsaturated fatty acid intake in the first 4 post-natal months and infant cognitive development: An observational study. Matern. Child Nutr., 8 (4), 471-482.

Kirschbaum, C., Gonzalez Bono, E., Rohleder, N., Gessner, C., Pirke, K. M., Salvador, A., Hellhammer, D. H. (1997). Effects of fasting and glucose load on free cortisol responses to stress and nicotine. J. Clin. Endocrinol. Metab., 82 (4), 1101-1105.

Kramer, M. S., Aboud, F., Mironova, E., Vanilovich, I., Platt, R. W., Matush, L., Igumnov, S., Fombonne, E., Bogdanovich, N., Ducruet, T., Collet, J. P., Chalmers, B., Hodnett, E., Davidovsky, S., Skugarevsky, O., Trofimovich, O., Kozlova, L., Shapiro, S. (2008). Breastfeeding and child cognitive development: New evidence from a large randomized trial. Arch. Gen. Psychiatry, 65 (5), 578-584.

Kretsch, M. J., Green, M. W., Fong, A. K., Elliman, N. A., Johnson, H. L. (1997). Cognitive effects of a long-term weight reducing diet. Int. J. Obes., 21 (1), 14-21.

Krikorian, R., Shidler, M. D., Dangelo, K., Couch, S. C., Benoit, S. C., Clegg, D. J. (2012). Dietary ketosis enhances memory in mild cognitive impairment. Neurobiol. Aging, 33 (2), 425 e419-427.

Kuklina, E. V., Ramakrishnan, U., Stein, A. D., Barnhart, H. H., Martorell, R. (2004). Growth and diet quality are associated with the attainment of walking in rural Guatemalan infants. J. Nutr., 134 (12), 3296-3300.

Lamport, D. J., Hoyle, E., Lawton, C. L., Mansfield, M. W., Dye, L. (2011). Evidence for a second meal cognitive effect: Glycaemic responses to high and low glycaemic index evening meals are associated with cognition the following morning. Nutr. Neurosci., 14 (2), 66-71.

Lamport, D. J., Lawton, C. L., Mansfield, M. W., Dye, L. (2009). Impairments in glucose tolerance can have a negative impact on cognitive function: A systematic research review. Neurosci. Biobehav. Rev., 33 (3), 394-413.

Lattka, E., Koletzko, B., Zeilinger, S., Hibbeln, J. R., Klopp, N., Ring, S. M., Steer, C. D. (2013). Umbilical cord PUFA are determined by maternal and child fatty acid desaturase (FADS) genetic variants in the Avon Longitudi- 
nal Study of Parents and Children (ALSPAC). Brit. J. Nutr., 109 (7), $1196-1210$

Launer, L. J. (2005). The epidemiologic study of dementia: A life-long quest? Neurobiol. Aging, 26 (3), 335-340.

Lee, Y., Morrison, B. M., Li, Y., Lengacher, S., Farah, M. H., Hoffman, P. N., Liu, Y., Tsingalia, A., Jin, L., Zhang, P. W., Pellerin, L., Magistretti, P. J., Rothstein, J. D. (2012). Oligodendroglia metabolically support axons and contribute to neurodegeneration. Nature, 487 (7408), 443-448.

Lieberman, H. R., Spring, B. J., Garfield, G. S. (1986). The behavioral effects of food constituents: Strategies used in studies of amino acids, protein, carbohydrate and caffeine. Nutr. Rev., 44 Suppl, 61-70.

Mahoney, C. R., Taylor, H. A., Kanarek, R. B., Samuel, P. (2005). Effect of breakfast composition on cognitive processes in elementary school children. Physiol. Behav., 85 (5), 635-645.

Mann, J., Truswell, S. (2012). Essentials of Human Nutrition (4th ed.). Oxford: Oxford University Press. 640 pp.

Margolis, R. (2010). Childhood morbidity and health in early adulthood: Life course linkages in a high morbidity context. Adv. Life Course Res., 15 (4), $132-146$

Martins, I. J., Hone, E., Foster, J. K., Sunram-Lea, S. I., Gnjec, A., Fuller, S. J., Nolan, D., Gandy, S. E., Martins, R. N. (2006). Apolipoprotein E, cholesterol metabolism, diabetes, and the convergence of risk factors for Alzheimer's disease and cardiovascular disease. Mol. Psychiatry, 11 (8), $721-736$.

Mattson, M. P. (2010). The impact of dietary energy intake on cognitive aging. Front. Aging Neurosci., 2, 5

Meikle, A., Riby, L. M., Stollery, B. (2004). The impact of glucose ingestion and gluco-regulatory control on cognitive performance: A comparison of younger and middle aged adults. Hum. Psychopharmacol., 19 (8), $523-535$

Meldrum, S. J., Smith, M. A., Prescott, S. L., Hird, K., Simmer, K. (2011). Achieving definitive results in long-chain polyunsaturated fatty acid supplementation trials of term infants: Factors for consideration. Nutr. Rev., 69 (4), 205-214.

Messier, C., Awad-Shimoon, N., Gagnon, M., Desrochers, A., Tsiakas, M. (2011). Glucose regulation is associated with cognitive performance in young nondiabetic adults. Behav. Brain Res., 222 (1), 81-88.

Messier, C., Tsiakas, M., Gagnon, M., Desrochers, A., Awad, N. (2003). Effect of age and glucoregulation on cognitive performance. Neurobiol. Aging, 24 (7), 985-1003.

Micha, R., Nelson, M. (2011). Glycemic index and glycemic load used in combination to characterize metabolic responses of mixed meals in healthy lean young adults. J. Amer. Coll. Nutr., 30 (2), 113-125.

Micha, R., Rogers, P. J., Nelson, M. (2010). The glycaemic potency of breakfast and cognitive function in school children. Eur. J. Clin. Nutr., 64 (9), 948-957.

Micha, R., Rogers, P. J. \& Nelson, M. (2011). Glycaemic index and glycaemic load of breakfast predict cognitive function and mood in school children: A randomised controlled trial. Brit. J. Nutr., 106 (10), $1552-1561$.

Morgan, J., Taylor, A., Fewtrell, M. (2004). Meat consumption is positively associated with psychomotor outcome in children up to 24 months of age. J. Pediatr. Gastroenterol. Nutr., 39 (5), 493-498.

Morris, M. C., Evans, D. A., Bienias, J. L., Tangney, C. C., Wilson, R. S. (2004). Dietary fat intake and 6-year cognitive change in an older biracial community population. Neurol., 62 (9), 1573-1579.

Nabb, S. L., Benton, D. (2006). The effect of the interaction between glucose tolerance and breakfasts varying in carbohydrate and fibre on mood and cognition. Nutr. Neurosci., 9 (3-4), 161-168.

Naqvi, A. Z., Harty, B., Mukamal, K. J., Stoddard, A. M., Vitolins, M., Dunn, J. E. (2011). Monounsaturated, trans, and saturated fatty acids and cognitive decline in women. J. Amer. Geriat. Soc., 59 (5), 837-843.
Northstone, K., Joinson, C., Emmett, P., Ness, A., Paus, T. (2012). Are dietary patterns in childhood associated with IQ at 8 years of age? A population-based cohort study. J. Epidemiol. Comm. Health, 66 (7), 624-628.

Okereke, O. I., Rosner, B. A., Kim, D. H., Kang, J. H., Cook, N. R., Manson, J. E., Buring, J. E., Willett, W. C., Grodstein, F. (2012). Dietary fat types and 4-year cognitive change in community-dwelling older women. Ann. Neurol., 72 (1), 124-134.

Owen, L., Scholey, A. B., Finnegan, Y., Hu, H., Sunram-Lea, S. I. (2012). The effect of glucose dose and fasting interval on cognitive function: A double-blind, placebo-controlled, six-way crossover study. Psychopharmacol., 220 (3), 577-589.

Papanikolaou, Y., Palmer, H., Binns, M. A., Jenkins, D. J., Greenwood, C. E. (2006). Better cognitive performance following a low-glycaemic-index compared with a high-glycaemic-index carbohydrate meal in adults with type 2 diabetes. Diabetologia, 49 (5), 855-862.

Peters, A., Schweiger, U., Pellerin, L., Hubold, C., Oltmanns, K. M., Conrad, M., Schultes, B., Born, J., Fehm, H. L. (2004). The selfish brain: Competition for energy resources. Neurosci. Biobehav. Rev., 28 (2), 143-180.

Pollitt, E., Gorman, K. S., Engle, P. L., Rivera, J. A., Martorell, R. (1995). Nutrition in early life and the fulfillment of intellectual potential. J. Nutr., 125 (4 Suppl), 1111S-1118S

Riby, L. M., McMurtrie, H., Smallwood, J., Ballantyne, C., Meikle, A., Smith, E. (2006). The facilitative effects of glucose ingestion on memory retrieval in younger and older adults: Is task difficulty or task domain critical? Brit. J.Nutr., 95 (2), 414-420.

Riby, L. M., Meikle, A., Glover, C. (2004). The effects of age, glucose ingestion and gluco-regulatory control on episodic memory. Age Ageing, 33 (5), 483-487.

Rochon, J., Bales, C. W., Ravussin, E., Redman, L. M., Holloszy, J. O., Racette, S. B., Roberts, S. B., Das, S. K., Romashkan, S., Galan, K. M., Hadley, E. C., Kraus, W. E. (2011). Design and conduct of the CALERIE study: Comprehensive assessment of the long-term effects of reducing intake of energy. J. Gerontol. A Biol. Sci. Med. Sci., 66 (1), 97-108.

Rogers, P. J., Lloyd, H. M. (1994). Nutrition and mental performance. Proc. Nutr. Soc., 53(2), 443-456.

Singh-Manoux, A., Kivimaki, M., Glymour, M. M., Elbaz, A., Berr, C., Ebmeier, K. P., Ferrie, J. E., Dugravot, A. (2012). Timing of onset of cognitive decline: Results from Whitehall II prospective cohort study. Brit. Med. J., 344, d7622.

Smith, A., Leekam, S., Ralph, A., McNeill, G. (1988). The influence of meal composition on post-lunch changes in performance efficiency and mood. Appetite, 10 (3), 195-203.

Smith, M. A., Foster, J. K. (2008). The impact of a high versus a low glycaemic index breakfast cereal meal on verbal episodic memory in healthy adolescents. Nutr. Neurosci., 11 (5), 219-227.

Smith, M. A., Riby, L. M., Eekelen, J. A., Foster, J. K. (2011). Glucose enhancement of human memory: A comprehensive research review of the glucose memory facilitation effect. Neurosci. Biobehav. Rev., 35 (3), 770-783.

Steer, C. D., Davey Smith, G., Emmett, P. M., Hibbeln, J. R., Golding, J. (2010). FADS2 polymorphisms modify the effect of breastfeeding on child IQ. PLoS One, 5(7), e11570.

Stranahan, A. M., Mattson, M. P. (2011). Bidirectional metabolic regulation of neurocognitive function. Neurobiol. Learn. Mem., 96 (4), 507-516.

Sünram-Lea, S. I., Owen, L., Finnegan, Y., Hu, H. (2011). Dose-response investigation into glucose facilitation of memory performance and mood in healthy young adults. J. Psychopharmacol., 25 (8), 1076-1087.

Sydenham, E., Dangour, A. D., Lim, W.-S. (2012). Omega-3 fatty acid for the prevention of cognitive decline and dementia. Cochrane Database Syst. Rev, No. 6, CD005379. 
Symmonds, M., Emmanuel, J. J., Drew, M. E., Batterham, R. L., Dolan, R. J. (2010). Metabolic state alters economic decision making under risk in humans. PLoS One, 5(6), e11090.

van de Rest, O., Geleijnse, J. M., Kok, F. J., van Staveren, W. A., Dullemeijer, C., Olderikkert, M. G., Beekman, A. T., de Groot, C. P. (2008). Effect of fish oil on cognitive performance in older subjects: a randomized, controlled trial. Neurology, 71 (6), 430-438.

Vanhanen, M., Koivisto, K., Kuusisto, J., Mykkanen, L., Helkala, E. L., Hanninen, T., Riekkinen, P., Sr., Soininen, H., Laakso, M. (1998). Cognitive function in an elderly population with persistent impaired glucose tolerance. Diab. Care, 21 (3), 398-402.

Received 16 December 2012
Victora, C. G., Adair, L., Fall, C., Hallal, P. C., Martorell, R., Richter, L., Sachdev, H. S. (2008). Maternal and child undernutrition: Consequences for adult health and human capital. Lancet, 371 (9609), 340-357.

Wesnes, K. A., Pincock, C., Richardson, D., Helm, G., Hails, S. (2003). Breakfast reduces declines in attention and memory over the morning in schoolchildren. Appetite, 41 (3), 329-331.

Witte, A. V., Fobker, M., Gellner, R., Knecht, S., Floel, A. (2009). Caloric restriction improves memory in elderly humans. Proc. Natl. Acad. Sci. U. S. A., 106 (4), 1255-1260.

Zhang, Y., Li, N., Yang, Z. (2010). Perinatal food restriction impaired spatial learning and memory behavior and decreased the density of nitric oxide synthase neurons in the hippocampus of adult male rat offspring. Toxicol. Lett., 193 (2), 167-172.

\section{ENERG̣IJAS UN BARĪBAS VIELU UZN̦EMŠANAS IETEKME UZ KOGNITĪVAJĀM FUNKCIJĀM DZĪVES LAIKĀ}

Šajā rakstā tiek apskatīta gan pārmērīga, gan nepietiekama barības vielu un enerğijas uzņemšana cilvēka dzīves laikā, ietverot grūtniecības periodu, zīdaina vecumu, bērnību un pieaugušā vecumā. Hipotalams ir jutīgs pret olbaltumvielu un enerğijas nepietiekamu uzņemšanu gan prenatālajā periodā, gan agrā bērnībā, izraisot traucētu neiroğenēzi, atminu un telpisko uztveri, palielina impulsivitāti, kas atspoguḷojas neiromediatoru sistēmā. Turpretim, pastiprināta olbaltumvielu uzṇemšana tỉek saistīta ar uzlabotu motoro attīstîbu, bet ne ar garīgo attīstību. Tomēr krūts barošana labvēelīgi ietekmē garīgo attīstību. Ir pierādīts, ka olbaltumvielu un enerǵ̉ijas papildus lietošana pirms un pēc dzimšanas uzlabo kognitīvās funkcijas vēlāk bērnībā, bet pieaugušo vecumā tās uzlabo tikai enerğija. Omega-3 taukskābju lietošanai grūtniecības laikā varētu būt ilgstoša iedarbība uz bērnu kognitīvajām spējām, lai gan jāatzīmē, ka pārmērīga to uzņemšana, sevišķi grūtniecības laikā, var izraisīt vielmaiņas traucējumus, kas kognitīvos traucējumus var palielināt. Skolas vecuma bērniem, kas nesaņem pietiekamu uzturu, brokastis var uzlabot kognitīvos rādītājus. Bērniem, kas saṇem pietiekamu uzturu, brokastu ievērošanas ietekme nav tik skaidra, tomēr brokastis ar samazinātu glikēmisko indeksu, var labvēlīgi ietekmēt atmiņu, savukārt brokastis ar augstu glikēmisko indeksu var palielināt modrību. Pieaugušā vecumā mērena og̣̣hidrātu uzṇemšana var labvēlīgi ietekmēt kognitīvās funkcijas ar nosacījumu, ka glikoregulācija ir optimāla un atbilstoša normai. Olbaltumvielu uzņemšana var labvēlīgi ietekmēt atmiņu. Palielinoties senioru vecuma iedzīvotāju skaitam, diētas ietekme uz kognitīvajām spējām pieaugušā vecumā ir viena no galvenajām pētījuma jomām. 
Mini Review

\title{
HEALTHY ALTERNATIVES OF THE MEDITERRANEAN DIET IN LATVIA
}

\author{
Andrejs Ërglis*, Iveta Mintāle*, and Anete Dinne** \\ * Latvian Centre of Cardiology, Pauls Stradinš Clinical University Hospital, Rīga, LV-1002, LATVIA; \\ iveta.mintale@gmail.com \\ ** University of Gastronomic Sciences, Bra, 12042, ITALY \\ Contributed by Andrejs Ërglis
}

The milestone of illness prophylaxis is a healthy lifestyle, which is composed of regular physical activity and a healthy diet. Following the Mediterranean diet for two years has been shown to have significant decrease in cardiovascular death by $9 \%$, cancer by $6 \%$, Parkinson's and Alzheimer's by $13 \%$. This diet helps to control the perfect weight, improves lipid profile and diminishes the risk of diabetes. The Mediterranean diet consists of extra virgin olive oil, vegetables and fruit, wholegrain products, legumes, nuts and seeds, dairy products (with no other sources of fat other than milk fat), fish (at least twice a week), poultry, veal, pork in limited amount, and eggs 0-4 per week. It is possible to adapt this kind of alimentation in the Nordic countries, but it is important to find products grown there with similar nutritional characteristics. Nowadays, fresh fruits and vegetables can be bought all year round, but it is essential to use seasonal products. In Latvia, at this point, attention should be brought to more efficient storage and conservation. We have a vast variety of legumes and cereals. The selection of dairy products should be bigger and of higher quality, because you rarely see local cheeses made in an artisanal manner at the marketplaces. There is good availability of saltwater fish in the cities, but in the countryside the only fish one can buy is salted and smoked, having exaggeratedly high amounts of salt. Consumption of meat and its products should be lowered to a maximum of three times per week. A special attention should be brought to game (such as deer), because it contains low levels of cholesterol and higher amounts of unsaturated fatty acids due to the alimentation of wild herbs. Unfortunately, there is a lack of good quality oil in Latvia, because no other product can be compared to the nutritious components of extra virgin olive oil and its effects on cardiovascular health. Consumption of high amounts of olive oil decreases the incidence of stroke by $41 \%$. Education should be conducted widely to promote tradition and gastronomic heritage as a cultural aspect. Healthy lifestyle has to be visible to everyone at any time as a constant reminder of its importance.

Key words: cardiovascular disease prevention, healthy lifestyle, Mediterranean diet.

\section{INTRODUCTION}

It is known worldwide nowadays that the most frequent cause of death is cardiovascular disease (CVD); about 4.3 million deaths in Europe annually (de Lorgeril et al., 1999). In Latvia the incidence is among the highest in Europe, for men in particular, being more than 130 deaths in 100000 people and 20 to 50 for women (Anonymous, 2006). Many uncontrollable factors influence the formation of CVD, such as age, genetics, race, but the primary cause of CVD is unhealthy lifestyle, such as bad diet, visceral obesity, smoking, little or no physical activity, which are all modifiable aspects for preventing the risk.

\section{HEALTH BENEFITS AND CULTURAL IMPORTANCE OF THE MEDITERRANEAN DIET}

After industrialisation, many refined foods have become available, industrial farming with substances of chemical synthesis has spread widely and physical activity for people has decreased significantly with the availability of transportation and sedentary work, encouraging an unhealthy lifestyle. People often complain about lack of time to prepare meals at home, meaning that sausages, sandwiches or frozen dumplings are their first choice. The problem here is not so much the little free time, but the insignificant value given to food. Considering eating as something important and cultural makes you organise your daily life more efficiently in order to be able to dedicate time for a meal. The Mediterranean way of life is a great example where food still today has great importance.

Since 2010, the Mediterranean diet has been inscribed for the UNESCO Representative List of the Intangible Cultural Heritage of Humanity. Based on century old traditions of Spain, Italy, Morocco and Greece, it has become very popular in the whole world and has been considered as one of the healthiest diets to follow. 
Latvia is one of the few countries left in Europe that still has a good concentration of small non-intensive farms, large areas covered with forests, many rivers and lakes, and the longest part of the boarder has access to the sea. We have a great potential for obtaining high quality products. This fact confirms the possibility to adapt a diet as healthy as the Mediterranean also in Latvia.

The Mediterranean diet "is a set of traditional practices, knowledge and skills passed on from generation to generation and providing a sense of belonging and continuity to the concerned communities." (UNESCO)

The climate of the Mediterranean Sea is very favourable for cultivation of grains, vegetables, fruit and most importantly the olive tree. It is essential to keep in mind that when we talk about the Mediterranean diet, we must consider not only what foodstuffs are used. It is a whole culture of techniques of production, conservation, preservation and conviviality, meaning time, place and people whom to share a meal with (Fundación Dieta Mediterránea). A part of the diet still remains touched only a little by the industrialisation.

As mentioned before, the Mediterranean diet is based mainly on wholegrain products (bread, pasta, couscous), extra virgin olive oil, vegetables and fruit. Fish and meat are consumed in a moderate amount and meals are accompanied by wine or herbal infusions. A lot of condiments and spices are used, which means that salt is added in limited quantities, because spices exalt the salty taste.

People tend to cook a lot at home even now when everything is readily available at the supermarket, so refined foods and carbonated soft drinks are not the first choice.

FOOD CATEGORIES LOOKED AT CLOSER. MEDITERRANEAN DIET AND LATVIAN ALTERNATIVES

Wholegrain products - rich in fibre, improve digestion and have a low glycemic index. Bread is mostly made from unrefined stone-milled flour. Pasta in Italy is consumed "al dente", digested slower than fully cooked pasta, letting the glucose levels in blood rise slowly. Rice is more healthy when consumed unrefined. Complex carbohydrates are the major part of the Mediterranean diet. Wholegrain category of foodstuffs is essential for patients with diabetes.

Cereals - wheat, rye and oats historically are the main cultivated plants in Latvia, so this category of diet is fully available locally.

Fruit and vegetables - full of vitamins, fiber, and phytonutrients. High consumption of tomatoes containing lycopene has been proved a good antioxidant. Cruciferous plants, like cabbages, broccoli, horseradish and other vegetables containing sulfurous compounds are anti-cancerogenic and some can be conserved for wintertime. Consumption of different vegetables and fruits should be a part of each meal.
Since the summer period is very short in Latvia, vegetable preserves can be made. More care should be brought to conservation of fresh produce. It is essential not to forget that salt is necessary only in the right amount for conservation.

Latvia has a wide variety of berries, which are excellent for summertime, like blackberries, cranberries, wild strawberries and raspberries. For winter, apples are a good choice if conserved properly. People who have a garden very often throw away the fruit that they are not able to consume until the end of summer. Instead of wasting a perfectly good product, juices and jams with low sugar content can be made, with low $\mathrm{pH}$ to keep them well preserved.

Greens and legumes. In the Mediterranean region a lot of salad is consumed, which contains bitter compounds of different chemical compositions that work as nutraceuticals. Chicory is a good example of bitter greens. The bigger the variety of green leafed plants consumed, the more the chance to consume enough microelements to improve one's health. Rockets, that can be bought at the market or grown in one's garden, have a tingling property that is due to an anti-cancerogenic compound. Spinach is a good source of iron.

Sometimes when a Latvian is asked, how often he consumes legumes, the response is: "At Christmas as the traditional dish of marble peas with bacon." Since one's daily diet should consist of $50 \%$ carbohydrates, legumes are the perfect source to substitute potatoes or rice. The variety is big - peas, chickpeas, different kinds of lentils, different kinds of beans.

Legumes are rich in soluble and insoluble fibre, they help digestion and are great for intestinal microbiota.

Lipids. High consumption of extra virgin olive oil rich in monounsaturated fatty acids and tocopherol fights free radicals and raises low-density cholesterol in blood. Little or no consumption of butter and no consumption of margarine is needed, as is sweet pastry and bread usually made with olive oil or butter, not margarine or tropical fruit oils.

There are many possible choices for oils in Latvia, such as linseed, sunflower, rapeseed oil, but most of them are refined, meaning that all the possible beneficial vitamins are long gone, but the high quality ones are expensive. It has been shown in many studies that extra virgin olive oil is the best, so this is one of the few products that only with difficulty can be replaced with anything else. Cold pressed extra virgin olive oil should be used for cooking and for fresh consumption, not plain olive oil that contains refined oil.

Dairy. Low consumption of milk and fatty cheese, moderate consumption of yoghurt and other fermented milk products is recommended.

Yoghurt in Greece is a very important part of breakfast served with honey, nuts and fruit making it a wholesome breakfast. 
In Latvia people consume fatty milk products - sour cream, full fat cheese, butter, cottage cheese.

Sour cream is used widely, even in soups. Kefir, however, is an excellent fermented milk product even for lactose intolerant people, because during fermentation all the lactose is consumed by bacteria and it has a significantly lower fat content than sour cream.

Spices and herbs. Adding more spices and herbs to a dish, like mint, basil, thyme, rosemary, makes it tastier and reduces the need for excessive salt. They also contain phytonutrients that can improve one's health. Chili, for example, contains capsaicin that has been seen to reduce inflammation. Rosemary is exceptionally rich in salicylic acid, which is the active compound of aspirin. Many patients suffering from heart disease are prescribed aspirin as an anti-inflammatory drug. Garlic and onions contain sulfurous compounds that lower blood pressure.

The above mentioned plants are used a lot in Latvia for any preparation.

Salt. Salt is used while cooking to season food, as elsewhere in the world, but the Mediterranean people consume less processed foods full of hidden salt that is the main worry for high blood pressure. The addition of pepper or chili makes the taste receptors more sensitive to salty taste, therefore less salt is needed.

Unfortunately, consumption of processed foods in Latvia is quite high, meaning that consumption of excessive salt is inevitable. One in ten males in Latvia add salt to their dish even before tasting it.

Wine. Moderate amounts of red wine is a good source of polyphenols (resveratrol). These antioxidants are found in the skin of red grapes, so white wine does not have the same characteristics. As the French paradox tells us, red wine is good for the cardiovascular system, but it is important to remember that wine is used during healthy meals not in excessive doses - products taken out of their context may not have the same desirable effect.

It is difficult to substitute wine with any other product available in Latvia, even though there are some people who are trying to produce it in cooler climates. White grapes definitely grow better more in the north than red, but polyphenols are found only in the skin of red grapes.

High quality beer could have some similar benefits as wine because of the presence of hop which has bitter compounds that work as an antibacterial. "High quality" should be underlined, meaning non-industrial beer with no extra additives and preservatives. No beer made from corn. Always keep in mind, that consumption of alcohol is not to be encouraged and should be done in moderation.

Fish. In Latvia very little fish is consumed, even though there is a variety of salt and sweet water species.
There is good availability of saltwater fish in the cities, but in the countryside the only fish one can buy is salted and smoked, having inappropriately high amounts of salt (Anonymous, 2008).

In the Mediterranean diet the small fish such as anchovies and sardines are widely used. Many small fish are also available in Latvia and they can substitute them. They have a short maturation period, so they are more sustainable than tuna and salmon, and they are very rich in Omega-3 fatty acids, one of the main reasons for fish consumption. Since they have a short life cycle, they are less polluted with heavy metals.

Sweet water fish is not as rich in Omega-3 as salt water fish; this depends mostly on the habitat it has lived in and on its alimentation. Still it is a good protein source as an alternative to meat.

Meat. Consumption of meat and its products should be lowered to a maximum of three times per week.

Latvians consume too much pork in the form of processed meat. The positive aspect of meat consumption is that recently game is becoming more and more popular.

Game is shown to be very low in fat and cholesterol, high in iron and unsaturated fatty acids, making it a great healthier choice. The composition of meat depends on the animal's diet. Wild animals feed on everything they find in the forests, which could be anything from lichens to berries. This is the reason for the high level of unsaturated fatty acids, if compared to a farm animal fed with corn silage and soy. Physical activity for animals living in the wild increases the amount of iron present in the meat.

It is true that game usually has to be cooked longer than farm-grown livestock, but a lot of prepared products are available, like cured venison. It is essential to keep in mind that when eating cured or smoked meats with bread it should not be accompanied with butter, because it has already enough saturated fatty acids. Wild boar is also a wonderful choice, even though its preparation might be long, but if made in the oven, it occupies no work at all.

In the Mediterranean diet a lot of preparations are composed of long sautéing or oven roasting on a low heat. Grilling should be kept to minimum because of the possible cancerogens that might form when fat is burned on open fire.

Dried fruit and seeds - full of unsaturated fatty acids. A lot of different types of edible seeds, nuts and dried fruit can be found in Latvia. Since the vegetal period is quite short, this sort of snack is great if fresh fruit is not available. Care must be taken with consumption of dried sweet fruit because they are full of sugar.

Non-alcoholic drinks. In the Mediterranean countries a lot of herbal infusions are prepared, especially after dinner to help the digestion. There are a lot of different plants that our great-grandmothers once used to collect every Midsummer 
Night's Eve (Jāņu nakts), such as peppermint, chamomile, nettle, cowslip and many others. Not only helpful after a hearty meal, they can also improve weight control.

Dietary supplements. In cases when not enough micronutrients can be ingested, there is always the possibility for dietary supplements. Many studies have been conducted on resveratrol, lycopene and others, but still we do not have enough evidence for benefits for using dietary supplements. It is always best to take in nutrients with a healthy varied diet, also because nutrients work in synergy.

\section{LATVIAN EATING HABITS}

Latvians are very fond of fatty foods and usually their diet is quite unbalanced. Most people consume boiled sausages that are filled with little meat and many additives. Anything fatty like cheese or meat is consumed on bread with a layer of butter or margarine. The intake of vegetables is quite poor, mostly potatoes with meat or fish dishes, fresh salad with the typical ingredients, like tomato, lettuce and cucumber, all covered with sour cream. Most of the fat and protein consumed are from the animal kingdom. People cook a lot with full fat cream that can be substituted with sauces based on vegetable stock.

Only $49 \%$ of Latvians consider their daily food as wholesome, $39 \%$ found it unhealthy.

Men in general have worse eating habits - low vegetable, whole grain products consumption (Anonymous, 2006).

For a nation living at the sea, it is shocking that only $1 \%$ consumes fish, about 2-4 times per week (Anonymous, 2008). Individuals, who consume fish very often, prefer it smoked which usually contains large amounts of salt.

As mentioned before, Latvia has a lot of small family farms. Unfortunately, the legislation concerning food production is very severe and the subsidies given are not sufficient, making the end product very expensive, if compared to the industrial one. Good quality meat cattle is raised for export only and meat available in the market is of lower quality. White bread at a supermarket does not have less than seven ingredients, when all it needs is water, flour, yeast and salt.

The consumer is not educated enough or willing to read the label to make sure it is healthy. This means that a producer will use any raw material to make production cheaper, since no one is there to protest. We have to keep in mind that, with the production technology, this is the first time in human history that food costs are this low for the way we live. People are willing to choose quantity over quality.

A lot of work should be done on the way supermarkets and markets work to introduce other healthy, local, seasonal products. It is a long process to make an evolution in the market and it is not a one person's job, but still there are products available even now consumed in low quantities that should be revalued.
People should be more educated and more responsible of their diet, intended as eating habits, and lifestyle.

Following the Mediterranean diet for two years has been shown to have a significant decrease in deaths concerning cardiovascular disease by $9 \%$, incidence of cancer by $6 \%$, Parkinson's and Alzheimer's by $13 \%$. This is because a correct diet helps control the perfect weight and improves lipid profile. The risk of diabetes diminishes because of the decrease of sugar metabolism disturbances, and there is an important fall of inflammation and tumour markers (Sofi et al., 2008). Usage of high amounts of extra virgin olive oil decreases the incidence of stroke by $41 \%$ (Anonymous, 2011).

It is not only what you eat that is important in the Mediterranean diet, but everything around it and how the dish came to your table. In Latvia there is a possibility to adapt this kind of lifestyle in a certain way. Old traditions should be brought back to life with the use of forgotten products, cooking and preservation of food. More attention should be brought to education of children in schools, kinder gardens, patients in the doctor's office. Good quality healthy food should be considered as pleasure.

\section{CONCLUSIONS}

Although cardiologists can tell very much about the diet failure of their CVD patients, we need a further nutritionbased research to move us closer to our long-sought goal of developing and implementing dietary strategies that have a major beneficial impact on CVD risk.

A lot of changes should be done in mass production and distribution of food in Latvia, but without a doubt there are products available to have a wholesome diet at any age. The key factor is variety and seasonality.

Education should be done widely to promote tradition and gastronomic heritage as a cultural aspect, as it is thought of in the Mediterranean countries. Healthy lifestyle has to be visible to everyone at any time as a constant reminder of its importance, meaning that teachers have to set an example to children, the doctors to their patients and so on. No credibility of a good diet can come from an obese doctor talking about healthy eating.

If you feel good about your lifestyle yourself, you are more likely to share it with others!

\section{REFERENCES}

Anonymous (2006). Health Compulsory Insurance State Agency. News No. 15. http://www.vmnvd.gov.lv/uploads/files/4fd09434cda66.pdf (last accessed 6 October 2013).

Anonymous (2008). European cardiovascular disease statistics 2008. http://www.bhf.org.uk/publications/view-publication.aspx?ps=1001443 (last accessed 6 October 2013).

Anonymous (2010). Mediterranean diet. UNESCO. http://www.unesco.org/culture/ich/en/RL/00394. 
Anonymous (2011). Medscape Medical News, WebMD.

Appendino, G., Banfi, L. (2011). Molecular diversity and natural products. Mol. Diversity, 15 (2), 291-292.

de Lorgeril, M., Salen, P., Martin, J. L., Monjaud, I., Delaye, J., Mamelle, N. (1999). Mediterranean diet, traditional risk factors, and the rate of cardiovascular complications after myocardial infarction: Final report of the Lyon Diet Heart Study. Circulation, 99 (6), 779-785.

Dumpe, L. (2009). Latviě̌u tautas èdieni. Latvijas vēstures institūta etnogrāfisko ekspedīciju materiāli [Latvian National Cuisine. Materials of Ethnographic Expeditions of the Institute of Latvian History]. Riga: Zinātne. 287 lpp. (in Latvian).

Received 24 September 2012
Erglis, A., Kalvelis. A., Lejnieks, A., Dzerve. V., Latkovskis, G., Mintale, I., Zakke, I., Rasa, I. (2007). CVD Prevention Guidelines. Rīga: Latvijas Kardiologu biedrība.

Fundación Dieta Mediterrịnea. La pirịmide de la Dieta Mediterrịnea se actualiza para adaptarse al estilo de vida actual.

http://dietamediterranea.com/piramide-dietamediterranea/.

McGee, H. (2004). On Food and Cooking: The Science and Lore of the Kitchen. Revised edition. New York: First Scribner. 884 pp. (at pp. 37-38; 555-556)

Pudule, I., Villerusa, A., Grinberga, D., Velika, B., Tilgale, N., Dzērve, V., Rutks, A., Prättälä, R. (2008). Health Behaviour among Latvian Adult Population, 2008, I-III; pp.1-153.

Sofi, F., Cesari, F., Abbate, R., Gensini, G. F., Casini, A. (2008). Adherence to Mediterranean diet and health status: meta-analysis. British Medical Journal, 337, a1344.

\section{VESELĪGAS ALTERNATĪVAS VIDUSJŪRAS DIĒTAI LATVIJĀ}

Slimību profilakses pamatā ir veselīgs dzīvesveids, ko veido regulāra fiziskā aktivitāte un veselīga diēta. L̦oti svarīgi ir balansēt uzṇemto kaloriju daudzumu ar adekvātām fiziskām aktivitātēm. Pēdējo gadu laikā tieši Vidusjūras diēta tiek uzskatīta par visveselīgāko dzīvesveidu sirds un asinsvadu slimību profilaksē. Sekojot Vidusjūras diētai divu gadu garumā, ir novērota mirstības mazināšanās no kardiovaskulārajām saslimšanām par $9 \%$, no vēža par $6 \%$, no Parkinsona un Alcheimera slimībām — par 13\%. Pozitīvie rezultāti ir skaidrojami ar to, ka veselīga diēta palīdz kontrolēt svaru un uzlabot lipīdu profilu. Samazinās arī risks saslimt ar cukura diabētu, jo uzlabojas glikozes vielmaiṇa. Ievērojami samazinās iekaisuma un audzēja markiieri. Vidusjūras diētu definē produktu grupas: auksti spiesta olīvellıa - svarīgs mononepiesātināto taukskābju avots; daudz aug̣̣u un dārzeṇu; pilngraudu produkti, pākšaugi, rieksti un sēklas; pazemināta tauku satura piena produkti (bez pievienotiem augu taukiem); zivis (vismaz divas reizes nedēlāa); putnu gaḷa, liellopa gal̦a un cūkgaḷa nelielos daudzumos; olas — 0-4 nedēḷā. Šāda veida uzturu ir iespējams pielāgot arī ziemeḷvalstīs, atrodot produktus ar līdzīgu uzturvērtību. L,oti svarīgi ir pievērst uzmanību svaigo produktu sezonalitātei. Tā kā Latvijā ir ḷoti īss veǵetatīvais periods, nepieciešams ir uzlabot konservēšanas un uzglabāšanas metodes ziemas mēnešiem. Ziemeḷos ir pieejama liela graudaugu un pākšaugu izvēle. Jāpievērš lielāka uzmanība piena produktu kvalitātei un jāveicina zemnieku ražoto produktu patērin̄š, kā arī jāsamazina rūpnieciski ražotu produktu patēriņšs. Gaḷas produktu īpatsvars diētā būtu jāsamazina līdz trīs reizēm nedēḷā, dodot priekšroku meža dzīvnieku gaḷai, kas ir bagāta ar nepiesātinātām taukskābēm un dzelzi, bet tajā ir zemāks piesātināto tauku saturs. Latvijā diemžēl netiek ražotas augstas kvalitātes augu ellıas. Auksti spiestas olīveḷlas (extra virgin) uzturvielas ir grūti salīdzināmas un aizvietojamas ar citām, tās ievērojami spēj uzlabot kardiovaskulāro veselību. Augsts šīs olīveḷlas patēriņš spēj samazināt insulta risku līdz pat $41 \%$. 


\title{
FEEDING INFANTS WITH COW'S MILK AND SOY ALLERGY: SOCIAL AND ECONOMIC ASPECTS OF EFFICACY
}

\author{
Irēna Putnina* Silvija Remberga**, and Ingrīda Rumba-Rozenfelde** \\ * Faculty of Biology, University of Latvia, Kronvalda bulv. 4, LV-1586, Rīga, LATVIA \\ ** Faculty of Medicine, University of Latvia, Raiṇa bulv. 19, LV-1586, Rīga, LATVIA
}

Contributed by Ingrïda Rumba-Rozenfelde

\begin{abstract}
Allergy to cow's milk protein and/or soy is common among allergic diseases in infants. They appear at an early infant stage and remain important in clinical practice from one up to three years. According to clinical research, cow's milk allergy affects about 1.9-4.9\% of babies and infants, respectively, and in addition some of them also suffer from soy protein allergy. Dietary prevention of allergic protein by its elimination in food is a significant part of treatment, and allows adequate development of babies and restricts the risk of progressive allergic diseases. Securing exclusive breastfeeding is one of the basic principles in successful therapy treatment. However, there are cases when breastfeeding does not prevent the development of cross milk protein allergy. Only adequate special feeding formulas can provide both energy needs and sufficient quantity of proteins (8.9-11.5\%) in food when breastfeeding is not possible. Knowledge of effective compensation mechanisms become apparent by analysing the situation in Europe and USA in the area of different available feeding formulas using both the medical insurance system and randomised formula providing tolerance of the mixture at about $90-95 \%$. The goal of research was to determine the correlation between the availability of a special mixture, parental adherence and treatment outcomes. Applying special formulas is a routine part of treatment, and there is no doubt about its efficacy. No compensation mechanisms exist in present-day Latvia, and the current complicated economic situation in Latvia reduces the ability of parents to choose and buy appropriate formula food. Therefore, a substantial part of therapy treatment is unavailable to infants. Dietary prevention of allergic diseases in infants and small children in Latvia needs special consideration also because of poor knowledge of parents regarding the real situation.
\end{abstract}

Key words: cow's milk protein allergy, soy allergy, breastfeeding, special formulas, reimbursement system.

\section{INTRODUCTION}

Cow's milk protein and/or soy allergies are common in infants. They appear at an early infant stage and remain important in clinical practice from one up to three years. This problem has arisen through a historical tradition to diversify infant feeding with cow's milk. One of the causes for this rarely observed allergy was the rapid increase in the use of artificial feeding formulas in the $20^{\text {th }}$ century, accompanied by aggressive marketing policy of their manufacturers. As a result, the importance of breastfeeding was compromised and the percentage of breast-fed infants fell dramatically. For example, in the 1970s in the USA, about $75 \%$ of babies were formula fed. From this time, the incidence of allergic disease amongst early babies stages grew noticeably. Now two tendencies have become urgent: dietary intervention for primary allergy prevention and providing appropriate feeding in the cases of allergic manifestation (Mavroudi et al., 2011). The last wide report made by Cohrana highlights the efficacy of exclusive breastfeeding in both prevention and treatment of allergy (Host et al., 2008).

Statistics on the estimated incidence of cow's milk protein allergy in infants varies in different counties. The European Paediatrician Association performed a Europe-wide study on clinical practice for ambulatory treatment in cases of cow's milk protein based allergy. It was found that during prime medical care, $47 \%$ of doctors selected the diagnosis of "allergy caused by cow's milk proteins"; on the other hand, allergy specialists have found that this type of allergy affects only an estimated one to three percent of babies. Confusingly, the amount of parents considering their infants suffering of cow's milk or other kind of allergy is between 5 and 20 percent (Venter et al., 2006). No other native milk instead of cow's milk can be used effectively, despite regularly arising promising prospects (D`Auria, 2011). Soy is a genetically modified product provoking cross allergy and food tolerance in infants (Kattan, 2011). Food allergy is a 
cause of bullying in behaviour of children with negative consequences in their future life quality (Schemech, 2012).

\section{NOURISHMENT-PROVOKED ALLERGY — REAL OR TEMPORARY, INAPPROPRIATE NUTRITION CAUS- ING PROBLEMS}

According to data of some other clinical research, cow's milk protein allergy prevalence in infants and babies ranges from 1.9 to 4.9 per cent. In addition, some of them also suffer from soy protein allergy. Nourishment-provoked allergy also could be connected with raised IgE or allergy specific secretion of IgG. It has been strongly shown that allergic disease impedes the quality of a babies' life, and the negative effect can increase for teenagers and families as a whole. Therefore, the correct diagnosis and appropriate therapy becomes one of the most significant problems for paediatricians. Detection of protein causing allergy, and its elimination, is an important part of treatment. Use of hypoallergenic formulas combined with restricting dietary intervention, chosen by parents singly, can cause insufficiency of nutrition, causing problems in future physical development of children (Carafelli, 2010).

The problem of nourishment allergy in infants in Latvia has not been widely studied. A research group at the University of Latvia conducted an inquiry of 500 parents with children under the age of 5. In this study, in children feeding pathology symptoms of the skin, respiration system, digestive apparatus were identified in about $25 \%$ of cases (Rumba et al., 2009).

The elimination of the protein provoking allergy from the diet has a significant role in the treatment of allergy. It helps to provide the adequate development of children and to diminish the risk of prolongation of allergy diseases. Therefore, the correct diagnosis is needed for choosing an appropriate treatment, including special formula fed in accordance with guidelines of ESPACI and ESPGHAN (Host et al., 1997).

\section{ELIMINATIVE DIETS, BREASTFEEDING SUPPORT}

Supporting and promotion of breastfeeding is the first step providing necessary nourishment to infants (Niel et al., 2010). However, there are cases when breastfeeding does not prevent the development of cross milk protein allergy (Brill, 2009). When breastfeeding is not possible, only use of appropriate feeding formula can cover an infants' energetic requirements, which can provide the sufficient amount of protein in food (from 8.9 to 11.5 per cent). It is important to take into consideration that when inflammation factors increase (because of skin or intestinal canal injuries) connected with decreased absorption of nutrients, a dangerous possibility of malnutrition arises even in the case of special nourishing. When the diagnosis has been incorrect or it has not been proven later, the elimination method and use of feeding formula is expensive and non-effective (Meyer et al., 2012).

The situation of Latvia in the field of cow's milk protein and soy protein allergy diagnosis is comparable with data given by research of the European Paediatrician Association. Only a limited part of patients obtain a confirmed diagnosis from an allergy specialist. Mainly, diagnosis is defined during prime medical care, and is based on anamnesis and clinical manifestation. After the prime medical care, as a rule, dietary prescriptions are given to the mother and breastfeeding is promoted; in some cases feeding formula is recommended, but often it is without any result due to lack of parents' being informed and training. Dietary prevention of allergic diseases in infant and small children in Latvia needs special consideration also because of poor knowledge of parents of the real situation and their wrong beliefs (Hays, 2012).

\section{FORMULA FEEDING COMPENSATION POSSIBILI- TIES: COMPARATIVE OVERVIEW}

Formula fed products are expensive and in combination with non-correct diagnosis their efficacy is low (Remberga, 2009).

The average cost of medical feeding formula ranges from 0.30 to $1.27 \mathrm{Ls}$ per $100 \mathrm{ml}$ of usable mixture.

During the first half-year of life, an infant needs about $850-900 \mathrm{ml}$ of usable mixture average per day and 600-700 $\mathrm{ml}$ of usable mixture per day. This amounts to 81.00 to 342.90 Ls for one baby.

According to data of the Latvian Central Statistics Department (11.06.2012), food expenses per one member of household per month were 50,47 Ls. Visibly non-useful and probably dangerous expenses should be excluded.

Thus, it is possible to conclude that high expenses of feeding formula combined with a low information level amongst parents, leads to non-use of feeding formula, or that it is used side by side with cow's milk or soy protein-containing food; so the treatment efficacy planned could not be gained.

The trends described above exist for more than some decades, not only in the USA and developed members of the European Union, but also in Estonia, where formula fed products are included in lists of medicaments and remedies to be compensated. In Estonia, for example, medical feeding formula has been compensated for 2000 children for a period from birth till 12 months of age, corresponding to diagnosis by International classification of diseases SSK10-K52.2; K90.4; L20.8; L27.2. Parents have only to prepay 1.27 Euro for a doctor's prescription, when 10 units are prescribed simultaneously. Diagnosis is arranged by the family doctor or by a paediatrician. No additional examination is required for clinic manifestation and a family's history is sufficient. The system described above is easily real- 
ised and sufficiently effective, but hyper-diagnostic risks are still possible.

When analysing the situation in accordance with accessibility of feeding formula to parents in Europe and the USA, effective compensative mechanisms exist through the medical insurance system and randomised prescription providing tolerance of formula fed at 90-95\% (Niggemann et al., 2008).

In Netherlands, on the other hand, the eliminative protocol completed by provocation test has been confirmed. Those who work in the area of primary care need to meet the requirements of said protocol; only later formula for compensative mixture could be prescribed (or not prescribed). If it is necessary to clarify the diagnosis, a patient can be sent to a specialist. In Bulgaria only specialists (allergologists or gastroenterologists) are allowed to write prescriptions. In Germany expenses are covered by means of the medical insurance system. In Lithuania only synthetic amino acid formula mixtures are included in the list of compensative medicaments; the recipe could be prescribed only by a narrow list of specialists allowed to write prescriptions for compensative medical formula fed, and annual quota exist.

\section{PARENTS AND ALLERGY SPECIALISTS: COLLABO- RATIVE ACTIVITIES; INFORMATION ACCESSIBIL- ITY AND FEEDBACK}

The role of the educational level of parents and their participation in treatment of allergies cannot be underestimated. Research conducted in the USA in 2008/2009 showed that the role of parents is very high not only in treatment of infants' allergy, but also during the school years. In total, 2495 respondents took part in the inquiry fully, and 558 respondents participated in different interrogatories partially. The best knowledge and most participation was amongst those of parents, who were visiting an allergy specialist regularly, in comparison with those who preferred prime care doctors (Gupta et al., 2010).

Taking into account the high expenses of feeding formula and insufficient knowledge and level of parents' participation creates a situation whereby the infant is not able to receive sufficient nutrition. As a result it becomes possible to predict an increase of allergy diseases in the nearest future, especially in cases of real cow's protein allergy — not only milk intolerance. A special feedback providing algorithm is necessary due to prevailing empiric healing consequences (Meyer, 2008).

It would be necessary to implement a unified system for cow's milk and soy protein allergy diagnosis in Latvia in accordance with the important needs of infants, excluding unsuitable use of special feeding formula when allergy due to milk and soy proteins has not been confirmed. On the other hand, when the treatment of young children depends on elimination of proteins, feeding formalas can protect children from future progress of allergy.
Now special formula compositions are available for consumers in Latvia not only in pharmacies but in also supermarkets and shops for children's goods - in contradiction to other states of European Union, where special formula fed compositions can be bought only in pharmacies, as medically prescribed products.

We analysed the experience of parents in using special fed formula compositions. The summary was based on enquiry of parents within the frame of the state research programme "Scientific study on main pathologies and factors exposing to danger the lifelong and life quality of Latvian inhabitants by means of multidiscipline research consortium". The work took part as the sub-project "Modern early diagnosis, prophylaxis and therapy of diseases provoking invalidity and mortality of children". We came to the conclusion that parents, when making a decision about which feeding formula composition to use, including special ones, act on the advice of relatives and friends; thereby, the used formula compositions change, parents begin feeding and assess the results themselves, without being consulted by specialist. An allergy nutrition compensating mechanism for babies in Latvia does not exist, thereby restricting a parents' ability to buy the appropriate medical formula compositions, which causes future manifestation of allergy diseases. Also, the connection between all participants - prime care specialists, allergists and parents supported by contionious feedback and state thoughtful policy could be able to significantly control food allergy effects.

\section{CONCLUSIONS}

In most cases parents in Latvia lack understanding about possible diseases of infants and the principles of their treatment; they are more convinced about the effectiveness of medicaments than about the importance of nourishment.

Cooperation between prime care specialists, allergists and parents could evade hyper diagnostics of allergy and unproved applying of an elimination diet.

A babies' allergy nutrition compensating mechanism in Latvia does not exist, thereby restricting a parents' ability to buy appropriate medical formula fed compositions; this causes future manifestation of allergy diseases.

It would be preferable to apply the experience of other countries and to diagnose cow's milk and soy protein food allergy in good time using unified criteria. This approach could provide the possibility of using special fed formula in cases when it is necessary, creating a mechanism of supplying free medical feeding for infants under the age of one year.

\section{REFERENCES}

Anonymous (2012). Estonian Health Insurance Fund. http://www.haigekassa.ee/eng/service/medicinal-products (last accessed 20 August 2012).

D’Auria, E., Mandelli, M., Ballista, P., Di Dio, F., Giovannini, M. (2011). Growth impairment and nutritional deficiencies in a cow's milk-allergic in- 
fant fed by unmodified donkey's milk. Case Rep. Pediatr., September. http://www.hindawi.com/crim/pediatrics/2011/103825/ (last accessed 2 October 2013).

Berg, A., Kramer, U., Link, E., Bollrath, C., Heinrich, J., Brockow, I., Koletzko, S., Grubl, A., Filipiak-Pittroff, B., Wichmann, H.-E., Bauer, C.-P., Reinhardt, D., Berdel, D., GINIplus study group. (2010). Impact of early feeding on childhood eczema: development after nutritional intervention compared with the natural course-the GINI plus study up to the age of 6 years. Clin. Exper. Allergy, 40, 627-636

Brill, H. (2008). Approach to milk protein allergy in infants. Can. Fam. Physician, 54 (9), 1258-1264.

Caffarelli, C., Baldi, F., Berdandi, B., Calzoen, L., Marani, M., Pasquinelli, on behalf of EWGPAG. (2010). Cow's milk allergy in children: Practical guide. Ital. J. Pediatr., 36, 5.

Gupta, R. S., Springston, E. E., Smith, B., Kim, J. S., Pongracic, J. A., Wang, X., Holl, J. (2010). Food allergy knowledge, attitudes, and beliefs of parents with food-allergic children in the United States. J. Pediatr. Allergy Immunol., 21, 927-934.

Host, A., Halken, S., Muraro, A., Dreborg, S., Niggemann, B., Aalberse, R., Arshad, SH., von Berg, A., Carlsen, K. H., Duschen, K., Eigenmann, P. A., Hill, D., Jones, C., Mellon, M., Oldeus, G., Oranje, A., Pascual, C., Prescott, S., Sampson, H., Svartengren, M., Wahn, U., Warner, J. A., Warner, J. O., Vandenplas, Y., Wickman, M., Zeiger, R. S. (2008). Dietary prevention of allergic diseases in infant and small children. J. Pediatr. Allergy Immunol., 19, 1-4.

Host, A., Koletzko, B., Dreborg, S., Murano, A., Wahn, U., Aggett, P., Bressen, J. I., Hernell, O., Lafebek, H., Michaelsen, K. F., Micheli, I. L., Rigo, J., Weaver, L., Heymans, H., Strobel, S., Vanderplas, Y. (1999). Joint statement of the European Society for Paediatric Allergology and Clinical Immunology (ESPACI) and European society for Paediatric Gastroenterology, Hepatology and Nutrition (ESPGHAN): Dietary products used in infant for treatment and prevention food allergy. Arch. Dis. Child., 81, 80-84.

Kattan, J. D., Cocco, R. R., Jarvinen, K. M. (2011). Milk and soy allergy. Pediatr. Clin. North Amer., 58 (2), 407-426.

Kneepkens, F., Meijer, Y. (2009). Clinical practise. Diagnosis and treatment of cow`s milk allergy. Eur. J. Pediatr., 168, 891-896.
Mavroudi, A., Xinias, I. (2011). Dietary intervention for primary allergy prevention in infants. Hipokrati, 15, 216-222.

Meyer, R., Venter, K., Fox, A. T., Shah, N. (2012). Practical dietary management of protein energy malnutriton in young children with cow's milk protein allergy. J. Pediatr. Allergy Immunol., 23, 307-314.

Meyer, R. (2008). New guidelines for managing cow`s milk allergy in infants. J. Fam. Health Care, 18 (1), 27-30.

Niel, M., Labbok, M., Abrahams, S. (2010). What are the risks associated with formula feeding? A re-analysis and review. Birth, 37, 50-58.

Niggemann, B., von Berg, A., Bollrath, C., Berdel, D., Schauer, U., Rieger, C., Haschke-Becher, E., Wahn, U. (2008). Safety and efficacy of new extensively hydrolyzed formula for infants with cow`s milk protein allergy. $J$. Pediatr. Allergy Immunol., 19, 348-354.

Remberga, S., Trapiņa, I., Sjakste, T., Rumba-Rozenfelde, I. (2009). Uztura alerğija bērniem - alerğisko slimību riska faktors [Food allergy in children — risk factor of allergic diseases].. Grām.: Rumba-Rozenfelde, I. (red.). Bērnu slimību riska faktori (67.-102. 1pp.). Rīga: LU Akadēmiskais apgāds (in Latvian).

Ring, J. (2012). Davos Declaration: Allergy as a global problem. Allergy, 67, $141-143$.

Shemech, E., Annunziato, R. A., Ambrose, A. M., Ravis, L. N., Mullarkey, C., Rubes, M., Chuang, K., Sicherer, M., Sicherer, S. (2013). Child and parental reports of bullying in a consecutive sample of children with food allergy. Pediatrics, 131, e10-e17.

Venter, C., Pereira, B., Grudy, J., Bernie, C. C., Graham, R., Bernie, H., Taraneh, D. (2006). Incidence of parentally reported and clinically diagnosed food hypersensitivity in the first year of life. J. Allergy Clin. Immunol., 117, 1118-1124.

Yin, Y-Y., Cao, R-M., Chen, J., Kaku, Y., Wu, J., Cheng, Y., Shimizu, T., Takase, M., Wu, S.-M., Chen, T.-X. (2011). Partially hydrolized cow's milk formula has a theurapeutic effect on the infant with mild to moderate atopic dermatitis: A randomized, double-blind study. J. Pediatr. Allergy Immunol., 22, 688-694

Mišak, Z. (2011). Symposium II: Infant and childhood nutrition and disease. Infant nutrition and allergy. Proc. Nutr. Soc., 70, 465-471.

Received 24 September 2013

\section{BĒRNU AR GOVS PIENA UN SOJAS ALERGIJU ĒDINĀŠANAS EFEKTIVITĀTES SOCIĀLI EKONOMISKIE ASPEKTI}

Govs piena olbaltuma alerğija un/vai sojas alerǵija ir viena no pirmajām alerğisko slimību izpausmēm, kas sākas jau agrīni zīdaiṇa vecumā un ir klīniski nozīmīga līdz 1-3 gadu vecumam. Saskaṇā ar klīnisko pētījumu datiem govs piena olbaltuma alerğijas izplatība ir no 1,9 līdz 4,9\% zīdaiṇu un mazu bērnu vidū, daḷai no šiem bērniem ir arī sojas olbaltuma alerğija. Ārstēšanas nozīmīga daḷa ir izraisošā olbaltuma alergēna eliminēšanai no uztura, lai nodrošinātu adekvātu bērna attīstību un mazinātu risku tālākai alerǵisko slimību attīstībai. Ekskluzīvas zīdīšanas nodrošināšana ir viens pamatnosacījumiem veiksmīgai uztura terapijai. Gadījumos, kad tas nav iespējams, tikai adekvāta ārstnieciskā maisījuma lietošana mākslīgi èdinātiem bērniem spēj nodrošināt enerǵêtiskās vajadzības un pietiekamu olbaltuma daudzumu no 8,9 līdz 11,5\% uzturā. Eiropas un ASV situācijas analīze par maisījumu pieejamību vecākiem parāda efektīva kompensācijas mehānisma darbību, gan izmantojot veselības apdrošināšanas sistēmu, gan receptūru, kas pierādītas alerğijas gadījumā nodrošina maisījumu toleranci par $90-95 \%$. Ārstniecisko maisījumu lietošana ir ikdienas terapijas daḷa, tās lietderība netiek apšaubīta. Latvijā kompensācijas mehānisms neeksistē, un valstī esošā ekonomiskā situācija ierobežo vecāku iespēju iegādāties maisījumus, līdz ar to bērnam nav iespēju saņemt nepieciešamo terapijas daḷ. 
Mini Review

\title{
OVERVIEW OF LINSEED PRODUCTION IN BOSNIA AND HERZEGOVINA
}

\author{
Miloš Nožinić*, Bojan Rajčević*, Duško Jović**, Linda Kluga***, Tanja Malčić*, \\ and Vesna Bojić* \\ * Agricultural Institute of the Republic of Srpska Banja Luka, Knjaza Miloša 17, Republic of Srpska, BOSNIA AND HERZEGOVINA; \\ milosn@blic.net \\ ** Faculty of Medicine, University of Banja Luka, Save Mrkalja 14, Banja Luka, Republic of Srpska, BOSNIA AND HERZEGOVINA \\ ${ }^{* * *}$ Faculty of Biology, University of Latvia, Kronvalda bulv. 4, Riga LV-1586, LATVIA
}

Communicated by Isaak Rashal

\begin{abstract}
Linseed (Linum usitatissimum L.), as one of the richest sources of omega-3 fatty acids, antitumoral phytoestrogens and plant mucilage, has great importance for human health. For this reason, the Agricultural Institute of Republic of Srpska promotes linseed production and processing through practical research activities. This paper provides an overview of linseed production and research activities on linseed since 2004, when this crop was returned into production in Bosnia and Herzegovina. The most important findings regarding linseed production and quality in recent years are discussed. So far, it seems that organic linseed production has better perspective in mountain regions compared to lowlands, mainly due to lack of invasive weeds $500 \mathrm{~m}$ above sea level. Until now, linseed diseases that can spoil the quality of seed, have not been recorded, due to extensive linseed production. The first comprehensive technological analyses of cold extracted linseed oil from the mountain region Petrovac showed unique quality characteristics. This mountain region is well known for its virgin nature and sunny microclimate. This has resulted in increased interest for linseed oil, as well as raised the price of domestic linseed oil.
\end{abstract}

Key words: linseed, linseed oil, organic production, unique quality, human health.

\section{INTRODUCTION}

Flax/linseed is an ancient crops that has been grown in many regions as an important fibre, oil and food source. The oldest flax findings date from Kavkaz 35000 years ago (Kvavadze et al., 2009). It is fascinating that some of these fibres were coloured and cut, indicating "advanced" technologies in the dawning of mankind. Using molecular methods, Danish scientists have proved growing of fibre and oil flax (linseed) forms in Denmark even 1600 years BC (Allaby et al., 2005; Runge and Henriksen, 2007).

The health traits of flax/linseed have been known to almost all civilizations. Flax clothing dominated in warm regions of ancient Mesopotamia and Egypt, as it offered ideal skin protection. Lignin in flax fibres is an excellent absorbent of ultraviolet radiation (Zimniewska et al., 2004). Numerous inscriptions in Sumerian clay tablets show that flax (sumerian "gu") had great importance for dressing, diet and healing. The multifunctional role of flax/linseed has been recorded on papyrus and wall drawings dating from all Pharaoh dynasties. Hippokrates (460-377 BC) successfully healed intestinal diseases with linseed. Respecting the im- portance of linseed oil for Russian dietary and healing needs, the emperor Peter the Great banned linseed exports.

Before the 1960's, flax/linseed was grown throughout the Balkan region organically. In that period, organic production was easier than today due to availability of rural labour. Unfortunately, flax/linseed production in the Balkan region was discontinued in the 1960's when cheap synthetic fibres replaced natural ones.

The interest for linseed products has been increasing after the recognition of the irreplaceable role of essential fatty acids and their acid derivates (DHA, EPA) for the structure and function of the neuro- and cardiovascular systems. About one half of population in the Balkan region suffers mortality due to consequences of irregular lipid status, which is (among other factors) the result of essential fatty acid deficit. Flax is the richest source of linolenic fatty acid (omega-3), which plays a key role for proper neuro- and cardiovascular functions.

The beneficial influence of linseed/flax products on human health has been an important subject of many multidisciplinary studies (Prasad, 1997; Simopoulos, 1999; Dahl et 
al., 2005). Linseed contains 600-800 times more lignans than other oil crops (Westcott et al., 2001). Lignans belong to phytoestrogens, which in a natural way compensate estrogen deficit in menopausa, reducing risk of mammal cancer (Thompson, 1998). Flax fibre (linen) can increase the alfa-immunoglobulin content in humans and result in lower miographic tension of muscles, lower body temperature and sounder sleep (Kozlowski, 2001; Zimniewska et al., 2004). An extended list of scientific studies about linseed/flax curative traits confirms the importance of this crop, which has been neglected in Balkan region for half of one century.

The FAO International Conference "Natural Fibres for Healthy Life", held in Banja Luka in October 2004 had a key role for launching of research activities on linseed in Bosnia and Herzegovina. This Conference was organised by the Agricultural Institute of Republic of Srpska and the Institute for Natural Fibres in Poznan, where coordination centre of the FAO European Cooperative Research Network on Flax and other Bast Plants is located.

In the frame of organising the Conference, linseed was returned into production in Bosnia and Herzegovina. The title of this scientific event symbolically defines the directions of the research and practical activities in the future. All these activities will aid health benefits through increased consumption of domestic linseed products. The processing of flax fibres is presently limited, as the domestic textile industry has not yet adapted to thus product.

The research activities, as well as an educational programme conducted by the Agricultural Institute of Republic of Srpska, have raised interest of farmers and buyers for domestic linseed and linseed products. Recently, cold extracted linseed oil has attracted farmer interest due to its high market price. In spring 2013, a few animal farms started growing linseed in order to produce meat and eggs with increased content of omega-3 fatty acids.

\section{LINSEED PRODUCTION AND RESEARCH ACTIVI- TIES IN 2004}

In 2004, the linseed variety 'Olin' was introduced into production in Bosnia and Herzegovina through a network of demonstration trials. These trials occurred at 20 locations, representing different agroecological conditions from 100 to $700 \mathrm{~m}$ above sea level. More detailed data were available from 16 locations (Table 1). The size of production plots varied from 0.5 to 1 ha. Two Czech fibre flax varieties ('Jitka' and 'Venica') were included in demonstration trials at locations Banja Luka and Drinić in 2004. The agrotechnology was adapted for each trial depending on climate conditions and soil fertility $(\mathrm{pH}$, humus content, available $\mathrm{P}_{2} \mathrm{O}_{5}$, and $\mathrm{K}_{2} \mathrm{O}$ ) The nitrogen treatment varied from 15 to $62 \mathrm{~kg} / \mathrm{ha}$. Field observations were focused on basic agronomic traits and the most important factors in practical production (weeds, harvest). Herbicides (bentazon) were recommended for plots where risk of weed development was observed. This treatment was particularly needed in the Brčko region, where the land had not been cultivated for a longer period due to migration of farmers in the war and post-war period.

The highest linseed yield (2.5 t/ha) was obtained at Šereg Ilova (Table 1). Excellent seed purity at this location was due to high herbicide efficiency. In the organic production system used in the neighboring village Velika Ilova, the yield was only $500 \mathrm{~kg} / \mathrm{ha}$ with $10 \%$ weed seed impurity.

Table 1

RESULTS OF DEMONSTRATION LINSEED/FLAX TRIALS IN BOSNIA AND HERZEGOVINA IN 2004

\begin{tabular}{|c|c|c|c|c|c|c|}
\hline No. & Municipality & Location & Alt. & Yield, kg/ha & $\mathrm{Cd} \mathrm{mg/kg}$ & Problem \\
\hline 1. & Banja Luka & Agricultural School & 150 & 1080 & - & difficult harvesting \\
\hline 2. & Banja Luka & Agricultural Institute & 150 & \multicolumn{3}{|c|}{ Fiber variety Jitka- $800 \mathrm{~kg} / \mathrm{ha}$, fiber variety Venica $-810 \mathrm{~kg} / \mathrm{ha}$} \\
\hline 3. & Banja Luka & Stričići & 700 & 1320 & 0.50 & high soil acidity \\
\hline 4. & Prnjavor & Šereg Ilova & 240 & 2500 & 0.54 & - \\
\hline 5. & Prnjavor & Velika Ilova & 220 & 500 & 0.39 & Ambrosia artemisifolia \\
\hline 6. & Prnjavor & Potočani & 300 & 1220 & 0.58 & harvesting \\
\hline 7. & Prnjavor & Vijačani & 330 & 1000 & 0.16 & grass weeds \\
\hline 8. & Prnjavor & Štrpci & 100 & 500 & 0.57 & lodging, grass weeds \\
\hline 9. & Brčko & Boderište & 140 & 1390 & 1.06 & - \\
\hline 10. & Brčko & Donje Dubrave & 120 & 1380 & 0.54 & Ambrosia artemisifolia \\
\hline 11. & Brčko & Omerbegovača & 120 & 1270 & 0.92 & Ambrosia artemisifolia \\
\hline 12. & Brčko & Bukvik & 120 & 870 & 0.44 & Ambrosia artemisifolia \\
\hline 14. & Brčko & Cerik & 150 & 700 & - & Ambrosia artemisifolia \\
\hline 15. & Brčko & Brezovo polje & 96 & 200 & - & various weeds \\
\hline 16. & Drinić & Drinić (fibre variety) & 700 & Fiber variety Jitka-810 kg/ha & & \\
\hline 17. & Petrovac & Vrtoče & 600 & 1.000 & - & disabled harvesting \\
\hline 18. & Gradiška & Kućište & 100 & 400 & - & Ambrosia artemisifolia \\
\hline \multicolumn{3}{|c|}{ Average yield-cultivar Olin } & & 1014 & & \\
\hline
\end{tabular}


Significant lodging $(80 \%)$ was observed at Štrbci, while at other locations it was recorded as $50 \%$. Because of old combines, harvest was quite difficult at seven locations. Twophase harvest caused loss of seed by $10-30 \%$.

Fibre flax varieties at Banja Luka and Drinić were sampled for grain yield (Table 1), fibre yield and quality. The Czech fibre variety 'Jitka' produced the highest average straw yield $(5800 \mathrm{~kg} / \mathrm{ha})$ in micro trials for the period 2008-2010, which was significantly higher the the average of all trials (Table 2).

Table 2

THE STRUCTURE OF FATTY ACIDS (\%) IN THE COLD PRESSED LINSEED OIL-PANONIAN CULTIVAR

\begin{tabular}{c|c|c|c|c|c|c|c}
\hline FFA & C16:0 & C16:1 & C18:0 & C18:1 & C18:2 & C18:3 & C20:0 \\
\hline 0.57 & 5.71 & 0.65 & 3.68 & 17.62 & 14.25 & 57.55 & 0.16
\end{tabular}

Micro trials in 2004 included 26 genotypes placed in four replications randomly. Plot size was $5 \mathrm{~m}^{2}$. The average linseed yield in the micro trials was $1074 \mathrm{~kg} / \mathrm{ha}$. It is interesting that the highest linseed yield of $2500 \mathrm{~kg} / \mathrm{ha}$, obtained at Šereg Ilova, was significantly higher than the average (1074 $\mathrm{kg} / \mathrm{ha})$ and maximal yield $(1740 \mathrm{~kg} / \mathrm{ha})$ in the micro trial in Banja Luka in that year (Garić and Mandić, 2004). Usually, under similar agroecological conditions and similar agrotechnology, seed yields in micro trials significantly exceed seed yields in demonstration trials. Therefore, as the obtained rank in yield is illogical, reasons for this trend need to be answered. Possibly, this was due to very different soil traits and increased activity of microelements in producing yield.

The fertile alluvial soil in Banja Luka has neutral reaction ( $\mathrm{pH}$ in water, 7.1), 2.6\% humus content, very high concentration of available $\mathrm{P}_{2} \mathrm{O}_{5}(35 \mathrm{mg} / 100 \mathrm{~g})$ and high $\mathrm{K}_{2} \mathrm{O}$ conconcentration $(45 \mathrm{mg} / 100 \mathrm{~g})$. The soil in Šereg Ilova is pseudoclay with moderate acidity ( $\mathrm{pH}$ in water, 5.3), $3.4 \%$ humus content, very low concentration of available $\mathrm{P}_{2} \mathrm{O}_{5}$ $(2.3 \mathrm{mg} / 100 \mathrm{~g})$ and high $\mathrm{K}_{2} \mathrm{O}$ concentration $(21.7 \mathrm{mg} / 100$ g). Moderate acid soils ( $\mathrm{pH}$ 5-6) with lower concentration of available $\mathrm{P}_{2} \mathrm{O}_{5}$, as in Šereg Ilova, contain higher concentration of available zinc, which has a very positive effect on linseed/flax yield (Moraghan, 1980; Jankauskiene, 2001). Most microelements are more available in acid soils, which occupy about $60 \%$ of the arable land in Bosnia and Herzegovina. For this reason, the effect of microelements on yield of flax should be studied more detailed. In the 2004 , the economically profitable yield was over 1.000 $\mathrm{kg} / \mathrm{ha}$.

High concentration of the heavy metal cadmium in food is a serious risk factor for renal disease (Vapa, M. and Vapa Lj., 1997). In 2004, the cadmium concentration was determined in the products to provide information for debates in the international conference held in Banja Luka. According to EU regulations, the acceptable level of cadmium in edible oil is $0.50 \mathrm{mg} / \mathrm{kg}$. Cadmium concentration in linseed oil from 10 locations (cultivar 'Olin') in Bosnia and Herzegovina in 2004 ranged from $0.16-1.06 \mathrm{mg} / \mathrm{kg}$ (Table 1). In that same year, in the micro trial with 26 linseed genotypes at Banja Luka, the concentration of cadmium in oil ranged from $0.31-0.60 \mathrm{mg} / \mathrm{kg}$. Higher accumulation of cadmium was observed in vegetative plant parts (fibres). In some cases, higher cadmium concentration in fibres can present a serious risk for skin health (Lukipudis, 2001).

\section{LINSEED PRODUCTION CONSTRAINTS}

Weeds have been the most important problem in the practical linseed production since 2004. Linseed yield and seed purity mainly depended on the weed spectrum and development. The period for herbicide application of linseed is quite short, when crop height is from 8 to $12 \mathrm{~cm}$, which is an additional problem.

In the period 2005-2010, a few farmers attempted organic linseed production in the lowlands, but weeds resulted in a halt of this. Ambrosia artemisifolia, Convolvulus arvensis and Cirsium arvense have been the most common weeds in lowland regions. In contrast to lowlands, in the mountain regions over $600 \mathrm{~m}$ a.s.1., organic linseed production has been easier, mainly because of the absence of Ambrosia artemisifolia (Nožinić et al., 2009; Nožinić et al., 2012). In 2008 , the variety Olin was grown organically at the mountain location Sitnica $(750 \mathrm{~m})$. The soil was enriched by sheep manure, and the problem of weed patches was solved by manual weeding.

Spread of thermopile invasive weeds has been promoted by climate warming in the recent two decenniums (Trkulja et al., 2010; Nožinić et al., 2012). Similar changes of weed distributions have been observed in Poland during a 30-year period (Heller, 2001).

Climate change effects have become more and more evident on linseed/flax production. Unfavourable weather conditions in 2007 caused lack of of linseed in subsequent years. April 2007 was recorded as the driest $\left(51 / \mathrm{m}^{2}\right)$ in Banja Luka since 1961. Because of drought, linseed emerged unevenly with significantly reduced number of plants. Mean temperature in April $\left(14.2^{\circ} \mathrm{C}\right)$ and May $\left(19.2^{\circ} \mathrm{C}\right)$ in that year was the warmest in meteorological records at Banja Luka.

Late frosts present risk for linseed production in mountain valleys. It was encouraging that linseed (in the phase of coleoptiles) at Vrtoče $(600 \mathrm{~m})$ survived (with small damage) at a minimal temperature of $-8{ }^{\circ} \mathrm{C}$ (April 10, 2012). The local authors noted that young linseed plants can withstand temperatures to $-5^{\circ} \mathrm{C}$ (Jevtić, 1986; Kocjan, 1999).

The main problem is the lack of the high yielding linseed cultivars. So far, Bosnia and Herzegovina has not adopted the EU cultivar list, which makes seed exchange difficult. 


\section{BETTER TIME FOR LINSEED AND LINSEED OIL PRODUCERS}

In 2011, organic linseed and linseed oil production was carried out successfully in the mountain valley Vrtoče in the municipality Petrovac $(600 \mathrm{~m})$. The variety originated from Srbija, but the name of the variety was not known. The production of the linseed was based on liquid cow manure.

The advantages for organic production in the Petrovac region are: unpolluted soils, moderate temperatures during the vegetation period, over 2.000 sunny hours per year, high precipitation $\left(1.200-1.3001 / \mathrm{m}^{2}\right)$, frequent winds and absence of the invasive weed Ambrosia artemisifolia.

The content of free fatty acids (FFA) in the cold extracted oil was $0.57 \%$ (Table 2), which is significantly lower than the maximum allowed content of $3 \%$. A very low peroxide concentration of $0.65 \mathrm{mmol} \mathrm{O}_{(2)} / \mathrm{kg}$ confirmed the excellent quality of cold extracted oil (Table 3 ). The analysis of microbiological oil status showed absence of bacteria.

Table 3

THE PARAMETERS OF LINSEED OIL QUALITY-PANONIAN CULTIVAR

\begin{tabular}{|c|c|c|c|}
\hline Characteristic & Determined & $\begin{array}{c}\text { Maximum } \\
\text { allowed }\end{array}$ & Method \\
\hline $\begin{array}{l}\text { Peroxide concen- } \\
\text { tration number }\end{array}$ & $\begin{array}{c}0.65 \mathrm{mmol} \mathrm{O}_{(2)} \\
/ \mathrm{kg}\end{array}$ & $\underset{\text { ulja }}{10 \mathrm{mmol} \mathrm{O}_{(2)} / \mathrm{kg}}$ & ISO 3960 \\
\hline $\begin{array}{l}\text { Water and other } \\
\text { evaporable sub- } \\
\text { stances }\end{array}$ & $0.02 \%$ & do $0.4 \%$ & ISO 662:1998 \\
\hline Phosphorus & $7.90 \mathrm{ppm}$ & No limits & $\begin{array}{c}\text { A.O.C.S. Ca } \\
12-55\end{array}$ \\
\hline $\begin{array}{l}\text { Non soapy sub- } \\
\text { stances }\end{array}$ & $5.16 \mathrm{~g} / \mathrm{kg}$ & $15 \mathrm{~g} / \mathrm{kg}$ & ISO 3596-2:1998 \\
\hline $\begin{array}{l}\text { The content of in- } \\
\text { soluble impurity }\end{array}$ & $0.01 \%$ & $0.05 \%$ & ISO 663 \\
\hline
\end{tabular}

Due to environmental advantages and proper agrotechnology, weeds did not appear, and thus the linseed was exceptionally pure. Weed seeds and impurities (soil dust, gasses absorbed during harvesting) can change the taste and smell of cold extracted oil.

So far, stronger infestation with common linseed diseases, like Fusarium wilt, has not been recorded in Bosnia and Herzegovina, which is extremely important for linseed and linseed oil quality. This is mainly due to the current extensive linseed production at several distant locations (regions). This status of uncontaminated seed should be maintained as longer as possible. Flax disease was described by local authors during the period when flax occupied a large area in Balkan countries (Panjan, 1968).

The organic production on the farm in Vrtoče, which was associated with high quality traits, as well as and educational programme (by the Agricultural Institute of Republic of Srpska) led to a price of 20 euros per litre of linseed oil.
Bearing in mind the obtained yields of 1.4 t/ha in 2011 and 2012, this yield had very high economic value.

The sowing area of linseed in spring 2013 will be higher than in previous years due to the good results on the farm in Vrtoče. It seems that raised awareness of the importance of omega three fatty acids, phyto estrogens as well as other linseed healing components has led to a better time for linseed producers.

\section{REFERENCES}

Allaby, R. G., Peterson, G. W., Merriwether, D. A., Fu, Y. B. (2005). Evidence of the domestication history of flax (Linum usitatissimum L.) from genetic diversity of the sad2 locus. Theor. Appl. Genet., 112, 58-65.

Brutch, N. B. (2002). The flax genetic resources collection held at the Vavilov Institute, Russian Federation. In: Collection of Papers from Ad hoc meeting Flax Genetic Resources in Europe, 7-8 December 2001 (pp. 61-66). Prague, Czech Republic: International Plant Genetic Resources Institute, Rome.

Dahl, W. J., Lockert, E. A., Cammer, A. L., Whiting, S. J. (2005). Effects of flax fiber on laxation and glycemic response in healthy volunteers. J. Med. Food, 8 (4), 508-511.

Garić, K., Mandić, D. (2004). Experimental production of flax seed in Bosnia and Herzegovina in 2004. In: Proceedings of the Third Global Workshop "Natural Fibers for Healthy Life", 24-28 October 2004 (CD form). Banja Luka, Bosnia and Herzegovina: FAO European Cooperative Research Network on Flax and other Bast Plants.

Heler, K. (2001). Monitoring and prognosis of weed infestation of fibre flax in Poland. In: Proceedings of the Second Global Workshop "Bast Plants in the New Millennium”, 3-6 June 2001 (pp. 286-288). Borovets, Bulgaria: Coordination Centre of the FAO European Cooperative Research Network on Flax and other Bast Plants at the Institute of Natural Fibres, Poznan, Poland.

Jankauskiene, Z.(2001). Zinc and phosphorus: Influence on flax yield. In: Proceedings of the Second Global Workshop "Bast Plants in the New Millennium”, 3-6 June 2001 (pp. 219-228). Borovets, Bulgaria: Coordination Centre of the FAO European Cooperative Research Network on Flax and other Bast Plants at the Institute of Natural Fibres, Poznan, Poland.

Jevtić, S. (1986). Flax. In: Special Field Crops (pp. 185-200). Beograd: Scientific book (in Serbian).

Kvavadze, E., Ofer, Bar-Y., Belfer-Cohen Anna, Boaretto Elisabetta, Jakeli, N., Matskevich, Z., Meshveliani, T. (2009). 30.000-Year-old wild flax fibers. Science, 325 (5946), p. 1359.

Kocjan, A. D. (1999). Flax. In: Forgotten Field Crops (pp. 83-99). Ljubljana: Farmers' Voice (in Slovenian).

Kozlowski, R. (2001). Future Trends in the Production, Processing and Application of Natural Fibers. In: Proceedings of the Second Global Workshop "Bast Plants in the New Millennium”, 3-6 June 2001 (pp. 15-31). Borovets, Bulgaria: Coordination Centre of the FAO European Cooperative Research Network on Flax and other Bast Plants at the Institute of Natural Fibres, Poznan, Poland.

Lukipudis, Z. (2001). Selectivity of some sorts of flax and common contamination of flax fibers by heavy metals. In: Proceedings of the Second Global Workshop "Bast Plants in the New Millennium", 3-6 June 2001 (pp. 215-218). Borovets, Bulgaria: Coordination Centre of the FAO European Cooperative Research Network on Flax and other Bast Plants at the Institute of Natural Fibres, Poznan, Poland.

Moraghan, J. (1980). Effects of soil temperature on response of flax to phosphorus and zinc fertilizers. Soil Sci., 5, 290-296.

Nožinić, M., Marković, M., Trkulja, V. (2009). Experimental Linseed Oil Production in Banja Luka Region. In: Scientific Bulletin of International Conference "Week of Natural Fibers within International Year of Natural Fibers" (vol. 1, pp. 45-48). Arad, Romany: FAO European Cooperative 
Research Network on Flax and other Bast Plants at the Institute of Natural Fibres, Poznan, Poland.

Nožinić, M., Šurica, R., Bojić, V., Bijelić, H. (2012). Ecological production of linseed and cold pressed linseed oil. In: Proceedings from the First International Congress of Ecologists “Ecological Spectrum”, 20-21 April 2012 (pp. 1039-1047). Banja Luka, Republic of Srpska, Bosnia and Herzegovina: University for Business Studies Banja Luka.

Nožinić, M., Šurica, R., Bojić, V., Bijelić, H. (2012). The influence of the climate changes to the agricultural production. In: Proceedings from the First International Congress of Ecologists "Ecological Spectrum”, 20-21 April 2012 (pp. 1081-1089). Banja Luka, Republic of Srpska, Bosnia and Herzegovina: University for Business Studies Banja Luka.

Panjan, M. (1968). Flax diseases. In: Diseases and Pests of Field Crops (pp. 347-349). Zagreb: Znanje (in Croatian).

Prasad, K. (1997). Dietary flaxseed in prevention of hypercholesterolemic atheorsclerosis. Atherosclerosis, 132 (1), 69-76.

Runge, M., Henriksen, P. S. (2007). Denmark's oldest flax industry. Fynske Minder, 145-165 (in Danish).

Simopoulos, A. R. (1999). Essential fatty acidis in health and chronic disease. Amer. J. Clin. Nutr., 70, 560-569.
Thompson, L. U. (1998). Experimental studies on lignans and cancer. Baillieres Clin. Endocrinal Metab., 12, 691-705.

Trkulja, V., Ostojić, I., Škrbić, R., Herceg, N., Petrović Danijela, Kovačević, Z. (2010). Ambrosia. Banja Luka: Society for Plant Protection in Bosnia and Herzegovina. 181 pp. (in Serbian).

Vapa, M., Vapa, L. (1997). Heavy metals and animals. In: Heavy Metals in the Environment (pp. 287-289). Novi Sad: Institute for Field and Vegetable Crops (in Serbian).

Westcott, N. D., Muir, A. D., Diederichsen, A. (2001). Flax lignan a health product for the new millennium. In: Proceedings of the Second Global Workshop “Bast Plants in the New Millennium”, 3-6 June 2001 (p. 54). Borovets, Bulgaria: Coordination Centre of the FAO European Cooperative Research Network on Flax and other Bast Plants at the Institute of Natural Fibres, Poznan, Poland.

Zimniewska, M., Kozlowski, R., Muzyczek, M., Florysiak, M. (2004). Towards more physiological friendly apparels made of natural fibers. In: Proceedings of the Third Global Workshop "Natural Fibers for Healthy Life", 24-28 October 2004 (CD form). Banja Luka, Bosnia and Herzegovina: FAO European Cooperative Research Network on Flax and other Bast Plants.

Received 15 April 2013

\section{PĀRSKATS PAR EL,ĽAS LINU AUDZĒĚŠAU BOSNIJĀ UN HERCEGOVINĀ}

Rakstā dots pārskats par eḷlas linu audzēšanu un zinātniskajiem pētījumiem par eḷlas liniem kopš 2004. gada, kad šo kultūru atsāka audzēt Bosnijā un Hercegovinā. Organisko linsēklu audzēšanai labākas perspektīvas, salīdzinājumā ar zemienēm, ir kalnu rajonos. To var izskaidrot galvenokārt ar nezāḷ neesamību $500 \mathrm{~m}$ augstumā virs jūras līmeņa. Pateicoties ekstensīvai linu audzēšanai, līdz šim nav novērotas linu slimības, kas varētu ietekmēt linsēklu kvalitāti. Pirmās visaptverošās tehnoloǵiskās analīzes par auksti ekstrahētas linsēklu ellıas kvalitāti no kalnu reğiona Petrovacas uzrādījušas unikālas kvalitātes īpašības. Šim kalnu reğionam raksturīga neskarta daba un saulains mikroklimats. Pētījumu rezultāti vairojuši interesi par linsēklu eḷıu un paaugstinājuši pašmāju linsēklu eḷıas cenu. 
Mini Review

\title{
HEALTH PROMOTING CHEMICAL COMPONENTS OF ORANGE JUICE
}

\author{
Gaḷina Zvaigzne and Daina Kārklina \\ Latvia University of Agriculture, Lielā iela 2, Jelgava, LV-3001, LATVIA; \\ g.zvaigzne@inbox.lv, daina.karklina@llu.lv
}

Contributed by Daina Kārkliṇa

\begin{abstract}
Citrus fruit or juice can be an excellent source of health-promoting substances at breakfast. $A$ 150-200 ml glass of orange juice daily provides many nutrients required for good human health. As has been reported, vitamin $C$, thiamine (vitamin $B_{1}$ ), riboflavin, vitamin $A$, vitamin $D$, vitamin $E$, pantothenic acid, vitamin $B 6$, folate are present in oranges. Citrus juices also provide minerals calcium, potassium, iron, zinc, magnesium, copper, and phosphorous, which are part of the vital enzyme system of the human body. In addition, several compounds - flavonoids and other health-promoting substances are present in citrus fruit. There are hundreds of useful products and substances with properties, which have origin in citrus products. There are also many patents for helpful products to be made from citrus substances. Treatment of major inflammation-related ailments target on phytochemicals involved in oxidative stress, metabolic syndrome (diabetes), cardiovascular diseases, bone health (osteoporosis), skin aging, cognitive function and brain diseases, aging, allergy and immune function and cancer. A clinical study published shows that orange juice and hesperidin increase nitric oxide production in human. Orange juices have been shown to provide several important health benefits, particularly for the cardiovascular system, bone and skin health, brain health, cognitive functions, aging, and also cancer. However, the number of clinical studies available remains limited and significant efforts are necessary to provide irrefutable proof of these benefits in human.
\end{abstract}

Key words: naringin, hesperidin, orange juice, nitric oxide, vitamins.

\section{INTRODUCTION}

Citrus is the world's most popular fruit. Citrus products have always been valued as excellent sources of human nutrition. Nutrition is the ability to engender growth, and many of the components of citrus products contribute to the growth and well-being of the human body. It is well established that citrus and citrus products are a rich source of vitamins, minerals, flavonoids and dietary fibre NSP (nonstarch polysaccharides) and that are essential for normal growth and development and overall nutritional well-being. For example, the recommended dietary allowances for average adults in the United States and India in terms of nutrients available in citrus juices are given in Table 1.

In addition, citrus contains no fat or sodium and, being a plant food, no cholesterol. The average energy value of fresh citrus is also low (see Table 2), which can be very important for consumers concerned about putting on excess body weight. For example a medium orange contains 60 to $80 \mathrm{kcal}$, a grapefruit $90 \mathrm{kcal}$ and a tablespoon $(15 \mathrm{ml})$ of lemon juice only 4 kcal (Whitney and Rolfes, 1999).

\section{CARBOHYDRATES}

Citrus fruits contain carbohydrates in the form of sugars: sucrose, glucose, and fructose as well as citric acid, which can also provide a small amount of energy. Total soluble solids in juice consist mainly of sugars. Fibrous rag and many other polysaccharides, which may also provide calories, are also eaten when fresh citrus fruit is consumed (Ladaniya, 2008). A reasonable goal for dietary NSP/fibre intake is 25 to $30 \mathrm{~g} /$ day, but in many developed countries the actual average intake is closer to $15 \mathrm{~g}$ (Cleveland et al., 1996). With one medium orange containing approximately $3.0 \mathrm{~g}$ of NSP, citrus fruit can make a valuable contribution to meeting the daily fibre goal (Whitney and Rolfes, 1999). An averagesize orange (7-8 cm diameter) can provide $0.8 \mathrm{~g}$ of fibre in the diet. Drinking of a cup of fresh orange juice provides $0.3 \mathrm{~g}$ of fibre. A half grapefruit eaten at breakfast adds $0.2 \mathrm{~g}$ of fibre to the meal, thus replacing fibre that has been removed from the breakfast cereal by the milling process (Church and Church, 1970). Fibre has its own importance for the people of industrialized nations who eat high-fat, low-fibre diets full of highly refined and processed carbohy- 
RECOMMENDED DIETARY ALLOWANCES FOR AVERAGE ADULTS IN THE UNITED STATES AND INDIA IN TERMS OF NUTRIENTS AVAILABLE IN CITRUS JUICES (one glass, $100 \mathrm{~g}$ )

\begin{tabular}{|c|c|c|c|c|c|}
\hline \multirow[b]{2}{*}{ Nutrient } & \multicolumn{2}{|c|}{ Recommended dietary allowance } & \multicolumn{3}{|c|}{ Content in citrus juices } \\
\hline & $\begin{array}{l}\text { essential in human } \\
\text { nutrition (USRDA) }\end{array}$ & $\begin{array}{c}\text { for average adult Indian } \\
(60 \mathrm{~kg} \text { weight })\end{array}$ & orange & tangerine & grapefruit \\
\hline Vitamin $\mathrm{C}$ & $90 \mathrm{mg}$ & $40 \mathrm{mg}$ & $45-50 \mathrm{mg}$ & $30-31 \mathrm{mg}$ & $30-35 \mathrm{mg}$ \\
\hline Vitamin A & $5000 \mathrm{IU}$ & $600 \mu \mathrm{g}$ retinal & 190-400 IU & $350-420 \mathrm{IU}$ & $21 \mathrm{IU}$ \\
\hline Vitamin D & $200 \mathrm{IU}$ & - & - & - & - \\
\hline Vitamin E & $15 \mathrm{mg}$ & $25 \mu \mathrm{g}$ & $100 \mu \mathrm{g}$ & - & - \\
\hline Riboflavin & $1.7 \mathrm{mg}$ & $1.6 \mathrm{mg}$ & $20-40 \mu \mathrm{g}$ & $20-40 \mu \mathrm{g}$ & - \\
\hline Niacin & $20 \mathrm{mg}$ & - & $300-600 \mu \mathrm{g}$ & $200-250 \mu \mathrm{g}$ & $200 \mu \mathrm{g}$ \\
\hline Calcium & $1 \mathrm{~g}$ & $400-1000 \mathrm{mg}$ & $10-11 \mathrm{mg}$ & - & $9-10 \mathrm{mg}$ \\
\hline Iron & $18 \mathrm{mg}$ & $28 \mathrm{mg}$ & $0.1-0.2 \mathrm{mg}$ & - & - \\
\hline Pyridoxine $\left(\mathrm{B}_{6}\right)$ & $2 \mathrm{mg}$ & $2.0 \mathrm{mg}$ & $47-66 \mu \mathrm{g}$ & $40-50 \mu \mathrm{g}$ & $18-20 \mu \mathrm{g}$ \\
\hline Folic acid & $0.4 \mathrm{mg}$ & $100 \mu \mathrm{g}$ & $34 \mu \mathrm{g}$ & $21 \mu \mathrm{g}$ & $8 \mu \mathrm{g}$ \\
\hline Vitamin $\mathrm{B}_{12}$ & $5-6 \mu \mathrm{g}$ & $1 \mu \mathrm{g}$ & - & - & - \\
\hline Iodine & $150 \mu \mathrm{g}$ & - & $0.25 \mu \mathrm{g}$ & - & - \\
\hline Magnesium & $400 \mathrm{mg}$ & - & $8-12 \mathrm{mg}$ & $10-15 \mathrm{mg}$ & $8-10 \mathrm{mg}$ \\
\hline Zinc & $15 \mathrm{mg}$ & - & $25-30 \mu \mathrm{g}$ & - & - \\
\hline Copper & $2 \mathrm{mg}$ & - & $50-160 \mu \mathrm{g}$ & - & - \\
\hline Biotin & $0.3 \mathrm{mg}$ & - & - & - & - \\
\hline Pantothenic acid & $10 \mathrm{mg}$ & - & $130-150 \mu \mathrm{g}$ & - & $280-300 \mu \mathrm{g}$ \\
\hline
\end{tabular}

Source: Anonymous (2004a); Gopalan et al. (1999). USRDA, United States Recommended Daily Allowance

Table 2

NUTRITIONAL FACTS ON CITRUS FRUIT

\begin{tabular}{l|c|c|c}
\hline \multicolumn{1}{c|}{$\begin{array}{c}\text { Weight } \\
(\mathrm{g})\end{array}$} & $\begin{array}{c}\text { Orange } \\
131\end{array}$ & $\begin{array}{c}\text { Grapefruit } \\
236\end{array}$ & $\begin{array}{c}\text { Tangerine } \\
84\end{array}$ \\
\hline Energy $(\mathrm{kcal})$ & 62 & 78 & 37 \\
Fibre $(\mathrm{g})$ & 3.1 & 2.5 & 1.7 \\
Ascorbic acid $(\mathrm{mg})$ & 70 & 79 & 26 \\
Folate $(\mu \mathrm{g})$ & 40 & 24 & 17 \\
Potassium $(\mathrm{mg})$ & 237 & 350 & 132
\end{tabular}

Source: Gutherie and Picciano, 1995.

drates that are more slowly absorbed through the intestines. In fresh citrus fruit, fibre contains cellulose, hemicellulose, lignin, and pectin - all found in citrus segments, membranes and other parts of the albedo (Ladaniya, 2008). Dietary fibre also adsorbs calcium and may increase its availability (Nishimura et al., 1992). Citrus fruits are not considered a major source of protein; but proteins are a constituent of citrus juices. In citrus fruits, seeds are very rich in protein. Citrus seeds contain $18.2 \%$ protein on a dry weight basis (in whole seeds) (Ladaniya, 2008).

\section{MINERALS}

Citrus juices also provide minerals that are part of the vital enzyme system of the human body. Citrus fruits have very high potassium $(\mathrm{K})$ content $(300 \mathrm{mg}$ in $178 \mathrm{ml}$ of orange juice and $200 \mathrm{mg}$ in grapefruit juice), while the sodium content is relatively low (3-4 mg/178 $\mathrm{ml}$ orange juice and $4.5 \mathrm{mg} / 178 \mathrm{ml}$ tangerine juice). The ratio of $\mathrm{K}$ and sodium
(Na) in orange juice plays an important role in maintaining electrolyte balance. Dietary levels are 50-150 meq (milliequivalent) per day for potassium (Araujo, 1977). The daily requirement of potassium is approximately $2000 \mathrm{mg}$ and, while frank deficiency of potassium is rare, there is some concern that a high sodium-to-potassium intake ratio may be a risk factor for chronic disease. Increased consumption of citrus fruits and juices is a good means of increasing potassium intake. One medium orange and one $225 \mathrm{ml}$ glass of orange juice provide approximately $235 \mathrm{mg}$ and $500 \mathrm{mg}$ of potassium, respectively (Whitney and Rolfes, 1999). The RDA for calcium in the diet of adult Indian men is $400 \mathrm{mg}$ per day; one orange provides about $2 \%$ of this amount. In addition to $\mathrm{K}$ and $\mathrm{Na}$, calcium and phosphorus, and magnesium are required in higher amounts. Like calcium and phosphorus, magnesium is sequestered in bone. Magnesium is present in mitochondria and other enzymes important in energy transfer. Zinc, manganese, and copper are also important for the body and supplied by citrus fruits. Ascorbic acid and citric acid increase the absorption of calcium and other minerals. A study indicated that ascorbic acid was not the only organic acid responsible for promoting the effects of citrus fruit juices on iron absorption. Iron absorption from laboratory orange juice containing $100 \mathrm{ml}$ water, 33 $\mathrm{mg}$ ascorbic acid, and $750 \mathrm{mg}$ citric acid was significantly better than that from $100 \mathrm{ml}$ water and $33 \mathrm{mg}$ ascorbic acid alone (0.097 and $0.059 \mathrm{~g}$, respectively). There was a close correlation between iron absorption and ascorbic acid content. A weaker but still significant correlation with the citric acid content also was observed (Ballot et al., 1987). A glass of chilled orange juice or few fresh oranges or mandarins are very refreshing in summer and also provide required 
electrolytes. One orange (200 g) provides about $2 \mathrm{mg}$ of iron. Two oranges a days can give $4 \mathrm{mg}$, which would be more than $10 \%$ of the Recommended Dietary Allowance (RDA) in the USA. The RDA is set assuming a $10 \%$ rate of intestinal absorption (Ladaniya, 2008).

\section{VITAMINS}

Ascorbic acid (vitamin C) is the most important nutrient in orange juice. Vitamin $\mathrm{C}$ is essential for the synthesis of collagen, the most abundant protein in mammals. Collagen is the major fibrous element of skin, bone, blood vessels and teeth. A lack of vitamin $\mathrm{C}$ leads to scurvy, which causes loss of teeth, bleeding skin and ulcers. Vitamin C is sometimes suggested to have anticancer effect by its reaction with and inactivation of tree radicals in the body. It is estimated that a glass of orange juice $(177.4 \mathrm{ml}$; Ladaniya, 2008) provides about $100 \%$ of the recommended daily allowance of vitamin $\mathrm{C}$ to the average American diet. The RDA set in 2000 for an average adult of good health is 75-90 $\mathrm{mg}$ (Anonymous, 2004). Too much vitamin C (above $500 \mathrm{mg}$ ), generally seen with very high levels of supplementation, may be dangerous, especially for those at risk of iron overload (Fleming et al., 1998). Consuming five servings of fruits and vegetables each day can result in an intake of about $200 \mathrm{mg}$ of vitamin C. Citrus fruits are a particularly good source of vitamin $\mathrm{C}$, with one medium orange or grapefruit providing approximately $70 \mathrm{mg}$ and 56 $\mathrm{mg}$, respectively. A $225 \mathrm{ml}$ glass of orange juice contains approximately $125 \mathrm{mg}$ of vitamin C (Whitney and Rolfes, 1999).

Among other vitamins present in fresh citrus fruit are compounds of the vitamin B complex. Folic acid, which is heat-sensitive and lost in food processing, can be obtained from fresh oranges, mandarins, and grapefruits. Folic acid or folate is required for the multiplication and maturation of red blood corpuscles; its deficiency can result in a type of anaemia. Folic acid plays a role in metabolic pathways by the formation of purine and pyrimidine nucleotides as well as certain amino acid conversions. Since growth requires proteins and nucleic acid synthesis, growing children and pregnant women are more sensitive to its deficiency (Ladaniya, 2008). Folate has also been associated with a reduced risk of heart disease by lowering blood serum homocysteine levels. Women at child-bearing age and those at the greatest risk of coronary heart diseases need to take sufficient folate in their diet (Widmer and Stinson, 2000). In the United States, recommended daily intake of folate is $180 \mathrm{mcg}$ for females and $200 \mathrm{mcg}$ for males. Over the past decade, however, it has become clear that higher levels of folic, $400 \mathrm{mcg}$, are associated with the prevention of neural tube defects, a severe birth defect (Center for Disease Control and Prevention, 1992). Thiamin (Vitamin $\mathrm{B}_{1}$ ) content ranges from 90 to $280 \mathrm{mcg}$ in a serving of $177 \mathrm{ml}$ of oranges, juice, which is 6-18\% of the USRDA (United States Recommended Daily Allowance)*.

\footnotetext{
* http://1stholistic.com/nutrition/hol_nutrition-RDA.htm
}

Citrus fruits are also a source of the $\mathrm{B}_{6}$ vitamins, known as pyridoxal, pyridoxamine and pyridoxine. These are interchangeable in the body. Some types of stomatitis and a type of anemia have been shown to be cured by the administration of pyridoxine. The average intake of $0.6-2.5 \mathrm{mg}$ of $\mathrm{B}_{6}$ is considered sufficient for all age groups of Indians (Gopalan et al., 1999).

\section{PHYTOCHEMICALS}

The effects of flavonoids from citrus juices, particularly those found in oranges and grapefruit, on blood circulation, as well as their anti-allergenic, anti-carcinogenic, and antiviral properties have been discussed by Rice-Evans et al. (1997), Filatova and Kolesnova (1999), who reviewed the antioxidant properties of phenolic compounds.

The effects of the citrus bioflavonoid naringin were tested by using it as a supplement in a high-cholesterol diet (Shin et al., 1999). A research team, from the University of East Anglia, UK, reported that women consuming the highest amounts of flavanones, a subclass of flavonoids that are found in especially high levels in citrus fruits, were associated with up to a $19 \%$ reduction in stroke risk, compared to those in the group who consumed the lowest amount (Cassidy et al., 2012).

\section{ROLE OF CITRUS FRUIT IN REDUCING RISK OF HU- MAN DISEASES}

Dietary fibre is reported to lower the incidence of ischemic heart diseases (Trowell, 1972). Synthetic fibrous substances have been utilised to promote the lowering of blood cholesterol from the intestinal lumen. Garvin et al. (1965) and Resnicow et al. (1991) reported that a type of strict vegetarian diet that is typically very low in saturated fat and dietary cholesterol and high in fibre can help children and adults maintain or achieve a desirable blood lipid level. Each $1 \%$ reduction in blood cholesterol yields an approximately $2 \%$ reduction in risk of coronary heart disease; thus a $7.6 \%$ decrease translates to a $15 \%$ decrease in the risk of coronary heart disease. Thus, without drastically changing lifestyle and/or diet, cholesterol levels can be lowered, and it also has been established that atherosclerosis is retarded in pigs fed a grapefruit pectin atherogenic diet (Attaway and Moore, 1992). These findings are important for people who have established atherosclerosis and whose only remedy at present is bypass surgery. These studies all indicated beneficial aspects of eating oranges and tangerines, showing that certain compounds, mostly flavonones, are promising for lowering low density lipoprotein cholesterol (so-called "bad cholesterol"), without causing any harmful side effects. Studies conducted by USDA with KGK Synergise Inc, Canada, have also shown that antioxidant compounds (called polymethoxylatedflavors, or PMF) are the most potent in reducing cholesterol (Anonymous, 2004b). Diets rich in citrus and citrus- based products have been negatively correlated with the risk of cardiovascular disease. Studies have 
been conducted to determine whether naringenin and hesperetin, two major flavanones in citrus plants, influence endothelium nitric oxide production (Liu et al., 2008). Limonoids (a group of triterpenoids) in citrus fruits possess important biological activity. The similar chemical structure of citrus limonoids to those of recognised anti-tumour agents led to their evaluation as potential anti-tumour agents in mammalian systems. Studies in mice showed that citrus limonoids induced a significant amount of the chemical carcinogen detoxifying enzyme system glutathione-s-transferase in the liver and intestinal mucosa. In-vitro tests with human breast cancer cells have shown that limonoids have significant anti-tumour activity (Manners and Hasegawa, 2000). Consumption of peel products is associated with reduced risk of squamous-cell carcinoma of the skin, as reported by I. A. Hakin and R. B. Harris of the Arizona Cancer Center (Anonymous, 2004c). Modified citrus pectin was also observed to interfere with the metastasis of other cancer cells. The alcohol of citrus peel is active in inducing apoptosis in tumour cells without affecting normal cells and can revert tumour cells back to a differentiated state. Applying peel extracts can inhibit the growth of melanoma and other skin cancer cells (Anonymous, 2004c).

Orange juice has also been reported to prevent the formation of kidney stones, due to the presence of citrates (Anonymous, 2006). Kidney stones are formed when urine is too concentrated, causing minerals and other chemicals in the urine to bind together. The studies of Dr. Clarita Odvima, UT, South-Western Medical Centre, indicated that orange juice increased the level of citrates in urine and reduced crystallisation of uric acid and calcium oxalate (Anonymous, 2006). The study indicated that potassium citrate, a generally prescribed medicine, had gastrointestinal side effects in some patients and therefore orange juice was the better option.

\section{CONCLUSIONS}

Orange juices have been shown to provide several important health benefits, particularly for the cardiovascular system, bone and skin health, brain health and cognitive functions, aging and also cancer. However the number of clinical studies available remains limited and significant efforts are necessary to provide irrefutable proof of these benefits in human.

\section{REFERENCES}

Anonymous (2004a). Food and Nutrition Board. Recommended Dietary Allowances. $9^{\text {th }}$ revised edition. Washington: National Academy of Sciences. http://www.iom.edu/Global/News\%20Announcements/ /media/Files/Activity\%20Files/Nutrition/DRIs/DRI_Summary_Listing.pdf

Anonymous (2004b). Healthy citrus. Citrus Industry Florida, 85 (8), 40.

Anonymous (2004c). Citrus buzz. Citrus Industry Florida, 85 (3), 5-6.
Anonymous (2006). Orange juice prevents recurrence of kidney stones. The Hitavada, September 2.

Araujo, P. E. (1977). Role of citrus fruit in Human Nutrition. In: Nagy, S., Shaw, P.E., Veldhuis, M.K. (eds.). Citrus Science and Technology (pp. 1-32). WestPort, CT: AVI Publishing Co.

Attaway, J. A., Moore, E. I. (1992). Newly discovered health benefits of citrus fruits and juices. In: Proceedings of the $7^{\text {th }}$ International Citrus. Congress, Acireale, Italy. Vol. 3 (pp. 1136-1139). Acireale (Italy): International Society of Citriculture.

Ballot, D., Baynes, R. D., Bothwell, T. H., Gillooly, M., Macfarlane, B. L., Macphail, A. P., Lyons, G., Derman, D. P., Bezwoda, W. R., Torrance, J. D., Bothwell, J. E., Mayet, F. (1987). The effects of fruit juices and fruits on the absorption of iron from rise meal. J. Brit. Nutr., 57, 555-559.

Cassidy A., Rimm, E.B., O'Reilly, É.J., Logroscino, G. (2012). Dietary flavonoids and risk of stroke in women. Stroke, 43 (4), 946-951.

Church, C. J., Church, W. A. (1970). Food Values of Commonly Used Portions of Fruits and Vegetables. Philadelphia, PA: Lippincott Publishing Company,

Cleveland, L. E., Goldman, J. D., Borr, L. G. (1996). Continuing Survey of Food Intakes by individuals diet and Health Knowledge Survey. Retrieved August, 27, 2012, from

http://www.ars.usda.gov/SP2UserFiles/Place/12355000/pdf/Tbs1994.PDF

Fleming, D., Jacques, P., Dallal, G., Tucker, K., Wilson, P., Wood, R. (1998). Dietary determinants of iron stores in a free living elderly population: The Framingham Heart Study. Amer. J. Clin. Nutr., 67, 722-733.

Garvin, J. E., Forman, D. T., Eiseman, W. R., Phillips, C. R., (1965). Lowering of human serum cholesterol by an oral hydrophilic colloid. Abstract. Proc. Soc. Exp. Biol. Med., 120 (3), 744-746.

Gopalan, C., Sastri, V. P. R., Balasubramaniam, S. C. (1999). Nutritive Value of Indian Foods. Hyderabad: National Institute of Nutrition (Indian Council of Medical Research), 156. pp.

Gutherie, H., Picciano, M. (1995). Human Nutrition. St. Louis, MO: Mosby.

Ladaniya M. S. (eds.). (2008). Citrus Fruit Biology, Technology and Evaluation. Amsterdam: Elsevier. 558 pp.

Liu, L., Xu, D. M., Cheng, Y. Y. (2008). Distinct effects of naringenin and hesperetin on nitric oxide production from endothelial cells. J. Agr. Food Chem., 56 (3), 824-829.

Manners, G. D., Hasegava, S. (2000). Citrus limonoids: Potential chemoprevetative agents. In: Proceedings of the $9^{\text {th }}$ Citrus Congress, 3-7 December 2000, Orlando, Florida (p. 61). Orlando.

Nishimura, K., Yoshida, N., Kosaka, K. (1992). Absorption of calcium on dietary fibre from 'Konatsu', a local orange grown in Kochi Prefecture. $J$. Jap. Soc. Nutr. Ed. Sci., 45, 545-550.

Resnicow, K., Barone, J., Engle, A., Miller, S., Haley, N. J., Fleming, D., Wynder, E. (1991). Diet and serum lipids in vegan vegetarians: A model for risk reduction. J. Amer. Dietic Assoc., 91, 447-453.

Shin, Y. W., Bok, S. H., Jeong, T. S., Bae, K. H., Jeoung, N. H., Choi, M. S., Lee, S. H., Park, Y. B. (1999). Hypocholesterolemic effect of naringin associated with hepatic cholesterol regulating enzyme changes in rats. J. Vit.. Nutr. Res., 69 (5), 341-347.

Trowell, H. (1972). Ischemic heart disease and dietary fiber. Amer. J. Clin. Nutr. 25, 926-932.

Whitney, E., Rolfes, S. (1999). Understanding Nutrition. $8^{\text {th }}$ edn. Belmont, Ca: West/Wadsworth.

Widmer, W. W., Stinson, W. S. (2000). Health benefits of folate in orange juice. In: Proceedings of the $9^{\text {th }}$ Citrus Congress, 3-7 December 2000, Orlando, Florida (p. 62). Orlando.

Филатова И. А., Колеснов А. Ю. (1999). Значение флавоноидов цитрусовых соков в профилактике заболеваний [Significance of flavonoids from citrus juices in disease prevention]. Пищевая промыиленность, № 8, 62-63. 


\section{VESELĪBU VEICINOŠI K̦ĪMISKIE KOMPONENTI APELSĪNU SULĀ}

Citrusaug̣̣i un citrusaug̣̣u sulas ir lielisks veselības avots — veselību veicinošu vielu uzṇemšana brokastīs. 150-200 ml glāze apelsīnu sulas nodrošina daudzas veselībai labas uzturvielas, kuras nepieciešams uzņemt katru dienu. Apelsīni satur C vitamīnu, tiamīnu, riboflavīnus, A vitamīnu, D vitamīnu, E vitamīnu, pantotēnskābi, B6 vitamīnu, folijskābi. Citrusaug̣̣u sulas satur minerālvielas — kalciju, kāliju, dzelzi, cinku, magniju, varu, fosforu, kas ir daļa no svarīgās enzīmu sistēmas cilvēka organismā. Turklāt citrusaugḷu sula satur arī vairākus savienojumus - flavonoīdus un citus veselību veicinošas vielas. Ir simtiem noderīgu produktu un vielu ar šādām īpašībām, un to pirmavots ir citrusaug̣̣i. Ir daudz patentu par veselīgiem produktiem, kuru izgatavošanā izmantotas citrusaug̣̣u vielas. Svarīgu ar iekaisumiem saistītu slimību ārstēšanā izmanto fitoḳīmiskās vielas, saistībā ar tādām slimībām kā oksidatīvais stress, metabolais sindroms (diabēts), sirds un asinsvadu slimības, kaulu slimības (osteoporoze), ādas novecošana, kognitīvo funkciju un smadzeņu slimības, novecošana, alerğijas, imūnsistēmas funkcijas un vēzis. Klīniskajos pētījumos iegūtie un publicêtie dati liecina, ka apelsīnu sula un hesperidīns veicina slāpekḷa oksīda ražošanu cilvēkā. Ir pierādīts, ka apelsīnu sula nodrošina vairākus būtiskus veselības uzlabojumus, galvenokārt, saistībā ar sirds un asinsvadu slimībām, kaulu un ādas veselību, smadzenu darbību, kognitīvajām funkcijām, novecošanu un vēzi. Tomēr pieejamo klīnisko pētîjumu skaits ir ierobežots, ir nepieciešami jauni pētîjumi, lai sniegtu neapgāžamus pierādījumus šiem cilvēka veselības uzlabojumiem. 


\title{
NUTRITION-RELATED DISEASES IN THE MEDICINES REIMBURSEMENT SYSTEM OF LATVIA
}

\author{
Diāna Arāja \\ Faculty of Economics and Management, University of Latvia, Aspazijas bulv. 5, Rīga LV-1050, LATVIA; \\ Diana.Araja@apollo.Iv
}

Communicated by Ingrīda Rumba

\begin{abstract}
In Latvia, the medicine reimbursement system for outpatient treatment operates under conditions of limited resources, and the state budget financing has been reduced in recent years. Under such circumstances, a necessity to identify additional possibilities to optimise resources allocation to health care programmes and prevention activities is important. The aim of this research was to identify nutrition-related diagnoses in the Latvian medicine reimbursement system and to determine potential efficiency of the resource allocation to complementary nutrition programmes. To meet the aim defined, theoretical research methods (analysis of legislative documents and special literature analysis) were used alongside empirical research methods (data collection: documentary analysis, statistical database analysis). The results of this research showed that the largest amount of reimbursed diagnoses, such as cardiovascular diseases, diabetes, cancer, digestive diseases, and osteoporosis, are identified as nutrition-related diagnoses in the review of special literature. Determination of the efficiency of complementary nutrition programmes is a crucial issue in the context of the evidence-based medicine, both in terms of direct and indirect costs to society and government, and in terms of disability-adjusted life years and other health determinants directly related to patients. For this reason, possibilities for the evaluation of relative efficiency of the nutrition programmes for reimbursed diagnoses are investigated in depth.
\end{abstract}

Key words: health care, allocation of resources, allocative and technical efficiency.

\section{INTRODUCTION}

The Latvian medicine reimbursement system for outpatient treatment has developed starting from the 1990s. The 2006 Regulations No. 899 of the Cabinet of Ministers of the Republic of Latvia, "Procedures for the Reimbursement of Expenditures for the Acquisition of Medicinal Products and Medicinal Devices Intended for Out-patient Medical Treatment" (hereafter - Regulations No. 899), regulate this system at the present. The procedures for reimbursement are a set of measures that provide patients with an opportunity to acquire medicinal products and medical devices, the expenditures for the acquisition of which are completely or partially covered by funds from the state budget for the current year, granted for the reimbursement of expenditures for the acquisition of medicinal products in accordance with these regulations, or by the funds granted in accordance with the Social Security Network Strategy (Anonymous, 2006).

Nineteen groups of diagnoses are reimbursed in accordance with the Regulations No. 899 (groups of diagnoses are classified by the International Statistical Classification of Diseases and Relates Health Problems $10^{\text {th }}$ Revision (ICD-10)). Expenditures for the reimbursement of medicinal products are covered under the following reimbursement categories (Anonymous, 2006):

- Category I - reimbursement in the amount of $100 \%$, if it has been determined that a patient has a chronic, lifethreatening disease or a disease, which causes serious irreversible disability and the medical treatment of which requires the use of the respective medicinal products in order to maintain the patient's vital functions;

- Category II - reimbursement in the amount of $75 \%$, if it has been determined that a patient has a chronic disease, in the medical treatment of which the maintenance of the patient's vital functions is made difficult or which causes serious disability without the use of the respective medicinal products; and

- Category III - reimbursement in the amount of 50\%, if it has been determined that a patient has a chronic or acute disease, in the medical treatment of which the use of the respective medicinal products is necessary in order to maintain or improve the patient's state of health or in the case where vaccines are paid for from the funds granted for reimbursement. 


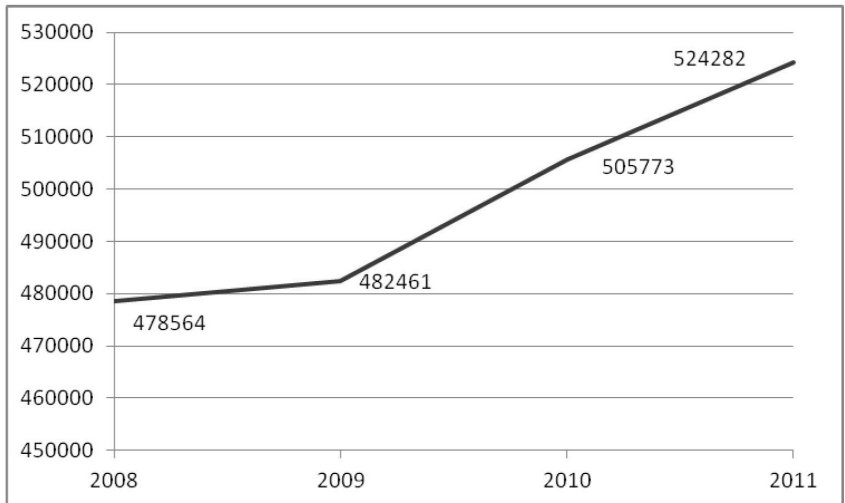

Fig. 1. Number of patients treated in the reimbursement system for outpatient treatment in Latvia, 2008-2011 (Anonymous, 2012).

The number of patients treated through the reimbursement system has increased yearly (Fig. 1). The biggest number of patients is treated through the reimbursement system in the group of diagnoses "Diseases of the circulatory system", "Endocrine, nutritional and metabolic diseases" and "Diseases of the respiratory system", and the number of patients ioural disorders" in which the number of patients has declined in 2011) (Fig. 2).

In spite of a relatively low number of patients with diseases of the digestive system, this group is one of the more important in mortality data (Table 1). Table 1 includes data of mortality in Latvia and in neighbouring Baltic States.

The largest part of the health care budget resourses for the reimbursement system is allocated for diseases of the circulatory system, endocrine, nutritional und metabolic diseases and neoplasms (Fig. 3). However, the data on total expenditure for reimbursed medicinal products (budget allocation and patients' co-payment) show that the patients' copayment has increased in circumstances of reduced budget is rising annually (excluded diagnoses "Mental and behav-

DEATHS BY CAUSE PER 100000 POPULATION IN ESTONIA, LATVIA AND LITHUANIA BY MAJOR GROUPS OF CAUSES (Anonymous, 2010)

\begin{tabular}{|c|c|c|c|}
\hline \multirow[t]{2}{*}{ Cause of death } & \multicolumn{3}{|c|}{$\begin{array}{c}\text { Deaths by cause per } 100000 \\
\text { population in Baltic States }\end{array}$} \\
\hline & Estonia & Latvia & Lithuania \\
\hline Diseases of the circulatory system & 652.9 & 727.1 & 718.8 \\
\hline Neoplasms & 269.0 & 273.6 & 251.2 \\
\hline $\begin{array}{l}\text { Injury, poisoning and certain other } \\
\text { consequences of external causes }\end{array}$ & 84.7 & 94.1 & 123.1 \\
\hline $\begin{array}{l}\text { Symptoms, signs and abnormal clinical } \\
\text { and laboratory findings, not elsewhere } \\
\text { classified }\end{array}$ & 23.7 & 85.0 & 16.7 \\
\hline Diseases of the digestive system & 45.9 & 46.7 & 67.5 \\
\hline Diseases of the respiratory system & 31.7 & 29.6 & 38.9 \\
\hline
\end{tabular}

allocation, as the need for treatment, based on growing patients number, increases independently of budget resources allocated (Fig. 4). In these circumstances, taking into account the limited state budget for the medicine reimbursement system and patient resources, the aim of this research was to identify additional possibilities to optimise resource allocation to the health care, based on nutrition-related diagnoses in the medicine reimbursement system and potential efficiency of complementary nutrition programmes.

\section{MATERIALS AND METHODS}

To meet the aim defined, theoretical research methods (analysis of legislation, special literature analysis and analysis of electronic resources) were used alongside empirical research methods (data collection: document analysis, statistical database analysis). For data processing and analysis, statistical analysis methods (comparison, grouping, calculation of averages) and methods of economic analysis were used.

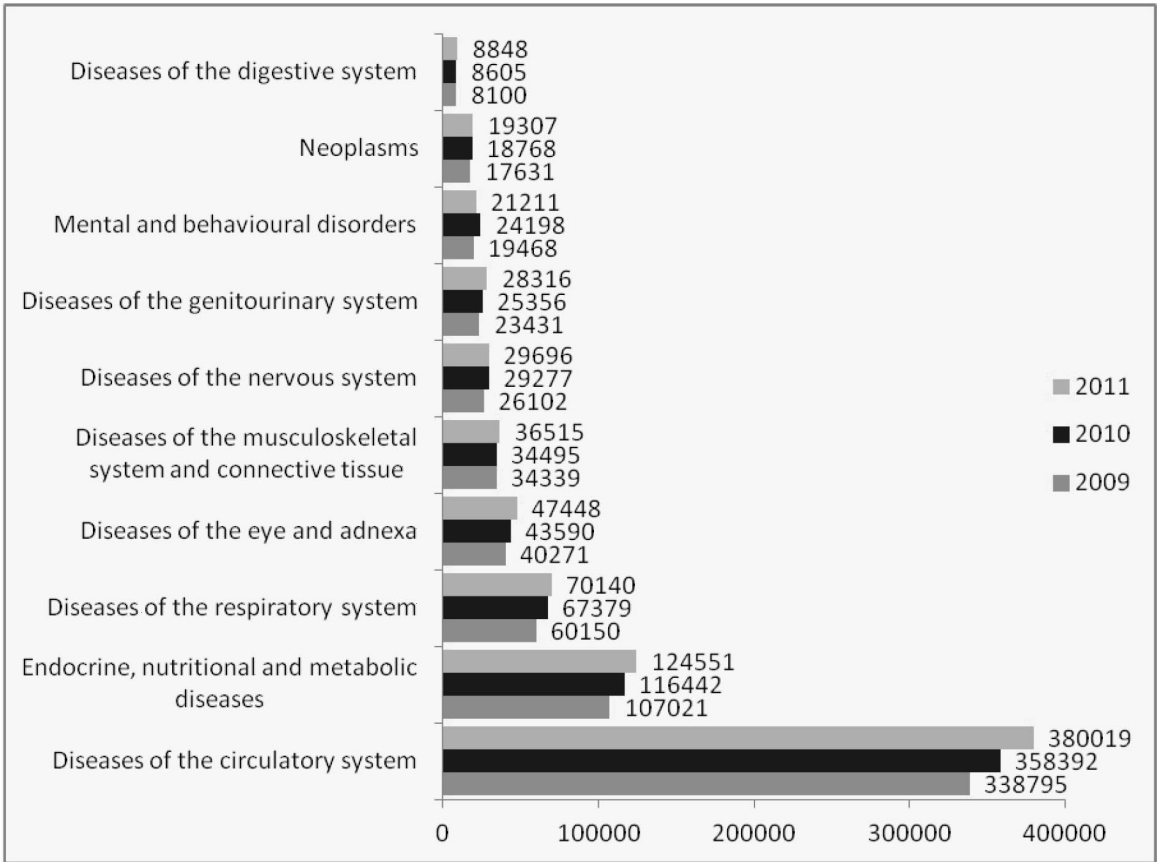

Fig. 2. Number of patients treated in the reimbursement system for outpatient treatment by the ten biggest diagnoses groups in Latvia, 2009-2011 (Anonymous, 2012). 


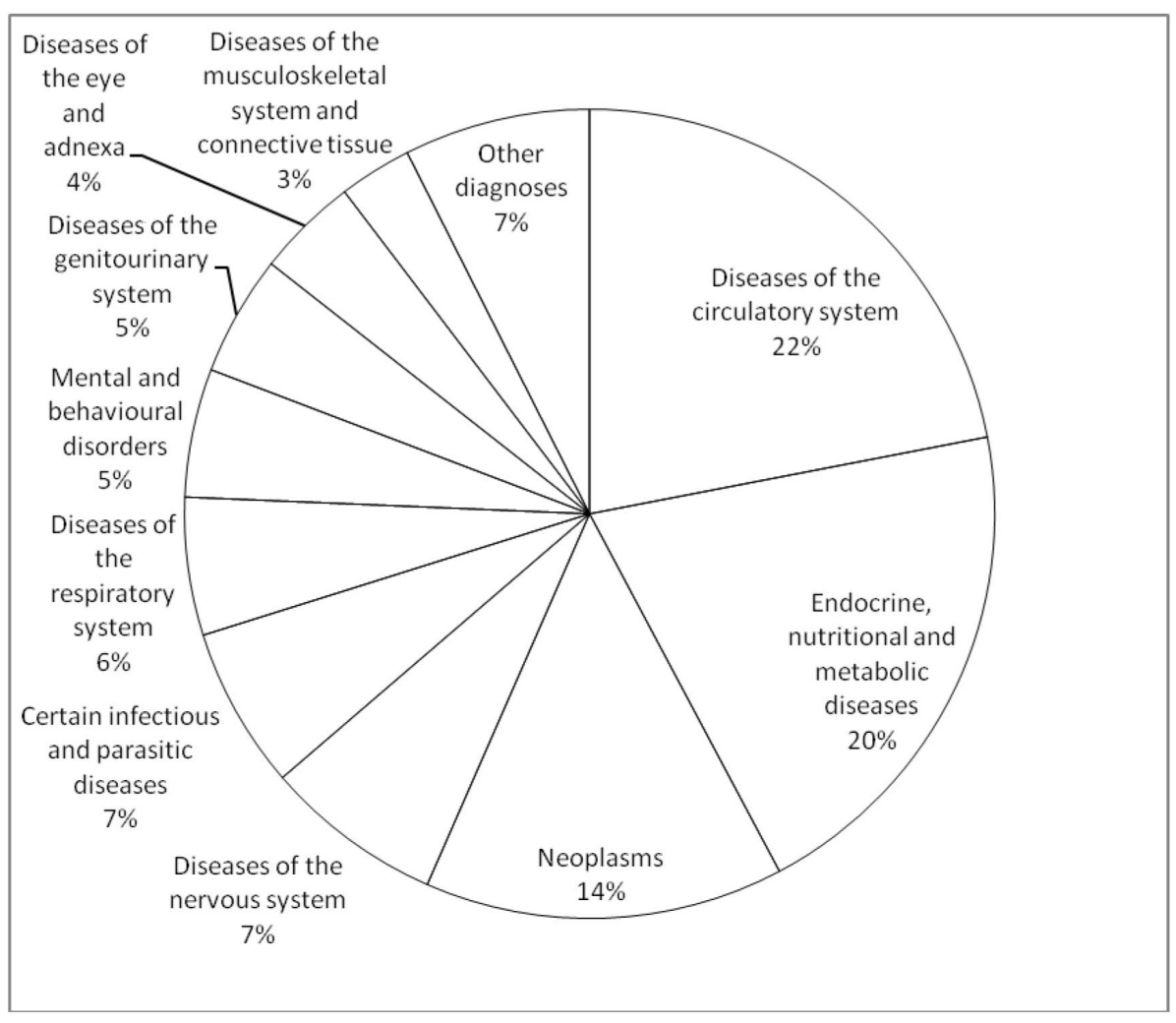

Fig. 3. Health care budget expenditure by groups of diagnoses in Latvia, 2011 (Anonymous, 2012).

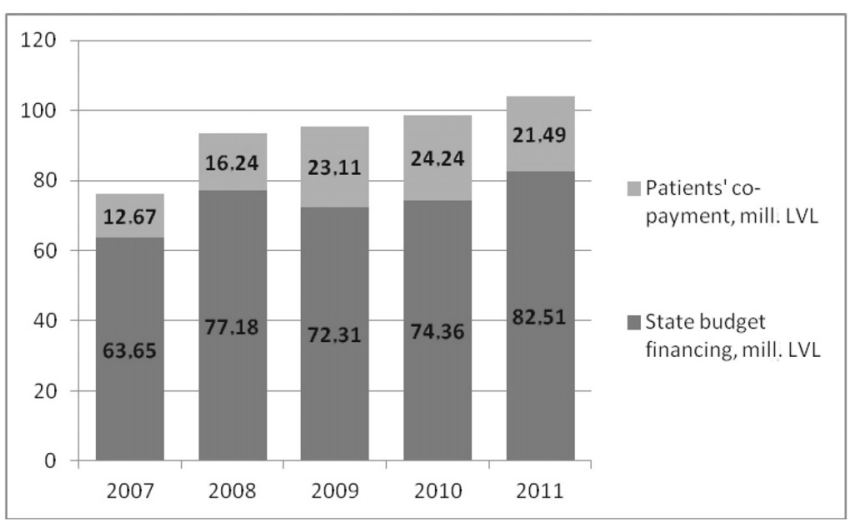

Fig. 4. State budget recourses allocated for the reimbursement system and patients' co-payment in Latvia, 2007-2011 (Anonymous, 2012).

\section{RESULTS}

The World Health Organisation in the Report of a Joint WHO/FAO Expert Consultation "Diet, Nutrition and the Prevention of Chronic Diseases", 2003, indicated that chronic diseases are largely preventable diseases. Although more basic research may be needed on some aspects of the mechanisms that link diet to health, the available scientific evidence provides a sufficiently strong and plausible role of prevention. Beyond the appropriate medical treatment for those already affected, the public health approach of primary prevention is considered to be the most cost-effective, affordable and sustainable course of action to cope with the chronic disease epidemic worldwide. The above mentioned report reviewed the evidence on the effects of diet and nutrition on chronic diseases and made recommendations for public health policies and strategies that encompass socie- tal, behavioural and ecological dimensions. In setting out ways to decrease the burden of chronic diseases (such as obesity, type 2 diabetes, cardiovascular diseases (including hypertension and stroke), cancer, dental diseases and osteoporosis), the report proposed that nutrition should be placed at the forefront of public health policies and programmes.

In the present study, a literature review provided sufficient evidence that the largest part of the reimbursed diagnoses in Latvia are nutrition-related diseases (in the following list the directly nutrition-related diagnoses are marked in bold and the indirectly nutrition-related diagnoses in italic):

\section{Specific infectious and parasitic diseases}

\section{Neoplasms}

III. Diseases of the blood and blood-forming organs and certain disorders involving the immune mechanism

IV. Endocrine, nutritional and metabolic diseases

V. Mental and behavioural disorders

VI. Diseases of the nervous system

VII. Diseases of the eye and adnexa

VIII. Diseases of the ear and mastoid process

\section{Diseases of the circulatory system}

X. Diseases of the respiratory system

\section{Diseases of the digestive system}

XII. Diseases of the skin and subcutaneous tissue 
XIII. Diseases of the musculoskeletal system and connective tissue

\section{Diseases of the genitourinary system}

\section{Pregnancy, childbirth and the puerperium}

\section{Specific conditions originating in the perinatal} period

XVII. Congenital malformations, deformations and chromosomal abnormalities XVIII. Injury, poisoning and certain other consequences of
external causes

\section{Factors influencing health status and contact with health services}

The diagnosis of diabetes mellitus, as an example, justifies the approach of the direct and indirect relation with nutrition.

There are two main types of diabetes mellitus:

- Type 1 diabetes (T1DM) usually develops in childhood and adolescence and patients require lifelong insulin injections for survival;

- Type 2 diabetes (T2DM) usually develops in adulthood and is related to obesity, lack of physical activity, and unhealthy diets. This is the more common type of diabetes (representing 90\% of diabetic cases worldwide (Diabetes Programme, WHO, 2012), as well as in Latvia (Anonymous, 2012g) and treatment may involve lifestyle changes and weight loss alone, or oral medications or even insulin injections.

In Latvia the direct treatment of type 2 diabetes patients (more than 70000 patients) consumes almost 15\% of the overall state budget for the reimbursement system (Anonymous, 2012g). At the same time, diabetes mellitus causes a lot of complications, such as following (Anonymous, 2012a):

- Diabetes mellitus increases the risk of heart disease and stroke $-50 \%$ of people with diabetes die of cardiovascular disease (primarily heart disease and stroke).
- Combined with reduced blood flow, neuropathy in the feet increases the chance of foot ulcers and eventual limb amputation.

- Diabetic retinopathy is an important cause of blindness, and occurs as a result of long-term accumulated damage to the small blood vessels in the retina. After 15 years of diabetes, approximately $2 \%$ of people become blind, and about $10 \%$ develop severe visual impairment.

- Diabetes mellitus is among the leading causes of kidney failure - 10-20\% of people with diabetes die of kidney failure.

- Diabetic neuropathy is damage to the nerves as a result of diabetes, and affects up to $50 \%$ of people with diabetes mellitus. Although many different problems can occur as a result of diabetic neuropathy, common symptoms are tingling, pain, numbness, or weakness in the feet and hands.

- The overall risk of dying among people with diabetes mellitus is at least double the risk of their peers without diabetes mellitus.

In 2011, the treatment of diabetes mellitus complications was ensured for 53400 patients, there were 314 direct disability cases and 486 deaths caused by diabetes in Latvia (Anonymous, 2012g). In the author's opinion, the calculation of the Potential Years of Life Lost (PYLL) and Disability-Adjusted Life Years (DALY) are the most appropriate methods to evaluate the economic impact of this disease, but for this purpose, data of mortality by age and gender should be used, which are not available on the statistic database websites.

Data on morbidity by groups of age and gender show that under age of 50 years the diabetes mellitus prevalence is higher for males, but beginning from 50 years the morbidity sufficiently increases with higher prevalence for females. The number of patients is particularly high in the 7080-year age group of (Anonymous, 2012b). According to provisional results of the Central Statistic Bureau, the average life expectancy of inhabitants will rise (Anonymous, 2012b), and taking into account the population age structure (Fig. 5), an increase in the number of patients needed to

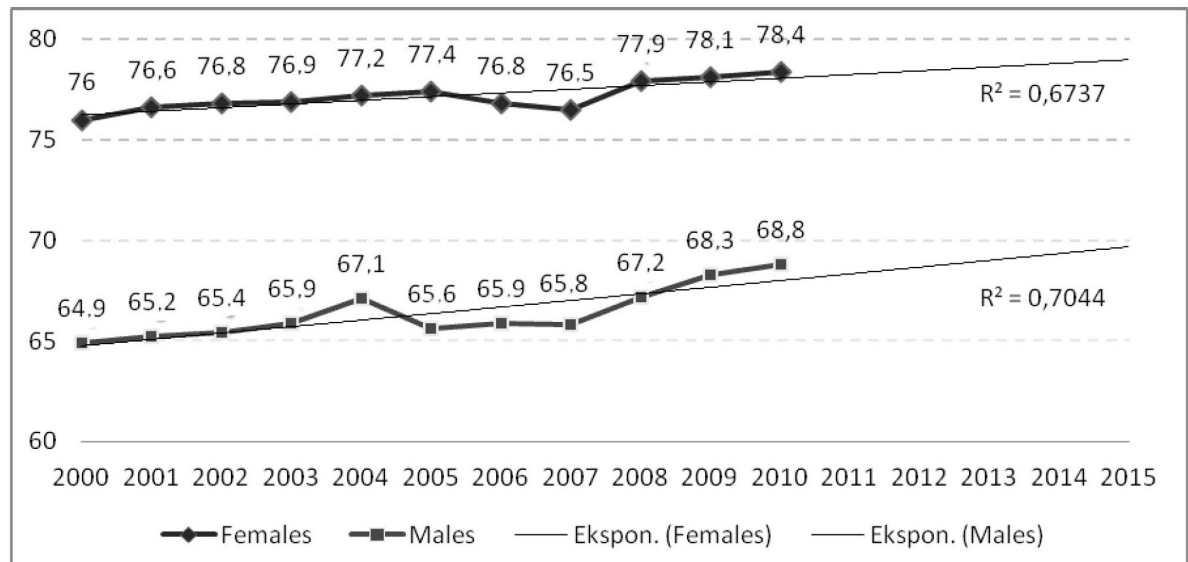

Fig. 5. Life expectancy at birth in Latvia, 2000-2010, and forecasts (Anonymous, 2011). 
treat is forecast not only for diabetes mellitus, but also for the other chronic diseases.

In these circumstances the search and assessment of alternative treatments, based on prevention, become important.

\section{DISCUSSION}

The author, by analysis of the medicine reimbursement system from allocative and technical efficiency points of view, notes that there has been a trend towards technical efficiency, rather than overall economic efficiency (Fig. 6). Figure 6 is based on the classic framework of the Farrell model, which makes it possible to decompose overall efficiency into technical and allocative efficiency. The output of the model is the treated patient, which is the outcome of two input variables (medicines, alternatives). Under the assumption that the production function is linearly homogeneous, the efficient unit isoquant shows all technically efficient combinations. In circumstances of a limited budget, represented by isocost line A1A2, the reimbursement result point is located at point $\mathrm{S}$ on line A1A2, which insures allocative efficiency, but not technical and overall efficiency, and therefore the patient does not receive complete treatment. There is a tendency to attempt to achieve technical efficiency at point $\mathrm{R}$ by increasing the budget assignation for medicine reimbursement (isocost line B1B2), but the treatment alternatives (nutrition programme, physician's time by consultation or manual therapy etc.) are not evaluated sufficiently. It should be taken into into account that the overall economic efficiency would be achieved by the evaluation and wider use of the alternatives (point $\mathrm{Q}$ on line A1A2). Any point on the isoquant line has technical efficiency, but only $\mathrm{Q}$ receives technical efficiency at minimum cost, by combination with allocative efficiency, to achieve the overall efficiency - the product of technical and allocative efficiency.

In the author's view, at least for individual reimbursement in the case when standard medicine therapy does not achieve the desired therapeutic effect, both the relative effectiveness of comparable medicines and other health technology assessment should be considered. In accordance with the International Society for Pharmacoeconomics and

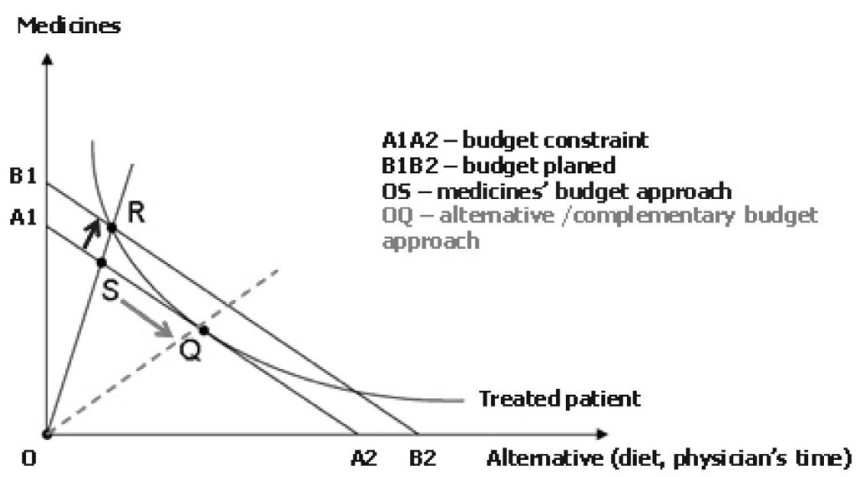

Fig. 6. Allocative, technical and overall efficiency in health care (Anonymous, 2008).
Outcomes Research, the goal of health technology assessment (HTA) is to provide policymakers with information on policy alternatives. Health care technology within the concept of HTA is defined broadly as consisting of medicines, biologicals, devices, equipment, supplies, medical and surgical procedures, support systems, organisational, delivery and managerial systems (Anonymous, 2003). For example, in the United Kingdom, competent authorities carry out complex HTA, which includes medicines, medical devices, vaccinations, screening programmes, medical staff services, procedures and public health programmes (Garrido et al., 2008). In Latvia, the evaluation of the economic efficiency is centered on assessment of medicines and medical devices, but there is not a competent authority for evaluation of the comparative efficiency of all applicable health technologies.

The essential role of the alternatives, for example, in the case of above mentioned type 2 diabetes, is justified by several randomised controlled trials (RCT), which show that lifestyle interventions based on diet and exercises, reduce the proportion of people with glucose tolerance that would otherwise develop T2DM. The results of RCT collected and evaluated in an academic dissertation on Assessment of Risk and Prevention of Type 2 Diabetes in Primary Health Care (Saaristo, 2011) showed that the 1-6 years incidence of diabetes was reduced in lifestyle trials by $30-60 \%$ compared with a control group. At the same time, the preventable use of Metforminum without lifestyle interventions showed less than $30 \%$ relative risk reduction of T2DM. Follow-up studies of the major lifestyle trials in prevention of type 2 diabetes in seven-year period showed a relative risk reduction of T2DM by 34-43\%, compared to the control group. Thus, these trials showed that T2DM can be prevented or delayed by lifestyle interventions. In scope of above mentioned academic dissertation, the effect of lifestyle interventions on weight and its association with glucose tolerance was evaluated in individuals at high risk for diabetes in a one-year follow-up. In total $17.5 \%$ of them lost more than $5 \%$ of weight. Their relative risk for diabetes decreased $69 \%$ compared with the group that maintained their weight (Saaristo, 2011).

Coming back to the issue of the limited budget and patient resources for the medicines reimbursement system, in the author's opinion a discussable question is also, data from the Central Statistical Bureau of Latvia that shows, based on the composition and structure of average consumption expenditure per household member, one third of the income of Latvian inhabitants is spent for food (Anonymous, 2012e). Thus, the rational diet is both the potential for disease prevention and saving resources for a healthy lifestyle.

The main conclusions of this research are following:

- The largest number of reimbursed diagnoses, such as cardiovascular diseases, diabetes, cancer, digestive diseases, osteoporosis, are identified as nutrient-related diagnoses by a special literature review. 
- The nutrient-related diagnoses contribute more than half of the state budget resources allocated to the reimbursement system in Latvia.

- The budget approach could be changed from medicinebased to an alternatives-based approach.

- There are not sufficient data to calculate indicators such as Potential Years of Life Lost (PYLL) and Disability-Adjusted Life Years (DALY), which can be used in economic assessment of treatment and preventive programmes.

- Prevention programmes for potential patients and educational programmes for patients should be encouraged.

- Data on composition and structure of consumption expenditure average per household member show that one-third of income is spent for food, and thus the Hippocrates' quote "Let food be thy medicine and medicine be thy food" can be important and useful also in the present epoch.

\section{REFERENCES}

Anonymous (2003). Diet, Nutrition and the Prevention of Chronic Diseases. WHO Technical Report Series 916, Report of a Joint World Health Organization. Food and Agriculture Organization of the United Nations Expert Consultation. Geneva: World Health Organization. http://www.fao.org/docrep/005/AC911E/AC911E00.HTM

Anonymous (2006). Procedures for the Reimbursement of Expenditures for the Acquisition of Medicinal Products and Medicinal Devices Intended for Out-patient Medical Treatment. Regulations No. 899 of the Cabinet of Ministers of the Republic of Latvia (adopted 31 October 2006, with amendments). http://www.likumi.lv/doc.php?id=147522

Anonymous (2008). Health Care Efficiency Measures: Identification, Categorization, and Evaluation. The Agency for Healthcare Research and Quality of the U.S. Department of Health \& Human Services. http://www.ahrq.gov/qual/efficiency/

Anonymous (2011). Composition and structure of consumption expenditure average per household member per month, 2010. Central Statistical Bureau of Latvia.

http://www.csb.gov.lv/en/composition-and-structure-consumption-expen diture-average-household-member-month
Anonymous (2011). Changes of demographic situation in Latvia in 2010. Central Statistical Bureau of Latvia.

http://www.csb.gov.lv/en/notikumi/changes-demographic-situation-latvia -2010-31979.html

Anonymous (2012a). Diabetes Programme. World Health Organization. http://www.who.int/diabetes/en/

Anonymous (2012b). Cukura diabēts (Statistikas dati par pacientu skaitu sadalījumā pa reǵioniem, vecuma grupām, dzimuma, cukura diabēta tipa, terapijas veida, diabēta komplikācijām, klīnisko izmeklējumu rezultātiem no 2007. gada līdz 2011. gadam) [Diabetes Mellitus (Statistical data on patients' number, allocation by regions, age groups, gender, type of Diabetes Mellitus, treatment methods, complications, results of clinical investigation, 2007-2011)]. Centre for Disease Prevention and Control of Latvia (in Latvian). http://www.spkc.gov.lv/veselibas-aprupes-statistika/

Anonymous (2012c). Health in the Baltic Countries, 2010 (19 $9^{\text {th }}$ edition). National Institute for Health Development of Estonia, the National Health Service of Latvia, Health Information Center of Lithuania.

http://www.spkc.gov.lv/veselibas-aprupes-statistika/

Anonymous (2012d). Invaliditāte [Statistical data on disability]. Centre for Disease Prevention and Control of Latvia (in Latvian).

http://www.spkc.gov.lv/veselibas-aprupes-statistika/

Anonymous (2012e). Population Census 2011 - Key Indicators. Central Statistical Bureau of Latvia.

http://www.csb.gov.lv/en/statistikas-temas/population-census-2011-keyindicators-33613.html

Anonymous (2012f). Statistikas dati par iedzìvotāju mirstību [Statistical data on population mortality]. Centre for Disease Prevention and Control of Latvia (in Latvian).

http://www.spkc.gov.lv/veselibas-aprupes-statistika/

Anonymous (2012g). Unpublished data of the National Health Service of Latvia on the medicines reimbursement system.

Berger, M. L., Bingefors, K., Hedblom, E. C., Pashos, C. L., Torrance, G. W. (2003). ISPOR Book of Terms. Health care cost, quality, and outcomes. Health Technology Assessment (pp. 133-134). International Society for Pharmacoeconomics and Outcomes Research. USA: ISPOR Press

Garrido, M. V., Zentner, A., Busse, R. (2008). Health technology assessment and health policy-making in Europe: Current status, challenges and potential. In: Health Systems, Health Policy and Health Technology Assessment (pp. 68-70). Copenhagen: WHO Regional Office for Europe.

Saaristo, T. (2011). Assessment of Risk and Prevention of Type 2 Diabetes in Primary Health Care. Academic dissertation, University of Oulu, Finland. http://herkules.oulu.fi/isbn9789514297113/isbn9789514297113.pdf

Received 1 October 2012

\section{UZTURA ATKARĪGĀS SLIMĪBAS ZĀḶU KOMPENSĀCIJAS SISTĒMA LATVIJĀ}

Latvijā ambulatorajai ārstēšanai paredzēto zāḷu un medicīnisko ierīču iegādes izdevumu kompensācijas sistēma darbojas stingri ierobežotu valsts budžeta līdzekḷu apstākḷos, līdz ar to aktuāls kḹūst jautājums par papildus iespēju izvērtēšanu līdzekḷu izlietojuma optimizācijai, ņemot vērā arī preventīvo pasākumu nozīmīgumu. Pētījuma mērkisis ir identificēt uztura atkarīgās slimības zāḷu iegādes izdevumu kompensācijas sistēmā un novērtēt iespējas noteikt papildinošo uztura programmu potenciālo efektivitāti. Mērka sasniegšanai izmantotas teorētiskās izpētes metodes (normatīvo dokumentu un speciālās literatūras analīze) un empīriskās izpētes metodes (statistikas datu vākšana, apkopošana un analīze). Pētījuma rezultāti liecina par to, ka lielākā dal̨a kompensējamo diagnožu, tādas kā sirds un asinsvadu slimības, diabēts, onkoloğiskās slimības, gremošanas sistēmas slimības, osteoporoze, ir uztura atkarīgās slimības, un tām tiek izlietota vairāk kā puse zāḷ kompensācijas sistēmai atvēlētā budžeta. Turklāt ir virkne slimību, kas ir netieši atkarīgas no uztura, bet tās rodas kā uztura atkarīgo slimību izraisītās komplikācijas. Uz pierādījumiem balstītās medicīnas laikmetā īpaši aktuāla kḷust ārstēšanas un preventīvo pasākumu ekonomiskās efektivitātes novērtēšana. Speciālajā literatūrā ir dati par uztura programmu pozitīvo nozīmi smagu slimību novēršanā vai ietekmes mazināšanā, tomēr jāatzīmēe, ka nav izstrādāta precīza metodolog̣ija, kas ḷautu veikt medikamentozās ārstēšanas un preventīvo pasākumu salīdzinošo ekonomiskās efektivitātes novērtěšanu, lai sagatavotu ar pierādījumiem pamatotu informāciju lēmumu pienemšanai par līdzekḷ sadali. Līidz ar to šis ir turpmākās izpētes objekts. 


\title{
MICROBIOLOGICAL RISK ANALYSIS IN CATERING ESTABLISHMENTS
}

\author{
Aija Melngaile* and Daina Kārkliṇa** \\ * Institute of Food Safety, Animal Health and Environment BIOR, Lejupes iela 3, Rĩga LV-1076, LATVIA; \\ aija.melngaile@bior.gov.Iv \\ ** Faculty of Food Technology, Latvia University of Agriculture, Lielā iela 2, Jelgava LV-3001, LATVIA; \\ daina.karklina@lu.lv
}

Contributed by Daina Kārkliṇa

\begin{abstract}
The epidemiological data suggest that the food preparation process in public catering establishments involves the risk of food microbiological contamination. To develop a preventive food safety assurance system based on HACCP (Hazard Analysis and Critical Control Points) principles, adequate identification, monitoring and communication of food safety hazards are important considerations. The aim of the research was microbiological risk analysis of catering establishments. Statistical analysis was used in microbiological risk assessment and to ensure science-based proposals for control of microbiological contamination and prevention of outbreaks of food-borne infections. The results on microbiological testing of 17192 food samples and 17604 surface swab samples were analysed using the SPSS 13.0 and MS EXCEL software packages. Statistically significant differences in microbiological contamination of food and environmental surfaces with regard to Aerobic Plate Count, coliforms and S. aureus were found. Impact of technological processing on safety of ready-to-eat foods was demonstrated. Petrifilm rapid test methods were tested for use as self-control purposes. The results of the research demonstrate characteristic trends in contamination of foods and environmental objects in catering establishments and ensure scientific justification for setting priorities with regard to relevant control measures during technological processing and serving of food.
\end{abstract}

Key words: risk analysis, microbiological risk assessment, catering food safety, HACCP.

\section{INTRODUCTION}

Improvement of food quality and safety is the overall aim of food policy to achieve a higher level of protection of consumer health. Food should not contain contamination that can create risk to human health. The primary responsibility with regard to implementation of food safety legislation rests with food business operators. To fulfil legal requirements, food establishments need to establish appropriate food safety management procedures based on HACCP (Hazard Analysis and Critical Control Points) principles (Farber et al., 2000; Luning et al., 2006).

The epidemiological data suggest that food preparation processes in catering establishments are often associated with increased food microbiological contamination risk (Griffith and Clayton, 2005; Koppanen et al., 2005; Szabo, 2005; Bohm et al., 2007). Pathogenic microorganisms can enter food due to unhygienic food handling procedures, and can multiply in food due to inadequate food storage, chilling, thawing and processing parameters (Pourkomailian, 2005; Scmhid et al., 2007).
Development of preventive food safety assurance systems comprises both the identification of important food safety hazards and the introduction of regular monitoring measures in critical control points of technological processes. It is widely recognised that management of technological processes should be based on detailed analysis of product characteristics and process conditions to assess the potential impact on quality and safety of the ready-to-eat foods (Kārkliņa et al., 2005; Burlingame and Pineiro, 2007; Schaffner, 2007).

According to global food safety standards, 'risk' means a function of the probability of an adverse health effect consequential to a hazard, and 'risk analysis' means a process consisting of three interconnected components: risk assessment, risk management and risk communication (Anonymous, 2006). It should be emphasized that implementation of risk management and risk communication measures should always be based on identification of objective risk factors (Stringer, 2005; Špoğis, 2005; Rivža et al., 2007). Microbiological risk assessment can be used as a supportive tool for establishment of scientifically justified control mea- 
sures within HACCP to improve the efficiency of risk management and communication procedures (Reij M.W et al., 2004; Sprenger, 2004; Anonymous, 2005; Buchanan, 2005; Tebbutt, 2007; Hugas et al., 2007; Melngaile and Karklina, 2007; 2006; Lammerding, 2007; Fretz, 2007; Rodgers, 2005). The concept of risk analysis should be applied for development of a food safety assurance strategy of both the food businesses and the governmental food safety surveillance and control institutions (Andersen et al., 2007). It should be mentioned that catering establishments still face serious problems in relation to identification of food safety hazards and implementation of adequate monitoring procedures (Bolton et al., 2008; Eves and Dervisi, 2005; Hielm et al., 2006).

The aim of the research was to investigate the application of microbiological risk analysis in public catering establishments. In order to achieve the aim of the research, the following tasks were identified a) to assess microbiological contamination risk that results from technological processing of foods in public catering establishments, including food cross-contamination risk; b) to highlight proposals for further improvement of microbiological risk management and communication procedures in public catering establishments.

\section{MATERIALS AND METHODS}

Microbiological testing of food samples. Results on microbiological testing of 17192 food samples from catering establishments obtained in the frame of the state surveillance programme and available in the Database of the Food and Veterinary Service of Latvia, including 3152 Aerobic Plate Count tests, 4481 coliform tests, 2138 Staphylococcus aureus tests, and 5283 Salmonella spp. tests, were statistically analysed.

Microbiological testing of surface swab samples. Results on microbiological testing of 17604 surface swab samples from catering establishments that were obtained in the frame of the state's surveillance programme and available at the Database of the Food and Veterinary Service of Latvia, including 8934 coliforms' tests, 5113 S. aureus tests, and 3385 Salmonella spp. tests, were statistically analysed.

Testing methods. The following testing methods were used in the frame of the state surveillance programme: a) Aerobic Plate Count (APC) in foods was determined according to the standard method LVS ISO 4833:2003 "Microbiology. General directions for enumeration of microorganisms. Colony counting method at $30^{\circ} \mathrm{C} "$; b) Enterobacteriaceae count in foods and environmental surface swab samples was determined according to the standard method ISO 21528-2:2004 "Microbiology of food and animal feeding stuffs. Horizontal methods for the detection and enumeration of Enterobacteriaceae - Part 2: Colony - count method"; c) Staphylococcus aureus count in food samples was determined according to the standard method LVS EN ISO 6888-1/A1-2003 "Microbiology of food and animal feeding stuffs - Horizontal method for enumeration of coagulase positive Staphylococcus aureus - Part 1: Method, using environment"; d) Coliforms in surface swab samples were determined in accordance with the test method VVMDC-T-012-010.5-2000 "Methods for microbiological analysis of surface swabs - Part 2: Detection of coliforms"; e) Staphylococcus aureus in surface swab samples was tested in accordance with the test method VVMDC-T-012010.5-2000 "Method for microbiological analysis of surface swabs - Part 5: Detection of Staphylococcus aureus".

Approbation of Petrifilm rapid test method. The Petrifilm rapid test method was tested for monitoring of cleaning efficiency - disinfection procedures in catering establishment, using ready-to-use selective media for cultivation of microorganisms. Swabs were taken from 20 visually clean surfaces, taking into account known significant trends in distribution of microbiological contamination. 3M Microbiology Products (USA) for enumeration of microorganisms were used for detection of aerobic plate count (APC), Enterbacteriaceae, Escherichia coli, Staphylococcus aureus, yeast and mould countc in swab samples.

Data arrangement for mathematical analysis. For statistical analysis, the following encoding of data was made:

1) food samples were grouped into 14 identification classes, 31 groups and 142 types, taking into account the food main components and characteristic methods of technological processing;

2) surfaces were grouped into 16 identification classes, 90 groups and 187 types, taking into account the characteristic application of equipment, utensils, constructions and other objects;

3) methods of technological processing were grouped into 18 groups taking into account the way of technological processing, including characteristic sequence of technological processes during food preparation processes.

Statistical analysis. Microbiological contamination of foods and surfaces of equipment and utensils was described by features: Aerobic Plate Count (APC), coliforms, Staphylococcus aureus and Salmonella spp. The statistical data were processed using software package SPSS 13.0.

Testing results on coliforms, Staphylococcus aureus and Salmonella spp. were qualitative parameters. Presence was designated as " 1 " and not detected ase " 0 ". The qualitative features were ranked with regard to the following factors: identification classes, groups and types of foods; identification classes, groups and designations of surfaces; methods of technological processing; and types of microorganisms. Significant differences $(P<0.05)$ in empirical and theoretical distributions were determined using the Chi-Square test.

Aerobic Plate Count was expressed quantitatively as colony-forming units (CFU) $\mathrm{g}^{-1}$. Analysis of variance ANOVA was used to test for differences in APC among public catering establishments, identification classes, groups and types 
of foods and methods of technological processing. Homogeneity of variance was tested. The post hoc Scheffe criterion was used in cases with similar variances and Dunnet's T3 criterion when variances were not similar.

MS EXCEL software was used for graphical description of the data. Proportions were shown as pie charts. Other data were depicted as bar charts and histograms.

\section{RESULTS}

Microbiological risk assessment with regard to readyto-eat foods. The results of the statistical analysis indicate that the mean value of APC in ready-to-eat foods, as well as probability of the presence of coliforms and $S$. aureus in ready-to-eat foods, significantly depended on the method of food technological processing $(P=0.000)$ (Figs. 1 and 2$)$. Increased microbiological contamination risk was proven for foods that were prepared using mechanical processing, for both thermally unprocessed foods and thermally processed and chilled foods. Characteristic trends in microbiological contamination were also detected for thermally processed foods.
The APC of ready-to-eat foods significantly differed among the identification classes of ready-to-eat foods (Fig. 3), as well as among certain groups and types of foods $(P=$ $0.000)$. The mean value of APC was significantly lower for thermally processed foods, such as hot soups, grain and vegetable foods, fish foods and meat foods. The mean value of APC was considerably higher for chilled foods, e.g. chilled entry foods, pastry foods, salads and dairy products.

The APC significantly differed for farinaceous foods, salads and pastry foods, with higher mean APC for foods with meat components. According to the results of microbiological risk assessment, ready-to-eat foods were grouped into four categories:

- thermally processed foods, the APC of which was usually less than $1000 \mathrm{CFU} \mathrm{g}^{-1}$ : thermally processed soups, grain foods, seafood, vegetable foods and meat foods;

- ready-to-eat foods, the APC of which was usually 1000-5000 CFU g ${ }^{-1}$ : thermally processed pasta foods, farinaceous foods and different dessert foods. A relatively large standard deviation was found for pasta foods (2.9), farinaceous foods (3.0), and different dessert foods (3.1);

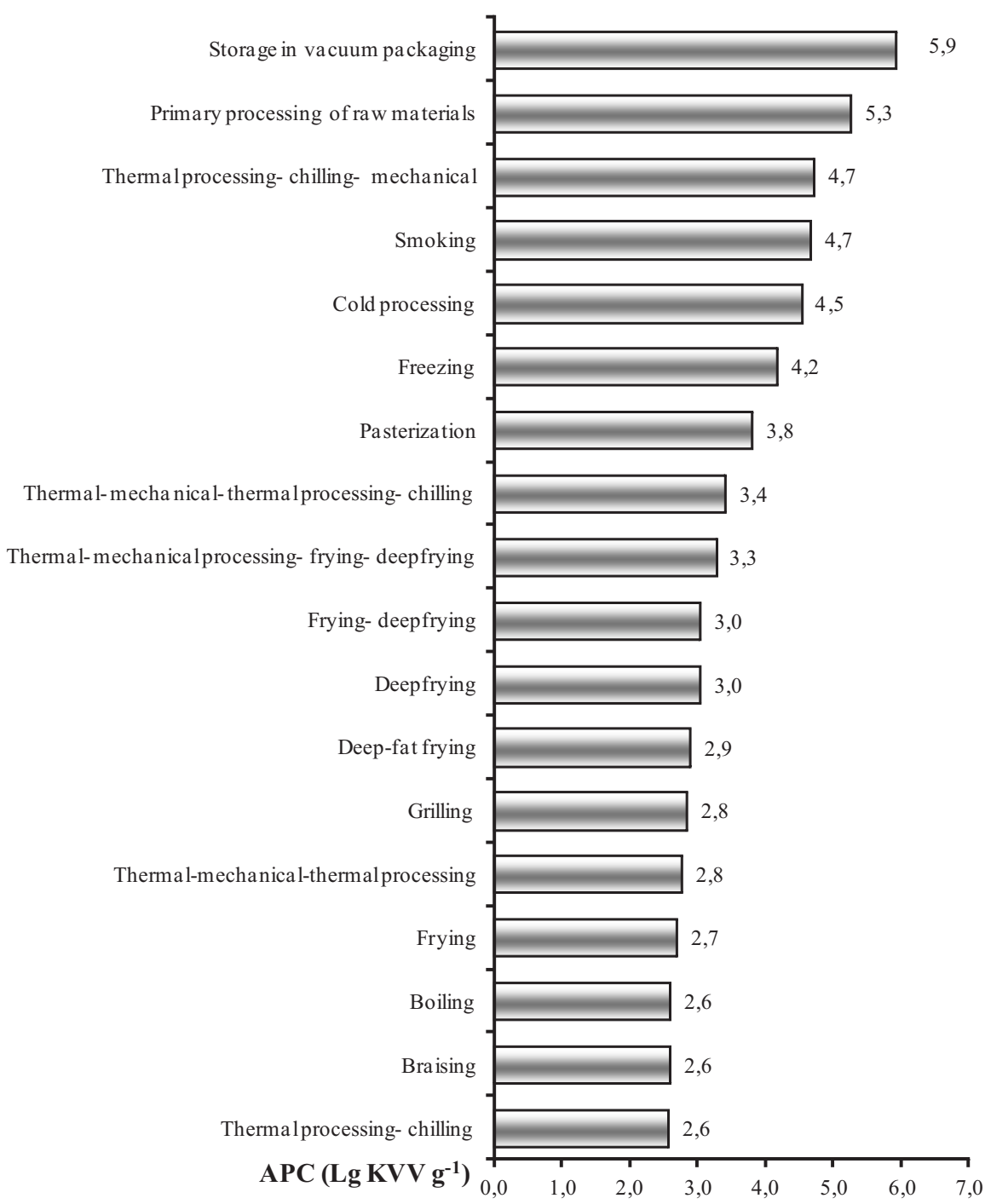

Fig. 1. Impact of the technological processing on APC (Aerobic Plate Count) of ready-to-eat foods $(P=0.000)$. 


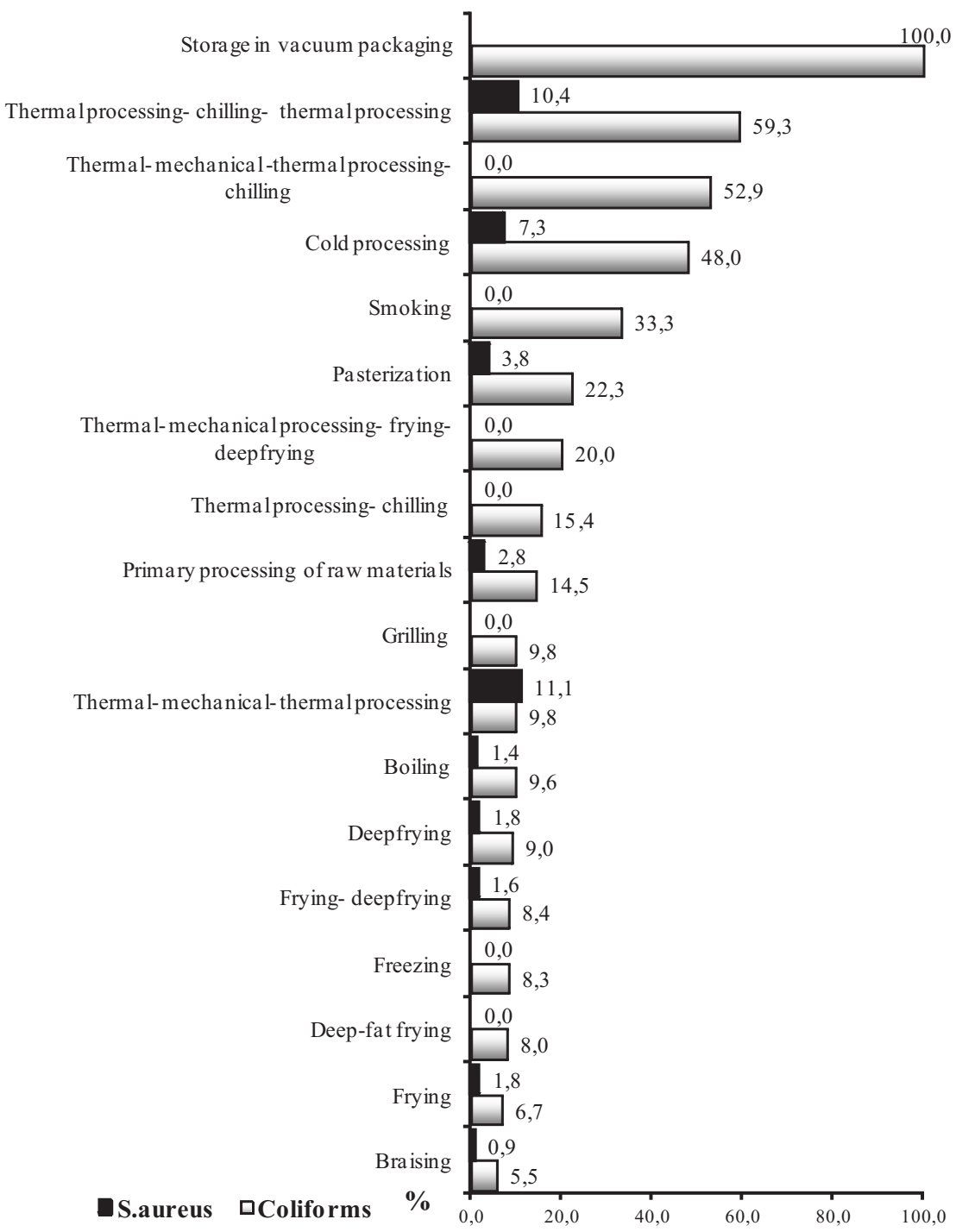

Fig. 2. Impact of the technological processing on the probability of presence of coliforms and $S$. aureus in ready-to-eat foods $(P=0.000)$.

- ready-to-eat foods, the APC of which was usually 5000$10000 \mathrm{CFU} \mathrm{g}^{-1}$ : curd foods, egg foods, cold entry foods, milk product foods. A relatively large standard deviation was found for curd foods (3.3), egg foods (5.3), and chilled entries (3.8);

- ready-to-eat foods, the APC of which was usually more than $10000 \mathrm{CFU} \mathrm{g}^{-1}$ : pastry foods and different salads (standard deviation 3.1 and 3.2, respectively).

Significant differences were observed in probability of presence of coliforms and $S$. aureus in foods of different identification classes (Fig. 4), groups and individual types of ready-to-eat foods $(P=0.000)$. APC and occurrence of coliforms and $S$. aureus in food samples were relatively low.

Relatively higher contamination risk with regard to coliforms and $S$. aureus was shown for the following chilled food groups: vegetable salads and salads containing components of animal origin, desert sweets, chilled meat entries and chilled curd foods. In the case of thermally processed foods, pasta and farinaceous foods had higher contamination risk.
Taking into account the mean APC value, as well as probability of presence of coliforms and $S$. aureus in different foods, higher microbiological contamination risk was observed for certain types of ready-to-eat foods: fried and braised meat and offal foods, especially fried poultry and fried minced-meat foods; pasta foods with meat components; pancakes with meat or curd stuffing; soups prepared on milk basis and rissole soup; salads containing raw vegetable components and salads containing cooked vegetable components; meat and fish entry foods; certain dessert sweets - dessert creams, mousse, sweet porridges; and for pastry foods with cream stuffing.

Microbiological risk assessment with regard to direct and indirect food contact surfaces. Significant differences were found in probability of presence of coliforms and $S$. aureus on different surfaces that come into direct or indirect contact with foods $(P=0.000)$ (Fig. 5). Relatively higher contamination risk was shown for utensils used for storage, display and serving of ready-to eat foods (e.g. bowls, pots, servers, ladles, spoons used for salads and dessert foods, pastry vessels, juice glasses), for utensils and equipment used for preparation of chilled foods (e.g. vegetable cutting boards, knifes, graters), as well as for surfaces 

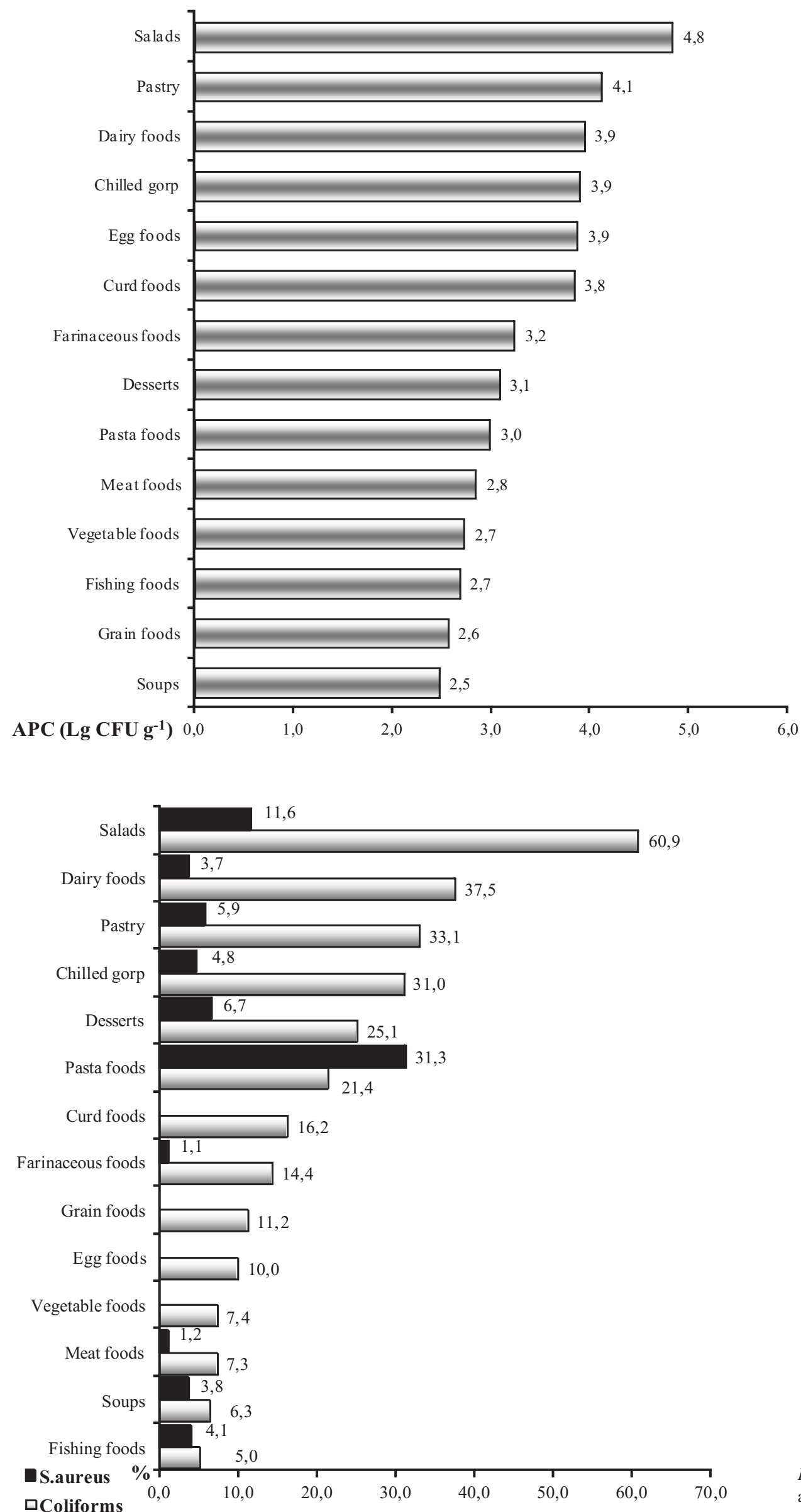

Fig. 3. Mean APC (Aerobic Plate Count) within identification classes of ready-toeat foods $(P=0.000)$.
Fig. 4. Probability of presence of coliforms and $S$. aureus within the identification classes of ready-to eat foods $(P=0.000)$. 


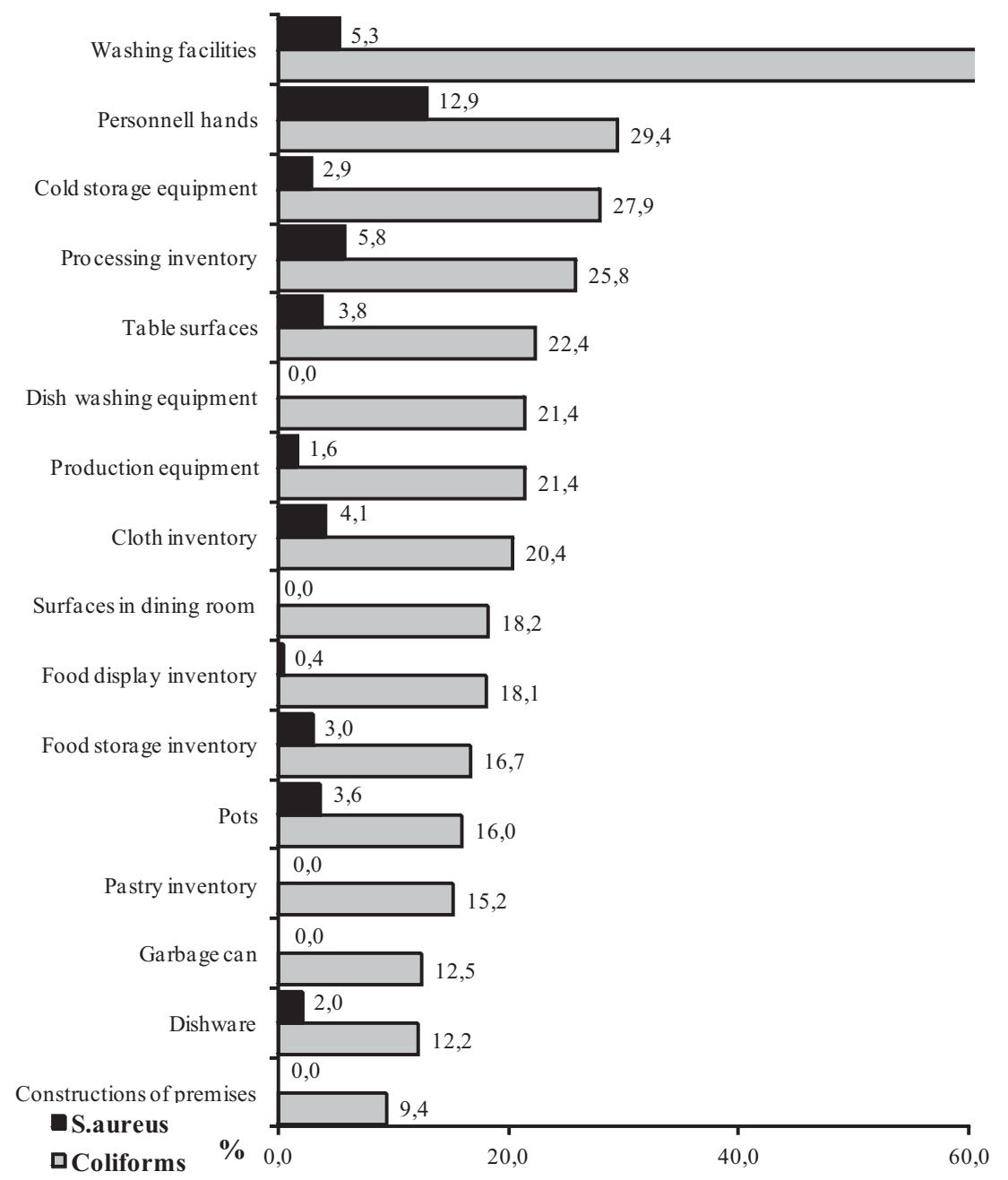

Fig. 5. Probability of the presence of coliforms and $S$. aureus on direct and indirect food contact surfaces $(P=0.000)$.

of certain work-tables (e.g. work-tables for salad an dessert preparation), sink taps and personnel hands. The results indicated that coliforms and $S$. aureus were most often found on surfaces that come into contact with ready-to-eat foods; surfaces that come into direct contact with personnel hands; and surfaces that come into contact with clean dishes. In total, the presence of coliforms was detected on 118 different contact surfaces (63\% of surfaces examined), and the presence of $S$. aureus on 34 contact surfaces (18\% of surfaces under investigation).

Taking into account that rapid hygiene tests have been recommended for verification of self-control measures in different areas of food industry (Park et al., 2001; Schoeller and Ingham, 2001; Ferrati, 2005; Silva et al., 2005; Sousa, 2005; Nyachuba and Donnelly, 2007), the approbation of Petrifilm rapid test methods in catering establishments was carried out during the study. Swabs were taken from surfaces for which the highest contamination risk was suggested by the statistical analysis. Significant microbiological contamination (APC), including Enterobacteriaceae, E. coli, S. aureus, yeasts and moulds was detected on 20 visually clean surfaces that come into contact with foods and hands of food service personnel. For example, the biggest APC values were observed in swab samples that were taken from surface of hands of food service personnel $\left(1.1 \times 10^{4}\right.$ and $\left.4.2 \times 10^{3} \mathrm{CFU} \mathrm{\textrm {cm } ^ { - 2 }}\right)$, drink containers $\left(6.5 \times 10^{3} \mathrm{CFU}\right.$

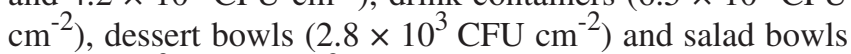

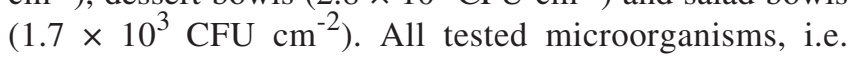
Enterobacteriaceae, E. coli, S. aureus, yeasts and moulds were detected on visually clean surfaces of salad bowls and vegetable cutting knives. Presence of $S$. aureus was detected on surfaces of 12 different utensils and equipment, due to presence of those bacteria on surface of hands of two food service personnel.

\section{DISCUSSION}

It is widely recognized that adequate preventive measures should be put in place to eliminate or reduce microbiological contamination of ready-to-eat foods in catering establishments. According to the research results, the main risk factors that lead to microbiological contamination of foods are: cross-contamination of foods due to poor hygiene practice, survival of bacteria due to insufficient temperature-time regime during thermal processing of foods, as well as multiplication of bacteria due to inadequate food chilling and storage conditions. Similar risk factors are mentioned in publications of other authors (Soriano et al., 2002; Evans et al., 2004; Beumer and Kusumaningrum, 2005; Koppanen et al., 2005; Medus, 2005; Bohm et al., 2007; Scmhid et al., 2007). It should be emphasized that, 
unlike previous studies, the distribution of microbiological contamination was examined by statistical analysis. The results of research carried out by the authors suggest that implementation of preventive hygiene measures is a critical step that may have substantial impact on catering food safety; unfortunately, the efficiency of hygiene procedures is not adequately controlled.

According to findings of the research the presence of hygiene indicator-microorganisms in ready-to-eat foods can be also detected in cases when overall APC is relatively low. Taking into account that even small amounts of pathogenic microorganisms can cause illness of food consumers, trends in distribution of microbiological contamination should be analysed and used to develop adequate control arrangements in a timely manner.

The statistical data obtained showed significant differences in distribution of microbiological contamination with regard to foods and food contact surfaces, and therefore, can be successfully used for improvement of procedures for both the technological processing of foods and the cleaning and disinfection of contact surfaces. The results on microbiological risk assessment can be successfully used for ranking of foods and food contact surfaces with regard to microbiological contamination, as well as for purposeful modelling of food microbiological contamination risk with regard to impact of certain technological processes. For example, the results on risk assessment suggest that there is high probability of cross-contamination of salads and desserts during preparation and serving of them in catering establishments, as we observed a probability of presence of coliforms and S. aureus (Fig. 6; Fig. 7). It should be mentioned that food and swab samples are rarely analysed within self-control procedures of catering establishments (e.g. only one readyto-eat food sample or aggregated swab sample during period of one-two years) and do not provide suitable information on the actual distribution of microbiological contamination within the course of technological processing of foods.

The data obtained in frame of the state's surveillance and control programmes suggest that control of Salmonella spp. in ready-to-eat foods and on food contact surfaces almost
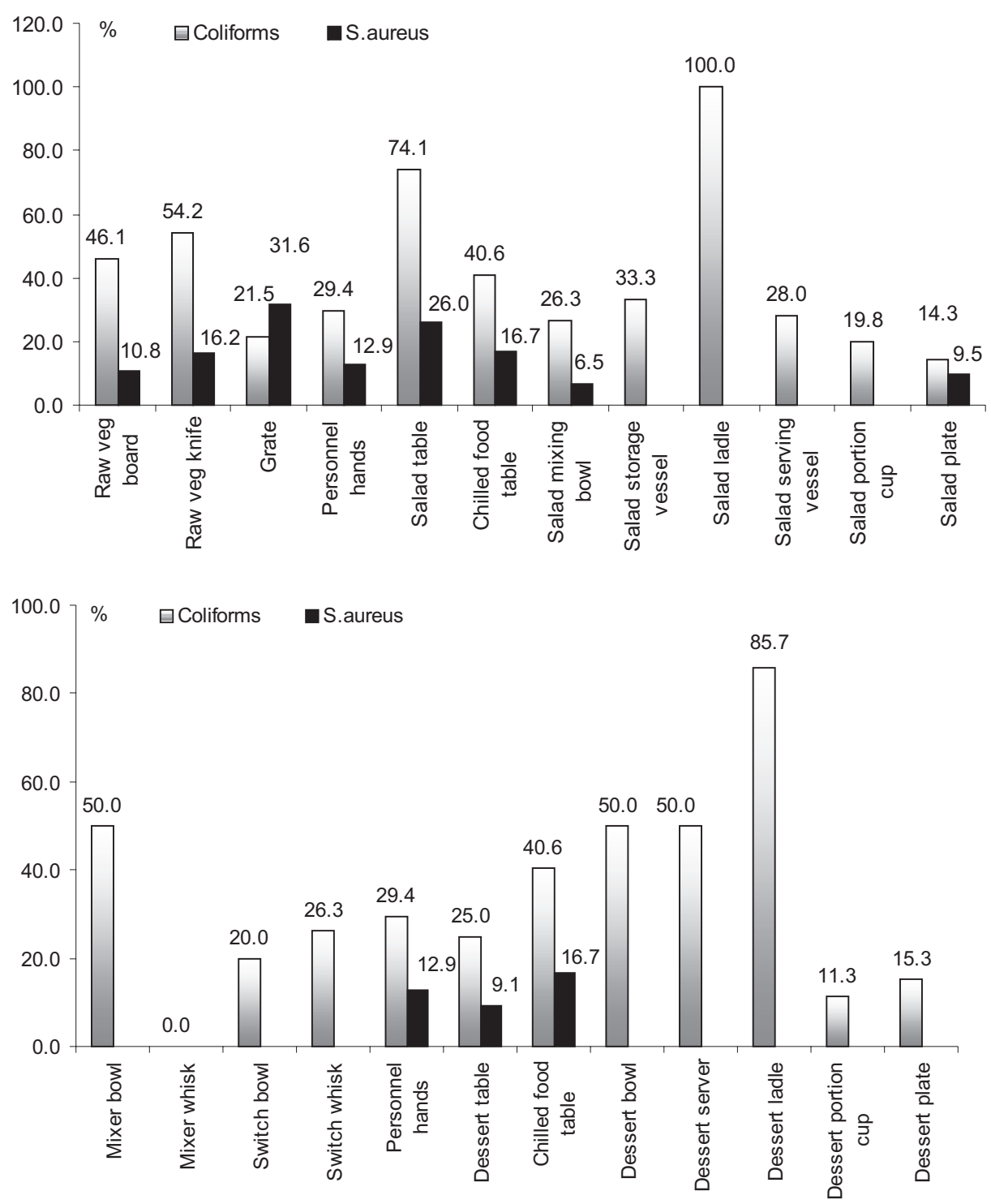

Fig. 6. Risk assessment with regard to food contact surfaces that contribute to crosscontamination of fresh vegetable salads.
Fig. 7. Risk assessment with regard to food contact surfaces that contribute to cross-contamination of desserts 
always give negative data that cannot be used for trend analysis in frame of HACCP procedures. According to data obtained during the research, 5283 food samples and 3385 surface swab samples were tested to monitor presence of Salmonella spp. and only one test result was positive, i.e. Salmonella spp. was detected in one sample of fried minced-meat product. It can be concluded that Salmonella spp. tests did not reveal characteristic trends in distribution of microbiological contamination, and therefore did not ensure relevant information for improvement of food safety management procedures.

The results of the research suggest that activities of microbiological risk management and communication can be implemented at several levels, namely at the level of identification class, group or individual type of ready-to-eat foods, according to the method of technological processing of food and/or taking into account food cross-contamination risk due to contact with contaminated surfaces.

The application of Petrifilm rapid test methods demonstrated that purposeful taking and operative testing of swab samples with emphasis on risky surfaces that have been identified by statistical analysis of risk ensures rapid feedback information on conformity of hygiene arrangements and necessity of corrective measures that should be taken immediately to avoid cross-contamination of ready-to-eatfoods. Results on approbation of the Petrifilm rapid test methods suggest that a large amount of microorganisms, including Enterobacteriaceae, E. coli and S. aureus, yeasts and moulds, can be present on visually clean surfaces that come into direct or indirect contact with ready-to-eat foods.

Microbiological risk assessment is tightly connected with development and improvement of microbiological risk management and communication measures in the frame of the HACCP procedure, the starting point of which should be objective analysis of microbiological hazards. The practical implementation of risk analysis in public catering establishments is summarized in Figure 8, which reflects the relationship between microbiological risk assessment and the HACCP procedure (Fig. 8).

The conclusion is that setting of priorities based on microbiological risk assessment is of great importance to ensure adequate monitoring and control activities with regard to catering food safety:

1. Random testing of food and surface swab samples in the frame of self-control procedures of catering establishments does not provide sufficient information on microbiological contamination of ready-to-eat foods and food contact surfaces. Trends in distribution of microbiological contamination should be analysed on a systematic basis.

2. Application of methods of mathematical statistics for microbiological risk assessment helps to reveal important trends in contamination of ready-to-eat foods and food contact surfaces and ensures science-based information for setting of priorities with regard to control of microbiological hazards in ready-to-eat foods.

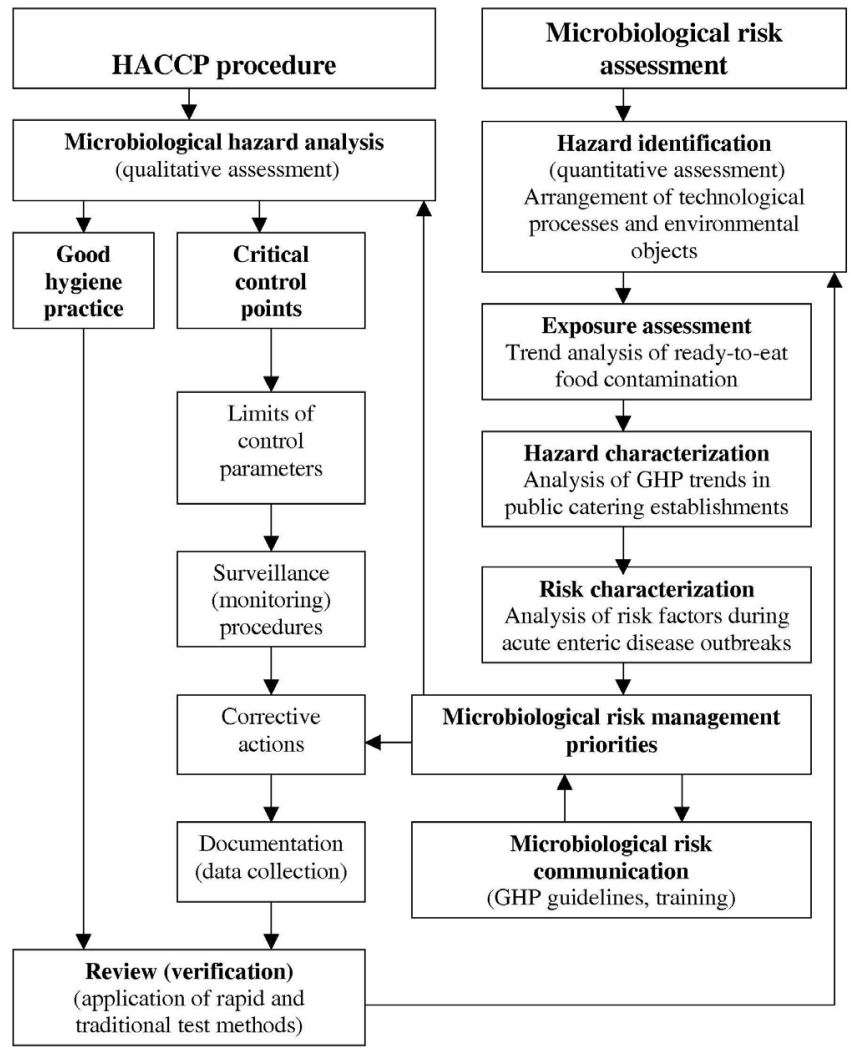

Fig. 8. Practical implementation of risk analysis in public catering establishments.

3. Application of the Petrifilm rapid test methods for purposeful identification of microorganisms on food contact surfaces and rapid assessment of adequacy of cleaning-disinfections procedures are a helpful tool to improve catering food safety.

4. Data on microbiological risk assessment should be used in development of science-based guidelines of good hygiene practice to improve adequacy and efficiency of self-control procedures of public catering establishments.

5. Data on microbiological risk assessment should be applied for risk-based inspection planning and setting of inspection priorities in the frame of state surveillance and control programmes in the catering area.

6. The results on microbiological risk assessment should be used for training of employees of public catering establishments, students of higher and vocational education establishments who study food safety management and food inspectors who are involved in surveillance and control in the public catering area.

7. Microbiological risk analysis can be applied in catering establishments to ensure objective data on distribution of microbiological hazards and to implement purposeful risk management and communication procedures in the frame of HACCP procedures to prevent outbreaks of food-borne diseases. 


\section{ACKNOWLEDGEMENTS}

The research was carried out by financial support of ESF. Scientific research and its elaboration was related to collaboration project No. 06.0040 "Latvian Agriculture Risk and Crisis Management Systems".

\section{REFERENCES}

Andersen, J. K., Hald, T., Nielsen, N. L., Fiedler, C. S., Nørrung, B. (2007). New strategies for the use of microbiological examination in food control in Denmark. Food Control, 18 (3), 273-277.

Anonymous (2005). Microorganisms in Foods 6: Microbial Ecology of Food Commodities. International commission for the microbiological specifications of foods (ICMSF). New York: Klewer Academic/Plenum Publishers. $736 \mathrm{pp}$

Anonymous (2006). Food Safety Risk Analysis: A Guide for National Food Safety Authorities. Food and Agricultural Organisation/World Health Organisation (FAO). Rome, Italy: The Joint FAO/WHO Publication. 107 pp.

Beumer, R. R., Kusumaningrum, H. D. (2005). Survival and cross-contamination of foodborne pathogens in the domestic kitchen: A review. In: Maunsell, B., Bolton, D. J. (eds.). Restaurant and Catering Food Safety: Putting HACCP on the Menu (pp. 42-60). Dublin, Ireland: TeagascAshtown Food Research Centre.

Bohm, S. R., Brennan, B. M., Schirmer, R., Cabose, G. (2007). Norovirus outbreak associated with ill food-service workers. Michigan January-February 2006. Morbidity and Mortality Weekly Report, 56 (46), 1212-1217.

Bolton, D. J., Meally, A. (2008). A Risk Assessment and Hazard Analysis and Critical Control Point [HACCP] study for the Irish Catering Industry. Dublin, Ireland: Agriculture and Food Development Authority. 21 pp.

Burlingame, B., Pineiro, M. (2007). The essential balance: Risks and benefits in food safety and quality. J. Food Compos. Anal., 20 (3-4), 139-146.

Buchanan, R. L. (1995). The role of microbiological criteria and risk assessment in HACCP. Food Microbiol., 12, 421-424.

Evans, J. A., Russel, S. L., James, C., Corry, J. E. L. (2004). Microbial contamination of food refrigeration equipment. J. Food Eng., 62 (3), 225-232.

Eves, A., Dervisi, P. (2005). Experiences of the implementation and operation of hazard analysis critical control points in the food service sector. Int. J. Hospit. Man., 24 (1), 3-19.

Farber, J. M., Todd, E. C. D. (2000). Safe Handling of Foods. New York: Marcel Dekker, Inc. 568 pp.

Ferrati, A. R., Tavolaro P., Destro, M. T., Landgraf, M., Franco, B. D. G. (2005). A comparison of ready-to-use systems for evaluating the microbiological quality of acidic fruit juices using non-pasteurised orange juice as an experimental model. Int. Microbiol., 8 (1), 49-53.

Fretz, K. A. (2006). Engineering-based probabilistic risk assessment for food safety with application to Escherichia coli O157:H7 contamination in cheese. Unpublished doctoral dissertation. University of Maryland, Maryland, USA.

Griffith, C. J., Clayton, D. (2005). Food safety knowledge, attitudes and practices of caterers in the UK University of Wales Institute. In: Maunsell, B., Bolton, D. J. (eds.). Restaurant and Catering Food Safety: Putting HACCP on the Menu (pp. 76-96). Dublin: Teagasc-Ashtown Food Research Centre.

Hielm, S., Tuominen, P., Aarnisalo, K., Raaska, L., Maijala, R. (2006). Attitudes towards own-checking and HACCP plans among Finnish food industry employees. Food Control, 17 (5), 402-407.

Hislop, L. N. (2003). Identifying risk factors for food poisoning in commercial eateries: a retrospective case-control study of health inspection records for food establishments in the Capital Health Region, Alberta, Canada, 2003. Unpublished doctoral dissertation. University of Alberta, Edmonton, Alberta, Canada.
Hugas, M., Tsigarida, E., Robinson, T., Calistri, P. (2007). Risk assessment of biological hazards in the European Union. Int. J. Food Microbiol., 120 (1-2), 131-135

Kārkliņa, D., Skudra, L., Arhipova, I. (2005). Riska analīze pārtikas produktu ražošanā [Risk Analysis in Manufacturing of Food Products]. Grām.: Rivža, P. (red.). Riski lauksaimniecībā un privātajā mežsaimniecībā (273.-294. lpp.). Jelgava: Latvijas Lauksaimniecības universitāte (in Latvian).

Koppanen, P., Moratall, V. T., Sjoberg, A. M. (2005). The future of catering food safety: A Finnish study. In: Maunsell, B., Bolton, D. J. (eds.). Restaurant and Catering Food Safety: Putting HACCP on the Menu (pp. 192-205). Dublin, Ireland: Teagasc-Ashtown Food Research Centre.

Lammerding, A. (2007). Using Microbiological Risk Assessment in Food Safety Management: Summary report of a workshop, October 2005, Prague, Chech Republic. Brussels, Belgium: International Association for Food Protection, International Life Sciences Institute (ILSI). 38 pp.

Luning, P. A., Devlieghere, F., Verhe, R. (2006). Safety in the Agro-food Chain. The Netherlands: Wageningen Academic Publishers. 684 pp.

Medus, C. (2005). Foodworkers as a source for Salmonella: A comprehensive review of the role of infected foodworkers in outbreaks of Salmonella in restaurants of Minnesota. Unpublished doctoral dissertation. University of Minnesota, Minnesota, USA.

Melngaile, A., Karklina D. (2007). Assessment of Food Safety Risks in Catering Establishments. In: International Scientific Conference "Research for Rural Development 2007”, 16-18 May May 2007 (pp. 87-97). Jelgava: Latvia University of Agriculture.

Melngaile, A., Karklina D. (2006). Application of Quantitative Risk Assessment in Catering Area. In: International Scientific Conference "Research for Rural Development 2006”, 19-21 May, 2006 (pp. 246-252). Jelgava: Latvia University of Agriculture.

Nyachuba, D. G., Donnelly, C. W. (2007). Comparison of 3M ${ }^{\mathrm{TM}}$ Petrifilm ${ }^{\mathrm{TM}}$ environmental Listeria plates against standard enrichment methods for the detection of Listeria monocytogenes of epidemiological significance from environmental surfaces. J. Food Sci., 72 (9), 346-354

Park, Y. H., Seo, K. S., Ahn, J. S., Yoo, H. S., Kim, S. P. (2001). Research Note: Evaluation of the Petrifilm plate method for the enumeration of aerobic microorganisms and coliforms in retailed meat samples. J. Food Protect., 64 (11), 1841-1843.

Pourkomailian, B. (2005). Food safety and HACCP in McDonald's restaurants. In: Maunsell, B., Bolton, D. J. (eds.). Restaurant and Catering Food Safety: Putting HACCP on the Menu (pp. 158-175). Dublin: TeagascAshtown Food Research Centre.

Reij, M. W., Aantrekker, E. D. (2004). ILSI Europe risk analysis in microbiology task force. Recontamination as a source of pathogens in processed foods. Int. J. Food Microbiol., 91 (1), 1-11.

Rivža, P., Šantare, D., Rivža, S. (2007). Risku un krīžu vadīšanas teorijas, iespējas un metodes [Theories of management of risks and crysis, opportunities and methods]. In: Rivža, P. (red.). Lauksaimniecības un pārtikas risku vadī̌ana (44.-70. lpp.). Jelgava: Latvijas Lauksaimniecības universitāte (in Latvian).

Rodgers, S. (2005). Food safety research underpinning food service systems: A review. Food Service Technol., 5 (2-4), 67-76.

Schaffner, D. W. (2007). Microbial Risk Analysis of Foods: Emerging Issues in Food Safety. Washington, USA: American Society for Microbiology. $270 \mathrm{pp}$.

Schmid, D., Stüger, H. P., Lederer, I., Pichler, A. M., Kainz-Arnfelser, G., Schreier, E., Allerberger, F. (2006). A foodborne norovirus outbreak due to manually prepared salad, Austria 2006. Infection, 35 (4), 232-239.

Schoeller, N. P., Ingham, S. C. (2001). Comparison of the Baird-Parker agar and $3 \mathrm{M}^{\mathrm{TM}}$ Petrifilm ${ }^{\mathrm{TM}}$ rapid $S$. aureus count plate methods for detection and enumeration of Staphylococcus aureus. Food Microbiol., 18 (6), $581-587$. 
Silva, B. O., Caraviello, D. Z., Rodrigues, A. C., Ruegg, P. L. (2005). Evaluation of Petrifilm for the isolation of Staphylococcus aureus from milk samples. J. Dairy Sci., 88 (8), 3000-3008.

Soriano, J. M., Rico, H., Moltó, J. C., Mañes, J. (2002). Effect of introduction of HACCP on the microbiological quality of some restaurant meals. Food Control, 13 (4-5), 253-261.

Sousa, G. B., Tamagnini, L. M., González, R. D., Budde, C. E. (2005). Evaluation of Petrifilm method for enumerating aerobic bacteria in crottin goat cheese. Revista Argentina Microbiol., 37 (4), 214-219.

Sprenger, R. A. (2004). Hygiene for Management. United Kingdom: Highfield Ltd. 416 pp.

Received 10 October 2012
Stringer, M. (2005). Impact of food safety objectives on microbiological food safety management. Food Control, 16 (9), 775-794.

Szabo, M. S. (2005). Foodborne disease outbreaks associated with the catering sector in Hungary. In: Maunsell, B., Bolton, D. J. (eds.). Restaurant and Catering Food Safety: Putting HACCP on the Menu (pp. 61-75). Dublin: Teagasc-Ashtown Food Research Centre.

Špoğis, K. (2005). Risku ekonomiskās iespējas vai draudi un to seku novērtēšana [Economical opportunities or threats and the assessment of their consequences]. In: Rivža, P. (red.). Riski lauksaimniecībā un privātajā mežsaimniecībā (385.-389. lpp.). Jelgava: Latvijas Lauksaimniecības universitāte (in Latvian)

Tebbutt, G. M. (2007). Does microbiological testing of foods and the food environment have a role in the control of foodborne disease in England and Wales? J. Appl. Microbiol., 102 (4), 883-891.

\section{MIKROBIOLOG̣ISKĀ RISKA ANALĪZE SABIEDRISKĀS ĒDINĀŠANAS UZN̦ĒMUMOS}

Epidemioloğiskie dati liecina, ka ēdienu gatavošanas process sabiedriskās ēdināšanas uzṇēmumos ietver ēdienu mikrobioloğiskās piesārṇošanās risku. Lai izveidotu profilaktisku, uz HACCP principiem balstītu pārtikas nekaitīguma nodrošināšanas sistēmu, ir būtiski veikt atbilstošu pārtikas drošuma apdraudējumu identifikāciju, monitoringu un komunikāciju. Pētījuma mērkis bija izpētīt mikrobioloğiskās riska analīzes metodolog̣ijas pielietošanu ēdināšanas uzṇēmumos. Lai veiktu mikrobioloğiskā riska novērtěšanu un izstrādātu zinātniski pamatotus priekšlikumus mikrobioloğiskā piesārņojuma kontrolei un pārtikas izcelsmes infekciju uzliesmojumu novēršanai, izmantotas matemātiskās statistikas metodes. Lietojot SPSS 13.0 un MS EXCEL programmatūras, analizēti 17192 èdienu un 17604 virsmu nomazgājumu paraugu mikrobioloǵiskās testēšanas rezultāti. Noskaidrotas statistiski nozīmīgas ēdienu un vides virsmu mikrobioloğiskā piesārṇojuma atšḳirības saistībā ar kopējo mikrobioloğisko piesārṇojumu un zarnu nūjiṇu grupas baktēriju un $S$. aureus klātbūtni. Atklāta tehnoloğiskās apstrādes ietekme uz gatavo ēdienu nekaitīgumu. Lai īstenotu paškontroli, aprobētas Petrifilm ātrās testēšanas metodes. Pētìjuma rezultāti liecina par raksturīgām ēdienu un vides objektu mikrobioloğiskā piesārņojuma tendencēm ēdināšanas uzṇēmumos un nodrošina zinātnisku pamatojumu prioritāšu izvirzišanai, lai ēdienu tehnoloğiskās apstrādes un pasniegšanas laikā ieviestu nepieciešamos kontroles pasākumus. 


\title{
EATING HABITS OF CHILDREN AND ADOLESCENTS WITH EPILEPSY IN LATVIA
}

\author{
Zane Vīksna* and Renāte Ligere** \\ * Faculty of Medicine, University of Latvia, Šarlotes iela 1a, Rīga, LV-1001, LATVIA; \\ z.viksna@inbox.lv \\ ** Pauls Stradiṇš Clinical University Hospital, Pilsoṇu iela 13, Rĩga, LV-1002, LATVIA; \\ renlig@ latnet.Iv
}

Contributed by Renāte Ligere

\begin{abstract}
The aim of the study was to evaluate the eating habits of epileptic children and adolescents. Forty one patients (12 girls and 14 boys aged 0-10 years, and 10 girls and 5 boys aged 11-18 years) were enrolled in the study. A survey on consumption rate of different dietary products was conducted. The diet groups considered were carbohydrates, fat, protein, fibre and liquid. We found that $35-58 \%$ of patients aged 0-10 years used soda drinks, juices and popcorn regularly. The proportion was more than two times in adolescents. Consumption of sweets in both age groups was $83-100 \%$. Half of children aged 0-10 years said that they ate chips and fried potatoes regularly and $80-100 \%$ of adolescents consumed these products at least once a week. Half of the boys and almost all younger girls consumed various milk products daily; adolescent epileptic boys consumed milk products two times more than girls. Among older girls, $40 \%$ did not drink milk. The youngest girls consumed meat and fish 1.5 to 3.5 times more than boys, while the number of boys consuming these products increased with age. It was estimated that $75-100 \%$ of patients ate fruits and vegetables daily. Only two children and two adolescents were found to drink lots of water. In conclusion, children and adolescents with epilepsy preferred meals rich in carbohydrates and fat, rather than protein; a high number of the evaluated patients drank soda drinks and juices several times a week; only a few had intake of water daily; and all patients ate fruits and vegetables daily, thus compensating unhealthy eating habits.
\end{abstract}

Key words: children and adolescents, epilepsy, growth and maturation, hormonal changes, antiepileptic drugs, bone metabolism.

\section{INTRODUCTION}

Epilepsy is a fairly prevalent neurological disorder in children and adolescents and is defined as a proneness to recurrent epileptic seizures. An epileptic seizure arises as a result of changed electrical activity in the brain, and is manifested as alterations in sensation (vision, hearing, touch, smell, taste), behaviour or consciousness (Neal and Cross, 2010). The incidence of epilepsy is 5-7 children in 100000 (about 3-4\%) aged 0-15 years (Nettekoven et al., 2008). There are still no available precise data regarding the frequency of epilepsy among children and adolescents in Latvia.

Although epilepsy is defined as a condition of recurrent spontaneous seizures not directly related to a specific event, many patients also report that seizures are occasionally provoked by external or internal stimuli (Asadi-Pooya and Sperling, 2007). The most common precipitating factors in adults and children and adolescents include sleep deprivation, consumption of alcohol among adolescents, premature awakening, menstruation, psychological stress, and visual stimulation. Other factors such as reading, thinking, writing, calculating, and playing musical instruments have been reported as well (Frucht et al., 2000; Spector et al., 2000; Sousa et al., 2005). Knowledge of factors promoting seizure precipitants is helpful, as it can modify patient's behaviour and, perhaps, lead to a reduction in seizure frequency.

Nutrition is fundamental in regulating the activity of electrical discharge in the brain. Unfortunately, there has been quite little research regarding nutrition and related eating habits in children and adolescents with epilepsy.

Already 1000 years ago, the great Iranian scientist Avicenna recommended that patients with epilepsy should avoid excessive eating and some foods such as cow and sheep meat, fish, onion, garlic, celery, cauliflower, and carrot (Avicenna, 1991). The ketogenic diet, which is compatible with avoiding excessive eating, is a high-fat, low-carbohydrate and low-protein regimen that has been used successfully for more than 70 years in thousands of patients (Asadi-Pooya et al., 2004). It has been calculated that this diet provides $75-100 \mathrm{kcal} / \mathrm{kg}$ body weight and 1-2 $\mathrm{g}$ of dietary protein/kg body weight per day. Such strict caloric re- 
quirements can be adjusted to minimise weight gain and to maximise ketonemia (excessive amount of keton bodies in the blood) (Nordli and De Vivo, 2001). A recent study suggested that caloric restriction reduces neuronal excitability in rats and that it has anticonvulsant effect, perhaps by an increase of fast inhibition (Bough et al., 2003).

There are several possible reasons why specific foods may lead to seizures. Firstly, some foods may lower the seizure threshold (food-disease interaction) (Gallagher et al., 1968; Bhagavan et al., 1971; Miwa et al., 2001). Such a fooddisease interaction has been observed in adult patients with migraine headache, in some of whom certain foods induced attacks, such as chocolate, hot dogs, smoked meats, aged cheese, orange, and monosodium glutamate (MSG). Some theories suggest that migraine may be triggered via an allergic or chemical reaction that affects the vascular system (Burns and Carr-Davis, 1996; Victor and Ropper, 2001).

Secondly, a food-drug interaction has been observed with carbamazepine: the bioavailability and plasma concentration of carbamazepine was increased in patients who consumed grapefruit juice and dairy products (Garg et al., 1998). Moreover, among patients who used carbamazepine, the belief and experience with a food-seizure relationship were reported more often than using phenobarbital or valproic acid.

There are several reports suggesting hazardous effect of certain foods on the brain by triggering seizures, including the occurrence of generalised convulsions after consumption of large amounts of Ginko nuts (Miwa et al., 2001). There are also reports about decrease of the seizure threshold in rats by intake of excessive amino acids (Gallagher et al., 1968), induction of convulsions by MSG in rats (Bhagavan et al., 1971), and the induction of status epilepticus by star fruit intoxication in patients with chronic renal disease (Tsai et al., 2005).

Noteworthy research regarding the preferences for food items in epileptic children and adolescents, compatible and incompatible with the ketogenic diet, has been conducted in the USA (Amari et al., 2007). Enrolled patients was asked to choose a food item from a list of high-fat and high-carbohydrate food items. The researchers observed that the most popular item among children with seizures was bacon, and among the control group, noodles. The obtained data supported the prediction that children with seizures would exhibit higher preferences for high-fat than high-carbohydrate foods, compared with controls. This was a novel finding, without precedent in the literature.

It has been hypothesised that humans and animals may prefer to choose certain items to compensate for physiological and metabolic imbalances (Weingarten and Elston, 1990). For instance, significantly increased sodium-seeking behaviour and hedonic preference for salty foods were observed among adolescents with congenital adrenal hyperplasia (Cohli et al., 2005). Another study demonstrated that carbohydrates are selectively craved by people who experience a depressed mood (Wurtman and Wurtman, 1986; 1988; Christensen and Pettijohn, 2001).

It has been proved that consumption of fat versus carbohydrates as the primary source of energy is highly effective in controlling seizures in individuals, as well as improving behaviour, alertness, and mood. Compared to carbohydrates, consumption of fat in epileptic patients has positive consequences - reduced abnormal electrical discharge activity in the brain, increased alertness, and improved mood (Amari et al., 2007).

Norwegian researchers evaluated nutritional habits in 1219-year-old youth with epilepsy who consumed unhealthy food (candy, coffee/tea, potato chips, French fries or soda pop) at least once a day. They found that being male and never eating breakfast were the strongest predictors for eating ,unhealthy food”. The authors also found that the significant increase among youth with epilepsy was associated with greater psychosocial problems within the adolescents (Clench Aas et al., 2006).

In other work, Iranian scientists questioned 125 families with children who had epilepsy (the mean age $8.4 \pm 4.3$ years) in order to identify the beliefs and experiences associated with specific dietary restrictions (Asadi Pooya and Ghafari, 2004). It was observed that most of the families believed in such relationship - one-third had personal experience with seizure occurrence after consumption of specific foods. Dairy products, sour foods (like vinegar and lemon juice), fruits and vegetables, and fish and meat were the most common foods reported as the responsible ones (Asadi-Pooya and Hossein-Zade, 2005).

Conversely, research on adult patients in the USA ( $n=193$; mean age $40.3 \pm 16$ years), identified that only 11 patients $(5.7 \%)$ reported foods as precipitating factors for seizures (Asadi-Pooya and Sperling, 2007). Moreover, there was no relationship between gender, education, seizure control, and certain food items. Thereby, authors suggested that reports of seizure precipitants were subjective impressions, which could easily be influenced by cultural beliefs or patterns of thought or superstitions. However, careful scientific studies are needed to establish the true incidence of food-induced seizures. It is also the responsibility of physicians and health care workers to provide patients and their families with appropriate and correct information regarding future changes in their lifestyle.

\section{PATIENTS AND METHODS}

In total, 41 epileptic patients (26 children and 15 adolescnts) were included in the study, conducted at the Children's Clinical University Hospital in Rīga. Patient groups were made according to gender and age of overall physical maturation: (1) 12 girls and 14 boys aged $0-10$ years; and (2) 10 girls and 5 boys aged 11-18 years. The survey consisting of detailed questions about the consumption rate of different dietary products (milk, kefir, yoghurt, 
sour cream, curd; pork, beef, poultry, fish; vegetables and fruits; sweets, soda drinks, water, coffee, tea; popcorn, potato chips, fried potatoes/French fries, and cereal products). Five dietary groups were made according to above mentioned dietary products: carbohydrates, fat, protein, fibre and liquid. All of the enrolled children had a written agreement from their parents or responsible persons, and the study was approved by the Ethical Commission.

\section{RESULTS}

Of the enrolled children, three girls (25\%) aged $0-10$ years were on ketogenic diet for more than three months. Of these girls, one was fed via nasogastric tube and one girl could not eat herself. Three boys aged 0-10 years (21.4\%) had difficulties in consuming food: one boy $(7.1 \%)$ had hypersensitivity (urticaria) from consuming potatoes, carrots, and apples, 1 boy $(7.1 \%)$ had difficulty in chewing meat and complained of nausea after he had eaten an egg, 1 boy $(7.1 \%)$ could not put a spoon in his mouth, and had difficulties in chewing and swallowing solid food items. One 11-year-old girl $1(10 \%)$ consumed food in small portions, because she was constantly having nausea.

On average, 3-4 meals per day were consumed by $71.4 \%$ boys and $83.3 \%$ girls in the youngest age group, and $100 \%$ boys and $60 \%$ girls in the oldest age group. $40 \%$ of girls aged 11-18 years had three and more snacks in between meals, which was twice higher than in boys (20\%). However, more young boys $(28.6 \%)$ had four or more snacks than girls $(8.3 \%)$, a 3.4 times difference. Parents of boys from the youngest patient group mentioned increased appetite 2.6 times more often than the parents of girls $(21.4 \%$ and $8.3 \%$, respectively); one 14-year-old boy complained of increased appetite (20\%), whereas 4 boys $(28.6 \%)$ and two girls (16.6\%) aged 0-10 years, as well as two girls (20\%) aged 11-18 years complained of reduced appetite. One 15-year-old and one 11-year-old girl (20\%) did not eat breakfast.
Carbohydrates. Of patients aged 0-10 years, $35-58 \%$ used soda drinks and juices regularly. With increase of age, the proportion rose more than two times (70-100\%). Similar proportions by gender of children in the youngest age group consumed sweets (chocolate cheese, chocolate, candies, cookies, cakes) regularly and ten girls (83.3\%) and ten boys $(81.7 \%)$, and nine $(90 \%)$ adolescent girls and five (100\%) boys consumed sweets every day. Two times more younger girls than boys consumed soda pop 1-3 times per month $(58.3 \%$ versus $21.4 \%)$, and in adolescents with epilepsy three boys (60\%) and seven girls (70\%). Every second boy $(57.1 \%)$ aged $0-10$ years did not eat popcorn, and in adolescent patient group $40 \%$ of boys and $30 \%$ of girls did not eat popcorn. Consumption of high-carbohydrate food items is shown in Figures 1 and 2.

Fat. Up to $66.6 \%$ girls and $50 \%$ boys aged $0-10$ years and more adolescent girls $(80 \%)$ and $100 \%$ boys consumed potato chips at least once a week. $357 \%$ boys and $83 \%$ girls in the youngest patient group, and 10\% girls aged 11-18 girls did not eat potato chips. $66.6 \%$ girls and $64.3 \%$ boys with epilepsy aged 0-10 years consumed fried potatoes at least once per week, and adolescents with epilepsy - considerably more often ( $100 \%$ girls and $80 \%$ boys, respectively). One $(10 \%)$ girl in the oldest patient group drinks cocoa every day, but in the youngest age group - three epileptic girls (25\%) drinks cocoa 1-3 times per week. Consumption of high-fat food items is shown in Figures 1 and 2.

Protein. Every second boy and almost all younger girls (90\%) consumed different dairy products (milk, kefir, yoghurt, curd, sour cream) daily, and almost two times more adolescent epileptic boys than girls $(60 \%$ girls and $100 \%$ boys). $40 \%$ older girls did not drink milk. $75 \%$ girls and $50 \%$ boys aged $0-10$ years consumed meat 2-4 times per week; these proportions were $70 \%$ in adolescent girls and 1.6 times more (80\%) in boys. Girls aged 0-10 years consumed fish 3.5 times more than boys (50\% versus $14.3 \%$, respectively), and in adolescents with epilepsy: $20 \%$ girls versus $40 \%$ boys. Consumption of high-protein food items is shown in Figures 3 and 4.

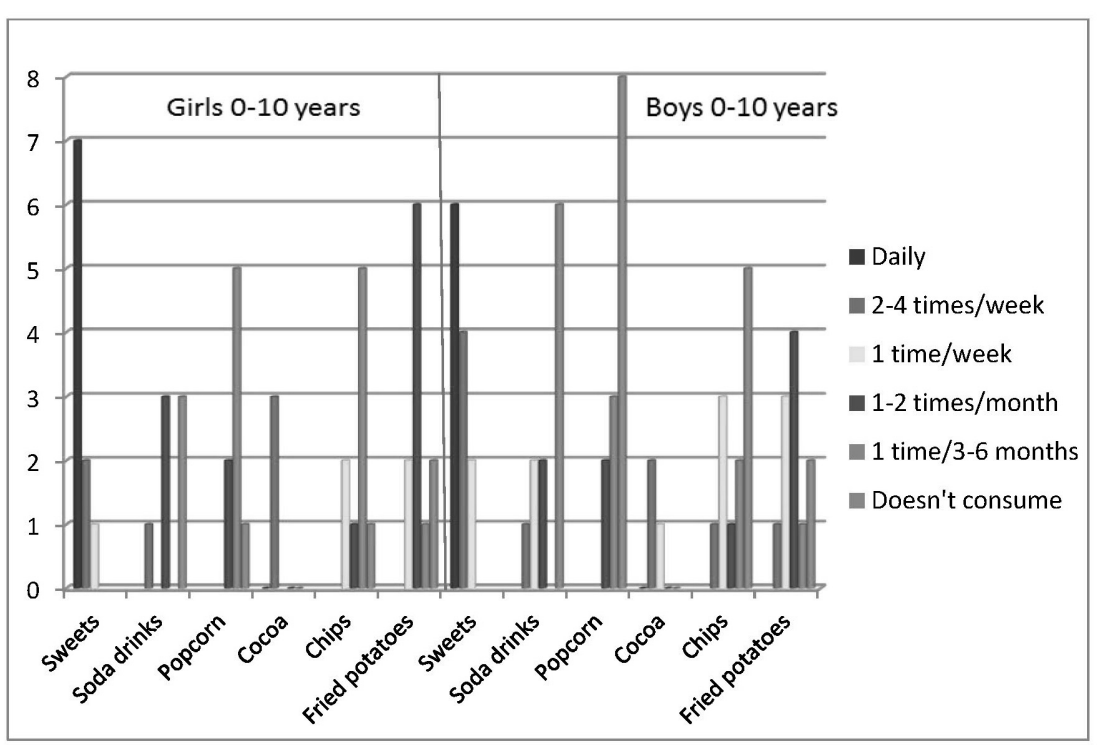

Fig. 1. Mean values of carbohydrate- and fat-rich dietary product consumption in $0-10$-year-old patients with epilepsy. 

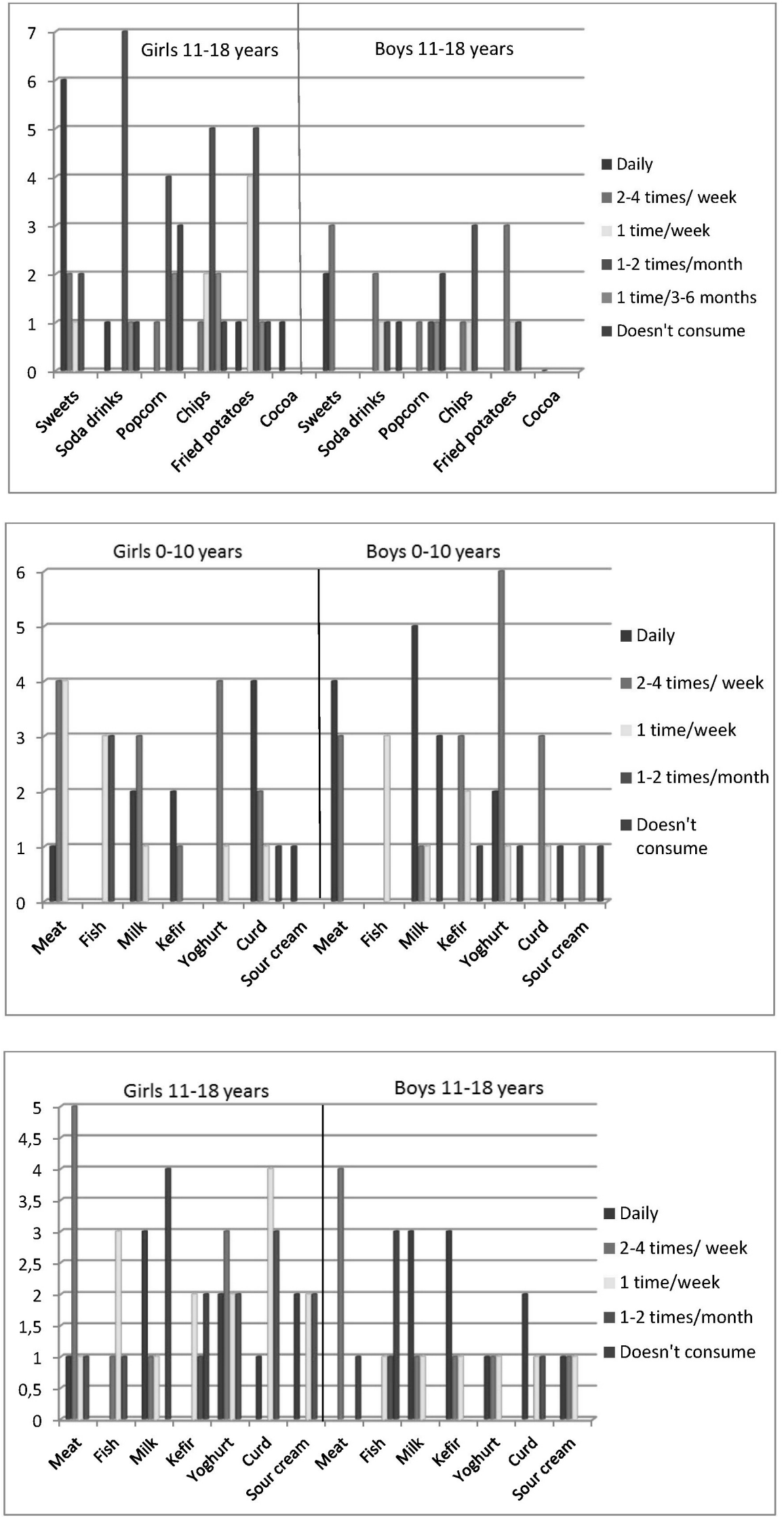

Fig. 2. Mean values of carbohydrate- and fat-rich dietary product consumption in 11-18-year-old patients with epilepsy.

Fig. 3. Mean values of protein-rich dietary product consumption in $0-10$-year-old patients with epilepsy.
Fig. 4. Mean values of protein-rich dietary product consumption in 11-18-year-old patients with epilepsy.
Fibre. Fruits were used daily among girls in both age groups, whereas boys - slightly less at the age of 0-10 years $(85.7 \%)$ and all of boys aged 11-18 years. Younger boys with epilepsy more often than girls consumed both fresh and heat-treated vegetables (100\% boys and $75 \%$ girls, respectively), and up to $100 \%$ patients of both genders aged 11-18 years consumed vegetables (fresh and heattreated) equally. Only one 5-year-old boy (7.1\%) consumed 

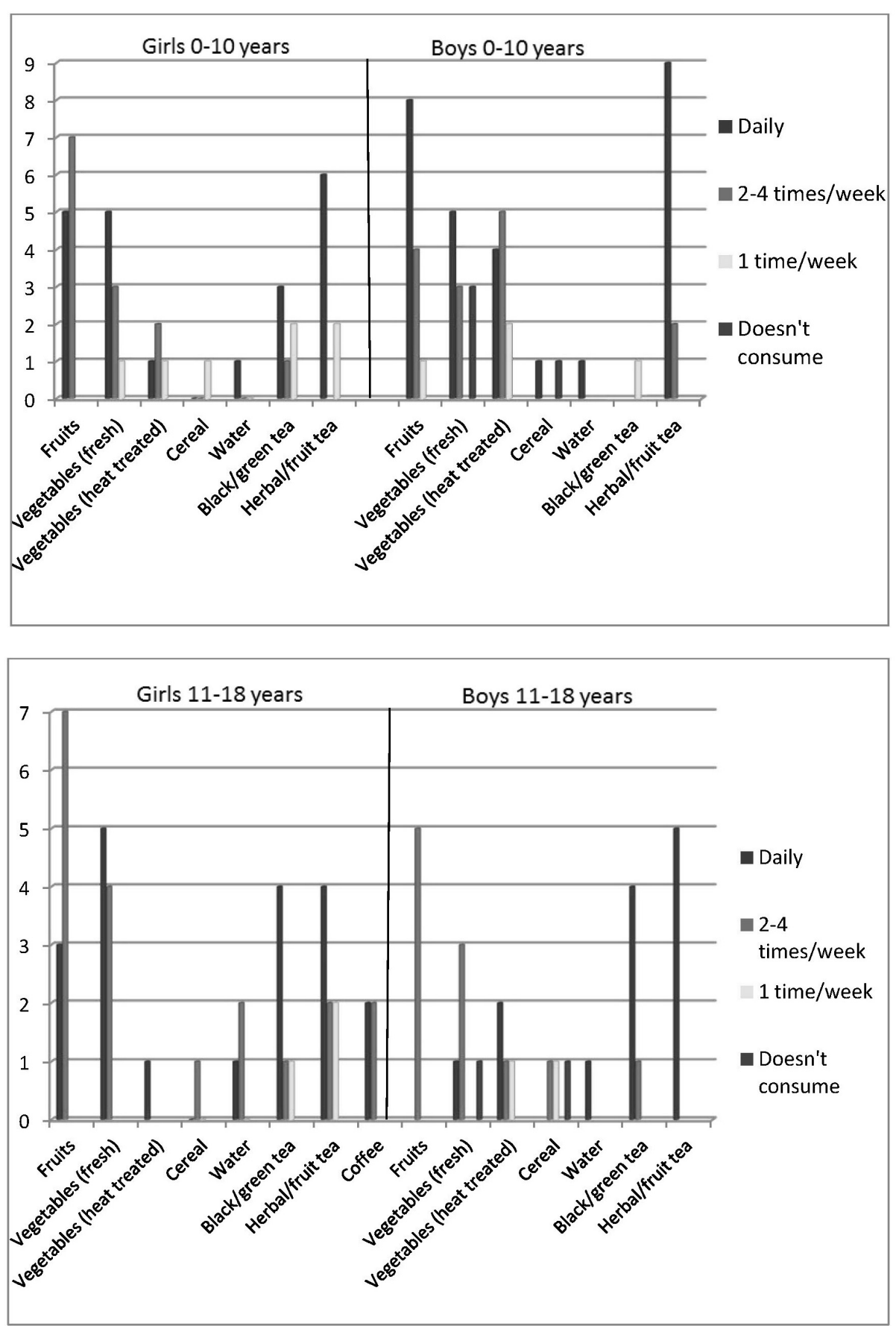

Fig. 5. Mean values of liquid and fiber-rich dietary product consumption in 0-10-year-old patients with epilepsy.
Fig. 6. Mean values of liquid and fiber-rich dietary product consumption in 11-18-yearold patients with epilepsy. porridge every day, and one 15-year-old girl (10\%) and one 13 -year-old boy (20\%) consumed wholemeal flakes or porridge every other day. Consumption of fibre-rich food items is shown in Figures 5 and 6.

Liquid. On average, every second child with epilepsy $(50 \%$ girls and $64.3 \%$ boys), and $75 \%$ girls and $100 \%$ boys in the older age group drank herbal (peppermint, camomile, sweet-briar, caraway etc.) and fruit tea daily. $25 \%$ of $0-10$ year old girls drank green or black tea daily, and adolescents consume this product 2-4 times more (50\% girls and $80 \%$ boys, respectively). Adolescent boys two times more than girls drank coffee. Only two children aged 0-10 years and two adolescents with epilepsy aged 11-18 years drank lots of water daily. Consumption of liquid is shown in Figures 5 and 6 .

\section{DISCUSSION}

In the study we observed that in general children with epilepsy consumed healthier food than adolescents with epilepsy. Most often, the choice of food was determined by family nutritional habits, food items that are included in the kindergarten and school menu, as well as the commercials in the mass media whose basic target audience often is children and adolescents. Interestingly, when questioning parents of the enrolled children about their eating habits, it was reported that only a small number of parents drink water, herbal or fruit tea, make fresh salad, buy different fruits and vegetables, dairy products, and cook fish foods regularly themselves. On average, every second child admitted that he or she would consume the above mentioned food item if their parents and other relatives were doing the same. 
Studies have shown that eating habits of adolescents are greatly influenced by their peers (Bisset et al., 2007), food eaten outside the house, and concepts of the youth themselves about their body, weight and beauty standards in the world of today (Cusatis and Shannon, 1996).

We observed that children and adolescents with epilepsy preferred to have high-carbohydrate and high-fat product items. In contrast to what might be expected, that older boys (11-18 years) would consume a rather small amount of dairy products, the results showed that adolescent girls with epilepsy are the ones who choose not to drink milk and kefir in lesser amounts because of personal prejudice.

The research also demonstrated that younger patients eat meat and fish more often than adolescents. Also, older girls generally ate meat and fish less times per week than boys because of different considerations (for example, fear of gaining weight).

Noteworthily, some adolescent girls with epilepsy did not eat breakfast. In most cases, this is associated with concerns of gaining weight. A quite recent study in a number of European countries indicated that skipping breakfast is one of preconditions of obesity (Szajewska and Ruszczynski, 2010).

It has been shown that children and adolescents who eat breakfast have a reduced risk of obesity and reduced body mass index (BMI), compared to those who skip breakfast (Szajewska and Ruszczynski, 2010). In this study, we did not analyze in detail how often children and adolescents skip breakfast, what they consume at all, and why they make such choices. This article only summarizes general hallmarks of eating habits. We have not evaluated changes in individual BMI according to each patient's eating habits.

It is possible that epileptic children and adolescents in Latvia, as has been shown in the USA, prefer high-fat to high-carbohydrate food items (Amari et al., 2007). Therefore, future studies are required in this field. Epileptologists and child neurologists should also educate relatives of patients about features of epilepsy and encourage them to make changes in their eating habits.

In summary, the observed 41 children and adolescents with diagnosed epilepsy: 1) chose to have meals rich of carbohydrates and fat, rather than protein; 2) a large number of the evaluated patients drank soda drinks and juices daily; 3) only several of the evaluated patients drank water daily; 4) all patients ate fruits and vegetables daily, thus compensating unhealthy eating habits.

\section{REFERENCES}

Amari, A., Dahlquist, L., Kossoff, E. H., Vining, E. P. G., Trescher, W. H., Slifer, K. J. (2007). Children with seizures exhibit preferences for foods compatible with the ketogenic diet. Epilepsy Behav., 11, 98-104.

Asadi Pooya, A. A., Ghafari, A. (2004). Do patients with epilepsy think they need specific dietary restrictions? Epilepsy Behav., 5, 945-948.
Asadi-Pooya, A. A., Hossein-Zade, A. (2005). What do nurses and physicians think about the need for specific dietary restrictions in the patients with epilepsy? Epilepsy Behav., 6, 604-606.

Asadi-Pooya, A., Sperling, M. R. (2007). Do foods precipitate seizures? A cross-cultural comparison. Epilepsy Behav., 11, 450-453.

Avicenna. (1991). The Conon of Medicine. Book III. 4th ed. Teheran: IRIB Publications, pp.144-156.

Bhagavan, H. N., Coursin, D. B., Stewart, C. N. (1971). Monosodium glutamate induces convulsive disorders in rats. Nature, 232, 275-276.

Bisset, S., Gauvin, L., Potvin, L., Paradis, G. (2007). Association of body mass index and dietary restraint with changes in eating behaviour throughout late childhood and early adoescence: A 5-year study. Public Health Nutr., 10 (8), 780-789.

Bough, K. J., Schwartzkroin, P. A., Rho, J. M. (2003). Calorie restriction and ketogenic diet diminish neuronal excitability in rat dentate gyrus in vivo. Epilepsia, 44, 752-60.

Burns, B. L., Carr-Davis, E. M. (1996). Nutritional care in diseases of the nervous system (p. 882). In: Mahan, L. K., Escott-Stump, S. (eds.). Krause's Food, Nutrition and Diet Therapy. 9th edn. Philadelphia: Saunders.

Christensen, L., Pettijohn, L. (2001). Mood and carbohydrate cravings. Appetite, 36, 137-45.

Clench Aas, J., Lossius, M. I., Gjerstad, L. (2006). Nutritional habits in Norwegian youth with epilepsy. A population base study. The Akershus health study. Epilepsia, 47 (S4), 11-12.

Cohli, A., Tanenbaum-Rakover, Y., Leshem, M. (2005). Increased salt appetite in patients with congenital adrenal hyperplasia 21-hydroxylase deficiency. Amer. J. Physiol. Regul. Integr. Comp. Physiol., 288, 1673-1681.

Cusatis, D. C., Shannon, B. M. (1996). Influences on adolescent eating behavior. J. Adol. Health, 18, 27-34.

Frucht, M. M., Quigg, M., Schwaner, C., Fountain, N. B. (2000). Distribution of seizure precipitants among epilepsy syndromes. Epilepsia, 41, 1534-1539.

Gallagher, B. B., Prichard, J. W., Glaser, G. H. (1968). Seizure threshold and excess dietary amino acids. Neurology, 18, 208-212.

Garg, S. K., Kumar, N., Bhargava, V. K., Prabhakar, S. K. (1998). Effect of grapefruit juice on carbamaepine bioavailability in patients with epilepsy. Clin. Pharmacol. Ther., 64, 286-288.

Miwa, H., Ijima, M., Taraka, S., Mizuno, Y. (2001). Generalized convulsions after consuming a large amount of Ginko nuts. Epilepsia, 42, 280-281.

Neal, E. G., Cross, J. H. (2010). Efficacy of dietary treatments for epilepsy. J. Hum. Nutr. Diet, 23, 113-119.

Nettekoven, S., Ströhle, A., Trunz, B., Wolters, M., Hoffmann, S., Horn, R., Welkoborsky, H. J., Tuxhorn, I., Hahn, A. (2008). Effects of antiepileptic drug therapy on vitamin D status and biochemical markers of bone turnover in children with epilepsy. Eur. J. Ped., 167 (12), 1369-1377.

Nordli, D. R., De Vivo, D. C. (2001). The ketogenic diet. In: Wyllie, E. (Ed.). The Treatment of Epilepsy. 3rd ed. (pp. 1001-1006). Philadelphia: Lippincott Williams \& Wilkins,

Sousa, P. S., Lin, K., Garzon, E., Sakamoto, A. C., Yacubian, E. M. T. (2005). Self-perception of factors that precipitate or inhibit seizures in juvenile myoclonic epilepsy. Seizure, 14, 340-346.

Spector, S., Cul, C., Goldstein, L. H. (2000). Seizure precipitants and perceived self-control of seizures in adults with poorly-controlled epilepsy. Epilepsy Res., 38, 207-216.

Szajewska, H., Ruszczynski, M. (2010). Systematic review demonstrating that breakfast consumption influences body weight outcomes in children and adolescents in Europe. Critical Rev. Food Sci.Nutr., 50, 113-119. 
Tsai, M. H., Chang, W. N., Lui, C. C., Chung, K. J., Hsu, K. T., Huang, C. R., Lu, C. H., Chuang, Y. C. (2005). Status epilepticus induced by star fruit intoxication in patients with chronic renal disease. Seizure, 14, 521-525.

Victor, M., Ropper, A. H. (2001). Adams and Victor's Principles of Neurology. 7th edn. New York: McGraw-Hill, p. 189.
Weingarten, H. P., Elston, D. (1990). The phenomenology of food cravings. Appetite, 15, 231-246.

Wurtman, R. J., Wurtman, J. J. (1986). Carbohydrate craving, obesity and brain serotonin. Appetite, 7, 99-103.

Wurtman, R. J., Wurtman, J. J. (1988). Do carbohydrates affect food intake via neurotransmitter activity? Appetite, 11 (Suppl 1), 42-47.

Received 15 September 2012

\section{ĒŠANAS IERADUMI BĒRNIEM UN PUSAUDŽIEM AR EPILEPSIJU}

Pētījumā tika iekḷauts 41 pacients: 12 meitenes un 14 zēni vecumā no 0 līdz 10 gadiem, 10 meitenes un 5 zēni vecumā no 11 līdz 18 gadiem. Tika veikta anketēšana par dažādu pārtikas produktu lietošanas biežumu uztura grupās: og̣̣hidrāti, tauki, olbaltumvielas, šķiedrvielas, šķidrums. Darba mērķis bija ēšanas paradumu izvērtēšana un noteikšana bērniem un pusaudžiem ar epilepsiju. No novērotajiem bērniem 33-58\% vecumā no 0 līdz 10 gadiem ikdienā dzer gāzētos dzērienus, èd popkornu, savukārt pusaudžiem šì proporcija palielinās 1,2-2,4 reizes. Saldumus regulāri ēd 83\%-100\% bērni un pusaudži. Vidēji katrs otrais bērns (0-10 gadi) vismaz vienu reizi nedēẹā ēd kartupelu čipsus, bet pusaudži ar epilepsiju - no 80\% līdz 100\%. Katrs trešais bērns vecumā no 0 līdz 10 gadiem un $80-100 \%$ pusaudžu regulāri èd ceptus kartupeḷus. Katrs otrais zēns un gandrīz visas meitenes no 0 līdz 10 gadiem regulāri ēd dažādus piena produktus, savukārt vecākajā pacientu grupā zēni piena produktus lieto divas reizes biežāk nekā meitenes, 40\% meiteņu nedzer pienu. Jaunākās meitenes gaḷu un zivis èd 1,5-3,5 reizes biežāk nekā zēni. Augḷus un dārzeņus ikdienā ēd 75-100\% bērni un pusaudži ar epilepsiju. Tikai divi bērni un divi pusaudži ikdienā dzer daudz ūdens. Kopumā bērni un pusaudži ar epilepsiju: 1) labprātāk izvēlas ēst ar og̣̣hidrātiem un taukvielām bagātus pārtikas produktus, nevis olbaltumvielas saturošus; 2) ievērojams skaits epilepsijas slimnieku ikdienā dzer gāzētus dzērienus vai saldinātas sulas; 3) ūdeni dzer tikai daži; 4) visi èd šḳiedrvielām bagātus augḷus un dārzeṇus, tādējādi kompensējot neveselīgos ěšanas paradumus. 


\title{
MONITORING OF EATING HABITS AND PHYSICAL ACTIVITY LEVELS AS A BASIS FOR A NEW NONCOMMUNICABLE DISEASE PREVENTION PROGRAMME IN THE REPUBLIC OF MACEDONIA
}

\author{
Vera Simovska-Jarevska*, **, Sasko Martinovski**, Dragan Damjanovski**, \\ Valentina Pavlova**, Daniela Nikolovska-Nedelkoska**, and Gjorgji Manceski *** \\ * Public Health Institutions-Skopje, Institute of Sports Medicine, Nutrition Research Department, \\ Krste Miairkov bb, Skopje 1000, REPUBLIC OF MACEDONIA; \\ vera.simovska@uklo.edu.mk \\ ** University of Bitola "St. Kliment Ohridski", Faculty of Technological and Technical Sciences-Veles, \\ Petre Prlicko 14, Veles 43000, REPUBLIC OF MACEDONIA; \\ ttfv@uklo.edu.mk \\ *** University of Bitola "St. Kliment Ohridski", Faculty of Economy, 4800 Prilep, Djordje Petrov bb, REPUBLIC OF MACEDONIA; \\ gmanceski@gmail.com
}

Communicated by Ingrīda Rumba

\begin{abstract}
Research evidence on health determinants has led to development of a national programme for noncommunicable disease (NCD) prevention. Numerous studies have confirmed the role of nutrition and physical activity in preventing main NCDs: cardiovascular disease, type 2 diabetes, cancer and chronic respiratory disease. The aim of the study was to analyse and evaluate the results obtained from the new "cross-sectional" study in 2012 offer monitoring of eating habits and physical activity levels monitoring related to socioeconomic status of the participants in 2012. The study was conducted in five regions of the Republic of Macedonia and included 1600 respondents aged 10 to 64 years. Monitoring was conducted using self-designed questionnaire. Eating habits were surveyed using questionnaires to monitor the frequency of consumption of main food groups during a week. Leisure time physical activity was a priority measure in the study. Also, in the study a model was applied for strategic planning in NCD prevention, based on the results of the health behaviour survey. The model was analysed using a software package. The results indicate that NCDs prevention through improving physical activity levels and changes in eating habits should be focused on changes in food content including availability of whole grain bread, guidelines and policy on food labelling and health claims, marketing and city planning that facilitates an active life.
\end{abstract}

Key words: NCDs prevention, eating habits, physical activity levels, socioeconomic differences.

\section{INTRODUCTION}

Four major noncommunicable diseases (NCDs) are the greatest public health problem in the WHO European region, with approximately $86 \%$ of all deaths in the region caused by this broad group of diseases that includes cardiovascular disease (CVD), cancer, type 2 diabetes (T2DM) and chronic respiratory disease. Nearly four out of five deaths $(80 \%)$ from NCDs occur in low- or middle income countries. Also, NCDs result in mortality at a younger age in low and middle-income countries - on average, ten years younger than in high-income countries (Anonymous, 2011).

NCDs have multifactorial etiology and they are a result of complex interaction between individual characteristics (gen- der, age, ethnicity, genetic predisposition) together with social, economic and environmental determinants (education, income, living and working condition). They are a consequence of a transition in lifestyles that leads to increased risk of NCDs. The most prominent NCDs are linked to common risk factors: an unhealthy diet and lack of physical activity, tobacco use and harmful use of alcohol. Six of the seven key determinants of mortality in developed countries are related to how we eat, drink and move. Diet and physical activity, together with tobacco and alcohol, are key determinants of contemporary public health. Nutrition is one of the main determinants (Anonymous, 1990).

A large percentage of NCDs can be prevented by reducing the main risk factors. The greatest potential for NCDs pre- 
vention and control lies in population based integrated preventive interventions targeting lifestyle risk factors: diet, physical activity and tobacco (Anonymous, (2008). The study of dietary habits and physical activity levels in the community action programmes both as major health determinants and also as important public health issues for which accurate, reliable and comparable information is needed as a basis for the development of evidence-based strategy and programmes in the field of NCDs prevention. The burden of NCDs is increasing rapidly in the developing world, very much as a result of changes in lifestyles. In addition to changes in tobacco use and physical activity, major changes are taking place in diets, which is contributing greatly to the growing epidemic of NCDs. Thus, a huge global public health challenge is how to influence the trends in diet and nutrition for effective global NCDs prevention.

The Republic of Macedonia needs to address its growing NCDs epidemic through health promoting partnerships, strategies and programmes. High-level political commitment, inter-sectoral coordination, and community mobilisation are important in developing a successful, national, multi-sectoral programme for the prevention and control of NCDs. An efficient multi-sectoral mechanism is also crucial at the stage of monitoring, evaluating enforcement of strategy, and analysing impact of multi-sectoral initiatives on reducing NCDs burden in the country.

Country-level surveillance and monitoring systems, including surveys that are integrated into existing national health information systems and include monitoring exposure to risk factors, outcomes, social and economic determinants of health, and health system responses are needed, recognising that such systems are critical in appropriately addressing NCDs (Puska et al., 1995).

The first Plan of Action for Integrated Community and Primary Care Based Prevention and Control of NCDs as well as the Cancer Prevention Programme of Republic of Macedonia were implemented in years 2002-2005 (Anonymous, 2003).

This paper presents the link between food habits and physical activity levels in socioeconomic groups in the Republic of Macedonia. Disparities in food habits are defined as the differences in food consumption based on education and/or occupation/income in population. Food consumption is measured as frequency of consumption of the following items or groups: fruit and vegetables, milk and dairy products, meat and type of bread (Ross et al., 1999).

We need more scientific knowledge on how socioeconomic differences in eating behaviour and physical activity among the Macedonian population can be explained. To establish the second health-risk behaviour surveillance system is a useful tool to obtain more specific data for strategic planning on regional and local levels related to socioeconomic status of population and regional or local situation in food and nutrition.
This study focuses on individual social determinants, such as education and incomes. It is known that education might provide potential cognitive resources that influence an individual's healthy choices. In addition, educational success may forecast future success: better jobs, higher income, good living area and better housing etc. Assessing how socioeconomic differences in food habits and physical activity levels can be explained, we can more efficiently promote healthier nutrition and physical activity among those with low socioeconomic position in the Republic of Macedonia.

Our hypothesis was that the differences in eating habits and physical activity levels are based on socioeconomic factors such as education, income, occupation/profession, poverty, ethnicity, locality and gender. Socioeconomic status affects the healthiness of the diet.

The general objective of the study was to obtain information and to describe socioeconomic differences in eating habits and physical activity levels.

The specific aims were:

- to analyze and evaluate the results obtained from the new "cross-sectional" study for socioeconomic differences: relationships of educational levels and income with the consumption of the main health-related foods and physical activity levels in the Republic of Macedonia, in 2012;

- to set-up a model that describes how multi-sectoral action can effectively address such challenges through mainstreaming NCDs prevention into national health and development programmes.

\section{MATERIALS AND METHODS}

The new "cross-sectional" population-based study was conducted at the Faculty of Technology and Technical Sciences-Veles at the University St. "Clement of Ohrid" in Bitola. The study was carried out between March and May 2012 in five regions in the Republic of Macedonia, and included 1600 respondents aged 10 to 64 years.

Eating habits were measured as frequencies of consumption of the following food groups: fruit and vegetables, milk and dairy products, meat and type of bread from responses in a food frequency questionnaire (FFQ).

Physical activity levels were measured as leisure time physical activity (LTPA). The questionnaire included a comprehensive list of examples of brisk walking and cycling, known as physical activity with moderate intensity as well as organized sports known as strenuous activity. Leisure time physical activity (LTPA) is a personally chosen activity undertaken in an individual's free time that can be motivated by several reasons, such as health benefits, aesthetics, social contacts and fun. Exercise and sports is a form of LTPA that is more planned, structured and aims at more specific objectives, for example the improvement of physical fitness. 
Several socioeconomic measures were linked from the national population register. Indicators of socioeconomic inequalities in health behaviour, including nutrition and physical activity levels by gender and age groups were education and income. Socioeconomic differences in food groups' consumption and physical activity levels were analysed.

Educational levels were often grouped according to a standard 5-level classification developed by the OECD (Anonymous, 1997). For practical reasons, educational levels were grouped as basic (elementary), secondary and higher education (university degree).

Income was measured as family monthly income divided by the number of family members. Income was grouped in three classes: up to 75 Euros, from 75 to 150 Euros and over 150 Euros per month.

In the study a model was applied for strategic planning for NCD prevention and health promotion using software package for data analyzing (Martinovski, 2012). This model was chosen for two reasons. The first was to show the application of the proposed concept in public health, food technology, nutrition and economy. The second reason was that the Faculty of Technology and Technical Sciences-Veles had been created a database from its current research on the socioeconomic impact on a healthy diet and physical activity level.

The results were presented in percentages (\%) of total numbers of the participants in the study by education and income.

\section{RESULTS}

Eating habits. A considerable part of the health behaviour study dealt with monitoring of food habits in Macedonian population, in 2012 .

Bread. The most remarkable result has observed was regarding the usage of black and whole grain bread; people with better income consumed more frequently black and whole grain bread in comparison with those with low socioeconomic status (Fig. 1).

Also, use of these types of bread was more prevalent among higher educated people (Fig. 2).
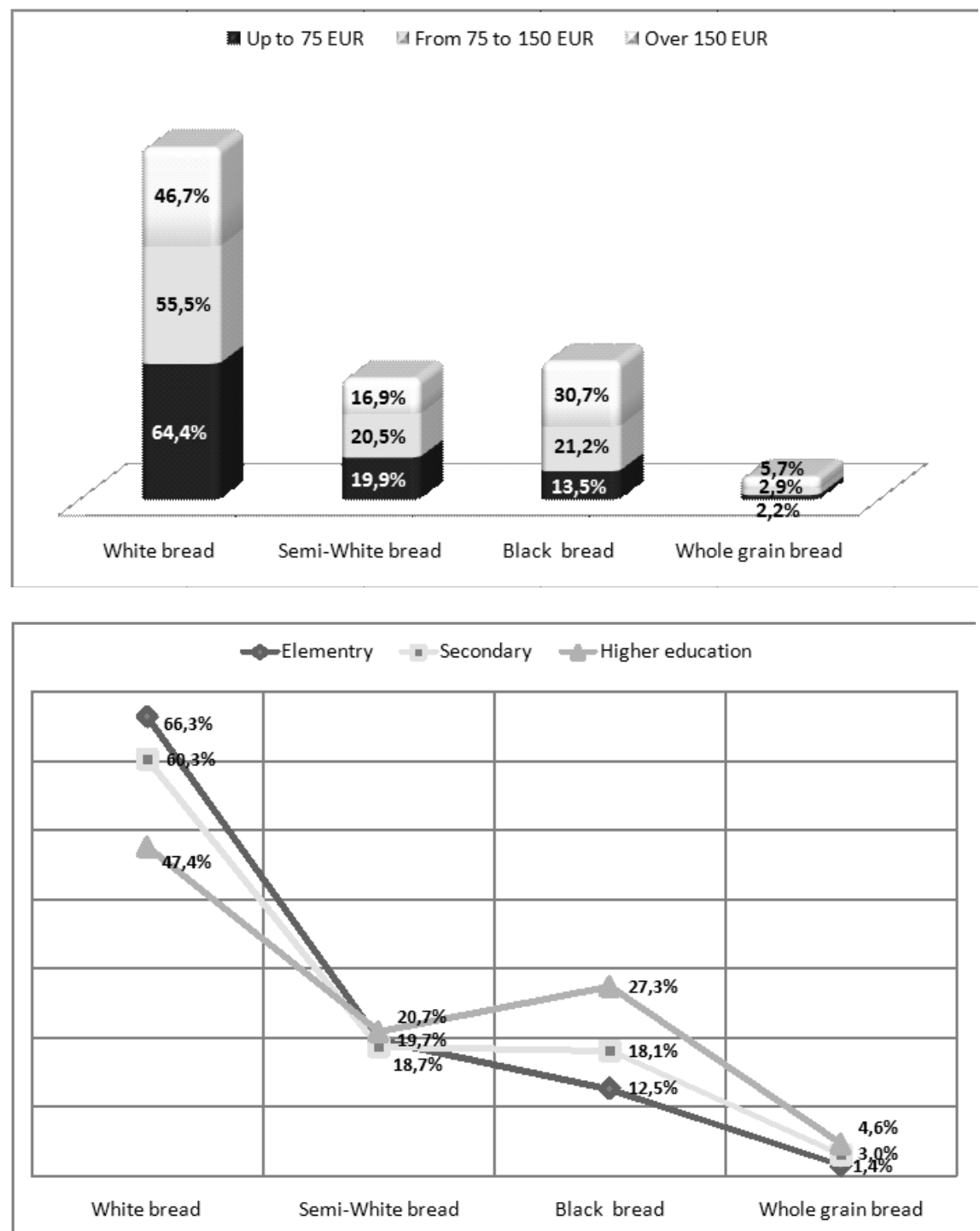

Fig. 1. Proportion (\%) of participants using different type of bread by income in 2012 .

Fig. 2. Proportion (\%) of participants using different type of bread by education levels in 2012 . 
Milk and dairy products. Education and monthly income of the participants had high impact on the frequency of consumption of milk and dairy products.

Less frequently consumption of selected foods in Republic of Macedonia in 2012 were related to lower income and less education (Figs. 3 and 4).

Regarding content of fat in milk and dairy products more frequently low-fat were used by people with higher education.

In general, we noticed less frequent consumption of dairy products that were enriched with vitamins and minerals.

Perhaps, media education regarding food labelling and health claims are needed.

Vegetables and fruit. Education and family monthly income had little impact on the frequency of consumption of fruits and vegetables (Figs. 3 and 4).

The main reason was the relatively low price, availability and relative good production of vegetables and fruits in the Republic of Macedonia.

Meat. Regarding consumption of meat and meat products, most of the study participants consumed more frequently chicken and pork, but less fish. One of the reasons for this is the low price of chicken in the country.
In general, participants with higher education and higher income, more frequently used fish and beef meat.

Physical activity levels. The results showed that monthly income had little impact on physical activity with low intensity such as walking. $35 \%$ of all participants from families with different monthly income walked regularly.

The proportion of sedentary participants who had only lower education was $40 \%$ of all study participants. Physical activity with moderate and higher intensity such as organized sports activities were related to the higher income.

\section{DISCUSSION}

This is the first national "cross-sectional" study in the Republic of Macedonia conducted with the aim to analyse and evaluate data on socioeconomic differences in educational levels and income on the consumption of the main healthrelated foods and physical activity levels of the population (10-64 years).

On the European level, the differences in food consumption in relation to education and income were examined in an adult population (18-65 years) in 1985-1997 as part of the FAIR-97-3096 project "Compatibility of The Household and Individual Nutrition Survey in Europe and Disparities in Food Habits" (Roos et al., 1999). Forty seven studies
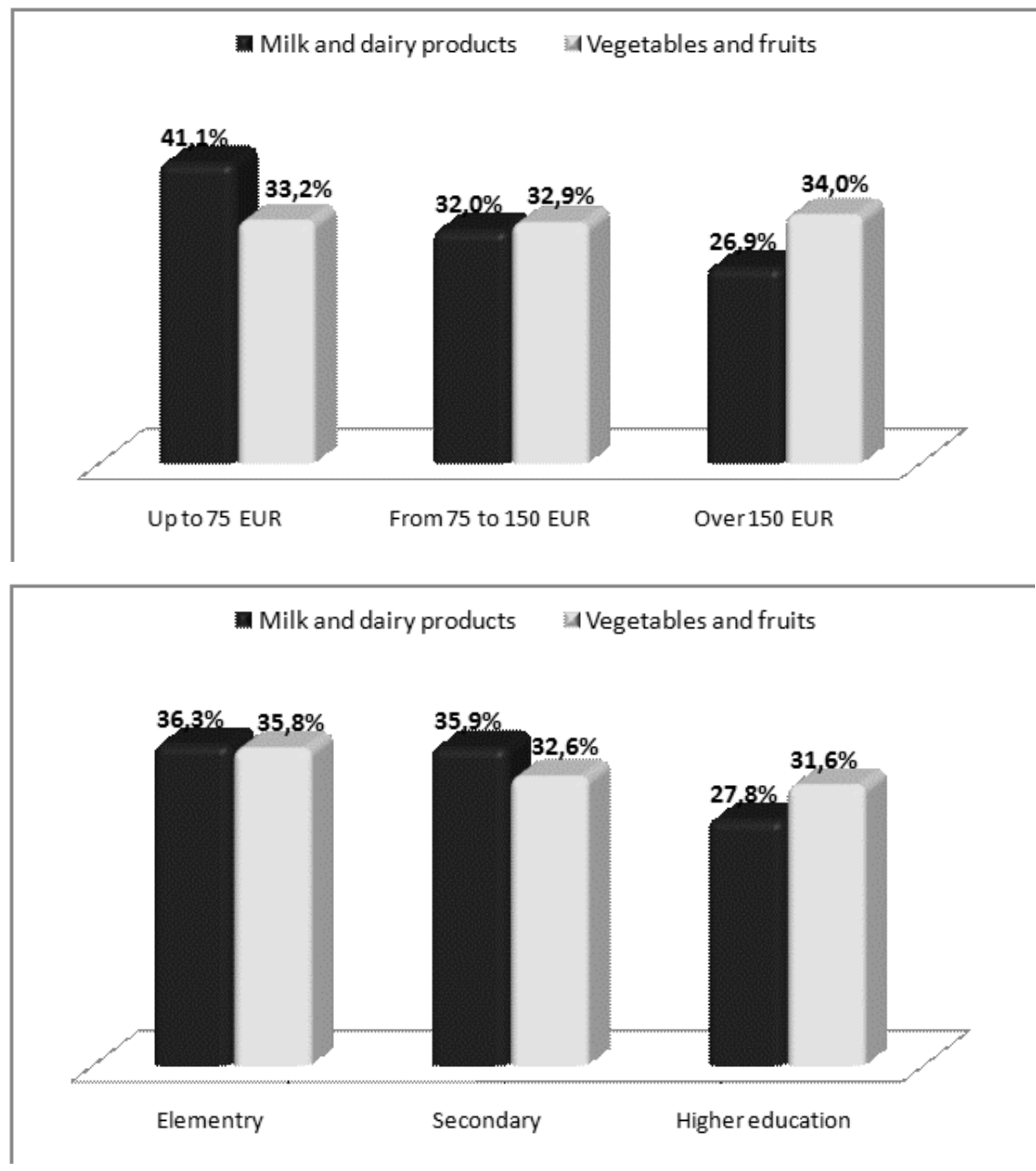

Fig. 3. Proportion (\%) of participants using less frequently consuming milk and dairy products by income in 2012.
Fig. 4. Proportion (\%) of participants less frequently consuming milk and dairy products by education in 2012 . 
from 15 countries were reviewed. These studies were mainly large-scale national dietary, household budget and health behaviour surveys. The meta-analysis showed that people belonging to higher social classes have healthier diets. Those with higher education, with the exception of inhabitants of the southern Europe, tended to consume more vegetables and fruit, and less fat. The socioeconomic differences in food consumption were not homogenous across Europe. The patterns varied by food groups and region.

Project results of food-related disparities observed in the present study were used in planning food and nutrition policy, programmes and dietary interventions aimed at promoting health among lower social classes and risk groups.

Clinical and epidemiology studies conducted over the past ten years in Republic of Macedonia have shown a reduced level of physical activity was found in $64.5 \%$ of the adult population and in $50 \%$ of girls aged from 7 to 12 years independent of educational level (Simovska, 2002). In the mentioned study conducted in the WHO European region (Currie et al., 2012) 31\% of participants were sedentary.

In accordance to UN Political Declaration on the Prevention and Control of Non-communicable Diseases (Anonymous, 2011), the Government should implement programmes that tackle the social determinants of NCDs with particular reference to the health in early childhood, the health of the poor, fair financing, and equitable access to primary health care services and essential medicines.
Also, governments should adopt the evidence-based global strategies developed by the WHO including the Global Strategy on Diet, Physical Activity and Health (Anonymous, 2004) and other programmes such as the Disease Control Priorities Project, as the foundation of future evidence-informed policies to reduce the burden of NCDs.

Various socioeconomic groups are differently affected by political and economics changes. Assessment of the trends in health and health behaviour of different socioeconomic groups in the Republic of Macedonia is essential for planning and evaluation of the NCDs prevention programme. Also, the research study provides results for health-policy decision-making and can be used for evaluating specific health promotion and NCDs prevention programmes. Changes in food content, guidelines and policy on food labelling and health claims, marketing, city planning that facilitates active transport (as opposed to motorised) are among the measures that will help to keep the NCDs epidemic under control. Projected future ratio of bread's economic status estimated using Buhlmann-Straub statistical method are presented in Table 1.

\section{ACKNOWLEDGMENTS}

The work was supported by the University Research Centre: "St. Clement of Ohrid", Bitola, in 2012. We extend our personal acknowledgment for their input to the whole team of the study including study coordinator, colleagues as well as to the students of "Study for Nutrition" who participated in the initial stage of the project.

ECONOMIC STATUS OF BREAD: PROJECTED FUTURE RATIO

(Standard Credibility Method: Buhlmann-Straub)

\begin{tabular}{|c|c|c|c|c|c|}
\hline $\begin{array}{c}\text { Number of participants } \\
\text { before } 2012 \\
\end{array}$ & $\begin{array}{c}\text { Economic status (income } \\
\text { per family member) }\end{array}$ & Actual excepted ratio & Credibility Factor Z & $\begin{array}{c}\text { Number of participants } \\
2012 \\
\end{array}$ & $\begin{array}{c}\text { Buhlmann empirical } \\
\text { Bayesian Estimate PFR }\end{array}$ \\
\hline \multicolumn{6}{|c|}{ White bread } \\
\hline 550 & Up to 75 EUR & $85.27 \%$ & 0.79 & 469 & $88.40 \%$ \\
\hline 502 & From 75 to 150 EUR & $96.02 \%$ & 0.78 & 482 & $96.89 \%$ \\
\hline 248 & Over 150 EUR & $92.74 \%$ & 0.64 & 230 & $95.36 \%$ \\
\hline Total 1300 & & & & Total 1181 & \\
\hline \multicolumn{6}{|c|}{ Semi White Bread } \\
\hline 138 & Up to 75 EUR & $105.07 \%$ & 0.65 & 145 & $103.28 \%$ \\
\hline 150 & From 75 to 150 EUR & $118.67 \%$ & 0.66 & 178 & $112.40 \%$ \\
\hline 63 & Over 150 EUR & $131.75 \%$ & 0.59 & 83 & $118.78 \%$ \\
\hline Total 351 & & & & Total 406 & \\
\hline \multicolumn{6}{|c|}{ Black Bread } \\
\hline 80 & Up to 75 EUR & $122.50 \%$ & 0.60 & 98 & $113.51 \%$ \\
\hline 184 & From 75 to 150 EUR & $100.00 \%$ & 0.70 & 184 & $100.00 \%$ \\
\hline 135 & Over 150 EUR & $112.59 \%$ & 0.60 & 152 & $107.60 \%$ \\
\hline Total 399 & & & & Total 434 & \\
\hline \multicolumn{6}{|c|}{ Whole grain bread } \\
\hline 11 & Up to 75 EUR & $145.45 \%$ & 0.38 & 16 & $117.08 \%$ \\
\hline 14 & From 75 to 150 EUR & $178.57 \%$ & 0.42 & 25 & $132.89 \%$ \\
\hline 15 & Over 150 EUR & $186.67 \%$ & 0.36 & 28 & $130.86 \%$ \\
\hline Total 40 & & & & Total 69 & \\
\hline
\end{tabular}




\section{REFERENCES}

Anonymous (1990). World Health Organization. Diet, Nutrition, and the Prevention of Chronic Diseases. Report of a WHO Study Group. Technical Report Series 797. Geneva: WHO, 1990. 203 pp.

Anonymous (1997). Education at the Glance: OECD Indicators. Paris: OECD.

Anonymous (2003). Annual Report for the "National Programme for Noncommunicable Disease Prevention and Control in Republic of Macedonia (WHO CINDI Programme). Ministry of Health of Republic of Macedonia and the WHO Country Office, 2003.

Anonymous (2004). WHO Global Strategy on Diet, Physical Activity and Health. http://www.who.int/dietphysicalactivity/strategy/eb11344/strategy_english_web.pdf (last accessed 11.05.2010).

Anonymous (2008). WHO. 2008-2013 Action plan for the Global Strategy for the prevention and control of NCDs, WHO, 2008. $42 \mathrm{pp}$.

http://www.who.int/nmh/Actionplan-PC-NCD-2008.pdf

Anonymous (2011). UN, Political declaration of the High-level Meeting of the General Assembly on the Prevention and Control of Non-communicable Diseases. Sixty-sixth session Agenda item 117 Follow-up to the outcome of the Millennium Summit, 2011.

http://ncdaction.org/page/the-solutions
Currie, C. et al. (eds.) (2012). Social determinants of health and well-being among young people. Health Behaviour in School-aged Children (HBSC) study: International report from the 2009/2010 survey. Copenhagen, WHO Regional Office for Europe, 2012 (Health Policy for Children and Adolescents, No. 6. http://www.euro.who.int/en/what-we-publish/abstracts/social-determinants-of-health-and-well-being-among-young-peopl e.-health-behaviour-in-school-aged-children-hbsc-study (last accessed 26 April 2012).

Martinovski, S. (2012). Geographic Information System (GIS) Modelling for Strategic Planning of Urban Environment Development. Unpublished doctoral thesis (PhD), University of Bitola "St. Clement of Ohrid", Faculty of Economy, Prilep.

Puska, P., Tuomilehto, J., Nissinen, A., Vartiainen, E. (eds.) (1995). The North Karelia Project. 20 Year Results and Experiences. Helsinki: National Public Health Institute. 363 pp.

Roos, G., Prattala, R. (1999). Disparities in Food Habits. Review of Research in 15 European Countries. Helsinki: National Public Health Institute.

Simovska V. (2002). Plan of action for integrated community and primary care based prevention and control of cardiovascular and other NCDs in FYR of Macedonia, 2002-2007. www.cindi.makedonija.com.

Simovska V. (2002). CINDI Health Monitor Survey-An integrated part of CINDI Conceptual Model in Macedonia.

http://www.cindi.makedonija.com/DOCS/CINDI_Health_Monitor_Survey_Macedonia_2002.pdf

18 September 2012

\section{ĒŠANAS PARADUMU UN FIZISKĀS AKTIVITĀTES LİMEN̦A MONITORINGS KĀ PAMATS JAUNAI NEINFEKCIJAS SLIMĪBU PROFILAKSES PROGRAMMAI MAĶEDONIJAS REPUBLIKĀ}

Pētījumā tika novērtēti 2012. gadā veikti ,,̌̌kērsgriezuma” pētījumi par ēšanas paradumu un fizisko aktivitāšu ietekmi uz neinfekcijas slimībām, no kurām galvenās ir sirds un asinsvadu slimības, 2. tipa diabēts, vēzis un hroniskas respiratorās slimības. Pētījums tika veikts piecos Maķedonijas republikas reǵionos un ietvēra 1600 respondentus vecumā no 10 līdz 64 gadiem. Tika izmantota aptaujas anketa par ēšanas paradumiem, kurā bija jautājumi par nedēḷas laikā patērētajām galvenajām produktu grupām. Pētījumā tika mērītas brīvā laika fiziskās aktivitātes. Pētījuma rezultāti parādīja, ka neinfekcijas slimību profilaksei, līdz ar fizisko aktivitāšu līmeṇa paaugstināšanu un èšanas paradumu main,u, ir jāfokusējas uz uztura sastāvu, ietverot pilngraudu maizes pieejamību, kā arī uz pārtikas etiķetēšanas politiku, veselīguma prasībām, mārketingu un pilsētu plānošanu, kas veicina aktīivu dzīvesveidu. 


\title{
DIETARY BEHAVIOUR IN STUDENTS WITH DIFFERENT BODY FAT PERCENT
}

\author{
Rudīte Lagzdina, Leons Blumfelds, Maija Rumaka, and Līga Aberberga-Augškalne \\ Department of Human Physiology and Biochemistry, Rīga Stradinšs University, Dzirciema iela 16, Rīga LV-1007, LATVIA
}

Communicated by Ingrīda Rumba

\begin{abstract}
Eating habits with uniform food preferences and increased energy intake can contribute to increased gain of body fat. An adequate diet, body self-evaluation, and recognition of unhealthy nutrition patterns should promote appropriate corrective actions. The aim of the present study was to determine whether energy intake, food diversity and corrective modification of body mass differed among student groups with low, normal and high body fat percentage. The study involved 737 (158 male and 579 female) students of the Riga Stradinš University (age 18-49 years). Dietary behaviour was determined using self-administered questionnaire. Body fat percentage was determined with a Tanita MC-180 bioimpedance analyser. Fluid and food intake, as well as physical activity before the test was restricted. The results showed that $15 \%$ of students in the low, $38 \%$ in the normal and $62 \%$ in the high body fat percentage groups considered that they eat too much. In the low, normal and high body fat percentage groups of students, $27 \%, 37 \%$ and $42 \%$, respectively, agreed that they do restrict food intake. There were no significant differences in normalised energy intake and food diversity indexes between these student groups. Students in the high body fat percentage group more frequently admitted eating to much, and their corrective behaviour was associated more with reduced amounts of eaten food rather than minimisation of energy intake and increased food diversity. In all fat percentage groups, female students more frequently admitted that they eat too much and more often tended to restrict food intake than male students.
\end{abstract}

Key words: body fat percent, eating habits, energy intake, food diversity.

\section{INTRODUCTION}

Incidence of obesity, especially in children and young adults, is increasing. This indicates a the need to determine the main causal factors and to advise on effective prevention (Chizuru, 2004). The adiposity in this age can predispone persons to diabetes mellitus, cardiovascular diseases, degenerative joint diseases, certain cancers and other health risks in further life (Anonymous, 2000). Energy balance of energy intake and energy expenditure enables to maintain normal body weight.

Nowadays energy intake is influenced by high availability of energy dense food, rich with fat and added sugars, while intake of complex carbohydrates, dietary fibers, as well as fruits and vegetables is reduced (Anonymous, 2003). This situation stimulates increased energy intake, but energy expenditure is markedly decreased due to low physical activity.

In such conditions the natural body weight regulation mechanisms in some cases are not able to provide effective body weight control, and therefore the importance of conscious activities to maintain normal body size is increased
(Lowe, 2003). Eating habits with uniform food preferences and increased energy intake can contribute to increased gain of body fat. An adequate diet, body self-evaluation, as well as recognition of unhealthy nutrition patterns, can promote appropriate corrective activity. Adoption of healthy dietary behaviour is an effective way to maintain normal body weight and composition (Roach et al., 2003).

The aim of the present study was to determine whether energy intake, food diversity and body mass corrective modification differ among students within low, normal and high body fat percentage groups.

\section{MATERIALS AND METHODS}

All students who were residents of Latvia and who attended a physiology course in Rịga Stradiňš University from 2009-2012 were invited to participate in the investigation. The investigation involved 737 (158 male and 579 female) students of the Rìga Stradiňš University with age 18-49 years. Persons were involved voluntarily and the investigation was conducted according to the requirements of Ethical Committee of the Rịga Stradiņš University. 
At onset all of the students were asked to identify their eating habits by completing a self-administered questionnaire. The questionnaire consisted of 64 questions examining eating style, food diversity and product preferences. In the questionnaire, groups of questions were selected that characterise energy intake and food diversity. The acquired score in each group of questions was expressed as energy intake index and food diversity index, respectively. Higher energy index indicates a tendency to consume products with higher caloric values. Higher food diversity index is associated with using a diet with higher variety of products, including fibre-rich and low-energy dense food.

Then, body height of participants was measured to the closest $0.1 \mathrm{~cm}$ using a standard wall-mounted height measuring device. Body weight to the closest $0.05 \mathrm{~kg}$ and fat percentage with accuracy $0.1 \%$ were estimated using a multifrequency body composition analyser MC-180MA (Tanita, Japan). To obtain more precise results, fluid and food intake, as well as physical activity level of the participants before the test were limited. Students with metal implants and pregnant female students were excluded from the investigation. Body fat percentage was evaluated according to the predicted values (Gallagher et al., 2000) (Table 1). The students were divided into three groups - low fat $\%$, normal fat $\%$ and high fat $\%$.

Table 1

CHARACTERISTICS OF THE STUDIED POPULATION (mean \pm SD)

\begin{tabular}{lcc}
\hline \multicolumn{1}{c}{ Parameter } & Males & Females \\
\hline Age (years) & $20.8 \pm 3.0$ & $21.3 \pm 3.7$ \\
Height $(\mathrm{cm})$ & $181.8 \pm 7.2$ & $168.7 \pm 5.7$ \\
Weight $(\mathrm{kg})$ & $75.4 \pm 10.8$ & $61.3 \pm 10.1$ \\
Fat percent $(\%)$ & $14.4 \pm 5.7$ & $24.7 \pm 5.8$
\end{tabular}

The obtained data were analysed using SPSS software version 17.0 (SPSS Inc., Chicago). Alpha level $P<0.05$ was considered as statistically significant. Differences in distributions between both genders were evaluated using a Chi square test.

\section{RESULTS}

Of the studied population, $75 \%$ males and $67 \%$ females had a normal fat percentage. $10 \%$ males and $25 \%$ females had a low fat percentage, and $15 \%$ males and $8 \%$ females had an increased fat percent (Figs. 1 and 2)

The frequency distributions of yes or no answers to the statement „In my opinion I eat too much” differed significantly between student groups with low, normal and high fat percentages. According to the questionnaire, 52\% males and $67 \%$ females with high fat percentage thought that they eat too much. In the group of students with normal fat percent this answer was given by $17 \%$ males and significantly more $(45 \%)$ females $(P<0.05$ for gender differences). Surprisingly, also $6 \%$ males and $16 \%$ females in the group of students with a low fat percentage thought that they eat too much (Fig. 3).

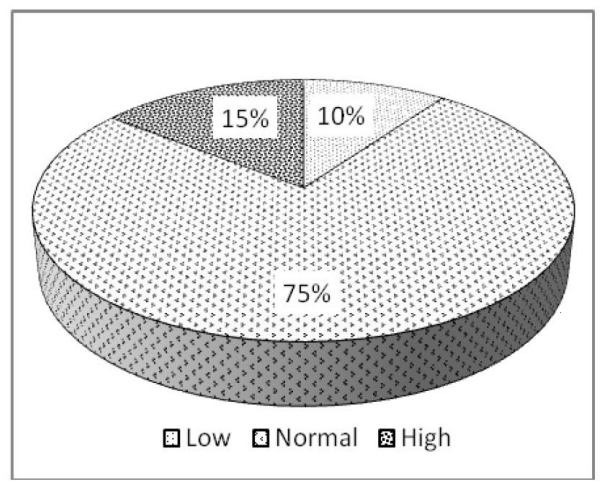

Fig. 1. Frequencies of low, normal and high fat percentage among males.
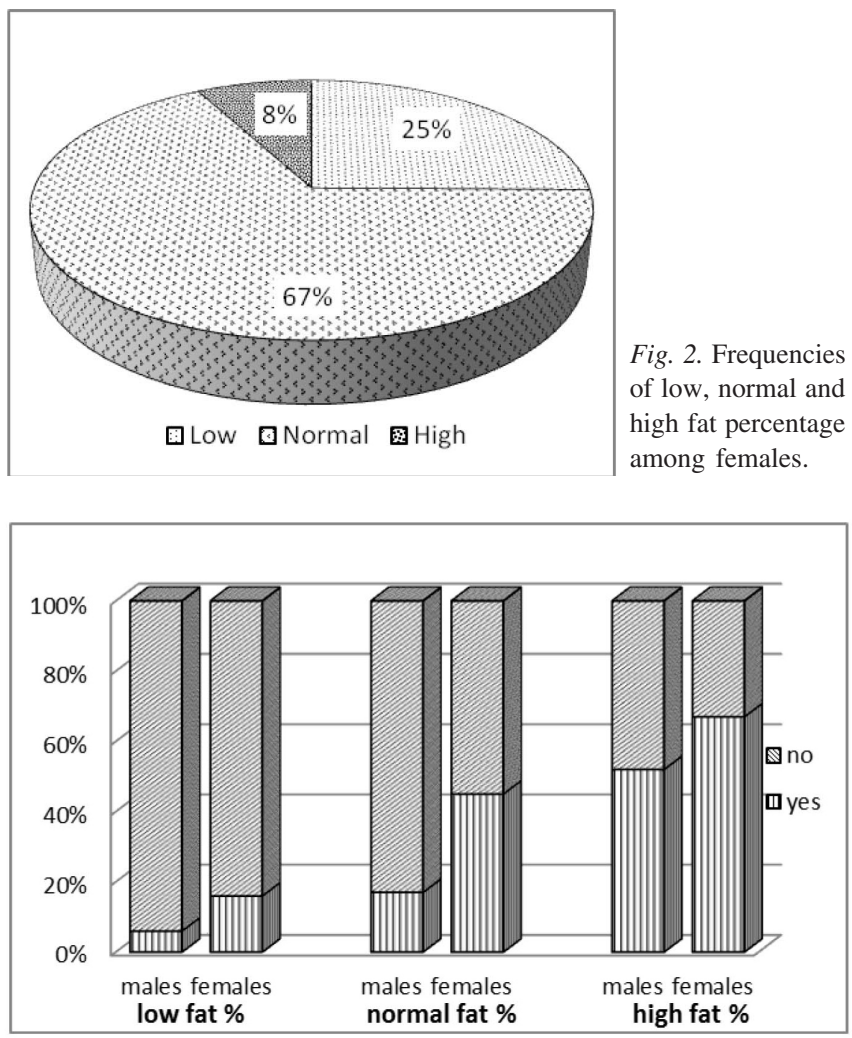

Fig. 3. Percentage of males and females in the low, normal and high fat percent groups, who answered yes or no to the statement „In my opinion I eat too much"

Significant $(P<0.05)$ difference between low, normal and high fat percent groups according to the Chi square test.

Statistically significant differences were observed between the groups of low, normal and high fat percentage groups according to the answers in the statement "I restrict my food amount". $33 \%$ males and $47 \%$ females with a high fat percentage agreed that they restrict their food amount. In the group of students with normal fat percentage only $27 \%$ males and $40 \%$ females agreed. Even $30 \%$ of females with a low body fat percentage agreed that they restrict their food amount (Fig. 4).

On average most of the students were in the low or medium tertile of energy intake index. There were no statistically significant differences in index of energy intake between males and females with different fat percentages. However, the energy intake index of females with normal and high fat percentages was lower than in males $(P<0.05)$ (Fig. 5). 


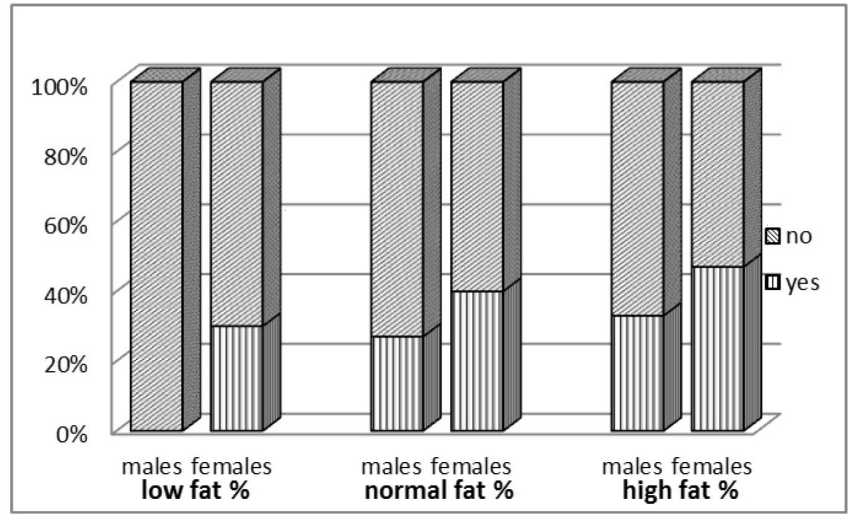

Fig. 4. Percentage of males and females in the low, normal and high fat percentage groups who answered yes or no to the statement „I restrict my food amount".

Significant $(P<0.05)$ difference between low, normal and high fat percent groups according to the Chi square test.

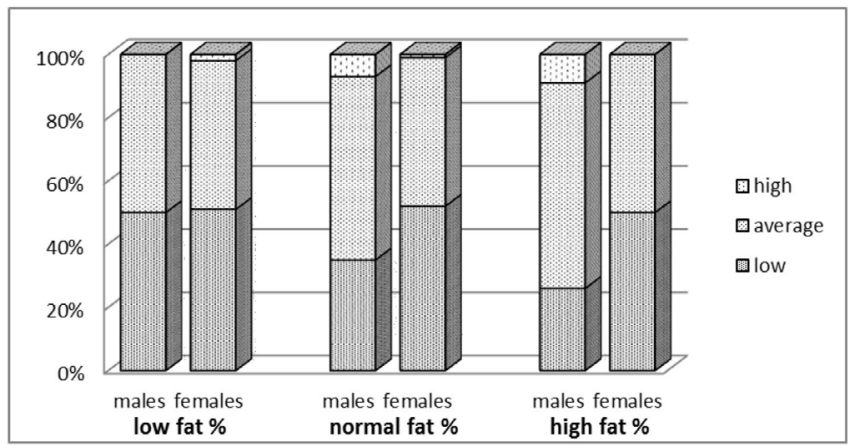

Fig. 5. Percentage of males and females in low, normal and high fat percentage groups according the tertile of energy intake index.

No significant $(P>0.05)$ difference between low, normal and high fat percent groups according to the Chi square test; significant $(P<0.05)$ difference between males and females in normal and high fat percent groups according to the Chi square test.

Generally, most of the students were in the high or medium tertile of food diversity index. Distribution of students in the three tertiles among groups of low, normal and high fat percentage groups was quite similar. No significant differences in distribution of this index were observed between males and females in any of these groups (Fig. 6).

\section{DISCUSSION}

The average fat percentage of students involved in the study was normal. In this, as well as in previous studies (Blumfelds et al., 2008), females prevailed in the group of low fat percentage, while males in the group of high fat percentage. These data are consistent with other reports about young adults (Mohsen, 2007); however, they show higher rates of overweight and obese men than in our study.

It is known that females are more exposed to eating disorders such as anorexia nervosa and bulimia nervosa (Hilbert et al., 2012). However, binge eating disorder and subthreshold binge eating disorder is more common in males than females (Hudson et al., 2007; Sepulveda et al., 2008).

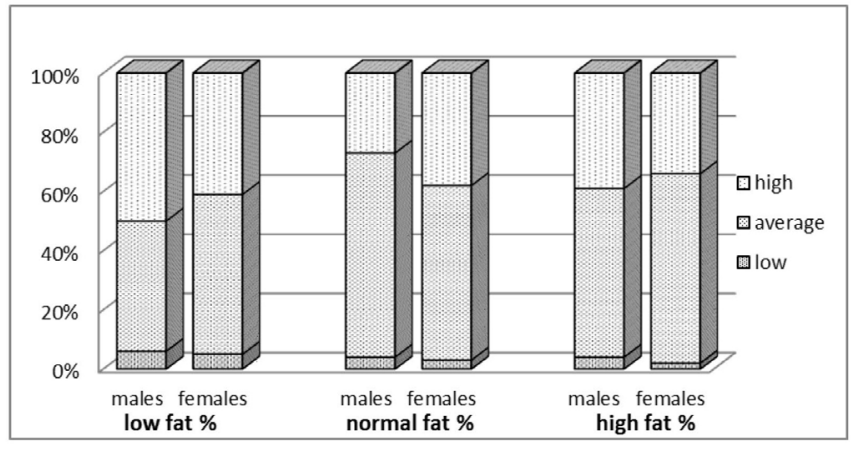

Fig. 6. Percentage of males and females in low, normal and high fat percent groups according the tertile of food diversity index.

No significant $(P>0.05)$ difference between low, normal and high fat percent groups according the Chi square test.

The ability to evaluate one's own body size is important when weight management activities are initiated. The self-evaluation of body size is not very accurate, especially when the body mass index (BMI) and fat percent are below or above normal range. Persons with higher BMI and fat percentage tend to underestimate their BMI, and persons with lower BMI overestimate it (Blumfelds et al., 2011). In another study involving students from 22 countries in which, body mass index was used to characterise the weight/height relationship, a steady increase in perceived overweight with increase of BMI decile was observed (Wardle et al., 2006).

A low body fat percentage might be the indication of engagement in sports and fitness (Hetland et al., 1995; 1998) or impending, or borderline eating disorder (Probst et al., 1996). Students with a low fat percent who answered that they are overeating most probably could be linked with the latter.

It is not surprising that people with a high fat percentage chose restriction of food intake as the first activity for body weight control. The higher the fat percent, the higher is the urge to implement some corrective activities in one's life. In studies of the general population of the USA and Germany, it was found that females restrict their food intake more than males (Striegel-Moore et al., 2009). Young women are pursuing extremely low ideal body weight and are risking their mental and physical health. They more frequently perceive themselves overweight and engage in different weight control activities that are irrational and even hazardous (Crawford and Owen, 1994; Patton et al., 1997; Wardle et al., 2006). A total of 44 to $81 \%$ of USA college females with normal and increased BMI, respectively, report consciously eating less than they want to promote their weight loss. This dietary behaviour, similar to that in our study, was more frequent in groups of overweight and obese females (Malinauskas et al., 2006).

Students who considered some corrections of body weight, more often tended to decrease the amount of food eaten and thus caloric intake rather than increasing product diversity. Females have been observed to be more concerned about their diet than males, in our and also in other studies 
(Mikulan et al., 2012). In people with a borderline high body fat percentage, a decrease of amount of food eaten may be effective to normalise body weight, in persons with a high fat percent it may be ineffective by only decreasing intake of products with high caloric value, if these are not substituted with alternatives with lower energy density (Prentice and Jebb, 2003).

The lack of significant differences in energy intake index across low, normal and high fat percentage groups in this study most probably could be related to composition of the questions used for the index analysis. This study did not consider weight of each separate question used in the questionnaire and each question was not studied specifically.

In conclusion, students in the high fat percentage group more frequently admitted eating to much, and their corrective behaviour was more associated with restriction of eaten food amount rather than reduction of energy intake and increase of food diversity.

Female students more frequently admitted that they eat too much and tended more to restrict food intake than male students in all fat percentage groups.

\section{REFERENCES}

Anonymous (2000). Obesity: Preventing and managing the global epidemic. Report of a WHO Consultation. WHO Technical Report Series 894. Geneva. 253 pp.

Anonymous (2003). Diet, nutrition and prevention of chronic diseases. Report of a joint WHO/FAO Expert Consultation. WHO Technical Report Series 916. Geneva. 149 pp.

Blumfelds, L., Rumaka, M., Lagzdina, R., Aberberga-Augskalne, L. (2011). Ar svaru saistītās k,ermeņa uzbūves pašnovērtējuma precizitāte studentiem [Accuracy of self-estimated body weight-height relationship in students]. 2011. gada RSU zinātniskās konferences tēzes: 141 (in Latvian).

Blumfelds, L., Aberberga-Augškalne, L., Rumaka, M., Lagzdina, R. (2008). Kermena sastāva komponentu analīze studentiem [Analysis of body compositions components in students]. 2008. gada RSU zinātniskās konferences tēzes: 77 (in Latvian).

Chizuru, N. (2004). Overweight and obesity a new nutrition emergency? SCN News, 29. United Nations Standing Committee on Nutrition. http://www.unscn.org/layout/modules/resources/files/scnnews29.pdf

Crawford, D., Owen, N. (1994). The behavioral epidemiology of weight control. Austr. J. Publ. Health, 18, 143-148.

Gallagher, D., Heymsfield, S. B., Moonseong, H., Jebb, S. A., Murgatroyd, P. R., Sakamoto, Y. (2000). Healthy percentage body fat ranges: An ap- proach for developing guidelines based on body mass index. Amer. J. Clin. Nutr., 72, 694-701.

Hetland, M. L., Haarbo, J., Christiansen, C. (1998). Regional body composition determined by dual X-ray absorptiometry. Relation to training, sex hormones, and serum lipids in male long-distance runners. Scand. J. Med. Sci. Sports, 8 (2), 102-108.

Hetland, M. L., Haarbo, J., Christiansen, C. (1995). Body composition and serum lipids in female runners: Influence of exercise level and menstrual bleeding pattern. Eur. J. Clin. Invest., 25 (8), 553-558.

Hilbert, A., de Zwaan, M., Braehler, E. (2012). How frequent are eating disturbances in the population? Norms of eating disorder examination questionnaire. PLoS ONE, 7 (1): e29125. doi:10.1371/journal.pone.0029125. http://www.plosone.org/article/ info\%3Adoi\%2F10.1371\%2Fjournal.pone.0029125

Hudson, J. I., Hiripi, E., Pope, H. G., Kessler, R. C. (2007). The prevalence and correlates of eating disorders in the National Comorbidity Survey Replication. Biol. Psychiatr., 61, 348-358.

Lowe, M. R. (2003). Self-regulation of energy intake in the prevention and treatment of obesity: Is it feasible? J. Obesity Res., 11, 44S-59S.

Malinauskas, B. M., Raedeke, T. D., Aeby, V. G., Smith, J. L., Dallas, M. B. (2006). Dieting practices, weight perceptions, and body composition: A comparison of normal weight, overweight, and obese college females. Nutr. J., 5, 11.

Mikulan, R., Piko, B. E., (2012). High school student's body weight control: Differences between athletes and non-athletes. Coll. Antropol., 36 (1), 79-86.

Mohsen, M., Obesity and dislipidemia among young general physicians in Iran. (2007). Int. J. Cardiol., 118 (1), 111-112.

Patton, G. C., Carlin, J. B., Shao, Q., Hibbert, M. E., Rosier, M., Selzer, R., Bowes, G. (1997). Adolescent dieting: Healthy weight control or borderline eating disorder? J. Child. Psychol. Psychiatry, 38, 863-880.

Prentice, A. M., Jebb, S. A. (2003). Fast foods, energy density and obesity: A possible mechanistic link. Obesity Rev., 4, 187-194.

Probst, M., Goris, M., Vandereycken, W., Van Coppenolle, H. (1996). Body composition in female anorexia nervosa patients. Brit. J. Nutr., 76 (5), 639-647.

Roach, J. B., Yadrick, M. K., Jonson, J. T., Boudreaux, J. L., Forsythe, W. A., Billon, W. (2003). Using self-efficacy to predict weight loss among young adults. J. Amer. Diet. Assoc., 103, 1357-1359.

Sepulveda, A. R., Carrobles, J. A., Gandarillas, A. M. (2008). Gender, school and academic year differences among Spanish university students at high risk for developing an eating disorder: An epidemiologic study. BMC Public Health, 8, 102.

Striegel-Moore, R. H., Roselli, F., Perrin, N., DeBar, L., Wilson, T. G., May, A., Kraemer, H. C. (2009). Gender difference in the prevalence of eating disorder symptoms. Int. J. Eat. Disord., 42 (5), 471-474.

Wardle, J., Haase, A. M., Steptoe, A. (2006). Body image and weight control in young adults: International comparisons in university students from 22 countrieas. Int. J. Obes., 30, 644-651.

Received 3 September 2012

\section{ĒŠANAS PARADUMI DAŽĀDA VECUMA STUDENTIEM AR DAŽĀDU RELATĪVO ĶERMEN̦A TAUKU DAUDZUMU}

Ěšanas paradumi ar vienveidīga uztura izvēli un pārmērīgu enerğijas uzṇemšanu var veicināt palielinātu ķermeņa tauku uzkrāšanos. Savas diētas un ķ,ermeņa adekvāts pašvērtējums, kā arī neveselīgu ēšanas paradumu atpazǐšana varētu veicināt piemērotu koriǵējošu rīcỉbu. Šī pētījuma mērķis bija noteikt, vai enerğijas uzņemšana, uztura dažādība un ķermeņa masu regulējoša rīcība ir atšķirīga studentu grupās ar zemu, normālu un augstu ķermeņa tauku procentu. Pētījumā brīvprātīgi tika iesaistīti 737 (158 vīrieši un 579 sievietes) Rīgas Stradiņa universitātes studenti vecumā no 18 līdz 49 gadiem. Uztura paradumu pētīšanai tika lietota anketa, ko studenti aizpildīja patstāvīgi. Kermeņa tauku daudzums dalībniekiem tika izmērìts ar bioimpedances analizatoru Tanita MC-180. Pirms mērījuma studentiem tika noteikti šķidruma, uztura uzņemšanas un fiziskās aktivitātes ierobežojumi. Rezultāti parādīja, ka 15\% studentu zema, 38\% normāla un 62\% augsta ķermeņa tauku procentu grupā uzskata, ka viņi èd par daudz. Attiecīgi — zema, normāla un augsta ķermeņa tauku procentu grupā — $27 \%, 37 \%$ un $42 \%$ studentu piekrita apgalvojumam, ka viņi ierobežo savu uztura daudzumu. Normalizētie enerğijas uzņemšanas un uztura daudzveidības indeksi būtiski neatškīrās studentiem ar dažādu relatīvo k̦ermeņa tauku daudzumu. Studenti augsta k̦ermeņa tauku procentu grupā biežāk nekā pārējie uzskatīja, ka viṇi êd par daudz, un viņu koriğèjošā rīcība galvenokārt bija saistīta ar uzṇemtā uztura daudzuma ierobežošanu, nevis uzṇemtās enerğijas apjoma samazināšanu un uztura daudzveidības palielināšanu. Visās kermen,a tauku procentu grupās sievietes biežāk nekā vīrieši atzina, ka èd par daudz un cenšas ierobežot savu uztura daudzumu. 


\title{
NUTRITIONAL SUPPLEMENTS IN OPTIMAL HUMAN NUTRITION
}

\author{
Maija Kronberga and Daina Kārklina \\ Faculty of Food Technology, Latvia University of Agriculture, Lielā iela 2, Jelgava, LV-3001, LATVIA; \\ maija.kronberga @inbox.Iv
}

Contributed by Daina Kārkliṇa

\begin{abstract}
The basic requirements for human health and life quality improvement are wholeness, variety and moderation in food choices. In industrial countries the numbers of adipose inhabitants is constantly growing. People consume insufficiently vegetables, fruits and fish. The missing nutrients must be augmented with the help of functional foodstuffs. The objective of the study was to compare the impact of food supplements and local products rich in fibre and polyunsaturated fatty acids on the human body. The research was conducted at the Riga Heart Consulting Room in 2010. For two months, 60 volunteers in three groups: using the food supplement "Wellness" in their diet (Wellness group), or Jerusalem artichoke (Helianthus tuberosus L.) and linseeds (Linum usitatissimum L.) (Nature group) and Control group were monitored. The participants' weight, girth, amount of glucose and level of cholesterol were measured by standard methods. Data acquired were analysed using Microsoft Excel and SPSS (level of significance $\mathrm{P}<0.05$ ). The cholesterol level was reduced by $14 \%$ in the Nature Group. Glucose normalised to $5.8 \mathrm{mmol} / \mathrm{l}$. Weight of participants was reduced by 2 to $7 \mathrm{~kg}$. The results show that by enriching the daily diet with food supplements, both as natural products and as a special complex, it is possible to reduce body weight, reduce cholesterol and glucose levels in the blood, and reduce the risks of obesity and coronary heart disease.
\end{abstract}

Key words: food supplements, Jerusalem artichoke, linseeds, cholesterol level.

\section{INTRODUCTION}

A wholesome and balanced diet, and safe and qualitative foodstuffs, are the basic requirements for human health and life quality improvement. The main criteria for qualitative food are wholeness, variety and moderation. The amount of food is less significant than its biological value, as determined by the presence of all necessary nutrients in the right proportions. The amount of food consumed must correspond to daily energy use. If the amounts of the consumed and expended energies are disproportionate for a prolonged time, the human body is not able to maintain its optimum weight, and deviation takes place. If, in previous centuries the reason for dietary imbalance was due to insufficient amounts of food, then nowadays the higher risk of illness is due to too much food, overly rich in calories.

The industrialisation of food production has changed accessibility to food, and the amounts now consumed cause many health problems. In Latvia there are very high levels of heart and coronary diseases, and the number of adipose inhabitants is constantly growing. Latvian inhabitants do not consume enough fresh vegetables, fruits and fish (Pudule et al., 2007; Mintāle et al., 2010). The missing fibre and polyunsaturated fats must be consumed additionally with the help of functional foodstuffs or special food supplements (Kaulinšs et al., 2001; Bekers et al., 2004).
Nowadays obesity is epidemic worldwide. In the United States, $20 \%$ persons suffer from obesity, in Europe, $15 \%$ (Willcox et al., 2001). Every year the number of overweight people increases. Latvia makes an effort to not fall behind in this aspect. According to a questionnaire administered in $2004,52.7 \%$ of Latvians were normal weight, overweight - 27.4\%, but obese - 19.9\% (Erglis et al., 2007).

The close connection between sickness prevention and food consumption has turned scientist attention to recommendations for a beneficial and balanced diet designed to reduce the risk of illness.

Food with high energy value but low nutritive value, combined with low physical activity, contributes to extra weight and obesity. Most people do not know or do not observe the principles of a healthy diet. The arrival of international eating traditions in Latvia has caused the consumption of atypical foods and, thus, metabolic disturbance. These factors dictate the necessity of replacing the missing food elements in the basic inferior diet with assorted food supplements.

Often weight reduction can be the decisive factor in normalising the level of fat in blood and stop the progress of sickness. Reduction of body mass mainly means a diet with lowered calorie intake and increased calorie use at high physical loads. 
A typical visitor to the Riga Heart Health Consulting Room is a person with an immobile lifestyle who is overweight and has an unbalanced diet, and who has a cholesterol level deviating from the norm. The inferior, unbalanced diet combines lack of fibre with too many fast carbohydrates and fats, as well as lacking microelements, natural vitamins, unsaturated fats and other biologically active compounds. If such a person is not motivated to correct his or her lifestyle, then dislipedemia progresses and drug-induced treatment becomes the only solution. Most people at this stage could successfully correct their risk factors with the help of diet, but do not yet realise the danger of their condition. On learning about heightened cholesterol levels, this person will try to change daily eating habits, however, soon finds it too difficult to resist favorite products in the long-term, and therefore, gives up any efforts to maintain his or her health. Some behaviours, especially where diet is concerned, are almost impervious to modification, and therefore, rapid change cannot be expected. So one of the possible options, to change one's diet completely, is not achievable for most people.

Another option is to supplement one's daily diet with nutrients that are significant for the human organism but are not present in sufficient amounts in food. To enrich one's diet would be the easiest lifestyle change.

Diet can be enriched both with foodstuffs containing the missing elements and with specially enhanced food supplements containing fibre, microelements, vitamins and bioactive compounds from vegetables. It is advisable to consume about 30-35 grams of fibre, since products rich in fibre have been proven to lower cholesterol levels.

Food enrichment can improve human well-being overall: working capacity, maintain health and improve the quality of life by reducing the risks of coronary heart disease, cholesterol levels, triglyceride and glucose measures, and weight reduction.

An alternative option is to enrich diets with natural local products that can supplement the diet with missing food elements and which are preferable for three reasons - commercial food supplements are comparatively expensive, some people prefer to use only natural foodstuffs, and many people prefer local agricultural products. In the research it was decided to use linseeds as a familiar foodstuff that is rich with polyunsaturated fats and lignans, as well as Jerusalem artichoke (Rickard and Thompson, 1997; Mazur et al., 1998). Jerusalem artichoke (Heliantus tuberosus L.) tubers are known to be health-promoting. They contain inulin instead of starch as a carbohydrate reserve. Inulin and its degraded byproduct, oligofructose, are major compounds of interest to the food industry as functional and low-calorie food materials. Many scientists have discovered that inulin has a beneficial effect on gastro-intestinal activity, stimulating reproduction of beneficial bacteria (Kaur and Gupta, 2002; Roberfroid, 2005). Jerusalem artichoke powder made from Jerusalem artichoke roots also is a valuable product, rich in inulin, as well as vitamins and minerals (Praznik et al., 2002; Cieslik et al., 2005; Gedrovica, 2012).

One final correction of dietary inadequacies can be addressed by ensuring sufficient water consumption.

Using different kinds of food supplements it is possible to reduce cholesterol and glucose levels, to reduce weight and to decrease the hazard of coronary heart diseases and obesity. The objective of this research was to compare the impact of food supplements and local products rich in fibres and polyunsaturated fatty acids on the human body.

\section{MATERIALS AND METHODS}

The research was conducted in 2010 at the Riga Heart Health Consulting Room (HHCR) in collaboration with the Latvia University of Agriculture, Faculty of Food Technology, and involved 60 volunteers. Qualitative methods observation and document analysis - were used in the research.

The visitors to the Consulting Room are chiefly people who do not have chronic diseases, who have not visited health care institutions for a long time, and who would like to know if their health indicators meet the norms.

Standardised examination was done by specially trained employees at the HHRC.

Anthropometric data - height, weight and girth. Height was measured by a Kirchner \& Wilhelm $\mathrm{GmbH}+\mathrm{Co}$ Kawe height measuring instrument, precision $0.5 \mathrm{~cm}$. Weight was measured by a medical scale made by Omron, precision $0.1 \mathrm{~kg}$ (weight was measured without footwear and in light clothes). Girth was estimated with a special measuring-tape, precision $0.1 \mathrm{~cm}$. Waist measurement was taken in the area from the pelvic bone to below the rib cage, with the abdomen relaxed, at exhalation phase.

After estimating weight and length, body mass index (BMI) was calculated according to the following formula: BMI = weight $(\mathrm{kg}) /$ height $\left(\mathrm{m}^{2}\right)$. The following data was also collected:

Physiological data - blood pressure, pulse.

Biochemical data - estimated cholesterol $(\mathrm{H})$, triglycerides and glucose concentration in the blood plasma using an Accutrend GCT device made by Roche and test strips Accutrend Cholesterol, Accutrend Glucose, and Accutrend Triglycerides.

Analyses were taken on an empty stomach (no food $8 \mathrm{~h}$ before measuring).

Subjective information was gathered in the form of a questionnaire about additional risk factors:

- adverse heredity factors: heart attack, insult, hypertension (some respondents' next of kin had diabetes mellitus before they reached 55 years of age); 
- smoking: currently or in the past. If the answer is positive then information about how many cigarettes per day and how many years of smoking;

- degree of physical activity: intensive, moderate, immobile;

- diagnosed and treated with medication for diseases such as: diabetes mellitus, arterial hypertension, fibrillation, stenocardia, heart attack / insult, dislipidemia, adiposity;

- regularly increased level of stress;

- attitude towards advice about healthy food: accepts most, accepts some, does not accept any.

For this research three homogeneous and equivalent groups with 20 participants in each group were created. All participants had increased weight/girth, and aberrant cholesterol levels. Their life style did not conform to healthy diet recommendations.

A balanced diet should contain optimum protein, fat and carbohydrate ratios, with protein comprising 10-15\%, fat $25-30 \%$, and carbohydrates $55-60 \%$, assuming a person of average physical activity ingesting $2000-2200 \mathrm{kca} / \mathrm{d}$. It is possible to ensure this by consuming $100 \mathrm{~g}$ of protein, $80 \mathrm{~g}$ of fat, and 400-500 $\mathrm{g}$ of carbohydrates daily. Human health also requires 30-35 g fibre, and 3-5 g omega 3 daily (Erglis et al., 2007).

The average research participant consumed 3120-3700 $\mathrm{kcal} / \mathrm{d}$. The total caloric intake included $13-15 \%$ protein, 40-48\% fat, and 44-48\% carbohydrates, consumed as 100-174 g protein, $145-174 \mathrm{~g}$ fat, and 366-417 g carbohydrates. Fresh fruits and vegetables were consumed once per week by $24 \%$ of participants, 2-3 times per week by $43 \%$, daily by $17 \%, 2-3$ times daily by $5 \%$, and not at all by $11 \%$. Fish was consumed 2-3 per week by $14 \%$ of participants, once per week by $38 \%, 2-3$ times per month by $28 \%$, several times per year by $6 \%$, and not at all by $14 \%$. As half of participants did not consume enough fish, the use of omega 3 supplements would compensate in maintaining a balanced diet in these cases. Fish oil was consumed year-round by $13 \%, 2-3$ times per year by $18 \%$, once a year by $12 \%$; in the event of illness, $12 \%$ remembered using fish oil; fully $45 \%$ of participants regarded fish oil as completely unnecessary. Necessary to human health is the consumption of 1.5-2 litres drinking water daily. Of the research participants, only 3\% achieved this optimal amount, $18 \%$ managed 1 litre, $46 \%$ felt 1-2 glasses of water daily was sufficient, and $24 \%$ regarded water as necessary only when taking medication. Most unsettling was the finding that $9 \%$ did not use drinking water at all, taking liquids only in the form of coffee, tea, soft drinks or beer. Insufficient fibre and polyunsaturated fat intake was recorded for $79 \%$ of participants.

The criteria of volunteer choice were: $\mathrm{BMI}>25<40, \mathrm{H}>5$ $\mathrm{mmol} / \mathrm{l}$, unbalanced diet (insufficient consumption of vegetables, fruits and water), and motivation to change lifestyle.
Division into groups was determined by their responses to the question: "Do you plan to change your lifestyle?" People who wanted to use food supplements were added into Wellness Group. People who wanted to use natural products to supplement their diet were added into Nature Group. The Control Group was comprised of people sharing similar habits and health indicators, and who wanted to change their lifestyle but could not motivate themselves. All participants had to keep to their usual eating habits and were not allowed to start new diets during this two-month research period.

Food supplements used were: Wellness Pack (multivitamin \& mineral, astaxanthin, Omega3) and Natural Balance Shake (pea protein, apple powder, whole egg, whey, ground sugar beet fibre, natural vanilla flavour) by Wellness from Oriflame (Sweden). In addition to daily food intake, the Wellness Group used:

- 1 package of Wellness Pack vitamins after lunch;

- 2 portions of Nature Balance Shake before lunch and dinner (18 $\mathrm{g}=1$ measurement spoon mixed with $150 \mathrm{ml}$ of water, juice or milk);

- 1 litre of noncarbonated drinking water, in doses of 200-250 ml 30 minutes before food.

The Nature Group products were: linseeds and linseed oil by „Viza Oil Group” (Latvia), and Jerusalem artichoke powder by "Herbe" (Latvia). The Nature Group additionally used daily:

- $20 \mathrm{~g}$ Jerusalem artichoke powder $(10 \mathrm{~g}$ inulin $)=1$ tablespoon mixed into drink or food;

- 10 g linseeds = 1 teaspoon;

- $10 \mathrm{ml}$ linseeds oil =1 teaspoon;

- 1 litre of noncarbonated drinking water, in doses of 200-250 $\mathrm{ml} 30$ minutes before food.

The Control Group used daily food without change.

Each research participant received a code ensuring anonymous participation and a registration card containing HHCR standard research data:

- anthropometric - length, weight and girth;

- physiological - blood pressure, pulse;

- biochemical - glucose, cholesterol and triglycerides;

- completed questionnaire about eating habits;

- volunteer's written agreement to participate in the research project.

During the two-month research period, food supplement usage data was collected repeatedly at HHCR using the same instruments and recording the results on each participant's card. 
Data acquired during the research was processed using Microsoft Excel and SPSS.

All results were evaluated using a level of significance $P<$ 0.05 .

The author has received the permission of the RSU (Rìga Stradiņš University) Ethics Committee to conduct biomedical research, and each volunteer subject has given his or her written, informed consent to participate in this research.

\section{RESULTS}

Measurements at the beginning of research: The average body mass of the participants in the beginning of the control period was $83.5 \pm 1.7 \mathrm{~kg}$. Body mass was similar for both experiment groups. In the Wellness Group the average weight was $80.9 \pm 3.5 \mathrm{~kg}$, in the Nature Group $-81.1 \pm 2.2$ $\mathrm{kg}$, and in the Control Group the body mass was slightly higher $-88.4 \pm 2.1 \mathrm{~kg}$; however, body mass fit within the allowed deviation of $10 \%$. All the participants (weight ranging from 57 up to $116 \mathrm{~kg}$ ) were overweight and some were already obese. BMI for all participants exceeded $25-$ in Wellness Group the average BMI was 28.7, in the Nature Group the average BMI was 29.7. The maximum BMI was registered for two participants in the Wellness Group 38.4. Girth is one of the most significant indicators signalling clinical obesity and heart/coronary disease risk. On average, the girth of research participants came to $100 \mathrm{~cm}$. The girth in the Wellness Group and Nature Group varied from the accepted 88 centimeters up to 114 centimeters.

Cholesterol levels in the blood in the Wellness Group were, on average, $6.07 \pm 0.07 \mathrm{mmol} / \mathrm{l}(5.28-7.41)$, and in the Nature Group, on average $6.0 \pm 0.11 \mathrm{mmol} / \mathrm{l}(5.48-6.81)$.

For some of the research participants, along with dislipedemia, initial glucose tolerance disturbances with slightly increased readings $(5.9-6.4 \mathrm{mmol} / \mathrm{l})$ were also detected. Experience has shown that quite often excess weight and dislipedemia facilitate development of diabetes mellitus type 2. Also, triglyceride levels for several participants were too high, on average $-2.1 \mathrm{mmol} / \mathrm{l}$ instead of the recommended $1.7 \mathrm{mmol} / \mathrm{l}$.

Measurements at the conclusion of study period were repeated, and new body mass indicators were obtained: in the Wellness Group - 77.2 $\pm 3.4 \mathrm{~kg}(53-105 \mathrm{~kg})$, in the Nature Group - 76.4 $\pm 2.1 \mathrm{~kg}(61-99 \mathrm{~kg})$, and in the Control Group $-88.35 \pm 2.9 \mathrm{~kg}(67-117 \mathrm{~kg})$ (Fig. 1). During the research period, the average body mass loss in Nature Group for each participant was about $4.7 \mathrm{~kg}$. The biggest loss of a single individual's weight was $7 \mathrm{~kg}$, and in general participants lost from 2 to $7 \mathrm{~kg}$ of excess weight.

Seven people reached normal BMI $<25$, but six participants reduced their weight, on average to BMI of 27.9. Representatives of the Nature Group on average lost $4.35 \mathrm{~cm} \pm$ $0.25 \mathrm{~cm}$.

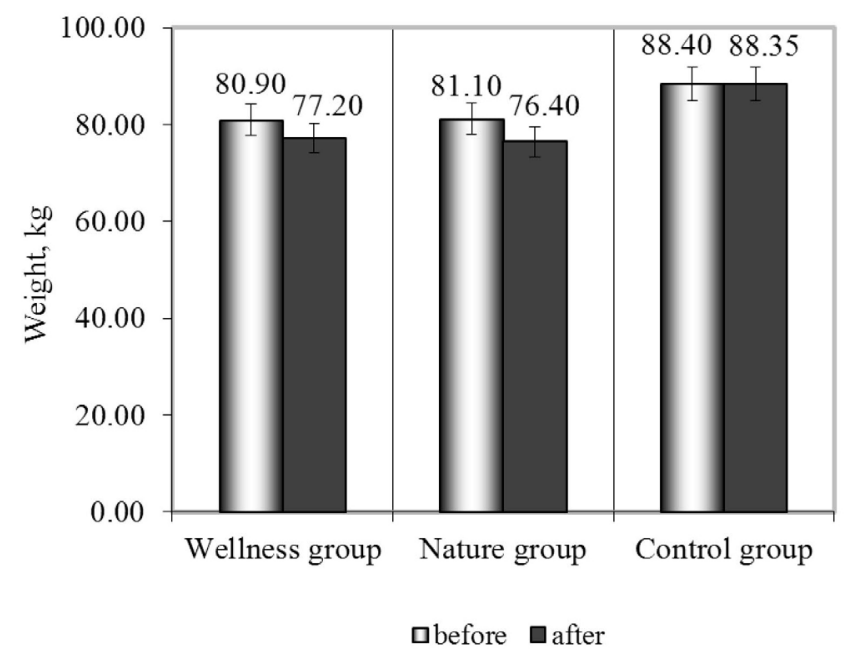

Fig. 1. Body mass at the beginning and end of the study period.

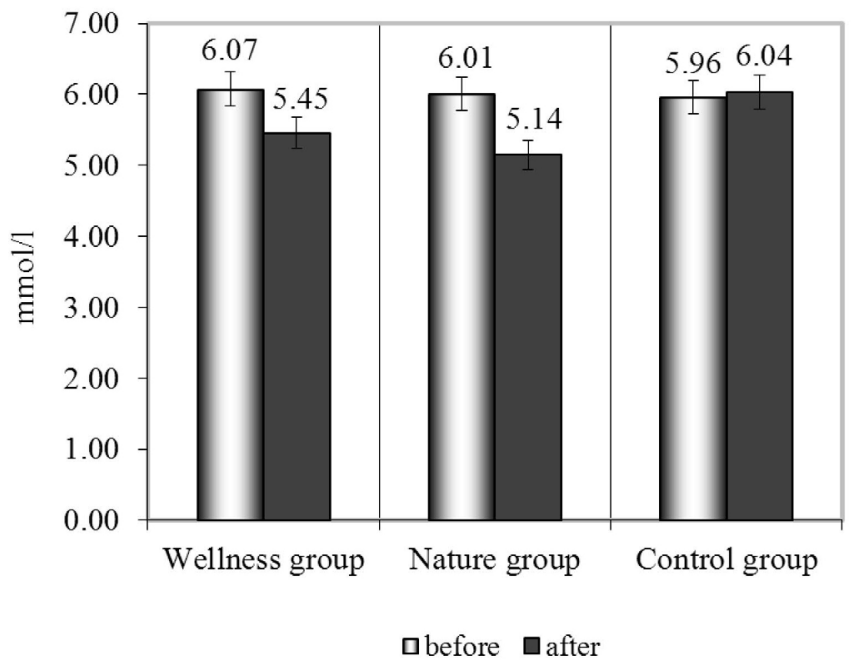

Fig. 2. Cholesterol level at the beginning and end of the study period

Cholesterol readings were reduced most in the Nature Group, on average by $0.86 \mathrm{mmol} / \mathrm{l}$, which proves the close connection between weight reduction and regulation of lipid levels. The average cholesterol measurement in the Nature Group was $5.14 \mathrm{mmol} / \mathrm{l} \pm 0.07$. As a result, all groups left the risk group. Also, in the Wellness Group there was a reduction by $0.62 \mathrm{mmol} / \mathrm{l}$, to average cholesterol level of 5.45 $\mathrm{mmol} / \mathrm{l} \pm 0.11$ (Fig. 2). No glucose disturbances were registered for any of the participants.

Results obtained during the research were registered in individual protocols, entered into a computer and analyzed with methods of mathematical statistics. The methods used were: analyses of case absolute and relative frequency, tests of independent selections and pair selection, analyses of variance (ANOVA), linear correlation and regression analyses.

At the onset of the research, the groups were similar in body mass, with a variations coefficient of $5-10 \%$. The difference is not big, which indicates the similarity of body mass. Since the groups at onset were similar, it is possible to compare the average changes during the research period. 
The parametric Pearson method of paired linear correlation analyses indicated a relationship between body mass and girth and BMI in all groups. Correlation analyses showed a strong correlation between body mass, girth and BMI at the outset of the research, both in the Wellness Group $(\mathrm{r}=0.81$; $P=0.01)$, Nature Group $(\mathrm{r}=0.78 ; P=0.01$ and $\mathrm{r}=0.67$; $P=0.01)$ and in the Control Group $(\mathrm{r}=0.76 ; P=0.01$ and $\mathrm{r}=0.78 ; P=0.01)$. The same correlation was oberved at the end of the study period $(\mathrm{r}=0.99 ; P=0.01)$.

Cholesterol levels showed explicit correlation between cholesterol level at the beginning of the research and at the end of the research, both in the Wellness Group $(\mathrm{r}=0.85 ; P=$ $0.01)$ and Nature Group $(\mathrm{r}=0.96 ; P=0.01)$. A not so explicit correlation was showed by girth $(\mathrm{r}=0.43 ; P=0.05)$. Correlation of cholesterol level and body lacked statistical significance $(P>0.05)$, indicating that a person can carry excess weight for a long time before metabolic changes start, developing over time into dislipedemia.

The indicators of glucose at the end of the period were correlated with glucose indicators at the onset of the research ( $\mathrm{r}=0.69 ; P=0.01)$, and slightly with cholesterol indicators in the beginning $(\mathrm{r}=0.47 ; P<0.05)$ and in the end $(\mathrm{r}=$ $0.56 ; P=0.01$ ), as disturbances of glucose norms are related to cholesterol production in the liver.

\section{DISCUSSION}

During the two-month study period, the participants' average results improved in all aspects. At the conclusion of the research, improvement in cholesterol levels was by $14 \%$ in the Nature Group and 10\% in the Wellness Group.

Body mass loss by the end of the study in the Nature Group was by $6 \%$, in the Wellness Group, $5 \%$ from the initial weight. Summarising the results, it is obvious that in the Nature Group the average results improved in all readings and the increases were statistically valid $(P<0.05)$. Expressed by absolute numbers this $10-14 \%$ loss corresponds to $6-8 \mathrm{~kg}$ of mass, which actually is not large, but, considering the fact that such results were achieved without any diets restricting calories and amount of food, the success is convincing.

At the conclusion of the study, the difference between average results was statistically significant but the percent improvement in the Nature Group in comparison to the Wellness Group is higher in three parameters.

The total body mass loss was less than $11 \%$, which, evaluated separately is not a convincing result, as weight was still in excess in all groups. However, they are optimistic as the results came closer to the recommended norms for health. Furthermore, loss of $10 \%$ excess weight reduces heart disease and diabetes mellitus development risk by $20 \%$. Glucose had normalised for all participants to $5.8 \mathrm{mmol} / \mathrm{l}$, corresponding to the norm.
All observed changes are statistically significant for body mass and cholesterol reduction, but change in cholesterol level was nor significantly correlated with body mass loss. This indicates that changes of cholesterol level cannot be regarded as a consequence of regular overeating but as a kind of organism illness manifestation. This is confirmed by comparing the changes between the experimental research groups and Control Group at the end of this experimental research. At the beginning of the study there were no statistical differences between the Nature Group, Wellness Group and Control Group, but at the end of the study differences were observed in three indicators.

Using food supplements, Wellness products and natural products, led to significant changes in the studies indicators $(P<0.05)$. The food supplement "Wellness" and local products rich in fibre and unsaturated fatty acids (Jerusalem artichoke and linseeds) demonstrated positive effect on human health and in a natural way reduced adipositivity and dyslipidemia. The results acquired during the study confirmed the hypothesis of this paper, i.e. by enriching daily diet with food supplements both as natural products and as a special complex it is possible to reduce body weight, reduce cholesterol and glucose levels in blood, and reduce the hazards of coronary heart disease and obesity.

Several research participants expressed interest in continuing the use of the supplements they learned about through the research in their daily diet and even to reconsider the option of changing their diet altogether. After two months, the idea of health improvement through healthy food was not so scary anymore. Observing the results of the other two groups, and knowing that this method is neither difficult nor complex for users, some of the research participants expressed an interest in starting the use of food supplements and healthy products in their own daily diets. Most convincing was their own negative result.

Dietary habits often are mechanisms of psychological problem reduction, and rapid change is regarded as a violent interruption that raises stress levels and provokes a desire to stop lifestyle corrections. Unlike the traditional weight loss approaches, participants were not restricted from their habitual foods and all volunteers were very cooperative during the study. Most probably a gradual change in old habits will give positive long-term result. The best indicators of the success of this approach were shown by Nature Group, which used powdered Jerusalem artichoke together with food, linseeds and linseed oil - they not only lost $4 \mathrm{~kg}$ on average, but also reduced cholesterol levels until the norm was achieved, and completely balanced their glucose levels. The most significant result was achieved in preventive education, since the greater number of the participants expressed their wish to continue the improvements in their lifestyles both by continuing consumption of Jerusalem artichoke, linseeds and vitamins and by analyzing their diet and making healthy corrections in it - more water, vegetables, fruits and fish. This study allowed people to understand that less food can be sufficient and that changes are not so difficult. In this case, the researchers can regard the stated tasks 
as fulfilled. Furthermore, the mission of the Health Centre food consultant is also fulfilled because the most difficult task is to make people think and act.

The obtained results show that comparing the impact on the human organism of the "Wellness" dietary supplement to the impact of local products rich in fibre and polyunsaturated fats — artichokes and linseeds — both appear to benefit and strengthen human health, resulting in the reduction of obesity and dislipidemia.

The conclusion is that since local products - artichoke, linseeds, linseed oil - both as consumables and as food enrichment products are much less expensive than commercially prepared supplements, it would appear to be more important to promote local products, and hope that people can be convinced to use them in their daily diets.

\section{ACKNOWLEDGEMENTS}

ESF project "Support for the Implementation of LLU Doctoral Studies" contract No. 2009/0180/1DP/ 1.1.2.1.2/09/ IPIA/VIAA/017.

National Research Programme "Sustainable Use of Local Resources (Earth, Food, and Transport) - New Products and Technologies (Nat Res)" (2010-2013), Project No. 3. "Sustainable Use of Local Agricultural Resources for Development of High Nutritive Value Food Products (Food)”.

\section{REFERENCES}

Bekers, M., Marauska, M., Grube, M., Karklina, D., Duma, M. (2004). New prebiotics for functional food. In: Acta Alimentarica, 33 (1), 31-37.

Cieslik, E., Kopec, A., Praznik, W. (2005). Healthly properties of Jerusalem artichoke flour (Helianthus tuberosus L.). Electronic J. Pol. Agr. Univ., 8
(2). http://www.ejpau.media.pl/volume8/issue2/art-37.html (accessed 8 December 2011).

Erglis, A., Kalvelis, A., Lejnieks, A., Dzērve, V., Latkovskis, G., Mintāle, I., Zakke, I., Rasa, I. (2007). Kardiovaskulāro slimību profilakses vadlīnijas [Cardiovascular Disease Prevention Guidelines]. Rīga: Latvijas Kardiologu biedrība. 126 lpp. (in Latvian).

Gedrovica, I. (2012). Ar kaltēta topinambūra (Helianthus tuberosus L.) pulveri bagātināti miltu konditorejas izstrādājumi [Pastry products enriched with dried Jerusalem artichoke (Helianthus tuberosus L.) powder]. Doctoral dissertation, Latvia University of Agriculture, Jelgava, Latvia (in Latvian). 177 lpp.

Kauliņš, U., Kārkliņa, D., Dūma, M., Melngalve, I., Skudra, L., Krūmiṇa, G. (2001). Uzturs un tā bagātināšana [Food and Nutrition Enrichment]. Jelgava: LLU 168 lpp. (in Latvian).

Kaur, N., Gupta, A. K. (2002). Applications of inulin and oligofructose in health and nutrition. J. Biosci., 27, 703-714.

Mazur, W. M., Duke, J. A., Wähälä, K. (1998). Isoflavonoids and lignans in legumes: Nutritional and health aspects in the human. J. Nutr. Biochem., 9, 193-200.

Mintāle, I., Ērglis, A., Dinne, A., Bajāre, I., Kalvelis, A., Latkovskis, G., Jēgere, S., Taluts-Dzērve, V., Zakke, I. (2010). Sirds un virtuve [Heart and Kitchen]. Rīga: Inovatīvās medicīnas centrs. 141 lpp. (in Latvian).

Praznik, W., Cieslik, E., Filipak-Florkiewicz, A. (2002). Soluble dietary fibres in Jerusalem artichoke powders: Composition and application in bread. Nahrung/Food, 46 (3), 151-157.

Pudule, I., Villeruša, A., Grīnberga, D., Velika, B., Tilgale, N., Dzērve, V., Zìle, S., Konttinen, H., Prattala, R. (2007). Health Behaviour Among Latvian Adult Population, 2006. Helsinki: Julkaisija-Utgivare-Publisher. 164 pp.

Rickard, S. E., Thompson, L. U. (1997) Phytoestrogens and Lignans: Effects on Reproduction and Chronic Disease. In: Antinutrients and Phytochemicals in Food. Chapter 16 (pp. 273-293). American Chemical Society.

Roberfroid, M. (2005). Inulin-Type Fructans. Functional Food Ingredients. Boca Raton, Florida: CRC Press. 359 pp.

Willcox, B. J., Willcox, C., Suzuki, M. (2001). The Okinawa Program. New York: Clarkson/PotterPublishers. 538 pp.

\section{UZTURA BAGĀTINĀTĀJI CILVĒKA OPTIMĀLA UZTURA IZVEIDĒ}

Mūsdienu cilvēka uzturs nav sabalansēts, jo ar pārtikas produktiem uzṇemtais škiedrvielu un polinepiesātināto taukskābju daudzums ir nepietiekams. Sabalansētu uzturu nodrošināt cilvēkam ir vieglāk, savu diētu papildinot ar uztura bagātinātājiem, tādējādi uzṇemot trūkstošās vai nepietiekamā daudzumā organismā esošās uzturvielas. Pētījums veikts Rīgas Sirds veselības kabinetā 2010. gadā, iekḷaujot 60 brīvprātīgas personas, kurām reǧistrēts palielināts svars/apkārtmērs, holesterīna līmeņa novirzes un veselīga uztura ieteikumiem neatbilstošs dzīvesveids. Divu mēnešu ilgā eksperimentā, lietojot uzturā divu veidu uztura bagātinātājus — "Wellness" un ar šķiedrvielām un nepiesātinātām taukskābēm bagātus vietējos produktus - linsēklas (Linum usitatissimum L.), no tām gatavotu eḷıu un topinambūra (Helianthus tuberosus L.) pulveri — konstatēts, ka, lietojot vietējās izcelsmes uztura bagātinātājus, eksperimentā iekḷauto dalībnieku masa samazinājās par 4 līdz 7 kg, bet ar uztura bagātinātāju "Wellness" — no 3 līdz 8 kg. Pētījuma laikā eksperimenta dalībniekiem samazinājās holesterīna un glikozes līmenis. Būtiski, ka vietējās izcelsmes uztura bagātinātāji ir lētāki, salīdzinot ar rūpnieciski ražotajiem uztura bagātinātājiem „Wellness”. Rezultāti parādīja, ka vietējās izcelsmes uztura bagātinātājus ir iespējams veiksmīgi izmantot uzturā ar mērḳi organismā samazināt holesterīna un glikozes līmeni asinīs, kā arī cīṇai ar lieko svaru, tādējādi samazinot sirds asinsvadu slimību un aptaukošanās risku. 


\title{
NUTRITION VALUE OF WILD ANIMAL MEAT
}

\author{
Vita Strazdina, Aleksandrs Jemeḷjanovs, and Vita Šterna \\ Research Institute of Biotechnology and Veterinary Medicine "Sigra", Latvia University of Agriculture, \\ Institūta iela 1, Sigulda, LV-2150, LATVIA; \\ sigra@lis.Iv
}

Contributed by Aleksandrs Jemeljanovs

\begin{abstract}
One of the most valuable foods is meat, due its nutritional value, largely determined by the essential amino acids, fatty acids, vitamins, minerals, etc. At the same time, concern needs to be given to health of consumers by used products with less calories, which can be ensured by greater variety of game animals, including also deer grown in captivity. The aim of our investigation was to compare the nutrition value of elk, wild deer, farm deer, roe deer, and wild boar that were killed during hunting in Latvia. Meat samples (m. logissimus lumborum) were collected in the autumn-winter season. The results of the conducted research suggest that game meat samples have higher protein and essential fatty acid content in comparison with domestic animals. The amount of fat in all analysed samples did not differ greatly, although the fatty acid content in wild game meat differed significantly. The fatty acid profile was used to calculate the atherogenicity index (Al), which has a positive correlation with the risk of cardiovascular disorders. The formula $A I=[C 12: 0+(C 14: 0 \times 4)+C 16: 0] /($ Total unsaturated fatty acids) was used to calculate the ratio of total saturated fatty acids, $\omega-6$ and $\omega-3$. Regarding the microelement content of meat there were great differences in iron and manganese concentration among animals.
\end{abstract}

Key words: hunting animals meat, healthy food.

\section{INTRODUCTION}

In recent years, in the Latvian population, public attention has been paid to the health and the value of it, which can be achieved using wholesome food. One of the most valuable foods is meat. In the "food pyramid" meat is one of the products that needs to be used moderately - about onefifth of all food. It provides the organism with wholesome, highly digestible proteins.

Protein varies among the meat animal species, and its content ranges between 13 and $23 \%$ of the fresh weight (Honikel, 2009). Our body uses $97 \%$ meat protein and $25 \%$ connective tissue.

The amino acid profile is important because some amino acids cannot be synthesised by humans and therefore must be supplied by the diet. Amino acids are divided into two groups: essential and substitutable. Essential amino acids are not synthesised in the body and therefore must be taken with food. If the diet lacks even one of the essential amino acids (such as tryptophan, lysine, methionine) the required protein synthesis is not possible. Meat is rich in the socalled essential or indispensable amino acids - lysine, leucine, isoleucine, and sulphur-containing amino acids — and in this sense meat has highly-quality protein (Young et al., 2001). Meat is also rich in B vitamins and is an important source of iron, phosphorus, copper and manganese. Depending on the type of meat fat content is $1-10 \%$ fat.

Meat has been identified, often wrongly, as a food having a high fat content and an undesirable balance of fatty acids. In fact, lean meat is very low in fat, with a content of 20-50 $\mathrm{g} / \mathrm{kg}$ (Wood and Enser, 2004). Game animals have a favourable balance between polyunsaturated and saturated fatty acids $(\mathrm{P}: \mathrm{S})$ and wild ruminants produce muscle with a desirable $\omega-6: \omega-3$ polyunsaturated fatty acid ratio.

Wild game meat is considered significant in the diet, and its share in consumption in recent years has increased. Currently, among consumers there is increased interest in meat from animals kept in conditions as close as possible to the natural ones. Such a requirement is undoubtedly fulfilled by game that is characterised by high nutritional value and specific sensory properties desired by consumers (Vergara et al., 2003; Soriano et al., 2006).

Game animals, such as elk (Alces alces), deer (Cervus elaphus), roe deer (Capreolus capreolus) and wild boar (Sus scrofa scrofa), every autumn and winter provide an excellent investment and diversification of many consumer meals. The statistics show that there are about 33000 hunters in the Latvian register, of which 17000 are active hunters. During the annual hunt, about 2789 tons (2712 - auxilliary service) of game meat is provided in Latvia (Data on 
number of hunted animals in 2010-2011 are from the State Forest Service official statistics).

The human body is composed of a broad range of chemical elements and their combinations, which must be in balance for us to feel good and be healthy. There are negative consequences for both under-and over-intake of a trace element (causing immune status and increased susceptibility to infections). The content of a trace elements in domestic meat products depends on the animal species and the quality of animal nutrition. Lack of minerals can be caused by animals age and physiological state, feed intake and housing conditions (Kalafova et al., 2003). In contrast, game animals move within an unlimited territory, and thus animal products contain all trace elements in sufficient quantities, but which varies according to the functional status of the body. The aim of our investigation was to compare the nutrition value of elk, wild deer, farm deer, roe deer, and wild boar that were killed during hunting in Latvia.

\section{MATERIALS AND METHODS}

Chemical analyses were conducted on a total of 54 meat samples (m. logissimus lumborum): elk (8), deer (18), roe deer (16), wild boar (12) collected after hunts throughout Latvia in the autumn-winter season (2008-2012). The analyses were conducted at the laboratory of Biochemistry and Microbiology of the Research Institute of Biotechnology and Veterinary Medicine „Sigra”. In the studied samples, protein, amino acids, fat, fatty acids, cholesterol content and micronutrient concentrations were determined. Samples were prepared within 48 hours after slaughtering or hunting. Meat samples of about $300 \mathrm{~g}$ were homogenised with a BÜCHI B-400 (ISO 3100-1).

Protein concentration was determined as total nitrogen content by Kieldahl method and using coefficient 6.25 for calculation (ISO 937:1974).

For determination of amino acids concentration, dried, defatted meat samples were treated with constant boiling $6 \mathrm{~N}$ hydrochloric acid in an oven at around $110{ }^{\circ} \mathrm{C}$ for $23 \mathrm{~h}$. Hydrolysate was diluted with $0.1 \%$ formic acid. Samples (2 $\mathrm{ml}$ ) were filtered using a siringe filter with a $0.45 \mu \mathrm{m}$ nylon membrane. Amino acid concentrations were determined using a reverse-phase HPLC/MS (Waters Alliance 2695, Waters 3100, column XTerra MS C18 $5 \mu \mathrm{m}, 1 \times 100 \mathrm{~mm}$ ): mobile phase (90\% acetonitrile: $10 \%$ dejonized water) $0.5 \mathrm{ml}$ $\min ^{-1}$, column temperature. $40{ }^{\circ} \mathrm{C}$. Data acquisition was conducted using the programme Empower pro.

Intramuscular fat concentration was determined by Sochlet method with hydrolysis procedure (boiling in hydrochloric acid) using SoxCap 2047 and SOX TEH 2055 equipment (FOSS) (LVS ISO 1443:1973).

Cholesterol concentration was determined by Blur colorimetric method using a spectrometer (Шманенков и Алиев, 1973).
Fatty acid analysis of meat. Homogenised meat samples were prepared for GLC (gas-liquid chromatography) analysis using direct saponification with $\mathrm{KOH} / \mathrm{methanol} \mathrm{followed}$ by derivatisation with (trimethylsilyl) diazomethane using the method of Aldai et al. (2006) An ACME, model 6100, GLC (Young Lin Instrument Co.) equipped with a flame ionisation detector, and an Alltech AT-FAME analytical column (fused silica $30 \mathrm{~m} \times 0.25 \mathrm{~mm}$ i.d.) was used. The individual FAMEs (fatty acid methyl esters) were identified according to similar peak retention times using standard mixture Supelco 37 Component FAME Mix.

From the fatty acid profile, the atherogenicity index (IA), a parameter proposed by Ulbricht and Southgate (1991), which has a positive correlation with risk of cardiovascular disorder, was calculated. The calculation was as follows:

$\mathrm{AI}=[\mathrm{C} 12: 0+(\mathrm{C} 14: 0 \times 4)+\mathrm{C} 16: 0] /($ Total unsaturated fatty acids).

The relative proportions of total saturated fatty acids and unsaturated $\omega-6$ and $\omega-3$ fatty acids were calculated.

Micronutrient concentrations in meat were measured according to ISO 6869-2002. The methods are based on flame atomic absorption using a spectrometer AAnalyst 200.

The experimental design was randomised and data were evaluated by analysis using SPSS 17. One-way ANOVA was used for comparison of mean values. Statistical significance was set at $P<0.05$. The biochemical composition (protein, fat, cholesterol, fatty acids, amino acids and trace elements) of wild game meat was determined as the amounts in $100 \mathrm{~g}$ of meat. Beef and pork samples were included for comparison (previously determined in the Research Institute of Biotechnology and Veterinary Medicine in Latvia SIGRA, unpublished data).

\section{RESULTS}

Proteins are an important part of our diet. All animal species given in Table 1 are excellent high-quality sources of protein. Protein concentration in game meat samples varied from 22.36 till $22.92 \%$. The results of the statistical analysis showed that the total protein concentration in the ruminants meat did not differ significantly $(F=1.286 ; P>0.05)$.

All of the animal species in the table has a low fat concentration $(1.33-1.90 \%)$ in meat samples (m. logissimus

Table 1

BIOCHEMICAL COMPOSITION OF GAME MEAT

\begin{tabular}{|c|c|c|c|c|}
\hline Group & $\mathrm{n}$ & Protein, \% & Fat, \% & 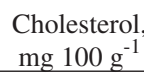 \\
\hline Elk & 8 & 22.72 & 1.33 & 64.41 \\
\hline Deer & 18 & 22.36 & 1.90 & 70.57 \\
\hline Roe deer & 16 & 22.82 & 1.59 & 67.92 \\
\hline Wild boar & 12 & 22.92 & 2.82 & 95.07 \\
\hline Beef & 15 & 19.61 & 1.48 & 76.31 \\
\hline Pork & 15 & 21.32 & 2.77 & 67.85 \\
\hline
\end{tabular}


lumborum), not only in ruminants, but also in wild boar meat $2.82 \%$.

Cholesterol found in muscles is free cholesterol and it is not related to that in animal blood, i.e. "good" or "bad" cholesterol. It is found in both fat and muscle in the range 64.41 to $95.07 \mathrm{mg} 100 \mathrm{~g}^{-1}$ among animal species (Table 1). From a nutritional point of view, in terms of cholesterol, none of ruminant meats is superior (preferred) over others. The exception is wild boar meat, in which higher cholesterol levels can be explained by the high level of adrenaline under stress during the hunting season. The cholesterol levels statistically differed between animals $(\mathrm{F}=2.55, P<0.05)$

The human body requires the essential amino acids lysine, isoleucine, phenylalanine, tryptophan, leucine, methionine, threonine, and valine. Each of these amino acids have a role in the human body. The concentrations of essential amino acids in game meat samples are shown in Figure 1.

Game muscle protein contains all essential necessary amino acids. Wild deer, roe deer and elk meat samples are similar in the summed concentrations of essential amino acids, suggesting that the diet of ruminants is sufficient in late autumn to winter (Fig. 1). Wild boar and pork samples, differed most in the summed concentrations of essential amino ac-

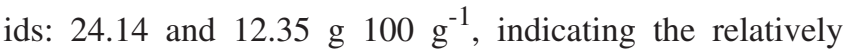
higher biological protein value of wild boar over pork.

Meat contains most of the essential fatty acids. Higher concentrations of saturated fatty acids are found in ruminant meat: $44 \%$ in cow and sheep. Lower concentrations of saturated fat are found in pork. These fat content of beef is greater than moose and roe deer meat (41\%) (Rule et al., 2002).

Composition of dietary fat is more significant for consumers than is total fat content. Therefore, composition of fatty acids, sum of saturated, monounsaturated, and polyunsaturated fatty acids was investigated (Table 2).

Results of investigation showed that lowest content of saturated fatty acids has meat samples of wild boar and elk meat samples - 34.79 and 35.75 , respectively. The highest sum of saturated fatty acids was found in deer meat samples $(42.13 \%)$, which is in agreement with Petkov (1986). Saturated fatty acids other than myristic, palmitic, and stearic

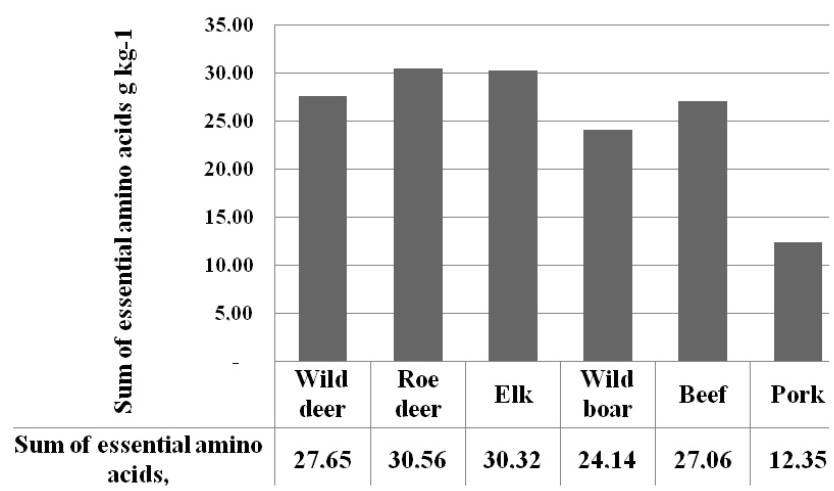

Fig. 1. Comparison of sums of essential amino acids in meat samples.
FATTY ACID COMPOSITION OF MEAT

\begin{tabular}{lcc|c|c|c|c}
\hline \multicolumn{1}{c}{ Fatty acid class } & Elk & Deer & $\begin{array}{c}\text { Roe } \\
\text { deer }\end{array}$ & $\begin{array}{c}\text { Wild } \\
\text { Boar }\end{array}$ & Beef & Pork \\
\hline Sum saturated (SFA) & $\mathbf{3 5 . 7 5}$ & $\mathbf{4 2 . 1 3}$ & $\mathbf{3 7 . 5 4}$ & $\mathbf{3 4 . 7 9}$ & $\mathbf{4 0 . 1 1}$ & $\mathbf{3 7 . 4 6}$ \\
Stearic (C 12: 0) & 0.19 & 0.30 & 0.01 & 0.11 & 0.24 & 0.15 \\
Myristic (C 14: 0) & 2.44 & 4.57 & 1.32 & 2.92 & 3.62 & 1.48 \\
Palmitic, (C 1: 0) & 18.08 & 21.02 & 18.72 & 23.12 & 21.43 & 26.65 \\
Sum mono-unsaturated & $\mathbf{3 4 . 0 9}$ & $\mathbf{2 6 . 5 7}$ & $\mathbf{2 8 . 9 6}$ & $\mathbf{3 5 . 6 3}$ & $\mathbf{3 4 . 6 0}$ & $\mathbf{5 0 . 8 7}$ \\
(MUFA) & & & & & & \\
Sum polyunsaturated & $\mathbf{1 8 . 9 7}$ & $\mathbf{2 3 . 4 7}$ & $\mathbf{2 5 . 3 8}$ & $\mathbf{1 7 . 2 5}$ & $\mathbf{1 5 . 3 6}$ & $\mathbf{5 . 9 5}$ \\
(PUFA) & & & & & & \\
Sum Omega-3* & 6.81 & 6.20 & 8.23 & 2.89 & 2.65 & 0.44 \\
Sum Omega-6** & 11.73 & 17.05 & 17.04 & 13.89 & 12.71 & 5.51 \\
Sum unsaturated & $\mathbf{5 3 . 0 6}$ & $\mathbf{5 0 . 0 4}$ & $\mathbf{5 4 . 3 4}$ & $\mathbf{5 2 . 8 8}$ & $\mathbf{4 9 . 9 6}$ & $\mathbf{5 6 . 8 2}$ \\
$\omega-6$ : $\omega-3$ & 1.72 & 2.75 & 2.07 & 4.81 & 4.8 & 12.52 \\
P : S ratio & 0.53 & 0.68 & 0.68 & 0.50 & 0.38 & 0.16 \\
Atherogenicity index AI & 0.53 & 0.79 & 0.44 & 0.66 & 0.82 & 0.58 \\
\hline * Linoleic and arachidonic acids & & & & \\
** Linolenic acid & & & & & & \\
& & & & & &
\end{tabular}

acids are found in extremely small amounts in meats. Conversely, myristic and palmitic acids may have a negative effect on cardiovascular health (Medeiros et al., 2002). Thus, myristic, palmitic, and stearic acids are the only saturated fatty acids presented in Table 2 . Regarding the concentrations of myristic acid (C $14: 0)$ and palmitic (C 16 : $0)$, lower concentrations of myristic acid (1.32\%) were found in roe deer meat compared to $4.57 \%$ and $3.62 \%$ in deer and beef meat, respectively. Palmitic acid concentration was the lowest in elk (18.08\%), followed by deer meat (18.72\%). Palmitic acid concentration was similar in deer and beef meat: $21.2 \%$ and $21: 43 \%$, respectively. Results of statystical analysis confirmed that summed SFA did not differ significantly $(P>0.05)$ among animals. The results showed that the PUFA:SFA ratio in game meat samples varied from 0.50 to 0.68 , and the ratio of $1-6: 1-3$ fatty acids varied from 1.72 to 2.75 .

The iron concentration in meat depends on the amount of fat and blood. Fe compounds in meat are utilised well by the human body. Meat samples of wild animal species contained iron from 1.300 to $5.04 \mathrm{mg} \mathrm{kg}^{-1}$. Manganese occurred at up to two times in game animal meat $(0.006$ to $\left.0.27 \mathrm{mg} \mathrm{kg}^{-1}\right)$ than in beef and pork samples $\left(0.09 \mathrm{mg} \mathrm{kg}^{-1}\right)$ (Fig. 3). The highest concentrations of zinc were observed in wild boar samples (2.560 to $4.200 \mathrm{mg} \mathrm{kg}^{-1}$ ) (Fig. 2). Copper concentrations were higher in beef $\left(0.39 \mathrm{mg} \mathrm{kg}^{-1}\right)$ and pork (0.410 mg kg-1) (Figs. 2, 3). All meats sampled were found to be excellent sources of trace elements.

\section{DISCUSSION}

The results of our investigation are similar with those of other studies: protein concentration in raw deer meat samples was reported as $21.7 \%$, in boar meat samples $21.9 \%$ (Paleari et al., 2003). Meat has most of the essential fatty 


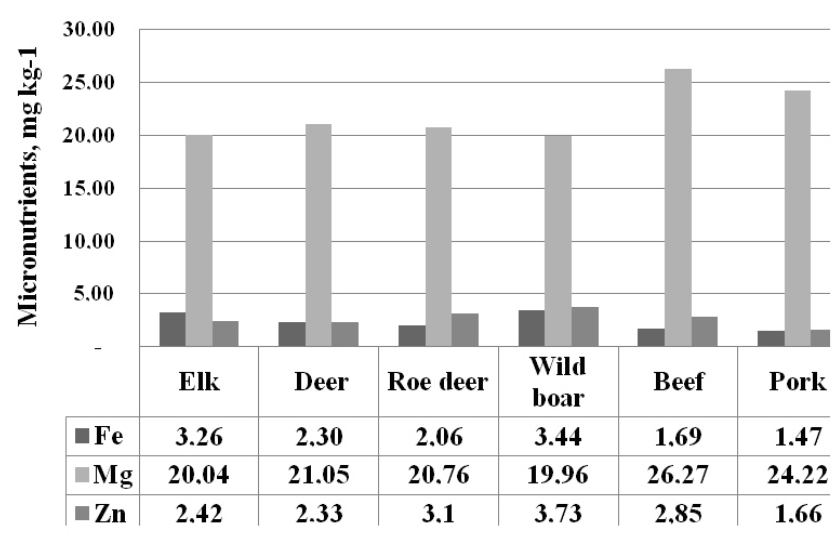

Fig. 2. Iron, magnesium, and zinc micronutrients composition of meat.

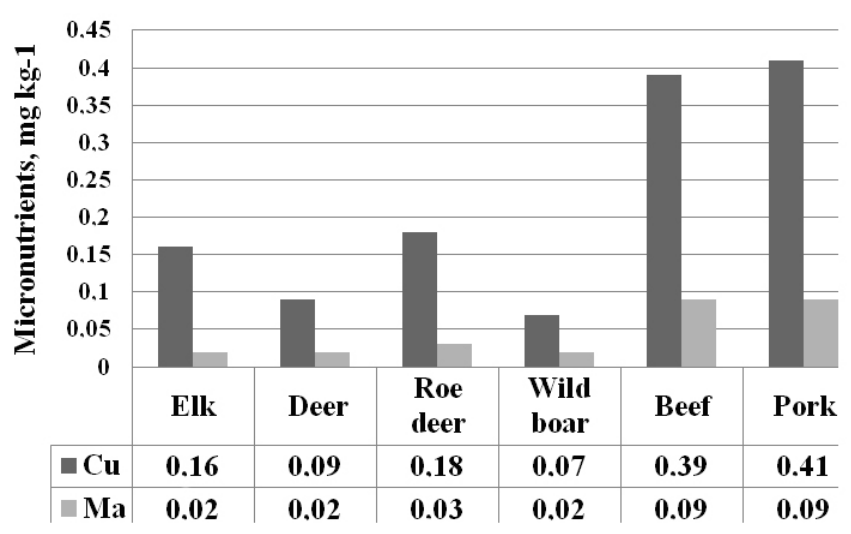

Fig. 3. Copper and manganese micronutrients composition of meat.

acids. Greater concentration of saturated fatty acids (44\%) is found in ruminant meat - cow, sheep. Less saturated fat is found in pork. The fat concentration in beef is greater than in moose and roe deer meat (41\%) (Rule et al., 2002). Wild game meat fats are more favourable to the human body, as the saturated fatty acid concentration is less, and polyunsaturated fatty acid concentration is higher (Cordan et al., 2002).

There are four interrelated factors that have important health ramifications: (1) the total fat content; (2) distribution of specific fatty acids; (3) the ratio of PUFA:SFA; and (4) the ratio of $\omega-6: \omega-3$ fatty acids. Each of these dietary lipid elements has been shown to influence the development of coronary heart disease (Cordan et al., 2002).

All types of meat are excellent sources of monounsaturated fatty acids, which can reduce cholesterol levels in human blood. The most important monounsaturated fatty acids in meat are oleic acid and palmitoleic acid. A diet rich in polyunsaturated FA (PUFA), especially long chained $\omega-3$ FA ( $\geq$ C20), has beneficial effects on human health, e.g. in prevention of arteriosclerosis. Game meat is a potential food source that is both lean and rich in $\omega-3$ PUFA (Sampels, 2005). Currently high intakes of fat containing high amounts of SFA and MUFA in modern Western diets are associated with adverse effects on human health, such as cardiovascular diseases, obesity and diabetes (Mann, 2000).
It is not only the amount of PUFA in the food that is important, but also the ratio between n- 6 and n-3 PUFA, for which values of 1 to 4 have been recommended (Simopoulos, 2002; Anonymous, 2003). In our study, in samples of game ruminants meat this ratio varied from 1.72 in elk meat till 2.75 in deer meat, but was higher in wild boar meat Medeiros et al. (2002) reported a ratio $\omega-6: \omega-3$ in deer meat of 3.45. In bovine animals (hogs and pigs), the ratio is above 4 . Thus, it can be concluded that wild animal (except wild boar) is favourable from the point of view of healthy nutrition, and that it is less associated with a variety of health problems. Improving the dietary ratio by decreasing the $\omega-6$ fatty acid concentration and increasing the $\omega-3$ fatty acid concentration is essential for brain function and for the management of cardiovascular disease, arthritis and cancer (Simopoulos, 2002).

WHO and Wood reported that the recommended ratio PUFA : SFA must be higher than 0.4 and that in domestic animals it is too low 0.1 (Wood et al., 2003). High relative proprtions of PUFA are characteristic of all wild ruminant muscle tissue, whereas the relative proportion of PUFA in muscle tissue of wild boar is lower than in wild ruminants. In the present investigation, the PUFA:SFA ratio was higher than 0.4 in all game meat samples (range from 0.50 till 0.68). Medeiros et al. (2002) reported that the PUFA: SFA ration of beef samples was 0.38 .

To calculate the atherogenicity index (IA), Ulbricht and Southgate (1991) used the fatty acid profile. This index has a positive correlation with the risk of cardiovascular disorders._Increases in dietary levels of saturated fat, particularly $12: 0,14: 0$ and $16: 0$ (palmitic acid) have been identified as the major dietary factor responsible for raising total and LDL serum cholesterol concentrations (Howell et al., 1997). Therefore, these fatty acids are included in the formula.

Consumers are interested in the environment and the products which are produced with sustainable farming methods. Hunting of wild moose, deer, roe deer and wild boar can provide food that perfectly complements and diversifies the daily assortment of meat, which is in line with current health and dietary recommendations, low-fat and high content of essential amino acids. All meat samples are excellent sources of trace elements

\section{ACKNOWLEDGEMENTS}

The present research is partly funded by the State Research Programme "Sustainable Use of Local Resources (Earth Entrails, Forests, Food and Transport) - New Products and Technologies (NatRes)", Project No. 3 "Sustainable use of local agricultural resources for development of increased nutrition value food products (FOOD)", Subproject 3.3 "Production of high quality deer farming products under sustainable farming conditions", and the publication was supported by project "Raising Awareness and Fostering International Cooperation of the Research Institute of Biotechnology and 
Veterinary Medicine "Sigra"”, agreement

No. 2010/0197/2DP/2.1.1.2.0/10/APIA/VIAA/016.

\section{REFERENCES}

Aldai, N., Osoro, K., Barrón, L. J. R., Najera, A. I. (2006). Gas-liquid chromatographic method for analysing complex mixtures of fatty acids including conjugated linoleic acids (cis9 trans 11 and trans 10 cis 12 isomers) and long-chain (n-3 or n-6) polyunsaturated fatty acids: Application to the intramuscular fat of beef meat. J. Chrom., 1110, 133 - 139.

Anonymous (2003). Diet, Nutrition and the Prevention of Chronic Diseases. World Health Organization Report of a Joint WHO/FAO Expert Consultation, Geneva, 160 pp. Cordan, L., Watkins, B. A., Florant, G. L., Kelher, M., Rogers, L., Li, Y.(2002). Fatty acid analysis of wild ruminant tissues: Evolutionary implications for reducing diet — related chronic disease. Eur. J. Clin. Nutr., 56, 181-191.

Honikel, K. O. (2009). Composition and calories. In: Nollet, L. M., Toldra, F. Handbook of Muscle Foods Analysis. CRC Press-Book: eBook.ISBN: 978-1-4200-4530-7369-384 (accessed 22 June 2012).

Howell, W. H., McNamara D.J., Tosca M.A., Smith B.T., Gaines J.A. (1997) Plasma lipid and lipoprotein responses to dietary fat and cholesterol: A meta analysis. Amer. J. Clin. Nutr., 65, 1747-1764.

Kalafova, A., Kovačik, J., Jurčik, R., Lukač, N., Massanyi, P., Capcarova, M., Schneiderova, M., Čupka, P. (2003). Mineral profile of rabbits after experimental addition of $\mathrm{Ni}$ a Zn VII. In: Celoslovensky seminar z fyziologie živočichov, 24-25 May (pp. 124-128). Nitra, Slovak Republic.

Mann, N. (2000). Dietary lean red meat and human evolution. Eur. J. Nutr., 39, 71-79.

Medeiros, L. C., Busboon, I. R., Field, R. A., Williams, I. C., Miller, G. I., Holmes, B. (2002). Nutritional Content of Game Meat. ces.uwyo.edu/PUBS/B920R.PDF (accessed 10 July 2012).

Paleari, M. A., Moretti, V. M., Beretta, G., Mentasti, T., Bersanni, C. (2003). Cured products from different animal species. Meat Sci., 63 (4), 485-489.
Petkov, R. (1986). Fatty acid content of the lipid fraction of the meat from deer and roe deer. Vet. Med. Nauki, 23 (1), 53-57 (in Bulgarian).

Rule, D. C., Broughton, K. S., Shellito, S. M., Maiorano, G. (2002). Comparison of muscle fatty acid profiles and cholesterol concentrations of bison, beef cattle, elk, and chicken. J. Animal Sci., 80, 1202-1211.

Samples, S. (2005). Fatty acids and antioxidants of reindeer and red deer Emphasis on animal nutrition and consequent meat quality. Doctoral dissertation. Uppsala: Swedish University of Agricultural Sciences. 62 pp. http://pub.epsilon.slu.se/800/1/Avhandling_nr_31_2005.pdf

Simopoulos, A. P. (2002). The importance of the ratio of omega-6/omega-3 essential fatty acids. Biomed. Pharmacother., 56, 365-379.

Soriano A., Cruz B., Gomez L., Mariscal C., Ruiz A.G. (2006). Proteolysis, physicochemicalcharacteristics and free fatty acid composition of dry sausages made with deer (Cervus elaphus) or wild boar (Sus scrofa) meat: A preliminary study. Food Chem., 96 (2), 173-184.

Ulbricht, T. L. V., Southgate, D. A. T. (1991). Coronary heart disease: Seven dietary factors. Lancet, 338, 985-992.

Vergara, H., Gallego, L., Garcia, A., Landete-Castillejos, T. (2003). Conservation of Cervus elaphus meat in modified atmospheres. Meat Sci., 65 (2), 779-783.

Wood, J. D, Richardson, R. I,. Nute, G. R, Fisher, A. V., Campo, M. M., Kasapidou, E. (2003). Effects of fatty acids on meat quality: A review. Meat Sci., 66, 21-32.

Wood, J. D., Enser, M. (2004). Factors influencing fatty acids in meat and the role of antioxidants in improving meat quality. Brit. J. Nutr., 66 (1), 21-32.

Young, O. A., Frost, D. A., West, J., Braggins, T. J. (2001). Analytical methods. In: Hui, Y. H., Wai-Kit, N., Rogers, R. W., Young, O. A. Meat Science and Applications. Chapter 5 (pp. 103-126). New York: Marcel Dekker, Inc.

Шманенов Н. А., Алиев Ф. Ф. (1973). Методические указания по исследованию липидного обмена у сельскохозяйственных животных [Guidelines for the Investigation of Lipid Metabolism in Farm Animals]. Боровск. 115 (in Russian).

\section{SAVVAḶAS DZĪVNIEKU GALLAS UZTURVĒRTĪBA}

Rakstā analizēts viens no vērtīgākajiem pārtikas produktiem — gaḷa, tās uzturvērtību nosaka neaizstājamās aminoskābes, taukskābes, vitamīni, minerālvielas. Darba mērķis bija salīdzināt uzturvērtību nomedītu savvaḷas dzīvnieku — aḷnu, savvaļas briežu, audzētavās audzētu briežu, stirnu, mežacūku un mājdzīvnieku - ar liellopu un cūku gạ̣as paraugiem (pētījumā tika izmantoti gaḷas paraugi no muguras garā muskuḷa (m. logissimus lumborum)). Veikto pētījumu rezultāti liecina, ka savvaḷas dzīvnieku gaḷas paraugi, salīdzinājumā ar mājdzīvnieku gal̦u, ir ar augstāku olbaltumvielu un būtiski vērtīgāku taukskābju sastāvu. Savvaḷā nomedītu aḷnu, briežu, stirnu un mežacūku gaļa var lieliski papildināt un dažādot ikdienas gaḷas sortimentu, saskaņā ar pašreizējiem veselīga uztura ieteikumiem — zemu tauku un augstu neaizvietojamo aminoskābju saturu. Visi medījuma gaḷas veidi ir lielisks mikroelementu avots. 


\title{
NUTRITIONAL BENEFITS OF Bifidobacterium lactis IN DAIRY PRODUCTS
}

\author{
Ilze Beitāne and Inga Ciproviča \\ Faculty of Food Technology, Latvia University of Agriculture, Lielā iela 2, Jelgava, LV-3001, LATVIA; \\ Ilze.Beitane@ @lu.Iv
}

Communicated by Edīte Birǵele

\begin{abstract}
Bifidobacteria are one of the most important probiotics in dairy products. They have positive effects on human health. Nutritional benefits of bifidobacteria are genetically determined and can be promoted with addition of prebiotics. The aim of the present study was to examine the properties of Bifidobacterium lactis in dairy products. Pasteurised milk, freeze-dried starter culture Bb-12 (Bifidobacterium lactis, Chr. Hansen, Denmark), syrup of lactulose (Duphalac ${ }^{\circledR}$, the Netherlands), and inulin ("Raftiline ${ }^{\circledR} H P$ ", ORAFI, Belgium) were used in the experiments. The optimal concentrations of lactulose (2\%) and inulin (4\%) were established in preliminary studies, based on quality indices and nutritional value of fermented dairy products (Beitane, 2008). Amino acids, carbohydrates, such as lactose, lactulose and inulin, as well as cholesterol were determined during the study using appropriate analytical procedures. The enzymatic activity of bifidobacteria determines nutritional value of the fermented dairy products. Addition of $2 \%$ lactulose resulted in significant increase of some amino acid concentrations, such as leucine, phenylalanine, lysine and arginine concentrations $(\mathrm{P}<0.05)$, compared with those in other treatments. The presence of prebiotics caused a decrease of cholesterol level by $35 \%$ and lactose content by $31 \%$ in fermented milk samples. The enzymatic activity of bifidobacteria should be promoted with addition of lactulose and inulin to increase nutritional value of functional dairy products.
\end{abstract}

Key words: bifidobacteria, lactulose, inulin, lactose, amino acids, cholesterol.

\section{INTRODUCTION}

Bifidobacteria are one of the most important probiotics in dairy products (Parvez et al., 2006; Russell et al., 2011). Probiotics are live microorganisms which when administered in adequate amounts confer a health benefit on the host (Oliveira et al., 2011). Bifidobacteria have positive effects on human health: (1) synthesis of vitamins (Crittenden et al., 2003; Beitane and Ciprovica, 2011); (2) immunostimulation (Dong et al., 2010); (3) cholesterol reduction (Ziarno et al., 2007; Beitane, 2008); (4) lactose hydrolysis (He et al., 2007); and (5) prevention of infectious diarrhoea (Qiao et al., 2002). Nutritional benefits of bifidobacteria are genetically determined. Bifidobacteria are saccharolytic and produce organic acids (Russell et al., 2011). They release various enzymes, such as leucine, valine and cystine aminopeptidases, $\alpha-, \quad \beta$-galactosidases, $\alpha, \quad \beta$-glucosidases, $N$-acetyl- $\beta$-glucosaminidase, esterases during multiplication (Martinez-Villaluenga and Gomez, 2007), which improve nutritional value of the end product: higher content of amino acids, and lower content of cholesterol and lactose in fermented dairy products. Thereby milk products are acceptable for patients with hypercholesterolemia and lactose intolerance. The growth of bifidobacteria can be promoted with addition of prebiotics (Rastall and Maitin, 2002).

Prebiotics are non-digestible food ingredients that beneficially effect the host by selective stimulating the growth and/or activity of one or a limited number of bacteria in the colon (De Vrese and Schrezenmeir, 2001). Lactulose and inulin are one of the widely used prebiotics for promotion of bifidobacteria growth in milk and the gastrointestinal tract (Szilagyi et al., 2001; Palframan et al., 2002; Holzapfel and Schillinger, 2002; Aider and de Halleux, 2007; Bouhnik et al., 2007). Lactulose is mostly used in Europe, Japan and the United States (Tuohy et al., 2005). It is a synthetic disaccharide created by the isomerisation of lactose (Aider and de Halleux, 2007). Fructo-oligosaccharides are widely used as commercial prebiotics, which contain a varying number of fructose monomers connected by $\beta$-2-1-glycosidic bonds (Russell et al., 2011). Evaluation of the suitability of prebiotics for promotion the growth of bifidobacteria in milk showed that the appropriate concentration were 2\% lactulose and 4\% inulin (Beitane and Ciprovica, 2008). The aim of the present study was to examine the specific properties of Bifidobacterium lactis in dairy products. 
Pasteurised milk with fat content $2.5 \%$ and freeze-dried Bifidobacterium lactis culture (Bb-12, Chr. Hansen, Denmark) were used for the experiments. During the experiments, the culture was maintained at $-18{ }^{\circ} \mathrm{C}$. As additions, the following prebiotics were used: inulin "Raftiline ${ }^{\circledR} \mathrm{HP}$ " (ORAFI, Belgium) with polymerization degree $\geq 5$ and degree of purity $99.5 \%$ and syrup of lactulose (Duphalac ${ }^{\circledR}$, the Netherlands) with the following composition (\%): lactulose - no less than 67 , lactose - less than 6 , galactose - less than 10 .

$2 \%$ lactulose and 4\% inulin were added individually to 100 $\mathrm{g}$ of milk. The concentrations of prebiotics were chosen according to previous study, in which the optimal bifidogenic effect of lactulose and inulin was established (Beitane and Ciprovica, 2008). Bifidobacterium lactis was inoculated with $2 \mathrm{ml}$ of milk suspension $\left(10^{6} \mathrm{cfu} \mathrm{m}^{-1}\right)$ and cultured at $37{ }^{\circ} \mathrm{C}$ for 16 hours. The control sample was prepared without prebiotics for comparison.

The content of amino acids was determined with an automatic amino acids analyser AAA 339 (Microtechna Praha, Czech Republic), according to requirements of „Amino acid standard solution for protein hydrolysates $-0.5 \mu$ moles per ml".

The level of cholesterol was determined according to AOAC Official Method 976.26A.

The concentrations of lactose and lactulose were determined by IDF standard 147B:1998 procedure, the content of inulin by AOAC Official Method 999.03 and by AACC Official Method 32.32.

Significant differences were determined by analysis of variance (ANOVA) and t-tests at $P$ value 0.05 .

\section{RESULTS}

The concentrations of amino acids in milk, control and fermented milk samples with $2 \%$ of lactulose and $4 \%$ of inulin are shown in Table 1.

The obtained results showed that the addition of lactulose increased amino acid concentration in fermented product more than with inulin; the highest total amino acids after fermentation in fermented dairy product was $2.829 \mathrm{~g}$ $100 \mathrm{~g}^{-1}$.

ANOVA indicated significant increase of isoleucine, leucine and lysine concentrations $(P<0.05)$ in fermented milk with $2 \%$ of lactulose, compared with other treatments. A significant decrease of leucine, phenylalanine, lysine and arginine concentrations $(P<0.05)$ were observed in fermented milk with $4 \%$ inulin, indicating promotion of glycolysis and suppression of proteolysis in fermented milk with $B$. lactis. Lactulose facilitated the proteolytic properties of bifidobacteria.
CONCENTRATIONS OF AMINO ACIDS IN FERMENTED MILK SAMPLES WITH LACTULOSE AND INULIN, g $100 \mathrm{~g}^{-1}$

\begin{tabular}{l|c|c|c|c}
\hline \multicolumn{1}{c}{ Amino acids } & Milk & Control & $\begin{array}{c}\text { Fermented } \\
\text { milk with 2\% } \\
\text { of lactulose }\end{array}$ & $\begin{array}{c}\text { Fermented } \\
\text { milk with 4\% } \\
\text { of inulin }\end{array}$ \\
\hline Threonine & 0.107 & 0.095 & 0.112 & 0.094 \\
Valine & 0.130 & 0.115 & 0.123 & 0.101 \\
Methionine & 0.061 & 0.064 & 0.075 & 0.052 \\
Isoleucine & 0.095 & 0.087 & 0.108 & 0.078 \\
Leucine & 0.254 & 0.232 & 0.271 & 0.207 \\
Phenylalanine & 0.115 & 0.114 & 0.093 & 0.095 \\
Tyrosine & 0.131 & 0.123 & 0.121 & 0.094 \\
Lysine & 0.197 & 0.181 & 0.208 & 0.151 \\
Aspartic acid & 0.233 & 0.212 & 0.223 & 0.201 \\
Serine & 0.133 & 0.115 & 0.154 & 0.109 \\
Glutamic acid & 0.620 & 0.569 & 0.711 & 0.366 \\
Proline & 0.248 & 0.221 & 0.277 & 0.178 \\
Glycine & 0.051 & 0.039 & 0.052 & 0.044 \\
Alanine & 0.086 & 0.069 & 0.094 & 0.073 \\
Histidine & 0.100 & 0.108 & 0.108 & 0.108 \\
Arginine & 0.089 & 0.092 & 0.099 & 0.087 \\
Total & 2.650 & 2.436 & 2.829 & 2.038 \\
& & & &
\end{tabular}

The ability of $B$. lactis to assimilate cholesterol during milk fermentation in the presence of prebiotics was studied. The levels of cholesterol in milk, control and in fermented milk samples with $2 \%$ of lactulose and $4 \%$ of inulin are presented in Figure 1.

The results showed that fermentation of milk with $B$. lactis decreased cholesterol concentrationt by $25 \%$ in samples, indicating promotion of this activity by prebiotics. Both prebiotics showed similar results. Significant differences were observed between milk and fermented milk samples with and without prebiotics $(P<0.05)$. Differences between control and fermented milk samples with prebiotics were insignificant $(P>0.05)$.

The lactose concentrations in samples with and without prebiotics before and after fermentation are presented in Figure 2. Decrease of lactose concentration during fermen-

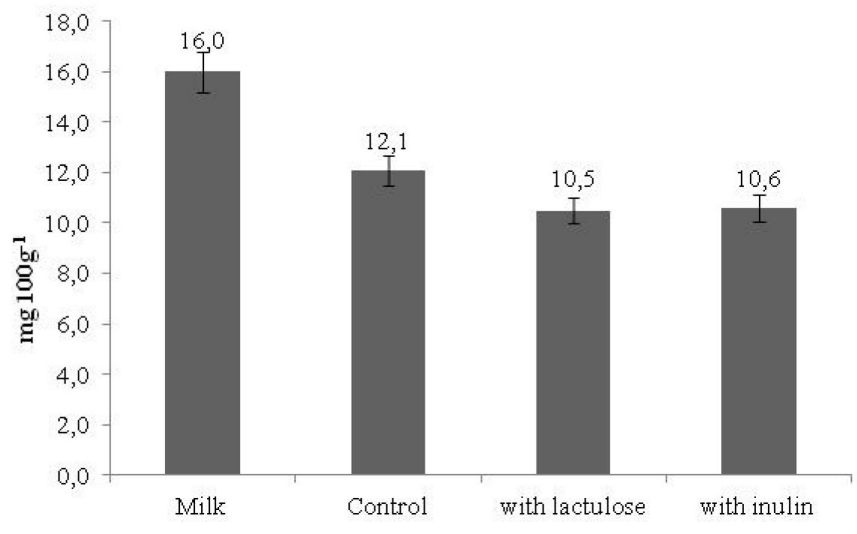

Fig. 1. Level of cholesterol in milk, control and in fermented milk samples with $2 \%$ lactulose and $4 \%$ inulin. 


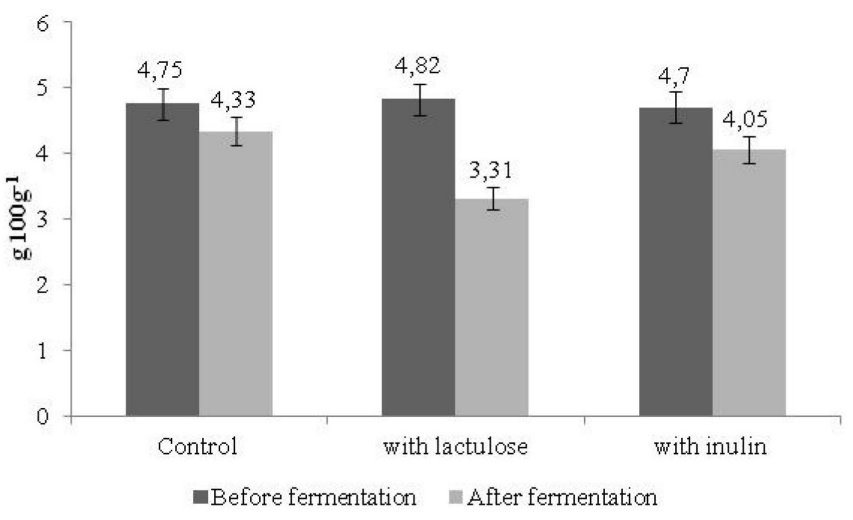

Fig. 2. Concentration of lactose in milk before and after fermentation with and without prebiotics (increasing of lactose content in milk samples before fermentation is associated with the presence of lactose in lactulose syrup).

tation occurred in all samples. The highest reduction of lactose content was observed in samples with $2 \%$ lactulose, i.e.

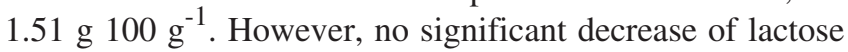
were established $(P>0.05)$ between fermented milk sample with $2 \%$ lactulose and other fermented milk samples with prebiotics. Changes of lactose content during fermentation in samples with and without prebiotics were significant $(P<$ $0.05)$.

Regarding the ability of $B$. lactis to hydrolyse with addition of prebiotics, the results showed that bifidobacteria have the ability to ferment up to $50 \%$ of added lactulose (from $1.34 \mathrm{~g}$

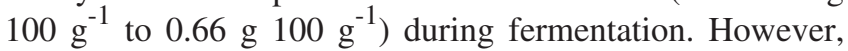
the decrease of inulin concentration was negligible (from

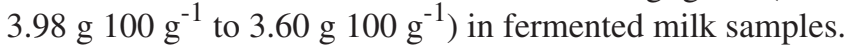
In the present study, inulin with a polymerisation degree $\geq 5$ and degree of purity $99.5 \%$ was used, which could explain the obtained results.

\section{DISCUSSION}

The growth of the starter bacteria in milk depends on their proteolytic activity to hydrolyse casein (Thomas and Mills, 1981), where casein is the main source of amino acids in milk (Walstra et al., 2006). It is known that proteolytic properties of bifidobacteria are quite weak (Sgorbati et al., 1995), however, they release aminopeptidases during multiplication (Martinez-Villaluenga and Gomez, 2007). They are vital for metabolic pathway regulation, cell maturation and protein turnover (Herrera-Camacho et al., 2007). Much research indicates that bifidobacteria are able to synthesise a considerable amount of amino acids (Matteuzi et al., 1978; Ballongue, 2003), which is in contrast with the present results. Regarding concentrations of amino acids in milk and control (Table 1), there was a decrease of amino acid concentrations, except histidine and arginine, in fermented milk samples. However, B. lactis has the ability to synthesise a remarkable amount of specific amino acids, such as threonine, methionine, tyrosine, lysine and aspartic acid, compared with lactic acid bacteria (Table 2). The differences of amino acids concentration in milk and fermented
CONCENTRATIONS OF AMINO ACIDS IN FERMENTED MILK SAMPLES USING DIFFERENT STARTER CULTURES, g $100 \mathrm{~g}^{-1}$

\begin{tabular}{l|c|c|c|c}
\hline Amino acids & B. lactis & $\begin{array}{c}\text { L. lactis } \\
\text { C15 }\end{array}$ & $\begin{array}{c}\text { L. bulgaricus } \\
\text { HP1 }\end{array}$ & $\begin{array}{c}\text { L. helveticus } \\
\text { MP12 }\end{array}$ \\
\hline Threonine & 0.095 & 0.005 & 0.035 & 0.011 \\
Valine & 0.115 & 0.096 & 0.138 & 0.092 \\
Methionine & 0.064 & 0.006 & 0.040 & 0.048 \\
Isoleucine & 0.087 & 0.003 & 0.254 & 0.144 \\
Leucine & 0.232 & 0.037 & 0.266 & 0.297 \\
Phenylalanine & 0.114 & 0.092 & 0.142 & 0.294 \\
Tyrosine & 0.123 & 0.022 & 0.022 & 0.020 \\
Lysine & 0.181 & 0.006 & 0.074 & 0.036 \\
Aspartic acid & 0.212 & 0.032 & 0.041 & 0.161 \\
Serine & 0.115 & 0.061 & 0.215 & 0.234 \\
Glutamic acid & 0.569 & 0.677 & 1.130 & 2.051 \\
Proline & 0.221 & 0.202 & 1.007 & 1.281 \\
Glycine & 0.039 & 0.032 & 0.057 & 0.158 \\
Alanine & 0.069 & 0.093 & 0.454 & 0.543 \\
Histidine & 0.108 & 0.050 & 0.174 & 0.232 \\
Arginine & 0.092 & 0.007 & 0.094 & 0.024 \\
Total & 2.436 & 1.421 & 4.143 & 5.465 \\
& & & &
\end{tabular}

After Simova et al., 2006

milk can be explained by the need of amino acids for bifidobacteria growth (Ballongue, 2003).

B. lactis can release high activity leucine and valine aminopeptidases (Martinez-Villaluenga and Gomez, 2007). This can be explained by the chemical composition of milk, method of preparation and storage conditions of experimental samples. We observed an increase of aminopeptidase activity by addition of $2 \%$ lactulose, which led to a significant increase $(P<0.05)$ of isoleucine, leucine and lysine. Amino acids released by bifidobacteria influenced the nutritional value of fermented products.

Bifidobacteria can decrease the serum cholesterol in blood (Xiao et al., 2003), which can be promoted by addition of prebiotics (Pereira and Gibson, 2002). The cholesterol-lowering effect of probiotics can be explained by, for example, enzymatic deconjugation of bile acids by bile salt hydrolase of probiotics (Kumar et al., 2012). The decrease of cholesterol concentration in fermented milk in the present study can be explained by the activity of esterases, which was determined as intermediate activity for B. lactis (MartinezVillaluenga and Gomez, 2007). Esterases have the capacity for hydrolysis and synthesis of esters by esterification of fatty acids and ethanol (Liu et al., 2004). Esterases from lactic acid bacteria release preferentially short-chain fatty acids, and furthermore, several strains possess more than one esterase (Oliszewski et al., 2007). The decrease of cholesterol level in milk depends mainly on the bacteria species used for fermentation (Oberman and Libudzisz, 1998). Lactobacillus acidophilus and Bifidobacterium spp. in fermented milk are able to assimilate cholesterol from $18 \%$ to $38 \%$ in fermented milk (Ziarno et al., 2007). The results of 
the present study showed that $B$. lactis can assimilate cholesterol by $25 \%$ in milk, whereas by $35 \%$ with addition of the studied concentrations of lactulose and inulin. Thus, the presence of prebiotics in milk promotes $B$. lactis esterase activity.

Two-thirds of the world's adult population suffers from lactose maldigestion (Vesa et al., 2000), which is caused by reduction of $\beta$-galactosidase activity in the small intestine after weaning (Russell et al., 2011). Jiang et al. (1996) indicated that $\beta$-galactosidase improves lactose utilization for lactose intolerant patients. Martinez-Villaluenga and Gomez (2007) reported that $\beta$-galactosidase activity for mostly bifidobacteria strains was high, but $B$. lactis had intermediate activity. $\beta$-galactosidase is widely employed for reduction of lactose content in milk products (Rhimi et al., 2010), thereby fermented milk products are acceptable for patients with lactose intolerance. Lactose is split by $\beta$-galactosidase into glucose and galactose (Kandler, 1983). The activity of $\beta$-galactosidase released from $B$. lactis can be described as intermediate (Martinez-Villaluenga and Gomez, 2007), which explain the results of the present study. Evaluating the ability of B. lactis to assimilate added lactulose and inulin, it was obvious that lactulose was most suitable substrate for growing of bifidobacteria in milk.

This confirmed the results mentioned in literature about the bifidogenic effect of lactulose in certain concentrations (Palframan et al., 2002; Bouhnik et al., 2004) and the ability of bifidobacteria to assimilate lactulose (Saarela et al., 2003). Semjonovs et al. (2004) reported that B. lactis is not able to assimilate inulin. Biedrzycka and Bielecka (2004) indicated that inulin assimilation decreases the inulin polymerisation degree and the degree of purity.

In conclusion, the enzymatic activity of bifidobacteria determines nutritional value of fermented dairy products. The addition of $2 \%$ lactulose resulted in significant increase of some amino acids, such as leucine, phenylalanine, lysine and arginine $(P<0.05)$, compared with the other treatment. The presence of prebiotics resulted in decrease of cholesterol level by $35 \%$ and lactose content by $31 \%$ in fermented milk samples. The enzymatic activity of bifidobacteria can be promoted by addition of lactulose and inulin to increase the nutritional value of functional dairy products.

\section{REFERENCES}

Aider, M., Halleux, D. (2007). Isomerization of lactose and lactulose production: Review. Trends Food Sci. Technol., 18, 356-364.

Ballongue, J. (2003). Bifidobacteria and probiotic action. In: Salminen, S., Wright, A., Ouwehand, A. (eds.). Lactic Acid Bacteria. Microbiological and Functional Aspects (pp. 67-125). New York: Marcel Dekker, Inc.

Beitane, I. (2008). The evaluation of lactulose and inulin for the development of a new functional milk product. Doctoral dissertation, Latvia University of Agriculture, Jelgava, Latvia. 124 pp.

Beitane, I., Ciprovica, I. (2008). Prebiotics - the influencing factors on growth and survival of probiotics in milk [Prebiotikas - probiotisko baktēriju vairošanās un dzīvotspējas veicinātājas pienā]. Proceedings of the Latvia University of Agriculture, 21 (316), 42-50 (in Latvian).
Beitane, I., Ciprovica, I. (2011). The study of added prebiotics on B group vitamins concentration during milk fermentation. AC Romanian Biotechnol. Lett., 16 (6) Supplement, 92-96.

Biedrzycka, E., Bielecka, M. (2004). Prebiotic effectiveness of fructans of different degrees of polymerization. Trends Food Sci. Technol., 15, $170-175$.

Bouhnik, Y., Attar, A., Joly, F. A., Riottot, M., Dyard, F., Flourie, B. (2004). Lactulose ingestion increases faecal bifidobacterial counts: A randomised double-blind study in healthy humans. Eur. J. Clin. Nutr., 58, 462-466.

Bouhnik, Y., Raskine, L., Champion, K., Andrieux, C., Penven, S., Jacobs, H., Simoneau, G. (2007). Prolonged administration of low-dose inulin stimulates the growth of bifidobacteria in humans. Nutr. Res., 27, 187-193.

Crittenden, R. G., Martinez, N. R., Playne, M. J. (2003). Synthesis and utilization of folate by yoghurt starter cultures and probiotic bacteria. Int. J. Food Microbiol., 80, 217-222.

Dong, P., Yang, Y., Wang, W.-P. (2010). The role of intestinal bifidobacteria on immune system development in young rats. Early Hum. Devel., 86, $51-58$.

He, T., Priebe, M.G., Zhong, Y., Huang, C., Harmsen, H. J. M., Raangs, G. C., Antoine, J. M., Welling, G. W., Vonk, R. J. (2007). Effects of yogurt and bifidobacteria supplementation on the colonic microbiota in lactose-intolerant subjects. J. Appl. Microbiol., 104, 595-604.

Herrera-Camacho, I., Rosas-Murrieta, N. H., Rojo-Dominguez, A., Millan, L., Reyes-Leyva, J., Santos-Lopez, G., Suarez-Rendueles, P. (2007). Biochemical characterization and structural prediction of novel cytosolic leucyl amino-peptidase of the M17 family from Schizosaccharomyces pombe. FEBS Journal, 274, 6228-6240.

Holzapfel, W. H., Schillinger, U. (2002). Introduction to pre- and probiotics. Food Res. Int., 35, 109-116.

Jiang, T., Mustapha, A., Savaiano, D. A. (1996). Improvement of lactose digestion in humans by ingestion of unfermented milk containing Bifidobacterium longum. J. Dairy Sci., 79, 750-757.

Kandler, O. (1983). Carbohydrate metabolism in lactic acid bacteria. Antonie van Leeuwenhoek, 49, 209-224.

Kumar, M., Nagpal, R., Kumar, R., Hemalatha, R., Verma, V., Kumar, A., Chakraborty, Ch., Singh, B., Marotta, F., Jain, Sh., Yadav, H. (2012). Cholesterol-Lowering Probiotics as Potential Biotherapeutics for Metabolic Diseases. Experimental Diabetes Research. Jan 2012, pp. 1-14. DOI: $10.1155 / 2012 / 902917$.

Liu, S. Q., Holland, R., Crow, V. L. (2004). Esters and their biosynthesis in fermented dairy products: A review. Int. Dairy J., 14, 923-945.

Martinez-Villaluenga, C., Gomez, R. (2007). Characterization of bifidobacteria as starters in fermented milk containing raffinose family of oligosaccharides from lupina as prebiotics. Int. Dairy J., 17 (2), pp. 116-122.

Matteuzi, D., Crociani, F., Enaldi, O. (1978). Amino acids produced by bifidobacteria and some clostridia. Ann. Microbiol., 129, 175-182.

Oberman, H., Libudzisz, L. (1998). Fermented milks. In: Wood, B. J. B. (Ed.). Microbiology of Fermented Foods (pp. 308-351). London: Blackie Academic\&Professional.

Oliszewski, R., Medina, R. B., Gonzalez, S. N., Perez Chaia, A. B. (2007). Esterase activities of indigenous lactic acid bacteria from Argentinean goats' milk and cheeses. Food Chem., 101, 1446-1450.

Oliveira, R. P. D. S., Florence, A. C. R., Perego, P., De Oliveira, M. N., Converti, A. (2011). Use of lactulose as prebiotic and its influence on the growth, acidification profile and viable counts of different probiotics in fermented skim milk. Int. J. Food Microbiol., 145, 22-27.

Palframan, R. J., Gibson, G. R., Rastall, R. A. (2002). Effect of pH and dose on the growth of gut bacteria on prebiotic carbohydrates in vitro. Anaerobe, 8, 287-292.

Parvez, S., Malik, K. A., Ah Kang, S., Kim, H.-Y. (2006). Probiotics and their fermented food products are beneficial for health. J. Appl. Microbiol., 100, 1171-1185. 
Pereira, D. I. A., Gibson, G. R. (2002). Effect of consumption of probiotics and prebiotics on serum lipid levels in humans. Critical Rev. Biochem. Mol. Biol., 37, 259-281.

Qiao, H., Duffy, L. C., Griffiths, E., Dryja, D., Leavens, A., Rossman, J. O. N., Rich, G., Riepenhoff-Talty, M., Locniskar, M. (2002). Immune responses in rhesus rotavirus-challenged BALB/c mice treated with bifidobacteria and prebiotic supplements. Pediatric Res., 51, 750-755.

Rastall, R. A., Maitin, V. (2002). Prebiotics and synbiotics: Towards the next generation. Curr. Opinion Biotechnol., 13, 490-496.

Rhimi, M., Boisson, A., Dejob, M., Boudebouze, S., Maguin, E., Haser, R., Aghajari, N. (2010). Efficient bioconversion of lactose in milk and whey: Immobilization and biochemical characterization of a $\beta$-galactosidase from the dairy Streptococcus thermophilus LMD9 strain. Res. Microbiol., $161,515-525$.

Russell, D. A., Ross, R. P., Fitzgerald, G. F., Stanton, C. (2011). Metabolic activities and probiotic potential of bifidobacteria. Int. J. Food Microbiol., 149, 88-105.

Saarela, M., Hallamaa, K., Mattila-Sandholm, T., Mättö, J. (2003). The effect of lactose derivatives lactulose, lactitol and lactobionic acid on the functional and technological properties of potentially probiotic Lactobacillus strains. Int. Dairy J., 13, 291-302.

Semjonovs, P., Marauska, R., Linde, R., Grube, M., Zikmanis, P., Bekers, M. (2004). Development of Bifidobacterium lactis Bb12 on $\beta-(2,6)$-Linked Fructan-Containing Substrate. Eng. Life Sci., 4 (5), 433-437.
Sgorbati, B., Biavati, B., Palenzona, D. (1995). The genus Bifidobacterium. In: Wood B. J. B., Holzapfel, W. H. (eds.). The Genera of Lactic Acid Bacteria (pp. 279-303). Glasgow: Chapman\&Hall.

Simova, E., Simov, Z., Beshkova, D., Frengova, G., Dimitrov, Z., Spasov, Z. (2006). Amino acid profiles of lactic acid bacteria, isolated from kefir grains and kefir starter made from them. Int. J. Food Microbiol., 107, $112-123$.

Szilagyi, A., Rivard, J., Fokeeff, K. (2001). Improved parametrs of lactose maldigestion using lactulose. Digest. Dis. Sci., 46 (7), 1509-1519.

Tuohy, K. M., Rouzaud, G. C. M., Bruck, W. M., Gibson, G. R. (2005). Modulation of the human gut microflora towards improved health using prebiotics - assessment of efficacy. Curr. Pharm. Design, 11, 75-90.

Vesa, T. H., Marteau, P., Korpela, R. (2000). Lactose intolerance. J. Amer. Coll. Nutr., 19, 165S-175S.

De Vrese, M., Schrezenmeir, J. (2001) Pro and prebiotics. Innov. Food Technol., May/June, 49-55.

Walstra, P., Wouters, J. T. M., Geurts, T. J. (2006). Dairy Science and Technology. Boca Raton: CRC / Taylor \& Francis. 782 pp.

Xiao, J. Z., Kondo, S., Takahashi, N., Miyaji, K., Oshida, K., Hiramatsu, A., Iwatsuki, K., Kokubo, S., Hosono, A. (2003). Effects of milk products fermented by Bifidobacterium longum on blood lipids in rats and healthy adult male volunteers. J. Dairy Sci., 86 (7), 2452-2461.

Ziarno, M., Sekul, E., Lafraya, A. A. (2007). Cholesterol assimilation by commercial yoghurt starter cultures. Acta Scientiarum Polonorum Technologia Alimentaria, 6, 83-94.

13 September 2012

\section{Bifidobacterium lactis RAUDZĒTU PIENA PRODUKTU UZTURVĒRTĪBAS PAAUGSTINĀŠANA}

Bifidobaktērijas ir vienas no nozīmīgākajām un plašāk lietotajām probiotikām piena produktu ražošanā, pateicoties to daudzveidīgajai labvēlīgajai ietekmei. Bifidobaktērijām vairojoties, substrātā tiek izdalīti šādi enzīmi: aminopeptidāzes, galaktozidāzes, esterāzes, kuru darbības rezultātā iegūst raudzētu piena produktu ar paaugstinātu aminoskābju, zemāku holesterīna un laktozes saturu. Bifidobaktēriju enzimātiskā aktivitāte pienā nosaka raudzētā produkta uzturvērtību. Tā kā dažādu enzīmu aktivitāte ir atškirīga, tad, pievienojot prebiotikas, ir iespējams veicināt enzīmu darbību, tādējādi palielinot vai samazinot atsevišķu uzturvielu saturu gatavajā produktā. Pievienojot pienam 2\% laktulozes, tika panākts būtisks $(P<0.05)$ atsevišḳu aminoskābju (leicīna, fenilalanīna, lizīna un arginīna) satura pieaugums raudzētajā produktā. Prebiotiku klātbūtne nodrošināja holesterīna satura samazinājumu par $35 \%$ un laktozes satura samazinājumu par $31 \%$ piena fermentēšanā. Pētījuma rezultāti pierādīja, ka bifidobaktēriju enzimātisko aktivitāti ir iespējams veicināt, pievienojot noteiktās koncentrācijas laktulozi un inulīnu, paaugstinot raudzēto piena produktu uzturvērtību. 


\title{
SALT AND BREAD: LATVIA'S EXPERIENCE
}

\author{
Daiga Kunkulberga* and Endija Mūrniece
}

Faculty of Food Technology, Latvia University of Agriculture, 2 Lielā iela, Jelgava, LV3001, LATVIA

daiga.kunkulberga@llu.Iv

Communicated by Daina Kārklina

\begin{abstract}
Much research has shown that reduction in salt intake can have a very positive impact on human health, as salt intake plays a critical role in regulating blood pressure. According to the World Health Organization, populations with low salt intake, all other factors being equal, usually have lower blood pressure level, in that way decreasing the risk of cardiovascular disease. The main source of salt in the diet is ready-made food, and only about $11 \%$ of overall salt intake is the salt people add to their food themselves. A common EU framework for salt reduction has been developed, which describes a common vision for a general European approach towards salt reduction. Bread has been identified as an important contributor to the daily salt intake in many countries. On the other hand, salt has important technological functions in bakery products. It improves the qualities of dough, fermentation, and flavour of bread. The aim of this paper was to evaluate the amount of salt in Latvian bread and to assess the need for decreasing the amount of salt in bread. The majority of Latvian bread contains 1.1 to $1.2 \%$ salt in flour, but in some other kinds of bread it is even less.
\end{abstract}

Key words: salt, bread, sodium chloride.

\section{INTRODUCTION}

Common salt or sodium chloride is a chemical compound $\mathrm{NaCl}$. Salt is a natural mineral halite, which exists as deposits in many world countries, and is the compound of sea water and salt lakes (Kurlansky, 2003). Salt is a significant element in the diet not only for humans, but also for animals and many plants. Salt is one of the most effective and popular food preservatives. Sodium is a mineral, an inorganic compound, and it performs a biological function in the human organism. Ions of sodium are located mainly outside cells, maintaining the amount of water outside cells in balance. Salt takes part in maintaining the balance of liquids and transmitting nervous impulses, and it affects the contraction and relaxation of muscles (Baltess, 1998). Salt participates in regulating the amount of water in the human organism. A strong desire for salt may be related to a lack of minerals, particularly sodium chloride, in the organism. Ions of sodium and chloride act in the function of kidneys. Sodium "seizes" water and together with chloride "holds" water in tissues. Water is absorbed from intestines by means of $\mathrm{NaCl}$. Salt is the central regulator of water exchange in this system. Ions of sodium and chloride are important components of digestive juices. Both ions maintain the tonus of tissues. The sodium-potassium exchange pump is required to maintain cell pressure (Denton, 1983).

The human organism contains approximately $70 \mathrm{~g}$ of $\mathrm{Na}$, and its amount has to be regularly replenished in small quantities. We ingest the necessary amount of sodium in the form of salt. Salt is the main source of sodium in the diet and is used as a seasoning that nowadays is usually consumed too much. A too large intake of salt affects the human organism very negatively, as it burdens physiological functions. For example, excessive salt will need to be exceted via kidneys. Too large intake of salt increases the amount of salt in the organism, which promotes hypertension, increases the risk of heart diseases or cerebral thrombosis, as well as promotes kidney diseases (Lejins and Kalvelis, 2011). Studies have shown that individuals consume on average $10-15 \mathrm{~g}$ of salt daily, which is much more than the $5 \mathrm{~g}$ recommended by dietary doctors. Salt is added to food bought in almost all supermarkets, not only to canned food and sausages, but also to bread, spaghetti, cheese, and even yogurt. The content of salt is so high in food products that the amount injested in one day would suffice for many days. Consumption of products with a high content of salt can result in dropping/swollen eyelids. If salt is regularly consumed too much, more serious health problems might arise. Regarding salt, women have to be very careful during menopause, as its excessive consumption causes greater excretion of potassium into urine, which may make bones fragile to a dangerous extent. There is a view that excessive intake of sodium chloride can promote asthma, stomach ulcer, duodenal ulcer, and cancer (Großklaus et al., 2009).

The mechanism by means of which salt causes hypertension is not completely known, but doctors consider that the kid- 
neys of patients suffering with hypertension are not able to excrete sodium as much as necessary. Blood pressure affects fluctuations of the $\mathrm{Na}$ level in blood plasma. With a decrease in the amount of $\mathrm{Na}$ in blood plasma, blood pressure also falls. Serum Na also determines the volume of extracellular fluid, which also affects blood pressure; yet, changes in blood pressure are determined by the sodium level, not changes in the volume (Valtnera, 1995).

Research has confirmed that nowadays salt is consumed through food too much, and that its consumption has to be reduced. A decrease of salt in the diet positively affects human health. It reduces blood pressure and improves the condition of heart and blood vessels. A decrease in the blood pressure of individuals, which is caused by a reduction in salt consumption, depends on age - in older individuals, blood pressure can decrease to a greater extent. Given the fact that older people more often have cerebral thrombosis and heart failure, they benefit more from a decrease in their blood pressure. Limiting salt in the diet of this group of people is of great importance (Lejins and Kalvelis, 2011).

Bread is one of the products that is consumed almost every day. To bake bread, the following raw materials are needed: flour, yeast, water, and salt. Salt is a very important seasoning in bread. Salt affects biochemical, colloidal, and microbiological processes in bread dough (Fig. 1). In water, salt splits into ions and a dissociated solution forms - sodium ions are positively charged, while chlorine ions are negatively charged. This affects the properties of gluten, i.e. gluten strengthens, the activity of ferments is hindered and the life processes of yeast are affected (Kunkulberga and Seglins, 2010). Salt obstructs the growth of undesired microorganisms and the structure of bread is more porous; it assists in keeping the shape of bread loaf and stabilises starch. The most significant property of salt is the improvement of taste, as bread without salt is tasteless and insipid.

Salt is added to dough in small quantities - from 1 to $2 \%$ of the total amount of flour. Without salt, dough is sticky and flabby, it rises fast during fermentation and does not maintain its form, and the bread is insipid and has a pale and hard crust. However, an excessive amount of salt more than $2 \%$ relative to the weight of flour - delays fermentation processes or dough does not rise at all, it is wet and hard to processed, and the bread has an unpleasant salty taste.

According to the recommendations of the European Commission, the amount of salt in producing bakery products

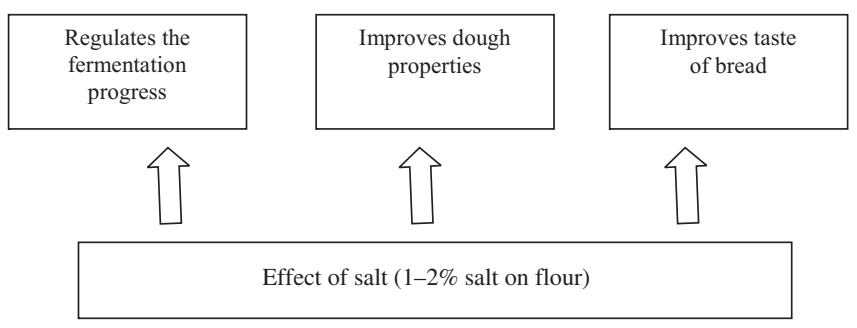

Fig.1. Technological role of salt in breadmaking. should be reduced at least to $1.5 \%$, and for some products to $1.8 \%$ per $100 \mathrm{~g}$ of flour. For instance, it is planned to reduce the amount of salt in dough from $2.2 \%$ to $1.8 \%$ per $100 \mathrm{~g}$ of flour in Ireland, Italy, Spain, and Great Britain during the coming years, while bread producers in Germany do not plan to take any special salt reduction measures (Galeone, 2009; Kleinert et al., 2009).

Scientists and practitioners of many countries have investigated the effects of salt on dough and bread baking processes. One disadvantage appears in dough with a low salt content if the dough is processed and formed at a higher temperature or during an extended period of fermentation. It is hard to precisely determine the critical amount of salt that negatively affects technological processes, as different equipment is exploited in industrial bread production. It is easier to adapt to the production of bread with a lower salt content in the sector of small and medium bakeries where dough is processed manually. According to Finnish specialists, it is necessary to convince bread producers to reduce the amount of salt in this sector, as processing dough with a low salt content may cause problems to industrial bread producers (Salovaara, 1982a; Salovaara et al., 1982).

A governmental system for proposals for voluntary salt consumption reduction has been introduced in the European Union, which is supported by action plans, to meet the recommendations of the member states and the World Health Organisation. The approaches of the EU member states need to be adapted to all socio-economic societal groups for salt consumption reduction in foods of all price groups. Also, the international aspect of changing salt content in food products and the role that might be played by the existing forums of interested individuals, for instance, the EU Action Platform on Diet, Physical Activity and Health, have to be considered. A significant role is played by food marking that provides visible, clear, and easy-to-understand information to consumers, thus enabling them to choose products with a lower salt content. The working group has decided to use the term "salt", instead of "sodium", as salt is the basic substance targeted by the mentioned recommendation, the term "salt" is easier to understand, and it is the main way of how to add sodium to food (Großklaus et al., 2009).

Given the statistical data on diseases of heart and blood vessels, the EU Council's working group on food products has decided to appeal for reducing salt consumption in the EU member states. It is known that excessive salt consumption is the main contributor to hypertension, which, in its turn, causes diseases of heart and blood vessels. These diseases cause $42 \%$ of all deaths in Europe, and the treatment of these diseases costs EUR 192 billion. The European Food Safety Agency stated that the majority of Europeans consume 8-11 grams of salt a day, which is much more than the recommended amount. The largest part of salt or up to $75 \%$ of its daily portion is consumed by people through ready-made food. Mainly people of industrially developed countries consume approximately $80 \%$ of salt through products to which salt has been added during their industrial 
production. Natural products contain a small amount of sodium and its salts, and some salt is added by us ourselves when we cook food or add it during eating our meals. According to studies, in natural products the amount of salt accounts for approximately $12 \%$ of the total intake of salt a day, ready-made food produced industrially and food from public caterers provides $77 \%$, while salt that is knowingly added by us accounts for only $11 \%$ (of which approximately $5 \%$ is additionally added to meals and $6 \%$ is added during cooking home meals) (Johnston, 2009).

The member states are requested to actively implement their salt consumption reduction programmes. These may include, for example, activities to inform the public and to encourage the food industry to reduce the amount of salt in food and ready-made meals as much as possible. The European Commission permanently supports the efforts of the member states regarding these issues. Together with the member states, the European Commission regularly identifies the lowest salt contents reached in various food categories in the European Union. Such a survey allows to determine the extent to which salt content can be reduced in products that are the main sources of salt in daily diets. The EU stresses the need for controlling the activities related to changes in the content of products, for informing the public on the consumption of salt by individuals to enable them to regularly analyse and review their actions, and for familiarising the general public with the corresponding findings. The EU appeals to the member countries for strengthening their coordinated and sustainable national nutrition policy as well as for elaborating a policy if one has not been yet introduced, which also includes salt consumption reduction programmes aimed at reducing intake to an appropriate level (Galeone, 2009).

Given the fact that the European Commission has established a high-level working group on diets and physical activities, one of the objectives of which is to reduce the salt content in food products, member states have to analyse their national statistics on salt consumption and the present amounts of salt in food. The research data show that bread is one of the key sources of salt in the diet of individuals; therefore, a salt consumption reduction plan has been elaborated in many countries, which envisages a $16 \%$ reduction in salt consumption over a period of four years. According to the European Commission recommendations, the member states have to make discussions with their food producers and local federations of food enterprises and hold activities for informing the public on the salt content in food and its reduction; therefore, it is important to ascertain the knowledge of consumers on salt consumption and their salt consumption behaviour.

No salt reduction programme has been elaborated in Latvia, and studies are needed to identify the salt content in bread baked in Latvia. No detailed information is available on the amounts of salt added to bread during its production process. Therefore, the aim of the present paper was to determine the salt content in bread produced in Latvia, to identify the possibilities for reducing the salt content, and to analyse the intake of salt through bread by Latvia's consumers.

\section{MATERIALS AND METHODS}

The study analyzes two types of bread, one - baked in the laboratory with different salt contents, other — industrially produced bread. Wheat bread with various salt content was experimentally baked at the Bread Technological Laboratory of the Faculty of Food Technology, Latvia University of Agriculture (LLU). The basic recipes for bread are presented in Table 1 . The amounts of salt relative to the weight of flour were selected as follows: $0.5 \%, 1 \%, 1.5 \%$, and $2 \%$ as well as no salt at all. The dough production technology and the baking of bread complied with the guidelines for experimental baking.

The dough was prepared in a dough mixer Varimixer bear AR10 2. The time of dough mixing: 2 minutes at Speed 1 and 4 minutes at Speed 2. After mixing the dough, it was fermented for 10 minutes, then it was divided and into pieces of $220 \mathrm{~g}$, the pieces were shaped and fermented in a post-fermentation camera for 45 minutes at a temperature of $36{ }^{\circ} \mathrm{C}$ and a relative humidity of $75 \%$. The bread was baked in a convection oven Sveba Dahlen S8, steam was supplied for 9 seconds, and the duration of baking was 18 minutes at a temperature of $200{ }^{\circ} \mathrm{C}$. After a period of 24 hours, the bread was tested for its organoleptic indicators, and the salt content was identified according to a chloride determination method by titrating it with mercury (II) nitrate.

The bread moisture content was determined according to ISO 6496:1999 method.

The salt content of some samples was determined at the Food and Environmental Test Laboratory of company BIOR Ltd according to the GOST 5698_51 method. At the Scientific Laboratory of Agronomic Research of LLU, the sodium content was determined by Atomic Absorption Spectrophotometry AACC Method 40-71.

In the present study, 103 wheat bread, rye bread, seed bread and toast samples produced in various Latvian bakeries, with different package labels, as well as information on the contents of salt and sodium available on the labels were analysed.

Table 1

WHEAT BREAD FORMULA WITHOUT SALT

\begin{tabular}{lc}
\hline \multicolumn{1}{c|}{ Raw materials } & Amount, kg \\
\hline Wheat flour, Type 550 & 0.500 \\
Yeast & 0.015 \\
Sugar & 0.010 \\
Water & 0.300 \\
Dough total & 0.825
\end{tabular}


Standard deviations and errors were calculated for the data by using the Microsoft Office package, Microsoft Excel (XLS), and SPSS.

\section{RESULTS}

To verify the effect of salt on the quality of bread and to determine the content of salt in the bread samples having a known amount of salt added to the dough, wheat bread was experimentally baked. The samples of bread were tested for organoleptic, physical, and chemical indicators. The acidity of the bread samples titrated ranged within a $\mathrm{pH}$ range of 1.8-2.0 and the moisture was 36-38\%, which corresponded to usual parameters of wheat bread. The dough prepared without salt was sticky and flabby and rose fast, and the bread was pale with a hard crust and tasteless and insipid. Salt content affected colour of the crust by becoming darker. According to the scientific literature, salt not only regulates the fermentation process, but it also improves the properties of proteins, which enhances the porosity and elasticity of the soft part of bread, the size of bread and what is the most important — its taste (Salovaara, 1982b).

Most often, salt is added to dough at an amount from 1.2 to $2 \%$ relative to the weight of flour. It is important to consumers to know the percentage of salt per $100 \mathrm{~g}$ of bread as well as the weight of sodium, in $\mathrm{mg}$, per $100 \mathrm{~g}$ of bread; therefore, an experiment was carried out to calculate correlation between the salt content, as percentage of the weight of flour, and the salt content as percentage in bread. The salt content in the bread samples was determined by the titration method, and the results obtained are presented in Table 2. A linear correlation existed between the percentage of salt content in bread and salt content calculated in flour ( $\mathrm{r}=$ 0.9984). The regression equation derived from the results (Fig. 2) was:

Table 2

\section{SALT AND SODIUM (\%) IN BREAD SAMPLES}

\begin{tabular}{c|c|c}
\hline Bread sample & $\mathrm{NaCl}$ of flour, $\%$ & $\mathrm{NaCl}$ in bread, $\%$ \\
\hline 1. & 0 & $0.1 \pm 0.03$ \\
2. & 0.5 & $0.48 \pm 0.04$ \\
3. & 1 & $0.74 \pm 0.02$ \\
4. & 1.5 & $1.08 \pm 0.02$ \\
5. & 2.0 & $1.36 \pm 0.04$
\end{tabular}

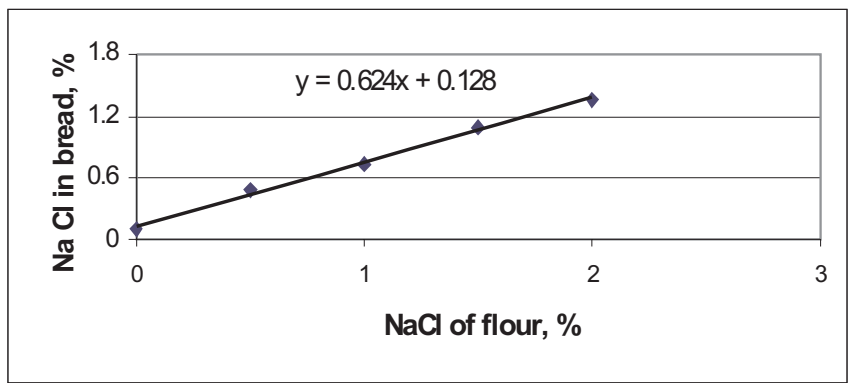

Fig. 2. Linear regression between the percentage of salt content in bread and in flour.
$\mathrm{NaCl} \%$ in bread $=\mathrm{NaCl} \%$ relative to the weight of flour $\mathrm{x}$ $0.6+0.1$.

However, this equation is precise only for bread baked according to the given recipes and the mentioned technological parameters of baking bread at the given output of dough; therefore, in relation to other kinds of bread, this equation can produce approximate values. Even if the same recipes are used, but the duration or temperature of baking is changed, the loss of bread weight is greater and the result is not precise; in this case, a correction has to be made. By using such equations, it is possible to easily and quickly calculate a salt content in bread if the amount of salt added to dough relative to the weight of flour is known.

Analysis of the information on the package labels of 103 bread samples regarding contents of salt and sodium in various kinds of bread showed that the salt contents in wheat, rye, seed, and toaster breads do not differ significantly, and per $100 \mathrm{~g}$ of bread, and according to package labels, varied from 1.1 to $1.2 \%$. The content of sodium is within the range from 0.4 to $0.5 \%$ per $100 \mathrm{~g}$ of bread.

According to the present study, Latvian bread producers show correct information on package labels, in accordance with Cabinet Regulation No. 964 of 23 November 2004 "Regulations regarding the Marking of Food Products". Although showing the energy and nutritional values on any package label of food products is mandatory only if a special note on the energy or nutritional value or the impact on health has to be made, it has to be noted that bread producers provide such information in $99 \%$ cases. On package labels, more and more often information is provided on the recommended daily portion of nutrients present in a product, as no occurs in $60.4 \%$ cases. One can conclude that bread producers understand that salt is a significant mineral, and they try to inform consumers about salt content in a product. It has to be noted that such information is not available on the package labels of other products, such as cheese, sausage, and salty meat snacks.

Six ryc bread samples (R1-R6) were tested for salt content at the Food and Environmental Test Laboratory of BIOR Ltd and at the Scientific Laboratory of Agronomic Research of LLU, which confirmed that the salt amount shown on the package label provided sufficiently precise information on its content (Table 3).

Table 3

SALT AND SODIUM CONTENT OF BREAD, \%

\begin{tabular}{|c|c|c|c|c|c|}
\hline \multirow{2}{*}{$\begin{array}{c}\text { Bread } \\
\text { sample } \\
\text { designation }\end{array}$} & \multicolumn{2}{|c|}{$\begin{array}{c}\text { Indicated on packaging, } \\
\%\end{array}$} & \multirow[t]{2}{*}{$\begin{array}{c}\text { Salt } \\
\text { content, \% }\end{array}$} & \multirow[t]{2}{*}{$\begin{array}{c}\mathrm{Na} \\
\text { content, \% }\end{array}$} & \multirow{2}{*}{$\begin{array}{l}\text { Salt content } \\
\text { by calcula- } \\
\text { tion from } \\
\text { the } \mathrm{Na}, \%\end{array}$} \\
\hline & Salt & $\mathrm{Na}$ & & & \\
\hline $\mathrm{R} 1$ & 0.9 & 0.3 & $0.9 \pm 0.1$ & $0.31 \pm 0.02$ & 0.78 \\
\hline $\mathrm{R} 2$ & 1.2 & 0.48 & $0.9 \pm 0.1$ & $0.37 \pm 0.01$ & 0.94 \\
\hline R3 & 1.0 & 0.4 & - & $0.34 \pm 0.03$ & 0.86 \\
\hline $\mathrm{R} 4$ & 2 & - & $1.2 \pm 0.1$ & $0.43 \pm 0.04$ & 1.09 \\
\hline $\mathrm{R} 5$ & 1.0 & 0.4 & - & $0.37 \pm 0.02$ & 0.94 \\
\hline R6 & - & 0.8 & - & $0.41 \pm 0.01$ & 1.04 \\
\hline
\end{tabular}


The daily intake of salt through bread at a daily bread consumption of 100, 200, and $300 \mathrm{~g}$ is shown in Table 4. On average, 1 slice of "Live-Seed Bread" produced by Fazer Bakeries Ltd weighs $15 \mathrm{~g}$, meaning that $100 \mathrm{~g}$ of the bread corresponds to approximately 6.5 slices of bread, and 1 slice of "Latvian Rye Bread" weighs on average $35 \mathrm{~g}$, thus $100 \mathrm{~g}$ of the bread comprises three slices. On average, 1 slice of "Special Rye Bread" from Liepkalni Ltd weighs $40 \mathrm{~g}$, thus $100 \mathrm{~g}$ of this bread comprises about two slices. If an adult consumes on average $250 \mathrm{~g}$ of bread a day, the salt content of which is $1.2 \%$, the salt intake is $3 \mathrm{~g}$, which accounts for $50 \%$ of the recommended daily salt portion. Yet, if bread contains only $0.9 \%$ salt, the daily intake of salt is $2.25 \mathrm{~g}$ by consuming the same amount of bread, which accounts for $26.6 \%$ of the recommended daily salt portion. If bread contains $1.6 \%$ salt, the salt intake is $4 \mathrm{~g}$ by consuming $250 \mathrm{~g}$ of bread, which accounts for $80 \%$ of the recommended daily salt portion.

\section{DISCUSSION}

Salt plays a very important role in the human organism. It takes part in regulating the amount of water and in kidney function; $\mathrm{Na}$ and $\mathrm{Cl}$ as ions are the main electrolytes of blood. People are not able to live without salt, whereas an excessive intake of salt negatively affects their health.

Adding salt to products is partially determined by technological needs, but salt is mainly used for improving the taste of products. Therefore, there is a real possibility to reduce the amount of salt in products added during their production. This can also apply to bread production. In Latvia, it is important to conduct studies on the lowest possible salt content in food products, which would include information on consumption of food products and would allow to elaborate legal acts regarding an optimal use of salt in food production, including bread baking.

The majority of bread producers show the content of both salt and sodium in bread on the package label. Some producers showed salt content (R4) relative to the weight of flour on their package label, which provides imprecise information and misinforms consumers, as the salt content in bread is lower. In accordance with European Council Regulation No. 1924/2006 (20 December 2006) regarding information on nutritional values and health that has to be shown on package labels of food products, the amounts of components have to be shown for the final product.

Every day people eat different food products, including bread, and every product contains some salt. Bread is a

Table 4

INTAKE OF SALT THROUGH BREAD CONSUMPTION, g

\begin{tabular}{c|c|c|c}
\hline $\begin{array}{c}\text { Type of bread and salt } \\
\text { content, } \%\end{array}$ & $100 \mathrm{~g}$ bread & $200 \mathrm{~g}$ bread & $300 \mathrm{~g}$ bread \\
\hline Live-Seed Bread 0,9\% & 0.9 & 1.8 & 2.7 \\
Latvian Rye Bread 1,2\% & 1.2 & 2.4 & 3.6 \\
Special Rye Bread 1,6\% & 1.6 & 3.2 & 4.8
\end{tabular}

valuable food product, yet, according to statistical data, the consumption of bread declined in Latvia from 70 to $48 \mathrm{~kg}$ per capita in the period 2004-2009. This trend may be explained not only by the economic situation, but also by a change in food consumption behaviour (Noort et al., 2010).

Many dietary specialists recommend increasing the consumption of bread up to $250 \mathrm{~g}$ a day, including the World Health Organisation. On average $27 \%$ of dietary fibres are provided by consuming the recommended amount of wheat bread, while rye bread provides $54 \%$.

In most cases, Latvian bread producers add salt to dough at an amount of $1.2-2 \%$ relative to the weight of flour. Yet it is important to consumers to know the percentage of salt in $100 \mathrm{~g}$ or in 1 slice of bread as well as the amount of sodium in $\mathrm{mg}$ in $100 \mathrm{~g}$ or in 1 slice of bread. The result of research shows that correlation between salt content as a percentage relative to the weight of flour and the salt content as a percentage in bread was $\mathrm{r}=0.9984$.

In $99 \%$ cases, bread producers provide information on the special energy value of bread, showing the contents of salt and sodium in bread on their package labels, and $60.4 \%$ of bread producers provide information on their package labels about the recommended daily portion of nutrients present in their product.

If an adult consumes on average $250 \mathrm{~g}$ of bread a day, the salt content of which is $1.2 \%$, the salt intake is $3 \mathrm{~g}$, which accounts for $50 \%$ of the recommended daily salt portion. Yet, if bread contains only $0.9 \%$ salt, the daily intake of salt is $2.25 \mathrm{~g}$ by consuming the same amount of bread, which accounts for $26.6 \%$ of the recommended daily salt portion.

Analysis of the salt amounts in bread baked in Latvia indicates that it was in the range of $0.8-1.2 \%$, which did not exceed the amount $(1.0-1.2 \%)$ recommended by the European Commission. Given the fact that nowadays food is oversaturated with salt, it is necessary to regularly hold informative campaigns for the public and discussions with food producers about reduction of salt content in food.

\section{ACKNOWLEDGEMENTS}

This research has been prepared within the framework of the ESF Project "Formation of the Research Group in Food Science”, Contract No. 2009/0232/1DP/1.1.1.2.0/09/ APIA/VIAA/122.

\section{REFERENCES}

Anonymous (2010). Action to reduce population salt intake for better health. The Council of European Union. Official Journal of the EU, C 305, 11/11/2010, 0003-0005.

http://eur-lex.europa.eu/LexUriServ/LexUriServ.do?uri=OJ:C:2010:305: 0003:0005:EN:PDF (last accessed 10 August 2012).

Baltess, V. (1998). Pārtikas k̦īmija [Food Chemistry]. Rīga: LU. 474 lpp. (in Latvian).

Denton, D. (1983). The Hunger for Salt. An Anthropological, Physiological and Medical Analysis. Berlin: Springer. $650 \mathrm{~S}$. 
Galeone, D. (2009). Italy: Salt reduction initiatives for bread. Available at: http://ec.europa.eu/health/nutrition_physical_activity/docs/ ev20091021_galeone_en.pdf (last accessed 23 August 2012).

Großklaus, R., Lampen, A., Wittkowski, R. (2009). Für und Wider einer Salzreduktion in der Gesamtbevölkerung. Tagungsband zum Expertengespräch im Bundesinstitut für Risikobewertung am 15. Oktober 2009 in Berlin. Available at:

http://www.ages.at/ages/ernaehrungssicherheit/thema-ernaehrung/salzko nsum-und-bluthochdruck/ (last accessed 10 August 2012).

Johnston, K. (2009). Salt reduction in plant and artisanal bread. Practical experience and bakery science. Available at:

http://ec.europa.eu/health/nutrition_physical_activity/docs/ ev20091021_johnston_en.pdf (last accessed 23 August 2012).

Kleinert, W., Spitz, M., Brugger, C., Fratus, F. (2009). Untersuchungen zum Salzgehalt und Konsumentenakzeptanz von salzreduziertem Weizenbrot. Getreidetechnologie, No. 1, 50-59.

Kunkulberga, D., Segliņ̌s, V. (2010). Maizes ražošanas tehnologija [Bread Production Technology]. Rīga: RTU izdevniecība. 292 lpp. (in Latvian).
Kurlansky, M. (2003). Salt: A World History. Penguin Books. 484 pp.

Lejiņš, A., Kalvelis, A. (2011). Viss par sāli [Everything About Salt]. Rīga: Latvijas hipertensijas biedrība. 33 lpp. (in Latvian).

Noort, M. W. J., Bult, J. H. F., Stieger, M., Hamer, R. J. (2010). Saltness enhancement in bread by inhomogeneous spatial distribution of sodium chloride. J. Cereal Sci., 52, 378-386.

Salovaara, H. (1982a). Effect of partial sodium chloride replacement by other salts on wheat dough rheology and breadmaking. Cereal Chem., 59 (5), 422-426.

Salovaara, H. (1982b). Sensory limitations to replacement of sodium with potassium and magnesium in bread. Cereal Chem., 59 (5), 427-430.

Salovaara, H., Hellemann, U., Kurkela, R. (1982). Effect of salt on bread flavour. Lebensmittel-Wissenschaft und Technologie, 15, 270-274.

Valtnera, A. (1995). Cilvēka fiziologíija [Human Physiology]. Rīga: Zvaigzne. 208 lpp. (in Latvian).

Zariņš, Z., Neimane, L. (2009). Uztura mācība [Nutrition Science]. Rīga: LU Akadēmiskais apgāds. 464 lpp. (in Latvian).

Received 14 September 2012

\section{SĀLS UN MAIZE: LATVIJAS PIEREDZE}

Pēc Eiropas Komisijas ieteikumiem, dalībvalstīm ir jāanalizē nacionālie dati par sāls patērinuu un pašreizējo sāls daudzumu pārtikā. Maize ir viens no galvenajiem uztura produktiem Eiropā, un ar to tiek uzṇemta 20-25\% no ikdienas sāls devas. Cilvēka organismam sāls ir nepieciešams, jo tas veic svarīgas bioloğiskas funkcijas, savukārt pārmērīga tā lietošana ir riska faktors dažāda veida slimībām — hipertensijai, nieru slimībām. Pētījumā ar dažādām metodēm maizes paraugos noteikts sāls un nātrija saturs un secināts, ka Latvijā ražotā kviešu, rudzu, sēklu un tostermaize pēc sāls satura būtiski neatšķiras un tas ir robežās no 1,1 līdz 1,2\%. Veikta maizes iepakojuma informācijas analīze un aprēḳini par uzņemto sāls saturu, apēdot noteiktu maizes daudzumu. Šāds aprēḳins l̦auj novērtēt uzṇemto sāls daudzumu pēc patērētā maizes apjoma, ko noderīgi zināt katram patēēēājam. Pēc iedzīvotāju domām, Latvijā ražotajai maizei nav nepieciešams samazināt sāls daudzumu, arī pēc iepakojumā norādītās informācijas un veiktajiem pētījumiem sāls saturs maizē ir ieteicamās normas $(1,0-1,2 \%)$ robežās. Tomēr jāatzīmē, ka nepieciešams plašāk organizēt sabiedrības un pārtikas produktu ražotāju informēšanas pasākumus par sāls saturu un tā samazināšanas nepieciešamību pārtikas produktos. 


\title{
CONTENT OF ALKYLRESORCINOLS IN CEREALS GROWN IN LATVIA DETERMINED BY HIGH PERFORMANCE LIQUID CHROMATOGRAPHY WITH UV
}

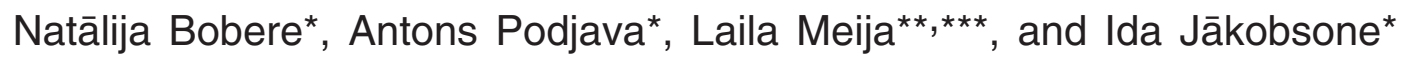 \\ * Faculty of Chemistry, University of Latvia, Kr. Valdemāra iela 48, Rīga LV-1013, LATVIA \\ ** Rīga Stradiṇš University, Dzirciema iela 16, Rīga LV-1007, LATVIA; natalia.bobere @icloud.com \\ *** Pauls Stradiṇš Clinical University Hospital, Pilsonu iela 13, LV-1002, Rīga, LATVIA
}

Communicated by Isaak Rashal

\begin{abstract}
Cereal alkylresorcinols (ARs) are a group of phenolic lipids mainly found in the outer parts of grains of rye and wheat. They have been suggested for use as selective biomarkers for intake of whole grain and bran products of these cereals. Consumption of whole grains and whole grain products has been associated with reduced risk of developing chronic diseases, such as cardiovascular disease, diabetes type 2, obesity and some types of cancer. In this article a sensitive and rapid method of High Performance Liquid Chromatography with UV detection for quantitative determination of ARs in the cereals grown in Latvia is described. Instrument detection limits (IDL) were determined for C17:0, C19:0 and C21:0 homologues (coefficient of variation < 3\%). According to the results of these studies, ARs were found in rye $(87.1-112.0 \mathrm{mg} / 100 \mathrm{~g})$, wheat $(24.0-40.2 \mathrm{mg} / 100 \mathrm{~g})$, triticale $(32.1-74.4 \mathrm{mg} / 100 \mathrm{~g})$, and in small amounts in barley (2.2-3.7 $\mathrm{mg} / 100 \mathrm{~g})$, but not in oats.
\end{abstract}

Key words: alkylresorcinols, HPLC-UV, whole grain cereal.

\section{INTRODUCTION}

Epidemiological studies have associated a diet rich in whole grain and cereal products with decreased risk of several chronic diseases, e.g. coronary heart disease (Liu et al., 1999), diabetes type 2 (Munter et al., 2007), obesity (Fung et al., 2001) and some cancers (Jacobs et al., 1998), although the mechanisms are poorly understood (Slavin, 2003). Also, there are concerns about the methodology used to determine dietary intake in epidemiological studies (Bingham et al., 2003). Studies are further complicated by the fact that consumers might have difficulty in identifying whole grain products (Lang and Jebb, 2003). Whole grain intake assessment also shares the common weaknesses, such as poor precision and bias, with assessment methods for other dietary constituents (Kaaks, 1997; Bingham et al., 2003). The use of a biomarker can establish complementary or alternative measurements of whole grain intake and is expected to overcome some of these obstacles (Ocke and Kaaks, 1997; Ross et al., 2004a). Alkylresorcinols (ARs) have been proposed to be biomarkers of whole grain wheat and rye intake (Ross et al., 2004b; Linko and Adlercreutz, 2005).

Alkylresorcinols are amphiphilic 1,3-dihydroxybenzene derivatives with an odd-numbered alkyl chain at position 5 (Fig. 1). The alkyl chain in cereal ARs varies from 15 to 27 carbon atoms. They are located in the intermediate layers between pericarp and testa in the grain (Landberg et al., 2008), and are found in high concentrations only in whole grain and/or bran products of wheat $(31.7-143.9 \mathrm{mg} / 100 \mathrm{~g}$ dry matter, DM) and rye (36.0-320.0 mg/100g DM), and in very small amounts in refined flour (white bread, most breakfast cereals, pasta) or in any other commonly consumed foods (Ross et al., 2003; Ross et al., 2004a; Ross and Kochhar, 2009; Annica et al., 2010). They are also present in triticale (43.9-64.7 $\mathrm{mg} / 100 \mathrm{~g} \mathrm{DM})$, and in small amounts in barley $(4.2-5.1 \mathrm{mg} / 100 \mathrm{~g} \mathrm{DM})$, but not in oats (Ross et al., 2003).<smiles>[R]c1cc(O)cc(O)c1</smiles>

Fig. 1. Structures of alkylresorcinols commonly found in cereal grains.

\begin{tabular}{c|c|c|c}
\hline $\mathrm{R}$ & ARs names & Short names & $\begin{array}{c}\text { Molecular } \\
\text { weight }\end{array}$ \\
\hline $\mathrm{C}_{15} \mathrm{H}_{31}$ & 5-n-pentadecylresorcinol & $\mathrm{C} 15: 0$ & 320 \\
$\mathrm{C}_{17} \mathrm{H}_{35}$ & 5-n-heptadecylresorcinol & $\mathrm{C} 17: 0$ & 348 \\
$\mathrm{C}_{19} \mathrm{H}_{39}$ & 5-n-nonadecylresorcinol & $\mathrm{C} 19: 0$ & 376 \\
$\mathrm{C}_{21} \mathrm{H}_{43}$ & 5-n-heneicosylresorcinol & $\mathrm{C} 21: 0$ & 404 \\
$\mathrm{C}_{23} \mathrm{H}_{47}$ & 5-n-tricosylresorcinol & $\mathrm{C} 23: 0$ & 432 \\
$\mathrm{C}_{25} \mathrm{H}_{51}$ & 5-n-pentacosylresorcinol & $\mathrm{C} 25: 0$ & 460
\end{tabular}


In vitro, ARs have been reported to have anticancer, enzyme-inhibiting, and DNA-cleaving properties (Kozubek and Tyman, 1999). ARs are reported to be antioxidants (Winata and Lorenz, 1996), although they are weak antioxidants in vitro compared with $\alpha$-tocopherol (Kamal-Aldin $e t$ al., 2001; Ross et al., 2004b; Korycińska et al., 2009). Another in vitro study (Ross et al., 2004c) showed that ARs significantly inhibited the conversion of $\gamma$-tocopherol to its water-soluble hydroxychroman metabolite, indicating that ARs may increase $\gamma$-tocopherol's levels via inhibition of tocopherol metabolism in vivo. A recent in vitro study (Stasiuk et al., 2008) showed that ARs isolated from rye grain decreased the enzymatic activity of acetylcholinesterase of erythrocytes. These findings are of interest due to the growing evidence that acetylcholinesterase could participate in the pathological processes of Alzheimer's disease. The biological activities of dietary and purified ARs have been previously reviewed (Kamal-Aldin et al., 2001; Ross et al., 2004b).

Different chromatographic methods for analysis of ARs in whole grain and cereal products have been developed over years. Gas chromatography - mass spectrometry (GC-MS) and high performance liquid chromatography (HPLC) are commonly used for the routine quantitative determination of ARs (Ross et al., 2001; Mattila et al., 2005; Landberg et al., 2006). For the rapid determination of total ARs content in cereal grain products, colorimetric method after formation of intense red complex with fast blue salt (the diazonium salt Fast Blue B) has been used (Mattila et al., 2005; Kulawinek and Kozubek, 2008). Fast Blue B has been used for quantitative determination of ARs in cereal grain extracts, but without reported validations of the methods used (Andersson et al., 2008). Recently, the HPLC method for the analysis of intact ARs in cereals using coularray detection (HPLC-CA) has been suggested. Use of the CA detector allowed detection of low concentrations of ARs in white wheat flour, which had not been reliably detected using previous methods (Ross and Kochhar, 2009).

In this paper we present a rapid and sensitive HPLC method for the analysis of ARs in whole grain cereals with ultra violet (UV) detector. This new method was developed based on method by Ross et al. (2001). HPLC-UV method is rather simple and does not require derivatization or any other sample pretreatment. However, validation parameters should be performed in next research.

\section{MATERIALS AND METHODS}

Chemicals and standards. The Alkylresorcinol standard C17:0 used had $\geq 95 \%$ purity as determined by the company from where it was purchased (Sigma-Aldrich, St.Luis, USA). Homologues C19:0 and C21:0 were of $>98 \%$ purity as determined by the company from where they were purchased (Reseachem Life Science, Burgdorf, Switzerland). All standards were prepared as stock solutions at $2.5 \mathrm{mg} / \mathrm{ml}$ in methanol/ethanol mixture and were stored in a freezer at $-18{ }^{\circ} \mathrm{C}$. All solvents were of HPLC-grade (Sigma-Aldrich, St.Luis, USA) and were used without further purification.
Cereal samples. Rye samples $(n=2)$ and triticale samples $(n=2)$ were provided by the State Priekuli Plant Breeding Institute (Priekuḷ, Latvia), and grains were harvested in 2010. Common spring wheat samples $(n=2)$ and barley samples $(n=2)$ were provided by the State Stende Cereals Breeding Institute (Stende, Latvia), and grain were harvested in 2010. Common winter wheat samples $(n=2)$, triticale samples $(n=1)$, rye samples $(n=4)$ and oat samples $(n=2)$ were also provided by the State Stende Cereals Breeding Institute (Stende, Latvia), and grains were harvested in 2011.

Extraction of samples. According to a slightly modified method of Ross et al. (2001), alkylresorcinols were extracted from $1.00 \mathrm{~g}$ cereal grains (coarsely ground in a coffee grinder, then milled with a mortar and pestle) with 40 $\mathrm{ml}$ of ethyl acetate for $24 \mathrm{~h}$ with continuous shaking at room temperature. The extracts were centrifuged at 4400 rpm for $10 \mathrm{~min}$ and the supernatants $(4 \mathrm{ml})$ were then evaporated to dryness in a rotary evaporator (Heidolph Laborata 4001 Efficient System, USA). Methanol (1 ml) was added and samples were filtered through $0.45 \mu \mathrm{m}$ filters before injection into the HPLC. All samples were extracted in duplicates, and the results are reported on a basis of fresh weight (FW). Alkylresorcinol homologues C17:0-C21:0 were quantified using an external standard method. Calibration curves were prepared with the following concentrations: 0 , 5, 20, 50, 70 and $100 \mu \mathrm{g} / \mathrm{ml}$. Alkylresorcinol homologues C15:0, C23:0 and C25:0 were identified according to their spectra (Kulawinek and Kozubek, 2008) and determined semiquantitatively by method of internal standard, with C21:0 homologue as an internal standard $(10 \mu \mathrm{g} / \mathrm{ml})$. Relative response factors for $\mathrm{C} 15: 0, \mathrm{C} 23: 0$ and $\mathrm{C} 25: 0$ homologues were calculated by taking into account the amount of homologue (based on molecular weight) injected into chromatographic column versus homologue C21:0. All quantifications were based on peak area.

HPLC-UV analysis. Method development and analysis were carried out on a Shimadzu Prominence HPLC with a SPD-20A Diode Array Detector scanning between 260 and $295 \mathrm{~nm}$. Separation of alkylresorcinol homologues was done with a Symmetry C-18 $(4.6 \times 150 \mathrm{~mm}, 5 \mu \mathrm{m})$ column from Waters. The gradient programme was used at a flow rate $1.00 \mathrm{ml} / \mathrm{min}$ starting with a mobile phase of methanol/water $(80 / 20)$ for $5 \mathrm{~min}$, followed by methanol/water (99.2/0.8) for $25 \mathrm{~min}$. The temperature of the column oven was set on $30{ }^{\circ} \mathrm{C}$ and $40 \mu \mathrm{l}$ of each sample were injected into the chromatographic column. Instrument detection limits (IDL) were determined for C17:0 homologue (0.48 $\mu \mathrm{g} / \mathrm{ml})$, for C19:0 homologue $(0.44 \mu \mathrm{g} / \mathrm{ml})$ and for C19:0 homologue $(0.47 \mu \mathrm{g} / \mathrm{ml})$, with a coefficient of variation < $3 \%$. IDL was determined to be signal (peak area) that is greater than the system noise. Within a specified probability, IDL was calculated according to the formula (Wells et al., 2011):

$\mathrm{X}_{\mathrm{IDL}}=\mathrm{t}_{\alpha, \mathrm{n}} \cdot$ relative standard deviation $\cdot$ amount standard / $100 \%$, where

$\mathrm{t}(\alpha=0.05 ; \mathrm{n}=8)=2.3646$ (Student T-table $).$ 


\section{RESULTS}

In the present study, a developed HPLC-UV method for quantitative determination of ARs in the cereals is described. A good homologue separation (an appropriate gradient), IDL lower then $0.5 \mathrm{mg} / 100 \mathrm{~g}$ and a relatively short time of total analysis, showed that this method is sensitive and rapid (Fig. 2).

The UV spectrum of the homologues in methanol is shown on Fig. 3. All the homologues showed characteristic spectra with maximum absorbance at $\lambda=275 \mathrm{~nm}$ and $\lambda=280 \mathrm{~nm}$.

Quantification of C15:0, C23:0 and C25:0 alkylresorcinol homologues was problematic due to the lack of these standards. We attempted to overcome this by using C21:0 as an internal standard. All data were converted to fresh weight $(\mathrm{FW})$, considering that the moisture content of cereals is about 14\% (Anonymous, 1992). Alkylresorcinols were found in rye, wheat, triticale, and barley, but not in oats (Table 1).

\section{DISCUSSION}

Results of the analysis of rye grains showed that ARs levels varied from 87.1 to $112 \mathrm{mg} / 100 \mathrm{~g} \mathrm{FW}$. These values are comparable to literature: $61.9-65.5 \mathrm{mg} / 100 \mathrm{~g}$ FW by Ross et al. (2003), $92.7 \mathrm{mg} / 100 \mathrm{~g} \mathrm{FW}$ by Mattila et al. (2005), $134.2 \mathrm{mg} / 100 \mathrm{~g} \mathrm{FW}$ by Landberg et al. (2009).

Average ARs concentration in the wheat samples analysed in this study was $34.8 \mathrm{mg} / 100 \mathrm{~g} \mathrm{FW}$. This value is comparable to the previously reported data: $28.8-425 \mathrm{mg} / 100 \mathrm{~g} \mathrm{FW}$ by Chen et al. (2004), 42.0-42.1 mg/100 g FW by Landberg et al. (2009). However, our results for wheat samples are
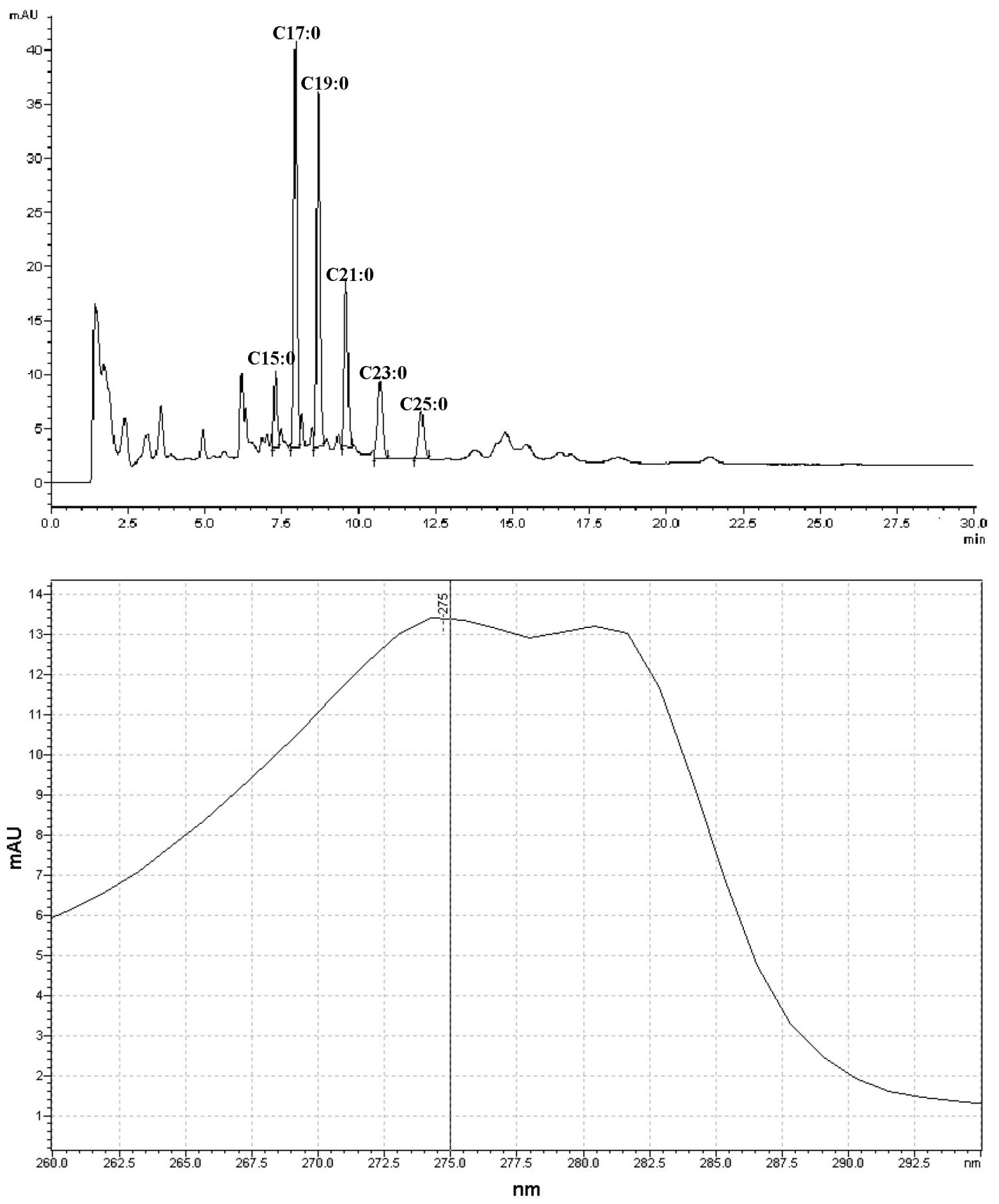

Fig. 2. HPLC-UV chromatogram of alkylresorcinol homologues in rye (Amilo) after extraction with ethyl acetate for $24 \mathrm{~h}$ at room temperature, centrifuged, evaporated and redissolved in methanol $(1 \mathrm{ml})$. See text for HPLC conditions.

Fig. 3. The characteristic spectrum of alkylresorcinol homologues in methanol. 
CONTENT OF ALKYLRESORCINOLS IN CEREAL GRAINS (mg/100 $\mathrm{g}$ of fresh weight) ${ }^{1}$

\begin{tabular}{|c|c|c|c|c|c|c|c|c|}
\hline Cereal & Cultivar & $\mathrm{C} 15: 0$ & C17:0 & C19:0 & C21:0 & $\mathrm{C} 23: 0$ & $\mathrm{C} 25: 0$ & Total ARs \\
\hline \multirow[t]{6}{*}{ Rye } & 04014-4 & $0.8 \pm 0.4^{2}$ & $24 \pm 4$ & $28 \pm 2$ & $21.8 \pm 0.3$ & $21 \pm 2^{2}$ & $12 \pm 1^{2}$ & 107.6 \\
\hline & Amilo & $2.18 \pm 0.05$ & $30.5 \pm 0.7$ & $26.8 \pm 0.5$ & $14.3 \pm 0.5$ & $9.6 \pm 0.7$ & $4.6 \pm 0.5$ & 88.0 \\
\hline & Kaupo & $1.14 \pm 0.07$ & $31.8 \pm 0.1$ & $29.5 \pm 0.1$ & $19.7 \pm 0.2$ & $14.6 \pm 0.7$ & $8.9 \pm 0.1$ & 105.6 \\
\hline & Dankovskie Diament & $2.8 \pm 0.3$ & $34 \pm 2$ & $30 \pm 2$ & $19 \pm 1$ & $14.5 \pm 0.3$ & $8.8 \pm 0.6$ & 109.1 \\
\hline & 9918 & $1.75 \pm 0.02$ & $25 \pm 2$ & $25 \pm 1$ & $16.3 \pm 0.8$ & $10.9 \pm 0.9$ & $8.1 \pm 0.4$ & 87.1 \\
\hline & Picaso & $2.0 \pm 0.4$ & $34 \pm 4$ & $31 \pm 2$ & $22 \pm 2$ & $14 \pm 2$ & $9 \pm 1$ & 112.0 \\
\hline \multirow{2}{*}{$\begin{array}{l}\text { Common spring } \\
\text { wheat }\end{array}$} & L920 Uffo & $\mathrm{nd}^{3}$ & $1.96 \pm 0.05$ & $13.7 \pm 0.2$ & $20.2 \pm 0.6$ & $4 \pm 1$ & $0.38 \pm 0.03$ & 40.2 \\
\hline & L934 Eminent & nd & nd & $5 \pm 1$ & $11 \pm 2$ & $7.7 \pm 0.2$ & $0.343 \pm 0.004$ & 24.0 \\
\hline \multirow{2}{*}{$\begin{array}{l}\text { Common winter } \\
\text { wheat }\end{array}$} & Spelta (ID) & nd & $3.9 \pm 0.1$ & $8.3 \pm 0.6$ & $18.3 \pm 0.4$ & $5.8 \pm 0.2$ & $0.97 \pm 0.09$ & 37.3 \\
\hline & $96-58$ & nd & $5 \pm 1$ & $13.6 \pm 0.2$ & $16.7 \pm 0.1$ & $2.1 \pm 0.1$ & $0.34 \pm 0.02$ & 37.7 \\
\hline \multirow[t]{3}{*}{ Triticale } & Falmoro & nd & nd & $3.2 \pm 0.3$ & $9.5 \pm 0.7$ & $16 \pm 3$ & $3.4 \pm 0.2$ & 32.1 \\
\hline & Nazaret & nd & $4 \pm 2$ & $12 \pm 4$ & $15 \pm 2$ & $11.1 \pm 0.4$ & $2.0 \pm 0.2$ & 44.1 \\
\hline & $9402-3$ & nd & $12.1 \pm 0.7$ & $23 \pm 1$ & $21.0 \pm 0.7$ & $15 \pm 2$ & $3.28 \pm 0.01$ & 74.4 \\
\hline \multirow[t]{2}{*}{ Barley } & Jet & nd & nd & nd & $1.5 \pm 2$ & $0.17 \pm 0.02$ & $2.0 \pm 0.8$ & 3.7 \\
\hline & 1196 & nd & nd & nd & $1.2 \pm 0.8$ & nd & $1.0 \pm 0.7$ & 2.2 \\
\hline \multirow[t]{2}{*}{ Oats } & S-156 & nd & nd & nd & nd & nd & nd & nd \\
\hline & Arta & nd & nd & nd & nd & nd & nd & nd \\
\hline \multicolumn{9}{|c|}{$\overline{{ }^{1} \text { Values are average } \pm \text { standard deviation }}$} \\
\hline \multicolumn{9}{|c|}{${ }^{2}$ C15:0, C23:0 and C25:0 - semiquantitative results. } \\
\hline - mot detes & & & & & & & & \\
\hline
\end{tabular}

lower than those obtained by Ross et al. (2003) - ARs levels in common wheat grains varied from 42 to 122.9 $\mathrm{mg} / 100 \mathrm{~g} \mathrm{FW}$, by Mattila et al. (2005) — whole wheat flour contained $75.9 \mathrm{mg} / 100 \mathrm{~g} \mathrm{FW}$ of ARs and, also by Kulawinek and Kozubek (2008) ground wheat grains contained $57.8 \mathrm{mg} / 100 \mathrm{~g} \mathrm{FW}$ of ARs (for C15:0-C 19:0 homologues). This variation is probably due in part to differences in analytical methods and also the ARs content of cereals appears to be highly variable, depending on cultivar and environmental conditions.

Alkylresorcinol concentration in triticale varied from 32.1 to $74.4 \mathrm{mg} / 100 \mathrm{~g} \mathrm{FW}$, and is comparable to those reported previously (37.8-55.6 mg/ 100g FW) by Ross et al. (2003). Unfortunately, this cereal is not commonly consumed by humans.

The total ARs concentration in barley varied from 2.2. to $3.7 \mathrm{mg} / 100 \mathrm{~g}$ FW. These values are in line with those reported by Ross et al. (2003 — from 3.6 to $4.4 \mathrm{mg} / 100 \mathrm{~g}$ FW, by Mattila et al. (2005) - $3.2 \mathrm{mg} / 100 \mathrm{~g} \mathrm{FW}$, although lower than reported by Landberg et al. (2009) - 7.7 $\mathrm{mg} / 100 \mathrm{~g} \mathrm{FW}$. The difference is probably because of use of different extraction solvents and, of course, different environmental conditions. Also, a cereal specific correction factor was used by Landberg et al. (2009). The factor was calculated by taking into account differences in molecular weight and the average relative homologue composition (determined by GC) of the particular cereal. None was found in oats.

According to our results, the main ARs homologues in rye are C17: 0 and C19:0; in wheat are C19:0 and C21:0; in triticale are $\mathrm{C} 21: 0$ and $\mathrm{C} 23: 0$; in barley are $\mathrm{C} 21: 0$ and
C25:0. In addition, the mean total content of ARs in analyzed grain samples was in the following sequence: rye $>$ triticale $>$ wheat $>$ barley $>$ oats. Nonetheless, more data need to be collected about ARs concentration in different cereals breed in Latvia.

This HPLC-UV method is appropriate for ARs determination in cereals, due to its simplicity, rapidity and sensitiveness.

\section{ACKNOWLEDGEMENTS}

The study was financed by the State Stende Cereals Breeding Institute (Stende, Latvia), project framework of the European Regional Development Fund (ERAF) „Assessment of Local Origin Cereal Species' Potential and Development of Varieties for Specific Dietary Foods Production" (No. 2010/0273/2DP/2.1.1.0/10/APIA/VIAA/083). Grain samples were provided by the State Priekulti Plant Breeding Institute (Priekuli, Latvia) and by the State Stende Cereals Breeding Institute (Stende, Latvia). The authors wish to thank Māris Jākobsons and Oksana Rotkaja for their skilled technical assistance.

\section{REFERENCES}

Andersson, M. A. A, Kamal-Eldin, A., Fras, A., Boros, D., Åman, P. (2008). Alkylresorcinols in wheat varieties in the HEALTHGRAIN Diversity Screen. J. Agric. Food Chem., 56 (21), 9722-9725.

Andersson, M. A. A, Åman, P., Wandel, M., Frølich, W. (2010). Alkylresorcinols in wheat and rye flour and bread. J. Food Compos. Anal., 23 (8), 794-801.

Anonymous (1992). Food and Agriculture Organization. European Community Intervention Regulations on Minimum Quality Standards (1992, 
March), Commission Regulation (EEC) No 689/92. http://www.fao.org/docrep/T1838E/T1838E0O.GIF

Bingham, A. S., Luben, R., Welch, A., Wareham, N., Khaw, T.-K., Day, N. (2003). Are imprecise methods obscuring a relation between fat and breast cancer? Lancet, 362 (9379), 212-214.

Chen, Y., Ross, B. A., Åman, P., Kamal-Eldin, A. (2004). Alkylresorcinols as markers of whole grain wheat and rye in cereal products. J. Agric. Food Chem., 52 (26), 8242-8246.

Fung, T. T., Rimm, B. E, Spiegelman, D., Rifai, N., Tofler, H. G., Willett, C. W., Hu, B. F. (2001). Association between dietary patterns and plasma biomarkers of obesity and cardiovascular disease risk. Amer. J. Clin. Nutr., 73, 61-67.

Jacobs, D. R. Jr., Marquart, L., Slavin, J., Kushi, L. H. (1998). Whole-grain intake and cancer: An expanded review and meta-analysis. Nutr. Cancer, 30 (2), 85-96.

Kaaks, J. R. (1997). Biochemical markers as additional measurements in studies of the accuracy of dietary questionnaire measurements: Conceptual issues. Amer. J. Clin. Nutr., 65 (4), 1232S-1239S.

Kamal-Eldin, A., Pouru, A., Eliasson, C., Åman, P. (2001). Alkylresorcinols as antioxidants: Hydrogen donation and peroxyl radical-scavenging effects. J. Sci. Food Agric., 81 (3), 353-356.

Korycińska, M., Czelna, K, Jaromin, A., Kozubek A (2009). Antioxidant activity of rye bran alkylresorcinols and the extracts from whole-grain cereal products. Food Chem., 116 (4), 1013-1018.

Kozubek, A., Tyman, J. H. (1999). Resorcinolic lipids, the natural nonisoprenoid phenolic amphiphiles and their biological activity. Chem. Rev., 99 (1), 1-26.

Kulawinek, M., Kozubek, A. (2008). Quantitative determination of alkylresorcinols in cereal grains: Independence of the length of the aliphatic side chain. J. Food Lipids, 15, 251-262.

Landberg, R., Kamal-Eldin, A., Salmenkallino-Marttila, M., Åman, P. (2008). Localization or alkylresorcinols in wheat, rye and barley kernels. $J$. Cereal Sci., 48 (2), 401-406.

Landberg, R., Kamal-Eldin, A., Andersson, R., Åman, P. (2006). Alkylresorcinol content and homologue composition in durum wheat (Triticum durum) kernels and pasta products. J. Agric. Food Chem., 54 (8), 3012-3014.

Landberg, R., Andersson M. A. A., Åman, P., Kamal-Eldin, A. (2009). Comparison of GC and colorimetry for the determination of alkylresorcinol homologues in cereal grains and products. Food Chem., 113 (4), $1363-1369$.

Lang, R., Jebb, A. S. (2003). Who consumes whole grains, and how much? Proc. Nutr. Soc., 62, 123-127.
Linko, A.- M., Adlercreutz, H. (2005). Whole grain rye and wheat alkylresorcinols are incorporated into human erythrocyte membranes. Brit. J. Nutr., 93 (1), 11-13.

Liu, S., Stampfer, J. M., Hu, B. F., Giovannucci, E., Rimm, E., Manson, E. J., Hennekens, H. C., Willet, C. W. (1999). Whole-grain consumption and risk of coronary heart disease: Results from the Nurses' Health Study. Amer. J. Clin. Nutr., 70 (3), 412-419.

Mattila, P., Pihlava, M. J., Hellström, J. (2005). Contents of phenolic acids, alkyl- and alkenylresorcinols, and aventramides in commercial grain products. J. Agric. Food Chem., 53 (21), 8290-8295.

Munter, S. J., Hu, B. F., Spiegelman, D., Franz, M., Dam van, M. R. (2007). Whole grain, bran, and germ intake and risk of type 2 diabetes: A prospective cohort study and systematic review. PLoS Med., 4 (8), e261.

Ocke, C. M., Kaaks, J. R. (1997). Biochemical markers as additional measurements in dietary validity studies: Application of the method of triads with examples from the European Prospective Investigation into Cancer and Nutrition. Amer. J. Clin. Nutr., 65 (4), 1240S-1245S.

Ross, B. A., Åman, P., Kamal-Eldin, A. (2004a). Identification of cereal alkylresorcinol matabolites in human urine - potential biomarkers of whole grain wheat and rye intake. J. Chromatogr., B 809 (1), 125-130.

Ross, B. A., Kamal-Eldin A., Åman, P. (2004b). Dietary alkylresorcinols: Absorption, bioactiviteis, and possible use as biomarkerz of whole-grain wheat- and rye- rich foods. Nutr. Rev., 62 (3), 81-95.

Ross, B. A., Kochhar, S. (2009). Rapid and sensitive analysis of alkylresorcinols from cereal grains and products using HPLC Coularray-Based Electrochemical Detection. J. Agric. Food Chem., 57 (12), 5187-5193.

Ross, B. A., Shepherd, J. M., Schüpphaus, M., Sinclair, V., Alfaro, B., Kamal-Eldin, A., Åman, P. (2003). Alkylresorcinols in cereals and cereal products. J. Agric. Food Chem., 51 (14), 4111-4118.

Ross, A. B., Chen, Y., Frank, J., Swanson, J. E., Parker, R. S., Kozubek, A., Lundh, T., Vessby, B., Åman, P., Kamal-Eldin, A. (2004c). Cereal alkylresorcinols elevate gamma-tocopherol levels in rats and inhibit gammatocopherol metabolism in vitro. J. Nutr., 134 (3), 506-510.

Ross, B. A., Kamal-Eldin, A., Jung, C., Shepherd, J. M., Åman, P. (2001). Gas chromatographic analysis of alkylresorcinols in rye (Secale cereale $\mathrm{L}$ ) grains. J. Sci. Food Agric., 81 (14), 1405-1411.

Slavin J. (2003). Why whole grains are protective: Biological mechanisms. Proc. Nutr. Soc., 62 (1), 129-134.

Stasiuk, M., Bartosiewicz, D., Kozubek, A. (2008). Inhibitory effect of some natural and semisynthetic phenolic lipids upon acetylcholinesterase activity. Food Chem., 108 (3), 996-1001.

Wells, G., Prest, H., Russ, C. W. (2011). Why use signal-to-noise as a measure of MS performance when it is often meaningless? Spectroscopy, 26 (5), S28-S34.

Winata, A., Lorenz, K. (1996). Antioxidant potential of 5- $n$-pentadecylresorcinol. J. Food Process. Preserv., 20 (5), 417-429.

Received 12 April 2013

\section{ALKILREZORCĪNU SATURA NOTEIKŠANA LATVIJĀ AUDZĒTOS GRAUDOS AR AUGSTI EFEKTĪVU ŠĶIDRUMU HROMATOGRĀFIJU AR ULTRAVIOLETU DETEKTORU}

Graudaugu alkilrezorcīni (AR) ir savienojumu grupa, kur viena molekulas daḷa ir fenola atlikums, bet otra ir lipīdu atlikums. AR lielā daudzumā atrodas grauda ārējos slān,os (graudapvalkos, aleirona slānī) galvenokārt rudzu un kviešu graudos, kā arī nelielos daudzumos miežos. Rafinētos produktos AR ir niecīgos daudzumos vai vispār nav. Tieši tāpēc AR tiek piedāvāts lietot par selektīvu pārtikas biomarķieri, lai patēēēājiem būtu vieglāk saprast, kurš produkts ir pilngraudu vai satur pilngraudus. Pilngraudu produktu patērēšana ir saistīta ar samazinātu risku saslimt ar dažādām hroniskām slimībām: aptaukošanās, 2. tipa diabēts, sirds slimības un vēzis. Šajā publikācijā tiek prezentēta ātra un jutīga augsti efektīvu škidrumu hromatogrāfija ar ultravioletu detektoru - metode alkilrezorcīnu noteikšanai Latvijā audzētos graudaugos. Instrumenta detektēšanas robeža tika noteikta C17:0, C19:0 un C21:0 homologiem (variācijas koeficients < 3\%). AR saturs rudzos bija robežās no 87,1 līdz 112,0 mg/100g, kviešos no 24,0 līdz 40,2 mg/100g, tritikālē no 32,1 līdz 74,4 mg/100g, nedaudz miežos no 2,2 līdz $3,7 \mathrm{mg} / 100 \mathrm{~g}$, bet auzās netika atrasts. 


\title{
SELENIUM EFFECT ON RYE MALT QUALITY
}

\author{
Kristine Antoṇenko*, Viesturs Kreicbergs*, Māra Dūma*, and Sandra Ozola** \\ * Faculty of Food Technology, Latvia University of Agriculture, Jelgava, LV-3001, LATVIA; \\ antokrist@inbox.lv \\ ** Ltd. "Naukšēni", Naukšēnu pag., "Straumēni", LV-4244, LATVIA
}

Communicated by Pēteris Trapencieris

\begin{abstract}
Rye (Secale cereale L.) is the most important cereal crop after wheat, rice and maize. A substantial part of the rye yield is used for bread making, especially in European countries. There have been numerous studies on grain enrichment with selenium (Se), as it is known that selenium is a fundamental trace element essential for human health and in the form of selenoproteins plays key structural and enzymic roles. The main aim of this study was to investigate the effect of different selenium concentrations on quality indices of rye malt - the content of malt extract, diastase activity, selenium and total phenol content in malt. Rye grain of $95 \%$ viability was soaked and germinated at temperature $+6 \pm 2{ }^{\circ} \mathrm{C}$ for three days $+18 \pm 2{ }^{\circ} \mathrm{C}$, using sodium selenate $\mathrm{Na}_{2} \mathrm{SeO}_{4}$ solutions (Se concentration $3 \mathrm{mg}^{-1}, 5 \mathrm{mg} \mathrm{I}^{-1}, 10 \mathrm{mg} \mathrm{r}^{-1}$ ), and dried in an oven for 24 hours at temperature $+70-112{ }^{\circ} \mathrm{C}$. Germination of grain with deionised water served as a control. The obtained results showed that an increase of selenium concentration caused increase of malt extract concentration (from 74 to $80 \%$ ), selenium concentration (from 0.0139 to $0.3251 \mathrm{mg} \mathrm{kg}^{-1}$ ) and total phenol concentration (from 3.13 to $3.63 \mathrm{mg} \mathrm{GAE} \mathrm{g}^{-1} \mathrm{DW}$ ) in rye malt, while diastase activity decreased from 330 to 216.
\end{abstract}

Key words: selenium, rye, malt extract, diastase activity, total phenols.

\section{INTRODUCTION}

Rye (Secale cereale $\mathrm{L}$.) is the most important cereal crop after wheat, rice and maize. A substantial part of the rye yield is used for bread making, especially in European countries (Michalska et al., 2008). Rye malt has amazing healing properties. It was well known to our ancestors. Porridge, bread drink and soup made from rye malt were actively used for human consumption as an effective means of winter-spring beriberi; treatment of exhausted long serious illness; and during farming work, raised strength and endurance (Смирнова и др, 1989). Rye malt is widely used in bread production today. Rye malt contains a much active enzyme (diastase) and is used for promotion of rye bread scald candying (Aly et al., 2004). Rye malt is a natural food product that is made from the best varieties of rye with a coefficient of germination not lower than $96 \%$. Its nutritional value lies on high content of protein, oligopeptides; digestible polysaccharides (glucose, maltose, dextrins), polyunsaturated fatty acids, minerals, vitamins (Michalska and Zieliński, 2006; Donkor et al., 2012).

The microelement selenium is needed for normal function of the human body, as it is a constituent of some enzymes and hormones, interacts with vitamins, participates in oxidising processes, and metabolism of proteins, carbohydrates, and fats (Duma et al., 2011). Selenium occurs in en- zyme glutathione peroxidase, the main part of the antioxidative defence system in living cells (Lyons et al., 2005). Therefore, selenium and its compounds have notable antioxidative properties (Surai, 1999). The selenium content in foodstuffs depends mainly on its content in plant and animal raw materials, and this is affected by the content of selenium in the soil.

It has been reported that cereals and cereal products have a wide range of selenium concentration, between 0.0010 and $0.550 \mathrm{mg} \mathrm{kg}^{-1}$ (Anonymous, 2001).

Germination of grains improves the nutritional value of grain - the content of protein, amino acids, and vitamins as well as activity of enzymes are changed. It is known that germination may influence the level and bioavailability of the bioactive compounds (Lintschinger et al., 1997; 2000; Katina et al., 2007; Tian et al., 2010).

There have been numerous studies that showed the effects of selenium (Se) on wheat, barley and oats sprouting activity and on raising concentration of biologically active substances and vitamins in germinated grain (Dūma, 2010).

The aim of this study was to investigate the effect of different selenium concentrations on quality indices of rye malt - malt extract, total phenols and selenium concentration, and diastase activity, in rye malt. 


\section{MATERIALS AND METHODS}

Plant material. The research object was rye grain (variety 'Kaupo') from Ltd. "Naukšēni”, harvested in 2011. Rye grain were soaked and germinated at temperature $+6 \pm 2{ }^{\circ} \mathrm{C}$ for three days, using sodium selenate $\mathrm{Na}_{2} \mathrm{SeO}_{4}$ solutions. The concentrations of selenium used were was 3,5 , and 10 $\mathrm{mg} \mathrm{l}^{-1}$. Germination of grain with deionised water served as a control. After germination, all sprouts were dried for $24 \mathrm{~h}$ at a temperature of $+70-112{ }^{\circ} \mathrm{C}$; then they were ground. Moisture of malt samples ranged from $7.10 \%$ till $8.97 \%$.

Determination of Se in germinated rye grains. The selenium concentration was determined by standard method AOAC 996.16, based on wet digestion with nitric and perchloric acids, reaction with 2.3-diaminonaphtalene (DAN) reagent and fluorimetrical determination at excitation wavelength of fluorimeter at $375 \mathrm{~nm}$ and emission at $525 \mathrm{~nm}$.

Determination of malt extract concentration. Concentration of unfermented malt extract was determined by hot extraction method.

$200 \mathrm{ml}$ of $47{ }^{\circ} \mathrm{C}$ warm distilled water was added to $50 \mathrm{~g}$ ground malt, maintained for 30 minutes at $45{ }^{\circ} \mathrm{C}$ in a water bath regularly stirring, then heated to $70{ }^{\circ} \mathrm{C}$, and $100 \mathrm{ml}$ distilled water at $70{ }^{\circ} \mathrm{C}$ was added. Stirring constantly for 1 hour, distilled water was added till $450 \mathrm{ml}$, mixed, and followed by filtering. The density of filtrate was determined and the mass of extract e, \% was found.

Concentration of malt extract was calculated on the the basis of air-dried substance $\mathrm{E}_{1} \%$, as follows:

$E_{1}=\frac{e(W+800)}{100-e}$, where

e - extract mass of the filtrate, $\%$;

$\mathrm{W}$ - malt moisture, \%

Determination of diastase activity with Phadebas. The unit of diastase activity, the Gothe unit, is defined as that amount of enzyme that will convert 0.01 gram of starch to the prescribed end-point in one hour at $40{ }^{\circ} \mathrm{C}$ under the conditions of test. Results are expressed in Gothe units per gram of malt (Sak-Bosnar and Sakac, 2012).

The diastase activity of samples was measured by the Phadebas method (Sak-Bosnar and Sakac, 2012). A tablet of an insoluble blue-dyed, cross-linked starch was used as the substrate for the degradation reaction. After dissolving $1.00 \mathrm{~g}$ of malt in acetate buffer in a volumetric flask, $5.0 \mathrm{ml}$ of malt solution was transferred to the test tube and incubated in a water bath at $40{ }^{\circ} \mathrm{C}$ for a few minutes. A blank was prepared by adding $5.0 \mathrm{ml}$ of acetate buffer solution and then treated in the same manner as sample solutions. After placing Phadebas tablets into both test tubes, a timer was started. The tubes were quickly removed from the water bath, stirred and then returned to the water bath. After 30 min, the reaction was terminated by adding $1.0 \mathrm{ml} 1 \mathrm{M}$ sodium hydroxide solution. The mixture was stirred again and filtered. The absorbance of the sample was measured at 620 $\mathrm{nm}$ with deionised water as a reference. The absorbance of the blank was subtracted from that of the sample solution (DA620). The diastase activity, expressed as DN or diastase number, was calculated from the absorbance measurements, respectively:

$\mathrm{DN}=28.2 \times \Delta A_{620^{-2}} .64$

Diastase activity was referred to as DN in the Schade scale, which corresponds to the Gothe scale number, or $\mathrm{g}$, of starch hydrolysed per hour at $40{ }^{\circ} \mathrm{C}$ per $100 \mathrm{~g}$ of malt.

Determination of total phenol concentration (TPC). Total phenol determination started with preparation of extracts from rye malt. Rye malt was finely ground in a laboratory mill CIATRONIC KSW 2669. Four grams of ground samples were extracted $10 \mathrm{~min}$ in an ultrasound bath (ULTRASONS, SELECTA P) with $40 \mathrm{ml}$ of solvent (7/7/6 ethanol/acetone/water (v/v/v) mixture). After centrifugation at $3000 \mathrm{~min}^{-1}$ for $10 \mathrm{~min}$ using a centrifuge MEDITRONIC BL-C, the supernatant was removed and the extraction was repeated once more. The supernatant was collected in a 50 $\mathrm{ml}$ volumetric flask and refilled with solvent to previous volume. The TPC of the malt extract was determined according to the Folin-Ciocalteu spectrophotometric method with some modifications (Singleton et al., 1999). First, 0.25 $\mathrm{ml}$ of sample was transferred to a $25.0-\mathrm{mL}$ volumetric flask containing $6 \mathrm{~mL} \mathrm{H}_{2} \mathrm{O}$, to which $1.25 \mathrm{~mL}$ of undiluted Folin-Ciocalteu reagent were subsequently added. After 1 min, $3.75 \mathrm{ml}$ of $20 \%$ aqueous $\mathrm{Na}_{2} \mathrm{CO}_{3}$ was added, and the volume was made up to $25.0 \mathrm{ml}$ with $\mathrm{H}_{2} \mathrm{O}$. The control sample contained all the reaction reagents except the extract. After $2 \mathrm{~h}$ incubation at $25{ }^{\circ} \mathrm{C}$, absorbance was measured at $760 \mathrm{~nm}$ using a spectrophotometer JENWAY 6300 (Dabina-Bicka, 2011). Total phenol concentration was expressed as gallic acid equivalents (GAE).

Statistical analysis. The statistical analyses of data were carried out using Microsoft Excel for Windows 7.0 (Microsoft Corporation, Redmond, WA). Mean value, standard deviations and significant values were calculated. $P$-values $<0.05$ were regarded as significant.

\section{RESULTS}

The selenium concentration in rye malt differed significantly $(P<0.05)$ between germination solutions with different selenium concentrations (Fig. 1). The concentration of selenium in rye malt using solution where selenium concentration was $3 \mathrm{mg} \mathrm{l}^{-1}$ was 5.4 times higher than in the control. Accordingly, when the concentration of selenium in solution was $5 \mathrm{mg}^{-1}$ the increase in grain was by 11.7 times. At a selenium concentration of $10 \mathrm{mg} \mathrm{l}^{1}$, selenium uptake increased by 22.4 times.

The influence of different selenium concentrations on the content of rye malt extract is shown in Figure 2. All Se concentrations used promoted increase of rye malt extract concentration, and the highest value was observed when the selenium concentration was $5 \mathrm{mg} \mathrm{l}^{-1}$. In this case, the 


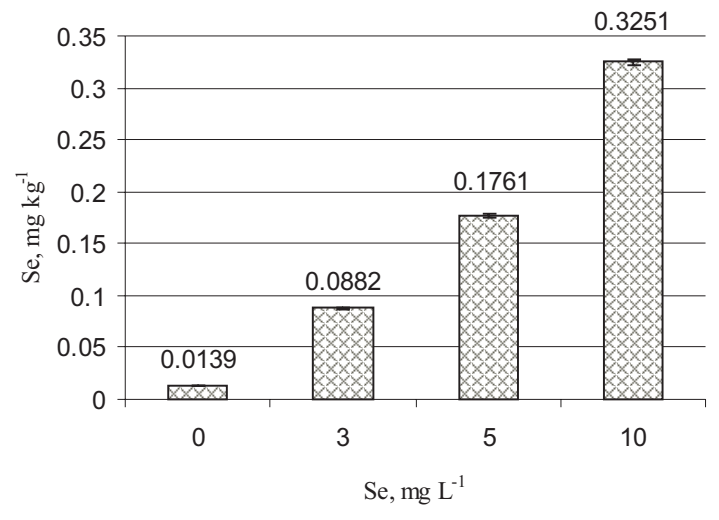

Fig. 1. Se concentration in malt, depending on the concentration of Se in solution.

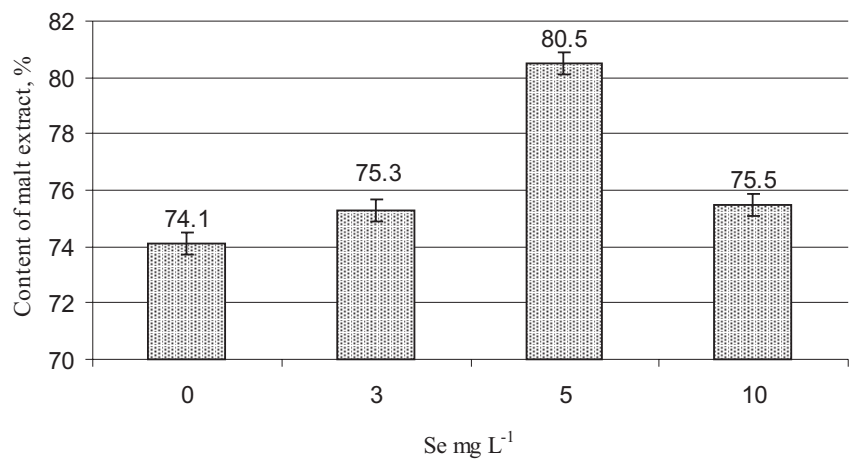

Fig. 2. Content of rye malt extract depending on Se concentration.

concentration of malt extract increased by $6.4 \%$, compared with the control sample. There is an insufficient amount of information in the literature about the effect of selenium on concentration of rye malt extract.

Change of diastase activity in rye malt in relation to Se concentration in solution are shown in Figure 3. Rye malt diastase activity depended on selenium concentration in solution - when selenium concentration was $3 \mathrm{mg} \mathrm{l}^{-1}$ and 5 $\mathrm{mg}^{-1}$, diastase activity increased by $33 \%$ and $5.6 \%$, respectively. At a selenium concentration of $10 \mathrm{mg} \mathrm{l}^{-1}$ rye malt diastase activity decreased by $12.9 \%$, compared with the control sample.

The use of selenium treatment also significantly increased $(P<0.05)$ the total phenol concentration (Fig. 4). When concentration of selenium was $3 \mathrm{mg} \mathrm{l}^{-1}$, the content of total phenols increased by $6.1 \%$, at concentration $5 \mathrm{mg}^{-1}$ the increase was by $14 \%$, and when $10 \mathrm{mg} \mathrm{l}^{-1}$ the concentration of total phenol increased by $16 \%$, compared with the control sample.

\section{DISCUSSION}

It is known that cereals belong to Se non-accumulating plants due to a limited ability of selenium uptake from the soil and incorporation in compounds (Terry et al., 2000). Selenium concentration in wheat, hull-less barley, hull-less

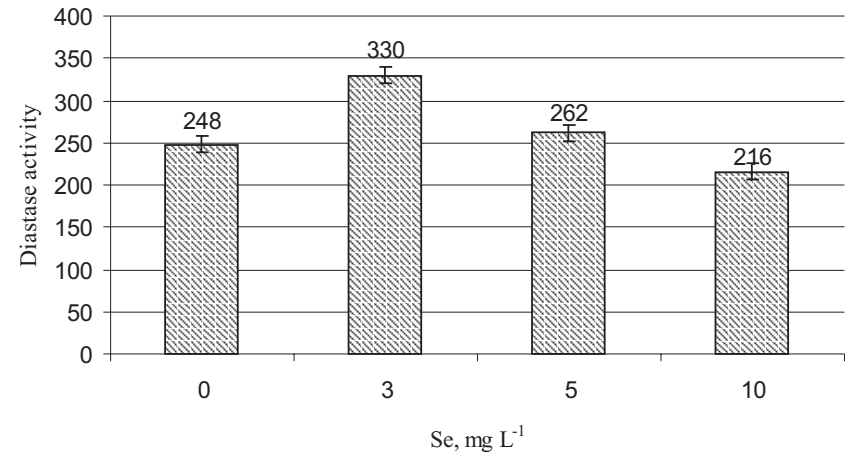

Fig. 3. Diastase activity (Gothe units) in rye malt depending on Se concentration in solution.

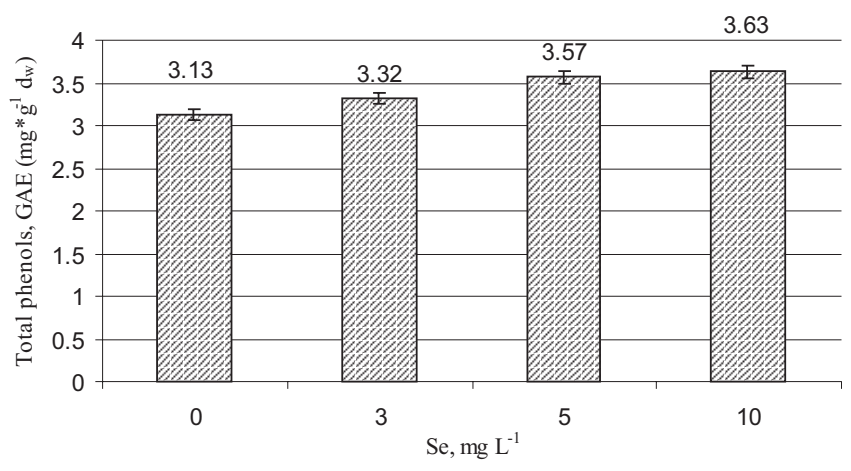

Fig. 4. Total phenol content in rye malt depending on Se concentration.

oat and rye grain harvested in Latvia is within the range from $0.01533 \mathrm{mg} \mathrm{kg}^{-1}$ to $0.03533 \mathrm{mg} \mathrm{kg}^{-1}$, in addition, the variety of cereal has a significant effect on the content of selenium $(P<0.05)$. The concentration of selenium is lower in hull-less grain (barley and oats) (Dūma, 2010). In comparison, the concentration of selenium in cereals cultivated in Finland is five times, and in Germany 25 times higher than in Latvia (Eurola, 1990; Combs, 2001). The obtained results showed that all analysed Se (VI) concentrations promoted uptake of selenium in rye malt. With increasing Se concentration in solution, the concentration of selenium in malt also significantly $(P<0.05)$. increased. This allows to conclude that selenium accumulation in malt is proportional to its concentration in solution and it is practically linear. These results are similar to those found previously (Lintschinger et al., 1997)

The most important parameter in the evaluation of the malting usability of rye grain is concentration of malt extract, estimated as the proporion of extractive substances obtained from malt produced from a given grain under optimal technological conditions. Concentration of malt extract varies in wide range, primarily depending on grain quality (Błażewicz et al., 2007). Concentration of malt extract in unfermented malt can be up to $80 \%$ (Смирнова и др., 1989). Variability in concentration of malt extract may be due to diversified water utilisation, affecting the yield and protein content of grain as well as efficacy of agricultural practices (Błażewicz et al., 2007). 
Malting includes germination and drying of cereal seeds and its prime aim is to promote the development of hydrolytic enzymes that are not active in raw seeds. The main enzymes produced during germination are starch hydrolases (Yamasaki, 2003; Traoré et al., 2004). Diastases are a group of starch-digesting enzymes including $\alpha$ - and $\beta$-amylase (Sak-Bosnar and Sakac, 2012). The amount of enzyme depends on various factors, such as type of cereal, environment, duration of germination and temperature. For example, the diastase activity of barley malt has been estimated to be about $190 \mathrm{CU} / \mathrm{g}$. (Helland et al., 2002; Mark et al., 2008; Kádár et al., 2011).

Plant phenolics, including, flavonoids and phenolic acid and tocopherols, are known to protect plants against tissue injuries, high levels of oxygen, free radicals and reactive oxygen species formed by the by-products of photosynthesis. These molecules also play an important role in the protection of food against lipid oxidation and in human health, by counteracting the risk of cardiovascular diseases, cancer and cataract, among other degenerative diseases of aging (Bondia-Pons et al., 2009). The concentration of total phenol in barley malt varieties has been reported to range from 2.51 to $3.45 \mathrm{mg} \mathrm{GAE} \mathrm{g}^{-1} \mathrm{DW}$ (Dabiņa-Bicka, 2011).

In conclusion, the concentration of selenium in rye malt increased with increasing concentration of selenium in water solution by 5.4 times $\left(3 \mathrm{mg} \mathrm{L}^{-1}\right)$ to 22.4 times $\left(10 \mathrm{mg} \mathrm{L}^{-1}\right)$. All analysed selenium concentrations increased the concentration of rye malt extract and the highest results were obtained using selenium concentration $5 \mathrm{mg} \mathrm{L}^{-1}$. The activity of rye malt diastase is in inverse ratio to the concentration of selenium in solution. The concentration of total phenol increased with increasing concentration of selenium.

\section{REFERENCES}

Aly, S. E., Abdel-Galil, M. M., Abdel-Wahhab, M. A. (2004). Application of adsorbent agents technology in the removal of aflatoxin B1 and fumonisin B1 from malt extract. Food Chem. Toxicol., 42, 1825-1831.

Anonymous (2001). Human vitamin and mineral requirements. Report of a Joint FAO/WHO Expert Consultation, Bangkok, Thailand, Food and Nutrition Division, FAO, Rome.

Błażewicz, J., Liszewsk, M., Zembold-Guła, A. (2007). Usability of bishop formula in evaluation of malting quality of barley grain. Pol. J. Food Nutr. Sci., 57 (4), 37-40.

Bondia-Pons, I., Aura, A. M., Vuorela, S., Kolehmainen, M., Mykkänen, H., Poutanen, K. (2009). Rye phenolics in nutrition and health. J. Cereal Sci., 49 (3), 323-336.

Combs, G. F., Jr. (2001). Selenium in global food systems. Brit. J. Nutr., 85, 517-547.

Dabina-Bicka, I., Karklina, D., Kruma, Z. (2011). Polyphenols and vitamin E as potential antioxidants in barley and malt. In: Proceedings of the 6th Baltic Conference on Food Science and Technology "Innovations for Food Science and Production" "FOODBALT-2011”, May 5-6, 2011, Jelgava (pp. 121-126). Jelgava: Latvia University of Agriculture.

Donkor, O. N., Stojanovska, L., Ginn, P., Ashton, J., Vasiljevic, T. (2012). Germinated grains: Sources of bioactive compounds. Food Chem., 135, 950-959.
Dūma, M. (2010). The qualitative evaluation of grain fortified with selenium. Doctoral thesis, Jelgava: LLU, pp. 50-95.

Dūma, M., Alsina I., Dubova, L., Stroksa, L., Smiltina, Z. (2011). The effect of sodium selenite and selenate on the quality of lettuce. In: Proceedings of the 6th Baltic Conference on Food Science and Technology "Innovations for Food Science and Production" "FOODBALT-2011", May 5-6, 2011, Jelgava (pp. 39-44). Jelgava: Latvia University of Agriculture.

Singleton, V. L., Orthofer, R., Lamuela-Raventos, R. M. (1999). Analysis of total phenols and other oxidation substrates and antioxidants by means of Folin-Ciocalteu reagent. Meth. Enzymol., 29, 152-178.

Surai, P. F. (1999). Tissue-specific changes in the activities of antioxidant enzymes during the development of the chicken embryo. Brit. Poultry Sci., 40, 397-405.

Eurola, M., Ekholm, P., Ylinen, M., Koivistoinen, P., Varo, P. (1990). Effects of selenium fertilization on the selenium content of cereal grains, flour, and bread produced in Finland. Cereal Chem., 67, 334-337.

Helland, M. H., Wicklund, T. Narvhus, J. A. (2002). Effect of germination time on alpha-amylase production and viscosity of maize porridge. Food Res. Int., 35 (2-3), 315-321.

Kádár, Z., Christensen, A. D., Thomsen, M. H., Bjerre, A. (2011). Bioethanol production by inherent enzymes from rye and wheat with addition of organic farming cheese whey. Fuel, 90 (11), 3323-3329.

Katina, K., Liukkonen, K. H., Kaukovirta-Norja, A., Adlercreutz, H., Heinonen, S. M., Lampi, A. M., Pihlava, J. M., Poutanen, K. (2007). Fermentation-induced changes in the nutritional value of native or germinated rye. J. Cereal Sci., 46 (3), 348-355.

Lintschinger, J., Fuchs, N., Moser, H., Jäger, R., Hlebeina, T., Markolin, G., Gössler, W. (1997). Uptake of various trace elements during germination of wheat, buckwheat and quinoa. Plant Food Hum. Nutr., 50, 223-237.

Lyons, G. H., Judson, G. J., Ortiz-Monasterio, I., Genc, Y., Stangoulis, J. C. R., Graham, R. D. (2005). Selenium in Australia: Selenium status and biofortification of wheat for better health. J. Trace Elements Medicine Biol., 19, 75-82.

Mark, R., Schmitt R., Laurie Marinac, L. (2008). Beta-amylase degradation by serine endoproteinases from green barley malt. J. Cereal Sci., 47 (3), $480-488$.

Michalska, A., Zieliński, H. (2006). Effect of flour extraction rate on bioactive compounds content of two rye varieties. Pol. J. Food. Nutr. Sci., 15 (56), 297-303.

Michalska, A., Amigo-Benavent, M., Zielinski, H., Castillo M. D. (2008). Effect of breadmaking on formation of Maillardreactionproductscontributing to the overall antioxidantactivity of ryebread. J. Cereal Sci., 48 (1), 123-132.

Sak-Bosnar, M, Sakac, N. (2012). Direct potentiometric determination of diastase activity in honey. Food Chem., 135, 827-831.

Terry, N., Zayed, A. M., de Souza, M. P., Tarun, A. S. (2000). Selenium in higher plants. Annu. Rev. Plant Physiol. Mol. Biol., 51, 401-432.

Tian, B., Xie, B., Shi, J., Wu, J., Cai, Y., Xu, T., Xue, S., Deng, A. (2010). Physicochemical changes of oat seeds during germination. Food Chem., 119 (3), 1195-1200

Traoré, T., Mouquet, C., Icard-Verničre, C., Traoré, A. S., Trčche, S. (2004). Changes in nutrient composition, phytate and cyanide contents and $\beta$-amylase activity during cereal malting in small production units in Ouagadougou (Burkina Faso). Food Chem., 88 (1), 105-114.

Yamasaki, Y. (2003). $\beta$-amylase in germinating millet seeds. Phytochemistry, 64 (5), 935-939.

Смирнова Н. А., Надежнова Л. А., Селезнева Г. Д., Воробьева Е. А. (1989). Товароведение зерномучных и кондитерских товаров [Commodity Grain Flour and Confectionery Product]. Москва. 352 c. (in Russian). 


\section{SELĒNA IETEKME UZ RUDZU IESALA KVALITĀTI}

Rudzi (Secale cereale L.) ir viena no svarīgākajām labības kultūrām pēc kviešiem, rīsiem un kukurūzas. Eiropas valstīs rudzus plaši izmanto maizes ražošanā. Pasaulē ir veikti vairāki pētījumi par graudu bagātināšanu ar selēnu (Se), bet ir maz pētījumu par selēna ietekmi uz rudzu iesala kvalitāti. Ir zināms, ka selēns ir mikroelements, kuram ir būtiska loma cilvēka veselībā, pie tam selēns ir daudzu selēnproteīnu vai selēnenzīmu svarīga sastāvdaḷa. Pētījuma galvenais mērḳis bija izpētīt selēna ietekmi uz ekstraktvielu daudzumu, diastāzes aktivitāti, selēna un fenolu saturu rudzu iesalā. Rudzu graudi ar $95 \%$ dzīvotspēju tika diedzēti trīs dienas $+6 \pm 2{ }^{\circ} \mathrm{C}$ temperatūrā dažādu koncentrāciju Se škīdumos ( $\left.3 \mathrm{mg} \mathrm{L}^{-1}, 5 \mathrm{mg} \mathrm{L}^{-1}, 10 \mathrm{mg} \mathrm{L}^{-1}\right)$, un kaltēti 24 stundas $+70-112{ }^{\circ} \mathrm{C}$ temperatūrā. Kontrole — graudi tika mērcēti dejonizētā ūdenī. Iegūtie rezultāti parādīja, ka, palielinoties selēna koncentrācijai šḳīdumā, palielinās iesala ekstrakta saturs (no 74 līdz 80\%), selēna (no 0.0139 lìdz $0.3251 \mathrm{mg} \mathrm{kg}^{-1}$ ) un fenolu (no 3.13 līdz $3.63 \mathrm{mg} \mathrm{GAE} \mathrm{g}^{-1} \mathrm{DW}$ ) daudzums rudzu iesalā, bet diastāzes aktivitāte samazinās no 330 līdz 216 vienībām. 


\title{
CHARACTERISATION OF PHYSICAL AND BIOCHEMICAL TRAITS OF HULLESS SPRING BARLEY GRAIN IN THE LATVIAN BREEDING PROGRAMME
}

\author{
Māra Bleidere*, Sanita Zute*, and Ida Jākobsone** \\ * State Stende Cereals Breeding Institute, Dižstende, "Dižzemes", LV-3258, LATVIA; \\ sanita.zute@stendeselekcija.Iv \\ ${ }^{* *}$ Faculty of Chemistry, University of Latvia, Kr. Valdemāra iela 48, Rīga LV-1013, LATVIA; \\ ida.jakobsone@lu.lv
}

Communicated by Daina Kārkliṇa

\begin{abstract}
Incorporation of whole grain, such as hulless barley, as a part of a balanced diet can help reduce the risk of coronary heart diseases, diabetes and specific cancers, and provide other health benefits as well. The objectives of this study were to determine the physical and chemical characteristics of grains of hulless barley genotypes from the Latvian spring barley programme. Field experiments were carried out in 2010-2011 at the State Stende Cereal Breeding Institute. Grain samples of 29 hulless spring barley breeding lines were analysed for grain physical traits (1000 kernel weight, test weight), macronutrients (crude protein, starch, $\beta$-glucans), and micronutrients (total phenolic content, DPPH antiradical scavenging activity and $\alpha$-tocopherol content). The variation of physical traits and macronutrients was mainly determined by genotype $\left(\omega^{2}=32-62 \%\right)$ and year $\left(\eta^{2}=8-42 \%\right)$ and to a lesser extent by interaction of factors. The difference between hulless genotypes, as indicated the coefficient of variation, was rather high for all micronutrients $(V \%=13.4-25.6)$. Significant $(\mathrm{P}<0.05)$ positive correlation was detected between radical scavenging activity and total phenolic content $(r=0.519)$ and starch content $(r=0.530)$. The best hulless breeding lines '1185' and 'IC 360' (variety 'Kornelija' submitted for DUS and VCU tests) were selected for future usage in clinical investigations.
\end{abstract}

Key words: hulless barley, physical and chemical traits, total phenolic content, scavenging activity, $\alpha$-tocopherol.

\section{INTRODUCTION}

Although barley (Hordeum vulgare L.) has a long history as food, it must compete with oats, rice, and wheat, which are already well-accepted food commodities in the market. At present, extensive food research has demonstrated the versatility and adaptability of barley for much more food products than pearled barley. The advent of new barley varieties, starch types, and hulless genotypes has presented to the cereal food industry an opportunity to develop new barley products, which are exciting and have many health benefits (Newman and Newman, 2008).

In covered barley, the flowering glumes are fused and adhere strongly to seed with a cementing substance. In hulless barley, fusion of the flowering glumes does not occur and the hull falls off during threshing (Bhatty, 1999). The seed coat of hulless barley is loosely attached and easily removed during harvesting, resulting in grain with a test weight and physical appearance similar to wheat (Evers and Millar, 2002).
Kernel size or plumpness can become important measures of quality in food barley. Plump grains contain significantly more starch, less protein, and less fibre than thin kernels. Barley kernels vary widely in size due to genotype, position on the spike, and environmental growing conditions. Typical hulless kernels usually weigh between 25 and $35 \mathrm{mg}$ (Newman and Newman, 2008). Thousand kernel weight provides a measure of average kernel weight, and this criterion is widely used in barley breeding to describe grain plumpness.

Comparison of covered and hulless barley has shown that the later generally contains more protein, starch and $\beta$-glucan. This is due to removal of the fibrous hull, which has a dilution effect on these components (Bhatty, 1999). Two large-molecular-weight polysaccharide soluble fibres (arabinoxilan and $\beta$-glucan) are structural components of the thick cell walls of the aleirone. The cell walls of the starchy endosperm contain the same two polysaccharides found in the cell walls of the aleirone tissue, but the amount of $\beta$-glucan is greater than of arabinoxilan (Newman and 
Newman, 2008). Barley kernels contain high levels of $\beta$-glucans, and much of the research on the health-promoting properties of barley has focused on mechanisms involving $\beta$-glucans (Pins and Kaur, 2006).

The interest in the role of natural antioxidant compounds in human health has increased recently. Barley grains in general contain different types of phytochemicals, which are sometimes referred to as phytonutrients, and in barley the most studied compounds are sterols, tocopherols, tocotrienols and phenolic compounds (Newman and Newman, 2008). Phenolic compounds are considered as a major group of compounds that contribute to the antioxidant activity of cereal and are considered with great interest for the development of functional foods. The antioxidant activity of polyphenols has been reported to be mainly due to their redox properties, which can play an important role in neutralising free radical and quenching oxygen or decomposing peroxides (Kahkonen et al., 1999).

Vitamin E is a complex of eight izomers, four tocopherols and four tocotrienols, collectively called tocols. The tocols are associated with lipid components in aleirone, endosperm, and embryo tissue (Newman, Newman, 2008). The tocols in barley germ are predominantly tocopherols (about 97\%), whereas those in the endosperm are predominantly tocotrienols (80-90\%). Therefore, the total amounts of tocotrienols are greater than those of tocopherols in barely oil prepared from ground barley kernels (Charalampopouos et al., 2002; Moreau et al., 2007). Both genotype and environment affect total tocol content (Cavarello et al., 2004). Specific forms of tocopherols and tocotrienols accumulate with different kinetics during barley grain development (Falk et al., 2004).

The objective of this study was to describe the physical and chemical characteristics of grains of hulless barley genotypes from the Latvian spring barley programme.

\section{MATERIALS AND METHODS}

Grain samples of 29 hulless spring barley breeding lines of Latvian origin were studied, including 26 lines from breeding programmes of the State Stende Cereals Breeding Institute (Stende) and three lines from the State Priekuli Plant Breeding Institute (Priekulii). One line with waxy endosperm from Priekuḷi was characterized.

Field experiments were carried out at the State Stende Cereal Breeding Institute for two seasons during 2010-2011. The soil was sod-podzolic sandy loam with humus content 21 (2010)-24 (2011) $\mathrm{mg} \mathrm{kg}^{-1}$, soil pH KCl 5.4 (2010) 5.8 (2011), available phosphorus $\mathrm{P}_{2} \mathrm{O}_{5} \quad 137.0$ (2010) 158.8 (2011) $\mathrm{mg} \mathrm{kg}^{-1}$, and potassium $\mathrm{K}_{2} \mathrm{O} 211.0$ (2010) 175.7 (2011) $\mathrm{mg} \mathrm{kg}^{-1}$. The pre-crop in both years of investigation was a mixture of peas and spring wheat. The barley was sown with a compact trial drill 'Hege 80' in a well prepared seedbed at a rate of 500 germinating seeds per $\mathrm{m}^{2}$. The yield was harvested by a combine 'Hege 140'.
The following grain physical traits were evaluated: 1000 kernel weight/TKW (g) by ISTA method, test weight/TW $\left(\mathrm{g} \mathrm{L}^{-1}\right)$ by automatic grain analyser Infratec Analysis 1241. Macronutrients crude protein content/CP $\left(\mathrm{g} \mathrm{kg}^{-1}\right)$, starch content/ST $\left(\mathrm{g} \mathrm{kg}^{-1}\right)$, $\beta$-glucans content/BGL $\left(\mathrm{g} \mathrm{kg}^{-1}\right)$ were determined by an automatic grain analyzer Infratec Analysis 1241.

For the determination of total phenolic content (TPC) and radical scavenging activity (RSA), 1.5 gram grain flour was mixed with $30 \mathrm{ml}$ of $50 \%$ (vol.) ethanol in an Erlenmeyer flask $(250 \mathrm{ml})$. The mixture was stirred at $40{ }^{\circ} \mathrm{C}$ for $15 \mathrm{~min}$ utes and then at room temperature for an hour. After extraction the supernatant was filtered through filter paper. The filtrate was used for the analysis of TPC and RSA.

TPC was determined according to colorimetric method described in literature (Ragaee et al., 2006) with some modifications. This method is based on the reduction of the FolinCiocalteu reagent by phenol to a mixture of the reaction products, having absorbance maximum at $765 \mathrm{~nm} .1 \mathrm{ml}$ of extract was mixed with $5 \mathrm{ml}$ of $10 \%$ Folin-Ciocalteu's reagent in distilled water and $4 \mathrm{ml} 7.5 \% \mathrm{Na}_{2} \mathrm{CO}_{3}$ solution, stirred for $30 \mathrm{~min}$ at room temperature and the absorbance at $765 \mathrm{~nm}$ was measured with a spectrophotometer UVIKON 930 (Kontron Instruments, Italy). TPC was calculated using gallic acid as a standard $(0.0075-0.060 \mathrm{mg} / \mathrm{mL})$ $\left(\mathrm{R}^{2}=0.9999\right)$ and expressed as $\mathrm{mg}$ gallic acid equivalents per $100 \mathrm{~g}$ of grain dry weight (DW).

2.2-diphenyl-1-picrylhydrazyl (DPPH) radical scavenging activity (RSA) assay was performed according to the modified method prescribed in literature (Ragaee et al., 2006). $0.4 \mathrm{ml}$ of extract (sample) or 50\% (vol.) ethanol (control sample) was added to $3.6 \mathrm{ml}$ of $10^{-4} \mathrm{M}$ DPPH solution in ethanol and mixed. The mixture was vigorously shaken and left to stand for $20 \mathrm{~min}$. The absorbance at $517 \mathrm{~nm}$ was measured against 50\% (vol.) ethanol as a blank. The DPPH radical scavenging activity (\%) was calculated using equation (1):

$\operatorname{RSA}(\%)=\frac{\left(A_{\text {control }}-A_{\text {sample }}\right)}{A_{\text {control }}} \cdot 100 \%$ where

$\mathrm{A}_{\text {control }}$ is the absorbance of the control sample; $\mathrm{A}_{\text {sample }}$ is the absorbance of the sample.

Mean samples from all replications were taken and milled for $\alpha$-tocopherol $(\alpha-\mathrm{T})$ determination in the Laboratory of Food and Environmental Investigations Institute of Food Safety, Animal Health and Environment "BIOR" using the high-performance liquid-chromatography method. The method is a standard for detection of $\alpha$-tocopherol in diet samples. Absorption was measured at $292 \mathrm{~nm}$. Chromatography was carried out on a C18 column using methanol/ water $(98 / 2 \mathrm{v} / \mathrm{v})$.

The growing seasons of 2010 and 2011 were characterised by temperature above to the long-term average and some extreme periods of drought. In 2010, low precipitation and 
high temperature occurred in the third decade of June and the first decade of July. In 2011, hot and dry conditions occurred during the third decade of May and in first decade of June.

ANOVA were used for statistical data analysis. The obtained results were statistically processed using methods of descriptive statistics. In the analysis of variance omega squared $\left(\omega^{2}\right)$ was calculated to measure the effect size or relative contributions of factors (genotype, year, genotype $\times$ year) using equation (2) (Grissom and Kim, 2012.):

$\omega^{2}=\left[\mathrm{SS}_{\text {Effect }}-\left(\mathrm{df}_{\text {Effect }}\right)\left(\mathrm{MS}_{\text {Residual }}\right)\right] /\left(\mathrm{SS}_{\text {Total }}+\mathrm{MS}_{\text {Residual }}\right)$.

The significance of the effect of factors was determined at probability level of 0.05 . The value of genotypic variability for traits was determined and expressed by standard deviation (s) and coefficient of variations (V\%) values. Pearson correlation coefficients between two year phenotypic means were calculated. The best lines according to food grain physical and chemical traits were selected using selection criterion - trait values $\geq$ mean $+s$.

\section{RESULTS}

Physical traits of grain. ANOVA showed that physical traits of grain for hulless barley lines in the tested breeding material were significantly $(P \leq 0.05)$ influenced by two main factors (genotype, year) and their interaction (Fig. 1).

The variation of thousand kernel weight (TKW) was mainly determined by genotype $\left(\omega^{2}=52 \%\right)$ and year $\left(\omega^{2}\right.$ hulled $=$ $31 \%$ ). TKW for hulless barley breeding lines was 40.7 and $43.8 \mathrm{~g}$ in 2010 and 2011, respectively. Significantly higher $(P \leq 0.05)$ values of this trait were observed in 2011 , but a greater difference between minimum and maximum value of this traits was found in 2010, as indicated also coefficient of variation (Table 1). In both years, some hulless breeding lines had significantly higher TKW than those of the hulless standard variety 'Irbe' (+3.9 and 6.9 g compared with hulless standard variety 'Irbe'; $\mathrm{Rs}_{0.05}=1.39-1.81 \mathrm{~g}$ ).

The main effect of variation of TW was due to year and genotype ( $42 \%$ and $32 \%$, respectively) and to a lesser extent

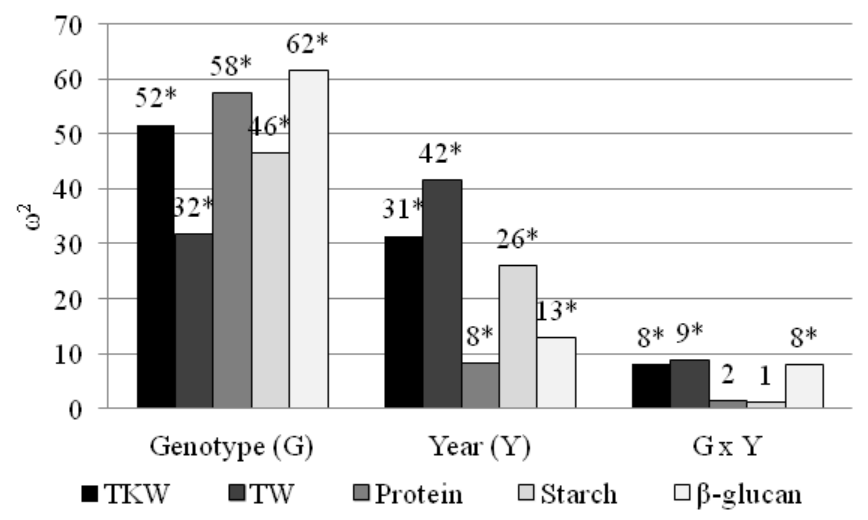

Fig. 1. Relative contribution of factors for hulless barley grain quality traits $\left({ }^{*} P \leq 0.05\right)$ (TKW, thousand kernel weight, TW, test weight).

by interaction of factors for both physical traits (Fig. 1). There was a significant $(P \leq 0.05)$ difference between years of investigation in mean value of TW for hulless breeding lines, and a higher test weight was observed in 2010 (Table 1). Grains of hulless genotypes were characterised by higher TW than that of hulled barley standard variety 'Ansis'. The best hulless breeding lines, according to TW value, were on the level of that of standard 'Irbe'.

Macronutrient content. ANOVA indicated that the variation of all macronutrients (crude protein, starch and $\beta$-glucan) content was mainly determined by genotype $\left(\omega^{2}=46-62 \%\right)$ and to a lesser extent by year and by interaction of factors (Table 1).

The difference between minimum and maximum value of crude protein was rather high and varied from 133.0 to $188.2 \mathrm{~g} \mathrm{~kg}^{-1}$ in 2010 and from 145.1 to $183.2 \mathrm{~g} \mathrm{~kg}^{-1}$ in 2011. A significantly higher crude protein for grain of hulless barley lines was observed in 2011. In both years, there were some hulless breeding lines with significantly higher crude protein content $\left(+30.4-47.9 \mathrm{~g} \mathrm{~kg}^{-1}\right.$, compared to the hulless standard variety 'Irbe'; $\mathrm{Rs}_{0.05}=14.25-17.32$ $\mathrm{g} \mathrm{kg}^{-1}$ ).

There was a significant $(P \leq 0.05)$ difference between years of investigation in mean value of starch content for grains

Table 1

CHARACTERISTICS OF GRAIN PHYSICAL TRAITS AND MACRONUTRIENT CONTENT FOR HULLESS SPRING BARLEY LINES AND HULLESS (HB) AND COVERED (C) STANDARDS (2010-2011)

\begin{tabular}{|c|c|c|c|c|c|c|c|c|c|c|}
\hline \multirow[t]{3}{*}{ Trait $^{1}$} & \multicolumn{5}{|c|}{2010} & \multicolumn{5}{|c|}{2011} \\
\hline & \multicolumn{3}{|c|}{ Breeding lines } & \multirow{2}{*}{$\begin{array}{c}\begin{array}{c}\text { Standards, } \\
\text { mean }\end{array} \\
\mathrm{HB} / \mathrm{C}^{2} \\
\end{array}$} & \multirow[t]{2}{*}{$\mathrm{Rs}_{0.05}$} & \multicolumn{3}{|c|}{ Breeding lines } & \multirow{2}{*}{$\begin{array}{c}\begin{array}{c}\text { Standards, } \\
\text { mean }\end{array} \\
\mathrm{HB} / \mathrm{C} \\
\end{array}$} & \multirow[t]{2}{*}{$\mathrm{Rs}_{0.05}$} \\
\hline & mean & $\min / \max$ & $\mathrm{V} \%$ & & & mean & $\min / \max$ & $\mathrm{V} \%$ & & \\
\hline TKW, g & $40.7 b^{3}$ & $33.9 / 44.7$ & 5.8 & $40.8 / 46.1$ & 1.39 & $43.8 \mathrm{a}$ & $38.7 / 48.8$ & 4.9 & $41.9 / 48.1$ & 1.81 \\
\hline $\mathrm{TW}, \mathrm{g} \mathrm{L}^{-1}$ & $783.8 \mathrm{a}$ & $724.8 / 808.5$ & 2.7 & $807.8 / 682.8$ & 17.88 & $749.3 b$ & $711.0 / 777.5$ & 2.0 & $764.5 / 648.5$ & 14.25 \\
\hline $\mathrm{CP}, \mathrm{g} \mathrm{kg}^{-1}$ & $153.0 \mathrm{~b}$ & $133.0 / 188.2$ & 6.4 & $140.3 / 116.5$ & 17.32 & $162.0 \mathrm{a}$ & $145.1 / 183.2$ & 5.8 & $152.8 / 140.7$ & 14.74 \\
\hline $\mathrm{ST}, \mathrm{g} \mathrm{kg}^{-1}$ & $619.0 \mathrm{a}$ & $602.1 / 632.0$ & 1.2 & $630.5 / 612.8$ & 11.89 & $606.8 \mathrm{~b}$ & $596.3 / 618.0$ & 1.1 & $615.8 / 602.0$ & 13.70 \\
\hline BGL, $\mathrm{g} \mathrm{kg}^{-1}$ & $46.0 \mathrm{~b}$ & $40.4 / 57.2$ & 9.4 & $44.8 / 38.8$ & 3.75 & $50.0 \mathrm{a}$ & $41.0 / 63.0$ & 11.7 & $47.3 / 43.3$ & 3.34 \\
\hline
\end{tabular}

\footnotetext{
${ }^{1}$ TKW, thousand kernel weight; TW, test weight; CP, crude protein; ST, starch; BGL, $\beta$-glucans

2 HB, 'Irbe'; C, 'Ansis'

${ }^{3}$ Trait means followed by different letters are significantly different between the years at the level of $P \leq 0.05$
} 
of hulless breeding lines and a higher test weight was observed in 2010. The best hulless breeding lines according to starch content did not exceed that of the standard 'Irbe' level.

As indicated by the coefficient of variation $(\mathrm{V} \%=9.4-$ $11.7)$, the difference between minimum and maximum value of $\beta$-glucan for grains of hulless breeding lines was rather high and varied from 40.4 to $57.2 \mathrm{~g} \mathrm{~kg}^{-1}$ in 2010 and from 41.0 to $63.0 \mathrm{~g} \mathrm{~kg}^{-1}$ in 2011 . Significantly higher $(P \leq$ $0.05)$ mean value of this trait and higher phenotypic variation within breeding lines were observed in 2011. Hulless barley genotypes showed substantially higher $\beta$-glucan content compared to that of the hulled standard variety 'Ansis'. According to results in both years, there were hulless breeding lines with significantly higher $\beta$-glucan content than that of hulless standard variety 'Irbe' $\left(+12.4\right.$ and $15.7 \mathrm{~g} \mathrm{~kg}^{-1}$ compared to hulless standard variety 'Irbe'; $\mathrm{Rs}_{0.05}=3.34-$ $3.75 \mathrm{~g} \mathrm{~kg}^{-1}$ ) (Table 2).

Micronutrient content. DPPH radical scavenging activity in hulless spring barley breeding material had rather high variation in antioxidant activity, with a minimum value of $44.6 \%$ and maximum value of $80.1 \%$ (Table 2).

Table 2

VARIATION OF MICRONUTRIENT CONTENT OF HULLESS SPRING BARLEY LINES, $2010^{1}$

\begin{tabular}{l|c|c|c}
\hline Indices & $\begin{array}{c}\text { Radical scaveng- } \\
\text { ing activity, } \%\end{array}$ & $\begin{array}{c}\text { Total phenolic } \\
\text { content, mg GAE } \\
100 \mathrm{~g}^{-1} \mathrm{DW}\end{array}$ & $\begin{array}{c}\alpha \text {-tocopherol, } \\
\mathrm{mg} \mathrm{kg}^{-1}\end{array}$ \\
\hline Mean value & 64.8 & 202.6 & 5.5 \\
Min & 44.6 & 143.6 & 3.3 \\
Max & 80.1 & 262.1 & 8.7 \\
s & 9.0 & 27.1 & 1.4 \\
V\% & 13.9 & 13.4 & 25.6 \\
'Irbe' (HB) & 64.3 & 177.9 & 7.9 \\
'Ansis' (C) & 49.7 & 187.5 & 6.5
\end{tabular}

The hulled variety 'Ansis' had lower radical scavenging activity $(49.7 \%)$ than that of the hulless variety 'Irbe' (64.3\%). Total phenolic compound amount expressed as gallic acid equivalent (GAE) in hulless barley breeding material had high variation: from 143.6 to 262.1 GAE mg 100 $\mathrm{g}^{-1}$ with coefficient of variation $13.4 \%$. There was no notable difference between hulled and hulless standard varieties in content of total phenolic compounds in grain. The coefficient of variation of $\alpha$-tocopherol among hulless genotypes was high and varied from 3.30 to $7.78 \mathrm{mg} \mathrm{kg}^{-1}$. The genotypic variation in $\alpha$-tocopherol content in grain of hulless barley breeding lines was also high $(\mathrm{V} \%=25.6)$. The content of $\alpha$-tocopherol varied from 3.3 to $8.7 \mathrm{mg} \mathrm{kg}^{-1}$. Hulless standard variety 'Irbe' had a higher $\alpha$-tocopherol content in grains than the covered variety 'Ansis' (Table 2).

There were significant correlations between physical and chemical composition variables for hulless barley genotypes. In both years of investigation significant negative correlation was found between starch content and 1000 grain weight $\left(\mathrm{r}_{10}=-0.480 ; \mathrm{r}_{11}=-0.483\right)$ and crude protein $\left(r_{10}=0.720 ; r_{11}=-0.868\right)$. Positive correlation was found between crude protein and $\beta$-glucan, and in 2010 this relationship was statistically significant (Table 3).

Table 3

PHENOTYPIC CORRELATION BETWEEN PHYSICAL AND BIOCHEMICAL TRAITS OF HULLESS BARLEY ${ }^{1}$

\begin{tabular}{c|c|c|c|c|c|c|c|c}
\hline Traits $^{2}$ & TKW & TW & CP & ST & BGL & TPC & RSA & $\alpha-T$ \\
\hline TKW & 1 & 0.057 & 0.319 & $-0.483^{*}$ & -0.128 & x & x & x \\
TW & 0.177 & 1 & $-0.431^{*}$ & 0.475 & 0.148 & x & x & x \\
CP & 0.357 & -0.138 & 1 & $-0.868^{*}$ & 0.375 & x & x & x \\
ST & $-0.48 *^{3}$ & 0.346 & $-0.720^{*}$ & 1 & -0.209 & $\mathrm{x}$ & $\mathrm{x}$ & $\mathrm{x}$ \\
BGL & -0.218 & 0.038 & $0.404^{*}$ & -0.004 & 1 & $\mathrm{x}$ & $\mathrm{x}$ & $\mathrm{x}$ \\
TPC & -0.307 & 0.082 & -0.195 & 0.255 & 0.201 & 1 & $\mathrm{x}$ & $\mathrm{x}$ \\
RSA & $-0.476^{*}$ & -0.148 & -0.347 & $0.530^{*}$ & 0.327 & $0.519^{*}$ & 1 & $\mathrm{x}$ \\
$\alpha-\mathrm{T}$ & -0.002 & -0.149 & 0.081 & -0.176 & -0.171 & $-0.471^{*}$ & 0.356 & 1
\end{tabular}

${ }^{1}$ Data of 2010 below diagonal, data of 2011 above diagonal

${ }^{2}$ TKW, thousand kernel weight; TW, test weight; CP, crude protein; ST, starch; BGL, $\beta$-glucans; TPC, total phenolic content; RSA, radical scavenging activity; $\alpha$-T, $\alpha$-tocopherol

${ }^{3}$ Significant at 0.05 probability level $\left(\mathrm{r}_{0.05 ; \mathrm{n}-2}=0.381\right)$

Significant $(P<0.05)$ positive correlation was detected between total DPPH radical scavenging activity and starch content $(r=0.530)$. There was a positive significant relationship between the content of total phenolic content in barley grain dry matter and radical scavenging activity $(\mathrm{r}=$ $\left.0.519 ; \mathrm{r}_{0.05}=0.381\right)$.

A summary of genotypes with food grain physical and chemical trait values that are above the mean levels are shown in Table 4.

Several hulless barley lines provided good results according to several grain quality traits simultaneously (indicated in bold). Hulless line 'IC 360' characterized with heightened 1000 kernel weight (46.2 g), crude protein (177.3 $\mathrm{g} \mathrm{kg}^{-1}$ ) and $\beta$-glucan content $\left(53.6 \mathrm{~g} \mathrm{~kg}^{-1}\right)$ as well as total phenolic content (221.6 mg GAE $100 \mathrm{~g})$.

Table 4

EVALUATION RESULTS OF HULLESS BARLEY GENOTYPES USING SELECTION CRITERIA, mean+s (2011-2012)

\begin{tabular}{|c|c|c|}
\hline Traits & mean+s & Lines with trait values $\geq$ mean $+s$ \\
\hline TKW, $g$ & 44.4 & IC 360; IC 361; 1194; 1236 \\
\hline $\mathrm{TW}, \mathrm{g} \mathrm{L}^{-1}$ & 787.2 & $1175 ; 1194 ; 1213 ;$ PR 4651 \\
\hline $\mathrm{CP}, \mathrm{g} \mathrm{kg}^{-1}$ & 168.2 & IC 360; IC 361;1216; 1226; 1244; 1217 \\
\hline ST, $\mathrm{g} \mathrm{kg}^{-1}$ & 623.7 & IC $363 ; \mathbf{1 1 8 5} ; 1214 ;$ PR 4651; 'Irbe' \\
\hline BGL, $\mathrm{g} \mathrm{kg}^{-1}$ & 52.4 & IC 360; 1196; 1226; PR 4651; PR 3440(w)* \\
\hline $\begin{array}{l}\text { TPC, } \\
\text { mg GAE } 100 \mathrm{~g}^{-1}\end{array}$ & 229.8 & $\begin{array}{l}\text { IC 363; 1165; 1196; PR 3440(w) } \\
\text { (IC360/221.6; 1185/222.3) }\end{array}$ \\
\hline RSA, \% & 73.8 & $1167 ; \mathbf{1 1 8 5} ; 1189 ;$ PR 3440(w) \\
\hline$\alpha-\mathrm{T}, \mathrm{mg} \mathrm{kg}^{-1}$ & 6.9 & IC 364; 1166; 1185; 1216; 1226; 'Irbe' \\
\hline
\end{tabular}

* (w) - waxy endosperm 
Hulless barley line ' 1185 ' was selected due to high starch content $\left(624.5 \mathrm{~g} \mathrm{~kg}^{-1}\right)$ micronutrient levels - total phenolic content (222.3 mg GAE $\left.100 \mathrm{~g}^{-1}\right)$, radical scavenging activity $(80.1 \%)$ and $\alpha$-tocopherol content $\left(6.9 \mathrm{mg} \mathrm{kg}^{-1}\right)$. Hulless line 'PR 3440' with waxy endosperm showed good results of food grain quality according to grain $\beta$-glucan $\left(59.9 \mathrm{~g} \mathrm{~kg}^{-1}\right)$ content in grains, total phenolic content (234.7 $\mathrm{mg} \mathrm{GAE} 100 \mathrm{~g}^{-1}$ ) and radical scavenging activity $(76.9 \%)$

\section{DISCUSSION}

Genetic variability in the material of a breeding programme is an important resource for creation of new variety ideotypes with desired traits for increased crop production and quality.

The absence of a hull results in a $10-13 \%$ average dry weight loss, and therefore hulless genotypes are commonly known to have a lower 1000 kernel weight, higher test weight, starch content and beta-glucan content in grains than covered ones (Bhatty, 1999). The data presented in this paper demonstrate notable variation among the spring barley breeding lines in all investigated grain physical traits as well as in macronutrient and micronutrient content in the grain dry matter.

In this study, significantly higher TKW, crude protein and $\beta$-glucan was observed in 2011 than in 2010. This can be explained by differences between these two years in periods of high temperature and low precipitation. Grain weight can be influenced by grain set, which should reflect conditions around anthesis and can be also influenced by earlier conditions as well. A reduction in TKW may be not only due to abiotic and biotic stress during grain filling, but a lower grain weight could indicate also the plasticity of yield components (Fisher, 2007). In 2010, during the first part of grain filling, the weather conditions were hot and dry, which could have influenced the final grain weight. In 2011, the critical period for plant development during the generative phase occurred at the end of May and beginning of June, when set of grain number in spikes were forming. Later, this development was a prerequisite for higher grain weight due to compensation during the grain filling period when moisture conditions became optimal. Barley protein usually varies inversely with the starch content, and exhibits the greatest fluctuation among the main nutrients. Accumulation of starch is more sensitive to high temperature than is accumulation of nitrogen, which frequently determines the grain nitrogen proportion and thus protein content (Schelling et al., 2003). This effect of temperature was observed in 2011. Also, $\beta$-glucan content increases gradually during grain development, depending on variety and growing season (Aman et al., 1989).

Several types of polyphenol extraction have been described, as well as various techniques have been used for the determination of polyphenolic compounds. For barley, total polyphenol contents measured by spectrofotometric method and expressed in gallic acid equivalent/GAE have been published in the literature (Singleton et al., 1999; Zhao et al., 2008; Dabina-Bicka et al., 2011). The present study indicated that hulless barley can be a good source of phenolic compounds as TPC content ranged from 143.6 to $262.1 \mathrm{mg}$ GAE $100 \mathrm{~g}^{-1}$. The obtained values are similar to those reported by H. Zhao et al. (2008) but higher than those reported by Singleton et al. (1996). Also, similar values for TPC content of hulless barley genotypes of Latvian origin were obtained by I. Dabina-Bicka et al. (2011) and TPC content did not significantly differ between covered and hulless barley.

The results showed a positive significant relationship between total phenolic content and radical scavenging activity. Total phenolic content showed strong correlation with DPPH radical scavenging activity in spring barley (Zhao, 2008). This confirms that metabolites like phenolic compounds possess antioxidant activity and can play a preventive role in the development of cancer, heart and age related diseases. They have also been reported to be chemopreventive agents by lowering cholesterol levels and repairing damaged cells (Kahkonen et al., 1999).

Significant $(P<0.05)$ positive correlation was observed between DPPH radical scavenging activity and grain starch content. Whole and unpolished grain of hulless barley consist mainly of starchy endosperm, and hence the ratio of amylose and amylopectin content can effect not only the quality of obtained baking products but also the antioxidant activity. For example, it has been shown that high-amylose corn has better antioxidant activity than typical corn genotypes (Li et al., 2007). In our study, the only genotype 'PR 3440 ' with waxy or high-amylopectin endosperm also showed higher radical scavenging activity and total phenolic content. In the future, wider investigation of genotypes with different amylose and amylopectin ratios is needed to find donors with high content of natural antioxidant compounds.

Among cereals, barley can be a good source of tocopherols and tocotrienols, which are important phytochemical compounds with antioxidant activity and potential benefits for human health (Colombo, 2010). The hulless barley genotypes included in this study showed rather high variability in $\alpha$-tocopherol content $\left(3.3-8.7 \mathrm{mg} \mathrm{kg}^{-1}\right)$. These results were similar to those reported by Ehrenbergerova et al. (2006) study in the Czech Republic, in which the average $\mathrm{i}$-tocopherols content was $6.7 \mathrm{mg} \mathrm{kg}^{-1}$. In Italy, for hulless varieties the $\alpha$-tocopherol content was higher ( 8.4 to 10.1 $\mathrm{g} \mathrm{kg}^{-1}$ ) and for covered varieties - 8.4-8.6 $\mathrm{g} \mathrm{kg}^{-1}$ (Cavarello et al., 2004). Genotype and growing conditions are known to significantly affect the content of $\alpha$-tocopherol (Zilienski et al., 2001; Ehrenbergerova et al., 2006).

The major aim of this study was determination of hulless barley genotypes with high nutritional value. Genotypic potential exists within the hulless spring barley material included in this study. This genetic variation can be used for the development of the improved barley breeding material 
specifically designed for food with high nutritional value. The study concludes that hulless barley has antioxidant activity, which is related to the total phenolic content of the grain dry matter samples. Hence, cereal species can be a potential source of natural antioxidant, which could be useful in physiological and pathological medicine, and of interest to food manufacturing industries. The best hulless breeding lines 'IC 360' and '1185' were selected for future use in clinical investigations. Genotype 'IC 360 ', by the name 'Kornelija', in 2012 was submitted for DUS and VCU tests.

\section{ACKNOWLEDGEMENT}

This study is performed with financial support of European Regional Development Fund co-financed project No. 2DP/2.1.1.1.0/10/APIA/VIAA/083.

\section{REFERENCES}

Aman, P., Graham, H., Tilly, A. C. (1989). Content and solubility of mixed-linked $\beta$-glucan in barley and oats during kernel development and storage. J. Cereal Sci., 10, 45-50.

Bhatty, R. S. (1999) The potential of hulless barley. Cereal Chemistry, 76, 589-599.

Cavarelo, A., Gianineti, A., Finocchiaro, D. A., Stanca, A. M. (2004). Tocols in hull-less and hulled barley genotypes grown in contrasting environments. J. Cereal Sci., 39, 175-180.

Charalampopouos, D., Wang, R., Pandiella, S. S., Webb, C. (2002). Application of cereals and cereal components in functional foods: A review. Int. J. Food Microbiol., 79 (1-2), 131-141.

Colombo, M. L. (2010). An update on vitamin E, tocopherol and tocotrienol-perspectives. Molecules, 15, 2103-2113.

Dabina-Bicka, I., Karklina, D., Kruma, Z. (2011). Polyphenols and vitamin $\mathrm{E}$ as potential antioxidants in barley and malt. Proceedings of 6th Baltic Conference on Food Science and Technology: Innovations for Food Science and Production, FOODBALT-2011, 5-6 May, 2011 (pp. 121-126). Jelgava.

Evers, T., Millar S. (2002). Cereal grain structure and development: Some implications in quality. J. Cereal Sci., 36, 261-284.
Ehrenbergerova J., Belcrediova, N., Pryma, J. K., Newman, C. W. (2006) Effect of cultival, year grown, and croping system on the content of tocopherols and tocotrienols in grains of hulled and hulless barley. Plant Foods Human Nutr., 61 (3), 145-150.

Falk, J., Krahnstover, A., van der Kooij, T. A., Schlensog, M., Krupinska, K. (2004). Tocopherol and tocotrienol accumulation during development of caryopses from barley (Hordeum vulgare L.). Phytochemistry, 65 (22), 2977-2985.

Fisher, R. A. (2007). Understanding the physiological basis of yield potential in wheat. J. Agricult. Sci., 145, 99-113.

Grissom, R. J., Kim, J. J. (2012). Effect Sizes for Research: Univariate and Multivariate Applications. 2nd ed. New York: Taylor \& Francis Group. 429 pp.

Kahkonen, M. P., Hopia, A. I., Vuorela, H. J., Rauha, J., Pihlaja, K., Kujala, S. T., Heinonen, M. (1999). Antioxidant activity of plant extracts containing phenolic compounds. J. Agricult. Food Chem., 47, 3954-3962.

Li, W., Wei, C. V., White, P. J., Beta, T. (2007). High-amylose corn exhibits better antioxidant activity than typical and waxy genotypes. J. Agricult. Food Chem., 55 (2), 291-298.

Moreau, R. A., Flores R. A., Hicks K. B. (2007). The composition of functional lipids in hulled and hulless barley, in fractions obtained by scarification, and in barley oil. Cereal Chem., 84, 1-5.

Newman, R. K., Newman, C. W. (2008). Barley for Food and Health. Science, Technology, and Products. A John Willey\&Son, Inc. 245. pp.

Pins, J. J., Kaur H. (2006). A review of the effects of barley $\beta$-glucan on cardiovascular and diabetic risk. Cereal Foods World, 51, 8-12.

Ragaee, S., Abdel-Aal, E.-S. M., Noaman, M. (2006) Antioxidant activity and nutrient composition of selected cereals for food use. Food Chem., 98 (1), 32-38

Rice-Evans, C. A., Miller, N. J., Bolwell, P. G., Bramley. P. M, Pridh, J. B. (1995). The relative antioxidant activities of plant-derived polyphenolics flavonoids. Free Radical Res., 22, 375-383.

Schelling, K., Born, K., Weissteiner, C., Kunbauch W. (2003). Relationships between yield and quality arameters of barley (Hordeum vulgare L.) and phenological and meteorological data. J. Agron. Crop Sci., 189, 113-122.

Singleton, V. L., Orthofer, R., Lamuela-Raventos, R. M. (1999). Analysis of total phenols and other oxidation substrates and antioxidants by means of Folin-Ciocalteu reagent. Meth. Enzymol., 29, 152-178.

Zhao, H., Fan, W., Dong, J., Lu, J., Chen, J., Shan, L., Lin, Y., Kong, W. (2008). Evaluation of antioxidant activities and total phenolic contents of typical malting barley varieties. Food Chem., 107, 296-304

Zielinski, H., Ciska, E., Kozlowska, H. (2001). The cereal grains: Focus on vitamin E. Czech J. Food Sci., 19, 182-188

\section{FIZIKĀLO UN BIOK̦ĪMISKO PAZĪMJU RAKSTUROJUMS KAILGRAUDU VASARAS MIEŽU GRAUDIEM LATVIJAS SELEKCIJAS PROGRAMMĀ}

Pilngraudu izejvielu, kā piemēram, kailgraudu miežu izmantošana veselīgas diētas sabalansēšanai var veicināt profilaksi sirds un asinsvadu saslimšanu, diabēta un specifisku vēža formu ierobežošanai. Pētījuma mērḳis bija novērtēt kailgraudu paraugus no Latvijas miežu selekcijas materiāla pēc graudu fizikālajām un biokīimiskajām pazīmēm. Lauka izmēǵinājumi iekārtoti Valsts Stendes Graudaugu selekcijas institūtā no 2010. gada līdz 2011. gadam. Pētījumā iekḷautajām 29 vasaras miežu kailgraudu līnijām analizēta 1000 graudu masa, tilpummasa, kopproteīna, cietes, $\beta$-glikānu, kopējais fenolu saturs, $\alpha$-tokoferolu saturs un antiradikālā aktivitāte. Graudu fizikālo un biokīmisko pazīmju mainību galvenokārt ietekmēja genotips $\left(\omega^{2}=32-62 \%\right)$ un gads $\left(\omega^{2}=8-42 \%\right)$, bet mazākā mērā - šo faktoru mijiedarbība. Kailgraudu miežu materiālam konstatēta augsta genotipiskās mainība pēc kopējā fenolu satura, antiradikālās aktivitātes un $\alpha$-tokoferolu satura graudos $(\mathrm{V} \%=13.4-25.6)$. Būtiska $(P<0.05)$ pozitīva korelācija noteikta starp antiradikālo aktivitāti un kopējā fenolu $(\mathrm{r}=0.519)$ un cietes saturu graudos $(r=0.530)$. Labākos rezultātus pēc analizētajām pazīmēm nodrošināja kailgraudu miežu selekcijas līnijas '1185' un 'IC 360' (iesniegta AVS un SĪN pārbaudei ar šḳirnes nosaukumu 'Kornelija'), kas iekḷautas klīniskajos pētījumos. 


\title{
INVESTIGATION OF THE OIL AND MEAL OF JAPANESE QUINCE (Chaenomeles japonica) SEEDS
}

\author{
Inese Mieriṇa, Rasma Seržane, Maija Strēle, Jūlija Moskalıka, Elga Ivdre, \\ and Māra Jure \\ Faculty of Material Science and Applied Chemistry, Rīga Technical University, Āzenes iela 14/24, Rĩga, LV 1048, LATVIA; \\ mara@ktf.rtu.Iv, inesem@ktf.rtu.Iv
}

\section{Communicated by Dalija Segliṇa}

\begin{abstract}
Various extracts of Japanese quince (Chaenomeles japonica) seeds obtained using organic solvents were studied for their polyphenol content and antiradical activity. It was established that petroleum ether, hexane, ethyl acetate, acetone, as well as toluene and chloroform extracts, in comparison to synthetic antioxidant butylated hydroxytoluene (BHT), demonstrate better (or comparable) activity against 2,2-diphenyl-1-picrylhydrazyl (DPPH). Methods for detoxification of seeds, meals and press-cakes are proposed. Phenolic composition of different extracts (80\% ethanol, $70 \%$ acetone), both acid and alkali hydrolysates of seeds, as well as seed oil methanol/water extract were analysed by means of high performance liquid chromatography (HPLC): chlorogenic acid was found for the first time in seed extract; protocatechuic acid predominated in all extracts. The content of other major phenolic acids was detected; it was found that seed oil contains syringic acid. It was determined that Japanese quince seeds contain almost ten times more $\alpha$-tocopherol than barley grain. Due to the presence of $\alpha$-tocopherol and phenolic compounds, seed oil and lipophilic extracts of seeds could serve as antioxidants.
\end{abstract}

Key words: Japanese quince seeds, polyphenols, amygdalin, antioxidant, oxidative stability.

\section{INTRODUCTION}

Japanese quince (Chaenomeles japonica) is cultivated mainly in Baltic and Scandinavian countries. The fruits of Japanese quince are mostly used to produce juice, jelly, candied fruits, purée, aroma-extracts, syrup, carbonated soft drinks, liqueur, wine; and fruit sugar extract has proven to be excellent as a flavouring in ice cream (Seglina, 2001; Hellin et al., 2003; Jordan et al., 2003).

From the economical viewpoint seeds and seed oil are interesting objects for investigation, as fruits have up to $10 \mathrm{wt} \%$ seeds, which contain up to $6 \%$ (Granados et al., 2003) to even 20\% (Mierina et al., 2011) of oil. The iodine value of seed oil is $94-105 \mathrm{~g} \mathrm{I}_{2} / 100 \mathrm{~g}$, acid number $-2.2-2.5 \mathrm{mg}$ $\mathrm{KOH} / \mathrm{g}$ (Granados et al., 2003). The two main fatty acids are linoleic (45\% (Ruisa, 1996), 50\% (Granados et al., 2003), 56\% (Дейнека и др., 2005), 58\% (Gora and Kurowska, 1979)) and oleic ( 27\% (Gora and Kurowska, 1979), 34\% (Дейнека и др., 2005), 38\% (Granados et al., 2003; Ruisa, 1996)) acids, which together form about $90 \%$ of the fatty acid composition (Gora and Kurowska, 1979; Ruisa, 1996). The main saturated fatty acid of Japanese quince seed oil is palmitic acid - 8\% (Дейнека и др., 2005) to $10 \%$ (Gora and Kurowska, 1979). The main triglycerides are trilinolenate and linolenate-linolate-oleate (together $\sim 17 \%$ ), dilinoleate-oleate and linolenate-dioleate (both together almost 30\%), linolate-dioleate (19\%), dilinolate-stearate, linolate-oleate-palmitate and linolenateoleate-stearate (all three together constitute about 10\%), dilinolate-palmitate, linolenate-linolate-stearate and linolenate-oleate-palmitate (the last three form about 10\%) (Deineka and Deineka, 2004). The total concentration of phospholipids (about $0.5 \%)$ and phytin $(\sim 1.4 \%)$ in seeds has also been previously determined (Mukhamedova et al., 1979); the total concentration of phosphorous is about $4 \%$ (Gora and Kurowska, 1979). Seeds contain phytosterols $(0.015 \%)$ and $\alpha$-tocopherol $(0.1 \%)$ (Gora and Kurowska, 1979). Till now only one publication (Sokolowska-Wozniak et al., 2002) has been devoted to analysis of free and bond phenolic acids in Japanese quince seeds: composition of $80 \%$ methanol extracts was studied.

Previously we found (Mierina et al., 2011) that hydrophilic extracts of Japanese quince seeds, due to the presence of phenolic compounds, can be used to improve stability of vegetable oils; we showed by high performance liquid chromatography (HPLC) that Japanese quince seeds contain amygdalin and observed that extracted seed oil or mechanically pressed oil lacks this compound and its degradation products. The aim of this study was to determine the phenolic concentration and profile as well as tocopherol concentration of seed oil and different seed extracts and to evaluate the antioxidative activity of Japanese quince seeds, seed meal and oil. 


\section{MATERIALS AND METHODS}

Japanese quince seeds. Fruits of Japanese quince were cut and seeds and pulp were separated. In order to remove damaged seeds, they were washed with water. Then seeds were air-dried at $40 \pm 2{ }^{\circ} \mathrm{C}$ with forced air circulation (oven Orakas, Finland). The water content of the seeds was $5.74 \%$. The seeds were packed under vacuum in $2 \mathrm{~kg}$ portions in bags made of polypropylene; they were stored at 18 $\pm 2{ }^{\circ} \mathrm{C}$ in dark until further experiments.

Japanese quince seed oil. Japanese quince seed oil was obtained by two methods:

1) seeds (finely ground in a coffee grinder and sieved by particle size $d<0.069 \mathrm{~mm}$ ) were extracted with organic solvent in Soxhlet apparatus;

2) ground seeds were extracted with organic solvent by mixing (at boiling or room temperature).

Determination of total concentration of cyanogenic compounds. Total concentration of cyanogenic compounds was determined by argentometry (Fend et al., 2003). Total concentration of cyanogenic compounds was expressed as $\mathrm{mg}$ of hydrogen cyanide $(\mathrm{HCN})$ per $1 \mathrm{~kg}$ of sample.

Analysis of polyphenol extracts of Japanese quince seeds. Total polyphenol content (TPC) was determined according to a modified method (Singleton et al., 1999) using Folin-Denis reagent. Absorption was measured with a spectrophotometer (Camspec M501, Single Beam Scanning UV/Visible Spectrometer) at $765 \mathrm{~nm}$. TPC was expressed as gallic acid equivalents (GAE) per $100 \mathrm{~g}$ of sample.

Preparation of polyphenol extracts. Seeds were defatted before extraction: $30 \mathrm{~g}$ of ground Japanese quince seeds were mixed with $100 \mathrm{ml}$ hexane at room temperature $15 \mathrm{~min}$, then the mixture was filtered. Extraction of seed meal was repeated twice. Hexane filtrates were combined, distilled in vacuum and used for preparation of extract $\mathrm{E}$.

Extracts A1 and A2: $2.5 \mathrm{~g}$ defatted seed meal was mixed with $50 \mathrm{ml} 80 \%$ ethanol for $1 \mathrm{~h}$ at room temperature (extract A1) or heated at boiling temperature (extract A2). The mixture was filtered and organic solvent removed in vacuum. The residual water solution was acidified with $6 \mathrm{M} \mathrm{HCl} \mathrm{up}$ to $\mathrm{pH} \sim 2$ and after that extracted with $2 \times 25 \mathrm{ml}$ ethyl acetate. The ethyl acetate layer was dried with anhydrous $\mathrm{Na}_{2} \mathrm{SO}_{4}$, filtered and solvent removed in vacuum. The extract was stored at $4{ }^{\circ} \mathrm{C}$ until further analysis.

Extracts B1 and B2 were prepared analogically as A1 and A2, but $70 \%$ acetone was used for extraction instead of $80 \%$ ethanol.

Extract C: $10 \mathrm{ml} 6 \mathrm{M} \mathrm{HCl}$ were added to $2.5 \mathrm{~g}$ defatted seed meal and the mixture was heated for $1 \mathrm{~h}$ at $75-80{ }^{\circ} \mathrm{C}$ and filtered. $6 \mathrm{M} \mathrm{KOH}$ solution was added to filtrate to reach $\mathrm{pH} 2$, followed by extraction with ethyl acetate, as in the case of extracts $\mathrm{A} 1$ and $\mathrm{A} 2$.
Extract D: $30 \mathrm{ml} 2 \mathrm{M} \mathrm{KOH}$ were added to $2.5 \mathrm{~g}$ defatted seed meal and mixed for one hour at room temperature in dark using an orbital shaker. The solution was filtered, filtrate acidified with $6 \mathrm{M} \mathrm{HCl}$ up to $\mathrm{pH} 2$, followed by extraction with ethyl acetate, as in the case of extracts A1 and A2.

Extract E: $2 \mathrm{~g}$ of seed oil, obtained in the defatting process (extraction of seeds with hexane), were dissolved in $1 \mathrm{ml}$ of hexane. $2 \mathrm{ml}$ of methanol:water $(6: 4, \mathrm{v}: \mathrm{v})$ were added to this solution and centrifuged to separate the methanol/water layer; the process was repeated twice. Methanol/water layers were combined and three times washed with $5 \mathrm{ml}$ of hexane; methanol and water were removed in vacuum.

HPLC analysis. The chromatographic analysis was performed on an Agilent Technologies HPLC system (model $1200)$ equipped with an UV/Vis detector. A reverse phase Gemini NX C18 column $(3 \mu \mathrm{m}, 4.6 \times 100 \mathrm{~mm})$ was used to separate the compounds. The mobile phase consisted of $1 \%$ acetic acid solution (solvent $\mathrm{A}$ ) and methanol (solvent $\mathrm{B}$ ). The gradient profile was $90 \% \mathrm{~A}$ at $0 \mathrm{~min}, 30 \% \mathrm{~A}$ at $30 \mathrm{~min}$, $0 \% \mathrm{~A}$ at $35 \mathrm{~min}$ and $90 \% \mathrm{~A}$ at $40 \mathrm{~min}$. Flow rate was $0.9 \mathrm{ml} / \mathrm{min}$. Chromatograms were recorded at $280 \mathrm{~nm}$. Polyphenol extracts A-E were dissolved in methanol $(10 \mathrm{mg} / \mathrm{ml})$. Injection volume was $5 \mu \mathrm{l}$. (+)-Catechin hydrate, gallic, chlorogenic, caffeic, ellagic, protocatechuic, vanillic, syringic and $p$-coumaric acid, quercetin hydrate, phlorizin hydrate, phloretin were used as analytical standards.

Tocopherol analysis in Japanese quince seed oil. The oil was obtained by extraction of ground seeds with hexane at boiling temperature.

A normal phase Zorbax RX-SIL column $(5 \mu \mathrm{m}, 4.4 \times$ $250 \mathrm{~mm}$ ) was used to separate tocopherols. The mobile phase consisted of $0.8 \%$ solution of isopropanol in hexane $(\mathrm{v} / \mathrm{v})$. Analysis was carried out in isocratic mode. Flow rate was $1 \mathrm{ml} / \mathrm{min}$, injection volume $10 \mu \mathrm{l}$. Chromatograms were recorded at $292 \mathrm{~nm}$. Samples were prepared by dissolving $17-22 \mathrm{mg}$ oil in $1 \mathrm{ml}$ hexane. Tocopherols were detected using $\alpha$ - and $\delta$-tocopherols as standard compounds.

Detection of antioxidant activity. Radical scavenging activity was evaluated by the 2,2-diphenyl-1-picrylhydrazyl (DPPH) test (Mierina and Jure, 2010). Absorption of solutions was measured with a Camspec M501, Single Beam Scanning UV/Visible spectrometer at $517 \mathrm{~nm}$.

Statistical analysis. Statistical analysis of data was carried out using the Microsoft Excel software package. The total concentration of phenolic compounds and tocopherols was calculated from calibration curves $\left(\mathrm{R}^{2}=0.9983\right.$ (gallic acid), $\mathrm{R}^{2}=0.9993$ (chlorogenic acid), $\mathrm{R}^{2}=0.9994$ (caffeic acid) $\mathrm{R}^{2}=0.9997$ (protocatechuic and sinapic acid), $\mathrm{R}^{2}=$ 0.9998 (syringic acid and $\alpha$-tocopherol) and $R^{2}=0.9999$ (vanillic and $p$-coumaric acid)); each calibration curve consisted of five points and was linear in the range of obtained results. Standard deviation was calculated by linear least 
squares regression. Total amount of cyanogenic compounds and TPC was measured at least twice; the average values and standard deviations are provided.

\section{RESULTS}

Detoxification of Japanese quince seeds, meal and presscake. Detoxification of both intact and ground seeds (which contained $\sim 260 \mathrm{mg} \mathrm{HCN} / \mathrm{kg}$ ) was carried out by heating at $105-110{ }^{\circ} \mathrm{C}$ or $160-180{ }^{\circ} \mathrm{C}$, as well as treatment with water steam. While heating at $105-110^{\circ} \mathrm{C}$ was unsuccessful, heating at $160-180{ }^{\circ} \mathrm{C}$ completely removed cyanides after $3 \mathrm{~h}$ in the case of intact seeds and within $2 \mathrm{~h}$ in the case of ground seeds. Treatment with steam (which can promote glycosidase enzymatic reaction and result in a greater removal of the $\mathrm{HCN}$ ) appeared applicable only for ground seeds - within $3 \mathrm{~h}$ seeds could be detoxified.

Japanese quince seeds can be detoxified very simply by pre-treatment of ground seeds with water, ethanol or water-ethanol $(1: 1 \mathrm{v} / \mathrm{v})$ solution: 15 min mixing with hydrophilic solvent at room temperature is sufficient, if it is followed by two times washing of seed material with the corresponding solvent.

Seed meal obtained after oil extraction (carried out by $2 \mathrm{~h}$ heating at boiling temperature) with different solvents (petroleum ether, toluene, hexane, chloroform, ethyl acetate, acetone, ethyl acetate:hexane $(1: 1 \mathrm{v} / \mathrm{v}))$ contained about the same amount of cyanogenic compounds (217-265 mg $\mathrm{HCN} / \mathrm{kg}$ ) as tested seeds (254 mg HCN/kg). Seed meal was detoxified easily by mixing with distilled water $(1: 10 \mathrm{w} / \mathrm{v})$ at room temperature for $15 \mathrm{~min}$; after that the mixture was centrifuged and washed again with water $(1: 5 \mathrm{w} / \mathrm{v})$ - triple washing was necessary to complete detoxification.

Press-cakes of blends of Japanese quince seeds and oil plant seeds also contained cyanogenic compounds. Oil plant seeds contained cyanides (see Table 1); the cyanide concentration in Japanese quince seeds used in these experiments was $256.6 \mathrm{mg} \mathrm{HCN} / \mathrm{kg}$. Press-cakes were successfully detoxified by treatment (mixing) with water for $30 \mathrm{~min}$ (in the case of rapeseed/Japanese quince seed and linseed/Japanese quince seed) or for $15 \mathrm{~min}$ (in the case of hempseed/Japanese quince seed) at room temperature and following two times washing with water.

Total polyphenol content and identification of phenolic compounds in Japanese quince seeds, oil and meal. We obtained Japanese quince seed oil by extraction of seeds with organic solvents of different polarity — petroleum ether, toluene, hexane, chloroform, ethyl acetate, mixture ethyl acetate:hexane (1:1), and acetone. Polyphenols were extracted from oil by $80 \%$ ethanol. TPC was higher in oil samples obtained with more polar solvents, e.g., chloroform or ethyl acetate - 286 and $352 \mathrm{mg}$ GAE/100 g oil, correspondingly (see Table 2). In contrast, the highest yield of oil was obtained in the case of lipophilic solvents (hexane and toluene) 12.5 and $12.2 \%$, correspondingly. Total polyphenol
Table 1

CYANIDE CONCENTRATION IN OIL SEEDS AND PRESS-CAKES OF SEED BLENDS AND TOTAL POLYPHENOL CONTENT (TPC) IN OIL EXTRACTS OF JAPANESE QUINCE SEEDS

\begin{tabular}{lccc}
\hline \multicolumn{1}{c}{ Analysed material } & $\begin{array}{c}\text { Content of cyanides, } \\
\text { mg HCN/kg }\end{array}$ & $\begin{array}{c}\text { TPC, } \\
\text { mg GAE/100 g oil }\end{array}$ \\
\hline & Oil seeds \\
Rapeseeds & $48.6^{*} \pm 1.6^{\mathrm{a}}$ & $\mathrm{NM}$ \\
Hempseeds & $64.8 \pm 3.8^{\mathrm{a}}$ & $\mathrm{NM}$ \\
Linseeds & $126.9 \pm 12.6^{\mathrm{a}}$ & $\mathrm{NM}$ \\
& Blends of oil seeds and Japanese quince seeds \\
$\mathrm{R}+0 \% \mathrm{Q}$ & $51.3 \pm 1.6^{\mathrm{a}}$ & $3.7 \pm 0.5^{\mathrm{a}}$ \\
$\mathrm{R}+3 \% \mathrm{Q}$ & $54.0 \pm 6.6^{\mathrm{b}}$ & $5.3 \pm 0.5^{\mathrm{a}}$ \\
$\mathrm{R}+4 \% \mathrm{Q}$ & $62.7 \pm 12.3^{\mathrm{b}}$ & $6.0 \pm 1.8^{\mathrm{c}}$ \\
$\mathrm{R}+5 \% \mathrm{Q}$ & $78.3 \pm 3.4^{\mathrm{a}}$ & $6.0 \pm 2.5^{\mathrm{c}}$ \\
$\mathrm{R}+10 \% \mathrm{Q}$ & $91.8 \pm 0.3^{\mathrm{a}}$ & $6.7 \pm 0.6^{\mathrm{a}}$ \\
$\mathrm{H}+0 \% \mathrm{Q}$ & $62.1 \pm 3.8^{\mathrm{a}}$ & $26.3 \pm 4.5^{\mathrm{b}}$ \\
$\mathrm{H}+3 \% \mathrm{Q}$ & $59.4 \pm 2.7^{\mathrm{a}}$ & $26.7 \pm 0.3^{\mathrm{a}}$ \\
$\mathrm{H}+4 \% \mathrm{Q}$ & $62.1 \pm 3.8^{\mathrm{a}}$ & $27.4 \pm 4.0^{\mathrm{b}}$ \\
$\mathrm{H}+5 \% \mathrm{Q}$ & $64.8 \pm 3.8^{\mathrm{a}}$ & $29.5 \pm 0.8^{\mathrm{a}}$ \\
$\mathrm{H}+10 \% \mathrm{Q}$ & $67.5 \pm 11.5^{\mathrm{b}}$ & $35.3 \pm 7.2^{\mathrm{b}}$ \\
$\mathrm{L}+0 \% \mathrm{Q}$ & $121.5 \pm 13.4^{\mathrm{b}}$ & $16.0 \pm 6.7^{\mathrm{c}}$ \\
$\mathrm{L}+3 \% \mathrm{Q}$ & $124.2 \pm 4.8^{\mathrm{a}}$ & $16.7 \pm 0.7^{\mathrm{a}}$ \\
$\mathrm{L}+4 \% \mathrm{Q}$ & $156.7 \pm 11.3^{\mathrm{a}}$ & $16.9 \pm 1.9^{\mathrm{a}}$ \\
$\mathrm{L}+5 \% \mathrm{Q}$ & $164.7 \pm 16.3^{\mathrm{a}}$ & $17.2 \pm 0.1^{\mathrm{a}}$ \\
\hline & $178.2 \pm 2.3^{\mathrm{a}}$ & $18.6 \pm 3.6^{\mathrm{a}}$ \\
& &
\end{tabular}

* Each value is the mean of two measurements, \pm standard deviation (SD). Values marked with the same letter are within the confidence interval $\left({ }^{\mathrm{a}} P<\right.$ $0.05,{ }^{\mathrm{b}} P<0.1,{ }^{\mathrm{c}} P<0.2$ ); Q, Japanese quince seeds; R, rapeseeds; H, hempseeds; L, linseeds; NM, the parameter was not measured.

Table 2

TOTAL POLYPHENOL CONTENT (TPC) AND FREE RADICAL SCAVENGING ACTIVITY (IC 50 )* OF OIL OF JAPANESE QUINCE SEED OIL AND MEAL

\begin{tabular}{|c|c|c|c|c|c|}
\hline \multirow{2}{*}{$\begin{array}{c}\text { Solvent } \\
\text { used for oil } \\
\text { extraction }\end{array}$} & \multirow[t]{2}{*}{$\begin{array}{c}\text { Oil yield, } \\
\%\end{array}$} & \multirow{2}{*}{$\begin{array}{c}\text { TPC, } \\
\text { mg } \\
\text { GAE/100 g } \\
\text { oil }\end{array}$} & \multirow[t]{2}{*}{$\begin{array}{l}\mathrm{IC}_{50} \\
\mathrm{mg} / \mathrm{ml}\end{array}$} & \multicolumn{2}{|c|}{$\begin{array}{c}\text { TPC, } \\
\text { mg GAE/100 g meal }\end{array}$} \\
\hline & & & & $\begin{array}{c}96.5 \% \\
\text { ethanol** }\end{array}$ & $\begin{array}{c}70 \% \\
\text { acetone } * *\end{array}$ \\
\hline $\begin{array}{l}\text { Petroleum } \\
\text { ether }\end{array}$ & $\begin{array}{l}11.6^{* * * *} \pm \\
2.0^{\mathrm{b}}\end{array}$ & $171 \pm 3^{\mathrm{a}}$ & 0.28 & $193 \pm 10^{\mathrm{a}}$ & $\mathrm{NM}$ \\
\hline Toluene & $12.2 \pm 0.4^{\mathrm{a}}$ & $275 \pm 11^{\mathrm{a}}$ & 0.30 & $205 \pm 7^{\mathrm{a}}$ & $2 \pm 0^{\mathrm{a}}$ \\
\hline Hexane & $12.5 \pm 2.8^{\mathrm{b}}$ & $186 \pm 1^{\mathrm{a}}$ & 0.33 & $208 \pm 3^{\mathrm{a}}$ & $44 \pm 6^{b}$ \\
\hline Chloroform & $11.0 \pm 1.4^{\mathrm{b}}$ & $286 \pm 10^{\mathrm{a}}$ & 0.26 & $232 \pm 11^{\mathrm{a}}$ & $104 \pm 6^{\mathrm{a}}$ \\
\hline $\begin{array}{l}\text { Ethyl } \\
\text { acetate: } \\
\text { hexane } \\
(1: 1)\end{array}$ & $9.2 \pm 1.2^{\mathrm{b}}$ & $284 \pm 0^{\mathrm{a}}$ & 0.10 & $\mathrm{NM}$ & NM \\
\hline $\begin{array}{l}\text { Ethyl } \\
\text { acetate }\end{array}$ & $7.6 \pm 0.7^{\mathrm{a}}$ & $352 \pm 4^{\mathrm{a}}$ & 0.09 & $\mathrm{NM}$ & $\mathrm{NM}$ \\
\hline Acetone & $8.0 \pm 1.4^{\mathrm{a}}$ & $199 \pm 17^{\mathrm{a}}$ & 0.40 & $\mathrm{NM}$ & NM \\
\hline
\end{tabular}

* $\mathrm{IC}_{50}$ was detected for ethanol extract of seed oil (obtained by corresponding solvent); ** solvent used for extraction of the polyphenols from the seed meal left after extraction of the oil; *** each value is the mean of 2 measurements, \pm SD. Values marked with the same letter are within the confidence interval $\left({ }^{\mathrm{a}} P<0.05,{ }^{\mathrm{b}} P<0.1\right)$; NM, the parameter was not measured. 
PHENOLIC COMPOUNDS (mg/kg DEFATTED SEEDS) IN EXTRACTS OF JAPANESE QUINCE SEEDS

\begin{tabular}{|c|c|c|c|c|c|c|}
\hline \multirow[t]{2}{*}{ Phenolic acid } & \multicolumn{6}{|c|}{ Extract } \\
\hline & A1 & $\mathrm{A} 2$ & $\mathrm{~B} 1$ & $\mathrm{~B} 2$ & $\mathrm{C}$ & $\mathrm{D}$ \\
\hline Proto-catechuic & $20.36^{*} \pm 0.21^{\mathrm{a}}$ & $46.14 \pm 0.33^{\mathrm{a}}$ & $14.20 \pm 0.12^{\mathrm{a}}$ & $36.93 \pm 0.30^{\mathrm{a}}$ & $24.91 \pm 0.21^{\mathrm{a}}$ & $32.63 \pm 0.27^{\mathrm{a}}$ \\
\hline Vanillic & $1.41 \pm 0.06^{\mathrm{a}}$ & $2.55 \pm 0.08^{\mathrm{a}}$ & $1.40 \pm 0.03^{\mathrm{a}}$ & $2.24 \pm 0.06^{\mathrm{a}}$ & $4.57 \pm 0.04^{\mathrm{a}}$ & $2.32 \pm 0.03^{\mathrm{a}}$ \\
\hline Syringic & $2.06 \pm 0.05^{\mathrm{a}}$ & $3.01 \pm 0.06^{\mathrm{a}}$ & $1.14 \pm 0.02^{\mathrm{a}}$ & $0.97 \pm 0.05^{\mathrm{a}}$ & $0.46 \pm 0.04^{\mathrm{a}}$ & $0.34 \pm 0.02^{\mathrm{a}}$ \\
\hline$p$-Cou-maric & $1.12 \pm 0.04^{\mathrm{a}}$ & $0.75 \pm 0.05^{\mathrm{a}}$ & $0.55 \pm 0.02^{\mathrm{a}}$ & $1.64 \pm 0.04^{\mathrm{a}}$ & $0.44 \pm 0.03^{\mathrm{a}}$ & $1.19 \pm 0.02^{\mathrm{a}}$ \\
\hline Gallic & $1.44 \pm 0.18^{b}$ & $4.64 \pm 0.23^{\mathrm{a}}$ & $0.40 \pm 0.10^{c}$ & $2.00 \pm 0.18^{\mathrm{a}}$ & $1.72 \pm 0.13^{\mathrm{a}}$ & NF \\
\hline Caffeic & $\mathrm{NF}$ & $\mathrm{NF}$ & $\mathrm{NF}$ & $\mathrm{NF}$ & $0.61 \pm 0.09^{\mathrm{b}}$ & $1.14 \pm 0.05^{\mathrm{a}}$ \\
\hline
\end{tabular}

* Each value is the mean of two measurements, \pm standard deviation $(\mathrm{SD})$. Values marked with the same letter are within the confidence interval $\left({ }^{\mathrm{a}} P<0.05\right.$, $\left.{ }^{\mathrm{b}} P<0.1,{ }^{\mathrm{c}} P<0.2\right)$; NF, the compound was not found in the extract.

content was determined for blends of oils (see Table 1) obtained by cold-pressing of mixtures of Japanese quince and oil plant seeds (Poiss, 2004). Polyphenols were extracted from oils with $80 \%$ ethanol.

Identified compounds of six extracts are given in Table 3 (+)-catechin, quercetin, phlorizin, phloretin and ellagic acid were not found in extracts. Two peaks, which were observed at $7.2 \mathrm{~min}$ and $11.9 \mathrm{~min}$ in HPLC chromatograms of all seed extracts, were not identified; the last peak was absent in the chromatogram of extract $\mathrm{C}$, but corresponded to the main component in extracts B2 and D. A considerable peak (corresponding to $90 \%$ of extract composition) at 3.7 min in the chromatogram of extract $\mathrm{C}$ was unidentified. The main polyphenol (found in all extracts of Japanese quince seeds) was protocatechuic acid (see Table 3) - its concentration was higher in extracts prepared by heating in organic solvent (extracts A2 and B2). Extracts prepared by mixing at room temperature (extracts A1 and B1) contained less protocatechuic acid. All extracts (except extract D) contained gallic acid. Ethanol (80\%) extract A2, prepared by heating contained more chlorogenic, vanillic and syringic acid. Higher concentration of $p$-coumaric acid was found in ethanol $(80 \%)$ extract $\mathrm{A} 1$, prepared at room temperature. Acetone (70\%) extract B2 (prepared by heating) contained more vanillic and $p$-coumaric acid, while extract B1 contained more syringic acid. Comparison of ethanol and acetone extracts (extracts $\mathrm{A} 1$ and B1, A2 and B2) showed that ethanol extracts had higher content of vanillic and syringic acid. Ethanol extracts A1 and A2, in contrast to acetone extracts, contained chlorogenic acid. Organic solvent extracts A2 and B2, obtained by heating, contained higher concentration of identified phenolic compounds almost in all cases, in comparison with extracts $\mathrm{A} 1$ and $\mathrm{B} 1$, which were prepared at room temperature.

Both acid and alkali hydrolysates (extracts C and D, correspondingly) of defatted seeds contained caffeic acid, which was not present in ethanol and acetone extracts. Higher concentration of protocatechuic, caffeic and $p$-coumaric acid was observed in alkali hydrolysates (extract D). In comparison, acid hydrolysates (extracts $\mathrm{C}$ ) contained more syringic and vanillic acid. The concentration of vanillic acid in acid hydrolysate was the highest $(4.57 \mathrm{mg} / \mathrm{kg}$ defatted seeds) among all six extracts studied.

The polyphenol profile of Japanese quince seed oil was investigated, too. Hydrophilic extract $\mathrm{E}$ of oil contained two compounds: one was identified as syringic acid $(0.06 \mathrm{mg} /$ $100 \mathrm{~g}$ oil), but the other was unidentified - it corresponded to the peak $(3.6 \mathrm{~min})$ of the main component observed in extract $\mathrm{C}$.

Detection of tocopherols in Japanese quince seed oil. $\alpha$-Tocopherol and $\delta$-tocopherol was analyzed in Japanese quince seed oil by HPLC. Seed oil contained a lot of $\alpha$-tocopherol $(85.96 \pm 0.97 \mathrm{mg} / 100 \mathrm{~g}$ oil or $109.20 \pm 1.23$ $\mathrm{mg} / \mathrm{kg}$ seeds). Thus, oil and lipophilic extracts can serve as antioxidants.

4. Evaluation of antioxidative properties of Japanese quince seed oil. Extracts of Japanese quince seeds obtained using organic solvents were studied for their antiradical activity. Petroleum ether, hexane, ethyl acetate, acetone, as well as toluene and chloroform extracts, in comparison to synthetic antioxidant 2,6-di-tert-butyl-4-methylphenol (BHT), demonstrated better (or comparable) activity against DPPH (see Table 2). The concentration of synthetic antioxidants that inhibits $50 \%$ of DPPH was estimated: $\mathrm{IC}_{50}$ in the case of quercetin was $0.02 \mathrm{mg} / \mathrm{ml}$, ascorbic acid $0.02 \mathrm{mg} / \mathrm{ml}$, ascorbyl palmitate - $0.03 \mathrm{mg} / \mathrm{ml}$, tert-butylhydroquinone $-0.04 \mathrm{mg} / \mathrm{ml}$ and BHT $-0.22 \mathrm{mg} / \mathrm{ml}$.

The highest activity was observed for seed oil obtained with ethyl acetate $\left(\mathrm{IC}_{50}=0.09 \mathrm{mg} / \mathrm{ml}\right)$ and with the mixture ethyl acetate:hexane $(1: 1)\left(\mathrm{IC}_{50}=0.10 \mathrm{mg} / \mathrm{ml}\right)$ - both samples were more active than BHT.

\section{DISCUSSION}

According to the composition of fatty acids, Chaenomeles japonica seed oil is similar to apple (Tian et al., 2010) and melon seed (Maria et al., 2001; Ismail et al., 2010) oils, which is known for its antioxidative properties and belongs to the group of oils low in palmitic acid and high in oleic and linoleic acids (Granados et al., 2003). The unique fatty 
acid composition of Japanese quince seed oil may be of interest for the food and cosmetics industry.

Previously we determined (Mierina et al., 2011) that the total concentration of cyanogenic compounds in Japanese quince seeds is $0.69 \mathrm{mg} / \mathrm{g}$ - such a cyanide concentration is similar to apple (Malus domestica) seeds $(0.6 \mathrm{mg} / \mathrm{g})$ and is low compared with bitter almond and apricot kernels (Barceloux, 2009). The oral lethal dose of hydrogen cyanide for human is $0.5-3.5 \mathrm{mg} / \mathrm{kg}$ body weight or about 50 $250 \mathrm{mg}$ for a typical adult human (Ballhorn, 2011): toxicity from the ingestion of Japanese quince seeds would be unusual. In order to use seed meal and press-cake in food industry or cosmetics, plant material should be detoxified. For this there are two possibilities: pre-treatment of seed material before oil production or detoxification of seed material after deoiling. In this study, the effective pre-treatment methods were developed for detoxification of seeds and further oil extraction. Ground seeds should be extracted with water $0.25 \mathrm{~h}$ at room temperature, followed by triple washing with water, which provides detoxified seed material that can be used for oil extraction with petroleum ether or hexane (oil yield in this case reaches 14.8-18.7\%). Detoxification of seed meal and press-cake can be carried out similarly.

The concentration of polyphenols was observed to reach $352 \mathrm{mg}$ GAE/100 $\mathrm{g}$ in seed oil and $232 \mathrm{mg}$ GAE/100 $\mathrm{g}$ in seed meal; the best results can be achieved with ethyl acetate in case of seed oil, but in the case of meal - ethanol; extraction should be carried out at the boiling temperature of solvent (duration 2-6 h). As Japanese quince seed oil and seed extracts contain natural antioxidants (various polyphenols), the oil could be used for stabilisation of other oils - similar examples of application of other plant seeds have been described (Yanishlieva and Marinova, 2001; Poiana, 2012; Rubilar et al., 2012); stabilisation by linseed oil has been studied more often (Omar et al., 2010; Michotte et al., 2011).

Till now only one publication (Sokolowska-Wozniak et al., 2002) has been devoted to analysis of phenolic composition of Japanese quince seeds: it was found that $80 \%$ methanol extracts of seeds contain protocatechuic, caffeic, gallic, 4-hydroxybenzoic, p-coumaric, ferulic, syringic, vanillic, salicylic, 4-hydroxyphenylacetic and ellagic acid.

In this study, the phenolic profile of Japanese quince seed extracts was analysed by HPLC method; composition of polyphenols $((+)$-catechin hydrate, quercetin hydrate, phlorizin hydrate and phloretin) and phenolic acids (gallic, chlorogenic, caffeic, ellagic, protocatechuic, vanillic, syringic and $p$-coumaric acid) was investigated. Phlorizin was chosen as reference compound because it is known as the predominant (79-92\%) phenolic compound in apple seeds (Fromm et al., 2012) and is present in some other plant species of the Rosaceae family. As Japanese quince is a member of the Rosaceae family, we thought that phlorizin or phloretin should be present in the seeds.
Japanese quince seeds contained high concentration of $\alpha$-tocopherol, which was greater than in some other species of the Rosaceae family, e.g., concentration in Cydonia oblonga Miller seeds were: $\alpha$-tocopherol $(16.03 \mathrm{mg} / 100 \mathrm{~g}$ dry seed), $\beta$-tocopherol (0.15), $\gamma$-tocopherol (0.32) and total tocopherol (16.49 mg/100 g dry seed) (Nogala-Kalucka et al., 2010). High concentration of $\mathrm{E}$ vitamin in Japanese quince seeds has been reported only in one publication (Gora and Kurowska, 1979). In comparison with an outstanding $\alpha$-tocopherol source - barley grain oil — Japanese quince seed oil often contains more of this valuable compound (concentration of $\alpha$-tocopherol in barley oil is $56.3-128.9 \mathrm{mg} / 100 \mathrm{~g}$ oil (Moreau et al., 2007), but the content of $\alpha$-tocopherol expressed per seed weight is almost ten times higher in the case of Japanese quince seeds in comparison with barley grain (8.2 up to $12.7 \mathrm{mg} / \mathrm{kg}$ grain (Panfili et al., 2008)).

As Japanese quince seeds appeared to be a good source of polyphenols and tocopherol, oil blends were prepared by cold-pressing method from mixtures of Japanese quince seeds and oilseeds. Addition of Japanese quince seeds increased TPC of blends only by 3-9 mg GAE/100 g: this parameter in the case of linseed oil increased by 2.6 , for rapeseed oil - 3.1 and in the case of hempseed oil by nine units. Nevertheless, lipophilic extracts of Japanese quince seeds demonstrated notable free radical scavenging properties in the DPPH test: it was established that activity of petroleum ether, toluene, hexane and chloroform extracts $\left(\mathrm{IC}_{50}=0.33-0.26 \mathrm{mg} / \mathrm{ml}\right)$ is only somewhat lower than that of synthetic antioxidant BHT $\left(\mathrm{IC}_{50}=0.22 \mathrm{mg} / \mathrm{ml}\right)$, and but the activity of the ethyl acetate extract even exceeded it $\mathrm{IC}_{50}$ is $0.09 \mathrm{mg} / \mathrm{ml}$.

It can be concluded that Japanese quince seeds produced as an agro-industrial by-product can serve as a valuable source of high-linoleic and high-oleic oil and natural antioxidants (phenolic compounds, $\alpha$-tocopherol), and therefore, Chaenomeles japonica seeds, seed oil and meal may be of interest for the food industry (for oil blends and stabilisation) and non-food uses.

\section{ACKNOWLEDGEMENTS}

This research was supported by EUREKA project No. E!6240 „,Development of new products from plant material for health improvement and cosmetics" and the European Social Fund within the project „Support for the implementation of doctoral studies at Riga Technical University". We are thankful to the Latvia State Institute of Fruit-Growing for donation of Japanese quince seeds.

\section{REFERENCES}

Ballhorn, D. J. (2011). Cyanogenic glycosides in nuts and seeds. In: Preedy, V. R., Watson, R. R., Patel, V. B. (eds.). Nuts and Seeds in Health and Disease Prevention (1st edn.) (pp. 129-136). London, Burlington, San Diego: Academic Press.

Barceloux, D. G. (2009). Cyanogenic foods (cassava, fruit kernels, and cycad seeds). Dis.-a-Mon., 55 (6), 336-352. 
Deineka, V. I., Deineka, L. A. (2004). Type composition of triglycerides from seed oils. II. Triglycerides from certain cultivated plants of the Rosaceae family. Chem. Nat. Comp., 40 (4), 293-294.

Fend, D., Shen, Y., Chavez, E. R. (2003). Effectiveness of different processing methods in reducing hydrogen cyanide content of flaxseed. J. Sci. Food Agric., 83 (8), 836-841.

Fromm, M., Bayha, S., Carle, R., Kammerer D. R. (2012). Characterization and quantitation of low and high molecular weight phenolic compounds in apples. J. Agric. Food Chem., 60 (5), 1232-1242.

Gora, J., Kurowska, A. (1979). Chemical composition of the seed oil from Japanese quince Chaenomeles Japonica. Herba Pol., 25, 53-56.

Granados, M. V., Vila, R., Laencina, J., Rumpunen, K., Ros, J. M. (2003). Characteristics and composition of Chaenomeles seed oil. In: Rumpunen, K. (Ed.). Japanese Quince - Potential Fruit Crop for Northern Europe (pp. 141-147). Alnarp: Balsgård-Department of Crop Science, Swedish University of Agricultural Sciences.

Hellin, P., Jordan, M. J., Vila, R., Gustafsson, M., Göransson, E., Åkesson, B., Gröön, I., Laencina, J., Ros, J. M. (2003). Processing and products of Japanese quince (Chaenomeles japonica) fruits. In: Rumpunen, K. (Ed.). Japanese Quince - Potential Fruit Crop for Northern Europe (pp.169-175). Alnarp: Balsgård-Department of Crop Science, Swedish University of Agricultural Sciences.

Ismail, M., Mariod, A., Bagalkotkar, G., Ling, H. S. (2010). Fatty acid composition and antioxidant activity of oils from two cultivars of cantaloupe extracted by supercritical fluid extraction. Grasas Aceites, 61(1), 37-44.

Jordan, M. J., Vila, R., Hellin, P., Laencina, J., Rumpunen, K., Ros, J. M. (2003). Volatile compounds associated with the fragrance and flavour of Chaenomeles juice. In: Rumpunen, K. (Ed.). Japanese Quince - Potential Fruit Crop for Northern Europe (pp. 149-157). Alnarp: Balsgård-Department of Crop Science, Swedish University of Agricultural Sciences.

Maria L. S., de Mello Bora, P. S., Narain, N. (2001). Fatty and amino acids composition of melon (Cucumis melo var. saccharinus) seeds. J. Food Comp. Anal., 14 (1), 69-74.

Michotte, D., Rogez, H., Chirinos, R., Mignolet, E., Campos, D., Larondelle, Y. (2011). Linseed oil stabilization with pure natural phenolic compounds. Food Chem., 129 (3), 1228-1231.

Mierina, I., Jure, M. (2010). Antioksidantu aktivitātes noteikšanas metodes [Methods of assessment of antioxidant activity]. Latvijas Kīmijas Žurnāls, 49 (2/4), 221-234 (in Latvian).

Mierina, I., Serzane, R., Strele, M., Moskaluka, J., Seglina, D., Jure M. (2011). Extracts of Japanese quince seeds - potential source of antioxidants. In Conference Proceedings of 6th Baltic Conference on Food Science and Technology: Innovations for Food Science and Production (pp. 98-103). Jelgava, Latvia: Latvia University of Agriculture.

Moreau, R. A., Wayns, K. E., Flores, R. A., Hicks, K. B. (2007). Tocopherols and tocotrienols in barley oil prepared from germ and other fractions from scarification and sieving of hulless barley. Cereal Chem., 84 (6), 587-592.
Mukhamedova, Kh. S., Akbarov, R. R., Akramov, S. T. (1979). Amounts of phospholipids and phytin in the seeds of various plants II. Chem. Nat. Comp., 13 (4), 422-424.

Nogala-Kalucka, M., Rudzinska, M., Zadernowski, R., Siger, A., Krzyzostaniak, I. (2010). Phytochemical content and antioxidant properties of seeds of unconventional oil plants. J. Amer. Oil Chem. Soc., 87 (12), 1481-1487.

Omar, K. A., Shan, L., Wang, Y. L., Wang, X. (2010). Stabilizing flaxseed oil with individual antioxidants and their mixtures. Eur. J. Lipid Sci. Technol., 112 (9), 1003-1011.

Panfili, G., Fratianni, A., Di Criscio, T., Marconi, E. (2008). Tocol and $\beta$-glucan levels in barley varieties and in pearling by-products. Food Chem., 107 (1), 84-91.

Poiana, M. A. (2012). Enhancing oxidative stability of sunflower oil during convective and microwave heating using grape seed extract. Int. J. Mol. Sci., 13, 9240-9259.

Poiss, G. (2004). Vairākkomponentu augu eḷlu ražošana ar aukstās izspiešanas pan̄emienu [Production of multi-component vegetable oils using cold pressing method]. LV Patent No. 13200. Riga: Patent Office of the Republic of Latvia. (in Latvian).

Rubilar, M., Morales, E., Sịez, R., Acevedo, F., Palma, B., Villarroel, M., Shene, C. (2012). Polyphenolic fractions improve the oxidative stability of microencapsulated linseed oil. Eur. J. Lipid Sci. Technol., 114 (7), $760-771$.

Ruisa, S. (1996). Investigations on organic acid content in fruits, processing products and seed oil content of Chaenomeles japonica. In: Collection of scientific articles: Problems of Fruit Plant Breeding. Vol. 1 (pp. 24-31). Jelgava: LLU, 1996.

Seglina, D. (2001). Processing of Chaenomeles japonica. In: Reports of the Scientific Practical Conference: Future Trends in Food and Nutrition Development (pp. 88-90). Jelgava, Latvia: Latvia University of Agriculture, University of Latvia.

Singleton, V. L., Orthofer, R. M., Lamuela-Raventos, R. M. (1999). Analysis of total phenols and other oxidant substrates and antioxidants by means of Folin-Ciocalteu reagent. Meth. Enzymol., 299, 152-178.

Sokolowska-Wozniak, A., Szewczyk, K., Nowak, R. (2002). Phenolic acids from Cydonia japonica Pers. Herba Polonica, 48 (4), 214-218.

Tian, H. L., Zhan, P., Li, K. X. (2010). Analysis of components and study on antioxidant and antimicrobial activities of oil in apple seeds. Int. J. Food Sci. Nutr., 61 (4), 395-403.

Yanishlieva, N. V., Marinova, E. M. (2001). Stabilisation of edible oils with natural antioxidants. Eur. J. Lipid Sci. Technol., 103 (11), 752-767.

Дейнека В. И., Григрев А. М., Дейнека Л. А., Ермаков А. М., Сиротин А. А., Староверов В. М. (2005). Анализ компонентного состава антоцианов плодов и жирных кислот масел семян некоторых видов семейства Rosaceae методом высокоэффективной жидкостной хроматографии [Component composition analysis of fruit anthocyanins and seed triglycerides of some Rosaceae species by HPLC method]. Растительные ресурсы, 41 (1), 91-98 (in Russian).

Received 11 March 2013

\section{KRŪMCIDONIJU (Chaenomeles japonica) SĒKLU ELLLAS UN SPRAUKUMU PĒTİJUMI}

Krūmcidoniju (Chaenomeles japonica) sēklu dažādu organisko šķīdinātāju ekstraktiem noteikts kopējais polifenolu saturs un antiradikāḷu aktivitāte. Petrolētera, heksāna, etilacetāta, acetona, kā arī toluola un hloroforma ekstraktu spēja inhibēt 2,2-difenil-1-pikrilhidrazilu (DPPH) ir augstāka (vai salīdzināma) nekā sintētiskajam antioksidantam BHT (butilēts hidroksitoluols). Izstrādātas cianīdus saturošo krūmcidoniju sēklu, spraukumu un spiedpalieku detoksifikācijas metodes. Izmantojot augstas izškirtspējas škiidrumhromatogrāfijas metodi (HPLC), analizēta krūmcidoniju sēklu dažādu ekstraktu (80\% etanola un 70\% acetona), skābo un bāzisko hidrolizātu, kā arī eḷlas metanola/ūdens ekstrakta polifenolu kompozīcija: sēklu ekstraktā pirmo reizi konstatēta hlorogēnskābe. Visos ekstraktos kā dominējošais savienojums atrasta protokatehīnskābe; noskaidrots arī citu galveno fenolskābju daudzums, un sēklu eḷ!ā atrasta sīringskābe. Eḷ!ā ir daudz $\alpha$-tokoferola, kura saturs krūmcidoniju sēklās ir gandrīz desmit reizes lielāks nekā miežu graudos. Tā kā sēklu eḷla un lipofîlie ekstrakti satur $\alpha$-tokoferolu un polifenolus, ekstraktus var izmantot kā antioksidantu avotus. 


\title{
CONTENT OF PHENOLIC COMPOUNDS IN VARIOUS SEA BUCKTHORN PARTS
}

\author{
Elga Šnē", Dalija Seglina*a Ruta Galoburda**, and Inta Krasnova* \\ * Latvia State Institute of Fruit Growing, Graudu iela 1, Dobele, LV-3701, LATVIA; \\ elga.sne@gmail.com \\ ** Faculty of Food Technology, Latvia University of Agriculture, Lielā iela 2, Jelgava, LV-3001, LATVIA
}

Contributed by Dalija Seglina

\begin{abstract}
All parts of the sea buckthorn (Hippophae rhamnoides L.) plant are considered to contain large amounts of compounds that are believed to have beneficial health effects. Till now, different parts of sea buckthorn plant have been used for the treatment of diseases in traditional medicine in various countries. Nevertheless, sea buckthorn parts would be a good raw material not only for medicinal properties but also for food products with functional properties; therefore, the aim of the research was to determine the concentration of different phenolic compounds and antioxidant activity in various sea buckthorn parts. The study was conducted on parts of female and male sea buckthorn bushes. Phenolic compounds (total phenols, total flavonoids and condensed tannins) and antioxidative activity (ferric reducing antioxidant power (FRAP) free radical scavenging activity (using 2.2-diphenyl-1-picrylhydrazyl, DPPH)) in ethanolic extracts of leaves, shoots, flowers, and berries were determined using various spectrophotometric methods. The study showed that concentration of phenolic compounds differed among parts of sea buckthorn plant and among gender. Leaves of female plants proved to be the most valuable, as they contained the highest total phenol concentration $(165.76 \mathrm{mg} / \mathrm{g})$ and antioxidant activity $(220.97 \mathrm{mg} / \mathrm{g}$ for FRAP and 43.76 $\mathrm{mg} / \mathrm{g}$ for DPPH), while lowest values were found in young shoots of male plants $(84.94 \mathrm{mg} / \mathrm{g}$, $94.24 \mathrm{mg} / \mathrm{g}$ and $24.63 \mathrm{mg} / \mathrm{g}$, respectively). The significant differences in chemical composition and biological activity of sea buckthorn leaves, shoots, berries, and buds indicate a need for detailed studies of their extracts, specific fractions and compounds during a whole vegetative season.
\end{abstract}

Key words: leaves, shoots, berries, flowers, gender, flavonoids, phenols, tannins, antioxidant activity.

\section{INTRODUCTION}

Sea buckthorn (Hippophae rhamnoides L.) is a thorny shrub, native to Europe and Asia (Saggu et al., 2007). Berries of sea buckthorn have been much studied and their chemical composition and positive qualities are well documented. This has led to the outcome that mainly berries of this particular plant are used as a raw material for food processing (Guliyev et al., 2004) in jams, beverages, candies, etc. Nevertheless all parts of sea buckthorn plant have been considered valuable, as they contain large amounts of different bioactive substances, including a wide range of polyphenols, tocopherols, carotenoids, fatty acids, sterols, vitamins, minerals, etc. (Saggu et al., 2007; Jain et al., 2008; Kumar et al., 2011). Till now, different parts of sea buckthorn (other than berries) have been used in traditional medicine for the treatment of diseases, such as flu, colitis and enterocolitis, also cardiovascular illnesses, mucosal injuries, dermatological, and digestion disorders (Guliyev et al., 2004; Kumar et al., 2011). These therapeutic effects mostly are related to the high amount of compounds possessing antioxidant activity (Saggu et al., 2007; Kumar et al., 2011). This is in accordance with many reports that have reported a positive correlation between daily intake of fruit, vegetables and other products of plant origin and health improvement (Michel et al., 2012).

Therefore, in recent years there is a growing interest and demand for natural substances, mainly phenolics derived from plants, which exhibit this property and could be used as food components or pharmaceuticals (Uttara et al., 2009; Wannes et al., 2010). Aromatic and medicinal plants are a good source of natural antioxidants, because of large amounts of secondary metabolites, such as polyphenols and essential oils (Wannes et al., 2010), which are produced by plants for normal growth and development (Kondakova et al., 2009) to defend against plant pathogens, UV stress or to attract pollinators (Michel et al., 2012). 
However, only some studies have conducted analyses of phenolic compounds and their activity in sea buckthorn leaves and shoots, and no information can be found regarding concentrations in flowers, green berries, and regarding effects of gender and harvest time on these qualities. Therefore, the aim of the research was to determine the concentrations of various phenolic compounds and antioxidant activity in various sea buckthorn parts.

\section{MATERIALS AND METHODS}

Plant material. Sea buckthorn material was collected in 2011, in Dobele, Latvia. Flowers of male plants were harvested at time of pollination (late April), while leaves, shoots, unripe berries of female plants and leaves, shoots of male plants after 7 weeks of blossoming (middle of June). Equal amounts $(100 \pm 0.1 \mathrm{~g})$ of every sea buckthorn part were dried by liophilisation (FreeZone, Labconco, USA) at $-50 \pm 2{ }^{\circ} \mathrm{C}$ under $0.056 \mathrm{mBar}$ pressure for $16 \mathrm{~h}$.

Extraction procedure. Dried parts of sea buckthorn were pulverised in a laboratory mill (Knifetec 1095, Foss, Sweden). Extraction was performed in three steps. First, $40 \mathrm{ml}$ $80 \%$ ethanol was added to $1 \mathrm{~g}$ of the sample, shaken for $1 \mathrm{~min}$, placed in the ultrasonic bath (Sonorex RK $510 \mathrm{H}$, Bandelin electronic GmbH \& Co. KG, Germany) for $15 \mathrm{~min}$ at $50{ }^{\circ} \mathrm{C}$ and centrifuged (Eppendorf Centrifuge 5804R, Eppendorf AG, Germany) at $10000 \mathrm{~g}$ for $10 \mathrm{~min}$ at $4{ }^{\circ} \mathrm{C}$. Clear supernatant was separated from sediments and placed in an $100 \mathrm{ml}$ flask. The second step was performed by taking the sediments, adding $30 \mathrm{ml} 80 \%$ ethanol and repeating the above described procedure. Thirdly, when $20 \mathrm{ml} 80 \%$ ethanol was added to sediments obtained from the second extraction step. When all of the supernatant was collected, the flask was filled to $100 \mathrm{ml}$, mixed well and centrifuged $\left(10000 \mathrm{~g}, 10 \mathrm{~min}\right.$ at $\left.4{ }^{\mathrm{O}} \mathrm{C}\right)$.

The concentration of obtained ethanolic extracts was 0.01 $\mathrm{g} / \mathrm{ml}$, and due to high concentration of bioactive substances, prior to analyses it was diluted 100 times for total phenol assay, 10 or 25 times for total flavonoid analyses, 30 times for ferric reducing antioxidant power assay, 10 times for free radical scavenging activity and two times for condensed tannin analyses.

\section{Analyses of phenolic compounds}

Total phenol cocentration. The total phenol concentration was determined according to Singleton et al. (1999). FolinCiocalteu reagent (FCR) was prepared from Folin-Ciocalteu stock solution $(10 \mathrm{ml})$ and water $(90 \mathrm{ml})$. The sea buckthorn extract $(1 \mathrm{ml})$ was added to FCR $(5 \mathrm{ml})$ and $\mathrm{Na}_{2} \mathrm{CO}_{3}$ solution $(4 \mathrm{ml})$, mixed and kept for $1 \mathrm{~h}$ in the dark. The absorption was measured at $765 \mathrm{~nm}$ using a spectrophotometer (UV - 1650 PC, Shimadzu, Japan). Results were expressed as mg gallic acid equivalents per $1 \mathrm{~g}$ of dry matter (mg GAE/g DM).

Total flavonoid concentration. Total flavonoid concentration was determined using a spectrophotometric method previously described by Kumar et al. (2011) and Upadhyay et al. (2010). The extract $(1 \mathrm{ml})$ was mixed with water $(2 \mathrm{ml}), 5 \% \mathrm{NaNO}_{2}(0.15 \mathrm{ml})$ and left to react for 6 minutes. Then $10 \% \mathrm{AlCl}_{3}(0.15 \mathrm{ml})$ solution was added, mixed and allowed to react for another 6 minutes Then $4 \% \mathrm{NaOH}$ $(2.0 \mathrm{ml})$ was added to the mixture, shaken and left for 15 minutes The absorption was read at $510 \mathrm{~nm}$. Results were expressed as $\mathrm{mg}$ rutin equivalents per $1 \mathrm{~g}$ of dry matter (mg RUE/g DM).

Condensed tannin concentration. Condensed tannin concentration was determined by a method described by Michel et al. (2012). Sea buckthorn part extract $(0.2 \mathrm{ml})$ was added to $4 \%$ vanillin--ethanolic solution $(2.4 \mathrm{ml})$ and concentrated $\mathrm{HCl}(1.2 \mathrm{ml})$ and allowed to stand for $15 \mathrm{~min}$. The absorption was detected at $500 \mathrm{~nm}$ by a spectrophotometer. Results were expressed as $\mathrm{mg}$ catechin equivalents per $1 \mathrm{~g}$ of dry matter (mg CE/g DM).

\section{Antioxidant activity}

DPPH free radical scavenging assay. The free radical scavenging activity was determined according to Brand-Williams et al. (1995) using 2.2-diphenyl-1-picrylhydrazyl (DPPH) reagent prepared by mixing with methanol to reach absorption about 0.9 at wavelength of $515 \mathrm{~nm}$. The extract $(0.131 \mathrm{ml})$ was mixed with DPPH solution $(2.9 \mathrm{ml})$ and left to stand for $30 \mathrm{~min}$ in a dark place. The absorption of samples was read at $515 \mathrm{~nm}$ using a spectrophotometer. Results were expressed in $\mathrm{mg}$ Trolox equivalents per $1 \mathrm{~g}$ of dry matter (mg TE/g DM).

Ferric reducing antioxidant power assay. Reducing antioxidant power evaluation was carried out by a spectrophotometric method described by Benzie and Strain (1996) and Kumar et al. (2011). Before analysis, fresh ferric reducing antioxidant power (FRAP) reagent was prepared by mixing $300 \mathrm{mM}$ acetate buffer ( $\mathrm{pH}$ 3.6), $10 \mathrm{mM}$ 2,4,6- Tripyridyls-Triazine made in $40 \mathrm{mM} \mathrm{HCl}$ and $20 \mathrm{mM} \mathrm{FeCl} \cdot 6 \mathrm{H}_{2} \mathrm{O}$ in the ratio of $10: 1: 1(\mathrm{v} / \mathrm{v} / \mathrm{v})$, respectively, and then warmed at $37{ }^{\circ} \mathrm{C}$ in a water bath. Each extract $(0.210 \mathrm{ml})$ was added to FRAP reagent $(3.8 \mathrm{ml})$ and allowed to stand for $10 \mathrm{~min}$ in the dark. The absorption was detected at wavelength $593 \mathrm{~nm}$. Results were expressed in mg Trolox equivalents per $1 \mathrm{~g}$ of dry matter (mg TE/g DM).

Statistical analysis. Data were analysed using SPSS Statistics 17.0 software. The results were expressed as means \pm standard deviations for at least three experimental measurements. One-way analysis of variance (ANOVA), Duncan multiple range test and Pearson correlation tests were used. Significance was set at $P \sim 0.05$. The Pearson correlation test was performed to determine relationships between chemical parameters.

\section{RESULTS}

There were significant differences $(P<0.05)$ in the concentrations of total phenols, total flavonoids and condensed tannins among parts of sea buckthorn plant (Table 1). 
PHENOL CONTENT IN VARIOUS SEA BUCKTHORN PARTS

\begin{tabular}{c|l|c|c|c}
\hline $\begin{array}{c}\text { Plant } \\
\text { gender }\end{array}$ & Part & $\begin{array}{c}\text { Total phenol } \\
\text { concentration, } \\
\text { mg GAE/g DM }\end{array}$ & $\begin{array}{c}\text { Total flavonoid } \\
\text { concentration, } \\
\text { mg RUE/g DM }\end{array}$ & $\begin{array}{c}\text { Condensed tan- } \\
\text { nin concentra- } \\
\text { tion, } \\
\text { mg RUE/g DM }\end{array}$ \\
\hline Female & Leaves & $165.76 \pm 2.52^{\mathrm{a}}$ & $47.76 \pm 0.43^{\mathrm{c}}$ & $1.32 \pm 0.28^{\mathrm{e}}$ \\
& Shoots & $119.63 \pm 3.67^{\mathrm{c}}$ & $79.57 \pm 0.75^{\mathrm{b}}$ & $22.47 \pm 0.12^{\mathrm{b}}$ \\
Male & Leaves & $123.78 \pm 2.53^{\mathrm{b}}$ & $36.47 \pm 0.27^{\mathrm{e}}$ & $1.03 \pm 0.16^{\mathrm{e}}$ \\
& Shoots & $84.94 \pm 0.91^{\mathrm{e}}$ & $47.01 \pm 1.69^{\mathrm{c}}$ & $11.00 \pm 0.52^{\mathrm{d}}$ \\
& Flowers & $120.16 \pm 0.92^{\mathrm{c}}$ & $81.72 \pm 0.76^{\mathrm{a}}$ & $18.94 \pm 0.73^{\mathrm{c}}$
\end{tabular}

Different letters in a column show significant differences between samples within each analysed parameter at $P \sim 0.05$. Results are expressed as mean \pm standard deviation $(n=4)$. GAE, gallic acid equivalent; RUE, rutin equivalent; CAE, catechin equivalent; DM, dry matter.

The leaves of female and male plants were the best sources of total phenols $(165.76 \mathrm{mg} / \mathrm{g}$ DW and $123.78 \mathrm{mg} / \mathrm{g} \mathrm{DW}$, respectively). The concentration of total flavonoids had the highest level in male flowers $(81.72 \mathrm{mg} / \mathrm{g} \mathrm{DW})$ and the lowest in male leaves $(36.47 \mathrm{mg} / \mathrm{g} \mathrm{DW})$. The shoots and green berries of female sea buckthorn plant contained the highest concentrations of condensed tannins, reaching 22.47 and $23.29 \mathrm{mg} / \mathrm{g}$ DW which was about 20 times higher than in leaves of both genders.

Similar to phenolic compounds, also antioxidant activity significantly differed ( $\mathrm{P} \sim 0.05$ ) between sea buckthorn leaves, shoots, green berries, and flowers. The activity de- termined by the FRAP method (Fig. 1) showed higher values than those by DPPH radical assay (Fig. 2).

The highest antioxidant activity by both methods was observed in leaves of female plants $(220.97 \mathrm{mg} / \mathrm{g}$ DW for FRAP and $43.76 \mathrm{mg} / \mathrm{g}$ DW for DPPH assay), followed by male leaves, female and male shoots.

Pearson correlation coefficients were strong and significant between total phenol and FRAP $(r=0.945)$, and between total phenols and DPPH $(r=0.883)$.

\section{DISCUSSION}

As sea buckthorn leaves and shoots are considered to have a great potential in food processing due to biologically active substances (Shunguang et al., 2003), and especially if collected in summer (as for herbal medicine) when shoots are still green, tender and non-woody. Together with the leaves and shoots, also small green berries were picked. Male flowers were harvested in the middle of spring, because at that time they are rich in pollen, which is thought to contain high amount of bioactive substances.

Although all parts of sea buckthorn plant are considered to contain high levels of hydrophilic (polyphenols, chlorophyll, vitamin C) and lipophilic (carotenoids, tocopherols, vitamin E) compounds (Jain et al., 2008; Saggu and Kumar, 2008; Kumar et al., 2011), only leaves have gained great interest during the last decades.
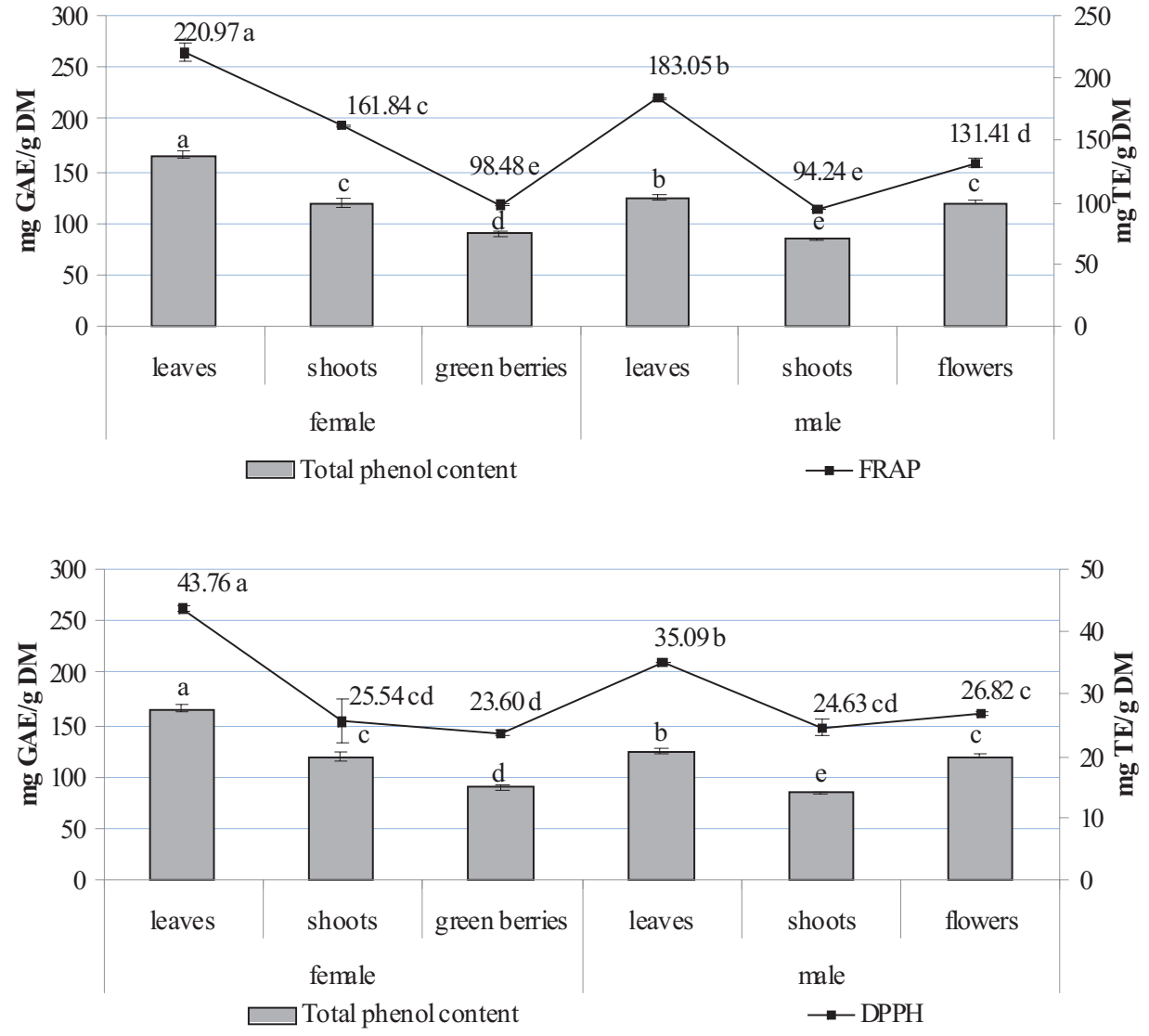

Fig. 1. Ferric reducing antioxidant power (FRAP) and total phenol concentration of sea buckthorn parts. Different letters show significant differences between samples within each analysed parameter at $P \sim 0.05$. Results are expressed as mean \pm standard deviation $(n=4)$. TE, trolox equivalent; GAE, gallic acid equivalent; DM, dry matter. 
In our study, the highest values for total phenol, total flavonoid and condensed tannin concentration were observed in leaves of female plants - $165.76 \mathrm{mg} / \mathrm{g}, 47.76 \mathrm{mg} / \mathrm{g}$ and $1.32 \mathrm{mg} / \mathrm{g}$, respectively. These values are lower than those reported by Upadhyay et al. (2010) for sea buckthorn leaf samples collected in the North-West Himalayas: $56.28 \mathrm{mg} / \mathrm{g}$ total phenols and only $20.76 \mathrm{mg} / \mathrm{g}$ total flavonoids. However, the values in our study were lower than in leaves collected from west Pamirs where flavonoid content varied from 31 to $123.8 \mathrm{mg} / \mathrm{g}$ (Singh, 2006). Michel et al. (2012) in their research found that leaves extracted by ethanol (as in our study) contain $65 \mathrm{mg} / \mathrm{g}$ total phenols and even $13 \mathrm{mg} / \mathrm{g}$ condensed tannins, but the authors used different extraction methods, solvents, and solvent-to-sample ratios, and even small differences can significantly affect the final value. In contrat to the study by Upadhyay et al. (2010), where autumn leaves were studied, we used leaves collected in the beginning of summer. Therefore, seasonal variation should be taken into consideration together with plant age, genetic, agronomic and storage variations. According to Kondakova et al. (2009), fruits of berry plants grown in a colder climate and under a shorter vegetation period have higher levels of phenolic compounds. These differences, governed by geographical region, probably also occur for other plant parts.

Phenolic compounds (flavonoids, phenolic acids, and tannins) are considered to be the major plant compounds possessing antioxidant activity (Upadhyay et al., 2010). Therefore, for better characterisation of sea buckthorn leaves, shoots, berries and flowers, two commonly applied antioxidant activity testing methods were used: ferric reducing antioxidant power and free radical scavenging activity (DPPH). The findings in the current study show that sea buckthorn leaves of both gender shrubs contained the highest amount of total phenols and also possessed the highest antioxidant activity. This was also indicated by Pearson correlation analysis, by a strong and significant relationships between total phenol concentration and FRAP/ DPPH activity in all tested sea buckthorn samples.

The study showed that different parts of sea buckhorn are rich in phenolic compounds and exhibit antioxidant activity, and that the most valuable part with regard to total phenol content and antioxidant activity is leaves from female tree, and the less valuable - shoots from male trees. There are differences in chemical composition and activity of various sea buckthorn parts, and more detailed investigation of their extracts, specific fractions and compounds and their activity during the whole vegetative season is needed.

\section{ACKNOWLEDGEMENTS}

The research was conducted and publication prepared within the framework of the ERAF project "Use of sea buckthorn vegetative parts for development of food products with high antioxidant activity" (2010/ 0246/ 2DP2.1.1.0/ 10/ APIA/ VIAA/ 159).

\section{REFERENCES}

Benzie, I. F, Strain, J. J. (1996). The ferric reducing ability of plasma (FRAP) as a measure of Antioxidant Power: The FRAP assay. Anal. Biochem., 239, $70-76$.

Brand-Williams, W., Cuvelier, M. E., Berset, C. (1995). Use of a free radical method to evaluate antioxidant activity. Lebensmittel-Wiss. Technol./Food Sci. Technol., 28, 25-30.

Guliyev, V. B., Gul, M., Yildirim, A. (2004). Hippophae rhamnoides L.: Chromatographic methods to determine chemical composition, use in traditional medicine and pharmacological effects. J. Chromatogr. B, 812, 291-307.

Jain, M., Ganju, L., Katiyal, A., Padwad, K. P., Mishra, K. P., Chanda, S., Karan, D., Yogendra, K. M. S., Sawhney, R. C. (2008). Effect of Hippophae rhamnoides leaf extract against Dengue virus infection in human blood-derived macrophages. Phytomedicine, 15, 793-799.

Jeong, H. J., Lee, J. W., Kim, K. S., Kim, J. S., Han, S. N., Yu, C. Y., Lee, K. J, Kwon, S. Y., Kim, J. M. (2010). Antioxidant and antimicrobial activities of extracts from a medicinal plant, sea buckthorn. J. Korean Soc. Appl. Biol. Chem., 53 (1), 33-38.

Kondakova, V., Tsvetkov, I., Batchvarova, R., Badjakov, I., Dzhambazova, T., Slavov, S. (2009). Phenol compound - qualitative index in small fruits. Biotechnology Biotechnol. Equip., 23, 1444-1448.

Kumar, Y. M. S., Dutta, R., Prasad, D., Misra, K. (2011). Subcritical water extraction of antioxidant compounds from sea buckthorn (Hippophae rhamnoides) leaves for the comparative evaluation of antioxidant activity. Food Chem., 127, 1309-1316.

Moure, A., Cruz, J. M., Franco, D., Dominguez, J. M., Sineiro, J., Dominguez, H., Nunez, M. J., Parajo, J. C. (2001). Natural antioxidants from residual sources. Food Chem., 72, 145-171.

Michel, T., Destandau, E., Le Floch, G., Lucchesi, M. E., Elfakir, C. (2012). Antimicrobial, antioxidant and phytochemical investigations of sea buckthorn (Hippophae rhamnoides L.) leaf, stem, root and seed. Food Chem., 131, 754-760.

Saggu, S., Divekar, H. M., Gupta, V., Sawhney, R. C., Banerjee, P. K., Kumar, R. (2007). Adaptogenic and safety evaluation of seabuckthorn (Hippophae rhamnoides) leaf extract: A dose dependent study. Food Chem. Toxicol., 45, 609-617.

Saggu, S., Kumar, R. (2008). Effect of seabuckthorn leaf extracts on circulating energy fuels, lipid peroxidation and antioxidant parameters in rats during exposure to cold, hypoxia and restraint $(\mathrm{C}-\mathrm{H}-\mathrm{R})$ stress and post stress recovery. Phytomedicine, 15 (6-7), 437-446.

Shunguang, L., Zhengping, J., Xiufeng W., Keqin W., Dengming L. (2003). Sea buckthorn breeding for the purpose of leaves utilization. In: Proceedings of the $1^{\text {st }}$ Congress of the International Seabuckthorn Association, 14-18 September 2003 (pp. 36-46). Berlin.

Singh, V. (2006). Free radicals, diseases, anti-oxidants and anti-oxidant properties of seabuckthorn (Hippophae rhamnoides L.). In: Singh, V. (Ed.). Seabuckthorn (Hippophae L.). A Multipurpose Wonder Plant. Vol. II: Biochemistry and Pharmocology (pp. 3-69). Delhi: Daya Publishing House.

Singleton, V. L., Orthofer, R., Lamuela-Raventos, R. M. (1999). Analysis of total phenols and other oxidation substrates and antioxidants by means of Folin-Ciocalteau reagent. Meth. Enzymol., 299, 152-178.

Upadhyay, N. K., Kumar, M. S. Y., Gupta, A. (2010). Antioxidant, cytoprotective and antibacterial effects of Sea buckthorn (Hippophae rhamnoides L.) leaves. Food Chem. Toxicol., 48, 3443-3448.

Uttara, B., Singh, A. V., Zamboni, P., Mahajan, R. T (2009). Oxidative stress and neurodegenerative diseases: A review of upstream and downstream antioxidant therapeutic options. Curr. Neuropharmacol., 7 (1), 65-74.

Wannes, W. A, Mhamdi, B, Sriti, J, Jemia, M. B., Ouchikh, O., Hamdaoui, G., Kchouk, M. E., Marzouk, B. (2010). Antioxidant activities of the essential oils and methanol extracts from myrtle (Myrtus communis var. italica L.) leaf, stem and flower. Food Chem. Toxicol., 48 (5), 1362-1370. 


\section{FENOLSAVIENOJUMU SATURS DAŽĀDĀS SMILTSĒRKŠĶU AUGA DAḶĀS}

Rakstā aplūkots fenolsavienojumu saturs dažādās smiltsērkšķu auga daḷās un to antioksidatīiā aktivitāte. Kā pētījuma objekts izvēlētas sievišķo un vīrišķo augu lapas, jaunie dzinumi, zal̦ās ogas, kas ievāktas jūnija vidū, un ziedi, kas ievākti aprīla beigās. Paraugiem analizēts kopējo fenolu, kopējo flavonoīdu un kondensēto tanīnu saturs, kā arī antioksidatīvā aktivitāte ar FRAP (ferric reducing antioxidant power) un DPPH (2.2-diphenyl-1-picrylhydrazyl) metodi. Vērtīgākā auga dą̣a izrādījās sievišķā auga lapas, kurām konstatēts augstākais kopējo fenolu saturs un antioksidatīvā aktivitāte, lietojot abas metodes, savukārt vismazākie minētie rādītāji bija jaunajiem dzinumiem no vīrišķā auga. Rezultāti norāda uz būtiskām atšḳirībām smiltsērkšḳu auga dạu kịmiskajā sastāvā un bioloǵiskajā aktivitātēe, tādēḷ nepieciešami padziḷināti pētījumi par ekstraktiem, to frakcijām vai atsevišḳiem savienojumiem un to izmaiṇām visā veğetācijas sezonā. 


\title{
CHANGES OF PHYSICALLY-CHEMICAL PARAMETERS OF 'NANTE' CARROT HYBRIDS DURING STORAGE IN TRADITIONAL CONDITIONS
}

\author{
Ingrīda Augšpole, Tatjana Rakčejeva, and IIze Grāmatiṇa \\ Department of Food Technology, Latvia University of Agriculture, Lielā iela 2, Jelgava LV 3001, LATVIA \\ ingrida.augspole@inbox.lv
}

Communicated by Dalija Seglina

\begin{abstract}
The current research focuses on changes of physically-chemical parameters of 'Nante' carrot hybrids during storage in traditional conditions. Quality parameters during carrot storage for six months at temperature $8 \pm 2{ }^{\circ} \mathrm{C}$ and relative air humidity $85 \pm 1 \%$ were evaluated using standard methods: soluble solids (digital refractometer), dietary fibre (AOAC 985.29), ascorbic acid (iodometric) and firmness (TA.XT.plus Texture Analyser). Before storage, hybrids 'Nante/Berlikum', 'Nante/Maestro' and 'Nante/Bolero' had higher soluble solid content: 1.6 times higher comparing with hybrid 'Nante/Forto' and 1.2 times higher compared with hybrid 'Nante/Champion'. These hybrids also had higher ascorbic acid content: 2.0 times higher than in 'Nante/Forto' and 'Nante/Champion'. Significant differences were not found in dietary fibre content and firmness of non-stored carrots. Substantial differences were observed in soluble solid content in the hybrid 'Nante/Berlikum' during six-month storage - the content decreased 2.0 times. However, nonsignificant decrease of soluble solids content decreases was found for the hybrid 'Nante/Forto'. Changes in hybrid firmness and dietary fibre amount were not significant during storage for four months. Ascorbic acid content of the carrot hybrids during storage decreased by 3.4 times.
\end{abstract}

Key words: carrot, soluble solids, dietary fibre, ascorbic acid, firmness, storage.

\section{INTRODUCTION}

Carrot is a globally important vegetable crop that is a source of important nutritional compounds (including pro-vitamin A) through their carotenoid content, and adds flavour and texture to many diets across the world (Rakcejeva et al., 2012). Vegetables are an important part of our diet. They provide not only the major dietary fibre component of our food, but also a range of micronutrients, including minerals, vitamins and antioxidant compounds (Rashidi, 2011; Rakcejeva et al., 2012; Singh et al., 2012). It is known that growth conditions and management practices affect the concentrations of these compounds, and thus also nutritional value and taste (Singh et al., 2012). As consumers move toward functional foods with specific health effects, scientists and food manufacturers have also taken an interest in the potential of the antioxidant constituents of carrots to maintain health (Yen et al., 2008). Considering that carrot is one of the primary vegetables in many countries and can adequately supply most, if not all, of the vitamin A daily requirement of humans (from a $100 \mathrm{~g}$ serving of raw carrot (Singh et al., 2012)), it is important to enhance the nutritional status of carrot when possible.

Carrots are an important source of vitamin $\mathrm{C}$ in the human diet, but the content can decrease during storage (Matejkova and Petrikova, 2010). Compared to other horticultural crops, it has been reported that New Zealand-grown carrots have higher vitamin $\mathrm{C}$ content than New Zealand-grown grapes, nectarines, pears and plums (Leong, 2012). Carrots can be consumed fresh or cooked, either alone or with other vegetables, in the preparation of soups, stews, curries and pies. Fresh grated roots are used in salads and tender roots are pickled (Soria et al., 2009; Rashidi, 2011). Ascorbic acid (vitamin C) is used extensively in the food industry, not only for its nutritional value but also for its many functional contributions to product quality. Leong in 2012 reported that the human body is unable to synthesise vitamin $\mathrm{C}$ due to the lack of enzyme L-gulonolactone oxidase. Vitamin $\mathrm{C}$ helps to prevent scurvy, reduce the risk of cancers and cardiovascular diseases and enhance the absorption of iron to prevent anaemia. In plants, the active form of vitamin C, i.e. L-ascorbic acid (L-AA) acts as an enzyme cofactor, electron donor or acceptor in the proton electron transport system and as a substrate for oxalate and tartrate biosynthesis. The stability of vitamin $\mathrm{C}$ in carrots can be influenced by factors from pre-harvest (including cultivars and environment conditions) to harvest and post-harvest handling (Leong, 2012). Some scientists believe that vitamin $\mathrm{C}$ acts as an antioxidant in plants and that its levels are sensitive to a variety of environmental or stress factors, for 
example, light, temperature, salt and drought, atmospheric pollutants, metals or herbicides (Singh et al., 2012). Fresh vegetables have a short durability, and are exposed to conditions that destroy their superior quality in a short period of time, before cooking and consumption (Giannakourou and Taoukis, 2003). Cultivar and soil climatic conditions affect the concentrations of compounds in carrot roots, which are important for both human nutrition and taste (Smoleń and Sady, 2009).

Fruits and vegetables are good sources of dietary fibre (DF). $\mathrm{DF}$ is a group of food components, which are resistant to hydrolysis by human digestive enzymes. The health benefits of dietary fibre have led to increased consumption of fibrerich products (Chantaro et al., 2008). Fibres are an integral part of the foodstuffs we consume daily; the main sources in which these fibres occur are plants, vegetables, cereal grains, woody plants, fruits, legumes, leguminous plants, etc. Based on their simulated intestinal solubility, dietary fibres are either classified as insoluble or soluble fibres. Insoluble fibres include lignin, cellulose, and hemicelluloses; soluble fibres include pectins, beta-glucans, galactomanan gums, and a large range of non-digestible oligosaccharides including inulin (Rodriguez et al., 2006; Chantaro et al., 2008; Slavin, 2008). At present, there are still many aspects about DF properties and functions that remain unclear. Botanists define fibre as a part of the plant organs, chemists as a group of chemical compounds, consumers as a substance with beneficial effects on human health, and for the dietetic and chemical industries DF is a subject of marketing (Rodriguez et al., 2006). DF is part of a plant matrix which is largely intact. Non-digestible plant carbohydrates in foods are usually a mixture of polysaccharides that are integral components of the plant cell wall or intercellular structure (Slavin, 2008). Post-harvest storage of fresh fruits and vegetables needs to be such that the organoleptic (colour, texture and flavour) and nutritional properties of the final product are maintained in optimal conditions. Changes in fibre quantity and quality depend to a great extent on storage conditions (Rodriguez et al., 2006). DF concentrates obtained after dehydration of fresh fruit and vegetables can be used in the food industry as functional ingredients with excellent results. DF from cereals is more frequently used than fibre from fruit or vegetables. However, fruit and vegetable fibre has better quality due to it's higher soluble DF content, better water and oil holding capacities and better colonic fermentability, as well as lower phytic acid contents and energy (Eim at al., 2008). Some scientists believe that DF acts as a protective agent against cardiovascular diseases, diverticulosis, constipation, irritable colon, colon cancer and diabetes (Chau et al., 2004; Eim at al., 2008; Slavin, 2008; Brownlee, 2011). Five specific methods of DF analysis and the certified values in dried carrots used as European Reference Material o(riginally certified as BCR515) are shown in the Table 1 (Emons, 2011).

Soluble solids in carrot roots consist mostly of soluble sugars, and therefore affect sensory sweetness impression (Gajewski et al., 2010). Soluble solid content has a pro-
Table 1

CONTENT OF DIETARY FIBRE IN DRIED CARROTS (Emons, 2011)

\begin{tabular}{c|c|l}
\hline Nr. & $\begin{array}{c}\text { Mass fraction } \\
\mathrm{g} \cdot \mathrm{kg}^{-1(*)}\end{array}$ & \multicolumn{1}{c}{ Dietary fibre according to } \\
\hline 1 & 311 & AOAC, 1990, 985.29 \\
2 & 271 & Englyst by GC \\
3 & 298 & Uppsala 994.13 \\
4 & 295 & AOAC, 1992, MES-TRIS, 991.43 \\
5 & 252 & Englyst by Colorimetry \\
\hline
\end{tabular}

(*) The values are expressed on dry mass basis.

found influence on the storage period length, mechanical properties and quality characteristics of fruits and vegetables (Rashidi, 2011). The sensory qualities of fresh vegetable such as carrot depend on their texture, which correlate well with the freshness of the produce. The cutting test is one of the common methods for determining textural changes in food products. It is generally applied with maximal cutting force as an attribute of the studied material quality (Rawson et al., 2012).

Texture is a major quality characteristic of fruits and vegetables. The notion of "texture engineering" has been introduced in the context of texture optimisation of processed fruits and vegetables (Roeck et al., 2010). Many earlier researchers employed instrumental texture measurement (also known as the hardness) to quantify product quality. Hardness is often defined as the peak force corresponding to the first compression of the sample. Product firmness and tissue elasticity are provided by pectic substances. Pectin is a major component present in middle lamella. Solubilisation of pectic compounds in the middle lamella results in intercellular weakening and cell separation leading to texture degradation. Under controlled conditions, the action of endogenous pectinases, such as pectinmethylesterase (PME) and polygalacturonase (PG), on the pectin is highly correlated with texture degradation of fruits and vegetables (Rastogi et al., 2008). Traditionally the harvesting of carrots in Latvia starts from middle of summer, however, the main harvest occurs in autumn. Worldwide carrots can have purplish, yellow, green, white and black colour, but in Latvia mainly bright orange. The main carrot variety is 'Nante' and its hybrids (Rakcejeva et al., 2012). Unfortunately, the brittleness that accompanies crisp texture tends to have a negative impact on the "durability" of carrots in mechanical harvesting and washing (Prohens et al., 2007).

The aim of the study was to determine changes of physically-chemical parameters of 'Nante' carrot hybrids during storage in traditional conditions.

\section{MATERIALS AND METHODS}

The study was carried out in the Department of Food Technology at the Latvia University of Agriculture. Carrots (Daucus carota L.) grown in Latvia and harvested in Zemgale region from four farms in the first part of October 
2011 were immediately used for experiments. Serotinous 'Nante' carrot hybrids 'Nante/Berlikum', 'Nante/Maestro', 'Nante/Forto', 'Nante/Bolero' and 'Nante/Champion' were used. Quality parameters of carrots were determined during six-month storage at temperature $+8 \pm 2{ }^{\circ} \mathrm{C}$ and relative air humidity $85 \pm 1 \%$ using standard methods. Carrots were sampled in October, December 2011 and February, April 2012 (sampling interval of two months). Meteorological data were obtained from the Latvian Environment, Geology and Meteorology Centre. Meteorological conditions of 2011 where characteristic with relatively high temperatures in the first two months of summer of 2011. June and July months were also warm, with average air temperature in June $+24.5{ }^{\circ} \mathrm{C}$ and maximum air temperature $+32.3{ }^{\circ} \mathrm{C}$. In summer 2011, average rainfall was $274 \mathrm{~mm}$, i.e. close to optimal precipitation. Autumn 2011 in Latvia was warm and relatively dry. All autumn months were warmer and drier than normal. The autumn temperature was 1.9 degrees above normal. Autumn precipitation was $67 \%$ of the average level.

Ascorbic acid. Ascorbic acid content was determined by titration with $0.05 \mathrm{M}$ iodine solution (Moor et al., 2005). Samples of $25 \mathrm{~g}$ carrot were mixed with $100 \mathrm{~mL} \cdot 6 \mathrm{~g} \cdot 100$ $\mathrm{g}^{-1}$ oxalic acid solution and homogenised for $60 \mathrm{~s}$, and then the sample was filtered. $10.0 \mathrm{ml}$ of the filtrate and $2.0 \mathrm{ml}$. $1 \mathrm{~g} 100 \mathrm{~g}^{-1}$ starch solution was titrated until the endpoint was reached (first sign of blue colour that persisted after $30 \mathrm{~s}$ ). The titration was repeated in triplicate for each sample. The ascorbic acid content was calculated as:

$x=\frac{V_{\text {sample }} \times 5000}{V_{s \tan \text { dard }} \times g}$, where

$\mathrm{V}_{\text {sample }}$ - iodine amount for sample titration, $\mathrm{ml}$;

$\mathrm{V}_{\text {standard }}$ - iodine amount for vitamin $\mathrm{C}$ standard solution titration, ml;

$\mathrm{g}$ - sample weight, $\mathrm{g}$.

Total dietary fibre. The total dietary fibre in samples was determined according to the AOAC approved method No. 985.29. The experiments were carried out by using a FOSS Analytical Fibertec E 1023 system with enzymatic processing by incubation in a thermostatic shaking water bath; residue filtration was conducted using a Filtration Module, and protein determination by Kjeldahl (Method 46-12, 1995) nitrogen equipment. The analyses were performed in three repetitions. The samples were defatted and dried with a particle size less than $0.5 \mathrm{~mm}$. Then each sample was enzymatically digested with $\alpha$-amylase incubation at $+100{ }^{\circ} \mathrm{C}$, and with protease and amyloglucosidase incubation at $+60{ }^{\circ} \mathrm{C}$. After digestion, the total fibre content was precipitated by adding $95 \mathrm{~g} \cdot 100 \mathrm{~g}^{-1}$ ethanol. The solution was then filtered and fibre was collected, dried and weighed. The protein and ash content were determined for correction of fibre content (Prosky, 1990).

Soluble solids content (SSC). The soluble solid content ( ${ }^{\mathrm{O}}$ Brix) was determined at temperature $+20 \pm 2{ }^{\circ} \mathrm{C}$ with a digital refractometer (deviation of measuring instrument $\pm 0.1 \%$ ) by standard method ISO 2173:2003.

Firmness. A structure analyser "TA.XT.plus texture Analyser" (Stable Micro Systems Ltd., Surrey, UK) and measuring probe HDP/BSK (blade set with knife, supplied with the Texture Analyser) were used for firmness determination. The system was equipped with a compression cell of $50 \mathrm{~kg}$ and software Texture Exponent 32. Firmness was measured as the maximum penetration force $(\mathrm{N})$ reached during tissue breakage. The measuring parameters were: pre-test speed $\cdot 2 \mathrm{~mm} \mathrm{~s}^{-1}$; test speed $2 \cdot \mathrm{mm} \mathrm{s}^{-1}$; post-test speed $10 \mathrm{~mm} \cdot \mathrm{s}^{-1}$; penetrating distance $23 \mathrm{~mm}$ into the carrot. The measurement was triggered automatically at 0.04903 N (Rakcejeva et al., 2012).

Statistical analysis. Data were expressed as mean \pm standard deviation; for mathematical data processing the value of $P<0.05$ was regarded as statistically significant. One-way analysis of variance (ANOVA) was used to determine the significance of differences. In cases of statistically significant differences, homogeneous groups were determined by Tukey's multiple comparison test at the level of confidence $\alpha=0.05$. The statistical analyses were performed using Microsoft Excel 2007.

\section{RESULTS}

Vitamin C. Vitamin C content $(P<0.05)$ (Fig. 1) significantly differed between fresh carrot hybrids. The highest vitamin C contents occurred in hybrids 'Nante/Maestro',

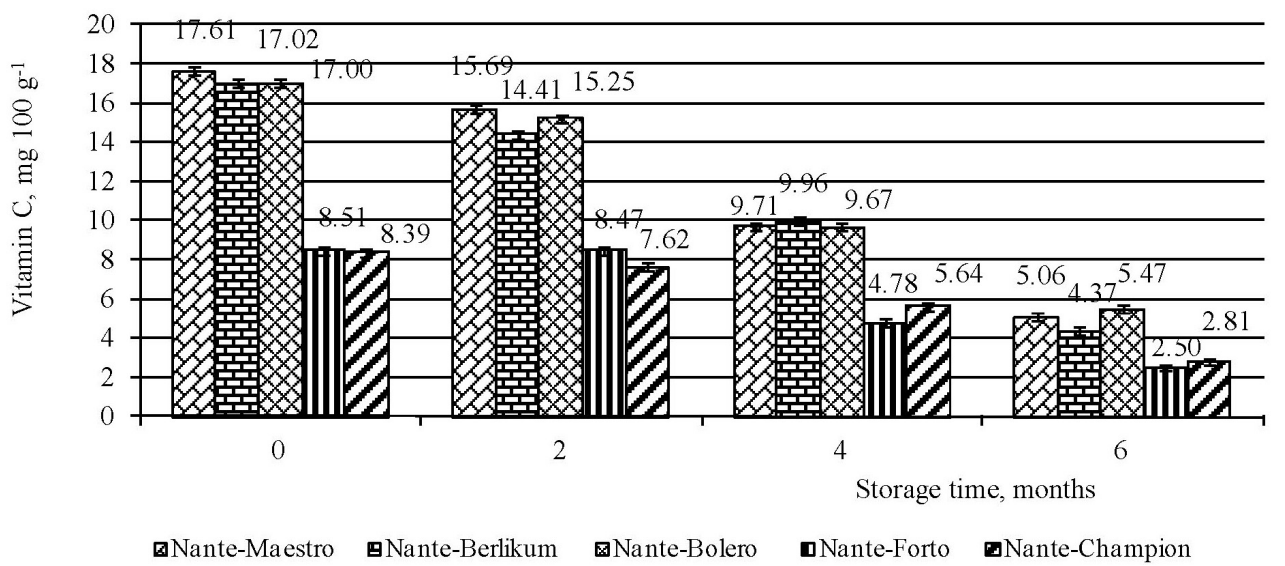

Fig. 1. Vitamin $\mathrm{C}$ content in variety 'Nante' carrot hybrids during storage. 
'Nante/Berlikum' and 'Nante/Bolero' (17.61 \pm 0.17, $17.02 \pm$ 0.01 and $17.00 \pm 0.01 \mathrm{mg} 100 \mathrm{~g}^{-1}$, respectively), which were significantly higher $(P<0.05)$ than in hybrids 'Nante/Forto' and 'Nante/Champion' $(8.51 \pm 0.01$ and $8.39 \pm$ $0.17 \mathrm{mg} \cdot 100 \mathrm{~g}^{-1}$, respectively). Vitamin C decreased significantly during carrot storage. After two-month storage, the decrease in ascorbic acid content was not significant $(P<$ 0.05): $~ 1.1$ times compared with initial $\mathrm{C}$ vitamin content. However, during carrot storage for four mounts, vitamin $\mathrm{C}$ content decreased by $\sim 1.7$ times, and after six-month storage by up to 3.3 times, particularly in hybrid 'Nante/ Berlikum' - 3.9 times less comparing with vitamin content in fresh carrots. These changes mainly could be explained by physically-chemical reactions in carrots during storage.

Total dietary fibre. It was found that the content of total dietary fibre in 'Nante' hybrid carrots ranged from $25.78 \pm$ 1.54 to $34.25 \pm 5.79 \mathrm{~g} \cdot 100 \mathrm{~g}^{-1}$. Higher total dietary fibre content was observed in non-stored hybrids 'Nante/Bolero', 'Nante/Maestro' and 'Nante/Berlikum': $34.25 \pm 5.79,29.80$

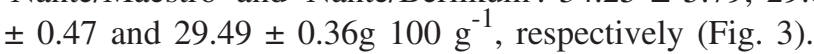

Soluble solids content and firmness. The soluble solid content (SSC) in fresh carrot hybrids ${ }^{\circ}$ Brix (Fig. 3) was within the range from $10.30 \%$ in 'Nante/Maestro' to $6.1 \%$ in 'Nante/Forto'. Soluble solid content was similar in 'Nante/Maestro', 'Nante/Bolero' and 'Nante/Berlikum': 10.30 $\pm 0.09 \%, 9.97 \pm 0.08 \%$ and $9.70 \pm 0.09 \%$, respectively. The lowest soluble solid content was observed in fresh carrots hybrids 'Nante/Champion' and 'Nante/Forto' (8.16 $\pm 0.18 \%$ and $6.11 \pm 0.07 \%$, respectively).
FIRMNESS (N) OF CARROT BEFORE AND AFTER STORAGE

\begin{tabular}{l|c|c|c}
\hline \multirow{2}{*}{ Carrot hybrids } & Before storage & $\begin{array}{c}\text { After six-month } \\
\text { storage }\end{array}$ & Whole period \\
\cline { 2 - 4 } & average $\pm \mathrm{SD}$ & average $\pm \mathrm{SD}$ & $\mathrm{X}_{\min }-\mathrm{X}_{\max }$ \\
\hline Nante/Bolero & $95.09 \pm 21.01$ & $100.41 \pm 7.50$ & $72.76-112.17$ \\
Nante/Maestro & $103.98 \pm 16.19$ & $87.99 \pm 9.03$ & $67.24-105.43$ \\
Nante/Berlikum & $82.24 \pm 14.78$ & $95.65 \pm 9.59$ & $53.62-109.96$ \\
Nante/Forto & $81.28 \pm 14.54$ & $114.47 \pm 9.91$ & $81.46-126.56$ \\
Nante/Champion & $82.93 \pm 15.08$ & $71.74 \pm 5.28$ & $62.08-95.11$ \\
Total & 89.70 & 94.05 & $67.43-109.85$
\end{tabular}

The firmness of carrot hybrids before and after storage is summarized in Table 2. Samples of 'Nante/Bolero', 'Nante/Berlikum' and 'Nante/Forto' required higher force for cutting than fresh carrot samples. During storage, 1.05 times higher cutting force needed to be applied than for fresh carrots. This was expected, as carrots contain about $90 \%$ water, which gives rigidity to the texture. Significant differences $(P<0.05)$ during the whole period of storage in firmness of carrot hybrids were found.

\section{DISCUSSION}

The retention of vitamin $\mathrm{C}$ is often used as an estimation of the overall nutritional quality of vegetables (GamboaSantos et al., 2012), as it is by far the least stable nutrient; it is highly sensitive to oxidation and leaching into water-soluble media during storage. It begins to degrade immediately

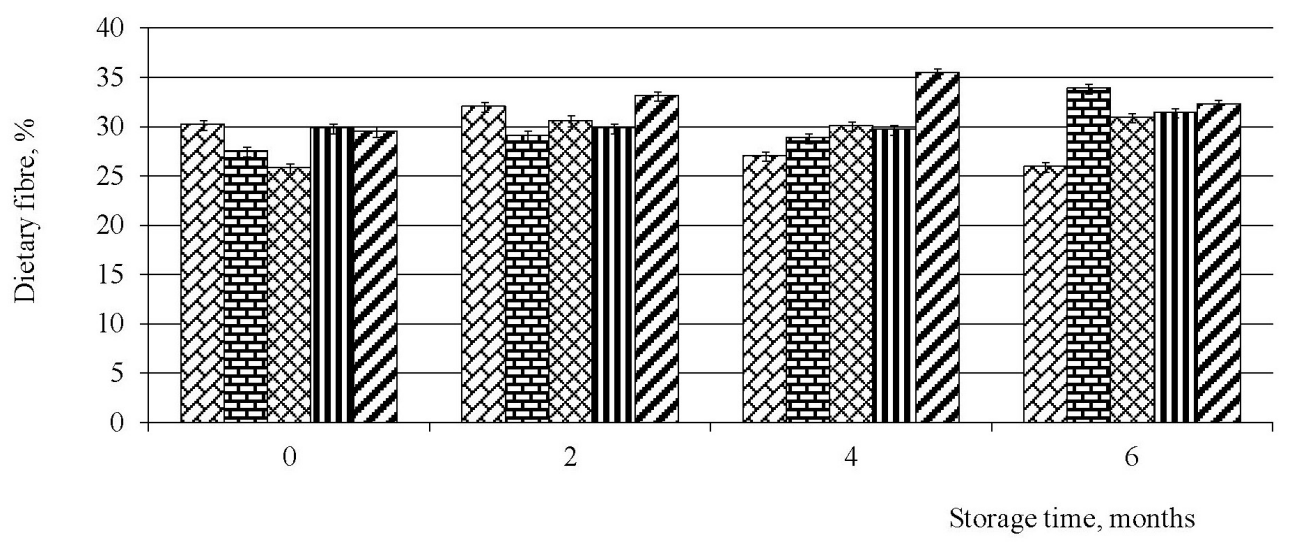

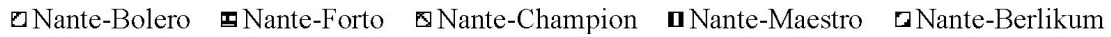

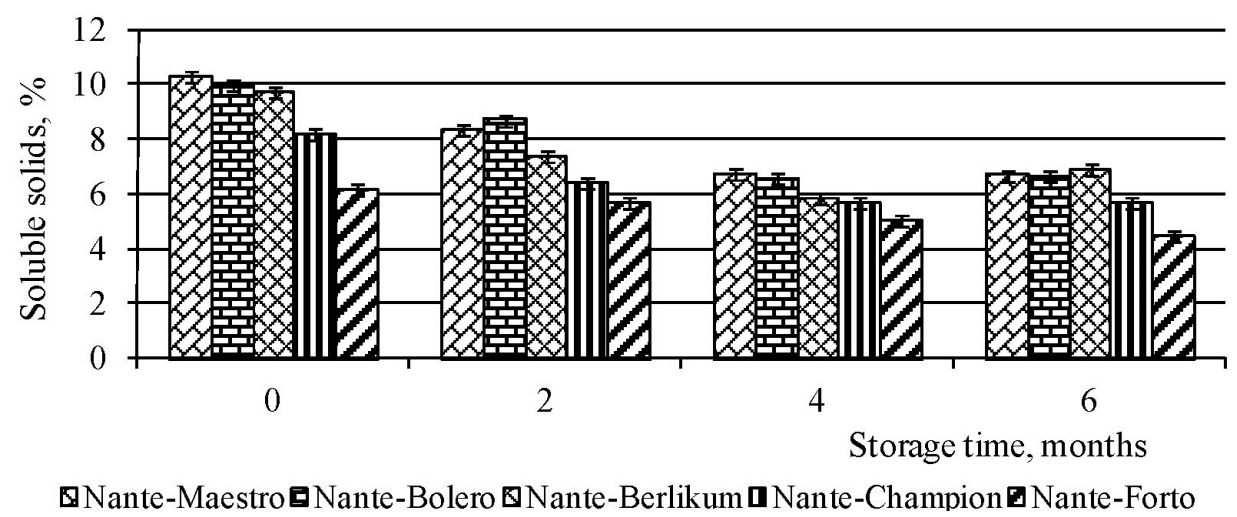

Fig. 2. Dietary fibre content in variety 'Nante' carrot hybrids during storage.
Fig. 3. Soluble solids content in variety 'Nante' carrot hybrids during storage. 
after harvest and degrades steadily during prolonged storage (Ajibola et al., 2009). In the case of vitamin C, the range of observed values was very wide, reflecting the differences known to exist between various cultivars (Matejkova and Petrikova, 2010). In the present study carrot cultivars were autumn carrots; this is strongly evidenced by the higher total vitamin $\mathrm{C}$ content in Nante carrots (Leong and Oey, 2012). Vitamin $C$ acts as an antioxidant in plants and its level is responsive to a variety of environmental or stress factors, for example light, temperature, salt and drought, atmospheric pollutants, metals or herbicides (Smoleń and Sady, 2009; Singh et al., 2012). Literature reports the vitamin $\mathrm{C}$ content in carrot roots as 0.25 to $3.50 \mathrm{mg} 100 \mathrm{~g}^{-1}$ (Singh et al., 2012); $5.70 \mathrm{mg} 100 \mathrm{~g}^{-1}$ (Schwedt, 2007); $4.40-6.50 \mathrm{mg} \cdot 100 \mathrm{~g}^{-1}$ (Fineli, 2011), $7.00 \mathrm{mg} \cdot 100 \mathrm{~g}^{-1}$ (Frede, 2006) and $8.00 \mathrm{mg} \cdot 100 \mathrm{~g}^{-1}$ (Belitz, et al., 2008). These levels are very similar with those of the present study. However, black carrot juice contains high amounts of ascorbic acid: $26.4 \mathrm{mg} \cdot 100 \mathrm{ml}^{-1}$ (Kirca et al., 2007). Researchers from Turkey have reported that such results can be explained by individual hybrid properties, such as chemical composition, and growing conditions (Smoleń and Sady, 2009). Vitamin C is the L-enantiomic form of ascorbic acid, which also encompasses the oxidation product of dehydroascorbic acid with a different oxidizing agent. Oxygen is the most destructive ingredient causing degradation of vitamin $\mathrm{C}$ in carrot. Many chemical reactions contribute to the loss of storage life of vitamin $\mathrm{C}$ and hence chemical deterioration of fruits. The majority of these reactions are enzymatically driven while others are chemical reactions that occur because of senescence (aging) processes (Ajibola et al., 2009). The decrease in vitamin C content with storage duration was attributed to oxidation of ascorbic acid to dehydro-ascorbic acid by the enzyme ascorbic acid oxidase (Jany et al., 2008). Matejkova and Petrikova (2010) reported vitamin $\mathrm{C}$ losses after after 14 days storage at $4{ }^{\circ} \mathrm{C}$ to be by $15 \%$. After 30 days of storage, there was an average decrease in vitamin $\mathrm{C}$ content by $47 \%$.

Researchers from Thailand reported that the average fibre content in fresh carrots is $45.45 \pm 0.41 \mathrm{~g} \cdot 100 \mathrm{~g}^{-1}$ (Chantaro et al., 2008), which is slightly higher than the levels obtained in the present study (Fig. 2). Physiological effects of dietary fibre are greatly dependent on the physicochemical properties of the ingested material, e.g. the water-binding capacity, the molecular weight distribution and the viscosity. Another factor of great nutritional importance is plant cellular structure, which may also play a role in storage stability and sensory characteristics (Nyman and Svanberg, 2002). During storage, toughening takes place, associated with an increase of fibrousness, which devalues the quality of the final product. This quick hardening is mainly located in the basal portions of the spears, and is related to modifications of fibre components by deposition of lignin, cellulose and hemicelluloses (Rodriguez et al., 2006).

In the study by Rashidi, soluble solids content was found to vary even more - from 8.5 to $12.5 \%$, and soluble solid content was similar after four and six-month storage
(Rashidi, 2011). After four- and six-month storage, soluble solid content decreased on average from 1.48 to 1.46 times. A lower content of soluble solid content was observed after storage for all cultivars of carrots in a study conducted in Poland (Gajewski et al., 2010). Soluble solids exert a profound influence on the storage period length, mechanical properties and quality characteristics of fruits and vegetables. It is known that, for example, when fruits are harvested unripe, although physiologically mature, they must be left to ripen (conversion of the stored starch into soluble solids) before consumption (Rakcejeva et al., 2012).

Water uptake phenomena and the resulting moisture content change in food products affect their shelf-life through undesirable modifications of their physical, sensory and microbial qualities. Therefore, it is very important to determine the moisture content of carrots to predict shelf life in general (Rakcejeva et al., 2012). However, there have been recent reports on texture increase in carrot tap roots during the first months of storage (Galindo et al., 2004). In the pectic part of cell walls, the content of uronic acids and their degree of methylation, and hence ionic cross-linking, do not change during storage, and therefore, is a mechanism unlikely to have an effect on storage-induced firmness of carrots (Galindo et al., 2004).

In conclusion, our results demonstrate that higher soluble solid content occurs in non-stored hybrids 'Nante/Berlikum', 'Nante/Maestro' and 'Nante/Bolero': 1.6 times higher compared with hybrid 'Nante/Forto' and 1.2 times higher compared with hybrid 'Nante/Champion'. Higher ascorbic acid content was found in the same hybrids, which was 2.0 times higher than in 'Nante/Forto' and 'Nante/Champion'. Significant differences were not found in dietary fibre content and firmness of the carrots before storage. Significant differences occurred in soluble solid content in hybrid 'Nante/ Berlikum' during six-month storage - the content decreased 2.0 times; however, a non-significant soluble solid content decrease was found for the hybrid 'Nante/Forto'. Changes of hybrid firmness and dietary fibre amount were not significant during storage for four months. A decrease of ascorbic acid content of the analysed carrots hybrids during storage was 3.4 times compared with initial levels.

\section{ACKNOWLEDGEMENTS}

The research and publication were prepared within the framework of the ESF Project "Formation of the Research Group in Food Science”, Contract No 2009/0232/1DP/1.1.1.2.0/09/APIA/VIAA/122.

Publication and dissemination of research results has been made due to the funding of the ERAF Project „Promotion of scientific activities of LLU”, Contract No. 2010/0198/2DP/2.1.1.2.0/10/APIA/VIAA/020.

\section{REFERENCES}

Anonymous (1995). Method 46-12. Crude Protein-Kjeldal Method Boric Acid Modification. Approved Methods of the American Association of cereal Chemists. 9th ed. Vol. 1. St. Paul, Minnesota: AACC Inc. pp., 487-520. 
Ajibola, V. O., Babatunde, O. A., Suleiman, S. (2009). The effect of storage method on the vitamin C content in some tropical fruit juices. Trends Appl. Sci. Res., 4 (2), 79-84.

Belitz, H. D., Grosch, W., Schieberle, P. (2008). Lehrbuch der Lebensmittelchemie, 6. Auflage. Berlin, Heidelberg: Springer. 1118 S.

Brownlee, I. A. (2011). The physiological roles of dietary fibre. Food Hydrocolloids, 25, 238-250.

Chantaro, P., Devahastin, S., Chiewchan, N. (2008). Production of antioxidant high dietary fiber powder from carrot peels. LWT: Food Sci. Technol., 41, 1987-1994.

Chau, C. F., Chen, C. H., Lee, M. H. (2004). Comparison of the characteristics, functional properties, and in vitro hypoglycemic effects of various carrot insoluble fiber-rich fractions. Lebensmittel-Wissenschaft undTechnologie, 37, 155-160.

Eim, V. S., Simal, S., Rossello, C., Femenia, A. (2008). Effects of addition of carrot dietary fibre on the ripening process of a dry fermented sausage (sobrassada). Meat Sci., 80, 173-182.

Emons, H. (2011). Sertificate of Analysis. Dried Carrot. European Reference Material ERM®-BC515, EC-DG JRC-IRMM, 2440, Geel, Belgium. http://www.erm-crm.org. Last accessed 20.07.2012.

Fineli (2011). Finnish Food Composition Database. Carrot. http://www.fineli.fi/food.php?foodid=300\&lang=en. Last accessed 17.07.2012.

Frede, W. (2006). Taschenbuch fūr Lebensmittelchemiker: Lebensmittel, Bedarfsgegenstände, Kosmetika, Futtermittel, 2. Auflage. Berlin, Heidelberg: Springer. $1162 \mathrm{~S}$.

Gajewski, M., Szymczak, P., Radzanowska, J. (2010). Sensory quality of orange, purple and yellow carrots stored under controlled atmosphere. $J$. Notulae Bot. Horti Agrobot. Cluj-Napoca, 38 (3), 169-176.

Galindo, F. G., Bräthen, E., Knutsen, S. H., Sommarin, M., Gekas, V., Sjöholm, I. (2004). Changes in the carrot (Daucus carota L. cv. Nerac) cell wall during storage. Food Res. Int., 37, 225-232.

Gamboa-Santos, J., Soria, A. C., Perez-Mateos, M., Carrasco, J. A., Montilla, A., Villamiel, M. (2012). Vitamin C content and sensorial properties of dehydrated carrots blanched conventionally or by ultrasound. Food Chem., accepted 31 July 2012.

Giannakourou, M. C., Taoukis, P. S. (2003). Kinetic modelling of vitamin C loss in frozen green vegetables under variable storage conditions. Food Chem., 83, 33-41.

Kirca, A., Özkan, M., Cemerošlu, B. (2007). Effects of temperature, solid content and $\mathrm{pH}$ on the stability of black carrot anthocyanins. Food Chem., 101, 212-218.

Jany, M. N. H., Sarker, C., Mazumder, M. A. R., Shikder, M. F. H. (2008). Effect of storage conditions on quality and shelf life of selected winter vegetables. J. Bangladesh Agr. Univ., 6 (2) 391-400.
Leong, S. Y., Oey, I. (2012). Effect of endogenous ascorbic acid oxidase activity and stability on vitamin $\mathrm{C}$ in carrots (Daucus carota subsp. sativus) during thermal treatment. Food Chem., 134, 2075-2085.

Matejkova, J., Petrikova, K. (2010). Variation in content of carotenoids and vitamin C in carrots. Notulae Sci. Biol., 2 (4), 88-91.

Moor, U., Karp, K., Poldma, P., Pae, A. (2005). Cultural systems affect content of anthocyanins and vitamin $\mathrm{C}$ in strawberry fruits. Eur. J. Hort. Sci., 70 (4), 195-201.

Nyman, M. G. L., Svanberg, M. S. J. (2002). Modification of physicochemical properties of dietary fibre in carrots by mono- and divalent cations. Food Chem., 76, 273-280.

Prohens, J., Prohens, J., Nuez, F. (2007). Vegetables II, 1 edn. Valencia, Spain: Springer. 365 p.

Prosky, L. (1990). Collaborative study of a method for soluble and insoluble dietary fiber. Adv. Exp. Med. Biol., 270, 193-203.

Rakcejeva, T., Augspole, I., Dukalska, L., Dimins, F. (2012). Chemical composition of variety 'Nante' hybrid carrots cultivated in Latvia. J. World Acad. Sci. Eng. Technol., pp. 1120-1126.

Rashidi, M. (2011). Modeling of carrot firmness based on water content and total soluble solids of carrot. J. Agr. Biol. Sci., 6 (8), 62-65.

Rastogi, N. K., Nguyen, L. T., Balasubramaniam, V. M. (2008). Effect of pretreatments on carrot texture after thermal and pressure-assisted thermal processing. J. Food Eng., 88, 541-547.

Rawson, A., Tiwari, B. K., Tuohy, M., Brunton, N. (2012). Impact of frozen storage on polyacetylene content, texture and colour in carrots disks. $J$. Food Eng., 108, 563-569.

Rodriguez, R., Jimenez, A., Fernandez-Bolanos, J., Guillen, R., Heredia, A. (2006). Dietary fibre from vegetable products as source of functional ingredients. Trends Food Sci. Technol., 17, 3-15.

Roeck, A. D., Mols, J., Sila, D. N., Duvetter, T.,. Loey, A. V, Hendrickx, M. (2010). Improving the hardness of thermally processed carrots by selective pretreatments. Food Res. Int., 43, 1297-1303.

Schwedt, G. (2007). Chemie für alle Jahreszeiten: Einfache Experimente mit pflanzlichen Naturstoffen. Weinheim: Wiley-VCH. 209 S.

Singh, D. P., Beloy, J., McInerney, J. K., Day, L. (2012). Impact of boron, calcium and genetic factors on vitamin $\mathrm{C}$, carotenoids, phenolic acids, anthocyanins and antioxidant capacity of carrots (Daucus carota). Food Chem., 132, 1161-1170.

Slavin, J. L. (2008). Health implications of dietary fiber. Position of the American Dietetic Association. J. Amer. Dietetic Assoc., 108, 1716-1731.

Smoleń, S., Sady, W. (2009). The effect of various nitrogen fertilization and foliar nutrition regimes on the concentrations of sugars, carotenoids and phenolic compounds in carrot (Daucus carota L.). Sci. Hort., 120 (3), 315-324.

Soria, A. C., Sanz, M. L., Villamiel, M. (2009). Determination of minor carbohydrates in carrot (Daucus carota L.). J. Food Chem., 114, 758-762.

Yen, Y. H., Shih, C. H., Chang, C. H. (2008). Effect of adding ascorbic acid and glucose on the antioxidative properties during storage of dried carrot. Food Chem., 107, 265-272.

Received 14 September 2012

\section{FIZIKĀLI ĶĪMISKO PARAMETRU IZMAIN̦AS 'NANTE' BURKĀNU HIBRĪDOS UZGLABĀŠANAS LAIKĀ TRADICIONĀLOS APSTĀKL,OS}

Pētījuma mērkis bija izvērtēt vēlās burkānu škirnes 'Nante' hibrīdu 'Nante/Forto', 'Nante'/'Čempion', 'Nante/Berlikum', 'Nante/Maestro' un 'Nante/Bolero' fizikāli ķīmiskos rādītājus pēc ražas novākšanas un tradicionālajos uzglabāšanas apstākḷos. Burkāni tika uzglabāti sešus mēnešus $8 \pm 2{ }^{\circ} \mathrm{C}$ temperatūrā, $85 \pm 1 \%$ relatīvā gaisa mitrumā. Kvalitātes parametru izmaiṇas tika noteiktas, izmantojot standarta metodes: šḳīstošā sausna (ar digitālo refraktometru), diētiskās šḳiedrvielas (AOAC 985.29), vitamīns C (jodometrijas metode) un stingrība (TA.XT.plus Texture Analyser). Pētījumos analizēto burkānu hibrīdos vitamīna C saturs uzglabāšanas laikā samazinājās 3,4 reizes, salīdzinot ar sākotnējiem rādītājiem. Būtiskas atškirības novērojām šḳīstošās sausnas saturā vēlo burkānu škiinnes 'Nante/Berlikum' hibrīdos. Pēc sešu mēnešu uzglabāšanas tas samazinājās 2,0 reizes. Stingrības un diētiskās šḳiedrvielas saturā būtiskas izmaiņas burkānu hibrīdos uzglabāšanas laikā līdz četriem mēnešiem netika konstatētas. Pētījumā iegūtie rezultāti dod pārskatu par Latvijā audzētu burkānu fizikāli kịmisko sastāvu un to piemērotību minimālās apstrādes produktu ražošanai. 


\title{
EVALUATION OF ROWANBERRY AND ROWANBERRY-PUMPKIN SAUCES
}

\author{
Elga Berṇa, Solvita Kampuse, Evita Straumīte, and Irisa Mūrniece
}

Latvia University of Agriculture, Lielā iela 2, Jelgava, LV-3001, LATVIA

elga@tvnet.Iv

Communicated by Daina Kārkliṇa

\begin{abstract}
Rowanberries (Sorbus aucuparia) are small orange-red fruits of a rowan tree. They have been described as an important source of flavonoids, and their antioxidant activity affects reactive oxygen species and lipid peroxidation. Cultivars of sweet rowanberries and hybrids with other species are sweeter and less astringent than wild rowanberries. The aim of the current study was to determine physical and chemical properties of sauces from various cultivars of wild and sweet rowanberries, and mixes of sweet rowanberries with pumpkins, and to assess their degree of acceptance. The experiments were carried out at the Faculty of Food Technology of the Latvia University of Agriculture. The sauces were made from purees of wild rowanberry and sweet rowanberry cultivars and purees of sweet rowanberry with apple or pumpkin using different species. The content of total dry matter, soluble solids, total carotene, $p H$, colour $L^{*} a^{*} b^{*}$ values and texture parameters were determined in samples of the sauces. The results showed large variability between the rowanberry and rowanberry-pumpkin sauces. The total dry matter content of sauce samples varied from 25.92 to $31.38 \%$, the total carotene content from $3.94 \pm 0.40$ to $7.34 \pm$

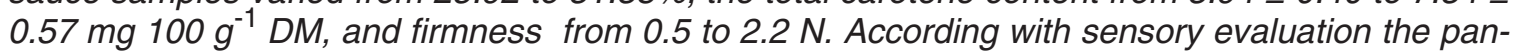
ellists liked $(\mathrm{P}<0.05)$ sauces samples made from rowanberry 'Michurinskaya krasnaya' puree and from 'Granatnaya' and pumpkin purees.
\end{abstract}

Key words: rowanberry, sauce, physical and chemical parameters, sensory evaluation.

\section{INTRODUCTION}

Sauces and dressings are commonly used in the everyday life of many consumers. The main advantage of sauces is their ability to improve the taste of food. For example, hot sauces add a piquant taste to various dishes, meats, and vegetables; sweet sauces are favoured on pancakes, rice, desserts and ice-creams. Sweet and sour sauces find application in meat dishes and are very often applied in Asian kitchens. Dressings of different taste are commonly used in American kitchens, bringing greater attractiveness to meat dishes (Sikora et al., 2008).

A variety of sauces, such as tomato, chilli, oyster, and white sauce, are used as seasoning to help enhance the taste of food. In general, colour, viscosity and stability are characteristics that contribute to the acceptance of a sauce. The main problem associated with quality of sauces is a tendency for separation of solids and liquid phase during storage. To prevent this the manufacturers usually use native starch (i.e. corn and rice starch), modified starch and hydrocolloids (i.e., gum, locust bean gum) as thickeners and stabilisers of sauces (Rengsutthi and Charoenrein, 2011).

Consumers are demanding high-quality healthy products, and therefore, it is very important to choose raw material with high content of bioactive compounds. There is still much potential to improve product quality using new, nontraditional fruits and vegetables with high contents of bioactive compounds as raw materials for production of sauces. Such raw materials include also rowanberries and pumpkins.

Rowanberries (Sorbus aucuparia L.) belong to the subfamily Maloideae of the family Rosaceae. Their berries have been promoted as a health-food and can be a source for health-promoting components. Ripe wild rowanberries are picked in the autumn and they are eatable, but very tart in flavour and taste, although they contain lots of sugar. Rowanberries have been traditionally used to make purees, juices or wine, but their use as a food ingredient has been less popular because of their bitter tast Wang, 2007). Cultivars of sweet rowanberries and hybrids with other species are sweeter and less astringent than wild rowanberries. According to food composition and nutrition tables, sweet rowanberry S. aucuparia L. var. edulis contains $98.0 \mathrm{mg}$ $100 \mathrm{~g}^{-1}$ vitamin $\mathrm{C}$ and $2.5 \mathrm{mg} 100 \mathrm{~g}^{-1}$ total carotenoids (Souci et al., 2008). In comparison with wild rowanberries, the sugar content in fruits of cultivars of sweet rowanberries is 1.2-2.1 times higher (Navys, 2001). The content of reducing sugars (i.e. total amount of glucose and fructose) in 


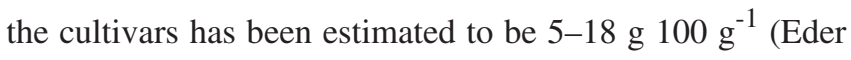
et al., 1991; Souci et al., 2008). The content of sorbitol, a sweetening agent that diabetics can tolerate, was high and varied from 3.5 to $12.0 \mathrm{mg} 100 \mathrm{~g}^{-1}$ (Eder et al., 1991; Стрельцина и др., 2010).

Pumpkin is a vegetable that meets the requirements of healthy nutrition. It is a tasty and valuable vegetable crop, contains many biologically active substances and is distinguished for its dietary qualities. There are three common types of pumpkin world-wide: Cucurbita pepo L., Cucurbita maxima L. and Cucurbita moschata L. (Lee et al., 2002). Pumpkins provide a valuable source of carotenoids and ascorbic acid, which have major roles in nutrition as provitamin A and as an antioxidant, respectively (See $e t$ al, 2007). Pumpkins are consumed in a variety of ways, such as fresh or cooked vegetables, and products are commonly stored frozen or canned (Figueredo et al., 2000).

The stability of many bioactive compounds is dependent on pre-treatment of the raw material, processing operations of the product, and storage conditions. In many fruits, carotenoids and flavonoids, which are located predominantly in epidermal tissues, are removed by peeling operations, which can greatly reduce concentrations of bioactive compounds in processed products. Removal of seeds can result in losses of phenolics (e.g. ellagitannins) (Howard, 2008). High temperature also causes the loss of important nutrients. At a temperature just above $50{ }^{\circ} \mathrm{C}$, degradation of several phenolic compounds occurs (Rózek et al., 2010). During thermal processing, 50-70\% losses of ascorbic acid can occur. The losses of this vitamin can be used as an indicator of food quality. Carotenoids after thermal processing are more easily extracted from plant tissues due to tissue softening and destruction of the membrane-protein complex (Howard, 2008).

Colour is one of the most important parameters to which consumers are sensitive when selecting foods. Colour stability of fruit and fruit products is influenced by many factors. At least three factors can cause colour deterioration: the loss of red anthocyanin pigment, formation of brown pigments, and discoloration through various factors such as heavy metal contamination. The fruit cultivar, temperature, $\mathrm{pH}$, presence of oxygen and time of processing were found to exert a great influence on colour stability of fruit products (García-Viguera et al., 1998; Kopjar et al., 2009).

The aim of current research was to determine physical and chemical properties, and degree of acceptance, of sauces made from various cultivars of rowanberries and and from sweet rowanberries with pumpkins.

\section{MATERIALS AND METHODS}

Experimental design. The research was carried out at the Faculty of Food Technology, Latvia University of Agriculture, in 2012. The object of the research was rowanberry and rowanberry-pumpkin sauces from wild and sweet row-
Table 1

THE DESCRIPTION OF ROWANBERRY CULTIVARS USED FOR MAKING SAUCES

\begin{tabular}{|c|c|c|c|}
\hline No & \begin{tabular}{|c|} 
Rowanberry \\
cultivar
\end{tabular} & Sort characteristics & Description of fruits \\
\hline 1 & 'Granatnaya' & $\begin{array}{l}\text { Hybrid rowanberry } \times \\
\text { hawthorn (Sorbus } \\
\text { aucuparia } \times \text { Crataegus } \\
\text { sanguinea } \text { Pallas) }\end{array}$ & $\begin{array}{l}\text { Dark red or brown col- } \\
\text { oured fruits with sweet and } \\
\text { sour taste }\end{array}$ \\
\hline 2 & $\begin{array}{l}\text { 'Michurinskay } \\
\text { a krasnaya' }\end{array}$ & $\begin{array}{l}\text { Hybrid rowanberry } \times \\
\text { hawthorn }(\text { Sorbus } \\
\text { aucuparia } \times \text { Crataegus } \\
\text { sanguinea } \text { Pallas) }\end{array}$ & $\begin{array}{l}\text { Dark red coloured fruits } \\
\text { with sweet and sour taste }\end{array}$ \\
\hline 3 & 'Moravica' & $\begin{array}{l}\text { Moravian group variety } \\
\text { of Sorbus aucuparia }\end{array}$ & $\begin{array}{l}\text { Orange-red coloured fruits } \\
\text { with sweet and sour taste }\end{array}$ \\
\hline 4 & $\begin{array}{l}\text { Sorbus } \\
\text { aucuparia }\end{array}$ & Wild rowanberry & $\begin{array}{l}\text { Orange or bright red col- } \\
\text { oured fruits with bitter } \\
\text { taste }\end{array}$ \\
\hline
\end{tabular}

anberry cultivars and pumpkin (Cucurbita maxima) purees. Description of the used fruits of rowanberry cultivars are given in Table 1. The rowanberries were harvested in the Pure Horticultural Research centre. The pumpkin was obtained from the household "Alejas" (Ilzene's rural municipality, Latvia).

Rowanberry puree was prepared from frozen and thawed rowanberries that were pressed through a sieve, and pumpkin puree made from cut pieces of pumpkin, boiled (in $100{ }^{\circ} \mathrm{C}$ ) and pressed through a sieve. The rowanberry sauces (further - samples A) were prepared according with the technological scheme given in Figure 1 and dried dill and basil was added. Rowanberry-pumpkin sauces (further - samples B) were prepared also according to this, but using rowanberry and pumpkin puree in weight ratio 1:1, and with addition of herbs: fresh garlic, cumin seeds, coriander seeds and dried rosemary (sample B1); dried ginger (sample B2); fresh garlic and dried basil (sample B3); and dried parsley, mustard seeds and cayenne pepper (sample B4).

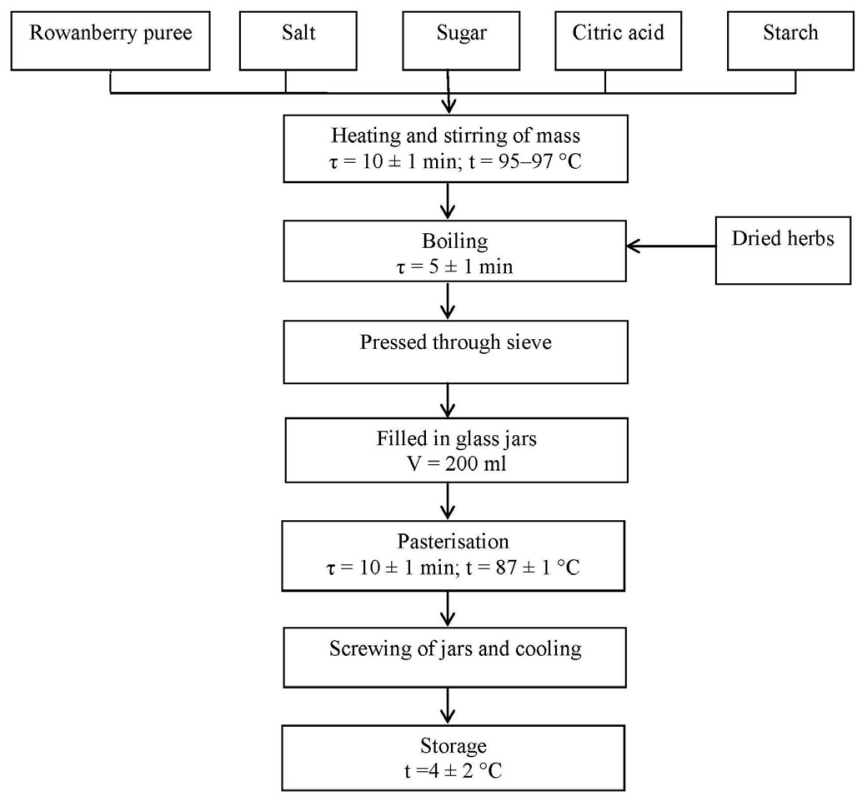

Fig. 1. Technological scheme of rowanberry sauces treatment 
Four samples of rowanberry sauces and four samples of rowanberry-pumpkin sauces were prepared.

Analysis. The total dry matter content of sauce samples was determined after drying in an oven (Mattila et al., 2006). A vacuum drying oven VD53 (Binder) and analytical scales BP-210s (Sartorius) were used. Measurements were carried out in three replications.

The soluble solid content $\left({ }^{\mathrm{O}} \mathrm{Brix}\right)$ was measured using a digital refractometer Rx-5000 $\alpha$ (Atago) by standard method ISO 2173:2003. Measurements were carried out in five replications.

$\mathrm{pH}$ was measured by a pH-meter (FieldLabpH), using standard method LVS ISO 5542:2010. Measurements were carried out in three replications.

The total carotene content was determined by spectrophotometric method at $440 \mathrm{~nm}$ (Ермаков, 1987) after extraction with petroleum ether (boiling temperature range 80$110{ }^{\circ} \mathrm{C}$ ). An UV-VIS-NIR spectrophotometer UV-3100PC (Shimadzu) with $10 \mathrm{~mm}$ cuvettes was used. The carotene equivalent (KE) was estimated, using a calibration curve with $\mathrm{K}_{2} \mathrm{Cr}_{2} \mathrm{O}_{7}$. Measurements were carried out in two replications for each sample.

The colour of sauces was measured in a CIE L*a*b* colour system using a ColorTec-PCM/PSM (Accuracy Microsensors Inc.). Before measurement, the colorimeter was calibrated using a white reference tile and a light trap (black tile). Ten random areas were measured through the plastic pockets and mean values were reported for each sample. Using this method, CIELAB coordinates show the degree of brightness $(\mathrm{L})$, the degree of redness $(+\mathrm{a})$ or greenness $(-\mathrm{a})$, and the degree of yellowness $(+b)$ or blueness $(-b)$ (Coultate, 2002; Chakrborty et al., 2011).

The textural analysis of sauces was conducted at room temperature $\left(20 \pm 2{ }^{\circ} \mathrm{C}\right.$ temperature $)$ with a Texture Analyser TA.XT.plus (Stable Micro Systems Ltd.) instrument according to the method described in literature (Bourne, 2002; Sikora et al., 2007; Cardona et al., 2010). The system was equipped with a compression cell of $50 \mathrm{~kg}$ and software Texture Exponent 32. A back extrusion test was carried out in a cylindrical container with $50-\mathrm{mm}$ internal diameter filled with sauce, in which the $40 \mathrm{~mm}$ diameter compression disc with an extension bar moved with a speed of $2 \mathrm{~mm} \mathrm{~s}^{-1}$, at distance $20 \mathrm{~mm}$.. Analyses were triplicated. The system was equipped with a compression cell of $50 \mathrm{~kg}$ and software Texture Exponent 32. A back extrusion test was carried out in a cylindrical container with $50-\mathrm{mm}$ internal diameter filled with sauce, in which the $40 \mathrm{~mm}$ diameter compression disc with an extension bar moved with a speed of $2 \mathrm{~mm} \mathrm{~s}^{-1}$, at distance $20 \mathrm{~mm}$. Analyses were triplicated.

Sensory evaluation of the sauce samples was performed in the Laboratory of Sensory Evaluation at the Faculty of Food Technology of the Latvia University of Agriculture. All sauce samples were evaluated by 25 trained panellists
(18 females and 7 males, mean age 32). Rowanberry and rowanberry-pumpkin samples were evaluated by degree of liking using a 9-point hedonic scale. The 9-point hedonic scale ( 9 - extremely like, 5 - neither like nor dislike, and 1 - extremely dislike) methods used were based on ISO 4121:2003 "Sensory analysis - Guidelines for the use of quantitative response scales".

The results are expressed as means \pm standard deviations. Significant differences were tested by analysis of variance (ANOVA) and the Tukey's test. Statistical differences with $P<0.05$ were considered as significant.

\section{RESULTS}

The physical parameters (the content of total dry matter and soluble solids, and $\mathrm{pH}$ ) of the rowanberry sauce samples are given in Table 2 . There were significant differences $(P \leq$ $0.005)$ in the total dry matter content and in the soluble solids among the samples of sauce samples. This can be explained by the use of different rowanberry cultivars and different composition of recipes for sauce samples $\mathrm{A}$ and $\mathrm{B}$.

The rowanberry and rowanberry-pumpkin sauce samples had $\mathrm{pH}$ levels ranging between $2.68 \pm 0.01$ and $3.23 \pm 0.01$ (Table 2), the levels significantly different between sauces $(P<0.05)$.

Total carotene content significantly differed $(P<0.005)$ between the rowanberry and rowanberry-pumpkin sauces (see Fig. 2). The highest total carotene content (7.75 \pm $0.51 \mathrm{mg} 100 \mathrm{~g}^{-1} \mathrm{DW}$ ) was in sample A2 (made from 'Michurinskaya krasnaya' puree), and the lowest (3.94 \pm $0.40 \mathrm{mg} 100 \mathrm{~g}^{-1} \mathrm{DW}$ ) in sample B4 (made from 'Moravica' and pumpkin purees). The content of total carotene of rowanberry-pumpkin sauces was lower $(23.0-32.7 \%)$ than that of rowanberry sauce made only from cultivars of rowanberry. The content of total carotene of sauces was

Table 2

THE PHYSICAL PARAMETERS OF THE ROWANBERRY AND ROWANBERRY-PUMPKIN SAUCE SAMPLES

\begin{tabular}{c|c|c|c}
\hline $\begin{array}{c}\text { Sample } \\
\text { designation }\end{array}$ & $\begin{array}{c}\text { Total dry matter, } \\
\%\end{array}$ & $\begin{array}{c}\text { Soluble solids } \\
\text { content, rBrix }\end{array}$ & $\mathrm{pH}$ \\
\hline A1 & $30.65 \pm 0.12^{\mathrm{a}}$ & $28.30 \pm 0.16^{\mathrm{a}}$ & $2.92 \pm 0.04^{\mathrm{c}}$ \\
A2 & $28.35 \pm 0.17^{\mathrm{b}}$ & $25.29 \pm 0.11^{\mathrm{c}}$ & $3.23 \pm 0.01^{\mathrm{a}}$ \\
A3 & $26.35 \pm 0.13^{\mathrm{c}}$ & $23.44 \pm 0.10^{\mathrm{d}}$ & $2.98 \pm 0.01^{\mathrm{b}}$ \\
A4 & $31.38 \pm 0.16^{\mathrm{a}}$ & $26.95 \pm 0.05^{\mathrm{b}}$ & $3.02 \pm 0.01^{\mathrm{b}}$ \\
B1 & $25.92 \pm 0.46^{\mathrm{c}}$ & $21.05 \pm 0.03^{\mathrm{d}}$ & $2.89 \pm 0.07^{\mathrm{a}}$ \\
B2 & $27.03 \pm 0.11^{\mathrm{b}}$ & $22.42 \pm 0.02^{\mathrm{b}}$ & $3.00 \pm 0.01^{\mathrm{a}}$ \\
B3 & $27.16 \pm 0.45^{\mathrm{b}}$ & $21.52 \pm 0.06^{\mathrm{ca}}$ & $2.95 \pm 0.01^{\mathrm{a}}$ \\
B4 & $30.18 \pm 0.25^{\mathrm{a}}$ & $26.30 \pm 0.05^{\mathrm{a}}$ & $2.68 \pm 0.01^{\mathrm{b}}$
\end{tabular}

* - values, marked with the same superscript letters in a column, are not significantly different $(P>0.05)$.

Rowanberry cultivars used for sauce preparation: A1 - 'Granatnaya'; A2 'Michurinskaya krasnaya'; A3 - 'Moravica'; A4 - wild rowanberry S. aucuparia; B1 - 'Michurinskaya krasnaya'; B2, B3 - 'Granatnaya'; B4 - 'Moravica'. 


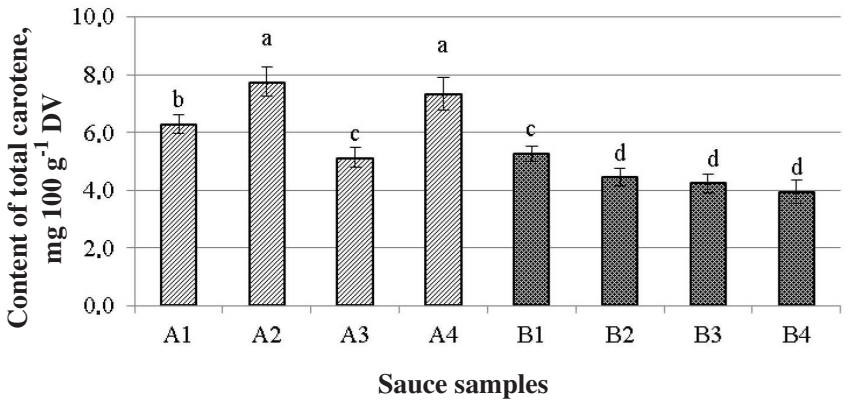

Fig. 2. Content of total carotene of rowanberry and rowanberry-pumpkin sauces

* - values, marked with the same small letters in a column, are not significantly different $(P>0.05)$.

Rowanberry cultivars used for sauce preparation are described below Table 2 .

lower when rowanberry puree was mixed with pumpkin puree.

The results of colour $L^{*} a^{*} b^{*}$ measurements of the rowanberry and rowanberry-pumpkin sauces are shown in Table 3 . The colour values significantly differed between samples $(P<0.005)$. Rowanberry sauce sample A1 (made from 'Granatnaya' puree) had the darkest colour ( $\mathrm{L}^{*}=$ $25.98 \pm 1.73$ ) and sample A2 (made from 'Michurinskaya krasnaya') was the reddest sauce sample $\left(a^{*}=24.49 \pm\right.$ 1.84). The fruits of these cultivars have dark red colour. Rowanberry-pumpkin sauce sample B4 (prepared from orange-red coloured rowanberries of 'Moravica' and pumpkin puree in proportion 50:50) was the most yellow $\left(b^{*}=40.05 \pm 4.12\right)$.

The textural parameters of the rowanberry sauces are shown are shown in Table 4. Firmness and cohesiveness as well as consistency and index of viscosity of the sauce samples significantly differed among the samples $(P<0.005)$. Sauce sample B4 (made from 'Moravica' and pumpkin purees) had high values for all of these parameters. Firmness of

Table 3

COLOUR L* $a * b *$ VALUES OF ROWANBERRY AND ROWANBERRY-PUMPKIN SAUCES

\begin{tabular}{c|ccc}
\hline \multirow{2}{*}{$\begin{array}{c}\text { Sample } \\
\text { designation }\end{array}$} & \multicolumn{3}{|c}{ Colour $\mathrm{L}^{*} \mathrm{a}^{*} \mathrm{~b}^{*}$ values } \\
\cline { 2 - 4 } & $\mathrm{L}^{*}$ & $\mathrm{a}^{*}$ & $\mathrm{~b}^{*}$ \\
\hline A1 & $25.98 \pm 1.73 \mathrm{a}$ & $18.86 \pm 2.57 \mathrm{~b}$ & $19.09 \pm 2.29 \mathrm{~b}$ \\
A2 & $29.06 \pm 2.52 \mathrm{a}$ & $24.49 \pm 1.84 \mathrm{c}$ & $30.24 \pm 1.24 \mathrm{a}$ \\
A3 & $43.88 \pm 1.73 \mathrm{c}$ & $13.22 \pm 1.42 \mathrm{a}$ & $30.13 \pm 2.21 \mathrm{a}$ \\
A4 & $36.01 \pm 2.78 \mathrm{~b}$ & $15.50 \pm 1.75 \mathrm{ab}$ & $21.67 \pm 2.34 \mathrm{~b}$ \\
B1 & $33.10 \pm 2.02$ & $17.29 \pm 0.74$ & $25.94 \pm 1.35$ \\
B2 & $30.80 \pm 1.94$ & $16.31 \pm 1.07$ & $27.72 \pm 3.34$ \\
B3 & $29.25 \pm 2.41$ & $17.70 \pm 1.24$ & $26.53 \pm 2.53$ \\
B4 & $42.58 \pm 1.48$ & $13.74 \pm 0.41$ & $40.05 \pm 4.12$
\end{tabular}

* - values, marked with the same small letters in a column, are not significantly different $(P>0.05)$.

Rowanberry cultivars used for sauce preparation are described below Table 2 .

Proc. Latvian Acad. Sci., Section B, Vol. 67 (2013), No. 4/5.
Table 4

TEXTURAL PARAMETERS OF THE ROWANBERRY AND ROWANBERRY-PUMPKIN SAUCES

\begin{tabular}{c|c|c|c|c}
\hline $\begin{array}{c}\text { Sample } \\
\text { designation }\end{array}$ & Firmness, N & $\begin{array}{c}\text { Consistency, } \\
\mathrm{N} \mathrm{s}\end{array}$ & $\begin{array}{c}\text { Cohesiveness, } \\
\mathrm{N}\end{array}$ & $\begin{array}{c}\text { Index of } \\
\text { Viscosity, N s }\end{array}$ \\
\hline A1 & $0.61 \pm 0.03^{\mathrm{b}}$ & $5.36 \pm 0.23^{\mathrm{b}}$ & $-0.66 \pm 0.06^{\mathrm{a}}$ & $-1.11 \pm 0.14^{\mathrm{a}}$ \\
A2 & $0.49 \pm 0.06^{\mathrm{b}}$ & $4.24 \pm 0.45^{\mathrm{b}}$ & $-0.44 \pm 0.05^{\mathrm{a}}$ & $-0.82 \pm 0.21^{\mathrm{a}}$ \\
A3 & $2.15 \pm 0.07^{\mathrm{a}}$ & $18.26 \pm 0.54^{\mathrm{a}}$ & $-2.89 \pm 0.11^{\mathrm{c}}$ & $-4.09 \pm 0.10^{\mathrm{c}}$ \\
A4 & $1.85 \pm 0.17^{\mathrm{a}}$ & $15.38 \pm 1.03^{\mathrm{a}}$ & $-1.81 \pm 0.09^{\mathrm{b}}$ & $-2.66 \pm 0.26^{\mathrm{b}}$ \\
B1 & $1.75 \pm 0.18$ & $13.55 \pm 1.30$ & $-1.79 \pm 0.23$ & $-2.16 \pm 0.13$ \\
B2 & $1.56 \pm 0.09$ & $12.02 \pm 0.95$ & $-1.60 \pm 0.18$ & $-2.08 \pm 0.12$ \\
B3 & $1.39 \pm 0.09$ & $12.26 \pm 0.74$ & $-1.83 \pm 0.13$ & $-2.49 \pm 0.11$ \\
B4 & $3.11 \pm 0.23$ & $19.73 \pm 1.18$ & $-3.14 \pm 0.31$ & $-2.98 \pm 0.16$
\end{tabular}

* - values, marked with the same small letters in a column, are not significantly different $(P>0.05)$.

Rowanberry cultivars used for sauce preparation are described below Table 2.

rowanberry and rowanberry-pumpkin sauce samples varied from $0.49 \pm 0.06$ (sample A2, made from 'Michurinskaya krasnaya' puree) to $3.11 \pm 0.23 \mathrm{~N}$ (sample B4, made from 'Moravica' and pumpkin purees).

The hedonic evaluation scores of the rowanberry sauce are summarised in Figure 3. The results of the ANOVA showed significant differences $\left(\mathrm{F}_{\text {calc }}=22.60>\mathrm{F}_{\text {crit }}=2.72\right)$ in the degree of liking among the rowanberry sauce samples. The hedonic scores of rowanberry sauce samples were within the scale interval from „dislike moderately" to "like slightly" (3.0-6.0). There was no significant differences between samples A1 (made from 'Granatnaya' puree) and A2 (made from 'Michurinskaya krasnaya' puree); these sauses had lower bitterness, which the panellists liked better (see Fig. 3). The panellists liked sauce sample A4 made from wild rowanberry $S$. aucuparia puree) the least $(P<$ $0.05)$, as it was too bitter and the used mountain ash gave an expressed aftertaste. Some of the panellists noted sample A1 (made from 'Granatnaya' puree) as bitter and unacceptable, but for other panellists this sauce was acceptable. Based on the results of sensory evaluation, we can conclude that wild rowanberries $S$. aucuparia fruits, which have a

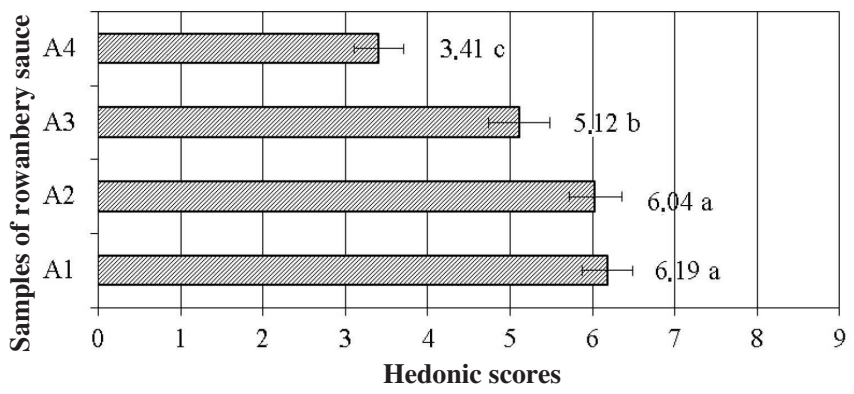

Fig. 3. Degree of liking of rowanberry sauces samples.

* - values, marked with the same small letters in a column, are not significantly different $(P>0.05)$.

Rowanberry cultivars used for sauce preparation are described below Table 2. 


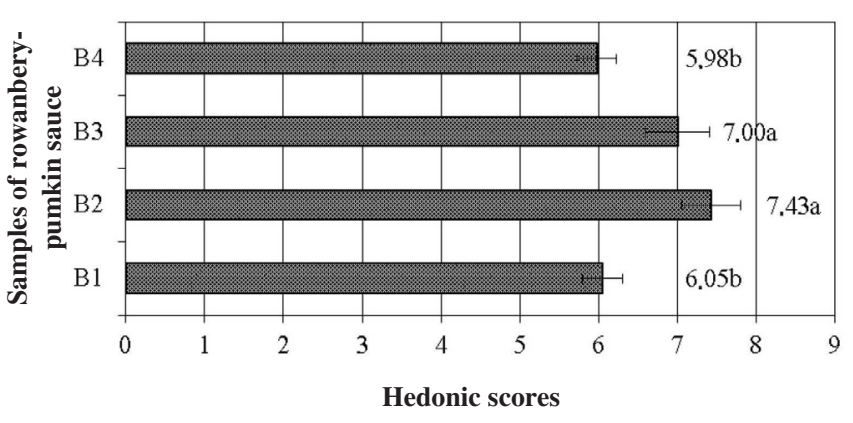

Fig. 4. Degree of liking of rowanberry-pumpkin sauces.

* - values, marked with the same superscript letters in a column, are not significantly different $(P>0.05)$.

Rowanberry cultivars used for sauce preparation are described below Table

distinct bitter taste, should not be recommended for sauce preparation.

ANOVA shows that the hedonic scores of rowanberriespumpkin sauces significantly different between samples $\left(\mathrm{F}_{\text {calc }}=7.87>\mathrm{F}_{\text {crit }}=2.67\right)$. The panellists liked rowanberry-pumpkin sauces samples B2 and B3 (both made from 'Granatnaya' and pumpkin purees), and between these samples there was no significant difference (Fig. 4).

\section{DISCUSSION}

In comparison with content of total dry matter of rowanberry and rowanberry-pumpkin sauce samples (25.92$31.38 \%$; Table 2), the content in commercial ketchup samples, which are sweetened with sucrose, and light ketchup, sweetened with aspartame, was $31.21 \pm 0.18 \%$ and $27.21 \pm$ $0.27 \%$, respectively (Bannwart et al., 2008). The content of soluble solids of rowanberry and rowanberry-pum Table 2) was similar to that of chili sauce, which ranges from 22.80 \pm 0.28 to $23.65 \pm 0.21^{\circ}$ Brix (Rengsutthi and Charoenrein, 2011), and with the content of soluble solids of light ketchup - $26.68 \pm 0.46 \%$ (Bannwart et al., 2008).

Among the parameters analyzed for the sauce quality, $\mathrm{pH}$ is very important because acidity influences the thermal processing conditions required for producing safe products. However, $\mathrm{pH}$ of tomato products not exceeding $\mathrm{pH}<4.5$ are generally classified as acid foods ( $\mathrm{pH} 4.5)$, which require moderate conditions of processing to control microbial spoilage and enzyme inactivation (Hayes et al., Lehkoživová et al., 2009). The rowanberry and rowanberrypumpkin sauce samples had lower $\mathrm{pH}$ and can classified as a high acid food item, such as tomato ketchup (Bannwart et al., 2008) and chilli sauce (Rengsutthi and Charoenrein, 2011).

The results showed that colour $\mathrm{L}^{*}$ and $\mathrm{b}^{*}$ values of sauces was increased by the replacing of part of rowanberry puree with pumpkin puree. The rowanberry-pumpkin sauce samples had lighter colour and more yellowness than rowanberry sauces.
Firmness of sauces was increased by replacing of part of rowanberry puree with pumpkin puree. In comparison with rowanberry sauce, rowanberry-pumpkin sauce was prepared with less salt and sugar. The parameters of sauce consistency, cohesiveness and index of viscosity were also higher. According to sensory evaluation remarks, the panellists did not like firmness of sauce samples A3, A4 and B3 (in range from $1.85 \pm 0.17$ to $3.11 \pm 0.23 \mathrm{~N}$ )

According to panellists, the evaluated sauces were sweet and salty, and they did not like colour of sample A3 (made from 'Moravica' puree), which was made from orange-red coloured rowanberries.

To obtain a softer taste and structure that would have a typical ketchup consistency, the pannellists recommended a mix of several rowanberry cultivars or addition of other fruit puree.

The summary of sensory evaluation questionnaires and the colour $\mathrm{L} *, \mathrm{a} *$ and $\mathrm{b} *$ values of rowanberry sauces indicated that the panellists liked colour of samples A1 (made from 'Granatnaya' puree) and A2 (made from 'Micurinskaya krasnaya' puree). It is possible that the red colour of the sauce is acceptable, as it has the colour of tomato and cranberry sauce. Sample A3 (made from 'Moravica' puree) was liked best by panellists (Fig. 3), but the colour of this sauce was not acceptable to them. This can be explained by the available and most popular sauces appearance in the market, i.e. the colour of the brown-orange sauce was "alien" for consumers.

The conclusions are:

1. There were significant differences $(P<0.01)$ in physical and chemical parameters among samples of rowanberry and rowanberry-pumpkin sauces. The total dry matter content of sauce samples varied from $25.92 \pm 0.46$ to $31.38 \pm 0.16 \%$, soluble solids from $21.05 \pm 0.03$ to $28.30 \pm 0.16{ }^{\circ} \mathrm{Brix}$, and $\mathrm{pH}$ from $2.68 \pm 0.01$ to $3.23 \pm 0.01$.

2. Total carotene content differed $(P=0.000)$ between samples of rowanberry and rowanberry-pumpkin sauces, and varied from $7.34 \pm 0.57 \mathrm{mg} 100 \mathrm{~g}^{-1} \mathrm{DW}$ (made from 'Michurinskaya krasnaya' puree) to $3.94 \pm 0.40 \mathrm{mg} 100 \mathrm{~g}^{-1}$ DW (made from 'Moravica' and pumpkin purees).

3. Sensory evaluation showed that wild rowanberries $S$. aucuparia fruits, which have a distinct bitter taste, should not be recommended for sauce preparation. The sensory evaluation of sauce samples from rowanberry $\times$ hawthorn hybrid 'Granatnaya' and pumpkin purees showed that this sample had the highest value (7.43).

4. There were significant differences $(P=0.000)$ in colour $\mathrm{L}^{*} \mathrm{a} \mathrm{b}^{*}$ values among the sauce samples. Colour $\mathrm{L} *$ values varied between $25.98 \pm 1.73$ and $43.88 \pm 1.73$, and the darkest sauce was from rowanberry $\times$ hawthorn hybrid 'Granatnaya'. 
5. The firmness and cohesiveness as well as consistency and index of viscosity of the sauce samples significantly differed $(P=0.000)$ among samples, and these texture parameters were higher in the sauce made from rowanberry puree with pumpkin puree. The firmness of sauce samples varied from $0.49 \pm 0.06$ (sample A2, made from 'Michurinskaya krasnaya' puree) to $3.11 \pm 0.23 \mathrm{~N}$ (sample $\mathrm{B} 4$, made from 'Moravica' and pumpkin purees).

\section{ACKNOWLEDGMENTS}

The research and publication has been prepared within the framework of the ESF Project No. 2011/0055/1DP/ 1.1.2.1.2/11/IPIA/VIAA/008,

Contract No. 04.4-08/EF10.PD.03.

\section{Authors thank the Pure Horticultural Research Centre for} rowanberry samples.

\section{REFERENCES}

Bannwart, G. C. M. de C., Bolini, H. M. A., Toledo, M. C. de F., Kohn, A. P. C., Cantanhede, G. C. (2008). Evaluation of Brazilian light ketchups II: Quantitative descriptive and physicochemical analysis. Ciźnc. Tecnol. Aliment., Campinas, 28 (1), 107-115.

Bourne, M. (2002). Food texture and viscosity. In: Taylor, S. L. (Ed.). Food Science and Technology. 2nd edn. (pp. 365-368). San Diego: Academic Press, Elsevier Science Imprint.

Cardona, L. de J. M., Salazar, B. L. C., Herrera, M J. A., Arbelįez, R. D., Gutiérrez, M. D. E. (2010). Anillisis sensorial e instrumental (textura) a una salsa agridulce de borojó [Sensorial and instrumental (texture) analysis for a bittersweet borojo sauce]. Revista Lasallista de Investigacion, 7 (1), 36-41 (in Spanish).

Chakrborty, R., Bera, M., Mukhopadhyay, P., Bhattacharya, P. (2011). Prediction of optimal conditions of infrared assisted freeze-drying of aloe vera (Aloe barbadensis) using response surface methodology. Separ. Purif. Technol., 80, 375-384.

Coultate, T. P. (2002). Food: The Chemistry of Its Components. 4th edn. Cambridge, UK: RSC Paperbacks, pp. 213-217.

Eder, R., Kalchgruber, R., Wendelin, S., Pastler, M., Barna, J. (1991). Vergleich der chemischen Zusammensetzung von süßen und bitteren Ebereschenfrüchte (Sorbus aucuparia L). Mitteilungen Klosterneuburg, 41 (4), 168-173 (in German).

Figueredo, E., Cuesta-Herranz, J., Minguez, A., Vidarte, L., Pastor, C., De Las Heras, M., Vivanco, F., Lahoz, C. (2000). Allergy to pumpkin and cross-reactivity to other Cucurbitaceae fruits. J. Allergy Clin. Immunol., $106,402-403$.

García-Viguera, Zafrilla, F. Artés, P., Romero, F., Abellán P., TomásBarberán, F. A. (1998) Colour and anthocyanin stability of red raspberry jam. J. Sci Food Agric, 78 (4), 565-573.

Hayes, W. A., Smith, P. G., Morris, A. E. J. (1998). The production and quality of tomato concentrates. Critical Rev. Food Sci. Nutr., 38 (7), 537-564.
Howard, L. (2008). Processing techniques and their effect on fruit and vegetable phytochemicals. In: Tomas-Barberan, F. A., Gil, M. I. (eds.). Improving the Health-promoting Properties of Fruit and Vegetable Product (pp. 449-471). UK: Woodhead Publishing Limited.

Kopjar, M., Piližota, V., Tiban, N. N., Šubarić, D., Babić, J., Ačkar, Š., Sajdl, M. (2009). Strawberry jams: Influence of different pectins on colour and textural properties. Czech J. Food Sci., 27, 20-28.

Lee, C. H., Cho, J. K., Lee, S. J., Koh, W., Park, W., Kim, C. H. (2002). Enhancing $\beta$-carotene content in Asian noodles by adding pumpkin powder. Cereal Chem., 79 (4), 593-595.

Lehkoživová J., Karovičová J., Kohajdová Z. (2009). The quality and authenticity markers of tomato ketchup. Acta Chim. Slovaca, 2 (2), 88-96.

Mattila, P., Hellström, J., Törrönen, R. (2006). Phenolic acids in berries, fruits, and beverages. J. Agr. Food Chem., 54 (19), 7193-7199.

Navys, E. (2001) The investigation of morphological and ecological peculiarities of Sorbus genera species and sorts in the botanical garden of Vilnius university. Acta Biol. Univ. Daugavpiliensis, 1 (2), 94-98.

Poyrazošlu, E. S. (2004). Changes in ascorbic acid and sugar content of rowanberries during ripening. J. Food Quality, 27, 366-370.

Rengsutthi, K., Charoenrein, S. (2011). Physico-chemical properties of jackfruit seed starch (Artocarpus heterophyllus) and its application as a thickener and stabilizer in chilli sauce. LWT — Food Science and Technology, 44, 1309-1313.

Rózek, A., García-Pérez, J. V., López, F., Güell, C., Ferrando, M. (2010). Infusion of grape phenolics into fruits and vegetables by osmotic treatment: Phenolic stability during air drying. J. Food Eng., 99, pp. 142-150.

See, E. F., Wan Nadiah, W. A., Noor Aziah, A. A. (2007). Physico-chemical and sensory evaluation of breads supplemented with pumpkin flour. ASEAN Food J., 14 (2), 123-130.

Sikora, M., Badrie, N., Deisingh, A.K., Kowalski, S. (2008). Sauces and dressings: A review of properties and applications. Critical Rev. Food Sci. Nutr., 48 (1), 50-77.

Sikora, M., Kowalski, S., Tomasik, P., Sady, M. (2007). Rheological and sensory properties of dessert sauces thickened by starch-xanthan gum combinations. J. Food Eng., 79, pp. 1144-1151.

Souci, S. W., Fachmann, W., Kraut, H. (2008). Rowanberry sweet. In: Deutsche Forschungsanstalt für Lebensmittelchemie (eds.). Food Composition and Nutrition Tables=Die Zusammensetzung der Lebensmittel, Nährwert-Tabellen. 7th edn. Stuttgart: Medpharm Scientific Publishers, 1087 pp..

Wang, S. (2007). Antioxidant capacity and phenolic content of berry fruits as affected by genotype, preharvest conditions, maturity, and postharvest handling. In: Zhao, Y. (Ed.). Berry Fruit: Value-added Products for Health Promotion (pp. 148-186). Boca Raton, USA: CRC Press, Taylor \&Francis Group.

Ермаков А. (1987). Методы биохимического исследования растений [Methods for Plant Biochemical Analysis]. Ленинград: Агропромиздат. 430 c. (in Russian).

Стрельцина С. А., Бурмистров Л. А., Никитина Е. В. (2010). Питательные и биологически активные вещества плодов рябины (Sorbus L.) в условиях северо-западной зоны садоводсва России [Nutrients and bioactive substances of fruits of mountain ash (Sorbus L.) in the north-western zone gardening of Russia]. Аграрная Россия, №. 3, 10-17 (in Russian). 


\section{PĪLĀDŽU UN PĪLĀDŽU-KSIRBJU MĒRČU NOVĒRTĒJUMS}

Pīlādži (Sorbus aucuparia) ir mazi oranžsarkanas krāsas pīlādžu koku augḷi, kas literatūrā raksturoti kā nozīmīgs flavonoīdu avots, un to antioksidatīvā aktivitāte ietekmē reaktīvo skābekli un lipīdu peroksidāciju. Pīlādžu šķirṇu un to starpǵinšu hibrīdu aug̣̣i ir saldāki un ar mazāk savelkošu garšu nekā savvaḷas pīlādži. Pētījumu mērḳis bija izvērtēt dažādu šķirņu pīlādžu un pīlādžu-ķirbju mērces paraugu fizikāāās un ķīmiskās īpašības, kā arī izpētīt to patikšanas pakāpi. Eksperimenti tika veikti Latvijas Lauksaimniecības universitātes Pārtikas tehnologijijas fakultātē. Mērces tika pagatavotas no savvaḷas un dažādu škiinnu saldo pīlādžu biezeṇiem, kā arī no saldo pīlādžu un kirbju biezeniem. Mērces paraugiem noteikts kopējā sausnas, šḳistošās sausnas un kopējo karotīnu saturs, pH, krāsas L * a * b * vērtības un struktūras parametri, kā arī novērtēta paraugu patikšanas pakāpe, izmantojot hedonisko skalu. Pētījuma rezultāti parādīja, ka būtiski atškiras pētīto pīlādžu un pīlādžu-kirbju mērces paraugu rādītāji. Tika noteikts, ka pīlādžu un pīlādžu-kirbju mērces paraugu kopējās sausnas saturs bija 25.92-31.38\%, kopējo karotīnu saturs - no $3.94 \pm 0.40$ līdz $7.34 \pm 0.57 \mathrm{mg} 100 \mathrm{~g}^{-1}$ sausnas, un cietība - 0.5-2.2 N. Saskaņā ar sensorās novērtēšanas rezultātiem, vērtētājiem vislabāk bija pieņemami $(P<0.05)$ mērces paraugi, kas tika pagatavoti no pīlādžu šķirņu 'Michurinskaya Krasnaya' un 'Granatnaya' biezen̦iem, dalı pīlādžu biezeņa aizstājot ar kirbju biezeni. 


\title{
DETERMINATION OF OXALATE AND SOME INORGANIC ANIONS IN GREEN AND BLACK TEA
}

\author{
Elena Yusenko*, Evgeniya Polyntseva*, Anna Lyzhova*, and Olga Kalyakina** \\ * Institute of Non-Ferrous Metals and Materials Science, Siberian Federal University, \\ 79 Svobodny Prospect Krasnoyarsk 660041, RUSSIA \\ elena.yusenko@yahoo.com \\ ** Institute of Petroleum and Natural Gas Engineering Siberian Federal University, \\ 82-6 Svobodny Prospect Krasnoyarsk 660041, RUSSIA
}

Communicate by Maija Dambrova

\begin{abstract}
Oxalate concentration differs in various daily consumed food products. The role of oxalic acid in the human body is very significant, as its compounds are responsible for the stability of biological membranes. However, insoluble calcium and magnesium oxalates can be accumulated in the body in the form of kidney stones. Oxalate concentration has been measured by high performance liquid, gas after derivatization and ion chromatography (IC). The most effective method for the simultaneous determination of oxalate and inorganic anions is ion chromatography with conductometric detection. Here, we report the results of the measurement of oxalic acid in bleak and green tea samples. Separation was performed by IC on an anion-exchange column Shodex IC SI-90 with surface-layer sorbent and conductimetric detection. The main analytical features of the method were: limit of detection of oxalic acid $0.03 \mathrm{mg} / \mathrm{l}$, linear range $0.1-20 \mathrm{mg} / \mathrm{l}$, correlation 0.9998 , relative standard deviation $1 \%$. The method did not need specific sample treatment and was successfully applied to the analysis of black and green tea samples. Oxalic acid was determined in the ranges 16.7-84 mg/l for green tea and 63-116 mg/l for black tea. Green tea contained lower oxalate ions concentration than black tea. The IC method has a lower detection limit for oxalate ions than HPLS and GC, ten and two times less, respectively.
\end{abstract}

Key words: tea, oxalic acid, ion chromatography, kidney stones.

\section{INTRODUCTION}

Oxalate can be found in food products such as sorrel, chocolate, cacao and tea (Schroder et al., 2011). After water, tea is the second most popular beverage, but it contains high levels of oxalic acid (Sang et al., 2011). In the human body, oxalic acid is formed by the metabolism of glycine and ascorbic acid (Rassam et al., 2005). The role of oxalic acid in the human body is very significant, because its compounds are responsible for the stability of biological membranes (Melnik, 1999). However, insoluble calcium and magnesium oxalates may be accumulated in the body in the form of kidney stones. Therefore, it is necessary to control the concentration of oxalic acid in food and the human body (Hodgkinson et al., 1968). Nowadays, oxalate ions can be identified in complex objects using titration, colorimetry, capillary electrophoresis (CE) (Fu et al., 1999), chemiluminescence (Rubinsteln, 1983), high performance liquid chromatography (HPLC), gas (GC) (Kawamura et al., 2010) and ion chromatography (IC) (Lachenmeir et al., 2005). However, these methods have disadvantages. CE has low reproducibility due to migration times of ions. GC involves difficult sample preparation. Since oxalic acid is a strong organic acid $\left(p K_{a_{1}}=1.27 ; p K_{a_{2}}=3.80\right)$, the most ef- fective method for the determination of oxalate ions is IC with conductometric detection (Geng et al., 2008). In this work, an approach for the simultaneous determination of oxalate, chloride, nitrate, phosphate, sulphate ions is proposed and applied to the analysis of these compounds in tea samples of different brands and manufacturers. We aimed to identify the optimal conditions for determination of oxalate ions in drinks, to determine interference of inorganic anions, describe the comparative characteristics of the method and to apply the method for determination of oxalate ions in tea samples.

\section{MATERIALS AND METHODS}

The chromatographic system HPLC LC-20 Prominence (Shimadzu, Japan) and conductivity detector were used. An anion-exchange column Shodex IC SI-90, $250 \mathrm{~mm} \times 4$ $\mathrm{mm}, 9 \mu \mathrm{m}$ of particle size and column was filled with KanK-ASt, $120 \mathrm{~mm} \times 5 \mathrm{~mm}, 14 \mu \mathrm{m}$ of particle size. The column oven was maintained at $33{ }^{\circ} \mathrm{C}$. Loop volume was $20 \mu \mathrm{l}$.

An isocratic elution was performed, using a mobile phase of $1.9 \mathrm{Na}_{2} \mathrm{CO}_{3}+2.4 \mathrm{mM} \mathrm{NaHCO} 3$ at a flow rate of $1.5 \mathrm{ml} / \mathrm{min}$, 
and a column was filled with KanK-ASt and $1.8 \mathrm{mM}$ $\mathrm{Na}_{2} \mathrm{CO}_{3}+1.7 \mathrm{mM} \mathrm{NaHCO}_{3}$ at a flow rate of $1.0 \mathrm{ml} / \mathrm{min}$ for column Shodex.

Oxalic acid dihydrate, sodium bicarbonate, sodium digidrokarbonat were HPLC grade. Sodium chloride, sodium nitrate, sodium phosphate, sodium fluoride were analytical grade. Water was purified with an aquaMAXTM Ultra 370 Series - Ultra Water Purification System (Young Lin Instrument Co, Korea). Standard solutions were prepared and diluted in deionised water. Oxalic acid solution was daily diluted.

Samples of black and green tea were purchased from Krasnoyarsk outlets, produced by Russia, Ceylon, China. Assay solutions were obtained by refluxing $2.0 \mathrm{~g}$ of tea with hot water $\left(100{ }^{\circ} \mathrm{C}\right)$ for $6 \mathrm{~min}$. The obtained extract was filtered through a disposable $0.45 \mu \mathrm{m}$ filter, diluted 10 times and injected into the chromatographic system.

\section{RESULTS}

In preliminary experiments, the conditions for the separation of the most common inorganic anions (fluoride, chloride, phosphate, nitrate, sulfate) in biological and food products were optimised. It was found out that the best separation conditions for the chromatographic system using a column filled with KanK-ASt was obtained with eluent consisting of $1.9 \mathrm{mM} \mathrm{Na}_{2} \mathrm{CO}_{3}+2.4 \mathrm{mM} \mathrm{NaHCO}_{3}$ at a flow rate of elution of $1.5 \mathrm{ml} / \mathrm{min}$. The retention time of oxalate ions in these conditions was $t_{R}=13.73 \pm 0.01 \mathrm{~min}$. Previous reports (Rassam et al., 2005) and the experimental data suggested interference from sulfate ions on oxalate ion determination. A chromatogram of a standard mixture of equivalent amounts of sulfate and oxalate ions is shown in Figure 1. Resolution of the peaks was $\mathrm{R}_{\mathrm{s}}=1.16$.

In these conditions quantitative identification of oxalate is unreasonable. Therefore, the effects of different factors on the degree of separation of the peaks were studied. The in-

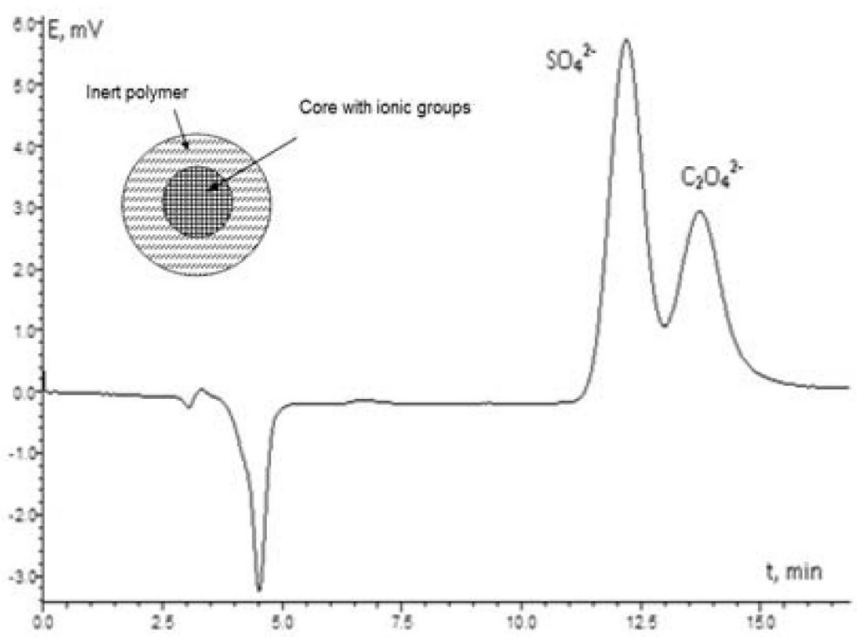

Fig. 1. Chromatogram of a standard mixture of equivalent amounts of sulfate and oxalate ions. Conditions: column was filled with KanK-ASt bipolar central-localised sorbent; eluent $1.9 \mathrm{mM} \mathrm{Na}_{2} \mathrm{CO}_{3}+2.4 \mathrm{mM} \mathrm{NaHCO}_{3}$; flow rate $1.5 \mathrm{ml} / \mathrm{min}$. fluence of various factors (flow rate and composition of the eluent) on the degree of separation of the peaks were studied by a full factorial experimental design. The data showed that a column was filled with KanK-ASt gave the best results, but was not sufficient to separate of sulfate and oxalate ions. Sorbent KanK-ASt is a bipolar central-localised sorbent, in which the act of sorption and desorption runs inside the grain. The diffusion inside the grain when anions are strongly retained anions, multiply charged and when hydrated ions have large size, is very difficult (Dolgonosov, 1984; Dolgonosov et al., 1988). This can explain the observed eroding peaks. Sulfate and oxalate ions have similar constants of ion exchange and retention times, and probably for this reason a satisfactory separation of sulfate and oxalate ions in this system is impossible.

The anion-exchange column Shodex IC SI-90 with surfacelayer sorbent was also applied for the separation of sulfate and oxalate ions. Under the selection experimental conditions, the retention time for the oxalic ions was $15.83 \pm 0.01$ min. Figure 2 shows a chromatogram of a standard mixture of equivalent amounts of sulfate and oxalate ions. The selectivity of the column Shodex IC SI-90 is correct, as because the peaks showed resolution 1.5 for all of the determined compounds. In further work, we used a column Shodex IC SI-90.

Table 1 gives the resolutions of sulphate and oxalate ions at different concentrations. The column Shodex allowed to separate the peaks at all sulphate:oxalate ratios used.

The accuracy of the method was evaluated from recovery assays, preparing spiked samples of tea in triplicate at three levels of concentrations higher than the limit of quantitation (LOQ). The obtained values ranged between $98 \%$ and $102 \%$ (Table 2). The linearity of the analytical response, calibration curve, limit of detection (LOD) and LOQ were examined (Table 3).

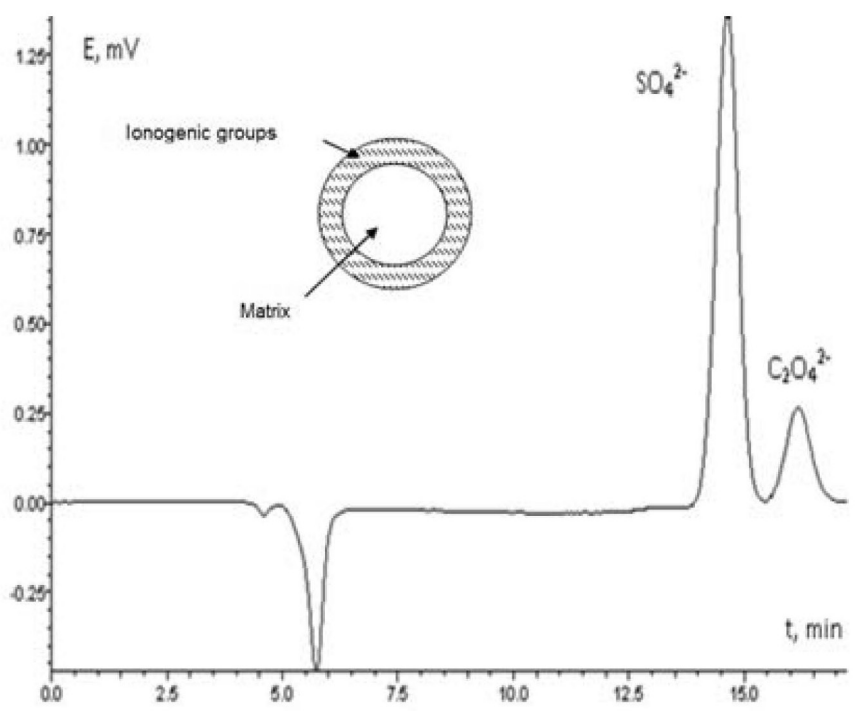

Fig. 2. Chromatogram of a standard mixture of equivalent amounts of sulfate and oxalate ions. Conditions: column Shodex IC SI-90 with surface-layer sorbent; eluent $1.8 \mathrm{mM} \mathrm{Na}_{2} \mathrm{CO}_{3}+1.7 \mathrm{mM} \mathrm{NaHCO} 3$; flow rate $1.0 \mathrm{ml} / \mathrm{min} ; \mathrm{R}_{\mathrm{s}}=1.64$. 
Table 1

RESOLUTIONS OF SULPHATE AND OXALATE IONS AT DIFFERENT RATIOS OF CONCENTRATIONS

\begin{tabular}{c|c|c|c}
\hline $\begin{array}{c}\text { Relation of } \\
\text { concentrations } \\
\mathrm{SO}_{4}{ }^{2-} / \mathrm{C}_{2} \mathrm{O}_{4}{ }^{2-}\end{array}$ & $\begin{array}{c}\text { Resolution, } \\
\mathrm{R}_{\mathrm{s}}\end{array}$ & $\begin{array}{c}\text { Concentration } \\
\text { ratio } \\
\mathrm{SO}_{4}{ }^{2-} / \mathrm{C}_{2} \mathrm{O}_{4}{ }^{2-}\end{array}$ & $\begin{array}{c}\text { Resolution, } \\
\mathrm{R}_{\mathrm{s}}\end{array}$ \\
\hline 1 & 1.64 & 20 & 1.58 \\
2 & 1.61 & 30 & 1.13 \\
5 & 1.59 & 50 & 1.01
\end{tabular}

Table 2

RESULTS OF RECOVERY OF OXALIC ACID IN TEA SAMPLES

\begin{tabular}{ccc}
\hline Added, $\mathrm{mg} / \mathrm{l}$ & Found, $\mathrm{mg} / \mathrm{l}$ & Recovery, $\%$ \\
\hline 5.0 & 4.9 & 98.0 \\
10.0 & 10.2 & 102.0 \\
20.0 & 19.7 & 98.5
\end{tabular}

Table 3

RESULTS OF SENSITIVITY AND LINEAR RANGE OF OXALATE ANIONS

\begin{tabular}{c|c|c|c|c|c}
\hline $\begin{array}{c}\text { Migration } \\
\text { time, min }\end{array}$ & $\begin{array}{c}\text { Linearity } \\
\text { range, } \\
\mathrm{mg} / \mathrm{l}\end{array}$ & Calibration curve & $\mathrm{r}$ & $\begin{array}{c}\mathrm{LOD}, \\
\mathrm{mg} / \mathrm{l}\end{array}$ & $\begin{array}{c}\mathrm{LOQ}, \\
\mathrm{mg} / \mathrm{l}\end{array}$ \\
\hline $15.83 \pm 0.01$ & $0.1-20.0 \quad \mathrm{C}=0.0002 \cdot \mathrm{S}+0.04$ & 0.9998 & 0.03 & 0.1
\end{tabular}

To check the precision of the method, seven replicate analysis of a standard solution were performed on different days. The precision expressed as R.S.D. remained $1 \%$.

Chloride, nitrate, phosphate, sulphate and oxalate ions were determined in tea samples using the method proposed. The

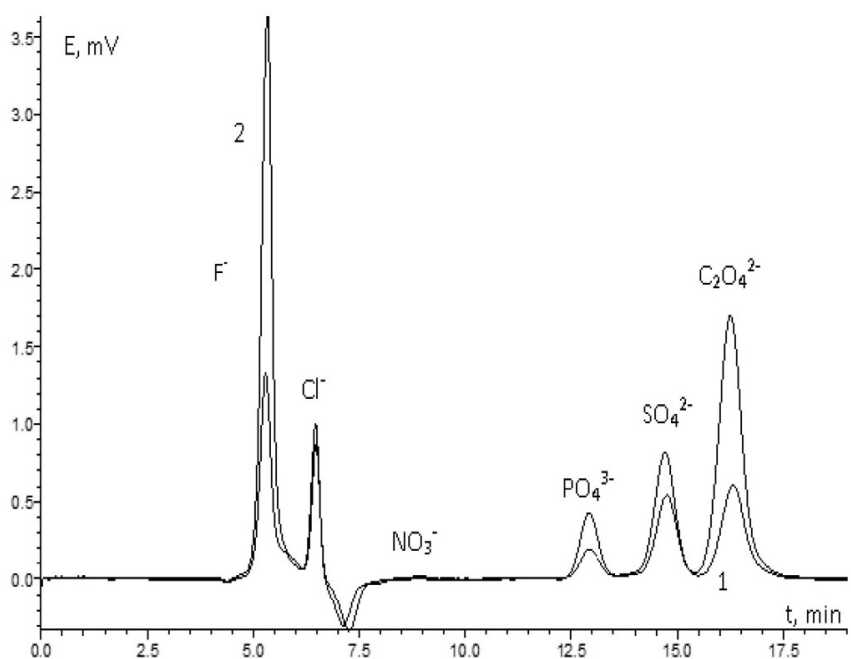

Fig. 3. Chromatograms of green (1) and black (2) tea samples brand "Tess". Conditions: column Shodex IC SI-90; eluent $1.8 \mathrm{mM} \mathrm{Na}_{2} \mathrm{CO}_{3}+$ $1.7 \mathrm{mM} \mathrm{NaHCO} 3$; flow rate $1.0 \mathrm{ml} / \mathrm{min}$.

presence of these compounds was confirmed by comparing their retention times with those of standard solutions. The results are summarised in Table 4 and the chromatograms of the green and black tea samples are shown in Figure 3.

\section{DISCUSSION}

As can be observed in chromatograms of samples the fluoride ion peak has an asymmetric shape, indicating the presence of several anions having similar retention times with fluorine; therefore, the separation between these peaks could not be obtained. According to the literature it is

Table 4

CONTENTS OF ANIONS IN TEA SAMPLES

\begin{tabular}{|c|c|c|c|c|c|c|}
\hline \multirow[t]{2}{*}{ Sample } & \multirow[t]{2}{*}{ Class tea } & \multicolumn{5}{|c|}{ Concentration of ions (average \pm standard error) ${ }^{*}, \mathrm{mg} / \mathrm{l}$} \\
\hline & & $\mathrm{Cl}^{-}$ & $\mathrm{NO}_{3}^{-}$ & $\mathrm{PO}_{4}{ }^{3-}$ & $\mathrm{SO}_{4}{ }^{2-}$ & $\mathrm{C}_{2} \mathrm{O}_{4}{ }^{2-}$ \\
\hline \multirow[t]{2}{*}{ Rowford } & Black & $45 \pm 2$ & $1,48 \pm 0,04$ & $38 \pm 2$ & $42 \pm 2$ & $89 \pm 4$ \\
\hline & Green & $28 \pm 1$ & $0,95 \pm 0,03$ & $25 \pm 1$ & $46 \pm 2$ & $53 \pm 2$ \\
\hline \multirow[t]{2}{*}{ Riston } & Black & $31 \pm 1$ & $\mathrm{Nd}$ & $42 \pm 2$ & $42 \pm 2$ & $99 \pm 5$ \\
\hline & Green & $20 \pm 1$ & $1,11 \pm 0,03$ & $35 \pm 1$ & $39 \pm 2$ & $84 \pm 4$ \\
\hline Ahmad & Black & $23 \pm 1$ & $\mathrm{Nd}$ & $24 \pm 1$ & $21 \pm 1$ & $63 \pm 3$ \\
\hline & Green & $14,5 \pm 0,7$ & $0,24 \pm 0,01$ & $6,7 \pm 0,3$ & $22 \pm 1$ & $34 \pm 2$ \\
\hline Princess Nuri & Black & $30 \pm 1$ & $0,85 \pm 0,02$ & $45 \pm 2$ & $46 \pm 2$ & $98 \pm 5$ \\
\hline Princess Yava & Green & $28 \pm 1$ & $1,37 \pm 0,04$ & $28 \pm 1$ & $60 \pm 3$ & $66 \pm 3$ \\
\hline \multirow[t]{2}{*}{ Tess } & Black & $35 \pm 1$ & $0,34 \pm 0,01$ & $41 \pm 2$ & $43 \pm 2$ & $113 \pm 5$ \\
\hline & Green & $26 \pm 1$ & $0,44 \pm 0,01$ & $18,9 \pm 0,9$ & $44 \pm 2$ & $43 \pm 2$ \\
\hline Indu & Black & $29 \pm 1$ & $0,35 \pm 0,01$ & $38 \pm 2$ & $48 \pm 2$ & $114 \pm 5$ \\
\hline \multirow[t]{2}{*}{ Curtis } & Black & $26 \pm 1$ & $\mathrm{Nd}$ & $50 \pm 2$ & $55 \pm 2$ & $116 \pm 5$ \\
\hline & Green & $15,6 \pm 0,8$ & $0,56 \pm 0,02$ & $17,9 \pm 0,9$ & $469 \pm 23$ & $16,7 \pm 0,8$ \\
\hline Da Hong Pao & Black & $35 \pm 1$ & $0,51 \pm 0,02$ & $25 \pm 1$ & $37 \pm 2$ & $64 \pm 3$ \\
\hline Tie Guan Yin & Green & $16,5 \pm 0,8$ & $0,25 \pm 0,01$ & $9,5 \pm 0,5$ & $28 \pm 1$ & $21 \pm 1$ \\
\hline
\end{tabular}

*Average of five analysis

$\mathrm{Nd}$, not detected 
known that these ions can be acetate and formate. Development of a method for quantification of fluoride ions requires further research. The presence of nitrate, phosphate, sulfate ions in tea samples can be explained by the use of various fertilisers and pesticides in cultivation. The most common class of pesticides is organochlorine and organophosphorus compounds. They easily dissolve in rain water and enter the soil. They are the most dangerous substances, causing of cancers, allergies and other diseases (Flaten, 2002; Tatarchenko et al., 2003).

Oxalic acid was present in the ranges $16.7-84 \mathrm{mg} / \mathrm{l}$ for green tea and $63-116 \mathrm{mg} / \mathrm{l}$ for black tea. Green tea contained lower oxalate ions concentration than black tea. It may be because green tea lacks oxidative processes. The lowest amount of oxalate ions was found in black tea brand Ahmad tea (black sheet tea "English breakfast", Ceylon) $(63 \pm 3 \mathrm{mg} / \mathrm{l})$ and green tea brand Curtis "Original green tea" (Chinese green long leaf tea, Russia) $(16.7 \pm 0.8 \mathrm{mg} / \mathrm{l})$. A high concentration of phosphate ions in all samples was indicated.

Finally, the approach developed was compared with other existing methods (Table 5). Table 5 shows that the IC method has a lower detection limit for oxalate ions than HPLS and GC, ten and two times less, respectively.

\section{REFERENCES}

Flaten, T. (2002). Aluminium in tea - concentrations, speciation and bioavailability. Coordin. Chem. Rev., 228, 385-395.

Fu, C., Wang, L., Fang, Y. (1999). Determination of oxalic acid in urine by co-electroosmotic capillary electrophoresis with amperometric detection. Talanta, 50, 953-958.

Geng, X., Zhang, S. (2008). Determination of organic acids in the presence of inorganic anions by ion chromatography with suppressed conductivity detection. J. Chromatogr. A., 1192 (1), 187-190.

Hodgkinson, A., Zarembski, P. (1968). Oxalic acid metabolism in man. Calc. Tiss. Res., 2, 115-132.

Judprasong, K., Charoenkiatkul, S., Sungpuag, P., Vasanachitt, K., Nakjamanong, Y. (2006). Total and soluble oxalate contents in Thai vegetables, cereal grains and legume seeds and their changes after cooking. $J$. Food Comp. Anal., 19, 340-347.

Kawamura, K., Barrie, L., Toom-Sauntry, D. (2010). Intercomparison of the measurements of oxalic acid in aerosols by gas chromatography and ion chromatography. Atmosph. Environ., 44, 5316-5319.
Table 5

COMPARISON OF METHODS FOR DETERMINATION OF OXALIC ACID

\begin{tabular}{c|c|c|c|c|l}
\hline $\begin{array}{c}\text { Method of } \\
\text { determina- } \\
\text { tion }\end{array}$ & $\begin{array}{c}\text { Detection } \\
\text { time, } \\
\text { min }\end{array}$ & $\begin{array}{c}\text { Linearity } \\
\text { range, } \\
\mathrm{mg} / 1\end{array}$ & $\begin{array}{c}\text { LOD, } \\
\mathrm{mg} / 1\end{array}$ & $\begin{array}{c}\text { R.S.D., } \\
\%\end{array}$ & \multicolumn{1}{c}{ References } \\
\hline HPLC & 3 & - & 0.3 & - & (Judprasong, 2006) \\
CE & 6 & $0.05-90.00$ & 0.01 & 4 & (Fu, 1999) \\
GC & 15 & $0.2-5.0$ & 0.06 & 1.3 & (March, 2003) \\
IC & 20 & $0.1-20.0$ & 0.03 & 1 & Approach developed
\end{tabular}

Lachenmeir, D., Richling, E., Lopez, G. (2005). Multivariatiate analysis of FTIR and Ion chromatographic data for quality control of tequila. J. Agric. Food Chem., 53 (6), 2151-2157.

March, J., Simonet, B., Grases, F., Munoz, J., Valiente, M. (2003). Determination of trace amounts of oxalate in renal calculi and related samples by gas chromatography-mass spectrometry. Chromatographia, 57, 811-817.

Rassam, M., Laing, W. (2005). Variation in ascorbic acid and oxalate levels in the fruit of Actinidia chinensis tissues and genotypes. J. Agric. Food Chem., 53 (6), 2322-2326.

Rubinsteln, I., Martin, C., Bard, A. (1983). Electrogenerated chemiluminescent determination of oxalate. Anal. Chem., 55, 1580-1582.

Sang, S., Lambert, D., Ho, C., Yang, C. (2011). The chemistry and biotransformation of tea constituents. Pharmacol. Res., 64, 87-99.

Schroder, T., Vanhanen, L., Savage, G. (2011). Oxalate content in commercially produced cocoa and dark chocolate. J. Food Comp. Anal., 24 (7), 916-922.

Мельник А. В., Мельник А. И. (1999). Особенности обмена щавелевой кислоты при расстройствах тонкокишечного переваривания и всасывания у детей [Particularities — the exchange of oxalic acid in enteric disorders of digestion and absorption for children]. Сборник научных работ имени Я. Д. Витебского. Вып. III, с. 127-133 (in Russian).

Долгоносов А. М. (1984). Ионная хроматография на центральнопривитом анионообменнике [Ion chromatography on centrally localized anion exchanger]. Журнал физической химии, 58 (8), 1989-1991 (in Russian).

Долгоносов А. М., Лазейкина М. А. (1988). Получение центральнопривитых анионитов и определение трудноразделяемых компонентов методом ионной хроматографии [Getting centrally localized ion exchanger and determination of difficult separation components by ion chromatography]. Журнал аналитической химии, 43 (11), 2048-2052 (in Russian).

Татарченко И. И., Мохначев И. Г., Касьянов Г. И. (2003). Химия субтропических и пищевкусовых продуктов [Chemistry of Subtropical and Drink Products]. Москва: Академия. 256 c (in Russian).

Received 27 March 2013

\section{OKSALĀTU UN DAŽU NEORGANISKO ANJONU NOTEIKŠANA ZAḶAJĀ UN MELNAJĀ TĒJĀ}

Skābeṇskābei ir nozīmīga loma cilvēka organismā, jo tās atvasinājumi ietekmē bioloğisko membrānu stabilitāti. Tomēr nešḳistoši kalcija un magnija oksalāti var uzkrāties organismā nierakmeņu formā. Oksalātu koncentrācijas mērījumiem izmantoja augstefektīvo šķidruma hromatogrāfiju, gāzhromatogrāfiju un jonu hromatogrāfiju. Jonu hromatogrāfija ar konduktometrisku detektoru bija visefektīvākā metode oksalātu un neorganisko anjonu noteikšanai. Pētījums veltīts skābeņskābes mērījumiem melnās un zaḷās tējas paraugos. Sadalīšanai izmantoja jonu hromatogrāfu ar anjonu apmaiņas kolonnu Shodex IC SI-90 ar virsmas slāņa sorbentu un konduktometrisko detektoru. Skābeņskābes noteikšanas robeža bija pie $0,03 \mathrm{mg} / \mathrm{l}$, lineārais apgabals no 0,1-20 g/l, korelācija 0,9998, relatīvā standartnovirze $1 \%$. Metodei nebija vajadzīga specifiska paraugu apstrāde, un to labi varēja izmantot melnās un zaḷās tējas paraugu analīzei. 


\title{
ANTIOXIDANT CHARACTERISTICS OF LATVIAN HERBAL TEA TYPES
}

\author{
Fredijs Dimiṇš, Velga Miḳelsone, and Miḳelis Kaṇeps \\ Department of Chemistry, Latvia University of Agriculture, Lielā iela 2, Jelgava, LV-3001, LATVIA; \\ fredisd@tvnet.Iv
}

Communicated by Dalija Segliṇa

The aim of the study was to characterise antioxidative properties and antiradical activity of the herbal tea collection in Latvia. High-pressure liquid chromatography and spectrophotometry methods were used to characterise antioxidant properties of herbal tea. Antiradical activity was determined spectrophotometrically. The antiradical scavenging activity was measured by the DPPH (2,2-diphenyl-1-picrylhydrazyl) reaction. The herbal tea antiradical scavenging activity was estimated as the broken down quantity of DPPH on 100 grams of the herbal tea. Individual polyphenols in the herbal tea were identified and determined by liquid chromatography. Antiradical scavenging activity of the herbal tea was found to be $104 \mathrm{~mol}_{100 \mathrm{~g}^{-1}}$ tea. The following polyphenols were identified chromatographically in herbal tea: gallic, caffeic, chlorogenic, ferulic acids, rutin, catechin, vanillin, and epicatechin. Altogether 12 different varieties of herbal tea samples were analyzed. The results showed that different types of herbal tea substantially differed in composition. Polyphenol content of herbal teas was in the range of $1 \mathrm{mg}$ in $100 \mathrm{~g}$ of tea up to $8 \mathrm{~g}$ per $100 \mathrm{~g}$ of tea. In the case of virus-related disease, infections and weakness of the organism, it is recommended to use tea with high content of rutin, as in Verbascum thapsiforme Schr., Alchemilla vulgaris $L$., Comarum palustre $L$. herbal tea.

Key words: herbal tea, polyphenols, antiradical scavenging activity.

\section{INTRODUCTION}

Herbal teas are widely used in traditional medicine. Antioxidant effect is one of the major descriptive characteristics of organic and medicinal activity.

In the body mitochondrial activity, during metabolism or as a result of environmental factors, such as pollution, radiation, smoking, pesticides, etc. exposure, leads to free radicals - atoms, molecules or ions with unpaired electrons superoxide, hydrogen peroxide, singlet acid, hydroxyl radical. These are highly reactive, unstable and can lead to oxidative stress - a chain reaction that causes cell and tissue damage, contributing to aging and increased risk of developing various diseases, such as cancer, heart disease, cataracts, etc. (Sailaja et al., 2011).

During oxidative stress, specific molecules actively react with proteins, lipids, and nucleic acid molecules, adding the missing electron, and thus creating other unstable molecules and inducing a chain reaction, such as via hydroxylated aromatic amino acids in protein molecules and oxidised-SH groups forming disulfide bridges - SS-bonds (Vīgants, 2008).

Unsaturated fatty acid-containing lipids with a large number of double bonds are readily oxidised. A variety of oxidation products, such as peroxides, hydroperoxide, alkanoles, aldehydes, carboxylic acids, etc., can inactivate the enzyme activity by binding to the active centres. Linoleic and arachidonic acid form malondialdehyde, as well as 4-hidroxynonenal, which is very toxic. Also cholesterol can be oxidised, resulting in total destruction of the cell membrane.

Nucleic acids participate in purine base guanine hydroxylation to form 8-hydroxy guanine (Vīgants, 2008).

Oxidative stress can reduce the body's antioxidant defense system and increase concentrations of oxygen and nitrogen in the active form (Vīgants, 2008).

Damage by free radicals can be reduced by antioxidant molecules that react with them, eliminating the unpaired electron, or making the active radical less active, terminating the chain reaction.

The endogenous system in the body is composed of several antioxidant enzymes - superoxiddismutase, catalase, glutationperoxidase, glutationreductase etc.

Well-known exogenous (with dietary imbibed) antioxidants are vitamins $\mathrm{C}$ and $\mathrm{E}$, lycopene, lutein, carotenoids, such as $\beta$-carotene, selenium, flavonoids, polyphenols, lignans, 
coenzyme Q10, and others. Most of them are vegetable products (Sailaja et al., 2011).

Polyphenols are chemical compounds with phenol rings. There is a big difference in the phenolic compounds regarding chemical structure, and they can be monomers or complex polymers.

Phenolic compounds of plants can be divided into two broad categories: 1) phenolic acids (oxometallic) and their derivatives, and 2) flavonoids (polyphenols). Phenolic acids and their derivatives, mainly esters, have more basic structures. Phenolic compounds constitute a wide group of representatives of caffeic acid, kumarin acid, vaniline, and gallic acid.

The flavonoid class of compounds has a more complex molecular structure, which is usually heterocyclic with attracted phenolic ring(s). Flavonoids include antocianidines (water-soluble pigment, which are oxidised flavonoles), catechins, isoflavones and proanthocyanidin (Robarts et al., 1999).

Polyphenols are the main antioxidant source from food. They are found in legumes, fruits and berries, and vegetables, red wine, chocolate, green tea, cereals and many herbal teas. Phenolic compounds constitute $50-70 \%$ of the weight of green tea, which is a key indicator of quality teas (Naghma and Hasan, 2007).

Plants consist of flavonoids, including catechins, proantocyanins, anthocyanins, flavones, flavonoles and their glycosides, which have antioxidant properties. The weight of these compounds can reach up to $30 \%$ of leaf dry matter (Naghma and Hasan, 2007).

The aim of the research was to describe the antioxidative characteristics of Latvian herbal teas by antiradical scavenging activity method and to determine the content of the main polyphenols.

\section{MATERIALS AND METHODS}

In this study, the antioxidative properties of Latvian herbal teas were estimated regarding polyphenol content and antiradical activity. Twelve varieties of herbal teas were analysed:

Origanum vulgaris L., Hypericum perforatum L., Chelidonium majus L., Achillea millefolium L., Calluna vulgaris L., Artemisia vulgaris L., Plantago major L., Comarum palustre L., Alchemilla vulgaris L., Calendula officinalis L., Verbascum thapsiforme Schr., Rubus idaeus L. (Rubine and Enina, 2004) (Table 1). All these plants are widely distributed in Latvia and are used every day in the form of herbal tea. They include a variety of polyphenols, which act as radical and nitrite neutralisers in the body, they may show antiviral effects (including HIV), and enzyme induction, such as in the cytochrome P-450 system and phase II conjugation systems. They are important in the human body, as they
HERBAL TEA VARIETIES ANALYSED IN THE STUDY

\begin{tabular}{|c|c|c|c|}
\hline No. & Tea sample & No. & Tea sample \\
\hline 1 & Plantain (Plantago major L.) & 7 & $\begin{array}{l}\text { Common origanum (Origanum } \\
\text { vulgaris L.) }\end{array}$ \\
\hline 2 & $\begin{array}{l}\text { Marsh cinquefoil (Comarum } \\
\text { palustre L. }\end{array}$ & 8 & $\begin{array}{l}\text { Common St. John's wort } \\
\text { (Hypericum perforatum L.) }\end{array}$ \\
\hline 3 & $\begin{array}{l}\text { Lady's mantle (Alchemilla } \\
\text { vulgaris L.) }\end{array}$ & 9 & $\begin{array}{l}\text { Greater celandine (Chelidonium } \\
\text { majus L.) }\end{array}$ \\
\hline 4 & $\begin{array}{l}\text { Calendula (Calendula officinalis } \\
\text { L.) }\end{array}$ & 10 & $\begin{array}{l}\text { Milfoil (Achillea millefolium } \\
\text { L.) }\end{array}$ \\
\hline 5 & $\begin{array}{l}\text { Wool mullein (Verbascum } \\
\text { thapsiforme Schr.) }\end{array}$ & 11 & $\begin{array}{l}\text { Wild wormwood (Artemisia } \\
\text { vulgaris L.) }\end{array}$ \\
\hline 6 & Red raspberry (Rubus idaeus L.) & 12 & Heather (Calluna vulgaris L.) \\
\hline
\end{tabular}

aid to avoid polyunsaturated fatty acid autoxidation (Higdon and Frei, 2012).

The scavenging activity of tea samples for the radical 2.2-diphenyl-1-picrylhydrazyl (DPPH) was measured as described (Meda et al., 2005) with some modifications.

$1 \mathrm{~g}$ of dry tea was extracted in $50 \mathrm{~mL}$ methanol. Extraction was carried out for 1 hour at $25^{\circ} \mathrm{C}$. The filtrate of the extract was used for further analysis. A volume $(1.5 \mathrm{ml})$ of each tea extract solution was mixed with $3 \mathrm{ml} \mathrm{DPPH}$ solution in methanol $\left(0.02 \mathrm{mg} \cdot \mathrm{ml}^{-1}\right)$, with methanol serving as the blank sample. The mixtures were left for $15 \mathrm{~min}$ at room temperature and then the absorbance was measured at 517 $\mathrm{nm}$.

As mentioned above, in the control analysis, methanol was used instead of tea extract. Based on the DPPH solution and sample solution concentration, light absorption was used to calculate the break down amount of DPPH ( $\mu$ mol per $100 \mathrm{~g}$ of tea), in relation to the control solution.

Chromatographic determination of individual polyphenols in tea samples was made by liquid chromatography. Eight polyphenols in teas were determined: rutin, gallic acid, epicatechin, catechin, ferulic acid, chlorogenic acid, vanillin and caffeic acid.

The analyses were carried out using a Shimadzu liquid chromatography LC-20AD, with a DAD (diode array detector: SPD M20A) using analytical C18 column chromatography. The eluting solvent was methanol (A, 20\%), water (B, $78.4 \%)$ and acetic acid $(1.6 \% \mathrm{C})$ in gradient mode: 17:50 minutes $-58.5 \% \mathrm{~B}$ concentration, $\mathrm{C}$ concentration of $1.2 \%$; 35 minute - end of analysis.

The sample injection into the chromatograph, using an automatic sample injection system SIL - 20AC. Fluent flow rate $1.0 \mathrm{ml} / \mathrm{min}$.

Determination of polyphenols was made by using multiple wavelengths: 253, 268, 278 and $298 \mathrm{~nm}$. $253 \mathrm{~nm}$ wavelength was used to determine rutin, and $263 \mathrm{~nm}$ - gallic acid, $278 \mathrm{~nm}$ - catechin, caffeic acid and vanillin, and 298 $\mathrm{nm}$ - chlorogenic acid, epicatechin and ferulic acid. 


\section{RESULTS}

A significantly higher concentration of rutin was observed in Hypericum perforatum. and Calluna vulgaris tea (Fig. 1).

The highest concentration of gallic acid occured in Rubus idaeus tea (Fig. 2). Rubus idaeus tea had a relatively higher concentration of catechin (Fig. 3).

Alchemilla vulgaris, Calluna vulgaris and Hypericum perforatum teas had higher concentrations of caffeic acid (Fig. 4).

Vanillin is known as a spice, and is used in a variety of foods. Vanillin is also found in tea. A relatively higher vanillin concentration was found in Alchemilla vulgaris, Calendula officinalis and Artemisia vulgaris tea (see Fig. $5)$.
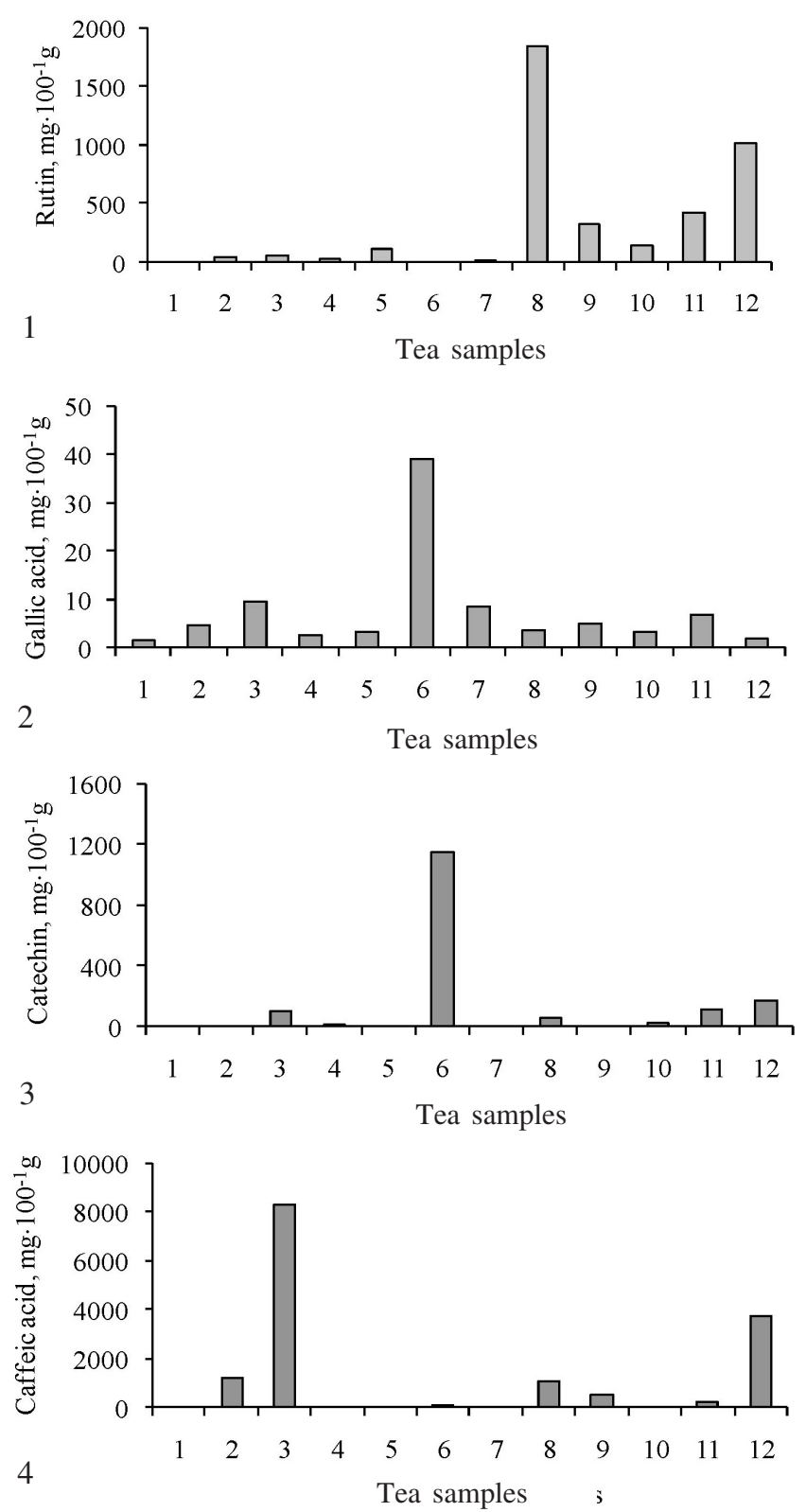

A relatively higher concentration of chlorogenic acid was found in Comarum palustre, and Achillea millefolium tea (Fig. 6). High chlorogenic acid concentration was also found in Alchemilla vulgaris and Hypericum perforatum teas.

The epicatechin concentration in teas was relatively low, and in the range from $0.07 \mathrm{mg} \cdot 100^{-1} \mathrm{~g}$ to $3.6 \mathrm{mg} \cdot 100^{-1} \mathrm{~g}$ of tea. Higher epicatechin concentration was found in Alchemilla vulgaris and Calendula officinalis teas (2.6 $\mathrm{mg} \cdot 100^{-1} \mathrm{~g}$ and $\left.3.6 \mathrm{mg} \cdot 100^{-1}\right) \mathrm{g}$.

Ferulic acid had relatively high concentrations in Origanum vulgaris tea (Fig. 7). Higher concentration of ferulic acid was also observed in Alchemilla vulgaris, Verbascum thapsiforme Schr. and Achillea millefolium tea.

In order to assess the total anti-oxidant tea value, they were assessed by total content of polyphenols in tea, as well as by
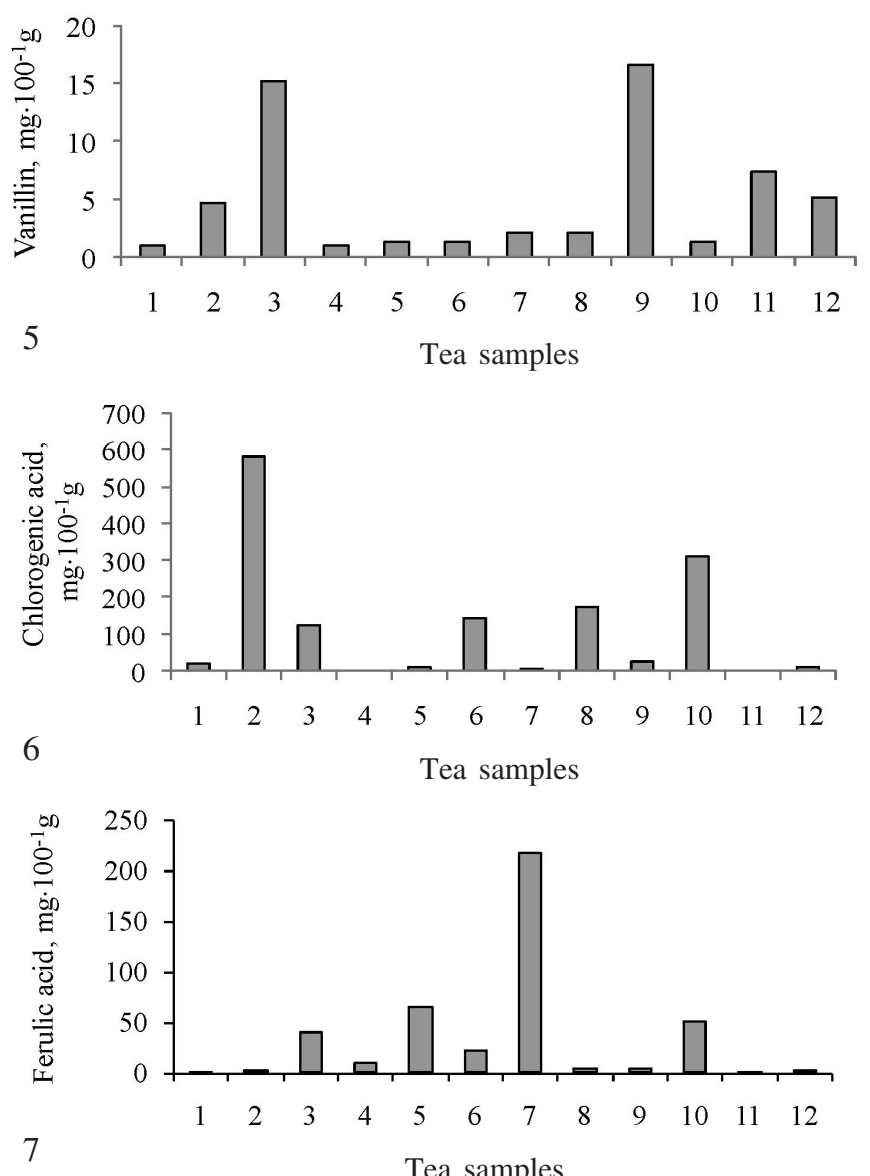

7

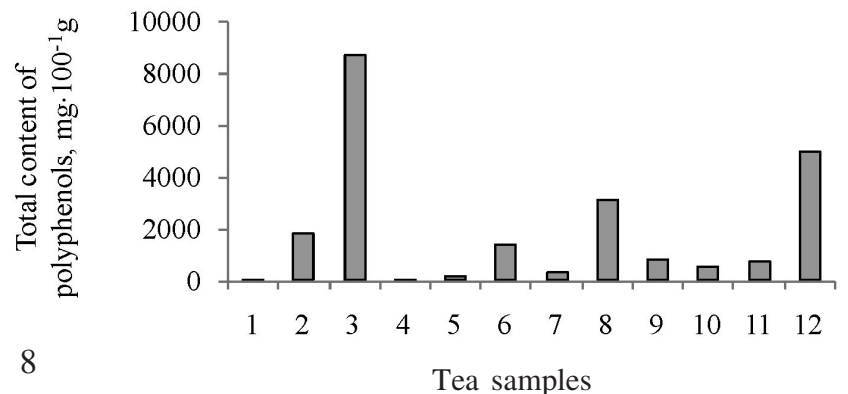

Fig. 1. Concentration of ployphenols in tea samples (numbers of tea samples identified in Table 1): 1) rutin; 2) gallic acid; 3) catechin; 4) caffeic acid; 5) vanillin, 6) chlorogenic acid; 7) ferulic acid; 8) total polyphnols. 
certain antiradical activity (Fig. 8). The highest polyphenol concentration was found in Alchemilla vulgaris and Calluna vulgaris tea, and somewhat lower in Comarum palustre, Rubus idaeus and Hypericum perforatum tea.

The antiradical scavenging activity in the analysed tea ranged from 6 to $104 \mu \mathrm{mol} \cdot 100^{-1} \mathrm{~g}$. The highest activity was in Calluna vulgaris tea (104 $\mu$ mol break down DPPH reagent per $100 \mathrm{~g}$ of tea). In other teas, the antiradical activity was in the range of 21 to $38 \mu \mathrm{mol} \cdot 100^{-1} \mathrm{~g}$.

\section{DISCUSSION}

It is known that rutin provides a more complete intake of vitamin $\mathrm{C}$ in the body. Therefore, it is used as a food supplement in combination with other substances. Rutin also has good anti-oxidant properties (Guardia et al., 2001).

Catechins have antibacterial properties and it is able to destroy viruses and bacteria. Similarly, it is a good natural antioxidant (Higdon, et al., 2003).

Caffeic acid has a spasmolytic and mitigating decreasing effect. Caffeic acid stimulates bile secretion. Chlorogenic acid has anti-bacterial, anti-inflammatory and antiviral properties. It also has antioxidant properties. Epicatechin is a powerful antioxidant. This is one of the rare flavonoids that in biologically active form is capable of reaching the brain (Mou-Tuan Huang et al., 1991).

Ferulic acid is widely used in cosmetics as an antioxidant and as a protective measure against the adverse effects of UV rays. Ferulic acid inhibits skin aging (Graf, 1992).

High antiradical activity assessed by total polyphenols content was found only in heather tea. However, teas have many other polyphenols, which were not analyzed. Also, anti-oxidant activity can be attributed not only to polyphenols, but also to specific vitamins, amino acids, etc.

To conclude, our results demonstrate that increased antioxidant concentrations were found in Alchemilla vulgaris, Calluna vulgaris, Comarum palustre, Rubus idaeus and Hypericum perforatum teas.
In cases of virus diseases, infections and weakness it is recommended to use tea to increase rutin, chlorogenic acid and catechin intake.

Tea with increased ferulic acid content can be used to prevent against skin aging and UV destructive exposure.

The estimated total antioxidant content is not the only parameter that should be used in tea evaluation, and other polyphenol and antioxidant concentrations should be considered.

\section{REFERENCES}

Frei, B., Higdon, V. (2003). Antioxidant activity of tea polyphenols in vivo: Evidence from animal studies. Proceedings of the Third International Scientific Symposium on Tea and Human Health: Role of Flavonoids in the Diet. http://jn.nutrition.org/content/133/10/3275S.full (accessed 27 July 2012).

Graf, E. (1992). Antioxidant potential of ferulic acid. Free Radical Biol. Med., 13 (4), 435-448.

Guardia, T., Rotelli, A. E., Juarez, A. O., Pelzer, L. E. (2001). Anti-inflammatory properties of plant flavonoids. Effects of rutin, quecetin and hesperidin on adjuvant arthritis in rat. II Farmaco, 56 (9), 683-687.

Higdon, J. V, Frei, B. (2003). Tea catechins and polyphenols: Health effects, metabolism, and antioxidant functions. Critical Rev. Food Sci. Nutr., 43 (1), 89-143.

Meda, A., Lamien, C. E., Romito, M., Millogo, J., Nacouluma, O. G. (2005). Determination of the total phenolic, flavonoid and proline contents in Burkina Fasan honey, as well as their radical scavenging activity. Food Chemistry, 91, 571-577.

Mou-Tuan Huang, Chi-Tang Ho, Chang Y. Lee. (1991) Phenolic Compounds in Food and Their Effects on Health. II. Antioxdants and Cancer Prevention. Washington, DC: American Chemical Society. 402 pp.

Naghma, K., Hasan, M. (2007). Tea polyphenols for health promotion. Life Sci., 81 (7), 519-533.

Rubine, H., Eniņa, V. (2004). Ārstniecības augi [Herbal plants]. Rīga: Zvaigzne. 344 lpp. (in Latvian).

Robarts, K., Prenzler, D. P., Tucker, G., Swatsitang, P., Glover, W. (1999). Phenolic compounds and their role in oxidative processes in fruits. Food Chem., 66 (4), 401-436.

Rao, P. S., Sireesha, K., Aparna., Y, Sadanandam, M. (2011). Free radicals and tissue damage: Role of antioxidants. Free Radicals Antioxid., 1 (4), $2-7$.

Vīgants, A. (2008). Cilvēka biok̦īmija un molekulārā ķīmija [Human Biochemistry and Molecular Chemistry]. Rīga: LU Akadēmiskais apgāds. 123 1pp. (in Latvian).

Received 16 March 2013

\section{LATVIJĀ VĀKTO ZĀLU TĒJU ANTIOKSIDATĪVO ĪPAŠİBU RAKSTUROJUMS}

Darbā ir pētītas dažādu Latvijā vāktu zāḷu tēju antioksidatīvās īpašības, izmantojot augstspiediena šķidruma hromatogrāfijas un spektrofotometrijas metodes. Tika analizētas 12 tējas: parastā raudene (Origanum vulgaris L.), divškautnuu asinszāle (Hypericum perforatum L.), lielā strutene (Chelidonium majus L.), parastais pelašķis (Achillea millefolium L.), sila virsis (Calluna vulgaris L.), parastā vībotne (Artemisia vulgaris L.), lielā cel̦teka (Plantago major L.), purva vārnkāja (Comarum palustre L.), parastais rasaskrēsliņ̌š (Alchemilla vulgaris L.), ārstniecības klingéerīte (Calendula officinalis L.), deviṇvīru spēks (Verbascum thapsiforme Schr.), meža avene (Rubus idaeus L.). Tēju antiradikālā aktivitāte tika noteikta spektrofotometriski, izmantojot DPPH (2,2-difenil-1-pikrilhidrazils) reaǵentu. Iegūtie antiradikālās aktivitātes rezultāti izteikti uz noārdītā DPPH reaǵenta daudzumu 100 g tējas. Atseviški fenolu savienojumi — galluskābe, kafijskābe, hlorogēnskābe, ferulskābe, rutīns, katehīns, vanilīns un epikatehīns — identificēti, izmantojot škidruma hromatogrāfiju. No iegūtajiem rezultātiem var secināt, ka palielināts antioksidantu saturs ir rasaskrēsliṇu, viršu ziedu, asinszāḷ, aveņu tējām. Dažādu infekciju, vīrusu saslimšanu un organisma vājuma gadījumā ieteicams lietot tējas, kas satur rutīnu, hlorogēnskābi un katehīnus. Tējas ar palielinātu ferulskābes saturu ieteicams lietot kosmētikā kā līdzekli pret ādas novecošanos un UV staru kaitīgo iedarbību. 


\title{
DETERMINATION OF BIOACTIVE COMPOUNDS AND MINERAL SUBSTANCES IN LATVIAN BIRCH AND MAPLE SAPS
}

\author{
Māra Kūka, Ilze Čakste, and Endija Geršebeka \\ Faculty of Food Technology, Latvia University of Agriculture, Lielā iela 2, Jelgava, LV-3001, LATVIA \\ marakuka@apollo.lv
}

Communicated by Maija Dambrova

\begin{abstract}
Birch and maple saps contain carbohydrates and organic acids, B complex vitamins and vitamin $C$, tannins, flavonoids, glycosides and mineral substances. The aim of the study was to quantitatively determine the concentrations of bioactive compounds and mineral substances in Latvian birch (Betula pendula Roth.) and maple (Acer platanoides L.) saps. Electrical conductivity was determined (629 and $967 \mathrm{~S} / \mathrm{cm}$ in birch and maple saps, respectively) to characterise the total amount of mineral substances. In birch and maple saps the titratable acidity $(0.50$ and $0.70 \mathrm{mmol}$ of $\mathrm{NaOH}$ per litre of sap, respectively) and formol number $(0.25$ and $0.20 \mathrm{mmol} \mathrm{NaOH}$ per litre of sap, respectively) were determined. The protein concentration was found to be higher in maple sap (171 and $127 \mathrm{mg} / \mathrm{l}$, respectively). The antioxidant concentration, determined using quercetin as a standard, was $0.35 \mathrm{mg}$ of quercetin equivalents (QE)// in birch sap and $0.77 \mathrm{mg} Q \mathrm{QE} / \mathrm{l}$ in maple sap. In conclusion, Latvian maple sap contains more bioactive and mineral compounds than birch sap. Latvian birch sap contains up to $20 \%$ more glucose and fructose than birch sap produced in Finland, but Latvian maple sap contains 10 to $40 \%$ less sucrose than sap produced in North America.
\end{abstract}

Key words: birch sap, maple sap, bioactive compounds, mineral substances.

\section{INTRODUCTION}

Birch and maple saps are rich in carbohydrates, mineral salts, proteins, organic acids including aminoacids. These saps also contain $\mathrm{B}$ complex vitamins, vitamin $\mathrm{C}$, phenolic compounds, tannins, flavonoids and glucosides. Birch and maple saps are pleasant and freshening dietary drinks and both are used to produce syrup. Both saps are also known to possess some curative properties. Saps have been shown to be effective in the treatment of stomach ulcer, bronchitis, radicular pain, arthritis, removal of some potentially unwanted substances from the body and stimulation of overall metabolism (Drozdova et al., 1995; Deslauriers, 2000; Jiang, 2001; Sehm, 2007; Perkins and van den Berg, 2009). Extracts of maple sap and syrup have been shown to possess some antiproliferative effects on the colon cancer cells (González-Sarrías et al., 2012).

In most studies birch and maple saps produced from trees growing in Finland and North America, respectively, have been used to characterise chemical composition and properties of the respective sap. In Finland birch sap is used to produce syrup (Kallio et al., 1987; Kallio and Ahtonen, 1987b; Kallio, 1989; Kallio et al., 1987; 1989; 2006). Several studies have described the chemical composition of birch sap: concentration of organic acids (Kallio et al., 1985; Kallio and Ahtonen, 1987a), amino acids (Ahtonen and Kallio, 1989; Patzold and Bruckner, 2005), proteins
(Kallio et al., 1995; Jiang et al., 2001), carbohydrates (Kallio et al., 1985; Kallio and Ahtonen, 1987b), and micro- and macroelements (Harju and Hulden, 1990). Similarly, the chemical composition of maple sap has been described: concentration of mineral substances (Robinson et al., 1989), seasonal changes in amino acid concentration (Kozlowski and Pallardy, 1997), sucrose concentration varied from $0.5-10 \%$, and malic acid was observed to be the most common organic acid (Gaucher et al., 2003; Wong et al., 2003; Perkins and van den Berg, 2009). Various phenolic compounds have been found in maple sap and the concentration of these compounds could reach up to $0.1 \mathrm{mg} / \mathrm{l}$. Dominant compounds are sinapic and p-coumaric acids, and syringal and coniferal acids. In lesser amounts also vanillic, syringic, homovanillic and ferulic acids are present. Maple sap contains a number of flavonoids, like catechins, campherol and its glucosides, quercetine and its glucosides and others (Kermasha et al., 1995; Deslauriers, 2000; Abou-Zaid, 2008; Perkins and van den Berg, 2009). Some studies have tested the antioxidant, antiradical and antimutagenic activities of maple sap and syrup (Theriault et al., 2003; Legault et al., 2010).

Although Latvia is known as a producer and consumer of birch and maple saps, up to date no studies have characterised chemical composition and properties of sap obtained from trees growing in Latvia. Previously we have character- 
ised only the total content of phenolic compounds in birch and maple saps from Latvia. It was found that maple sap contains on average by $48 \%$ more total phenolic compounds than the birch sap (Kuka et al., 2010). The aim of the present study was quantitative determination of bioactive compounds and mineral substances in birch (Betula pendula Roth.) and maple (Acer platanoides L.) saps collected from trees grown in Latvia.

\section{MATERIALS AND METHODS}

Saps were obtained from birch (Betula pendula) and maple (Acer platanoides) trees growing in sandy soil away from roads near towns of Ozolpils $(56.685507 \mathrm{~N} 23.731600 \mathrm{E})$, Jelgava $(56.649137 \mathrm{~N} 23.651331 \mathrm{E})$ and Tukums $(56.8553437 \mathrm{~N} 23.0115635 \mathrm{E})$. Saps were collected in the early spring 2010 (end of March maple sap, beginning of April birch sap) during the most intense period of their production (first week of sap production).

Determination of titratable acidity and electrical conductivity. Titratable acidity was determined by potentiometric titration as described previously (Tanner, 1987). In brief, $25 \mathrm{ml}$ of sap was titrated with $0.25 \mathrm{M} \mathrm{NaOH}$ solution till $\mathrm{pH}$ 8.1, as measured using electrode SenTix 97T for potentiometric titration connected to a $\mathrm{pH}$-meter $\mathrm{pH} 538$ from WTW. Titratable acidity was calculated as $\mathrm{NaOH}$ $\mathrm{mmol} / \mathrm{l}$ of sap. Electrical conductivity was determined to characterise the total content of mineral substances using an electrode TetraCon 325 connected to a conductometer inoLab $\mathrm{pH} / \mathrm{Cond} 720$ from WTW.

Determination of content of mineral substances. Concentration of mineral substances was determined by microprocessor photometer MPM 3000 from WTW and commercially available reagent kits from MERCK according to manufacturer's protocol. The concentration of calcium ions was determined according to MERCK method $\mathrm{Nr}$. 1.14815.0001. The concentration of potassium ions was determined according to MERCK method Nr. 14562. The concentration of iron was determined according to MERCK method Nr.14761/2. The concentration of copper (II) ions was determined according to MERCK method Nr. 14767. The concentration of manganese ions was determined according to MERCK method Nr. 14770. The concentration of nickel ions was determined according to MERCK method Nr. 14785. The concentration of ammonium ions was determined according to MERCK method $\mathrm{Nr}$. 1.14752.0001 and the result was calculated as concentration of nitrogen in ammonia. The concentration of sulphate ions was determined according to MERCK method Nr. 1.14791.0001. The concentration of phosphate ions was determined according to MERCK method Nr. 1.14848.0001. The concentration of chloride ions was determined according to MERCK method Nr. 1.14897.0001. The concentration of nitrate ions was determined according to MERCK method Nr. 14556 and the result was calculated as concentration of nitrogen in nitrate ions. The concentration of nitrite ions was determined according to MERCK method $\mathrm{Nr}$.
N4/25 and the result was calculated as a concentration of nitrogen in nitrite ions.

Determination of formol number and protein amount. The formol number, which characterises the concentration of free amino acids, was determined as described previously (Tanner, 1987). In brief, to neutralise weak organic acids, $0.25 \mathrm{M} \mathrm{NaOH}$ solution was added to $25 \mathrm{ml}$ of sap till $\mathrm{pH}$ 8.1 , as determined by potentiometric titration. Then, formaldehyde solution (35\%) was added and the solution was titrated with $0.25 \mathrm{M} \mathrm{NaOH}$ solution till $\mathrm{pH} 8.1$ was reached. Results were calculated as the volume of $0.1 \mathrm{M} \mathrm{NaOH}$ in $\mathrm{ml}$ required to neutralise hydrogen ions liberated from $100 \mathrm{ml}$ of sample solution treated with water solution of formaldehyde.

The protein amount was determined by Lowry procedure (Lowry et al., 1951) using albumin as a standard. Results were calculated as $\mathrm{mg}$ of protein per litre of sap.

Determination of carbohydrate content by HPLC. Concentration of carbohydrates in sap was determined by high performance liquid chromatography (HPLC), (Shimadzu LC-20 prominence) as described previously (Kūka, 2008). In brief, calibration was made using standard solutions of fructose, glucose, sucrose and maltose at the following concentrations: $0.05 \mathrm{~g} / \mathrm{ml}, 0.01 \mathrm{~g} / \mathrm{ml}$ and $0.025 \mathrm{~g} / \mathrm{ml}$. Samples of sap $(10 \mu \mathrm{l})$ were injected into the chromatograph and analysed using $\mathrm{CH}_{3} \mathrm{CN}: \mathrm{H}_{2} \mathrm{O}$ (70:30 volume/volume, \%) as a mobile phase by flow rate $1.3 \mathrm{ml} / \mathrm{min}$.

Determination of ascorbic acid and antioxidant content. The ascorbic acid concentration was determined using iodometry. $50 \mathrm{ml}$ of sap were titrated with $0.01 \mathrm{M}$ iodine solution in the presence of starch as an indicator. The results were calculated as $\mathrm{mg}$ of ascorbic acid per litre of sap.

The antioxidant concentration was determined with 2,2-diphenyl-1-picrylhydrazyl $(0.02 \mathrm{mg} / \mathrm{ml})$ measuring absorbance at $517 \mathrm{~nm}$ using UV/VIS spectrophotometer Jenway UV 6405. Quercetin was used to produce the standard curve (concentrations $0.5-4.0 \mu \mathrm{g} / \mathrm{ml}$ ). The antioxidant content was expressed as quercetin equivalents (QE) - mg/l of sap (Theriault et al., 2006).

Data analysis. The results are presented as the mean \pm standard deviation. Data analysis was performed using in-built analysis of Microsoft Excel 2007.

\section{RESULTS}

Titratable acidity and electrical conductivity. Titratable acidity was determined using birch (Ozolpils) and maple sap (Ozolpils) samples obtained in the first week of sap production. Average titratable acidity in the maple sap samples was $40 \%$ higher than in the birch sap samples (Table 1). Electrical conductivity was determined in birch (Ozolpils, Jelgava) and maple sap (Ozolpils, Tukums) samples. The electrical conductivity in maple sap was higher than in birch 
VARIOUS PARAMETERS OF BIRCH (Betula pendula Roth.) AND MAPLE (Acer platanoides L.) SAPS

\begin{tabular}{c|c|c|c|c|c}
\hline Sap & $\begin{array}{c}\text { Titratable } \\
\text { acidity, } \\
\mathrm{NaOH} \\
\mathrm{mmol} / \mathrm{l}\end{array}$ & $\begin{array}{c}\text { Formol } \\
\text { number, } \\
0.1 \mathrm{M} \mathrm{NaOH} \\
\mathrm{ml} / 100 \mathrm{ml}\end{array}$ & $\begin{array}{c}\text { Protein, } \\
\mathrm{mg} / \mathrm{l}\end{array}$ & $\begin{array}{c}\text { Ascorbic } \\
\text { acid, } \\
\mathrm{mg} / \mathrm{l}\end{array}$ & $\begin{array}{c}\text { Antioxidant } \\
\text { content } \\
\text { QE, } \mathrm{mg} / \mathrm{l}\end{array}$ \\
\hline Birch & $0.50 \pm 0.01$ & $0.25 \pm 0.01$ & $127 \pm 2$ & $3.2 \pm 0.01$ & $0.35 \pm 0.03$ \\
Maple & $0.70 \pm 0.02$ & $0.20 \pm 0.01$ & $171 \pm 8$ & $8.8 \pm 0.03$ & $0.77 \pm 0.09$
\end{tabular}

Data are presented as mean $\pm \mathrm{SD}$.

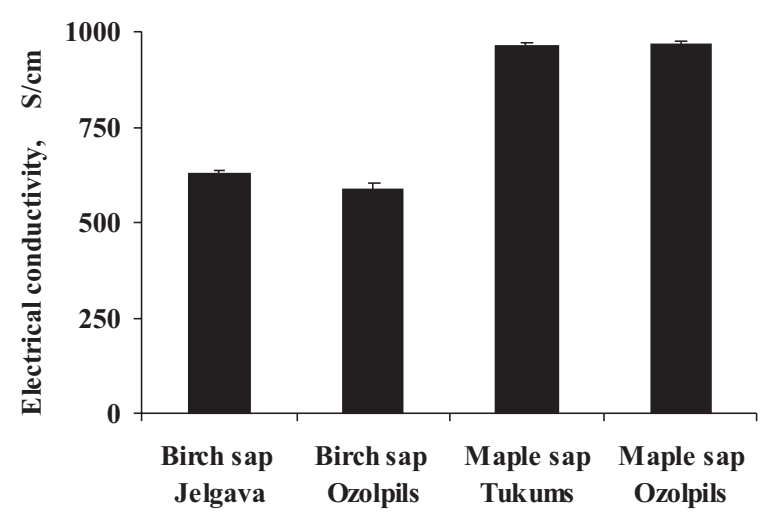

Fig.1. Electrical conductivity of birch (Betula pendula Roth.) and maple (Acer platanoides L.) saps. Data are presented as mean \pm SD.

sap on average by $58 \%$ (Fig. 1), indicating greater concentration of strong electrolytes in maple sap samples.

Content of mineral substances. The predominant macroelements in the birch and maple saps were found to be $\mathrm{Ca}^{2+}$ and $\mathrm{K}^{+}$ions and the prevailing trace elements were $\mathrm{Mn}^{2+}$ ions, while the dominant anions were sulphate ions (Table 2). Nitrate and nitrite concentrations in both birch and maple sap samples were negligible.

Formol number and protein amount. The formol number, which characterizes the concentration of free amino acids, was determined in birch (Ozolpils) and maple sap (Ozolpils) samples. The concentration of free amino acids was similar and negligible in both birch and maple sap samples (Table 1). The concentration of proteins was by $34.6 \%$ higher in maple sap than in birch sap (Table 1).

Carbohydrate content. Carbohydrate concentration was determined using HPLC in birch (Ozolpils) and maple sap (Ozolpils) samples. The monosaccharides glucose and fructose and disaccharide sucrose were identified in sap samples. The concentration of sucrose in the maple sap was 31-fold higher than in birch sap, while the concentration of fructose and glucose was 10-fold and 3-fold higher, respectively, in birch sap than in maple sap (Table 3). Other carbohydrates were below the identification threshold.

Content of ascorbic acid and total content of antioxidants. Concentration of ascorbic acid was determined using birch (Ozolpils) and maple sap (Ozolpils) samples. Concen-
CONCENTRATION OF MINERAL SUBSTANCES IN BIRCH (Betula pendula Roth.) AND MAPLE (Acer platanoides L.) SAPS

\begin{tabular}{l|ccccc}
\hline \multirow{2}{*}{$\begin{array}{c}\text { Mineral } \\
\text { substances }\end{array}$} & \multicolumn{2}{|c|}{ Birch sap, mg/l } & \multicolumn{2}{c}{ Maple sap, mg/l } \\
\cline { 2 - 5 } & Jelgava & Ozolpils & Tukums & Ozolpils \\
\hline $\mathrm{Ca}^{2+}$ & $53.3 \pm 0.1$ & $41 \pm 1$ & $61 \pm 1$ & $91 \pm 1$ \\
$\mathrm{~K}^{+}$ & $41.1 \pm 0.5$ & $66.4 \pm 0.1$ & $70.1 \pm 0.2$ & $78.9 \pm 0.1$ \\
$\mathrm{Mn}^{2+}$ & 0.5 & $0.520 \pm 0.006$ & - & $0.24 \pm 0.01$ \\
$\mathrm{Ni}^{2+}$ & - & $0.03 \pm 0$ & $0.15 \pm 0.02$ & $0.13 \pm 0$ \\
$\mathrm{Cu}^{2+}$ & 0.04 & - & - & - \\
$\mathrm{Fe}^{3+}$ & 0.10 & - & - & - \\
$\mathrm{NH}_{4}{ }^{+}-\mathrm{N}$ & $0.050 \pm 0.001$ & - & $0.080 \pm 0.001$ & - \\
$\mathrm{SO}_{4}{ }^{2-}$ & $36.10 \pm 0.06$ & $34.0 \pm 0.1$ & $39 \pm 1$ & $62.6 \pm 0.5$ \\
$\mathrm{PO}_{4}{ }^{3-}-\mathrm{P}$ & $2.06 \pm 0.01$ & $2.36 \pm 0.02$ & $4.13 \pm 0.09$ & - \\
$\mathrm{Cl}^{-}$ & - & $9.0 \pm 0.1$ & $9.0 \pm 0.1$ & $12.0 \pm 0.1$ \\
$\mathrm{NO}_{3}{ }^{-}-\mathrm{N}$ & $3.40 \pm 0.01$ & $3.40 \pm 0.01$ & $3.40 \pm 0.01$ & $3.40 \pm 0.01$ \\
$\mathrm{NO}_{2}{ }^{-}-\mathrm{N}$ & $0.008 \pm 0$ & $0.012 \pm 0$ & - & $0.115 \pm 0$ \\
\hline
\end{tabular}

Data are presented as mean $\pm \mathrm{SD}$.

Table 3

CONCENTRATION OF CARBOHYDRATES IN BIRCH (Betula pendula Roth.) AND MAPLE (Acer platanoides L.) SAPS

\begin{tabular}{l|c|c|c}
\hline \multicolumn{1}{c|}{ Sap } & Fructose, $\mathrm{g} / \mathrm{l}$ & Glucose, $\mathrm{g} / \mathrm{l}$ & Sucrose, $\mathrm{g} / \mathrm{l}$ \\
\hline Birch & $5.39 \pm 0.05$ & $4.46 \pm 0.04$ & $0.58 \pm 0.01$ \\
Maple & $0.55 \pm 0.01$ & $1.33 \pm 0.03$ & $17.95 \pm 0.05$
\end{tabular}

Data are presented as mean $\pm \mathrm{SD}$.

tration of ascorbic acid in maple sap was by $56 \%$ higher than in birch sap (Table 1).

Total concentration of antioxidants was characterised using quercetin equivalents and the obtained results show that maple sap samples contained around two times higher concentration of compounds with antioxidant properties than in birch sap samples (Table 1).

\section{DISCUSSION}

The present study quantitatively determined the concentration of bioactive compounds and mineral substances in saps obtained from birch (Betula pendula) and maple (Acer platanoides) trees growing in Latvia. The obtained results indicate that Latvian maple sap contains significantly more bioactive and mineral compounds than birch sap. The concentration of mineral substances in sap obtained from birch (Betula pendula) trees reflects the chemical composition of the soil where trees grow (Harju and Hulden, 1990). In addition, our results indicate that a similar tendency can be observed in sap obtained from maple (Acer platanoides) trees (Table 2). Overall, the concentration of mineral substances was higher in maple than in the birch sap (Table 2). These findings were in compliance with the results of electrical conductivity measurements (Fig. 1), which showed that maple sap contains higher concentrations of strong electrolytes 
and thus the concentration of mineral substances must be higher. It should be noted that the concentration of mineral substances much varies in maple sap and increases during the period of sap production (Robinson et al., 1989; Perkins and van den Berg, 2009). Dominant mineral substances are calcium and potassium. Maple sap is also rich in magnesium and manganese, while only small amounts of zinc, copper, iron, sodium and aluminium can be found. Birch sap mainly contains salts of potassium, calcium, magnesium, manganese and zinc (Harju and Hulden, 1990).

Although the overall concentration of bioactive compounds was higher in maple sap, the concentrations of free amino acids were similar and both birch and maple saps contained very low concentration of free amino acids (Table 1). This could be explained by the use of the first-week saps for the study. It has been shown that the concentration of free amino acids increases during the birch sap production period (up to $100-500 \mathrm{mg} / \mathrm{l}$ ) and that the most prevalent amino acids are glutamine, citrulline and glutamic acid (Ahtonen and Kallio, 1989; Jiang et al., 2001). In both birch and maple saps, the concentration of proteins increases in the last stage of the season (Kallio et al., 1995; Kozlowski and Pallardy, 1997; Jiang et al., 2001). Similarly, the total content of all organic acids found in the saps increases during the production period and the predominant acid in both birch and maple saps is malic acid (Kallio et al., 1985; Kallio and Ahtonen, 1987a; Perkins and van den Berg, 2009). Glucose, fructose and sucrose were the only carbohydrates identified in the sap samples (Table 3). Although birch and maple saps contain other carbohydrates, their content is negligible and they were not quantified. It has been shown that carbohydrate content does not depend on species or variety of the tree and the amount of carbohydrates in birch sap decreases in the following order: glucose, fructose, sucrose and galactose (Kallio and Ahtonen, 1987b). Sucrose is the dominant carbohydrate in the maple sap, while other carbohydrates like glucose and fructose are in small quantities, but the concentrations of stachyose, raffinose and xylose are negligible (Wong et al., 2003; Perkins and van den Berg, 2009). Latvian birch sap contains up to $20 \%$ more glucose and fructose (Table 3) than birch sap produced in Finland (Kallio and Ahtonen, 1987b), but Latvian maple sap contains up to 10 to $40 \%$ less sucrose (Table 3) than sap produced in North America (Kozlowski and Pallardy, 1997).

In conclusion, our results demonstrate that the overall content of Latvian maple (Acer platanoides) sap is richer in bioactive substances and mineral salts as compared to birch (Betula pendula) sap. The dominant carbohydrates in birch sap are glucose and fructose, while the sucrose is predominant in maple sap.

\section{ACKNOWLEDGMENTS}

The authors would like to thank Dr. pharm. Jānis Küka for his help in preparing this manuscript.

\section{REFERENCES}

Abou-Zaid, M. M., Nozzolillo, C., Tonon, A., Coppens, M., Lombardo, A. (2008). High-performance liquid chromatography and identification of aantioxidant polyphenols in maple syrup. Pharm. Biol., 46 (1-2), 117-125.

Ahtonen, S., Kallio, H. (1989). Identification and seasonal variations of amino acids in birch sap used for syrup production. Food Chem., 33 (2), $125-132$.

Deslauriers, I. (2000). Recovery, Separation and Characterization of Phenolic Compounds and Flavonoids from Maple Products. Montreal, Quebec: McGill University. 104 pp.

Drozdova, G., Demurov, E., Bakhilov, V., Frolov, V. (1995). Some aspects of pharmacological activity of birch sap and birch drag-preparations. In: Terazawa, M. (Ed.). Tree Sap (pp. 85-89). Sapporo: Hokkaido University Press.

Gaucher, C., Gougeon, S., Mauffette, Y, Messier, C. (2003). Seasonal variation in biomass and carbohydrate partitioning of understory sugar maple (Acer saccharum) and yellow birch (Betula alleghaniensis) seedlings. Tree Physiol., 25, 93-100.

González-Sarrías, A., Li, L., Seeram, N.P. (2012). Effects of maple (Acer) plant part extracts on proliferation, apoptosis and cell cycle arrest of human tumorigenic and non-tumorigenic colon cells. Phytother. Res., 26 (7), 995-1002.

Harju, L., Hulden, S. G. (1990). Birch sap as a tool for biogeochemical prospecting: [about micro and macro elements]. J. Geochem. Explor., 37 (3), $351-365$.

Jiang, H., Sakamato, Y., Tamai, Y., Terazawa, M. (2001). Proteins in the exudation sap from birch trees, Betula platyphylla Sukatchev var. japonica Hara and Betula verrucosa Her. Eurasian J. For. Res., 2, 59-64.

Kallio, H. (1989). Aroma of birch syrup. J. Agric. Food Chem., 37, 1367-1371.

Kallio, H., Ahtonen, S. (1987a) Seasonal variations of the acids in birch sap: [acids in birch sap]. Food Chem., 25 (4), 285-292.

Kallio, H., Ahtonen, S. (1987b). Seasonal variations of the sugars in birch sap: [sugars in birch sap]. Food Chem., 25 (4), 293-304.

Kallio, H., Lahenoja, M., Penttin, R. (1995). Electrophoretic profiles of birch sap proteins of Betula pubescens, $B$. pendula and $B$. pendula forma Carelica in Finland with reference to overall composition of sap. In: Terazawa, M. (Ed.). Tree Sap (pp.13-21). Sapporo: Hokkaido University Press.

Kallio, H., Ahtonen, S., Raulo, J., Linko, R.R. (1985). Identification of the sugars and acids in birch sap: [about acids and sugars]. J. Food Sci., 50 (1), 266-269.

Kallio, H., Karppinen, T., Holmbom, B. (2006). Concentration of birch sap by reverse osmosis. J. Food Sci., 50 (5), 1330-1332.

Kallio, H., Rine, S., Pangborn, R.-M., Jennings, W. (1987). Effect of heating on the headspace volatiles of Finnish birch syrup. Food Chem., 24 (4), 287-299.

Kallio H., Teerinen T., Ahtonen, S., Suihko, M., Linko, R. R. (1989). Composition and properties of birch syrup (Betula pubescens). J. Agric. Food Chem., 37, 51-54.

Kermasha, S., Goetghebeur, M., Dumont, J. (1995). Determination of phenolic compound profiles in maple products by high-performance liquid chromatography. J. Agric. Food Chem., 43 (3), 708-716.

Kozlowski, T. T, Pallardy, S. G. (1997). Nitrogen metabolism. In: Physiology of Woody Plants (pp. 189-209). New York: Academic Press.

Kuka, M., Cakste, I., Dimins, F., Gersebeka, E. (2010). Determination of phenolic compounds in birch and maple saps. In: Foodinnova 2010, International Conference on Food Innovation, 25-29 October 2010. (108 p.) Valencia.

Kūka, P. (2008). Pārtikas produktu analī̌̌u fizikāli k̦īmiskās metodes [Physical-Chemical Methods of Food Products Analysis]. Jelgava: LLU, 174 lpp. 
Legault, J., Girard-Lalancette, K., Grenon, C., Dussault, C., Pichette, A. (2010). Antioxidant activity, inhibition of nitric oxide overproduction, and in vitro antiproliferative effect of maple sap and syrup from Acer saccharum. J. Med. Food, 13 (2), 460-468.

Lowry, O. H., Rosebrough, N. J., Farr, A. L., Randall, R. J. (1951). Protein measurement with the Folin phenol reagent. J. Biol. Chem., 193 (1), $265-275$.

Patzold, R., Bruckner, H. (2005). Mass spectometric detection and formation of D-amino acids in processed plant saps, syrups, and fruit juice concentrates. J. Agric. Food Chem., 53, 9722-9729.

Perkins, T. D., van den Berg, A. K. (2009). Maple syrup - production, composition, chemistry, and sensory characteristics. In: Taylor, S. (Ed.). Advances in Food and Nutrition Research, 56, (pp. 104-140). Amsterdam: Elsevier/Academic Press.
Robinson, A. R., MacLean, K. S., MacConnell, H. M. (1989). Heavy metal, $\mathrm{pH}$, and total solid content of maple sap and syrup produced in eastern Canada. J. Assoc. Anal. Chem. 72 (4), 674-679.

Sehm, E. (2007). Birkensaft. Das Gesundheitselixier aus der Natur. Norderstedt: Books on Demand GmbH. $52 \mathrm{~S}$.

Tanner, H., Brunner, H. R. (1987). Getränke - Analytik. Schwäbisch Hall: Heller Chemie - Verwaltungsgesellschaft mbH, S. 93-94.

Theriault, M., Caillet, S., Kermasha, S., Lacroix, M. (2006). Antioxidant, antiradical and antimutagenic activities of phenolic compounds present in maple products. Food Chem., 98 (3), 490-501.

Wong, B. L., Bagget, K. L., Rye, A. H. (2003.). Seasonal patterns of reserve and soluble carbohydrates in mature sugar maple (Acer saccharum). Can. J. Bot., 81 (8), 780-788.

Received 31 August 2012

\section{BIOLOĢISKI AKTĪVO SAVIENOJUMU UN MINERĀLVIELU NOTEIKŠANA BĒRZU UN KLAVU SULĀS}

Bērzu un kḷavu sulas satur ogḷhidrātus un organiskās skābes, B grupas vitamīnus un C vitamīnu, flavonoīdus, glikozīdus un minerālvielas. Pētîjuma mērḳis - noteikt bioloǵiski aktīvo savienojumu un minerālvielu saturu Latvijas bērzu (Betula pendula Roth.) un kḷavu (Acer platanoides) sulās. Lai raksturotu minerālvielu kopējo daudzumu, tika mērīta elektrovadītspēja (bērzu un kḷavu sulās atbilstoši 629 un 967 $\mu \mathrm{S} / \mathrm{cm}$ ). Minerālvielu saturs tika noteikts spektrofotometriski. Bērzu un kḷavu sulās tika noteikti kopējais skābums (atbilstoši 0,50 un 0,70 mmol NaOH uz litru sulas) un formaldehīdskaitḷi (atbilstoši (0.25 and $0.20 \mathrm{mmol} \mathrm{NaOH}$ uz litru sulas). Kḷavu sula satur vairāk proteīnus nekā bērzu sula (atbilstoši 171 and $127 \mathrm{mg} / \mathrm{l}$ ). Fruktozes, glikozes un saharozes saturs tika noteikts, izmantojot augstefektīvu škiidrumu hromatogrāfiju. Askorbīnskābes saturs tika noteikts jodometriski. Kā standartvielu izmantojot kvercetīnu, tika raksturots antioksidantu saturs un bērzu sulā tas bija $0,35 \mu \mathrm{g}$ kvercetīna ekvivalentu $(\mathrm{QE}) / 1$, bet kḷavu sulā $0,77 \mu \mathrm{g}$ QE/l. Kopumā Latvijas kḷavu sula satur vairāk bioloğiski aktīvo savienojumu un minerālvielu nekā bērzu sula. 


\title{
CONSUMER ATTITUDE AND SENSORY EVALUATION OF MARSHMALLOW
}

\author{
Eva Ungure, Evita Straumite, Sandra Muižniece-Brasava, and Lija Dukalıska
}

Faculty of Food Technology, Latvia University of Agriculture, Jelgava, LV-3001, LATVIA;

eva.ungure@gmail.com; evita.straumite@Ilu.Iv; sandra.muizniece@ Ilu.Iv; lija.dukalska@Ilu.Iv

Communicated by Daina Kārkliṇa

\begin{abstract}
Marshmallow is sugar-candy with foam-like structure. Many studies have revealed the high nutritional value of bee pollen. Due to the nutritional composition of pollen, and according to nonscientific studies, dried bee pollen has been used as an additive in human diets, which provides a well-being sensation and contributes to functional and harmonious balance of the body. Sensory evaluation and market research are an important part of developing a new product. The research was aimed to clarify the situation in the Latvian market, to summarise Latvian consumer attitude on marshmallow, and to determine the sensory properties and quality of marshmallows with bee pollen. A questionnaire was developed - 900 respondents answered questions about their consumption patterns, opinions on quality indices, and possible types of marshmallow packaging. Marshmallow was enriched with three different pollen concentrations: 1.0; 1.5 and 2.5\%. Sensory evaluation was carried out to estimate the optimal concentration of bee pollen that which should be added to marshmallow. Sensory evaluation of experimental marshmallow was characterised by using a 9-point hedonic scale (determination degree of liking). The obtained results showed that consumers liked the marshmallow with $1.5 \%$ bee pollen best of all.
\end{abstract}

Key words: marshmallow, bee pollen, sensory evaluation, consumer attitude.

\section{INTRODUCTION}

The meaning of the term 'confectionery' is different in every country and may cover a very large amount of different products manufactured in various manners. Chocolate confectioneries include bars, blocks, and bonbons, and sugar confectionery encompasses boiled sweets, toffees, fudge, fondants, jellies, and pastilles. Confectionery goods are a very heterogeneous group of products made with milk powder and other dairy products; cocoa and chocolate products; sugar, honey, syrups or sweeteners; nuts, fruits or jams; starches, gelatine, pectin or other thickeners; egg albumen; spices, colours, flavours or acidulates (Cakebread, 1975; Konkel, 2001; Vaclavik and Christian, 2008; Kawo and Abdulmumin, 2009).

The confectionery industry is enormous, ranging from small shops to branches of the largest companies in the food industry. The sweets are divided into three classes: chocolate, flour and sugar confectionery (Manley, 1998; Quinton and Kennedy, 2002). Sugar confectionery has been developed over the centuries with increasing sophistication, and it exists in countless formats with different degrees of sweetness, flavours and aromas, textures and mouth feel. Confectionery serves a very simple purpose; the rush of sweetness coupled with pleasant flavours, and aromas. The feeling in the mouth provokes almost instantaneous feeling of well-being and happiness. Sugar confectionery includes by definition products that contain predominantly one form or another of the following sugars: sucrose (usually cane or beet sugar); dextrose (otherwise known as glucose, usually corn sugar); fructose (often refered to fruit sugar) or lactose (otherwise known as milk sugar) (Zumbé et al., 2001).

The specific kind of confectioneries considered here has foam-like structures (marshmallows, soufflés, and nougats). Marshmallows are simply described as air bubbles surrounded by sugar syrup. The sugar syrup, made of sucrose, corn syrup, and water, is cooked at appropriate temperature to reach the desired water content, which allows air to be whipped into the matrix by mechanical agitation. Proteins, such as gelatine, gum Arabic, egg albumen, agar-agar, pectin, milk or soy protein, are typically added to the sugar syrup to stabilise the foam. During whipping, the density of the product decreases as the syrup and foam mixture expands into a light, fluffy marshmallow. Marshmallows may be either non-grained or grained crystal aggregate, depending on the ratio of sucrose to corn syrup (Sucharzewska et al., 2003; Ergun et al., 2010). Certain glassy sugars tend to be hygroscopic, rapidly picking up moisture from the air, which causes significant changes that lead to the end of shelf life. These products need to be protected from moisture uptake during storage (Ergun et al., 2010). 
The aim of quality properties is to provide a safe, inoffensive, as well as nutritionally rich food. Pollen is important in bee life cycle, and it is understandable that people's interest in its composition and applicability as a dietary supplement is high (Graikou et al., 2011; Feás et al., 2012).

Bee honey has been used by man since the beginning of humanity. Although this is the most common beehive product, there are other goods, such as bee pollen, royal jelly, propolis and beeswax. These natural goods are well appreciated by consumers due to the high number of quality checks they go through, as well as for their dietetic and therapeutic qualities. The major components of bee pollen are carbohydrates, crude fibres, proteins and lipids at proportions ranging between 13 and 55\%, 0.3 and 20\%, 10 and 40\%, 1 and $10 \%$, respectively. Other minor components are minerals and trace elements, vitamins and carotenoids, phenolic compounds, flavonoids, sterols and terpens. In fact, bee pollen is referred to as the "only perfectly complete food", since it contains all the essential amino acids needed for the human organism (Silva et al., 2005; Carpes et al., 2009; Le Blanc et al., 2009; Graikou et al., 2011; Feás et al., 2012).

Since in a healthy diet sweets are allocated less than $5 \%$ of the daily food consumption, they must be high quality in every respect and attractive for consumers. Enriching sugar confectionery with pollen would supplement the diet with biologically active substances.

The formulation and marketing of consumer products today have become very complex operations in which both sensory testing and market research have important parts to play. Both disciplines are united by a common goal to produce goods with an optimum combination of product attributes, compatible with manufacturing costs that will sell successfully and profitably in the market place. Despite of this common goal, the different requirements of technical and marketing personnel have led to the separation and interaction between the two disciplines. There are, however, techniques and approaches used by both the sensory and market researcher, which when combined, can offer improved product testing (Wilton and Greenhoff, 1988; Moskowitz et al., 2006).

Food choice is not determined solely by the perceived properties of a foodstuff. It depends on personal attitude towards the attributes a product possesses. Consumer responses are vital in the development of a product if it is to compete successfully in the market place (Frances and Piggott, 1991-1992). There is a wide variety of market research procedures that could be used to elicit information about product attributes, and to measure attitudes and beliefs. These include unstructured spontaneous techniques, such as interviews and projective methods, and also highly structured methods, such as dissimilarity scaling where appropriate statistical procedures are used to obtain product spaces (maps) and identify salient product dimensions (McEwan and Thomson, 1989).
Sensory evaluation techniques are frequently used; however, applied sensory is most often used within the private industry. Basic sensory techniques can be an invaluable aid to research on nutritional or functional benefits of natural products, such as whole fruits, nuts and vegetables (through varietal selection, breeding, (etc.) in addition to clinical trials of botanicals). As part of the effort to discover, develop and market healthier products, understanding nutritional and functional benefits is a key aspect. Of additional importance is highlighting and refining the products' sensory properties in an attempt to ultimately appeal to consumers: no matter how healthy and nutritious a food is, if it does not appeal to its intended end user, it is unlikely to succeed in today's marketplace (Civille and Oftedal, 2012).

The aim of this study was to determine the Latvian consumer attitude on marshmallow packaging presentation, and the potential marshmallow market expandability. Furthermore, sensory evaluation was carried out to estimate the degree of liking of pollen-rich marshmallow and to determine the optimal desired pollen concentration.

\section{MATERIALS AND METHODS}

The research was aimed to assess consumer attitude to marshmallow as well as its quality. The study was organized in two stages:

1. A consumer questionnaire was developed to analyze the situation in the Latvian market and to determine Latvian consumer attitude concerning their consumption patterns, opinion on quality indices, and possible packaging types of marshmallows. The questionnaire was used as a basic tool, which consisted of ten questions answered by consumers. Respondents were asked to answer both multiple-choices and open-type questions. The survey was designed using website www.visidati.lv, which gives an opportunity to obtain a quick and effective survey distribution and data collection. In order to obtain a link between the average population answers and the web-based questionnaire, it was also sent to people. The data consisted of the answers of all 900 respondents who completed questionnaires.

2. Experiments were performed in the International Food exhibition "Riga Food 2011", to assess the degree of liking and optimal desired pollen in marshmallow. Consumers evaluated the degree of liking of marshmallow samples that had additions of $1.0,1.5$ and $2.5 \%$ bee pollen. The control sample was marshmallow without bee pollen. The marshmallow used consisted of: sugar, glucose syrup, water, apple puree (apple, preservatives E202, E211), gelling agent - pectin, protein powder, acidity regulator - lactic acid, bulking — sodium lactate, and vanillin $(0.05 \%)$. The 9point hedonic scale (9, extremely like, 5 , neither like nor dislike, and 1, extremely dislike) method was used based on ISO 4121:2003 "Sensory analysis — Guidelines for the use of quantitative response scales". One hundred and thirty consumers (age 14 to 66 years) were involved in the evaluation. 


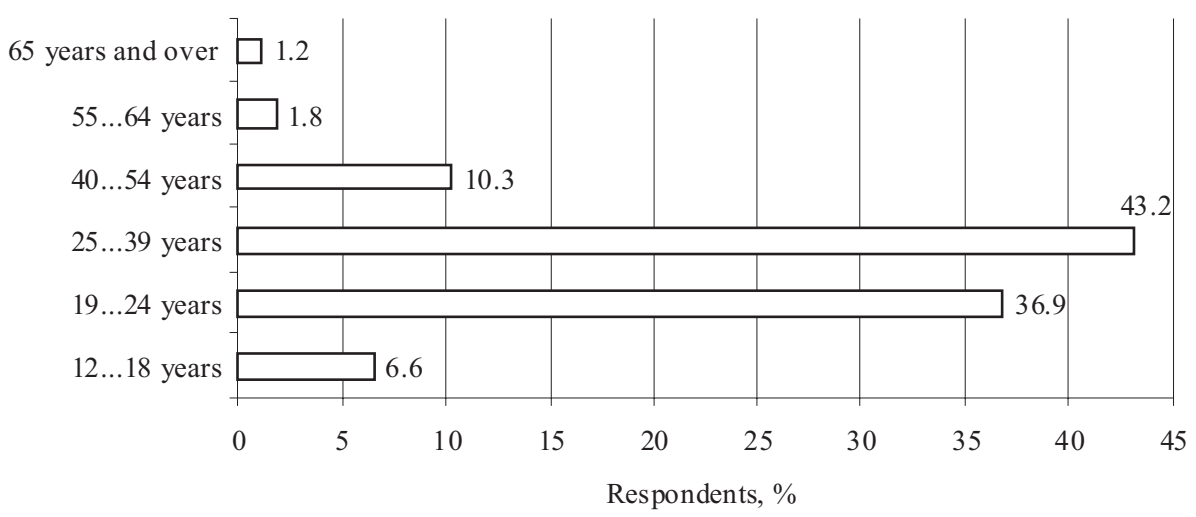

Fig. 1. Respondent division according to age, $\%$.

Most respondents were up to 40 years, who were also considered as the main body of consumers who were likely to consume marshmallow (Fig. 1).

The test results were processed using software SPSS package 16. $P$ value 0.05 was considered as a significant difference. One-way and two-way factor analysis of variance (ANOVA) as well the Tukey's test were used to test for significant differences.

\section{RESULTS}

The 900 respondents ( $28 \%$ men and $72 \%$ women) answered ten questions regarding how well-recognized is marshmallow, and the main features for this kind of sweets for choice by consumers. One of most important questions was to understand the consumer opinion about sweets, mainly the type of marshmallow packaging for marketing, and the market turnover. Respondents were asked to evaluate the consumer demand for marshmallow, likeness and the packaging options. Of the ten questions associated to the product (marshmallow), two were aimed to obtain basic information about the consumer.

All 900 respondents liked marshmallow. The majority (96\%) of consumers asserted that marshmallow is tasty, and $4 \%$ of respondents considered this product as unpalatable and too sugary; some consumers did not like the structure of marshmallow.

According to frequency of purchase of marshmallow (Fig. 2), $35 \%$ of respondents infrequently purchased marshmallow, $17.4 \%$ — at least once a week, $46.8 \%$ — monthly and
$0.8 \%$ admitted they did not routinely use marshmallow, but consumed this sweet when available as a treat.

The respondents mentioned that they purchased marshmallow in various cases (Fig. 3). The majority favoured buying marshmallow daily, indicating a demand for fresh marshmallow in small appropriate packaging for purchase as a frequently used sweet. The majority of consumers (586) considered that they would like to choose marshmallow for a gift or social evening (234).

Subsequent questions on the product were aimed to evaluate respondent opinion about the packaging style as well as on how the packaging design influences the choice of product in the market. Most respondents admitted that both style and the manner how the product is offered to the costumer in the retail sector are important (Fig. 4).

An important consumer opinion was on the amount of marshmallow in one package (Fig. 5). It is determined that the optimal amount for most of people (35.1\% to $45.4 \%$ ) was two to four pieces in one package.

A sensory evaluation was performed to determine the optimal bee pollen addition to marshmallow raw material mass, (Fig. 6). ANOVA indicated significant difference between concentrations of bee pollen used $(P>0.05)$. The Tukey's test was used to test for differences between preference of the marshmallow samples. The analysis showed significant difference $(P>0.05)$ in the degree of liking between the control sample and samples with pollen A (1.0\%) and C $(2.5 \%)$. Consumers recognised the marshmallow sample with $2.5 \%$ bee pollen as having a too typical taste, sharp af-

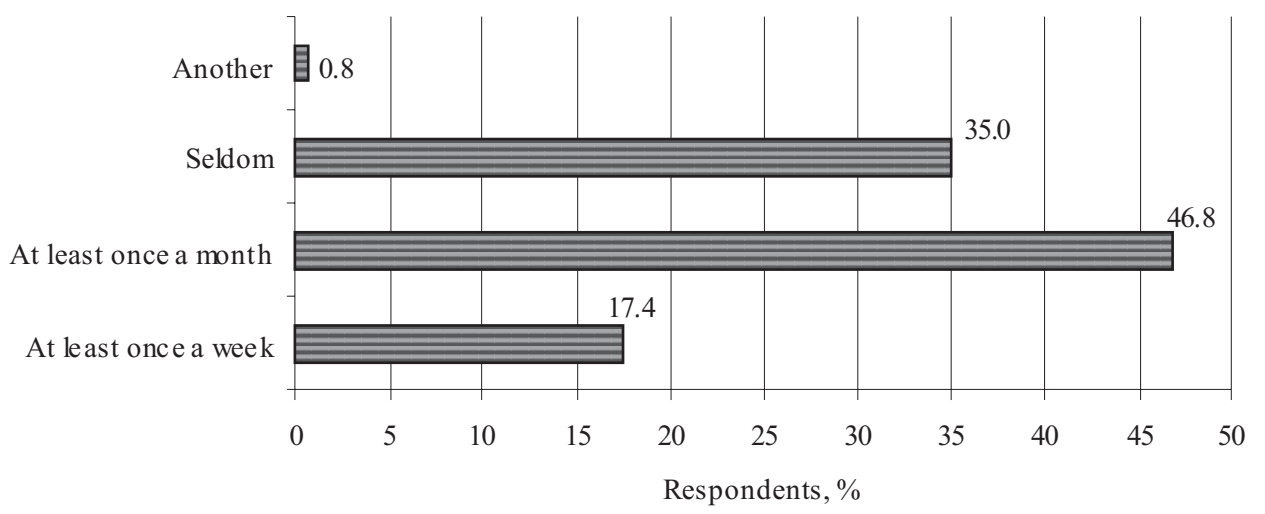

Fig. 2. Purchasing frequency of marshmallow, \%. 

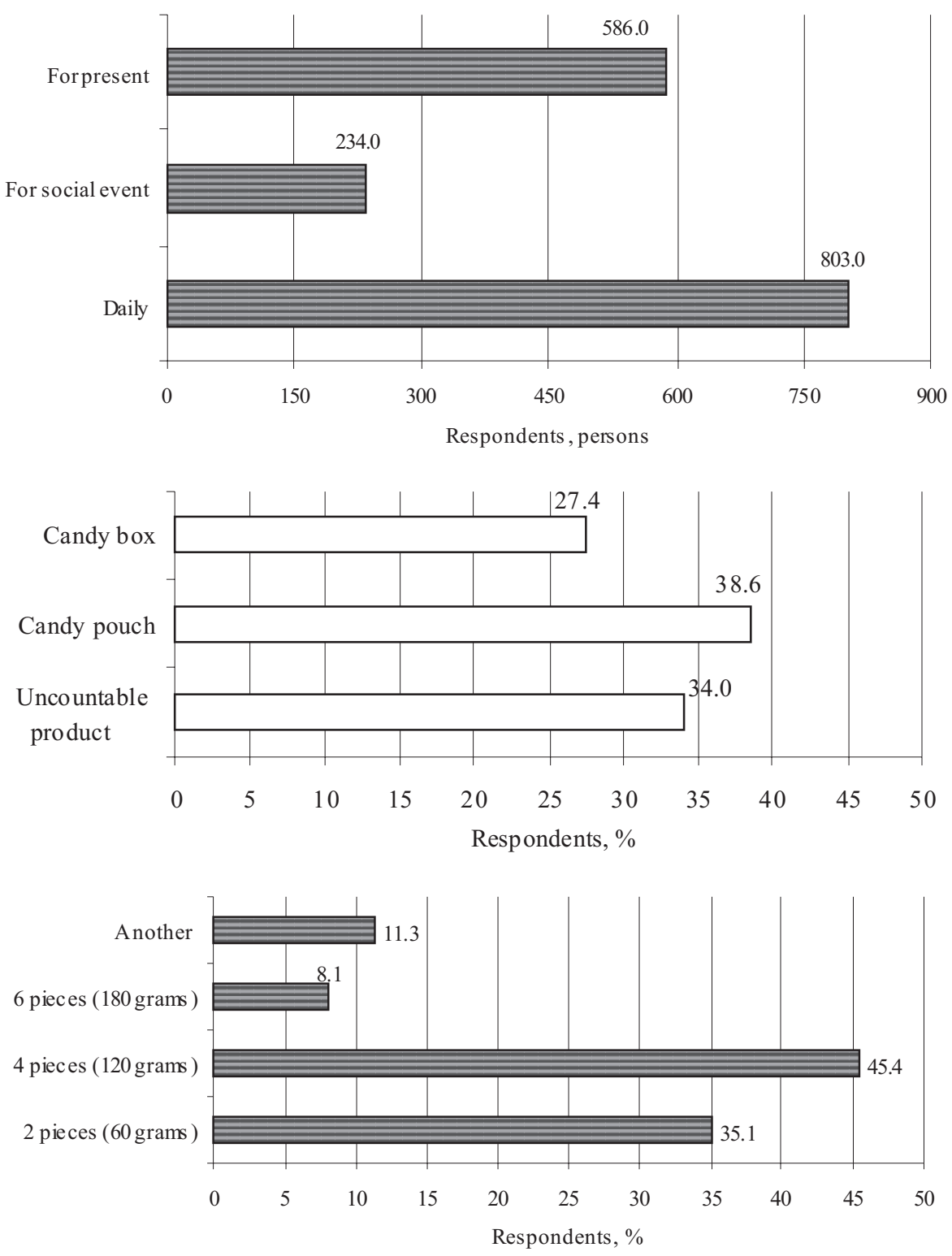

Fig. 3. Purchase intent of marshmallow.

Fig. 4. The choice of marshmallow purchasing style, $\%$.

Fig. 5. Consumer view on the optimum marshmallow quantity (pieces) in one package.

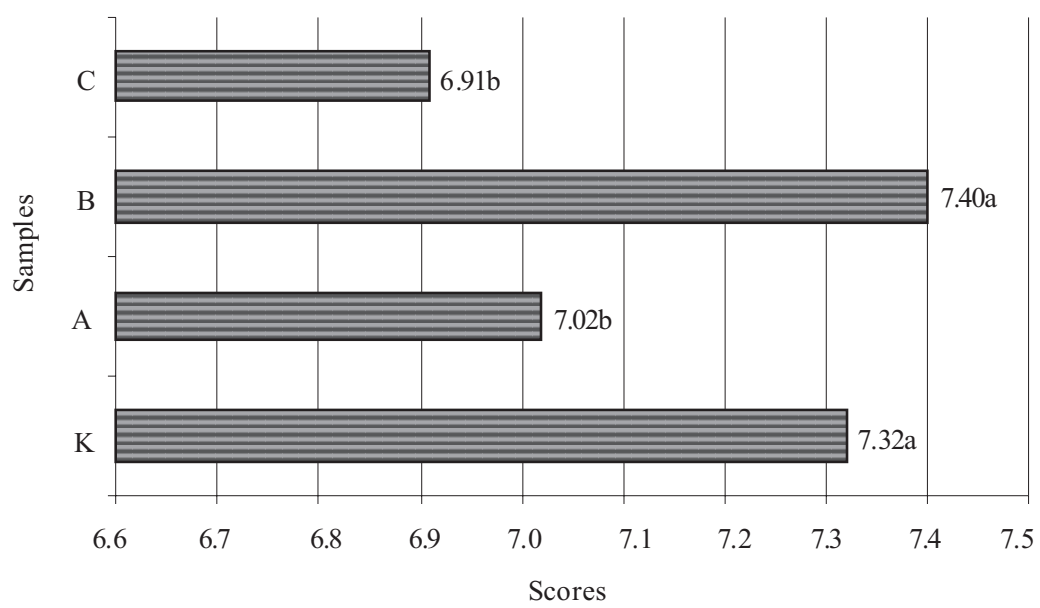

Fig. 6. Evaluation results of marshmallow with bee pollen using 9-point hedonic scale.

$\mathbf{K}$ - marshmallow without pollen (control); $\mathbf{A}$ - marshmallow with $1.0 \%$ pollen addition; $\mathbf{B}$ - marshmallow with $1.5 \%$ pollen addition; $\mathbf{C}$ - marshmallow with $2.5 \%$ pollen addition.

*Values, marked with the same letters, are not significantly different $(P>0.05)$.

tertaste, and a not so airy structure. Significant differences also were found between $\mathrm{B}$ and $\mathrm{A}$, and between $\mathrm{B}$ and $\mathrm{C}$ $(P>0.05)$, in liking degree. Results of the hedonic scores showed that the panellists most liked samples K (control) and B (with $1.5 \%$ bee pollen), and there was no significant difference beween these $(P>0.05)$. Thus, the consumer preferred both the classical marshmallow with vanilla, and with bee pollen $(1.5 \%)$ enriched marshmallow. 


\section{DISCUSSION}

The European confectionery market grew at a fairly steady rate during the period 2005-2009, as a result of steady sales growth in the chocolate category. Although the overall market growth is expected to decelerate slightly in the forecast period, the annual rate of growth is set to rise from a low of $2.5 \%$ in 2009 to a high of $2.9 \%$ in 2014 . Chocolate in 2009 is the largest segment of the confectionery market in Europe, accounting for $51.7 \%$ of the market's total value. The sugar confectionery segment accounts for a further $34.6 \%$, gum $11.1 \%$ and cereals bars $2.6 \%$ of the market (Anonymous, 2010).

In Europe, the main distribution channels for the confectionery market are supermarkets and hypermarkets (30.4\%), independet retailers $(26.5 \%)$, convenience stores $(21.4 \%)$ and other of the market value (21.7\%) (Anonymous, 2010). Supermarket chains are often able to negotiate very strongly on price with confectionery producers; this boosts their buyer power significantly. An increasing number of product lines have been developed to create healthier alternatives to their existing lines, with substitute versions offering no artificial colours, low sugar, as well as the inclusion of additives such as ingredients with high nutrition value.

The leading players in the Eastern European confectionery market include Mars, Inc. (14.3\%), The United Confectionary Manufacturers management company and Nestle S.A. (8.9\%), Cadbury plc (8.6\%) and others - 68.3\%. In Latvia the leading players are GmbH Laima, Ltd Skriveru saldumi, Ltd Pure Chocolate and Ltd Bona Dea. The largest marshmallow manufacturer in Latvia is GmbH Laima, however, other manufacturers, like Ltd. Bona Dea, Ltd. Mikas M, as well as importers from Russia and Lithuania are coming into the market.

The Latvian consumer survey results showed that the amount of choice sweets in a package strongly affect whether they are purchased daily. Often in proposed packagings the amount of sweets is too large. This suggests that a purchasing manner could be goods sold by weight, but in this case the quality of product often does not conform to consumer wishes. Marshmallows packed in boxes usually are chosen as gifts, since they are too expensive for daily consumption. Consumers normally purchase marshmallows in simple polypropylene (PP) pouch packaging. The respondents suggested that they would like to buy marshmallows packed as one piece in a pouch, as this could provide a good solution for a replacement of small chocolate bars or candy packs. This kind of supply on the market could present good opportunities for sales concerning coffee breaks during conferences and other public activities.

Further questions were given to determine respondent reaction to the wide assortment of marshmallows in the market. There are several marshmallow forms currently in retail: traditional (with vanilla), covered with chocolate layer or glazed, as well as marshmallow refined with various additions, like strawberries, apricots, condensed milk, or cappuccino. Most respondents $(97 \%)$ had noticed the high diversity of marshmallow in the market, but $3 \%$ of respondents did not pay attention to new products in the retail. $69 \%$ of respondents preferred marshmallows with additions, while $31.4 \%$ preferred traditional vanilla marshmallow (Fig. 5). Marshmallow flavour needs to follow the market demand and trends.

Much research has been carried out that has revealed high nutritional value of bee pollen. Considering pollen nutritional composition and according to non-scientific studies, dried bee pollen used as food in human diets provides a sense of well-being and contributes to functional and harmonious balance of the body. Confectionery products are usually selected for consumption based upon flavour and textural properties and are often considered as sources of fats and carbohydrates (Grembecka and Szefer, 2012). By enriching sugar confectionery with pollen, it would be possible to supplement the diet with biologically active substances. Increased competition and new opportunities stimulated by progressively vanishing trade barriers and expanding world markets have greatly accelerated the food industry's world-wide requirement for new products, quality improvements and extended shelf-life (Sidel and Stone, 1993). The survey data and consumer attitude towards bee products (marshmallow with 1.0, 1.5 and $2.5 \%$ bee pollen) can be used to determine preferences. Traditional marshmallow without pollen was used as a control. The marshmallow enriched with $1.5 \%$ bee pollen had an agreeable bee pollen taste, aftertaste and aroma. This indicated that the optimal bee pollen concentration for further experiments should be $1.5 \%$. Regarding willingness to buy, most of the respondents $(91.9 \%)$ after testing considered that they would buy this product as interesting. However, $8.1 \%$ of respondents had a dislike to the new product, because they did not like honey and bee pollen taste, and they would not choose any product with this taste. Since about $92 \%$ of the respondents considered marshmallow with $1.5 \%$ bee pollen as tasty and with a pleasant pollen taste and aftertaste, it can be expected that the new product would take a certain niche of the market.

The conclusions are:

- Latvian consumers recognise marshmallow, sugar-candy with foam-like structure. It is purchased every day and in social events. The data showed that consumer choice is affected by the type of packaging and the variety of flavours. For everyday use, consumers would prefer smaller package size. Consumers admitted that they would like to see a new product with pollen rich marshmallow on the market.

- The results of sensory evaluation demonstrated that there was no significant difference between the control sample (marshmallow without bee pollen) and the marshmallow sample with $1.5 \%$ bee pollen $(P>0.05)$. 


\section{ACKNOWLEDGEMENTS}

The research was supported by the ESF "Support for doctoral studies in LLU", Contract

No. 2009/0180/1DP/1.1.2.1.2./09/IPIA/VIAA/017.

\section{REFERENCES}

Anonymous (2010). Confectionery in Europe. Industry profile. Datamonitor, references code: 0201-0710, pp. 1-36 (last accessed 28 May 2012, from www.docin.com/p-288623130.html).

Cakebread, S. (1975). Sugar and Chocolate Confectionery. Oxford: Oxford University Press. 60 pp.

Carpes, S. T., Mourao, G. B., Alencar, S. M., Masson, M. L. (2009). Chemical composition and free radical scavenging activity of Apis mellifera bee pollen from Southern Brazil. Brazil. J. Food Technol., 12 (3), 220-229.

Civille, G. V., Oftedal, K. N.. (2012). Sensory evaluation techniques Make "good for you" taste "good". Physiol. Behav., 107 (4), 598-605

Ergun, R., Lietha, R., Hartel, R. W. (2010). Moisture and shelf life in sugar confections. Crit. Rev. Food Sci. Nutr., 50 (2), 162-192.

Feás, X., Vázquez-Tato, M. P., Estevinho, L., Seijas, J. A., Iglesias, A. (2012). Organic bee pollen: Botanical origin, nutritional value, bioactive compounds, antioxidant activity and microbiological quality. Molecules, 17 (7), 8359-8377.

Frances, R. J., Piggott, J. R. (1991-1992) Free choice profiling in consumer research. Food Quality Pref., 3 (3), 129-134.

Graikou, K., Kapeta, S., Aligiannis, N., Sotiroudis, G., Chondrogianni, N., Gonos, E., Chinou, I. (2011). Chemical analysis of Greek pollen - antioxidant, antimicrobial and proteasome activation properties. Chem. Centr. J., 5 (1), 33, 1-9.

Grembecka, M., Szefer, P. (2012). Differentiation of confectionery products based on mineral composition. Food Anal. Meth., 5 (2), 250-259.

Kawo, A. H., Abdulmumin, F. N. (2009). Microbiological quality of re-packaged sweets sold in metropolitan Kano, Nigeria. Bayero J. Pure Appl. Sci., 2 (1), 154-159.
Konkel, P. J. (2001) Confectionery products. In: Downes, F. P., Ito, K. (eds.). Compendium of Methods for the Microbiological Examination of Foods (4 ${ }^{\text {th }}$ edn.) (pp. 555-561). Washington: American PublicHealth Association.

Le Blanc, B. W., Davis, O. K., Boue, S., Delucca, A., Deeby, T. A. (2009). Antioxidant activity of Sonoran Desert bee pollen. Food Chem., 115 (4), 1299-1305.

Manley, D. (1998). Biscuit, Cookie and Cracker Manufacturing: Manual 1 Ingredients. D. Cambridge, UK: Woodhad Publishing Limited, 82 pp.

McEwan, J. A., Thomson, D. M. H. (1989). The repertory grid method and preference mapping in market research: A case study on chocolate confectionery. Food Quality Prefer., 1 (2), 59-68.

Moskowitz, H. R., Beckley, J. H., Resurreccion, A. V. A. (2006). Sensory and consumer research in food product design and development. Oxford: Blackwell Publishing. 358 p.

Quinton, L. A., Kennedy, J. F. (2002). Book review: The Science of Sugar Confectionery: W.P. Edwards, The Royal Society of Chemistry, 2000. Carbohydr. Polym., 47 (1), 88-89.

Sidel, J. L., Stone, H. (1993). The role of sensory evaluation in the food industry. Food Quality Prefer., 4 (1-2), 65-73.

Silva, T. M. S., Camara, C. A., Lins, A. C. S., Barbosa-Filho, J. M., Da Silva, E. M. S., Freitas, B. M., Santos, F. A. R. (2005). Chemical composition and free radical scavenging activity of pollen load from stingless bee Milipona subnitida Ducke. J. Food Compos. Anal., 19, 507-511.

Sucharzewska, D., Stochmal, A., Oleszek, W. (2003). The effect of Yucca schidigera extract on the physical structure and on the oxidative stability of sugar-candy foam products. Lebensmit. Wiss. Technol., 36 (3), 347-351.

Vaclavik, V. A., Christian, E. W. (2008). Sugar sweeteners, and confections. In: Essentials of Food Science. $3^{\text {rd }}$ edn. (pp. 331-348). New York: Springer Science+Business Media, LLC.

Wilton, V., Greenhoff, K. (1988). Integration of sensory techniques into market research. Food Quality Prefer., 1 (1), 33-35.

Zumbé, A., Lee, A., Storey, D. (2001). Polyols in confectionery: the route to sugar-free, reduced sugar and reduced calorie confectionery. Brit. J. Nutr., $\mathbf{8 5}, 31-45$.

Received 24 September 2012

\section{ZEFİRU SENSORĀ VĒRTĒŠANA UN PATĒRĒTĀJU ATTIEKSME}

Sensorai vērtēšanai un tirgus izpētei ir liela nozīme jaunu produktu izstrādē. Lai arī zefīrs Latvijas tirgū ir pieejams sen, tomēr arvien ir novērojamas tendences šī produkta bagātināšanai ar dažādām piedevām. Zinātniskajā literatūrā atspoguḷoti pētījumu, kas parāda ziedputekšṇu augsto uzturvērtîbu, līdz ar to ir saprotama cilvēku interese par to sastāvu un izmantošanas iespējām uztura papildināšanai un pilnveidošanai. Pētījuma mērḳis ir noskaidrot situāciju Latvijas tirgū, izvērtēt patērētāju informētību par zefìru, tā pieprasījumu, optimālo iepakojuma daudzumu un tā noformējumu, kā arī veikt sensoro vērtēšanu ar ziedputekšniem bagātinātam zefïram. Anketēšana veikta interneta vietnē www.visidati.lv. Kopumā aptaujāti 900 respondenti (28\% vīrieši un $72 \%$ sievietes). Lai noskaidrotu potenciālo patērētāju viedokli, ar ziedputekšņiem bagātināts zefîrs vērtēts Starptautiskajā pārtikas izstādē „,Riga Food 2011”. Vērtēšanā piedalījās 130 izstādes apmeklētāji. Sensori pēc hedoniskās skalas novērtēts zefīrs ar dažādu ziedputekšn̨u koncentrāciju (1, 2 un 2.5\%). Lai noteiktu paraugu patikšanas pakāpi (ISO 4121:2003), izmantota 9 punktu hedoniskā skala (9 - ārkārtīgi patīk, 1 - ārkārtīgi nepatīk). Pēc sensorās vērtēšanas rezultātiem var secināt, ka patērētājiem vislabāk patīk kontroles paraugs (klasiskais zefïrs) un zefīrs ar 1,5\% ziedputekšniem, starp tiem patikšanas zinā nepastāv būtiska atškirība $(P<0,05)$. Tas liecina, ka patērētājiem vienlīdz labi patīk gan klasiskais zefìrs, gan ar ziedputekšniem bagātināts $(1,5 \%)$ zefïrs. 